\title{
Erven naar Marokkaans recht : aspecten van Nederlands internationaal privaatrecht bij de toepasselijkheid van Marokkaans erfrecht
}

Citation for published version (APA):

Rutten, S. W. E. (1997). Erven naar Marokkaans recht : aspecten van Nederlands internationaal privaatrecht bij de toepasselijkheid van Marokkaans erfrecht. [Doctoral Thesis, Maastricht University]. Intersentia. https://doi.org/10.26481/dis.19970919sr

Document status and date:

Published: 01/01/1997

DOI:

10.26481/dis.19970919sr

Document Version:

Publisher's PDF, also known as Version of record

Please check the document version of this publication:

- A submitted manuscript is the version of the article upon submission and before peer-review. There can be important differences between the submitted version and the official published version of record.

People interested in the research are advised to contact the author for the final version of the publication, or visit the DOI to the publisher's website.

- The final author version and the galley proof are versions of the publication after peer review.

- The final published version features the final layout of the paper including the volume, issue and page numbers.

Link to publication

\footnotetext{
General rights rights.

- You may freely distribute the URL identifying the publication in the public portal. please follow below link for the End User Agreement:

www.umlib.nl/taverne-license

Take down policy

If you believe that this document breaches copyright please contact us at:

repository@maastrichtuniversity.nl

providing details and we will investigate your claim.
}

Copyright and moral rights for the publications made accessible in the public portal are retained by the authors and/or other copyright owners and it is a condition of accessing publications that users recognise and abide by the legal requirements associated with these

- Users may download and print one copy of any publication from the public portal for the purpose of private study or research.

- You may not further distribute the material or use it for any profit-making activity or commercial gain

If the publication is distributed under the terms of Article $25 \mathrm{fa}$ of the Dutch Copyright Act, indicated by the "Taverne" license above, 
Erven naar Marokkaans recht

Aspecten van Nederlands internationaal privaatrecht bij de toepasselijkheid van Marokkaans erfrecht 
Van dit proefschrift verschijnt een handelseditie in de Ius Commune Europaeum Reeks onder ISBN 90-5095-009-4 


\section{ERVEN NAAR MAROKKAANS RECHT}

Aspecten van Nederlands internationaal privaatrecht bij de toepasselijkheid van Marokkaans erfrecht

\section{PROEFSCHRIFT}

ter verkrijging van de graad van doctor aan de Universiteit Maastricht, op gezag van de Rector Magnificus, Prof. mr M.J. Cohen, volgens het besluit van het College van Decanen, in het openbaar te verdedigen op vrijdag 19 september 1997 om 16.00 uur

door

Susanne Wilhelmine Eugenie Rutten geboren te Breda 
Promotores: $\quad$ Prof.mr G.R. de Groot

Prof.dr.mr R. Peters (UvA)

Beoordelingscommissie: Prof.mr C. Flinterman LL.M. (voorzitter)

Prof.mr M.J.C. Koens

Dr. S.F.G. Rammeloo

Prof.mr L. Strikwerda (RUG)

Dr. F.J.A. van der Velden (Ministerie van Justitie, Den Haag) 


\section{Voorwoord}

In de jaren dat ik aan dit proefschrift heb gewerkt is mij regelmatig gevraagd hoe ik er bij kwam om me als Nederlands jurist te verdiepen in het Marokkaanse erfrecht. Of ik nog iets exotischers kon bedenken. Hoewel er ook andere misschien meer voor de hand liggende onderwerpen te bedenken zijn waarover kan worden geschreven, heeft deze vraag me toch dikwijls verbaasd. Afkomstig uit een Brabants dorp en pas in directe aanraking gekomen met in Nederland wonende personen van buitenlandse herkomst tijdens mijn studie in een grote stad, veronderstelde ik dat iedereen in Nederland toch wel wist en besefte dat we in een multiculturele samenleving leefden. Voor niet-juristen en rechtenstudenten is het vaak een openbaring als wordt geconstateerd dat in Nederland buitenlandse rechtsstelsels worden toegepast. In het internationaal privaatrecht is dit een vanzelfsprekendheid. Zolang in het internationaal familie- en erfrecht de nationaliteit als aanknopingsfactor of als een van de aanknopingsfactoren wordt gebezigd of een rechtskeuze voor het recht van de nationaliteit wordt erkend, betekent de aanwezigheid van buitenlanders in Nederland dat juristen in tal van zaken worden genoopt kennis te nemen van buitenlandse rechtsstelsels. Er wonen thans enkele honderdduizenden Marokkaanse staatsburgers in Nederland. Bijna allemaal zijn zij moslim. In dit licht is een keuze voor een studie naar het Marokkaanse erfrecht te verklaren. Het Marokkaanse familierecht was reeds uitvoerig onderzocht (mijn Leidse collega Léon Buskens promoveerde in 1993 op dit onderwerp) en in het verlengde hiervan was het erfrecht aan de beurt. Te verwachten is dat Nederlandse notarissen, advocaten en rechters, evenals hun collega's in de ons omringende landen, in het bijzonder in België en Frankrijk, in toenemende mate zullen worden geconfronteerd met nalatenschappen van Marokkaanse erflaters. In dit boek heb ik getracht uiteen te zetten wat dit vanuit internationaal privaatrechtelijk oogpunt kan betekenen, althans als op grond van de verwijzingsregel het Marokkaanse erfrecht toepasselijk wordt verklaard. De bestudering van dit recht en het zoeken naar theoretisch haalbare maar ook praktisch wenselijke oplossingen daar waar de twee rechtsculturen ver uiteen lopen, zijn voor mij tot het einde toe een boeiende en leerzame bezigheid geweest. 
Opmerkingen en suggesties van derden hebben mij doen beseffen dat een onderzoek als het onderhavige, waarin vele disciplines samenkomen, niet of nauwelijks zonder de hulp van anderen tot stand kan komen. Mijn dankbaarheid jegens een aantal van hen wil ik dan ook graag in dit voorwoord tot uitdrukking brengen. Het was de Vereniging tot bestudering van het Recht van de Islam en het Midden Oosten (RIMO), in 1982 opgericht door Frans van Bakelen, die mij in 1985 inlijfde in de club van wetenschappers die zich bezighielden met de bestudering van het islamitische recht en de betekenis hiervan in West-Europa. Toen ik een aantal jaren later besloot een proefschrift te gaan schrijven over het Marokkaanse erfrecht in het Nederlandse internationaal privaatrecht, was het René de Groot die onmiddellijk enthousiast was. Hoewel de ideeën over hetgeen ik over dit onderwerp wilde schrijven in de loop der tijd nogal eens veranderden, bleef hij geloven dat het project tot een goed einde zou worden gebracht. Voor de vrijheid die hij me hierbij liet, zijn hartelijkheid en zijn verstandige opmerkingen wil ik hem van harte danken. De tweede promotor, Ruud Peters, "coverde" het islamitische recht en al hetgeen hiermee in direct verband kan worden gebracht. De vele onderwerpen die ik met hem voornamelijk per e-mail besprak werden door hem op vakkundige en snelle wijze behandeld. De Faculteit der Rechtsgeleerdheid van de Universiteit Maastricht stelde mij in de gelegenheid de juistheid van mijn bevindingen over het Marokkaanse recht in Marokko zelf te controleren. Ik geloof dat mijn verblijf aldaar het inzicht in en begrip van het Marokkaanse rechtssysteem aanmerkelijk heeft vergroot. Van de vele personen die ik er heb gesproken, en die allemaal een ongekende bereidheid toonden mij van informatie te voorzien, wil ik er enkelen in het bijzonder noemen. Allereerst is dit Jaouad Idrissi van het Marokkaanse Ministerie van Justitie. Met veel geduld en precisie heeft hij mij voorzien van voor het onderzoek onmisbare gegevens en heeft hij te starre opvattingen over het Marokkaanse familierecht weten te relativeren. Waardevol waren ook de gesprekken met Fatna Sarehane (Universiteit van Casablanca), die vanwege haar betrokkenheid bij de positie van de Marokkaanse vrouw in Marokko en in Europa over zowel theoretische als praktische kennis beschikte. Veel beslag heb ik gelegd op de tijd van Khalid Berjaoui (Universiteit van Rabat). Ondanks de voortdurende aanloop van studenten en het onophoudelijk gerinkel van de telefoon, bleef hij kalm de vragen beantwoorden van mijn ellenlange vragenlijst. Het was voornamelijk Mimoun Hajji, juridisch attaché bij de Marokkaanse Ambassade te Den Haag, die mij informeerde over de bevoegdheden van Marokkaanse consulaire en diplomatieke vertegenwoordigers in Nederland op het gebied van het familie- en erfrecht. Op vriendschappelijke wijze hebben wij gezamenlijk tal van dossiers en documenten doorgenomen. Verschillende mensen zijn bereid geweest de tekst van het gehele manuscript of een gedeelte ervan door te nemen. Caroline Forder en Aalt Willem Heringa wil ik bedanken voor hun opmerkingen bij het zesde hoofdstuk over de openbare orde. Verrast was ik met de spontane bereidheid van Arie-Jaap Warnaar om als niet-jurist het gehele manuscript te lezen. Prof. Brugman heeft jarenlang belangstelling getoond voor het onderwerp van mijn onderzoek en las, alsof het vanzelfsprekend was, eveneens het manuscript van het proefschrift. Veel heb ik geleerd en genoten van zijn bijzondere ervarenheid en scherpzinnigheid. Een belangrijk moment was dat waarop de beoordelingscommissie het 
manuscript goedkeurde. Na jarenlange arbeid ben je er opeens doorheen. Voor de bereidheid het manuscript door te nemen zonder de indruk te wekken dat dit belastend zou zijn, ben ik Kees Flinterman, Theo Koens, Stephan Rammeloo, Prof. Strikwerda en Frans van der Velden dan ook zeer dankbaar. Frans neemt hierbij wel een zeer bijzondere positic in. In 1984 mocht ik als een van zijn student-assistenten reeds een eerste studie doen naar het Marokkaanse erfrecht. Sindsdien is hij eigenlijk altijd betrokken gebleven bij mijn onderzoeksactiviteiten op het gebied van het islamitische recht in $\mathrm{Ne}$ derland. Zijn kritische en inspirerende houding en hulp bij het leggen van contacten met Marokkaanse autoriteiten, hebben ervoor gezorgd dat het onderzoek niet beperkt bleef tot een eenzaam studeerkameronderzoek. Al die personen met wie ik in de afgelopen jaren contact heb gehad over het onderzoek hebben mij laten zien dat het onderwerp dat ik beschrijf vanuit verschillende oogpunten gezien en benaderd kan worden. Ik heb dit gedaan vanuit een juridisch, en dan nog in het bijzonder een internationaal privaatrechtelijk oogpunt. Zou ik antropologe zijn geweest of deskundige op het gebied van het internationaal recht, dan waren de accenten vast anders gelegd. Het vinden van het juiste evenwicht tussen de verschillende disciplines is bij een dergelijk onderwerp geen gemakkelijke maar wel belangrijke zaak.

De professionele vertalingen van de samenvatting van dit boek naar het Engels respectievelijk het Frans, zijn verzorgd door Wies Rayar (Engels) en Marie-Claude Dumas (Frans). De mooi verzorgde opmaak van het boek is te danken aan Ine Corstjens. Bij haar en bij de andere medewerkers van het secretariaat privaatrecht kon ik altijd aankloppen voor hulp bij tal van praktische zaken die behoren bij de afwerking van een proefschrift en de organisatie van een promotie.

Bert, Pieterjan en Naud, het was fijn om met jullie dicht bij me het boek te kunnen schrijven.

Maastricht, mei 1997 


\section{Inhoud}

Voorwoord $\ldots \ldots \ldots \ldots \ldots \ldots \ldots \ldots \ldots \ldots$

Inhoudsopgave $\ldots \ldots \ldots \ldots \ldots \ldots \ldots \ldots \ldots \ldots \ldots \ldots \ldots \ldots$

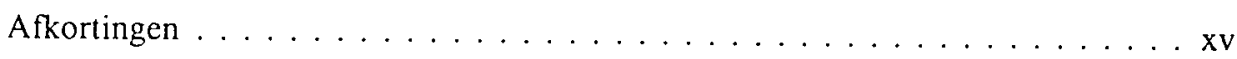

Inleiding $\ldots \ldots \ldots \ldots \ldots \ldots \ldots \ldots \ldots \ldots \ldots \ldots \ldots \ldots \ldots \ldots \ldots \ldots \ldots$

Hoofdstuk I Islamitisch recht $\ldots \ldots \ldots \ldots \ldots$

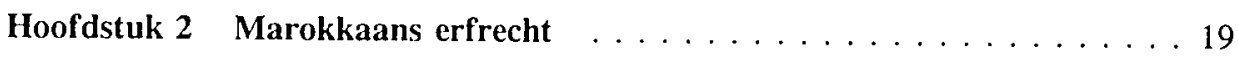

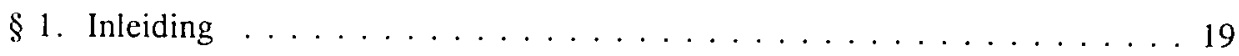

$\$ 2$. Inleidende opmerkingen over het islamitische erfrecht $\ldots \ldots \ldots \ldots 21$

A. ONTSTAAN VAN HET ISLAMITISCHE ERFRECHT $\ldots \ldots \ldots \ldots \ldots \ldots 21$

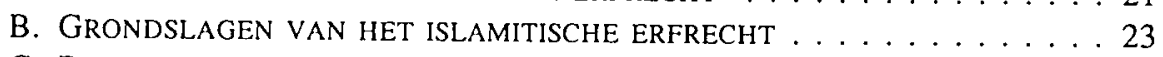

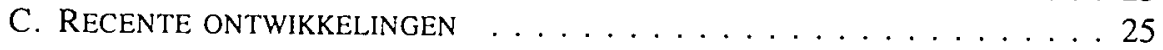

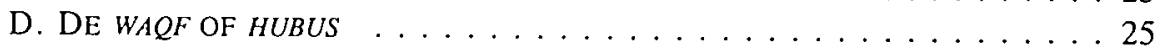

1. De hubus in Marokko . . . . . . . . . . . . . . . . 30

$\S 3$. Het Marokkaanse erfrecht $\ldots \ldots \ldots \ldots \ldots \ldots \ldots \ldots \ldots \ldots$

A. Het testament . . . . . . . . . . . . . . . . 34

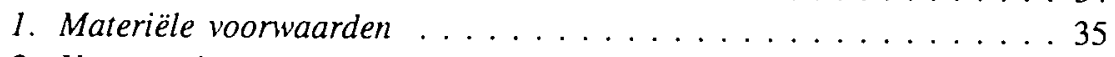

2. Vormvereisten ................... 40

3. Gevolgen van het testament . . . . . . . . . . . 41

4. De testamentaire hubus . . . . . . . . . . . . . . . . 42

5. De aanwijzing van erfgenamen (tanzil) $\ldots \ldots \ldots \ldots \ldots \ldots$ 


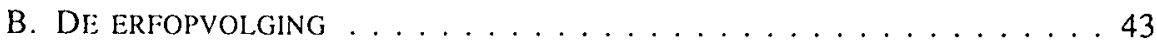

1. Voorwaarden voor erfopvolging ................. 43

2. Beletselen voor erfopvolging ................. . 47

3. Het verkrijgen van de hoedanigheid van erfgenaam ......... 48

a. Huwelijk ........................ . . . 48

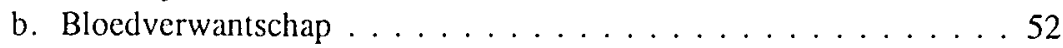

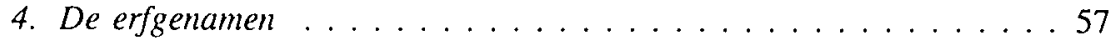

5. Rangorde waarin de erfgenamen worden geroepen .......... . 59

6. De erfdelen . . . . . . . . . . . . . . . . . . . . . . 61

a. Erfdelen van de koranische erfgenamen ............ 62

b. Erfdelen van de 'asaba-erfgenamen . . . . . . . . . . . . 72

c. Bijzondere gevallen ..................... 78

d. Het verplicht testament . . . . . . . . . . . . . . . . 85

C. DE AFWIKKELING VAN DE NALATENSCHAP . . . . . . . . . . . 90

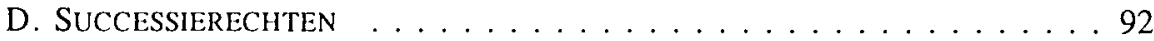

\section{Hoofdstuk 3 Bevoegdheden van diplomatieke} vertegenwoordigers en consulaire ambtenaren ........993

Hoofdstuk 4 Nederlands internationaal erfrecht . . . . . . . . . . . 97

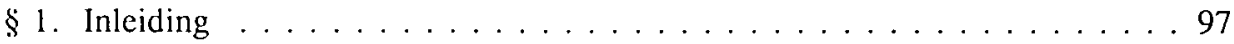

$\S 2$. Bevoegdheid van de Nederlandse rechter . . . . . . . . . . . . 97

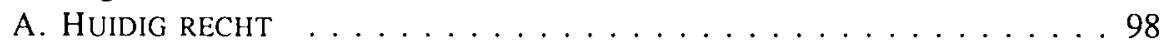

B. VOORSTEL VAN WET ............................ 101

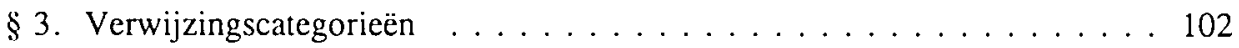

$\$ 4$. Erfopvolging: de toepasselijke erfwet . . . . . . . . . . . . . 105

A. OUDE CONFLICTENRECHT INZAKE DE ERFOPVOLGING . . . . . . . . 105

B. ERFRECHTVERDRAG EN WET CONFLICTENRECHT ERFOPVOLGING . . . 108

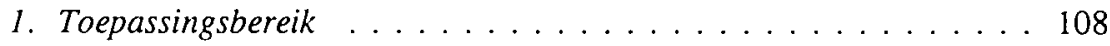

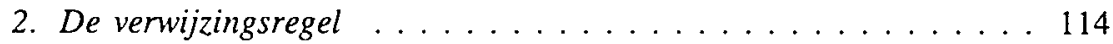

a. Rechtskeuze ....................... . . 114

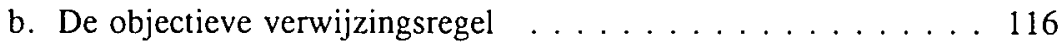

c. Overige bepalingen ................... 121

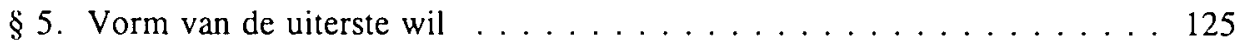

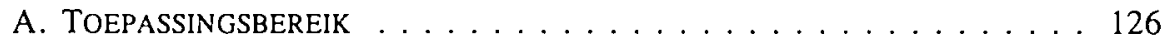

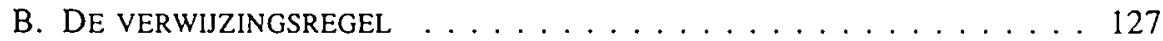


$\S 6$. Bekwaamheid om bij uiterste wil te beschikken $\ldots \ldots \ldots \ldots \ldots \ldots$

§7. Afwikkeling van de nalatenschap . . . . . . . . . . . . . . . . . 129

A. WET CONFLICTENRECHT ERFOPVOLGING . . . . . . . . . . . . 129

1. Vereffening van de nalatenschap . . . . . . . . . . . . . 129

2. Verdeling van de nalatenschap $\ldots \ldots \ldots \ldots \ldots \ldots$

$\$ 8$. Erkenning van consulaire werkzaamheden $\ldots \ldots \ldots \ldots \ldots$

A. ERKENNING VAN EEN CONSULAIRE AFWIKKELING VAN DE

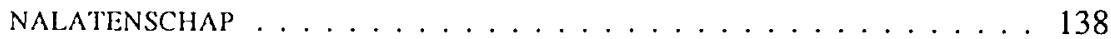

$\S 9$. Het Haags Trustverdrag en de Marokkaanse hubus . . . . . . . . . . . 140

A. Het HaAgs Trustverdrag . . . . . . . . . . . . . . . 141

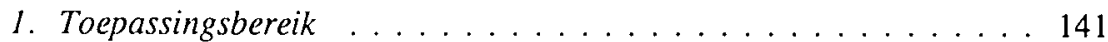

2. Toepasselijk recht .................... 142

3. Erkenning ..................... . 143

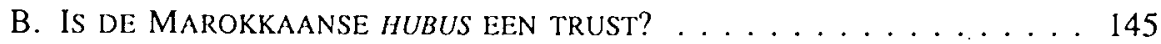

C. ERKENNING VAN de MAROKKAANSE hUbUS . . . . . . . . . . 147

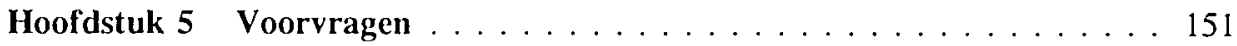

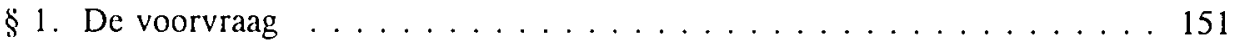

$\S 2$. Marokkaans IPR betreffende het personeel statuut $\ldots \ldots \ldots \ldots \ldots$

§3. Huwelijk . . . . . . . . . . . . . . . . . . . . . . 159

A. HuwElIJK ALS VOORVRAAG . . . . . . . . . . . . . 159

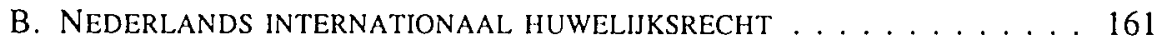

C. MAROKKAANS INTERNATIONAAL HUWELIJKSRECHT . . . . . . 163

D. VOORBEELDEN . . . . . . . . . . . . . . . . . . . . 167

$\S 4$. Huwelijksontbinding . . . . . . . . . . . . . . . . 170

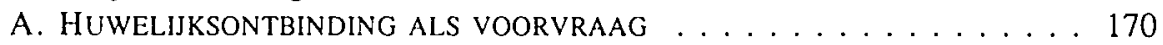

B. NEDERLANDS INTERNATIONAAL HUWELIJKSONTBINDINGSRECHT . . . 170

C. MAROKKAANS INTERNATIONAAL HUWELIJKSONTBINDINGSRECHT $\ldots 172$

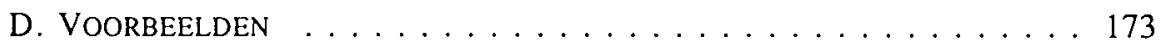

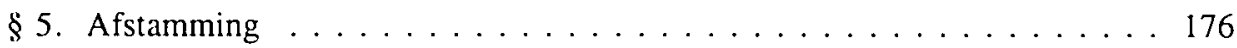

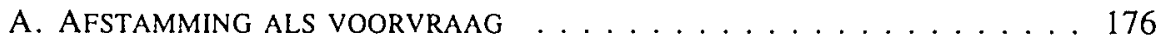

B. NEDERLANDS INTERNATIONAAL AFSTAMMINGSRECHT . . . . . 177

C. MAROKKAANS INTERNATIONAAL AFSTAMMINGSRECHT $\ldots \ldots \ldots 178$

D. VOORBEELDEN . . . . . . . . . . . . . . . . . . . 179 
$\S 6$. Adoptie . . . . . . . . . . . . . . . . . . . . . . . . . . 182

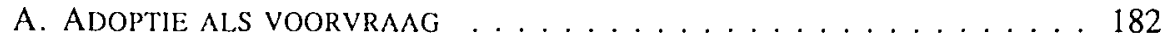

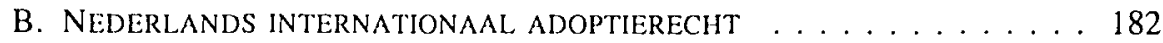

C. MAROKKAANS InTERnATIONAAL ADOPTIERECHT . . . . . . . . 184

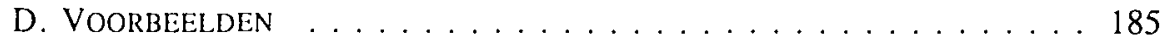

$\S 7$. Huwelijksvermogensregime . . . . . . . . . . . . . 186

A. HUWELIJKSVERMOGENSREGIME ALS VOORAFGAANDE VRAAG . . . . 186

B. NEDERLANDS INTERNATIONAAL HUWELIJKSVERMOGENSRECHT $\ldots \ldots 186$

C. MAROKKAANS INTERNATIONAAL HUWELIJKSVERMOGENSRECHT . . . . 190

D. VOORBEELDEN . . . . . . . . . . . . . . . . . . . 191

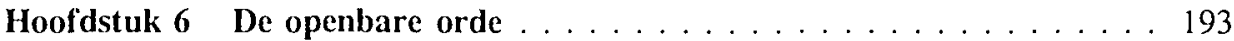

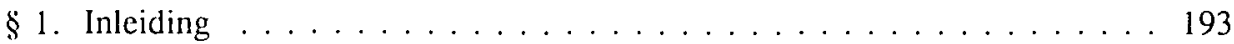

$\S 2$. De openbare orde . . . . . . . . . . . . . . . . . . . . . 194

A. BEGRIPSOMSCHRIJVING . . . . . . . . . . . . . . . . 194

B. DE EXCEPTIE VAN DE OPENBARE ORDE . . . . . . . . . . . . 194

C. GEVOLGEN VAN EEN BEROEP OP DE EXCEPTIE VAN DE OPENBARE ORDE . . . . . . . . . . . . . . . . . . . . . . 198

§3. Marokkaans erfrecht en de openbare orde . . . . . . . . . . 200

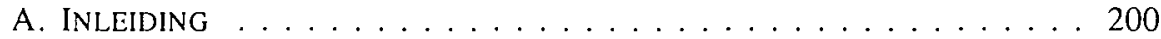

1. Onderscheid naar geslacht . . . . . . . . . . . . . . 202

a. Gelijkheidsbeginsel: verbod van discriminatie naar geslacht . . . . . . . . . . . . . . . . 202

b. Is het Marokkaanse erfrecht in strijd met het verbod van discriminatie naar geslacht? . . . . . . . . . . . . . . . . 204

c. Conclusie ... . . . . . . . . . . . . . . 212

2. Onderscheid naar geboorte . . . . . . . . . . . . 214

a. Gelijkheidsbeginsel: verbod van discriminatie naar geboorte . . . . . . . . . . . . . . . . . . 214

b. Is het Marokkaanse erfrecht in strijd met het verbod van discriminatie naar geboorte? . . . . . . . . . . . 217

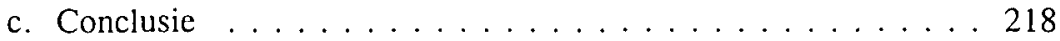

3. Onderscheid naar godsdienst . . . . . . . . . . . 219

a. Gelijkheidsbeginsel: verbod van discriminatie naar godsdienst . . . . . . . . . . . . . . . 219

b. Is het Marokkaanse erfrecht in strijd met het verbod van discriminatie naar godsdienst? 
c. Conclusie ... . . . . . . . . . . . . . . . . 221

4. Afwijkingen van grondslagen van het Nederlandse erfrecht . . . . 221

a. Testeervrijheid; dwingend recht en regelend recht . . . . . . 223

b. Het verkrijgen van de hoedanigheid van erfgenaam . . . . . 228

c. Kring der erfgenamen . . . . . . . . . . . . . . . . . . . 229

d. Onderscheid tussen koranische en 'asaba-erfgenamen . . . . . . 231

e. Omvang van $d e$ erfdelen . . . . . . . . . . . . . . 232

f. Overige afwijkingen . . . . . . . . . . . . . 233

5. Voorvragen en openbare orde . . . . . . . . . . . . 233

6. Betekenis van het religieuze karakter van het Marokkaanse erfrecht en van de islamitische godsdienst van de erflater . . . . . 242

7. Betekenis van de rechtskeuze voor de openbare orde-exceptie . . 243

B. Gevolgen van Een BEROEP oP DE OPENBARE ORdE . . . . . . . . 245

$\$ 4$. Toetsing aan Verdragen . . . . . . . . . . . . . . . . . . . . 249

A. BETEKENIS VAN MENSENRECHTEN IN HET IPR . . . . . . . 249

B. VERDRAGSBEPALINGEN DIE VOOR DE ERFOPVOLGING VAN BELANG KUNNEN ZUN . . . . . . . . . . . . . . . . . 255

1. Rechten van erfopvolging . . . . . . . . . . . 257

a. Art. 8 EVRM . . . . . . . . . . . . . . . . 257

b. Art. 16 lid 1 aanhef en sub h Vrouwenverdrag . . . . . . 269

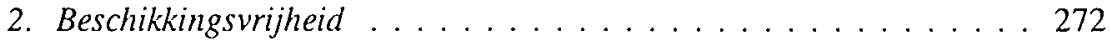

a. Art. 1 Eerste Protocol EVRM . . . . . . . . . . . . . 272

b. Art. 8 EVRM . . . . . . . . . . . . . . . . 274

C. TOETSING AAN VERDRAGSBEPAlingen OF AAN DE OPENBARE ORDE? . 275

Hoof dstuk 7 Erkenning en tenuitvoerlegging in Marokko . . . . . . . . 279

$\S 1$. Verwijzingsregels inzake de erfopvolging . . . . . . . . . . 279

$\S 2$. Erkenning en tenuitvoerlegging van rechterlijke beslissingen $\ldots \ldots \ldots 280$

$\S 3$. Erkenning en tenuitvoerlegging van authentieke akten . . . . . . . 285

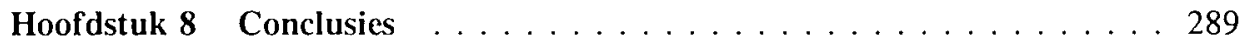

Samenvatting . . . . . . . . . . . . . . . . . . . . . . 299

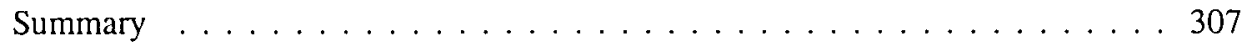




\section{Résumé}

Trefwoordenregister ............................... 319

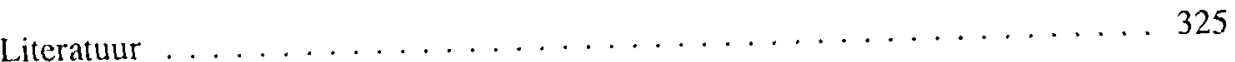

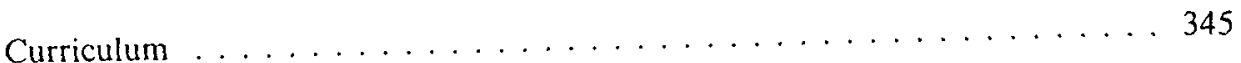




\section{Afkortingen}

$\begin{array}{lll}\text { AAc } & : \text { Ars Aequi } \\ \text { AAS } & : \text { Asian and African Studies } \\ \text { AJCL } & : \text { The American Journal of Comparative Law } \\ \text { ALQ } & : \text { Arab Law Quarterly } \\ \text { B.O. } & : \text { Bulletin officiel } \\ \text { BSOAS } & : \text { Bulletin of the School of Oriental and African Studies } \\ \text { BVerfGE } & : \text { Bundesverfassungsgericht } \\ \text { BW } & : \text { Burgerlijk Wetboek } \\ \text { CBS } & : \text { Centraal Bureau voor de Statistiek } \\ \text { Clunet } & : \text { Journal du droit international } \\ \text { CPC } & : \text { Code de procédure civile } \\ \text { CS } & : \text { Cour suprême } \\ \text { CSPS } & : \text { Code de statut personnel et des successions } \\ \text { DCC } & : \text { Dahir sur la condition civile des Français et des étrangers dans le } \\ & : \text { Protectorat français du Maroc } \\ \text { DOC } & : \text { Dahir des obligations et des contrats } \\ \text { DS } & : \text { Recueil Dalloz Sirey de doctrine, de jurisprudence et de législation } \\ \text { EHRM } & : \text { Europese Hof voor de Rechten van de Mens } \\ \text { EuGRZ } & : \text { Europäische Grundrechte-Zeitschrift } \\ \text { EVRM } & : \text { Europees Verdrag tot bescherming van de Rechten van de Mens en } \\ & : \text { de fundamentele vrijheden } \\ \text { FamRZ } & : \text { Zeitschrift für das gesamte Familienrecht } \\ \text { FJR } & : \text { Tijdschrift voor Familie- en Jeugdrecht } \\ \text { Gr.w. } & : \text { Grondwet } \\ \text { GTM } & : \text { Gazette des Tribunaux du Maroc } \\ \text { HI } & : \text { Hamdard Islamicus } \\ \text { HPS } & : \text { Het Personeel Statuut } \\ \text { HR } & : \text { Hoge Raad } \\ \text { IC } & : \text { Islamic Culture } \\ \text { ICLQ } & : \text { International and Comparative Law Quarterly }\end{array}$


IJMES

ILS

IPR

IPRax

IS

IsCLQ

IVBPR

IVESCR

JBN

$\mathrm{JuD}$

JUU

MDR

MisLR

MR

NBW

NILR

NIPR

NJ

NJB

NJCM

NJV

NJW

NTBR

NTIR

NVIR

Publ. EHRM

RabelsZ

RASJEP

RATMLJ

$\mathrm{Rb}$

RCDIP

RDE

RDIDC

RDSS

RDU

Rec.dC

REI
: International Journal of Middle East Studies

: Islamic Law and Society

: Internationaal Privaatrecht

: Praxis des Internationalen Privat- und Verfahrensrechts

: Islamic Studies

: Islamic and Comparative Law Quarterly

: Internationaal Verdrag inzake burgerrechten en politieke rechten

: Internationaal Verdrag inzake economische, sociale en culturele rechten

: Juridische Berichten voor het Notariaat

: Juridisch up to Date

: Jernal Undang Undang

Monatsschrift für deutsches Recht

Missouri Law Review

: Migrantenrecht

: Nieuw Burgerlijk Wetboek

: Netherlands International Law Review

: Nederlands Internationaal Privaatrecht; repertorium op verdragenrecht, wetgeving, rechtspraak en literatuur

: Nederlandse Jurisprudentie

: Nederlands Juristenblad

: Nederlands Tijdschrift voor de Mensenrechten, NJCM-Bulletin

: Nederlandse Juristenvereniging

: Neue Juristische Wochenschrift

: Nederlands Tijdschrift voor Burgerlijk Recht

: Nederlands Tijdschrift voor Internationaal Recht (vanaf 1972 voortgezet als NILR)

: Nederlandse Vereniging voor Internationaal Recht

: Publications of the European Court of Human Rights

: Rabels Zeitschrift/Zeitschrift für ausländisches und internationales Privatrecht

: Revue algérienne des sciences juridiques, économiques et politiques

: Revue algérienne, tunisienne, marocaine de législation et de jurisprudence

: Rechtbank

: Revue critique de droit international privé

: Revue de droit et d'économie

: Revue de droit international et de droit comparé

: Revue de droit sanitaire et social

: Revue de droit uniforme

: Recueil des cours: collected courses of the Hague Academy of International Law

: Revue des études islamiques 
RIDC

RJL

RJPEM

RJPIC

RJPOM

RJPUF

RMD

RMDC

RMDED

RM Themis

R.O.

ROMM

RSV

RTD

RTDF

Rv

RvdW

SI

StAZ

Stb.

$S \& V$

TAR

Trb.

TvC

TVCR

TVVS

TwK

WCE

WCEO

WCH

$\mathrm{WCHb}$

WCHv

WCT

Wet $A B$

WPNR

ZfRV

ZVR
: Revue internationale de droit comparé

: Revue de la jurisprudence et des lois

: Revue juridique, politique et économique du Maroc

: Revue juridique et politique, indépendance et coopération

: Revue juridique et politique d'Outre-Mer

: Revue juridique et politique de l'Union française (voortgezet als RJPOM)

: Revue marocaine de droit

: Revue marocaine de droit comparé

: Revue marocaine de droit et d'économie du développement

Rechtsgeleerd Magazijn Themis

Wet op de Rechterlijke Organisatie

: Revue de l'Occident musulman et de la Mediterranée (voortgezet als: Revue du monde musulman et de la Mediterranée)

: Rechtspraak Sociale Verzekering

: Revue tunisienne de droit

: Revue trimestrielle de droit familial

: Wetboek van Burgerlijke Rechtsvordering

: Rechtspraak van de Week

: Studia Islamica

: Das Standesamt/Zeitschrift für Standesamtswesen, Familienrecht, Staatsangehörigkeitsrecht, Personenstandsrecht, internationales Privatrecht des In- und Auslands

: Staatsblad

: Stichting en Vereniging

: Tijdschrift voor Antilliaans Recht/Justicia

Tractatenblad

: Tijdschrift voor Consumentenrecht

: Tijdschrift voor Civiele Rechtspleging

Maandblad voor Ondernemingsrecht en Rechtspersonen

: Tweede Kamer

Wet conflictenrecht echtscheiding

Wet conflictenrecht erfopvolging

Wet conflictenrecht huwelijk

Wet conflictenrecht huwelijksbetrekkingen

Wet conflictenrecht huwelijksvermogensregime

Wet conflictenrecht trusts

Wet Algemene Bepalingen

Weekblad voor Privaatrecht, Notariaat en Registratie

Zeitschrift für Rechtsvergleichung, Int. Privatrecht und Europarecht

Zeitschrift für Vergleichende Rechtswissenschaft 



\section{Inleiding}

Een huis of een stuk grond in Marokko, gouden sieraden, een bankrekening, het hoeft niet veel te zijn. Wanneer iemand overlijdt en er valt iets te verdelen, krijgt men te maken met de regels van het erfrecht. Volgens gegevens van het Centraal Bureau voor de Statistiek woonden er op 1 januari 1996149.841 Marokkanen in Nederland '. Tot op heden is er weinig bekend over de afhandeling van nalatenschappen van Marokkaanse erflaters in Nederland. Enerzijds wordt dit veroorzaakt door het feit dat er nalatenschappen zijn die door de erfgenamen zelf worden afgehandeld, of welke met tussenkomst van een notaris worden geregeld, zodat hiervan weinig openbaar wordt. Anderzijds is het aantal sterfgevallen van in Nederland woonachtige (vermogende) Marokkanen nog gering ${ }^{2}$. Het is pas sedert de jaren zeventig dat Marokkaanse immigranten zich met of zonder hun familie in Nederland vestigen. De gemiddelde overlijdensleeftijd moet ten aanzien van Marokkanen in Nederland dus waarschijnlijk nog worden bereikt. Ook het verblijf van latere generaties in ons land rechtvaardigt de conclusie dat het aantal sterfgevallen onder Marokkanen in Nederland in de toekomst zal toenemen. In die gevallen is het internationaal privaatrecht (IPR) van belang. Wanneer een erflater een andere nationaliteit bezit dan die van het land van zijn gewone verblijfplaats, of er vermogen in een ander land is gelegen, kunnen verschillende rechtsstelsels voor toepassing in aanmerking komen: het recht van het land waarvan de erflater de nationaliteit bezit, de lex domicilii, of de lex rei sitae. Volgens de verwijzingsregel van Nederlands internationaal erfrecht zal in een aantal gevallen aangeknoopt worden aan de nationaliteit van de erflater, en zal het Marokkaans recht de erfopvolging beheersen. De nationaliteit als aanknopingsfactor mag dan in de afgelopen jaren wel aan waarde

1. CBS maandstatistiek van de bevolking januari 1997, p. 23. Geteló zijn personen die als Marokkaanse ingezetenen in de Basisadministratie van de Nederlandse gemeenten zijn opgenomen. Volgens mondelinge informatie van het CBS zijn ten behoeve van deze in de statistiek opgenomen cijfers alleen de niet-Nederlanders geteld. Dat wil zeggen dat Marokkaanse ingezetenen die tevens de Nederlandse nationaliteit bezitten in het genoemde aantal niet zijn inbegrepen.

2. Volgens gegevens van het CBS, maandstatistiek van de bevolking oktober 1995, p. 37 , betrof het aantal Marokkaanse overledenen in 1994: 228 personen. 
hebben ingeboet, verdwenen is zij nog niet. Tot 1 oktober 1996 stond in het internationaal erfrecht aanknoping aan de nationaliteit van de erflater nog voorop. Op 1 oktober 1996 is de Wet conflictenrecht erfopvolging (WCEo) in werking getreden. In deze wet worden de verwijzingsregels uit het Erfrechtverdrag van 1989 toepasselijk verklaard. Het Erfrechtverdrag zelf is door Nederland wel reeds goedgekeurd maar is nog niet in werking getreden. De nicuwe verwijzingsregel inzake de erfopvolging kent behalve een expliciete erkenning van de rechtskeuze, een tweetal aanknopingsfactoren, te weten de nationaliteit en de gewone verblijfplaats van de erflater. Of het nationale recht van de erflater dan wel het recht van zijn laatste gewone verblijfplaats toepasselijk is, wordt voor hen bij wic nationaliteit en woonplaats niet samenvallen, in hoofdzaak afhankelijk gesteld van de duur van het verblijf in Nederland. De grens is getrokken bij vijf jaren: verblijft een buitenlander minder dan vijf jaren in Nederland, dan wordt het nationale recht van de erflater van toepassing verklaard, tenzij hij op dat moment nauwere banden had met een andere Staat dan die van zijn nationaliteit. Bij een verblijf van meer dan vijf jaren in Nederland, is Nederlands recht als recht van het laatste domicilie van toepassing, tenzij er sprake is van uitzonderlijke omstandigheden en de erflater ten tijde van zijn overlijden kennelijk nauwere banden had met zijn nationaliteitsstaat. Hoewel onder de nieuwe verwijzingsregel naar verwachting minder vaak het nationale recht van de erflater zal worden aangewezen dan voorheen, zal het nationale erfrecht nog in een niet gering aantal gevallen een rol blijven spelen. Voor Marokkaanse erflaters is dit het Marokkaanse erfrecht.

Mijn bijzondere belangstelling voor het Marokkaanse (moslim) erfrecht werd reeds gewekt tijdens mijn rechtenstudie aan de juridische faculteit van de Universiteit Utrecht, waar destijds een nieuw vak Turks en Marokkaans privaatrecht (familierecht en erfrecht) werd opgezet en mensen werden gezocht die bereid waren hierbij te helpen. In het kader van dit assistentschap heb ik een ecrste studie gemaakt naar het Marokkaanse erfrecht. Nadien werd mijn belangstelling weer aangewakkerd toen vanuit juridisch en maatschappelijk Nederland signalen kwamen dat behoefte bestond aan kennis van het islamitisch erfrecht, en meer in het bijzonder van het Marokkaanse erfrecht. Na een breed georiënteerd onderzoek te hebben verricht naar de invloed van alle mogelijke normen en waarden uit het islamitisch recht in de Nederlandse rechtspraak, heb ik een aanvang genomen met een diepgaander onderzoek naar het Marokkaanse erfrecht. De structuur van dit erfrecht is niet eenvoudig en er moet rekening worden gehouden met een sterk religieuze inslag. Dankzij de vertaling naar het Nederlands van Berger en Kaldenhoven van de Marokkaanse wet op het personeel statuut en het erfrecht ${ }^{3}$, kan op vrij eenvoudige wijze de toegang worden verkregen tot de relevante wetsbepalingen. Zonder aanvullende achtergrondinformatie zijn deze bepalingen, die uitgaan van een eigen systematiek en een ingenieus doch ingewikkeld stelsel van erfdelen, uitsluitingen,

3. De Mudawwanah: Marokkaans wetboek inzake personen-, familie- en erfrecht. Vertaald uit het Arabisch door M.S. Berger en J.H. Kaldenhoven, Nijmegen, Ars Aequi Libri, 2e druk 1997. 
bijzondere gevallen en dergelijke, echter niet makkelijk te doorgronden. Evenals in Nederland zijn het in Marokko - wanneer de erfgenamen niet zelf de verdeling en afwikkeling van de nalatenschap regelen - degenen die gespecialiseerd zijn in het vak die zich met de toepassing van het erfrecht bezighouden, te weten de notarissen. In Marokko kent men drie soorten notarissen: de notarissen voor moslims, de zogenaamde 'udûl, die exclusief bevoegd zijn ten aanzien van het personeel statuut van moslims, de notarissen voor joden, en de latijnse notarissen voor buitenlanders. Deze laatsten kunnen voor enkele zaken, bijvoorbeeld de transactie van geregistreerd onroerend goed ${ }^{4}$, ook door moslims worden ingeschakeld. Waar in dit boek gesproken wordt over het Marokkaanse erfrecht, wordt gedoeld op het erfrecht dat van toepassing is op de moslims, het erfrecht dat in Marokko wordt toegepast door de moslim-notarissen, de 'udûl. Tijdens een werkverblijf in Marokko heb ik verschillende keren te horen gekregen van Marokkaanse juristen dat zij het vrijwel ondenkbaar achtten dat Nederlandse notarissen of althans niet in het Marokkaanse islamitische erfrecht gespecialiseerde personen, in staat zouden zijn het Marokkaanse erfrecht toe te passen. Dit probleem zal wellicht ook voor andere onderdelen uit buitenlandse rechtsstelsels gelden, doch deze consequentie is in het IPR voor lief genomen. Dat neemt niet weg, en dat verlangt zelfs, dat het vanuit wetenschappelijk en praktisch oogpunt van belang is de Nederlandse rechtstoepasser die op grond van een verwijzingsregel een buitenlands rechtsstelsel zal moeten toepassen, zo goed mogelijk uit te rusten.

Een verwijzing naar de toepasselijkheid van Marokkaans erfrecht zal in veel gevallen betekenen dat niet kan worden volstaan met een kennisname van de inhoud van dit recht. Vaak zullen nog problemen rijzen die met name vanuit internationaal privaatrechtelijk oogpunt interessant en belangrijk zijn. Zo kunnen er kwalificatievragen rijzen. Het Marokkaanse recht kent bijvoorbeeld niet de saisine en kent rechtsfiguren die in het Nederlands rechtsstelsel onbekend zijn. De vraag zal ook rijzen of het Marokkaanse erfrecht wel verenigbaar is met de Nederlandse openbare orde. In dit recht wordt immers bijvoorbeeld nadrukkelijk onderscheid gemaakt naar geslacht en naar godsdienst. Ook zullen voorvragen kunnen rijzen. In Marokko wordt ervan uitgegaan dat Marokkaanse moslims, waar zij zich ook bevinden, wat betreft hun personeel statuut (incl. het erfrecht) zijn onderworpen aan het Marokkaanse moslimrecht. In Nederland daarentegen zal de toepassing en erkenning van het nationale recht in zaken betreffende het personeel statuut en erfrecht niet altijd onverkort worden geaccepteerd. Dat betekent dat hinkende rechtsverhoudingen kunnen ontstaan: een huwelijk dat in Nederland geldig gesloten is, wordt in Marokko niet steeds erkend; een huwelijksontbinding die naar Marokkaans recht geldig is tot stand gekomen, wordt in Nederland niet steeds erkend, enzovoorts. Alsdan rijst de vraag naar welk recht moet worden beoordeeld of iemand bijvoorbeeld al dan niet als echtgenoot(ote) van de erflater moet worden aangemerkt. Verder kunnen er nog allerlei andere juridische vragen rijzen, zoals de vraag welk recht moet worden toegepast wanneer in de verwijzingsregel wordt aangeknoopt aan de nationaliteit maar 
de erflater bipatride was. Deze vraag zal regelmatig aan de orde kunnen komen gezien het aantal Marokkanen dat zich in Nederland laat naturaliseren of voor het Nederlanderschap opteert met bchoud van de eigen Marokkaanse nationaliteit, dan wel tevens als Nederlander is geboren.

De reden voor het schrijven van het onderhavige proefschrift was dus meerledig: een vermoeden, deels gebleken, behoefte aan kennis van het Marokkaanse erfrecht, de bijzondere inhoud van dit recht, het praktisch belang van kennis van het Marokkaanse erfrecht nu dit immers op grond van Nederlandse verwijzingsregels toepasselijk kan zijn, de internationaal privaatrechtelijke aspecten waarmee men in Marokkaanse nalatenschappen zal worden geconfronteerd, een en ander indachtig de aanwezigheid van cen aanzienlijke Marokkaanse moslimpopulatie in Nederland.

\section{Afbakening van het onderzoek}

Het onderzoek dat tot het onderhavige boek heeft geleid, strekt zich uit tot internationaal privaatrechtelijke aspecten die aan het licht treden wanneer bij het overlijden van Marokkanen die hun laatste gewone verblijfplaats in Nederland hadden op grond van de Nederlandse conflictregel het Marokkaanse recht inzake de erfopvolging als toepasselijk wordt aangewezen. Deze aspecten worden in kaart gebracht en onderzocht wordt op welke wijze vanuit het Nederlandse internationaal privaatrecht tot oplossingen kan worden gekomen. Dit onderwerp, of zo men wil deze probleemstelling, impliceert een aantal beperkingen waarvan ik er drie nader wil toelichten.

Gekozen is voor een behandeling van situaties waarin het Marokkaanse erfrecht als toepasselijk recht is aangewezen. Dit betekent een beperking van gevallen waarin in Nederland woonachtige Marokkanen overlijden. Uitgesloten is de behandeling van situaties waarin op grond van de verwijzingsregel het Nederlandse recht toepasselijk wordt verklaard. Ook met de inwerkingtreding van de WCEo (en in een later stadium wellicht het Erfrechtverdrag zelf) zal het nationale recht nog een belangrijke plaats kunnen innemen, en wordt een behandeling van (uitsluitend) het Marokkaanse erfrecht niet zonder belang geacht. Hoewel de conflictregel inzake de erfopvolging regelmatig zal kunnen leiden tot de toepasselijkheid van Nederlands recht, heeft mij dit er niet toe bewogen om ook de toepasselijkheid van Nederlands erfrecht in erfopvolgingskwesties van Marokkanen te bespreken. De bijzondere internationaal privaatrechtelijke complicaties die bij toepassing van Nederlands erfrecht optreden zijn aanzienlijk beperkter dan bij toepassing van Marokkaans recht. Niettemin zal ook hier soms rekening moeten worden gehouden met enkele bijzonderheden uit het Marokkaanse recht. Niet alleen zal de executie van in Nederland genomen beslissingen in Marokko problematisch zijn, ook reeds bij de toepassing van Nederlands recht kan men moeilijkheden tegenkomen. Men kan worden geconfronteerd met rechtsfiguren en rechtsverhoudingen die niet in het Nederlandse stelsel inpasbaar zijn. Enkele voorbeelden mogen dit verduidelijken. In Marokko bestaat de mogelijkheid om goederen voor altijd onvervreemdbaar te maken 
en de opbrengst te bestemmen voor bepaalde groepen personen of voor bepaalde doelen (wayf of hubus). Deze goederen vallen geheel buiten de nalatenschap. De erfgenamen hebben zelfs geen aanspraak op een soort bloot eigendom. De vraag is hoe deze rechtsfiguur bij toepassing van Nederlands recht moet worden gewaardeerd. Een ander voorbeeld betreft het polygame huwelijk. Wanncer de erflater twee weduwen achterlaat, rijst de vraag of zij beiden afzonderlijk aanspraak maken op het erfdeel van de langstlevende echtgenoot dan wel of zij dit erfdeel samen moeten delen, of eventueel zelfs dat slechts één weduwe aanspraak op de nalatenschap kan maken. Voorts kan men te maken krijgen met verkregen rechten, en de vraag of deze in het kader van de erfopvolging dienen te worden gerespecteerd. In het Marokkaans recht is het in beginsel toegestaan om tijdens leven onbeperkt schenkingen te doen, zonder dat deze moeten worden ingebracht in de nalatenschap. Kan hiermee rekening worden gehouden nu het Nederlandse recht wel een inbrengverplichting kent?

De tweede beperking die de afbakening van het onderwerp impliceert betreft de beperking tot problemen bij de crfopvolging. Omdat het toepasselijk recht inzake de erfopvolging direct van belang kan zijn voor de mogelijkheid om beslissingen in Marokko ten uitvoer te leggen, zal echter niet geheel aan de afwikkeling van de nalatenschappen voorbij kunnen worden gegaan.

Een derde beperking die overigens in de onderwerpafbakening niet met zoveel woorden tot uitdrukking is gebracht, betreft een beperking binnen de groep Marokkaanse erflaters zelf. De Marokkaanse gemeenschap in Nederland bestaat verreweg voor het grootste deel uit moslims ${ }^{5}$. Het onderhavige werk heeft uitsluitend betrekking op nalatenschappen van Marokkaanse moslims op wie het Marokkaanse moslimrecht van toepassing is. Niet wordt ingegaan op de erfrechtregels die van toepassing zijn op Marokkanen die geen moslim zijn.

Tijdens het onderhavige onderzoek hebben zich omstandigheden voorgedaan die tot gevolg hadden dat de aanvankelijke probleemstelling enigszins werd aangepast. In de eerste plaats gold er bij de aanvang van dit onderzoek een ongeschreven verwijzingsregel op grond waarvan de erfopvolging (in beginsel) werd beheerst door het nationale recht van de erflater. De tekst van een nieuw Erfrechtverdrag was reeds gereed en Nederland onderzocht de wenselijkheid om tot bekrachtiging ervan over te gaan. Al gauw bleek dat Nederland hier positief tegenover stond. Hiermee kwam de inwerkingtreding van dit Verdrag voor Nederland, in verband waarmee tevens nationale conflictregels werden voorbereid, steeds dichterbij. In het laatste stadium van het proefschriftonderzoek trad de Wet conflictenrecht erfopvolging in werking. Vanaf die datum golden nieuwe conflictregels zowel voor de erfopvolging als voor de afwikkeling van nalatenschappen. Verder bestond bij de aanvang van het onderzoek de idee uitsluitend na te

5. Volgens gegevens van het CBS, overgenomen uit The Stateman's Yearbook 1990, bedraagt het percentage moslims in Marokko 98 \%, CBS maandstatistiek van de bevolking, februari 1994, p. 24, staat 2. 
gaan welke internationaal privaatrechtelijke problemen verwacht kunnen worden bij de tocpasselijkheid van Marokkaans erfrecht als het sterfhuis van een Marokkaanse erflater zich in Nederland bevindt. De doelstellingen die hierbij werden gesteld waren het geven van een overzicht van het Marokkaanse erfrecht, het signaleren en analyseren van de mogelijke problemen, om vervolgens na te gaan op welke wijze deze het hoofd zouden kunnen worden geboden. De belangrijkste problemen die voorzien werden betroffen ten eerste de mogelijke onverenigbaarheid van Marokkaanse erfbepalingen met de Nederlandse openbare orde, en ten tweede de voorvraagproblematick. Al heel snel werd een derde probleem zichtbaar, dat van de erkenning en executie van in Nederland genomen beslissingen in Marokko. In de loop van het onderzoek begonnen zich ook kwalificatievraagstukken, bipatridie-problemen en andere vragen in volle omvang te tonen. Afhankelijk van de resultaten van de bespreking van de "problemen" en de mogelijke aanpak ervan was de gedachte om vervolgens na te gaan of de materiële resultaten aanleiding zouden kunnen vormen voor kritische kanttekeningen bij de verwijzingsregel inzake de erfopvolging en van invloed zouden kunnen zijn op de vraag naar het toepasselijke recht. Als zou blijken dat de exceptie van de openbare orde veelvuldig zou moeten of kunnen worden ingeroepen ter afwering van onderdelen uit het Marokkaanse recht, en als zou blijken dat voorvragen aan de hand van Nederlands recht werden beoordeeld, als naar vreemd recht verkregen rechten niet zouden worden gerespecteerd, als kwalificatic op een zodanige wijze zou geschieden, dat het buitenlandse recht zou worden aangetast, zou immers een verwijzingsregel zijn werkelijke betekenis verliezen. Voorts zou bij de vraag naar het toepasselijke recht kunnen worden bekeken of de in de verwijzingsregel opgenomen aanknopingsfactoren, nationaliteit en gewone verblijfplaats, als enige aanknopingsfactoren wel steeds tot gewenste resultaten leiden, of dat het wellicht wenselijk zou zijn ook rekening te houden met bijvoorbeeld de onmogelijkheid om een beslissing in het buitenland te executeren (waarvoor formeel nu enkel de weg van de Näherberechtigung en retorsie een gedeeltelijke oplossing kan bieden), en de belangen, de wil en de godsdienst van betrokkenen. Mede gezien de huidige ontwikkelingen in de methodenstrijd in het internationaal privaatrecht, leek het niet verantwoord om bij al deze doelstellingen tot eindresultaten te concluderen.

In de loop van het onderzoek bleek dat naast een theoretische analyse, de praktijk ook behoefte had aan informatie. Erflater en erfgenamen is het er immers om te doen een resultaat te bereiken dat beantwoordt aan hun wensen. De rol van de Nederlandse rechter in erfrechtzaken is gering. Hij treedt slechts op wanneer er een geschil is, en voorts wanneer er processuele maatregelen moeten worden genomen. Met name in het eerste geval heeft hij behoefte aan een zo sterk mogelijk theoretisch kader. In veel gevallen zal een notaris met een erfrechtzaak worden belast. Ook voor hem is een duidelijk theoretisch kader van groot belang, al zal voor hem het belang van zijn cliënten voorop staan. Als zich vermogen in het buitenland bevindt zal hij ook rekening houden met de erkennings- en executiemogelijkheden in het buitenland. 
Een ander voor de praktijk belangwekkend gegeven dat tijdens het onderzoek aan het licht trad, betrof de bevoegdheden die door de Marokkaanse overheid aan personen op Marokkaanse diplomatieke vertegenwoordigers en consulaire ambtenaren in Nederland zijn toegekend. Bekend was reeds dat zij vergaande bevoegdheden bezaten bij het totstandbrengen en verbreken van familierechtelijke verhoudingen. Nauwgezetter onderzoek maakte ook hun bevoegdheden in erfrechtzaken duidelijker.

Was het aanvankelijk de bedoeling enkel een wetenschappelijke beschouwing te geven voor de Nederlandse rechtspraktijk en IPR-wetenschap, uiteindelijk heeft daarnaast ook praktijkgerichte informatie een plaats gekregen. Dit laatste werd nict alleen wenselijk geacht om de praktijkbehoefte te bevredigen maar hiermee kon eveneens worden bereikt dat cen zo volledig mogelijk overzicht geboden werd van de wijzen waarop in Nederland nalatenschappen van Marokkanen kunnen worden afgehandeld.

Een en ander heeft geleid tot een behandeling van de volgende onderwerpen. In het eerste hoofdstuk wordt een inleidende beschouwing gegeven over het islamitisch recht. De noodzaak hiervan is gelegen in het feit dat het Marokkaanse erfrecht is gebaseerd op het islamitische recht, meer in het bijzonder op de leer van de islamitische malikitische rechtsschool. Deze leer vormt de verklaring voor het erfrecht zoals dit in de Marokkaanse wet is neergelegd. Zij moet worden geraadpleegd wanneer de Marokkaanse wet een leemte bevat of als deze moet worden uitgelegd. Deze islamitische rechtsleer biedt niet alleen de rechtsgeschiedenis en de wetsgeschiedenis van het Marokkaanse erfrecht, maar ook de rechtsbeginselen die in het Marokkaanse erfrecht in acht zijn en moeten worden genomen.

In het tweede hoofdstuk wordt een beschrijving gegeven van het Marokkaanse erfrecht, waarbij de nadruk is gelegd op de erfopvolging. Kennis van dit recht is onontbeerlijk wanneer dit recht als toepasselijk wordt aangewezen, en voor het inzichtelijk maken van de problemen waarmee men bij de toepassing ervan kan worden geconfronteerd. Bij de beschrijving van dit recht is op de eerste plaats gebruik gemaakt van de Marokkaanse wetgeving, de belangrijkste bron waaruit het Marokkaanse erfrecht gekend kan worden. De Marokkaanse wet op het personeel statuut en erfrecht bevat zes boeken. De eerste vier boeken zijn gewijd aan het familierecht. In het vijfde en zesde boek worden het testament respectievelijk de erfopvolging behandeld. De eerste vijf boeken zijn van overheidswege gepubliceerd zowel in het Frans als in het Arabisch. Het zesde boek heeft alleen een officiële versie in het Arabisch. Van de gehele wet bestaat een Nederlandse vertaling vanuit het Arabisch ${ }^{6}$. Een populaire handelseditie in zowel het Frans als Arabisch is verzorgd door Blanc en Zeidguy ${ }^{7}$. In het onderzoek is hoofdzakelijk gebruik gemaakt van de Nederlandse en van de Franse tekst. Daar waar in dit boek

6. Zie noot 3 .

7. F-P Blanc et R. Zeidguy, Moudawana: Code de Statut Persontel et des Successions, Casablanca, Sochepress Université, 1994. 
verwezen wordt naar wetsbepalingen is uitgegaan van de Nederlandse vertaling. Op punten waar de Franse (of Arabische) tekst meer duidelijkheid bood, is van de Nederlandse tekst afgeweken. Voor vraagstukken waarvoor in de wet geen oplossing kon worden gevonden, moesten andere bronnen worden geraadpleegd. In de wet zelf wordt aangegeven dat in deze gevallen de rechtspraktijk van de malikitische rechtsschool en de gevestigde mening moeten worden aangewend. De originele bronnen waarin de doctrine van de malikitische rechtsleer is te vinden, zijn de oude gezaghebbende rechtsboeken, de zogenaamde $f i q h$-boeken, van de malikitische rechtsschool. Om deze te bestuderen is nict alleen kennis van het Arabisch nodig maar ook een scholing in het lezen van fiqh-teksten. Deze beide kwaliteiten waren bij mij tijdens het onderzoek in onvoldoende mate aanwezig. Dit gebrek aan kennis, waarvan niet te voorzien was dat het op korte termijn geheeld zou kunnen worden, heeft mij enige tijd doen aarzelen of het überhaupt wel mogelijk was om het Marokkaanse erfrecht op een acceptabele wijze te beschrijven. Gelukkig bestaan er gedegen en betrouwbare werken over de islamitische malikitische rechtsleer in wél toegankelijke talen. De bestudering van de malikitische rechtsleer, daar waar dit nodig werd geacht om voldoende duidelijkheid te krijgen in het Marokkaanse erfrecht, heeft dan ook plaatsgevonden via deze secundaire bronnen. Hiermee was de hierboven genoemde aarzeling goeddeels weggenomen, temeer omdat de nadruk in het onderzoek was gelegen op de Nederlandse internationaalprivaatrechtelijke aspecten in Marokkaanse nalatenschappen. Bovendien heb ik tijdens mijn werkverblijf in Marokko kunnen constateren dat de doorsnee jurist, althans zij die werden opgeleid aan die juridische faculteiten waar ik dit heb nagevraagd, ook niet worden opgeleid in de figh. Bestudering van de figh, of zelfs van de secundaire bronnen over de figh, behoort niet of vrijwel niet tot het verplichte curriculum. Mij werd gezegd dat zij die zowel de rechtenstudie hebben voltooid als kenners van de figh zijn, de hoogste graad bezitten welke men als kenner van het Marokkaanse familie- en erfrecht kan bereiken. Ik heb toen geconcludeerd dat ik deze eis niet aan mezelf behoefde te stellen.

De verwijzing naar de rechtspraktijk van de malikitische rechtsschool en de prevalente heersende mening impliceert in Marokko ook een verwijzing naar enkele andere bronnen ${ }^{8}$ die eveneens bij de codificatie van de Marokkaanse wet op het personeel statuut en erfrecht een rol hebben gespeeld. In dit verband zij met name genoemd de 'amal, de praktijk van de rechters of rechtspraak, waaraan in Marokko al sinds de late Middeleeuwen betekenis wordt toegekend. Omdat derhalve ook jurisprudentic een rol speelt bij de uitleg van de Mudawwanah, leek een bestudering van de rechtspraak onvermijdelijk. Het probleem in Marokko is echter dat rechtspraak niet gestructurcerd noch uitputtend wordt gepubliceerd. Zelfs de uitspraken van de hoogste rechter, de Cour suprême, worden maar mondjesmaat openbaar gemaakt, zonder dat uit de wel gepubliceerde uitspraken zou kunnen worden afgeleid dat het hierbij om de meest belangrijke gaat. Het ontbreken van voldoende gepubliceerde jurisprudentie vormt ook voor de juristen in Marokko een probleem. Ook zij kennen deze jurisprudentie doorgaans niet. 
Wegens het gebrek aan kennis van de rechtspraak, speelt deze laatste een beduidend geringere rol in de ontwikkeling van het recht dan bijvoorbeeld in Nederland het geval is. In de doctrine treft men dan ook zelden een analyse aan van ontwikkelingen die in de rechtspraak zijn te signaleren. Het ontbreken van openbaarheid van rechtspraak betekent ook dat de contrôle op de rechtspraak gering is, en dat ook rechters niet kunnen bogen op een vaste lijn in de rechtspraak. Hiermee zij overigens niet beweerd dat rechters naar willekeur rechtspreken. De indruk die ik heb gekregen uit een bestudering van cen aantal uitspraken, het zij toegegeven dat dit niet een zeer groot aantal betrof, en uit gesprekken die ik heb gehad met een aantal Marokkaanse juristen, is dat de rechter niet altijd enkel op basis van de wetgeving kan rechtspreken omdat deze ontocreikend is, en dat voor de rechtsvinding gebruik wordt gemaakt van verklaringen van getuige-deskundigen, in dit geval specialisten op het gebied van de fiqh.

Het derde hoofdstuk is gewijd aan de bevoegdheden in erfrechtelijke aangelegenheden van Marokkaanse diplomatieke vertegenwoordigers en consulaire ambtenaren in Nederland. De reden voor het behandelen van dit onderwerp is hierboven reeds gegeven. Het betreft hier voornamelijk bevoegdheden in de afwikkelingsfase van een nalatenschap. Een bespreking van deze bevoegdheden bracht onvermijdelijk met zich mee dat ook zou worden behandeld de vraag of deze in Nederland moeten worden erkend. Deze vraag is in het vierde hoofdstuk besproken.

In het vierde hoofdstuk wordt het Nederlands internationaal privaatrecht inzake het erfrecht, ofwel het internationale erfrecht behandeld. Hierin ligt de nadruk op de verwijzingsregels inzake de erfopvolging. In gevallen waarin op grond van de verwijzingsregel tot toepasselijkheid van Marokkaans erfrecht zou moeten worden geconcludeerd, zijn tevens de problemen waarop men dan kan stuiten (kort) uiteengezet. Twee van deze problemen zijn eruit gelicht, en aan een diepgaander onderzoek onderworpen, te weten de voorvraagproblematiek en de mogelijkheid tot het inroepen van de exceptie van de openbare orde ter afwering van Marokkaans recht. Juist voor deze twee onderwerpen is gekozen wegens de grote verschillen tussen het Marokkaanse en Nederlandse recht die hierin naar voren komen.

De voorvraagproblematiek die wordt besproken in het vijfde hoofdstuk ziet met name op familierechtelijke verhoudingen waarvan de geldigheid in Nederland anders wordt gewaardeerd dan in Marokko. In het kader van de erfopvolging zal veelal moeten worden vastgesteld of de erflater gehuwd was en er dus een langstlevende echtgenoot is, alsmede of de erflater afstammelingen of ascendenten heeft met wie hij of zij in een zodanige betrekking staat dat zij de hoedanigheid van erfgenamen kunnen bezitten. In gevallen waarin Marokkaans recht de hoofdvraag van de erfopvolging beheerst, kan het nogal wat uitmaken of de voorvraag naar het bestaan van familierechtelijke betrekkingen ook naar Marokkaans recht wordt beoordeeld dan wel autonoom, dus naar Nederlands recht, inclusief Nederlands IPR, moet worden beoordeeld. Ter illustratie hiervan kan met een enkel voorbeeld worden volstaan. Een huwelijk waarbij een van de aanstaande 
echtgenoten de Marokkaanse nationaliteit bezit en dat uitsluitend wordt voltrokken ten overstaan van de Nederlandse ambtenaar van de burgerlijke stand, zal in Nederland een geldig huwelijk zijn maar in Marokko niet worden erkend. Zou men de geldigheid van dit huwelijk naar Marokkaans recht beoordelen, dan zouden noch de langstlevende echtgenoot noch de uit dit huwelijk geboren kinderen erfgenamen zijn. Zou de voorvraag autonoom worden behandeld, en zou het huwelijk volgens Nederlands IPR wel een geldig huwelijk zijn, dan zijn de langstlevende echtgenoot en kinderen wel erfgenamen.

In hoofdstuk 6 wordt vervolgens ingegaan op de vraag of het Marokkaanse erfrecht de openbare orde toets kan doorstaan. Reeds bij een eerste blik op het Marokkaanse erfrecht kan een aantal bepalingen worden waargenomen die direct de vraag oproepen naar de verenigbaarheid ervan met in Nederland geldende beginselen. Een van de grondregels uit het Marokkaanse erfrecht wordt gevormd door het hierin gemaakte onderscheid naar geslacht. Ook wordt in dit recht onderscheid gemaakt naar godsdienst. In het zesde hoofdstuk is getracht om gemotiveerd te bespreken of tegen deze beginselen de exceptie van de openbare orde kan worden ingeroepen. Een dergelijke toetsingsmogelijkheid is ook bekeken ten aanzien van verschillen tussen het Marokkaanse en het Nederlandse erfrecht waarbij een mogelijke schending van in Nederland geldende beginselen minder in het oog springt. Tot deze categorie zijn te rekenen bepalingen betreffende de omvang van de kring van erfgerechtigden, beperkingen die aan de testeervrijheid zijn gesteld en dergelijke. In dit hoofdstuk wordt eveneens stilgestaan bij de mogelijkheid om de toepassing van onderdelen van het Marokkaanse erfrecht te toetsen aan volkenrechtelijke verdragsbepalingen.

In hoofdstuk 7 wordt nagegaan of en, zo ja, in hoeverre in Nederland genomen beslissingen betreffende de erfopvolging, in Marokko uitvoerbaar zijn. Het spreekt voor zich dat deze vraag in het bijzonder relevant is als zich vermogen in Marokko bevindt, hetgeen niet zelden het geval zal zijn. Behandeld wordt uitsluitend de vraag of beslissingen in Marokko voor erkenning en tenuitvoerlegging in aanmerking komen. De verdere afwikkeling in Marokko en de (praktische) problemen die men hierbij nog kan tegenkomen, zijn hier verder buiten beschouwing gelaten.

Tenslotte zal in het afsluitende hoofdstuk worden getracht een beknopte beschouwing te geven van de problematiek waar het om gaat. Hoe ver reikt in het Nederlandse IPR het respect voor het Marokkaanse erfrecht, en welke middelen staan het Nederlandse IPR ter beschikking om ongewenste resultaten te voorkomen en onbekende instituten te implementeren? Vanuit de idee dat de Savignaanse verwijzingsregel onmogelijk rekening kan houden met alle belangen die in concrete gevallen in het geding kunnen zijn, zal tevens worden aangegeven welke mogelijkheden een erflater heeft om zelf de verdeling van zijn vermogen te beïnvloeden. 
Hoewel dit proefschrift zich uitsluitend richt op nalatenschappen waarin het Marokkaans recht toepasselijk is, zal een aantal van de in dit werk besproken problemen ook relevant kunnen zijn wanneer een ander buitenlands rechtsstelsel toegepast zal moeten worden. In zoverre kan de keuze voor een behandeling van nalatenschappen van Marokkaanse erflaters worden gezien als een voorbeeld om het groot aantal juridische aspecten aan te tonen waarmee men geconfronteerd kan worden bij de toepasselijkheid van een vreemd erfrecht.

Tot slot nog een verantwoording over het gebruik van en de spellingswijze van de uit het Arabisch getranscribeerde terminologie. Hierbij is gebruikt gemaakt van een vereenvoudiging van de spellingswijze zoals deze wordt gehanteerd in de (Shorter) Encyclopaedia of Islam, met die uitzondering dat daar waar in de Encyclopaedia een $k$ wordt gebruikt, gekozen is voor de transcriptie $q$. De diacritische puntjes onder de letters zijn weggelaten en de lengte van klinkers wordt weergegeven door middel van een circonflexe. 



\section{Islamitisch recht}

Het Marokkaanse erfrecht is, een enkele hervorming daargelaten, een getrouwe weergave van het islamitisch erfrecht volgens de leer van een van de islamitische rechtsscholen, te weten de malikitische rechtsschool. Voor een beter begrip van het inmiddels gecodificeerde Marokkaanse erfrecht is een inzicht in de achtergronden ervan van belang. Het is in dit licht dat in het onderhavige hoofdstuk kort wordt ingegaan op het islamitische recht.

Voordat de Islam zijn intrede in het Arabisch schiereiland deed, in de pre-islamitische tijd, was er geen sprake van cen eenvormig georganiseerd rechtssysteem. Het recht was gewoonterecht ${ }^{9}$. Het familierecht, erfrecht en strafrecht werden bijvoorbeeld bepaald door het gewoonterecht binnen de verschillende stammen, terwijl het handelsrecht werd bepaald door de gewoonte binnen de handel, met name die van de belangrijkste handelssteden. Was er dus geen uniform recht, evenmin was er sprake van een georganiseerd handhavingssysteem of rechterlijke macht. Geschillen loste men zelf op, en lukte dit niet, dan werd het geschil voorgelegd aan een door partijen zelf aangewezen arbiter, de hakam. Voorts ontbrak een georganiseerd politiek gezag, zodat een georganiseerd rechtssysteem ook niet van bovenaf werd opgelegd. Dit was de situatie die de Profeet Mohammed aantrof. Als profeet wilde Mohammed vooral mensen leefregels geven voor het aardse leven, gericht op een "goede plaats" in het hiernamaals. Zijn intentie was niet het maken van rechtsregels of het veranderen van het bestaande gewoonterecht ${ }^{10}$. Mohammed trad ook op als hakam, als arbiter in geschillen die hem werden voorgelegd. Naar islamitische opvatting werd Mohammed bij zijn uitspraken geholpen door God, van wie hij openbaringen ontving. Een aantal van deze openbaringen, de eigen woorden van God, werd tijdens het leven van Mohammed her en der vastgelegd, doch een volledige optekening van de openbaringen vond pas plaats na zijn dood door Mohammeds tijdgenoten en directe volgelingen. De eerste officiële neerslag van de openbarin-

10. Aldus Schacht 1982, 11. 
gen vindt nog in de zevende eeuw plaats onder het bestuur van de derde Kalief Othman ${ }^{11}$. Deze vastgelegde heilige tekst is de Koran, welke tot op vandaag de dag in ongewijzigde vorm is blijven bestaan. De tweede bron van het islamitische recht na de Koran is het voorbeeld van de Profeet Mohammed, de Sunna. Deze is te vinden in de Overlevering (Hadîh) die aanvankelijk mondeling werd doorgegeven, maar geleidelijk werd opgeschreven. In de loop van de derde eeuw van de Islam werden de overleveringen verzameld in standaardwerken. In de tweede eeuw van de Islam vormden zich geografisch geconcentreerde rechtsscholen, de zogenaamde oude rechtsscholen, waarbinnen religieuze specialisten zich bezighiclden met het bezien van de plaatselijke gewoonten tegen het licht van de leefregels uit de Koran ${ }^{12}$. De Koran werd wetenschappelijk bestudeerd en getracht werd hicrin systeem aan te brengen. Het theoretiseren en systematiseren verlangden een bepaalde mate van menselijk redeneren. Zo werd bijvoorbeeld al gauw geaccepteerd dat bij tegenstrijdige koranbepalingen een oudere bepaling door een latere bepaling (lees: openbaring) werd afgeschaft. Onvermijdelijk ook hebben bij dit redeneren de persoonlijke opvattingen van de geleerden, de plaatselijke gewoonten en de maatschappelijke omstandigheden een rol gespeeld. Tegen de oude rechtsscholen keerden zich de zogenaamde Traditionisten. Volgens hen mocht bij het zoeken naar de bedoeling van de heilige teksten alleen worden uitgegaan van de Koran en van die overleveringen ${ }^{13}$ die mondeling waren overgebracht door middel van een onafgebroken en te herleiden keten van personen ${ }^{14}$. De Traditionisten waren tegen een menselijke interpretatie waarvan in de oude rechtsscholen gebruik werd gemaakt. Toen de specialisten uit de oude rechtsscholen in de tweede eeuw van de Islam een zekere minimum overeenstemming bereikt hadden over hun doctrines, kregen deze doctrines met hun meester individuele aanhangers. Er ontstonden groepen binnen de oude rechtsscholen die zich later tot de nieuwe rechtsscholen hebben ontwikkeld ${ }^{15}$.

Er is gezocht naar de grondslagen waarop de figh, de plichtenleer, was gebaseerd. Al Shafi'i, de grondlegger van de shafi'itische rechtsschool, signaleerde vier bronnen die in de sunnitische rechtsscholen werden aangewend ${ }^{16}$, en welke ook nu nog als de grondslagen, usîl, van de fiqh bekend staan. Diı zijn:

1. de Koran;

2. de Sunna of Hadîth;

11. Juynboll 1930,6 .

12. Coulson, A history 1978, 38; Schacht, Origins 1959, 190-192.

13. In de eerste eeuwen van de Islam was er sprake van een toenemende groei van het aantal overleveringen dat in omloop kwam. De valse moesten van de echte worden onderscheiden. Coulson noemt dit groeiend aantal overleveringen als een belangrijke oorzaak voor een kunstmatige interpretatie ervan door de geleerden, Coulson, A history 1978, 224.

14. Schacht $1982,33-34$.

15. Schacht 1982, 57.

16. Coulson, A history 1978, 55-60. 
3. de Idjmâ': de consensus over cen bepaald onderwerp uit de plichtenleer onder de meerderheid van erkende moslimse geleerden in een bepaald tijdvak;

4. de Qiyâs: de redenering naar analogie.

Naast deze vier bronnen werd in de scholen ook gebruik gemaakt van andere bronnen en interpretatiemethoden. Over de toelaatbaarheid hiervan werd in de verschillende scholen uiteenlopend gedacht ${ }^{17}$.

De belangrijkste ontwikkeling van het islamitisch recht heeft plaatsgevonden in de eerste twee en een halve eeuw van de Islam. Over een groot aantal onderwerpen is dan consensus bereikt. Mede door het tegenwicht van de Traditionisten en door een grote tocname van het aantal overleveringen, wordt de ruimte voor eigen menselijk interpreteren vanaf de tweede helft van de tiende eeuw steeds beperkter ${ }^{18}$. Ongeveer vanaf de elfde of twaalfde ecuw zou de menselijke interpretatie niet langer zijn toegestaan; de poort van de idjtihâd werd gesloten. Vanaf dat moment was men verplicht de opvattingen van de gezaghebbende geleerden te respecteren; men was verplicht tot taqlid. In de praktijk bleven echter problemen rijzen waarvoor in de rechtsgeleerde werken geen concrete oplossingen werden geboden, maar die wel met behulp van de toegelaten instrumenten en binnen de grenzen van de sharí 'a zouden moeten worden opgelost. Met dergelijke problemen wendde men zich tot deskundigen, de muftî's. Deze gaven een gezaghebbende opvatting voor het concrete geval, een fatwâ. Via bepaalde methoden en technicken ${ }^{19}$ konden zij tegemoet komen aan veranderende behoeften in de islamitische samenleving. De muftî's, die niet alleen hun opvattingen gaven in aan hen door burgers voorgelegde gevallen maar ook optraden als adviseurs van de rechter, hebben op deze wijze een belangrijke rol kunnen spelen in de (verdere) ontwikkeling door de geleerden van het islamitische recht ${ }^{20}$. De opvattingen van muftî's die als gezaghebbend werden erkend door de "common opinion" van de geleerder, gingen ook tot de rechtsleer van de rechtsscholen behoren.

Van de nieuwe sunnitische rechtsscholen zijn er sinds circa 1300 a.D. nog vier overgebleven. Zij zijn genoemd naar hun stichters:

1. de hanafitische, genoemd naar Abû Hanîfah (699-767). Officiële school in onder meer: Egypte, Syrië, Libanon en Afghanistan. Veel aanhangers in onder meer: Irak, Turkije, Pakistan, Turkestan, India en Jordanië;

17. Zie voor een overzicht van de wel en niet erkende methoden in de verschillende scholen: Coulson, A history 1978, o.m. 89-102; Juynboll 1930, 379-382 (aantekeningen 17 en 18); Schacht 1982, 60 e.v., en over de hiyal: Coulson, A history 1978, 139-141; Schacht 1982, 78-84.

18. Schacht 1982, 70 .

19. Bijvoorbeeld de hiyal: het gebruik van wettelijke middelen voor buitenwettelijke doeleinden, die niet kunnen worden bereikt met behulp van voorzieningen uit de shari'a.

20. Coulson, A history 1978, 142-148. 
2. de malikitische, genoemd naar Mâlik B. Anas (712-795). Officiële school in onder meer: Marokko en Algerije. Veel aanhangers in onder meer: Opper-Egypte, Tunesië, Libië, Koeweit en Soedan;

3. de shafi' 'itische, genoemd naar Abû 'Abd Allâh Muhammad al-Shâfi'î B. Idrîs (767-820). Belangrijkste school in Jordanië. Veel aanhangers in onder meer: Syrië, Libanon, Irak, Pakistan, India, Indonesië, Yemen en Oost-Afrika;

4. de hanbalitische, genoemd naar Ahmad B. Muhammad B. Hanbal (781-855). Officiële school in Saoedi-Arabië. Aanhangers in onder meer: Syrië, Irak en de Perzische Golf.

Naast de orthodoxe sunnitische scholen bestaat de shi'itische stroming. Shi'ieten zijn de volgelingen van 'Alî, de schoonzoon van de Profeet Mohammed. Zij gaan er van uit dat het leiderschap van de islamitische gemeenschap erfelijk is en dat Mohammed voor zijn dood 'Alî als opvolgend kalicf had aangewezen.

Alle rechtsscholen hebben een of meer gezaghebbende boeken, de zogenaamde fiqhbocken, waarin de doctrine van de desbetreffende school is neergelegd ${ }^{2 !}$. De fiqh kent twee soorten normen. De eerste zijn de ethisch religieuze normen die de verhouding tussen moslims en God regelen. Het gaat hier niet om geboden of verboden op de niet naleving waarvan sancties zijn gesteld, maar om richtlijnen voor het handelen als goed moslim, richtlijnen waarvan naleving in het hiernamaals wordt beloond, en niet-naleving in het hiernamaals wordt bestraft. De handelingen waarom het hier gaat worden in de fiqh vaak geklassificeerd als verplicht, aanbevelenswaardig, indifferent, afkeurenswaardig en verboden. Dergelijke richtlijnen gelden ook voor juridische handelingen. De tweede categorie betreft de juridische normen die gelden tussen de mensen onderling, en waarvan de naleving op aarde (door de rechter) kan worden afgedwongen. Religieuze normen die betrekking hebben op een juridische handeling, bijvoorbeeld een huwelijk of huurovereenkomst, zijn bijvoorbeeld normen die aangeven voor wie en in welke omstandigheden het sluiten van een huwelijk of van huurovereenkomst verplicht, aanbevelenswaardig, dan wel verboden is. Het al dan niet naleven van deze normen zou dan consequenties hebben in het hiernamaals. De juridische normen geven bijvoorbeeld aan of en onder welke voorwaarden de juridische handeling, i.c. het huwelijk of de huurovereenkomst geldig is en wat de gevolgen hiervan zijn. Deze normen zijn rechtens afdwingbaar. Deze tweedeling heeft ook invloed op de in de fiqh-literatuur behandelde onderwerpen. Naast juridische regels wordt ook veel aandacht geschonken aan rituele regels en religieuze omgangsvormen.

Bij de religieuze voorschriften kunnen vijf hoofdverplichtingen worden onderscheiden, de zogenaamde vijf zuilen van de Islam, te weten: de geloofsbelijdenis (shahâda), het gebed (salât), het geven van "aalmoezen" (zakât), de bedevaart (Hadjdj), en de ramadan-vasten. Religieuze onderwerpen met een politieke inslag die zijn geregeld zijn 
bijvoorbecld het imamaat en de heilige oorlog. De fiqh behandelt in grotere of kleinere mate vrijwel alle terreinen van het recht: personen-, familie- en erfrecht, vermogensrecht, recht met betrekking tot de godsdienstige "stichtingen" (waqf), strafrecht, procesrecht en staatsrecht. De mate waarin de figh op deze onderwerpen ook in de praktijk werd toegepast verschilde van tijd tot tijd en van Staat tot Staat. Op het terrein van het familie- en erfrecht en het recht met betrekking tot de godsdienstige "stichtingen" werd de shari 'a echter altijd toegepast. Op gebieden die in de shari ' $a$ onderontwikkeld waren was reeds in een vroeg stadium aan seculiere autoriteiten de bevoegdheid gegeven de sharî' $a$ aan te vullen. Op deze terreinen heeft een seculiere rechtsontwikkeling plaatsgevonden die uit een oogpunt van algemeen, economisch en sociaal belang noodzakelijk werd geacht.

Wanneer tegenwoordig gesproken wordt over het islamitische recht, de shari ' $a$, wordt in de regel gedoeld op een recht zoals dit in de eerste eeuwen van de Islam is tot stand gekomen, en dat is te vinden in de $f i q h$-boeken van de rechtsscholen ${ }^{22}$. De primaire bronnen van het islamitische recht, te weten de Koran en Hadith, hebben een religieus karakter. De andere bronnen en de verdere ontwikkeling van het islamitisch recht is het werk geweest van geleerden.

Vanaf de negentiende eeuw wordt er een daadwerkelijke verandering in het recht van islamitische landen zichtbaar. Enerzijds wordt deze veroorzaakt door het feit dat autoriteiten van islamitische landen regelgeving van bovenaf gaan opleggen, uit efficiëncyoverwegingen en als reactie op de koloniale overheersing ${ }^{23}$, anderzijds juist door contacten met het westen via deze koloniale overheersing ${ }^{24}$. De rechterlijke macht werd beïnvloed door westers georiënteerde juristen. De seculiere rechter won steeds meer veld ten koste van de shari' $a$-rechter, de qâdî, welke laatste als zodanig in de loop van de twintigste eeuw in veel islamitische landen geheel is verdwenen. Op grote schaal vond een codificatie naar westers model plaats. Reeds in de negentiende eeuw komen in islamitische landen codificaties tot stand op het gebied van het handelsrecht, strafrecht, strafprocesrecht, verbintenissenrecht en dergelijke, de gebieden die in de fiqh verre van volledig waren geregeld. In de meeste islamitische landen werden deze codificaties geïnspireerd door westers recht. De eerste veranderingen in en codificatie van het personen- en familierecht naar westers model vonden pas plaats vanaf $1915^{25}$. Deze verandering werd niet van bovenaf opgelegd maar ontstond van onderaf, op grond van een sociale noodzaak ${ }^{26}$. Slechts in twee landen, te weten in Albanië en Turkije, werd

22. Vgl. ook Brugman 1993, 1.

23. Anderson 1976, 14-15; Peters 1987, 196

24. Zie over deze ontwikkelingen: Anderson 1976; Coulson, A history 1978, 149 e.v.; Peters 1987, 296 312; Schacht 1982, 86-111.

25. Over de codificatie van het personen- en familierecht: Anderson 1963, 1-17; Schacht, Problems 1959 , 99-129.

26. Anderson 1976, 39, 82 . 
het islamitische recht volledig afgeschaft. In enkele landen werden moderniseringen doorgevoerd, doch de meeste landen bleven bij de codificatie van het personen- en familierecht, het crfrecht en de wagf, in hoge mate trouw aan het islamitische recht. Hervormingen dic werden doorgevoerd hadden een economische of sociale noodzaak. $\mathrm{Zij}$ werden dan ook niet gepresenteerd als veranderingen in de shari ${ }^{\prime} a^{27}$, maar werden bereikt door een vernuftig gebruik van in de Islam niet ontoelaatbare technieken. Zo was het toelaatbaar om opvattingen uit een andere rechtsschool of een minderheidsopvatting uit de eigen rechtsschool over te nemen ${ }^{28}$. In een aantal landen waarin de hanafitische, hanbalitische of shafi' itische leer word gevolgd, zijn op deze wijze bij de codificatie bijvoorbeeld de ruimere echtscheidingsgronden uit de malikitische rechtsleer overgenomen ${ }^{29}$. In Marokko is het personen-, familie- en erfrecht gecodificeerd in 1957 en 1958 in de Code de statut personnel et des successions (Mudawwanah). Ook hier gaat het om een codificatie naar westers model. Inhoudelijk is de Marokkaanse Mudawwanah een codificatie van de leer van de malikitische rechtsschool.

Voorzover er sprake was van een codificatie van islamitisch recht, betekende dit een "revolutie" ten aanzien van de gelding van dit recht. Voorheen was islamitisch recht immers recht omdat het dit gezag in zichzelf droeg, wat afgeleid was van het gezag van de religieuze rechtsgeleerden. Nu konden de politieke autoriteiten kennelijk bepalen of en in hoeverre het islamitische recht het geldende recht was. Een systematische wijze waarop de shari 'a kan worden gemoderniseerd en worden verantwoord, is nog niet gevonden. Coulson spreekt in dit verband ook van een opportunistisch en pragmatisch beleid dat heden ten dage wordt gevoerd ${ }^{30}$. Dat het maken van keuzes zo moeilijk is, wordt mede veroorzaakt door het feit dat er in de Islam geen centrale autoriteit is die het gezag van de shari' $a$ bepaalt; geen autoriteit ook die aangeeft of en hoever de deur van de idjtihâd geopend kan worden en er expliciet ruimte gegeven kan worden aan menselijk redeneren. Dat de deur van de idjtihâd sinds de elfde of twaalfde eeuw altijd zo stevig gesloten is geweest zoals moslims vaak doen willen geloven wordt in het wetenschappelijk discours regelmatig ter discussie gesteld. De verplichting tot taqlid zou eerder een religieuze wens dan een weergave van de werkelijkheid zijn ${ }^{31}$. Veel islamologen wijzen op de noodzaak onderzoek te doen naar de originele bronnen van de Islam, om mede van hieruit te kunnen bepalen hoe het islamitische recht zich (verder) kan ontwikkelen ${ }^{32}$.

27. Anderson 1976, 36.

28. Over de gebezigde methoden en technieken: Anderson 1976, 43-77.

29. Zoals bijwoorbeeld in Egypte, Anderson 1983, 71; Pearl 1987, 131-132.

30. Coulson, A history $1978,222-223$.

31. Coulson, A history 1978, 201; Johansen 1988, 125.

32. Aboe Zaid 1996; Coulson, A history 1978, 224; Motzki 1996, 7 en vele anderen. 
Hoofdstuk 2

\section{Marokkaans erfrecht}

\section{$\S 1$. Inleiding}

In Marokko leven verschillende bevolkingsgroepen die lange tijd ieder hun eigen rechtsregels hebben gekend. Grofweg kunnen drie bevolkingsgroepen worden onderscheiden, te weten de moslims uit de steden en de omgeving van de steden, de berberbevolking die voor het grootste deel eveneens uit moslims bestaat, en de joden. Tot aan de tweede helft van de twintigste eeuw, toen in Marokko tot codificatie van het familie- en erfrecht naar westers model werd overgegaan, gold voor de moslims in de steden en omgeving het islamitische recht van de malikitische rechtsleer, voor de berberbevolking het eigen lokale gewoonterecht, en voor de joden het joodse recht. Bij wet (dahir) van 1914 werd officieel erkend dat de berberstammen onderworpen bleven aan hun eigen lokale recht. In 1930 werd door de Franse autoriteiten zelfs een zogenaamde "Berberwet" afgekondigd, regelende de aanstelling van speciale "tribunaux coutumiers", bevoegd om recht te spreken in alle aangelegenheden betreffende het personeel statuut en erfrecht. Deze rechters mochten alleen recht spreken volgens regels van gewoonterecht en niet volgens de sharî' $a$. Bij wet van 1956 werd de wet van 1930 afgeschaft. De wet op het personeel statuut en erfrecht (Code de statut personnel et des successions, CSPS), ofwel de Mudawwanah, die in 1958 in werking is getreden, is op alle moslims van toepassing. Dit heeft overigens niet kunnen verhinderen dat de berberbevolking zich in de praktijk nog vaak aan het lokale gewoonterecht houdt. De joden zijn nimmer onderworpen aan een ander dan het joodse recht. De Mudawwanah heeft hierin geen verandering gebracht. Het zeer kleine deel van de Marokkaanse bevolking dat noch islamitisch noch joods is (m.n. christenen), is wat het personeel statuut betreft eveneens onderworpen aan de Mudawwanah. Op hen zijn niet van toepassing de bepalingen omtrent de polygamie, 
verstoting en de zoging. Dit volgt uit art. 3 van de Marokkaanse Code de la nationalité ${ }^{33}$.

In de loop van de twintigste eeuw drongen in de Maghreb de invloeden van feministische bewegingen en gedachten vanuit het Midden Oosten door. Deze leverden met name in Tunesië en Algerije een belangrijke bijdrage aan de ontwikkelingen die plaatsvonden op het gebied van het familierecht en ten aanzien van de positie van de vrouw. In de jaren voorafgaande aan de codificatie van het familierecht en het erfrecht nam de aandacht voor familierechtelijke aangelegenheden en voor de positie van de vrouw ook in Marokko toe. Er werd meer onderzoek op deze gebieden verricht, de nationalistische beweging, een beweging die de Islam wilde aanpassen aan de moderne tijd en die kwam met voorstellen tot wijziging van de traditionele islamitische opvattingen, kwam op, en er werden bijeenkomsten georganiseerd gericht op een gelijke positie van mannen en vrouwen $^{34}$. Direct nadat Marokko haar onafhankelijkheid had verkregen in $1956^{35}$ werd een commissic geïnstalleerd (bij decreet van 19 augustus 1957) met als opdracht het opstellen van een wet betreffende het personeel statuut gebaseerd op de islamitische leer. In oktober 1957 begon deze commissie met de daadwerkelijke voorbereiding van de wet. Reeds een maand later, in november 1957, werd de tekst van de eerste twee boeken van de wet op het personeel statuut en het erfrecht, die uiteindelijk zes boeken zou bevatten, gepresenteerd. Deze cerste twee boeken, betreffende het huwelijk en de huwelijksontbinding, traden op 1 januari 1958 in werking ${ }^{36}$. De vier andere boeken, betreffende de geboorte en haar gevolgen, de handelingsbekwaamheid en wettelijke vertegenwoordiging, het testament, en de erfopvolging, volgden in hetzelfde tempo ${ }^{37}$.

33. Art. 3 luidt: "A l'exception des marocains de confession juive qui sont soumis au statut personnel hébraique marocain, le code du statut personnel et successoral régissant les marocains musulmans s'applique à tous les nationaux. Toutefois, les prescriptions ci-après s’appliquent aux marocains ni musulmans ni israélites:

1) La polygamie leur est interdite;

2) Les règles régissant l'allaitement ne leur sont pas applicables;

3) Leur divorce doit étre prononcé après une tentative de conciliation demeurée infructueuse, et une enquête sur les motifs de denande de séparation.

En cas de conflit, la loi du mari ou celle du père prévaudra."

34. Voor een overzicht van literatuur over (ook hedendaagse) modernistische en feministische stromingen en de juridische positie van de vrouw in Marokko, kan worden verwezen naar het bibliografie-overzicht in Moulay R'chid, La femme 1991, en Hadraoui en Monkachi 1991.

35. Over de codificatie (van het familie- en erfrecht) in Marokko in verband met de onafhankelijkheid: Cherkaoui 1981, 178; Lapanne-Joinville 1959, 97; Oufir 1986, 396-398.

36. Dahir 22 november 1957, B.O. 6 december 1957 (Arabisch), B.O. 23 mei 1958 (Frans).

37. Boek 3: Dahir 18 december 1957, in werking getreden op 1 januari 1958, B.O. 3 januari 1958 (Arabisch), B.O. 25 juli 1958 (Frans): Boek 4: Dahir 25 januari 1958, in werking getreden op 25 januari 1958, B.O. 7 februari 1958 (Arabisch), B.O. 7 november 1958 (Frans); Boek 5: Dahir 20 februari 1958, in werking getreden op 20 februari 1958, B.O. 7 maart 1958 (Arabisch), B.O. 20 februari 1959 (Frans); Boek 6: Dahir 3 maar 1958, in werking getreden op 3 maart 1958, B.O. 4 april 1958 (Arabisch). 
Het laatste boek is op 3 maart 1958 in werking getreden ${ }^{38}$. Ondanks de voorstellen die van verschillende zijden werden gedaan om veranderingen in het personen- en familierecht te brengen, is de Mudawwanah een vrij getrouwe weergave van het malikitische recht. Van een verbetering van de positie van de vrouw is hierbij geen sprake geweest. Andere bronnen die de inhoud van het familierecht hebben beïnvloed zijn de 'amal ${ }^{39}$, dit zijn opvattingen uit de rechtspraktijk, de gewoonten voorzover deze althans nict strijdig met de shari 'a waren ${ }^{40}$, en een enkele keer zijn opvattingen uit een andere rechtsschool dan de heersende malikitische overgenomen. Voorzover in de Mudawwanah zaken ongeregeld zijn gelaten, wordt aangegeven welke bronnen dan dienen te worden geraadpleegd. Vier van de boeken van de Mudawwanah worden afgesloten met een bepaling inhoudende een verwijzing naar de prevalente gevestigde mening, danwel de rechtspraktijk van de rechtsschool van Imam Mâlik voor alles waarin de wet nict voorzict ${ }^{41}$.

\section{$\S 2$. Inleidende opmerkingen over het islamitische erfrecht}

\section{A. ONTSTAAN VAN HET ISLAMITISCHE ERFRECHT}

In de pre-islamitische tijd kwam erfrecht uitsluitend toe aan mannelijke bloedverwanten van de erflater in de patriarchale linie ${ }^{42}$. De bevoorrechte positie van mannen boven vrouwen is in de Islam gehandhaafd, zij het dat in de Koran ook aan vrouwelijke verwanten erfaanspraken worden toegekend ${ }^{43}$. De Koran kent relatief uitvoerige regelin-

38. Zie over de totstandkoming van de Mudawwanah o.m. Bormans 1977, 193-196; Colomer 1963, 1222; Lapanne-Joinville 1959, 97-101.

39. Bousquet Tome IV 1962, 175; Milliot en Blanc 1987, 149-160, i.h.b. 152; Schacht 1982, 109-110.

40. Zie over de invloed van de gewoonte in Noord-Afrika: Milliot en Blane 1987, 140-149.

41. Art. 82 Bock 2, art. 172 Boek 4, art. 216 Boek 5 en art. 297 Boek 6 van de Mudawwanah. Doorgaans wordt aangenomen dat aan het ontbreken van een expliciete verwijzing naar de malikitische rechtsleer in Bock 3 van de Mudawwanah (de geboorte en haar gevolgen) - het ontbreken van een verwijzing in het eerste Boek wordt ondervangen door de verwijzing in Boek 2 - geen betekenis moet worden gehecht (in andere zin overigens eenmaal het Cour supreme (chambre sociale) 22 september $1980, \mathrm{n}^{\circ}$ 327, GTM $1983, n^{\circ} 25$, p. 23). Een van de belangrijkste malikitische figh-werken is de Mukhtasar van Khalîl ben Is'hậ, veraald en samengevat door G-H Bousquet, Abrégé 1956-1962 (4 delen). Gedegen werken over het malikitisch recht zijn voorts Linant de Bellefonds, Traité 1965 (Tome I en II), 1973 (Tome III); verschillende werken van Pesle; Milliot en Blanc 1987. Aan het malikitische recht in Marokko wordt vooral aandacht besteed in de werken van Colomer en Lapanne-Joinville.

42. Coulson 1971, 1; Juynboll 1930, 241.

43. In de literatuur wordt meestal aangenomen dat het agnatische erfrecht met de komst van de Islam werd aangevuld met een Koranische regeling. Zie bijvoorbeeld Anderson 1976, 147; Coulson, A history 1978, 17: Juynboll 1930, 244; Rahmàn 1988, 48-64. In andere zin: Powers 1986, die er niet van uitgaat dat de regeling uit de Koran het reeds bestaande erfrecht aanvult, maar beargumenteerd stelt dat de Koranische regeling een volledig systeem van erfrecht bevat dat in de plaats is getreden van het pre-islamitische stammenerfrecht. Hij betoogt dat de islamitische rechtsgeleerden de lezing en interpretatie van de Koran zodanig manipuleerden dat zij feitelijk het door Mohammed ingevoerde erfrechtssys- 
gen omtrent het erfrecht ${ }^{44}$. In de Koran wordt een aantal personen genoemd aan wie erfrechten tockomen. Door middel van uitleg kwamen de wetsgeleerden tot een totaal van twaalf. Tot deze erfgenamen behoren acht vrouwen ${ }^{45}$ en vier mannen, die in de pre-islamitische tijd ofwel geen erfrecht hadden ${ }^{46}$ ofwel door de aanwezigheid van een andere mannelijke erfgenaam van het erfrecht konden worden uitgesloten ${ }^{47}$. In de Koran is tevens aangegeven tot welk deel van de nalatenschap elk van de koranische erfgenamen gerechtigd is. Ook vloeit uit de koranbepalingen voort dat vrouwen slechts de helft ontvangen van hetgeen mannen van dezelfde verwantschapsgraad ontvangen. Door enerzijds het agnatische erfrecht te handhaven en anderzijds de in de Koran aangewezen erfgenamen te erkennen, kent het islamitische recht in eerste instantie twee groepen erfgenamen: de koranische erfgenamen (de al-farâ'id-erfgenamen) en de mannelijke erfgenamen in agnatische lijn (de 'asaba-erfgenamen). Bij het ontbreken van 'asaba- en koranische erfgenamen, de zogenaamde primaire erfgenamen, worden in de hanafitische, hanbalitische en shafi'itische rechtsscholen erfaanspraken toegekend aan andere bloedverwanten, de dhawu al-arhâm. Deze vormen een subsidiaire groep van

$43 . \rightarrow$

teem onderuit hebben gehaald. Zorgvuldig onderzoek naar de verhouding tussen het pre-islamitisch erfrecht en het Koranisch erfrecht is eveneens verricht door Bousquet en Peltier 1935, deel 2, en Marçais 1898. Zie ook Bnunschvig, Système peu connu 1976, 53-64; Mundy 1988, 24 e.v.

44. De belangrijkste regels omtrent het erfrecht zijn te vinden in de sûra's 4:11, 4:12 en 4:176. Deze luiden (in de vertaling van Kramers) (S. 4:11) "Allah draagt u ten aanzien van uw kinderen op: voor de knaap zoveel als het aandeel van twee meisjes, maar indien er slechts vrouwen zijn, boven de twee, dan aan haar twee derden van wat hij nalaat, en indien er een enige is, dan aan haar de helft. En aan zijn ouders, aan elk van beiden een zesde van wat hij nalaat, indien hij kinderen heeft; en indien hij geen kinderen heeft en zijn ouders hem beërven, dan aan zijn moeder een derde, maar indien hij broeders heeft, dan aan zijn moeder een zesde; na voldoening van een beschikking, die hij gemaakt heeft of van een schuld. Uw vaders en uw zoons, gij weet niet wie hunner $u$ het naast is in nutbrenging. Dit als vaste verplichting vanwege Allah. Allah is waarlijk wetend en wijs."

(S. 4:12) "En voor u is de helft van wat uw echtgenoten nalaten, indien zij geen kinderen hebben. Maar indien zij kinderen hebben, dan is er voor u een vierde van wat zij nalaten; na voldoening van een beschikking die zij genaakt hebben of van een schuld. En aan haar koml toe een vierde van wat gij nalaat, indien gij geen kinderen hebt; maar indien gij kinderen hebt, dan is voor haar een achtste van wat gij nalaat; na voldoening van een beschikking die gij gemaakt hebt of van een schuld. En indien een man of een vrouw beërfd wordt in de zijlinie en hij heeft een broeder of een zuster, dan zijn zij deelgenoten in een derde; na voldoening van een beschikking die hij gemaakt heeft of van een schuld, zonder dat iemand benadeeld wordt. Dit is als opdracht vanwege Allah. En Allah is wetend en zachtmoedig."

(S. 4:176) "Zij zullen u een uitspraak vragen. Zeg: Allah geeft u een uitspraak over de verwanten in de zijlinie. Indien een man omkomt, zonder dat hij kinderen heeft en hij heeft een zuster, dan is voor haar de helft van wat hij nalaat; en ook hij beërft haar, indien zij geen kinderen heeft. En indien er twee zijn, dan is voor haar beiden twee derden van wat hij nalaat; en indien zij broeders zijn, mannen en vrouwen, dan is voor de mannelijke zoveel als het aandeel van twee vrouwelijke. Allah maakt het u duidelijk voor het geval, dat gij dwaalt. En Allah is omtrent alle dingen wetend."

45. Te weten de dochter(s), de zoonsdochter(s), de moeder, de grootmoeder, de echtgenote, de volle zus, de halfzus van vaderszijde en de halfzus van moederszijde.

46. De echigenoot en de halfbroer van moederszijde.

47. De vader en de grootvader. 
erfgenamen. In de malikitische rechtsschool wordt deze groep van erfgenamen niet erkend. Daar treedı de Staat (althans de staatskas, bayt al-mâl) als restant-erfgenaam op. Tijdens zijn leven heeft de profeet Mohammed de regeling uit de Koran reeds op enkele punten aangevuld door in concrete gevallen ad hoc regels te formuleren, die vervolgens op grond van de Sunna als geldend recht werden aangenomen ${ }^{48}$. Tot ongeveer dertig jaar na de dood van Mohammed werden door zijn vier opvolgende kaliefen concrete gevallen beslecht. De in deze beslissingen gegeven regels werden in de figh geaccepteerd als regels die in een aantal bijzondere gevallen dienen te worden toegepast.

Over de tot dusver geformuleerde erfrechtregels bestond onder alle moslimse geleerden van de sunnitische rechtsscholen ${ }^{49}$ overeenstemming ${ }^{50}$. Tussen hetgeen uiteindelijk in de fiqh-boeken van de vier sunnitische rechtsscholen is neergelegd, bestaan op een aantal punten wel verschillen, die zijn veroorzaakt door verschillen in de toelaatbaarheid van bepaalde interpretatie- en redeneermethoden, en de naar tijd en plaats variërende maatschappelijke gewoonten en omstandigheden.

\section{B. GRONDSLAGEN VAN HET ISLAMI'TISCHE ERFRECHT ${ }^{51}$}

Van grote betekenis is dat het islamitische erfrecht is gebaseerd op een religieuze grondslag. Deze religieuze grondslag heeft geleid tot een rigide systeem waarbinnen weinig ruimte bestond en nog bestaat voor maatschappelijke ontwikkelingen. Het belangrijkste doel van de erfrechtelijke regeling is het vermogen binnen de familie en binnen de

48. Coulson, A history 1978. 22.

49. Tussen het erfrecht van de sunnitische en dat van de shi'itische rechtsscholen bestaan fundamentele verschillen. In de shi'itische rechtsleer wordt niet uitgegaan van een tweedeling tussen enerzijds de mannelijke 'asaba-erfgenamen en anderzijds de koranische erfgenamen. Met inachtneming van de preislamitische familiestructuren heeft men uit de koranische regeling een volledig erfrechtsysteem afgeleid. Hierbinnen worden onderscheiden degenen die erfgerechtigd zijn op grond van bloedverwantschap en zij die op andere grond erfgerechtigd zijn (de langstlevende echtgenoot). De bloedverwanten worden in het erfrecht onderscheiden in drie klassen, waarbij geldt dat erfgenamen uit een hogere klasse de verwanten uit een lagere klasse van de nalatenschap uitsluiten. Tot de eerste klasse behoren de ouders en de afstammelingen; tot de tweede klasse de oudere ascendenten, de broers en zussen en hun afstammelingen; tot de derde categorie behoren de zijverwanten van zowel vaderszijde als moederszijde. In het shi'itisch erfrecht hebben mannen geen prioriteit boven vrouwen.

50. Coulson, A history 1978, 48.

51. Het islamitische erfrecht wordt hier niet uitvoerig beschreven omdat dit indirect bij de bespreking van het Marokkaanse erfrecht nog aan de orde komt. Een zeer toegankelijk overzicht van het islamitische erfrecht wordt gegeven door Coulson 1971. In het werk van Tanzil ur-Rahman 1979 wordt een overzicht geboden van het erfrecht van de verschillende islamitische rechtsscholen en wordt eveneens moderne wetgeving besproken. Voor een bespreking van het erfrecht volgens de leer van de malikitische rechtsschool kan in het bijzonder worden verwezen naar Pesle 1932 en 1940, en de werken van Bousquet. Voor de vele andere, ook oudere, werken waarin het islamitische erfrecht wordt besproken zij verwezen naar Baillie 1832; Boulos 1925; Bousquet en Peltier 1935; Brugman 1969; Brugman 1984; Chatti 1991; Cherbonneau en Sautayra 1873-74; Clavel 1895; Durand 1991; Fauvelle 1905; Grove Grady 1869; Khan 1980; Loubignac 1929; Luciani 1890; Marçais 1931; Pritsch 1953; Roberts 1968; Rumsey 1880; Rumsey 1890; von Tomauw 1984. 
moslimgemeenschap te houden en de familieleden een materiële voorziening te ge$v^{2}{ }^{52}$. Dit heeft ertoe geleid dat alleen familieleden van de erflater tot de erfgenamen kunnen behoren, dat niet-moslims geen erfgenamen van moslims kunnen zijn, en dat er sprake is van een privilege van mannelijke verwanten. Om te voorkomen dat familieleden buiten de nalatenschap vallen of dat de nalatenschap aan niet-moslims ten goede komt, is de testeervrijheid vergaand beperkt ${ }^{53}$. Het islamitische erfrecht is een intestaat-erfrecht. Een erflater mag bij uiterste wil over maximaal eenderde deel van zijn vermogen beschikken. De regels inzake het testament betreffen "legaten", legaten ten behoeve van derden, want testeren ten behoeve van wettige erfgenamen is in het islamitische recht verboden ${ }^{54}$. Bij de intestaat-erfopvolging kunnen twee categorieën erfgenamen worden onderscheiden: erfgenamen die slechts aanspraak kunnen maken op een vastgesteld deel, en erfgenamen die onbeperkt kunnen erven. Voordat de regels van de erfopvolging worden toegepast dienen eerst de schulden van de erflater, de begrafeniskosten, en de legaten te worden voldaan. De nalatenschap die voor verdeling onder de erfgenamen in aanmerking komt bestaat dan ook uitsluitend uit activa (zaken en rechten). Een regeling omtrent de verwerping van nalatenschappen in het intestaat-erfrecht ontbreekt in het islamitische recht. Doordat de schulden van de erflater worden voldaan alvorens tot een toepassing van de verdelingsregeling onder de erfgenamen wordt gekomen, zijn de erfgenamen niet aansprakelijk voor de schulden ${ }^{55}$. Zij zijn geen rechtsopvolgers in de persoon van de overledene, maar de erfopvolging is een overgang van de rechten van de overledene op de rechthebbenden nadat de schulden zijn voldaan. In het islamitische erfrecht wordt uitgegaan van een eenheid van vermogen. Het vermogen wordt beoordeeld op het moment van overlijden van de erflater. Met handelingen die tijdens het leven van de erflater zijn verricht, bijvoorbeeld door hem verrichtte schenkingen, wordt geen rekening gehouden ${ }^{56}$.

52. Coulson 1971, 1; Pesle 1940, 9-10.

53. Volgens Schacht 1982, 24, heeft de beperking van de testeervrijheid ook een fiscale bedoeling gehad; wanneer een erflater overlijdt zonder erfgerechtigde verwanten na te laten, gaat alles waarover niet kan zijn beschikt naar de Staatskas.

54. De beperkingen dat bij uiterste wil niet mag worden beschikt over meer dan eenderde deel van het vermogen en dat niet mag worden beschikt ten behoeve van wettige erfgenamen, wordt in het islamitjsche recht algemeen erkend. Powers heeft echter in zijn onderzoek naar de Koran en Hadith geconcludeerd dat deze beperkingen niet teruggaan op het door Mohammed geïntroduceerd erfrecht, Powers $1986,18$.

55. Overigens is het volgens islamitisch recht voor de erfgenamen aanbevelenswaardig om de schulden van de erflater te voldoen.

56. Behalve wanneer deze schenkingen op het sterfbed zijn gedaan. Een op het sterfbed gedane schenking is onderworpen aan dezelfde beperkingen als een testament. Dat wil zeggen dat niet meer dan eenderde van het vermogen dat zou resteren nadat de hieraan verbonden lasten zijn voldaan, mag worden weggeschonken, en das geen schenkingen mogen worden gedaan aan wettige erfgenamen, een en ander behoudens de toestemming van de (andere) erfgenamen. Zie over de schenkingen gedaan op het sterfbed: Ibrahin 1987, 59-93. De tijdens leven gedane schenkingen spelen in het erfrecht verder alleen een rol bij het verplicht testament, zie p. 86 . 


\section{RECENTE ONTWIKKELINGEN}

Vanwege de sterke verbondenheid van het erfrecht met de godsdienst is door moslims aan het islamitische erfrecht altijd veel waarde gehecht ${ }^{57}$. Het erfrecht vormde een afspicgeling van de familiestructuur en van erkende waarden en verantwoordelijkheden in de islamitische maatschappij ${ }^{58}$. In de twintigste ceuw treedt er echter een verandering op in de bestaande familiestructuren, onder meer veroorzaakt door een grotere mobiliteit: de geïndustrialiseerde economie heeft een grote trek naar de steden tot gevolg, de arbeid wordt verricht ver van de thuishaven. De ruime kring van familieleden vormt (vaak) niet langer de sociale eenheid ${ }^{59}$. Er ontstaan problemen met de islamitische erfopvolgingsregels en de rigiditeit van het erfrecht, dat uitgaat van verouderde familiestructuren. De praktijk zocht naar oplossingen ${ }^{(*)}$. Mede onder invloed van de opvattingen van modernisten om de sharí $a$ aan te passen aan veranderde maatschappelijke omstandigheden, waarin ruimte wordt gelaten voor cen nieuwe interpretatie van de oorspronkclijke bronnen (neo-idjtihâd), zijn op cen gering aantal punten hervormingen doorgevoerd ${ }^{61}$. Over het algemeen moet echter gezegd worden dat het islamitische erfrecht ook heden ten dage nog op grote schaal in de praktijk wordt gebracht en dat er van een juridisch inhoudelijke ontwikkeling nauwelijks sprake is. De belangrijkste ontwikkeling die in de tweede helft van de twintigste eeuw heeft plaatsgevonden is dat het erfrecht in verschillende islamitische landen, waaronder Marokko, is gecodificeerd naar westers model ${ }^{62}$.

\section{DE WAQF OF HUBUS}

Niettegenstaande de grote religieuze betekenis die door moslims aan het islamitische erfrecht wordt toegekend, blijkt in de praktijk vaak dat men een grotere waarde hecht aan de wens om zelf over zijn vermogen te beschikken. Deze wens om zelf te bepalen aan wie het vermogen na overlijden toekomt, wordt in de weg gestaan door de beperkte testeervrijheid in het islamitische recht en daarmee de onmogelijkheid om af te wijken van de in het erfrecht vastgestelde verdeling van erfporties. Er bestaan echter verschillende mogelijkheden om de islamitische regels van erfopvolging te omzeilen. Twee

57. Anderson 1965, 12; Anderson 1976, 17, 146; Coulson 1971, 3-4; Fleming 1978, 234; Juynboll 1930 , 50 .

58. Coulson 1971, 3; Fleming 1978, 234.

59. Faruki $1965,254$.

60. Anderson 1965, 350-352; Bnugman 1969, 90; Faruki 1965, 254-256.

61. Anderson 1965, 349-365; Anderson 1976, 146-162; Coulson, A history 1971, 138; Coulson 1978, 203-208; Faruki 1965, 253-274. Een van de hervormingen die in verschillende islamitische landen heeft plaatsgevonden betreft de invoering van de mogelijkheid van "plaatsvervulling " bij het vooroverlijden van een erfgenaam.

62. Egypte 1943 en 1946; Syrië 1953; Tunesië 1956 (aanvulling in 1959); Marokko 1958; Irak 1959 (afschaffen shari'a) en 1963 (wederinvoering shari' a); Pakistan 1961; Soedan (circulaires 1925, 1939. 1943, 1945). 
belangrijke zijn ten eerste het doen van schenkingen tijdens leven, en ten tweede het gebruik maken van de in een aantal islamitische landen nog bestaande mogelijkheid tot het vestigen van een waqf, in het bijzonder een familie waqf ${ }^{63}$. Bij de waqf worden de vruchten, het vruchtgenot, van vermogensbestanddelen van de insteller van de wagf aangewend voor een goed doel of deze komen toe aan door de insteller aan te wijzen personen. De zaken verlaten het vermogen van de insteller. De zaken behoren ten tijde van het overlijden van de insteller niet meer tot zijn (onder de erfgenamen te verdelen) nalatenschap. Hoewel zowel het doen van schenkingen als het vestigen van een waqf tot voordeel kunnen strekken van zowel mannen als vrouwen, blijken deze methoden in de praktijk veelal te worden aangewend om vrouwelijke verwanten van aanspraken op het vermogen uit te sluiten ${ }^{64}$. Andere methoden die met dit doel ook wel worden gehanteerd zijn het - al dan niet onder druk - bewegen van een vrouwelijk erfgenaam om haar crfdeel te doen afstaan aan cen mannelijk familielid, of haar dit laten verkopen aan een mannelijk familielid tegen een symbolisch bedrag ${ }^{65}$.

$\mathrm{Bij}$ de waqf zal uitvoeriger worden stilgestaan ${ }^{6 *}$, niet alleen omdat dit een methode is om de islamitische erfrechtregels te omzeilen, maar ook om te kunnen bepalen wat de vermogensrechtelijke positie is van een erflater die (een deel van) zijn vermogen tot waqf-zaken heeft bestemd, en wat de vermogensrechtelijke positie is van een erflater die begunstigde is van een waqf. Beschreven wordt de regeling van de waqf volgens de malikitische leer. Op enkele punten wijkt deze regeling af van die uit de andere rechtsscholen.

De termen wagf en hubus zijn synoniemen. Het vestigen van een waqf kan worden gedefinieerd als een juridische handeling waarbij een zaak of zaken aan het handelsverkeer worden onttrokken en waarbij de opbrengst (het vruchtgebruik in ruime zin) ten goede komt aan een religieus, liefdadig of sociaal doel, hetzij direct, hetzij indirect doordat het vruchtgebruik van de zaken aan door de insteller aangewezen begunstigden ten goede komt, en pas bij het uitsterven van de begunstigden aan het goede doel ${ }^{67}$. Meestal betreft het onroerende zaken, maar ook roerende zaken kunnen voorwerp van een waqf zijn. De bestemming van een waqf is eeuwigdurend. De zaken die voorwerp

63. Bousquet en Peltier 1935, 150; Brugman 1969, 90; Coulson, A history 1978, 199-200; Decroux 1977, 461; Gerholm 1985, 131; Kneller 1966, 12; Layish 1982, 344-352; Layish 1983, 21, 28, 29; Layish 1995, 282 e.v., i.h.b. 283; Leveau 1985, 62; Luccioni 1942, 168-169; Pesle 1940, 13-15; Reitner 1995,174 e.v.; Rycx 1987, 20, 32.

64. Aldus 0.m. Bedoucha 1987, 77-78; Luccioni 1942, 168; Pesle 1940, 13-15. Voor Tunesië: Ferchiou $1987,57,61$ e.v. Overigens merkt zij op dat met name in rijkere families vrouwen zich soms bevinden aan het hoofd van een groot fortuin dat in hubus is overgedragen.

65. Zie over de verschillende methoden Layish 1973, 39-53; Layish 1995, 283.

66. Werken over de waof of hubus: Bashir 1977; Busson de Janssens 1953; Cattan 1955; Clavel 1896; Dulout 1938; Fratcher 1971; Layish 1983; Layish 1995; Layish 1996; Luccioni 1942; Mahmood 1988; E. Mercier 1895; E. Mercier 1899; Milliot 1918; Morand 1904; Omar 1921; Othman 1984; Pesle 1941; Saad 1928; Suhrawardy 1910; Tarâbulusî 1893.

67. Vgl. Luccioni 1942, 15. 
zijn van een wagf worden onvervreemdbaar ${ }^{68}$, niet langer vatbaar voor (verkrijgende) verjaring ${ }^{6 "}$ en zijn niet langer vatbaar voor beslag of confiscatie. Over de vraag wie na het vestigen van een waqf eigenaar is van de zaken, bestaat onder de islamitische geleerden verschil van mening ${ }^{70}$. Een veel gehoorde opvatting is dat in de malikitische school de insteller eigenaar blijft van de tot waqf bestemde zaken. Deze eigendom heeft geen inhoud meer. De insteller heeft slechts de blote eigendom. Na zijn dood zou hij eveneens fictief eigenaar blijven, of zou de bloot eigendom over gaan op zijn erfgenamen $^{\text {pl }}$.

Onderscheiden kunnen worden de publieke waqf en de privé of familie waqf. Bij de publicke wagf worden zaken direct bestemd voor een religieus, liefdadig of sociaal doel. Voorbeelden van dergelijke zaken zijn moskeeën, scholen, ziekenhuizen, en badhuizen. Bij de familic waqf komt de opbrengst, het vruchtgenot, van de zaken toe aan de door de insteller van de waff aangewezen personen. Pas wanneer deze begunstigden zijn uitgestorven, wordt de familie waqf een publicke waqf en komen de zaken ten goede aan een religicus, liefdadig of sociaal doel. Het is met name via de familie waqf dat een eigenaar kan bepalen wie er na zijn dood van zijn vermogen kunnen genieten. Bij het vestigen van een familie wagf staat dan ook veelal niet het goede doel voorop, maar heeft men doorgaans andere motieven, waarvan er drie te noemen zijn, namelijk ${ }^{72}$ :

1. het vestigen van een onaantastbaar familievermogen ${ }^{73}$, door te ontsnappen aan de regels van erfopvolging. Door als begunstigden alleen mannelijke afstammelingen aan te wijzen, kan worden voorkomen dat via het erfrecht een deel van het vermogen bij vrouwelijke verwanten terecht komt, die immers door een huwelijk tot een andere familie gaan behoren. Overigens wordt door het instellen van een

68. Behoudens uitzonderingsgevalten. In Pesle 1941, 136-145, wordtonderscheid gemaakt tussen het ruilen en het verkopen van het goed. Voor de mogelijkheid een wagf-goed te nilen verwijst hij naar El Fassi volgens wie hieraan vier voorwaarden moeten worden gesteld te weten: het goed moet in verval zijn, het moet niet meer voldoende opbrengsten opleveren om het goed te kunnen onderhouden, er kan geen persoon meer worden gevonden om het gratis te herstellen, en de nuilwaarde is groter dan de waarde van het goed. Een aantal auteurs voegt hieraan een vijfde voorwaarde toe, namelijk dat voor de ruil de toestemming van de rechter nodig is. In de praktijk zouden deze voorwaarden niet zo strikt worden nageleefd, en zou wel tot ruil worden overgegaan indien dit voordeliger is, Pesle 1941, 138. Ten aanzien van de verkoop van walf-zaken stelt men zich over het algemeen terughoudender op, Pesle 1941, 139-145. Zic ook Clavel 1896, par. 165-170) (ruil van een wayf-zaak) en par. 153-164 (verkoop van een w'aqf-zaak).

69. Althans volgens de malikitische rechtsleer. De hanafieten kennen een verjaring na 33 jaar, Luccioni $1942,65,69-73$.

70. Hierover o.m. Clavel 1896, par. 23; Husain 1989, 12-15; Luccioni 1942, 31-36; Othman 1984, 56-60.

71. In deze laatste zin o.m. Mercier 1899. Andere opvattingen over de vraag naar de eigendom van de wayf-zaken zijn: de eigendom gaat over naar God; het doel waarvoor de wagf bestemd is, verkrijgt de eigendom: de zaken gaan behoren tot het domein van God zonder dat God als eigenaar is aan te merken; de eigendom in de strikte zin van het woord verdwijnt. Zie over een en ander Luccioni, 31. 37.

72. Clavel 1896, par, 17; Luccioni 1942, 168-169.

73. Aldus ook Decroux 1977, 461; Layish 1995, 282-283. 
wagf het erfrecht onverlet gelaten: de regels van het erfrecht kunnen volledig worden toegepast, doch het vermogen dat door deze regels wordt beheerst kan door de gevestigde waqf aanzienlijk zijn geslonken. Dit geldt eveneens voor de testamentaire waqf aangezien het testament wordt uitgevoerd vóór de verdeling onder de erfgenamen ab intestaat (zie p. 34).

2. bescherming tegen "spilzucht en zwakheid van geest" van de erfgenamen;

3. vrees voor een willckeurige beroving of confiscatie van overheidszijde.

Een waqf kan worden gevestigd onder levenden of bij testament, de zogenaamde testamentaire waqf $f^{74}$. In het eerste geval is de insteller volledig vrij in zijn beschikking en in het aanwijzen van begunstigden. De erfopvolgingsregels zijn hier niet van toepassing. In het tweede geval, bij de testamentaire waqf, gelden de regels van het testament (zie \$ 3.A). De insteller kan dan slechts beschikken over maximaal eenderde deel van zijn vermogen en niet ten behoeve van wettige erfgenamen ${ }^{75}$.

Geldigheidsvereisten voor het vestigen van een waqf ${ }^{76}$ :

a. bekwaamheid van de insteller (man of vrouw ${ }^{77}$ ). Dit vereiste bevat een antal elementen: de insteller moet vrij zijn, dat wil zeggen geen slaaf zijn, hij moet meerderjarig zijn, hij moet gezond van geest en gezond van lichaam zijn ${ }^{78}$, en hij moet solvabel zijn. Niet vereist is dat hij moslim is. Een niet-moslim kan echter geen geldige waqf vestigen ten behoeve van een islamitisch doel (bijvoorbeeld een moskee) ${ }^{79}$, maar wel ten behoeve van een ander doel (bijvoorbeeld een ziekenhuis).

b. het voorwerp van de waqf, dat wil zeggen de zaak waarop de waqf is gevestigd, moet een eeuwigdurend karakter hebben ${ }^{80}$.

c. het voorwerp moet wettig zijn (niet verboden, harâm).

d. het voorwerp moet bepaald zijn.

e. de insteller moet eigenaar zijn van de zaak die voorwerp van de waqf is.

74. Pesle 1941, 17-18.

75. Of men zich in de praktijk aan deze beperkingen houdt is mij niet bekend. Volgens Layish 1983, 3, is dit niet het geval ten aanzien van het verbod te beschikken ten behoeve van wettige erfgenamen. en soms ook niet ten aanzien van het kwantitatieve verbod.

76. Luccioni 1942, 48-61; Peste 1941, 25-48.

77. Bij de malikieten geldt dat de bekwaamheid van een gehuwde vrouw tot het vestigen van een waqf is beperkt tot maximaal eenderde van haar vermogen. Voor het beschikken over meer dan eenderde deel heeft zij de toestemming van haar echtgenoot nodig. Heeft de vrouw meer dan eenderde van haar vermogen zonder toestemming van haar echtgenoot tot waqf bestemd, dan kan de man de waqf herroepen zolang het huwelijk in stand is, Clavel 1896, par. 57.

78. Indien hij tijdens zijn ziekbed een waqf heeft gevestigd en vervolgens weer herstelt is de waqf geldig; herstelt hij niet dan is de waqf slechts geldig tot maximaal eenderde van zijn vermogen.

79. Cardahi 1937, 544-545; Luccioni 1942, 51. Volgens Pesle 1941, 34, kan een niet-moslim ook geen waqf vestigen ten behoeve van een moslim.

80. Zie voor de vraag wanneer dit het geval is: Luccioni 1942, 51-52; Pesle 1941, 36-37. 
f. het doel waarvoor de waqf is bestemd moet een religieus, dat wil zeggen islamitisch, doel zijn, of een liefdadig of sociaal doel.

g. de bestemming moet in principe eeuwigdurend zijn ${ }^{81}$. Het malikitische recht kent ook de tijdelijke familie waqf ${ }^{82}$, welke wordt gevestigd ten behoeve van een generatic kinderen of een of meer kinderen zolang zij leven. Na hun overlijden keren de waqf-zaken terug in het vermogen van de insteller of van diens erfgenamen. In feite gaat het hier om een gift voor het leven ${ }^{83}$.

h. er gelden geen vormvereisten. (Een verklaring van) de wil van de insteller is voldoende.

De testamentaire wagf krijgt rechtskracht ${ }^{84}$ door het overlijden van de insteller. De levering volgt de regels van het testament. De waqf onder levenden wordt bindend en onherroepelijk door de verklaring van de insteller. Volgens de malikitische leer krijgt deze wagf rechtskracht, hetgeen wil zeggen dat zij perfect en uitvoerbaar wordt, door levering van de zaak ${ }^{85}$. Bij een waqf onder levenden die is bestemd voor een onbepaalde persoon, instelling of doel is geen aanvaarding nodig; bij een waqf ten behoeve van een bepaalde persoon wordt door de meeste geleerden aangenomen dat aanvaarding door de begunstigden wel nodig is. Aan de aanvaarding zijn geen vormvereisten gesteld. Het verwerpen van een waqf is mogelijk.

Uitvoering van de waqf:

De uitvoering of het beheer van een wagf is in de regel toevertrouwd aan een beheerder, de nâzir. De nâzir wordt aangewezen door de insteller van de waqf, en bij gebreke hiervan, door de qâdî. De nâzir is belast met het beheer van de waqf, dat wil zeggen de bescherming van de hem toevertrouwde zaken, het onderhoud ervan, en het zorgdragen voor revenuen uit de zaken hetzij door middel van huur of pacht hetzij door een directe exploitatie ervan. Hij is eveneens belast met het aanwenden van de revenuen overeenkomstig het in de vestigingshandeling bepaalde, dat wil zeggen het zorgdragen voor de uitkeringen aan de rechthebbenden. De nâzir handelt onder direct toezicht en controle van de qâdî, aan wie hij eveneens rekening en verantwoording verschuldigd is. Uiteindelijk geschiedt de uitvoering en het beheer onder het gezag van de Souverein ${ }^{86}$. Bij de uitvoering van de wagf is de wil van de insteller wet. De vestigingshandeling wordt naar de letter uitgevoerd, en wanneer deze onduidelijk is wordt gezocht naar de

81. Pesle 1941, 19-20, geeft aan dat de eeuwigdurende bestemming geen substantieel vereiste is, maar wel bijdraagt aan het vormen van het klimaat van het instituut van de waqf.

82. Clavel 1896, par. 26 en 188; Layish 1983, 4-5; Luccioni 1942, 56-57.

83. Luccioni $1942,57$.

84. Pesle 1941, 49-58; Luccioni 1942, 58-59, 61.

85. Gaat het om een familie wagf waarbij de eigen kinderen als begunstigden zijn aangewezen, dan is een feitelijke overgave niet vereist, Luccioni 1942, 59.

N.B. Indien de vestiger van de waqf onder levenden overlijdt of insolvent raakt voordat de zaak aan zijn vermogen is onttrokken, wordt de waqf nietig.

86. Luccioni $1942,76-78$. 
bedoeling van de insteller, en wordt er uitgevoerd zoals de insteller dit zelf tijdens zijn leven zou hebben gedaan. Alle handelingen die met betrekking tot de zaken die voorwerp van de waqf zijn worden verricht, worden uitsluitend verricht in het belang van het doel waarvoor de wayf gevestigd is, en van het voortbestaan hiervan ${ }^{87}$.

Verdeling van de familie waqf:

Ook hier is de wil van de insteller wet. De waqf wordt verdeeld volgens het bepaalde in de vestigingshandeling. De regels van het erfrecht zijn niet van toepassing. De begunstigden erven in hun hoedanigheid als begunstigden van de waqf, ongeacht of zij erfgenaam zouden zijn. Regel is dat de begunstigden, ongeacht sexe, recht hebben op gelijke delen, tenzij de insteller anders heeft bepaald. Heeft een insteller zijn afstammelingen als begunstigden aangewezen zonder verder iets te regelen, dan geldt dat de verdeling successievelijk, gradueel, gezamenlijk en gelijktijdig is ${ }^{88}$. Dat wil zeggen dat (het vruchtgenot van) het vermogen overgaat van generatie op generatie. In de malikitische rechtsschool geldt dat bij het vooroverlijden van een kind, diens kinderen opkomen voor het deel van hun overleden ouder naast de andere kinderen ${ }^{89}$.

Het instituut van de waqf is inmiddels niet onomstreden. Met name in de praktijk blijken hieraan grote bezwaren te kleven. Zaken die voorwerp zijn van een wagf zijn voor het handelsverkeer niet langer aantrekkelijk. Zij kunnen niet alleen niet meer worden verhandeld maar ook niet meer tot zekerheid dienen. Ook het beheer van waqf-zaken schoot nogal eens tekort. Het beheren van een waqf levert financieel in de regel niet veel op, hetgeen een goed beheer niet stimuleert. Waqf-zaken dreigen hierdoor in verval te geraken. Voor de familie waqf geldt bovendien dat, nu zij overgaat van generatie op generatie, er na verloop van tijd een te grote kring van begunstigden ontstaat. Deze bezwaren hebben ertoe geleid dat een aantal islamitische landen de waqf, en in het bijzonder de familie waqf, heeft afgeschaft, dan wel aan soepelere regels heeft onderworpen ${ }^{90}$.

\section{De hubus in Marokko}

In Marokko zijn zowel de publieke waqf als de familie waqf nog toegestaan. Het aantal waqfs in Marokko is talrijk, waarvan overigens de publieke waqf verreweg het ruimst

87. Luccioni $1942,76$.

88. Luccioni 1942, 172-173.

89. Luccioni $1942,173$.

90. In Turkije is bij een wet van 1926, inwerkingtreding in 1928, de mogelijkheid om nieuwe waqfs te vestigen afgeschaft. De familie waqf is afgeschaft in Syrië (1949), Egypte (1952), Tunesië (19561958), Libië (1973), Verenigde Arabische Emiraten (1980). Een versoepeling van de regels omtrent de familie waqf heeft plaatsgevonden in Libanon (1947) en Kuweit (1951). Zie over de wijzigingen in het wagf-recht van de verschillende islamitische landen: Anderson 1976, 162-171; Kneller 1966, 13-19; Mahmood 1988, 1-20; Schacht 1982, 103. 
vertegenwoordigd is ${ }^{91}$. Beide vormen nemen een belangrijke plaats in het religieuze, sociale en economische leven van de Marokkaanse moslims ${ }^{92}$. Tal van zaken in Marokko kunnen tot waqf zijn gemaakt: gebouwen met uiteenlopende bestemmingen, stukken grond, gehele woonwijken, wegen, ondergrondse leidingen, zoutmijnen etcetera. De publieke waqf heeft velerlei bestemmingen, zoals moskeeën, scholen, begraafplaatsen, opvangcentra, bibliotheken, het onderhoud van zieke ooievaars, het gratis verstrekken van drinkwater onder de armen op markten etcetera ${ }^{93}$. De familie waqf, waarbij de opbrengst "in eerste instantic" naar de begunstigden gaat, hebben bijvoorbeeld vaak tot voorwerp woningen, winkels, olijventuinen, ovens, boeken etcetera.

Bij dahir van 31 oktober 1912 werd een centrale autoriteit in het leven geroepen (vanaf 1915 de Vizier, sinds 1956 de Minister) ten bchoeve van de organisatie en het beheer van de waqfs in Marokko", het huidige "Ministère des Habous et des affaires islamiques". De publieke waqf, in Marokko spreekt men van hubus, wordt beheerd door dit Ministerie van Habous, die voor de concrete uitoefening van deze taak nâzir's aanstelt. De verplichtingen en bevoegdheden van de nâzir zijn bij wet geregeld. Bij de familie hubus fungeert dit Ministerie slechts als toezicht houdend orgaan. Het beheer wordt uitgeocfend door een private nâzir. In de praktijk is het beheer in de regel in handen van een van de begunstigden of van de begunstigden gezamenlijk ${ }^{95}$. De centralisering van de organisatie heeft tot cen grote verbetering van de publieke hubus geleid: de hubus-zaken werden beter onderhouden, de inkomsten stegen en het personeel werd betaald ${ }^{\%}$.

De hubus is onderworpen aan de regels van het (plaatselijke) islamitische recht. Voor geregistreerde onroerende zaken is de hubus geregeld in de art. 73 tot en met 75 van de dahir van 2 juni $1915^{97}$. Deze bepalingen luiden:

Art. 73: $\quad$ "Les habous sont des biens immeubles, immobilisés par le fondateur musulman et dont la jouissance profite aux catégories de bénéficiaires qu'il désigne".

91. Luccioni $1928,10$.

92. Luccioni 1928, 7-11; Sefrioui 1989, 75 .

93. Decroux 1977, 457; Luccioni 1928, 11.

94. Luccioni 1928,15 e.v. Zie ook de dahirs van 13 juli 1913 waarin de bevoegdheden van de beheerder van de hubus worden vastgesteld, B.O. 19 september 1913, p. 357 (Arabisch), dahir van 13 januari 1918 regelende de controle van het "Vizirat des Habous" over de familie hubus, B.O. 4 februari 1918 , p. 85 (Arabisch), de dahir van 11 februari 1918 waarbij de publieke ahbâs onder controle van het "Vizirat des Habous" worden geplaatst, B.O. 11 maar 1918, p. 243 (Arabisch), de dahir van 12 april $1976\left(n^{\circ} 1-75-300\right)$, waarin de organisatie en bevoegdheden van het Ministerie van Habous en islamitische zaken worden vastgesteld, B.O. 28 april 1976, p. 529 (Arabisch).

95. Luccioni 1942, 177-178.

96. Luccioni 1928, 21 e.v.: Luccioni 1942, 7.

97. Zie voor een overzicht van regelgeving die toepasselijk is op de hubus: Decroux 1977, 458-460. 
Art. 74: "Il existe des habous publics gérés par l'administration générale des habous, et des habous de zaouia ${ }^{98}$ et privés sur lesquels cette même administration exerce un droit de surveillance".

Art. 75: "Les habous restent soumis aux lois, réglements spéciaux et coutumes musulmanes qui les régissent".

Het feit dat art. 75 van de dahir aangeeft dat de hubus is onderworpen aan "lois, règlements spéciaux et coutumes musulmanes" betekent dat de hubus intern wordt geregeld door de sharía (dat wil zeggen wat betreft de oprichting, oprichtingseisen, geldigheid, gevolgen, verdeling etcetera), maar extern door de seculiere regelgeving (bijvoorbeeld met betrekking tot belastingen en andere lasten, waarvan de verplichting om deze te voldoen op de nâzir berusten) ${ }^{\infty}$. Gaat het om geregistreerde onroerende zaken die voorwerp zijn van een familie hubus dan kunnen de begunstigden op hun naam een speciale titel in de registers laten opnemen ${ }^{i(x)}$. Niet geregistreerde hubus-zaken zijn volledig onderworpen aan het islamitische recht.

In het kader van het erfrecht verdient met name de familie hubus een aparte bespreking. In zijn standaardwerk wijst Luccioni er tot vier keer toe op dat bij de familie hubus, anders dan bij de publicke hubus, niet het uiteindelijke goede doel voor de insteller de inspiratiebron is geweest voor het vestigen van de hubus, maar de bescherming van het eigen vermogen ${ }^{10 !}$. Volgens Luccioni zou in Marokko naast de wens om het vermogen binnen de familie te houden, ook een gebrek aan vertrouwen in de erfgenamen ofwel angst voor verkwisting van het vermogen een belangrijke oorzaak zijn voor het vestigen van een familic hubus ${ }^{102}$. Hoewel de familie hubus in Marokko theoretisch zowel ten behoeve van mannelijke als ten behoeve van vrouwelijke verwanten of ten behoeve van buitenstaanders kan worden gevestigd, wordt zij meestal gevestigd uitsluitend ten behoeve van de afstammelingen in de mannelijke linie ${ }^{103}$.

98. Dit zijn ahbâs ten behoeve van religieuze broederschappen of gebouwen ten behoeve van broederschappen, welke ahbâs na het "verdwijnen" van de begunstigde broederschap bestemd zijn tot publieke ahbâs. De hubus de zaouia heeft in Marokko naast de privé hubus geen zelfstandige praktische betekenis meer, aldus Decroux 1977, 458.

99. Luccioni 1942, 42-43.

100. Decroux 1977, 461: Luccioni 1942, 42.

101. Luccioni 1942, 8, 29, 46-47, 168-169.

102. Luccioni 1942, 169.

103. Decroux 1977, 461; Luccioni 1928, 10; Luccioni 1942, 170. Onder de islamitische geleerden is er discussie geweest over de vraag of dochters wel van de hubus kunnen worden uitgesloten. Pesle 1941, 28-30, wijst op opvattingen van geleerden waaruit valt af te leiden dat het in de eerste eeuwen van de Islam verboden was een hubus te vestigen uitsluitend ten behoeve van mannelijke afstammelingen met ujtsluiting van de vrouwelijke afstammelingen. Vanaf de negende eeuw zou dit enkel afkeurenswaardig zijn, terwijl dergelijke ahbâs vanaf de elfde eeuw geldig konden worden ingesteld. Zie ook Luccioni 1942, 169-170. 
De nadelen waarmee ook andere islamitische landen te kampen kregen ${ }^{104}$, hebben zich ten aanzien van de familie hubus ook in Marokko gemanifesteerd. Dit heeft geleid tot een dahir van 8 oktober $1977^{105}$, welke het mogelijk maakt dat de familie hubus wordt geliquideerd door het bevoegde gezag ${ }^{10 \%}$, wanneer ten genoege van dit gezag wordt aangetoond dat het algemeen belang of het belang van de rechthebbenden zulks vereist (art. 3) ${ }^{107}$. Van de liquidatie-opbrengst gaat eenderde deel naar het Ministerie van Habous ${ }^{108}$ (art. 5), en tweederde deel naar de erfgenamen van de insteller van de hubus (en als er geen erfgenamen meer in leven zijn, naar de begunstigden van de hubus) (art. 6). De verdeling onder de erfgenamen vindt plaats overeenkomstig de regels van erfopvolging (art. 6).

Deze verdeling leidt in de praktijk tot vele procedures hetgeen wordt veroorzaakt enerzijds door het feit dat moet worden uitgezocht welke erfgenamen van de insteller van de hubus nog in leven zijn - de hubus kan lange tijd, soms enkele eeuwen geleden zijn gevestigd -, en anderzijds omdat een verdeling volgens de Marokkaanse erfopvolgingsregels veelal niet overeenkomt met de genotsrechten die de begunstigden tot op het moment van de liquidatie bezaten. Begunstigden dienen plotseling de zaken af te staan aan vrouwelijke verwanten of aan verwanten van de insteller die nog nooit iets met de zaken te maken hebben gehad.

\section{$\S$ 3. Het Marokkaanse erfrecht}

Het erfrecht is in de CSPS, de Mudawwanah, geregeld in de Boeken 5 en 6 . Boek 5 (art. $173 \mathrm{t} / \mathrm{m} \mathrm{216}$ ) is gewijd aan het testament. Boek 6 (art. $217 \mathrm{t} / \mathrm{m} \mathrm{297)} \mathrm{is} \mathrm{gewijd} \mathrm{aan}$ de erfopvolging bij versterf. In de wet zelf is aangegeven dat voor zaken waarin de wet niet voorziet, men de gezaghebbende mening danwel de rechtspraktijk van de malikitische rechtsschool dient te volgen. Voor Boek 5 is deze bepaling neergelegd in art. 216, voor Boek 6 in art. 297. De in deze artikelen genoemde bronnen hebben niet alleen een aanvullende werking bij leemten in de wet maar worden ook aangewend bij de uitleg van wetsbepalingen.

104. Namelijk (zie p. 30) dat de zaken onttrokken zijn aan het handelsverkeer, zich vaak in een deplorabele staat bevinden, en de kring van begunstigden een zeer grote omvang kan aannemen, het vermogen mitsdien verbrokkelt.

105. Dahir $n^{\circ} 1-77-83$ relatif aux Habous de famille et mixtes, B.O. 10 oktober 1977 , p. 2854-2855 (Arabisch), en uitvoeringsdecreet van 18 april 1979, B.O. 18 april 1979, p. 1121-1122 (Arabisch).

106. Volgens ant. 1 van het uitvoeringsdecreet van 18 april 1979 bestaat de commissie die belast is met de liquidatie van de familie hubus uit het genoemde Ministerie van Habous, alsmede uit vertegenwoordigers van het Ministerie van Financiën, het Ministerie van Landbouw en Landbouwhervorming, het Ministerie van Woongelegenheid, van Stedebouw, en van Ruimtelijke Ordening.

107. Er is gebruik gemaakt van een niet officiële vertaling van de tekst van deze dahir.

108. Behalve wanneer de hubus bestaat uit een huis waarin de begunstigden wonen en zij geen ander huis bezitten, of de hubus bestaat uit agrarische grond waarvan de omvang niet meer is dan 10 hectaren en deze grond de enige grond is warvan de begunstigden leven. 
Art. 217 bepaalt dat de nalatenschap alles is wat de overledene aan vermogen en vermogensrechten nalaat. Blijkens art. 218 zijn aan de nalatenschap vijf lasten verbonden die in de volgende volgorde moeten worden voldaan ${ }^{(x)}$ :

$1^{\circ}$ de schulden die zijn verbonden aan tot de nalatenschap behorende zaken ${ }^{110}$;

$2^{\circ}$ de kosten - naar billijkheid - van de begrafenis van de overledene;

$3^{\circ}$ de schulden zonder beperking ${ }^{\prime \prime \prime}$;

$4^{\circ}$ het geldige en uitvoerbare testament;

$5^{\circ}$ de erfopvolging volgens hun volgorde in deze Mudawwanah.

De erfopvolgingsregels zijn pas aan de orde nadat een aantal lasten is voldaan, maar ook pas nadat een eventueel testament is uitgevoerd. Deze volgorde, waarbij het testament wordt afgehandeld alvorens de regels van erfopvolging worden toegepast, zal ook bij de bespreking van het Marokkaanse erfrecht in het onderhavige hoofdstuk worden aangehouden.

Het beschikken bij testament is in het Marokkaanse recht aan belangrijke beperkingen onderworpen. Er mag slechts worden beschikt over maximaal eenderde deel van het vermogen, en wettige erfgenamen mogen niet bij testament worden begunstigd. Hiermee is het Marokkaanse erfrecht een intestaat-erfrecht. De meeste aandacht zal in dit hoofdstuk dan ook worden besteed aan de intestaat-erfopvolging, geregeld in Boek 6 .

\section{A. Het testament}

Nadat de aan de nalatenschap verbonden lasten, te weten de schulden die rusten op tot de nalatenschap behorende zaken, de begrafeniskosten, en de (overige) schulden van de overledene, zijn voldaan, en vóór de verdeling onder de erfgenamen ab intestaat, moet het testament worden uitgevoerd. Het testament is geregeld in Boek 5 van de Mudawwanah ${ }^{12}$.

Het Marokkaanse recht maakt geen onderscheid tussen de verschillende testamentsvormen zoals erfstellingen, legaten en lasten. Van een zuivere verkrijging onder algemene titel is - evenmin als bij de intestaat-erfopvolging - bij een testamentaire verkrijging geen sprake. De testamentair bevoordeelde volgt de erflater niet in zijn vermogen op. De testamentair bevoordeelde heeft slechts een recht op maximaal eenderde deel van de goederen van de erflater (art. 173). Het Marokkaanse testament is altijd een legaat. In deze paragraaf wordt de testamentair begunstigde daarom aangeduid als legataris.

109. Ook de kosten van de vereffening komen ten laste van de nalatenschap, art. 279.

110. Hierbij is in het bijzonder te denken aan zakelijke zekerheidsrechten. Vgl. Colomer 1968, 164.

111. Hieronder vallen in het islamitische recht strikt genomen niet alleen schulden uit verbintenissen, maar bijvoorbeeld ook hetgeen de overledene aan Allah schuldig is gebleven, zoals niet betaalde zakât, geld ten behoeve van een niet verrichte Hadjdj - die dan door een plaatsvervanger alsnog kan worden ondernomen -, en een vergoeding voor niet verrichte salât.

112. Over het testament in het islamitische (malikitische) recht: Pesle 1932; Zaid 1986. 


\section{Materiële voonwaarden}

\section{Voorwaarden aan de testateur gesteld}

De testateur moet onderscheidingsvermogen bezitten ten tijde van het maken van het testament (art. 175). Het ontbreken van onderscheidingsvermogen kan zijn gelegen in de leeftijd of in de geestelijke gesteldheid van een persoon. Uit art. 138 volgt dat een minderjarige die de leeftijd van 12 jaar nog niet heeft bereikt, geen onderscheidingsvermogen heeft. Een testament van een geestelijk gestoorde is alleen dan geldig, indien het is gemaakt gedurende een moment van helderheid (art. 175) ${ }^{113}$.

\section{Voonwaarden aan de legataris gesteld}

Aan de legataris worden de volgende voorwaarden gesteld (art. $176 \mathrm{t} / \mathrm{m} \mathrm{179}$ ):

1. hij moet het gelegateerde goed rechtens of in werkelijkheid rechtsgeldig kunnen verkrijgen (art. 177);

2. hij moet ten tijde van het opmaken van het testament bestaan of zijn bestaan moet verwacht worden (art. 178);

3. hij mag geen wettig erfgenaam zijn op het moment dat de erflater overlijdt (art. 176 en 179 lid 1);

4. er mag geen beletsel bestaan voor verkrijging krachtens testament: hij mag niet onwaardig zijn krachtens testament te verkrijgen (art. 179 lid 2);

5. hij moet de erflater overleven (art. 211 sub 1).

Verschil in godsdienst staat niet in de weg aan verkrijging krachtens testament. Een islamitische erflater kan ten voordele van een niet-moslim testamentair beschikken ${ }^{114}$.

ad 1. Bekwaamheid te verkrijgen

De legataris moet in staat zijn eigendom te verkrijgen. Geestelijk gestoorden en minderjarigen kunnen wel eigendom verkrijgen. Ten behoeve van hen kan dus ook worden getesteerd. Het is de voogd die juridisch het aan hen gelegateerde goed in bezit neemt ${ }^{\text {IIS }}$. Eigendomsverkrijging van een gelegateerd goed is voorts niet mogelijk voor degenen die niet voldoen aan de in de art. 178 en 179 gestelde voorwaarden (zie punten 2 tot en met 4).

ad 2. Bestaan of verwacht bestaan ten tijde van het opmaken van het testament

\section{Bestaan}

Voor gevallen waarin het bestaan van de legataris onzeker is, bijvoorbeeld omdat hij is verdwenen in een periode waarin zich grote calamiteiten hebben voorgedaan, of hij

115. Pesle 1932, 59. 
reeds gedurende lange tijd afwezig is zonder dat men nog bericht van hem heeft vernomen, zij verwezen naar p. 45-46.

\section{Venwacht bestaan}

Het is toegestaan te beschikken ten voordele van een ongeboren vrucht. Ten aanzien van de ongeboren vrucht geldt dat deze recht heeft op zijn legaat indien aan twee voorwaarden is voldaan:

a. het kind moet levend ter wereld zijn gekomen (art. 204). Dit kan worden vastgesteld door een kreetje van de baby, zoging of een vergelijkbare aanwijzing ${ }^{116}$;

b. het kind moet zijn verwekt vóór het tijdstip waarop de erflater het testament opmaakte of de erflater moet het bestaan van de ongeboren vrucht uitdrukkelijk erkennen. Bij uitdrukkelijke erkenning van de ongeboren vrucht is voldoende dat het kind wordt geboren binnen de maximale zwangerschapsduur, gerekend vanaf het tijdstip van erkenning ${ }^{117}$. Er wordt uitgegaan van een minimale zwangerschapsduur van zes maanden en een maximale zwangerschapsduur van (in beginsel) een jaar.

Tot het moment waarop het kind wordt geboren komt het vruchtgebruik toe aan de erfgenamen (art. 201).

\section{ad 3. Geen wettig erfgenaam}

De legataris mag geen wettig erfgenaam van de erflater zijn. Deze regel lijdt uitzondering indien de andere erfgenamen toestemmen in een beschikking ten behoeve van de wettige erfgenamen. Wie wettig erfgenaam zijn is geregeld in Boek 6 van de Mudawwanah en wordt besproken in $\$ 3$. B.3 e.v. Erfgenamen ten aanzien van wie een beletsel voor erfopvolging bestaat, en erfgenamen die door de aanwezigheid van een bepaalde andere erfgenaam rechtens van de erfenis worden uitgesloten, behoren in dit verband niet tot de wettige erfgenamen. Ten voordele van hen kan wel worden getesteerd ${ }^{118}$. Geen duidelijkheid bestaat er op dit punt ten aanzien van erfgenamen die weliswaar niet rechtens door de aanwezigheid van een andere erfgenaam van de erfenis zijn uitgesloten, maar voor wie na verdeling onder andere erfgenamen, niets meer resteert. De neiging bestaat om deze erfgenamen gelijk te stellen met erfgenamen die rechtens van de erfenis zijn uitgesloten ${ }^{119}$. Beschikken ten voordele van hen zou dan mogelijk zijn.

Een beschikking ten voordele van wettige erfgenamen is wel toegestaan indien de andere erfgenamen hiervoor hun toestemming geven. De wettige erfgenaam kan zich slechts

116. Aldus art. 227.

117. Coulson 1971, 227.

118. Coulson 1971, 239-242.

119. Zie onder meer Coulson 1971, 243. 
op zijn rechten uit testament beroepen jegens de erfgenamen die deze toestemming hebben gegeven.

ad 4. Beletselen voor verkrijging krachtens testament ${ }^{120}$

\section{Onwaardigheid}

Art. 179 lid 2 bepaalt dat aan de legataris de voorwaarde wordt gesteld dat hij de erflater nict opzettelijk en onrechtmatig heeft gedood ${ }^{121}$, tenzij de erflater hiervan vóór zijn dood op de hoogte was en zijn testament (niettemin) niet heeft gewijzigd ${ }^{122}$.

ad 5. Overleven van de erflater

Voor gevallen waarin het bestaan van de legataris onzeker is, zij verwezen naar p. 4546. Het vereiste dat de rechthebbende de erflater moet overleven, geldt niet wanneer is beschikt ten behoeve van een algemene liefdadige bestemming ${ }^{123}$.

\section{Voonwaarden aan het testament gesteld}

Hier kunnen worden onderscheiden:

1. voorwaarden aan de totstandkoming en verbindendheid van het testament gesteld;

2. voorwaarden aan de inhoud van het testament gesteld.

ad 1. Totstandkoming en verbindendheid van het testament

\section{Aanbod en aanvaarding}

Het testament is een rechtshandeling, waarbij een recht wordt vastgelegd op een deel van het vermogen van de erflater (art. 173). Het aanbod van de overeenkomst wordt gedaan door de erflater (art. 180). De aanvaarding en verwerping zijn geregeld in de art. $184 \mathrm{t} / \mathrm{m} \mathrm{187.} \mathrm{Het} \mathrm{Marokkaanse} \mathrm{recht} \mathrm{kent} \mathrm{niet} \mathrm{de} \mathrm{overeenkomst} \mathrm{van} \mathrm{erfopvolging.}$

\section{Aanbod}

In het aanbod kan een voorwaarde zijn opgenomen die moet worden vervuld teneinde het testament verbindend te doen zijn (art. 181). Tot zijn overlijden heeft de testateur het recht zijn testament te herroepen, nietig te verklaren of te wijzigen (art. 182). Een herroeping geschiedt door een duidelijke of stilzwijgende verklaring of door een daad zoals de verkoop van een gelegateerde zaak (art. 183). Aan de herroeping worden

120. Buiten de hier genoemde onwaardigheid is in het islamitisch recht ook apostasie een beletsel om krachtens testament te erven. Khalîl ben Ish'âq, vertaald door Bousquet Tome IV 1962, 75; Pesie $1932,148$.

121. Uitvoerig hicrover: p. 47.

122. Dit beletsel te erven krachtens testament geldt niet voor de geestelijk gestoorden en jonge kinderen, die niet met het oordeel des onderscheids kunnen handelen. Zie o.m. Pesle 1932, 46.

123. Coulson 1971, 228. 
dezclfde materiële en formele voorwaarden gesteld (art. 194) als aan het testament zelf. Ook in geval van geestelijke stoornis kan de erflater herroepen ${ }^{124}$.

\section{Aanvaarding}

Een testament kan zijn opgemaakt ten behoeve van bepaalde of onbepaalde personen, instellingen of bestemmingen. Aanvaarding van het testament is vereist als het testament is opgemaakt ten behoeve van bepaalde personen, en, als ten behoeve van een bepaalde instelling is beschikt en dezc instelling een erkende vertegenwoordiger heeft ${ }^{125}$. Aanvaarding van cen deel van het testament is mogelijk (art. 187). De aanvaarding dient na het overlijden van de erflater plaats te vinden. Bij een beschikking ten behoeve van bepaalde personen dient de aanvaarding door de betrokken persoon zelf te geschieden. Is de bepaalde persoon minderjarig, een nog ongeboren vrucht, of geestelijk gestoord, dan dient aanvaarding door de voogd te geschieden. Indien het testament duidelijk ten voordele is van de aangewezen persoon, is de voogd verplicht te aanvaarden. Bij een beschikking ten behoeve van een bepaalde instelling dient de aanvaarding te geschieden door de vertegenwoordiger van de instelling. Aanvaarding van het testament is niet vereist indien is beschikt ten behoeve van niet individueel bepaalde personen, religieuze of liefdadige doelen, religieuze, liefdadige, wetenschappelijke of algemeen belang dienende instellingen die geen erkende vertegenwoordiger hebben ${ }^{126}$.

Vruchten die uit het gelegateerde voortkomen tussen het moment van overlijden van de erflater en het moment van aanvaarding, komen aan de legataris toe ${ }^{127}$.

\section{Verwerping}

Een testament ten behoeve van een bepaalde persoon kan door deze persoon worden verworpen (art. 185). Verwerping van een deel van het testament is mogelijk (art. 187). Een testament ten behoeve van een niet individueel bepaalde persoon, behoeft niet alleen niet te worden anvaard, maar kan ook niet worden verworpen (art. 184).

\section{ad 2. De inhoud van het testament}

Niet alleen zaken maar ook vruchtgebruik kunnen voorwerp zijn van een testament (art. 190). Een testament kan aan degene ten behoeve van wie men wenst te beschikken voorwaarden stellen met betrekking tot de getesteerde zaak (art. 182), bijvoorbeeld inhoudende een verbod van verkoop of onder recht van vruchtgebruik ${ }^{128}$.

124. Pesle 1932, 131, alwaar hij Tsouli citeert.

125. Over de vraag of aanvaarding van een testament noodzakelijk is, bestaat in de rechtsscholen geen unanimiteit. Hierover o.m. Brunschvig, Acquisition 1976, 104-118. De Marokkaanse wet volgt hier de malikitische rechtsleer, Khalîl ben Ish'âq, vertaald door Bousquet Tome IV 1962, 75; Colomer $1968,191$.

126. Coulson 1971, 231-232.

127. Pesle 1932, 172-175.

128. Coulson 1971, 222; Pesle 1932, 66 e.v. 
Aan de inhoud van het testament worden de volgende vereisten gesteld:

a. er mag slechts beschikt worden over maximaal eenderde deel van het vermogen van de erflater (art. 173) dat overblijft nadat de lasten en schulden van de nalatenschap en de begrafeniskosten zijn voldaan (art. $198 \mathrm{j}^{\circ} 218$ );

b. het testament mag geen tegenstrijdigheden en verwarring bevatten (art. 174);

c. de inhoud van het testament mag niet in strijd zijn met de wet (art. 174);

d. er mag niet worden beschikt ten behoeve van een wettig erfgenaam (art. 176);

c. het gelegateerde goed moet geschikt zijn voor eigendomsverkrijging (art. 188).

ad. a. Beschikken over maximaal eenderde deel

De testateur mag over maximaal eenderde decl van het resterend vermogen beschikken. Deze regel lijdt uitzondering indien de (meerderjarige) erfgenamen toestemming geven voor een beschikking over meer dan eenderde deel (art. 197 en 200). Voorzover het legaat eenderde decl der nalatenschap overschrijdt kan het meerdere slechts worden tegengeworpen aan de erfgenamen die hiervoor hun toestemming hebben gegeven ${ }^{129}$. Voor gevallen waarin meer is getesteerd dan eenderde deel van de nalatenschap zonder dat de andere erfgenamen hiermee instemmen, is in art. 199 geregeld hoe de verdeling onder de legatarissen plaatsvindt. De legaten die gelijk in rang zijn worden proportioneel verminderd. In de Mudawwanah wordt niet aangegeven hoe deze rangorde moet worden bepaald. Hiervoor zou moeten worden teruggevallen op de shari ' $a{ }^{130}$. Vervolgens neemt degene aan wie een bepaalde zaak is vermaakt, zijn deel van die zaak en degene aan wie een onbepaalde zaak is vermaakt, neemt uit de rest zijn deel ${ }^{131}$.

Uit art. 198 volgt dat het derde deel moet worden berekend nadat aan de verplichtingen die vóór het testament uit de nalatenschap voortkomen (zie art. 218) is voldaan ${ }^{132 .}$ Dit tijdstip is met name van belang indien tussen het tijdstip van het overlijden van de erflater en het tijdstip waarop het derde deel wordt gewaardeerd, goederen in waarde verminderen, vermeerderen of tenietgaan.

129. Voor bijzonderheden bij een beschikken op het sterfbed kan worden verwezen naar Carroll 1987, 103 105 .

130. Voor deze rangorde zie men Khalil ben Ish'âq, vertaald door Bousquet Tome IV 1962, 79-80, ook opgenomen in Pesle 1932, 86-87. De in deze rangorde opgenomen legaten betreffen bijvoorbeeld het losgeld voor een gevangene, het betalen van belasting, zoengelden, boetedoening in verband met het verzaken van een religieuze plicht, de vervulling van een wens, en de vrijlating van een slaaf.

131. Zijn er op het sterfbed zowel giften gedaan als een testament gemaakt tezamen het derde deel van het nalatenschapsvermogen overschrijden, dan gaan de giften boven het testament, Coulson 1971, 274.

132. De Mudawwanah volgt hier de opvatting uit de malikitische rechtsschool waarin wordt uitgegaan van het tijdstip waarop het testament wordt uitgevoerd. De shafi'ieten en hanbalieten gaan uit van het tijdstip van overlijden van de erflater; de hanafieten gaan uit van het tijdstip waarop tot verdeling wordt overgegaan. 
ad b. Geen tegenstrijdigheden noch verwarring

Deze voorwaarde brengt niet met zich mee dat het testament met name ten aanzien van hetgeen wordt getesteerd in alle opzichten duidelijk moet zijn. Het getesteerde kan specifiek zijn omschreven, maar ook kan worden volstaan met een algemene omschrijving, bijvoorbeeld twee drie-jarige kamelen. Onzekere bepalingen, zoals "een kleinigheid" zijn eveneens toegestaan ${ }^{133}$.

ad c. De inhoud mag niet in strijd zijn met de wet

In de wet wordt niet aangegeven wanneer er sprake is van een verboden inhoud. De testateur heeft een grote vrijheid ten aanzien van hetgeen hij wil vermaken. Wel moet de legataris eigenaar van de gelegateerde zaak kunnen worden (zie onder e), hetgeen niet kan bij verboden (harâm) zaken, zoals wijn of varkens ${ }^{134}$.

ad d. Geen beschikking ten behoeve van wettige erfgenamen

Wie wettig erfgenaam is, wordt beoordecld op tijdstip van het overlijden van de erflater.

ad e. Geschikt voor eigendomsverkrijging

Buiten de verboden zaken is ieder goed waarvan de testateur eigenaar is, en dat voorwerp kan zijn van een geldig contract onder levenden ${ }^{135}$, geschikt voor eigendomsverkrijging ${ }^{136}$.

\section{Vormvereisten}

Een testament kan schriftelijk worden gemaakt, maar ook mondeling, en zelfs, indien de testateur hiertoe niet bij machte is, door middel van een begrijpelijk gebaar (art. 191). De voorwaarden die aan het testament worden gesteld zijn geregeld in de art. 192 tot en met 194. Uit art. 192 blijkt dat een testament geldig is wanneer het aan een van de volgende vormvereisten voldoet ${ }^{137}$ :

er is cen 'adl-getuigenis: de testateur heeft zijn laatste wil tegenover twee 'udûl kenbaar gemaakt. Hiervan zal een adoulaire akte zijn opgemaakt;

133. Coulson 1971, 219.

134. Coulson 1971, 218; Pesie 1932, 65-66.

135. Vergetijk in dit verband art. 57 DOC dat luidt: "Les choses, les faits et les droits incorporels qui sont dans le commerce peuvent seuls former objet d'obligation; sont dans le commerce toutes les choses au sujet desquelles la loi ne défend pas expressément de contracter."

136. Zie hierover Coulson 1971, 218; Pesle 1932, 88-91.

137. Zie ook Colomer 1968, 196. 
- bij gebreke van een 'adl-getuigenis wordt ook de lafif-getuigenis geaccepteerd ${ }^{138}$. De lafif-getuigenis is een getuigenis van (minimaal) twaalf ${ }^{139}$ moslims die geen 'adl hoeven te zijn" ${ }^{140}$;

- $\quad$ er is een door de testateur zelf geschreven en door hem zelf ondertekend schriftelijk testament opgemaakt (geheim testament). Hierin moet hij de wijze van uitvoering van het testament duidelijk hebben aangegeven (art. 193) ${ }^{141}$;

- als zich de dwingende noodzaak voordoet een mondeling testament te maken, dient er een getuigenis van toevallig aanwezigen te zijn ${ }^{142}$. De getuigenis moet worden afgelegd ten overstaan van twee 'udîl.

Behalve het geheime testament dient ieder testament binnen drie dagen nadat de getuigenis heeft plaatsgevonden, te worden opgemaakt en ingeschreven in het register van de bevoegde Rechtbank (art. 194). De registratie is slechts een administratiefrechtelijke handeling, welke niet vereist is voor de geldigheid van het testament.

\section{Gevolgen van het testament}

Op het moment van overlijden van de erflater worden de rechten uit zijn testament bindend (art. 173). Het testament wordt uitgevoerd door degene die door de testateur met de uitvoering crvan is belast (executeur testamentair). Is er geen executeur testamentair aangewezen, dan stelt de rechter een executeur aan (art. 195). De waarde van cen getesteerde zaak wordt gewaardeerd op het nut ervan (art. 208).

138. On 'adl ti zijn moet aan een aantal voorwaarden zijn voldaan, zoals: het zijn van moslim, een moreel verantwoord leven leiden, volwassen zijn, gezond van geest zijn, een vrij man zijn. Hierover: C.E. Bosworh e.a. (ed.), The Encyclopaedia of Islam, vol. IX, onder shâhid. Het 'adl-schap in Marokko is geregeld in een dahir van 1982, gewijzigd bij decreet van 1995, en een decreet van 1983. Zie noot 274. In plaats van de getuigenis van twee 'udül wordt in Marokko ook de getuigenis van twaalf "gewone getuigen" geaccepteerd (lafff-getuigenis). Aan een lafif worden minder strenge eisen gesteld als aan een 'adl. Het grote aantal getuigen wordt geacht het gebrek aan officieel vastgestelde morele integriteit te compenseren (Buskens 1993, 170). Van de laff-getuigenis wordt met name gebruik gemaakt bij afwezigheid van twee 'udûl die kunnen getuigen. Men kan getuigen over hetgeen men heeft gehoord of heeft gezien (directe getuigenis). Ten aanzien van bepaalde onderwerpen, zoals de wettige afstamming van kinderen, de huwelijkse staat, of het overlijden, kan een getuigenis die is gebaseerd op algemene bekendheid van het feit, worden geaccepteerd zonder dat de getuige aanwezig is geweest bij de geboorte, de huwelijkssluiting of het overlijden, The Encyclopaedia of Islam, onder shâhid.

139. Als het er minder dan twaalf zijn, is er een mogelijkheid de getuigenis niettemin te accepteren. Alsdan zal de betrouwbaarheid van de getuigen moeten worden vastgesteld door middel van de tezkiya-procedure, welke resulteer in een tezkiya-akte. Colomer 1968, 196; Pesle 1932, 103-104.

140. Over de lafif-getuigenis: Buskens 1993, 170-171: Milliot en Bianc 1987, 568-572. Zie ook LapanneJoinvilte $1950,67$.

141. Colomer 1968, 199. De Marokkaanse wetgever heeft hiermee een beslissing genomen op een punt waarover onder de islamitische geleerden discussie bestond, namelijk de vraag welke (vorm)vereisten aan een geheim testament moeten worden gesteld, Colomer 1968, 197-199.

142. Het mondeling testament is in dit geval geldig indien de toevallige getuigen zo snel mogelijk tot het afleggen van hun getuigenis zijn overgegaan, en aan hun getuigenis niet kan worden getwijfeld, Colomer 1968, 196. 
In de art. $205 \mathrm{t} / \mathrm{m} 207$ wordt geregeld waaraan het getesteerde moet worden besteed wanneer aan religieuze, liefdadige, wetenschappelijke of het algemeen belang dienende doeleinden is getesteerd. De bepalingen luiden achtereenvolgens (in de Nederlandse vertaling):

Art. 205 "Testeert iemand aan God de Verhevene of aan vrome werken zonder specificatie van een bepaalde bestemming, dan wordt zijn legaat besteed aan liefdadige doeleinden."

Art. 206 "Het testament ten voordele van plaatsen van verering, liefdadige en wetenschappelijke instellingen of overige algemene belangen, betaalt het gebouw, hun werken, de armen en de overige aangelegenheden ervan."

Art. 207 "Het testament ten voordele van een bepaalde liefdadige bestemming waarvan het bestaan verwacht wordt, is geldig. Is het bestaan onmogelijk gebleken, dan wordt het legaat besteed aan wat het meest op die bestemming lijkt."

\section{De testamentaire hubus}

Hoewel dit in de Mudawwanah niet expliciet wordt geregeld, kan bij testament een waqf of hubus worden gevestigd (zie hierover $\S 2 . D$ ). De testamentaire hubus volgt de regels van het testament. Heeft de erflater zowel een testamentaire hubus gevestigd als een gewoon testament opgemaakt, dan zijn beide testamenten geldig, zij het dat wanneer hierdoor is beschikt over meer dan eenderde van het vermogen, ten aanzien van beide testamenten een proportionele vermindering plaatsvindt ${ }^{143}$.

\section{De aanwijzing van erfgenamen (tanzîl)}

De erflater heeft de mogelijkheid om de kring van erfgenamen bij testament uit te breiden. Hij kan dit doen middels de tanzîl, waarbij hij iemand die geen wettig erfgenaam is, in de plaats stelt van een erfgenaam ${ }^{144}$. Dit kan gedaan worden ten behoeve van een buitenstaander of ten behoeve van een familielid ${ }^{145}$. In dit laatste geval laat de erflater dit familielid treden in de plaats van een vooroverleden erfgenaam door wie deze met de erflater verbonden is. Hierbij dient hij gebruik te maken van een van de in art. 212 genoemde formules, te weten: "Die en die is erfgenaam met mijn kind of met mijn kinderen", of: "Voegt hem bij mijn erfenis" of: "Laat hem erven in mijn vermogen". Als de erflater wil beschikken ten voordele van een kleinzoon wiens vader is overleden, gebruikt hij de formule: "Laat hem erven in de plaats van zijn vader". Uit

143. Luccioni 1942,28

144. In de leer van de shafi'itische en hanbalitische rechtsschool wordt de tanzîl gebruikt om de erfrechten van verwanten uit de "outer family", de dhawu al-arhâm, te bepalen. De verwanten uit de "outer family" treden in de plaats van de "asaba- of koranisch erfgenaam door wie zij met de erflater verbonden zijn, Coulson $1971,92$.

145. Ammar, Tenzîl 1958, 1. 
art. 215 blijkt dat de erflater op deze wijze ook aan zijn kleindochters kan testeren. Worden zowel kleinzonen als kleindochters aangewezen, dan is de portie van de kleinzoon gelijk aan die van twee kleindochters (art. 215). Een voorbeeld van een bepaling walarin naar de mogelijkheid van het aanwijzen van erfgenamen wordt verwezen is art. 83 van de Mudawwanah: adoptie bij testament. Een dergelijke adoptie vestigt geen afstamming. De tanzîl, zijnde een legaat, volgt de regels van het testament, hetgeen onder meer betekent dat de erflater hier niet over meer dan eenderde deel van de nalatenschap kan beschikken, en dat de tanzil niet ten behoeve van wettige erfgenamen kan worden opgemaakt. Via de tanzîl kan de erflater bij vooroverlijden van een afstammeling zelf de plaatsvervulling regelen. Doet hij dit niet, dan gelden de regels van het verplicht testament (art. $266 \mathrm{t} / \mathrm{m} \mathrm{269}$, zie p. 85-90). In het hieronder opgenomen schema heeft de erflater middels een tanzil zijn kleindochter als erfgenaam aangewezen.

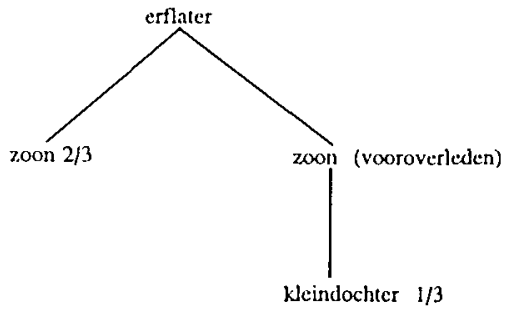

\section{B. DE ERFOPVOLGING}

De erfopvolging heeft betrekking op dat deel van de nalatenschap dat overblijft nadat de daaraan verbonden lasten, inclusief het testament, zijn voldaan. Omdat het normale testament in het Marokkaanse recht enkel legaten betreft, kent dit recht niet de testamentaire erfopvolging. Bij de erfopvolging wordt mitsdien uitsluitend gedoeld op de erfopvolging bij versterf. Bij deze erfopvolging is geen sprake van saisine. Er is geen sprake van een verkrijging onder algemene titel. In art. 219 wordt de erfopvolging gedefinieerd als de overgang van een recht vanwege het overlijden van de eigenaar na de vereffening van de nalatenschap, aan de wettige rechthebbende.

\section{Voorwaarden voor erfopvolging}

De Marokkaanse wet kent de volgende drie voorwaarden voor erfopvolging (art. 226 jo 220):

1. zekerheid omtrent het overlijden van de erflater, in werkelijkheid of rechtens;

2. het bestaan van de erfgenaam op het moment van het overlijden van de erflater, in werkelijkheid of rechtens;

3. kennis omtrent de band (met de erflater) op grond waarvan erfrechten worden toegekend. 


\section{ad 1. Dood van de erflater}

In de meeste gevallen zal de voorwaarde dat de erflater moet zijn overleden geen problemen opleveren. Er zijn twee omstandigheden denkbaar waarin de voorwaarde wél een probleem kan zijn. Ten eerstc kunnen zich omstandigheden voordoen waarin omtrent het overlijden van de erflater geen zekerheid kan worden verkregen. De erflater wordt al enige tijd vermist, en er kan niet met zekerheid worden vastgesteld of hij nog in leven is of dat hij overleden is. Ten tweede kan onzekerheid bestaan omtrent het moment van het overlijden van de erflater. Dit moment is met name van belang in verband met de tweede voorwaarde voor erfopvolging, namelijk dat de erfgenaam moet bestaan op het moment dat de erflater overlijdt. Komen meerdere personen dic van elkaar zouden erven op of omstreeks dezelfde tijd om het leven, en kan het moment van beider overlijden niet worden vastgesteld, dan kan geen zekerheid worden verkregen over de vraag of de erflater was overleden vóór de erfgenaam.

\section{Vermissing van de erflater}

Wanneer de dood van de erflater niet kan worden vastgesteld, kan de voor de erfopvolging vereiste zekerheid hieromtrent alleen nog worden verkregen via een rechterlijke uitspraak. Art. 221 bepaalt immers dat de rechtens overledene is degene over wie bericht uitblijft en over wie de rechter beslist heeft dat hij als overleden wordt beschouwd. De rechterlijke uitspraak geeft een vermoeden van overlijden. In art. 223 wordt aangegeven wanneer een dergelijke uitspraak mogelijk is. De rechter kan beslissen dat iemand als overleden wordt beschouwd als de vermiste persoon is verdwenen in uitzonderlijke omstandigheden waarin zijn dood waarschijnlijk is (zoals in geval van oorlog, epidemie van een dodelijke ziekte, of een andere ramp) ${ }^{146}$ en een jaar is verstreken vanaf de datum dat geen hoop bestaat op de hoogte te komen van een bericht omtrent zijn leven of plaats van overlijden ${ }^{147}$. In alle overige gevallen bepaalt de rechter zelf een termijn waarbinnen onderzoek en naspeuring naar de vermiste persoon wordt gedaan op de wijzen die bij de speciale instellingen voor onderzoek naar vermiste personen mogelijk zijn. Als dit onderzoek is beëindigd en de door de rechter gestelde termijn is verstreken en er van de vermiste persoon geen nieuws is vernomen, stelt de rechter het overlijden vast ${ }^{148}$. Op grond van art. 2 van een dahir van $1960^{149}$, ingevoerd na een in Agadir plaatsgevonden aardbeving, kan de rechter een verklaring van overlijden geven van een vermiste persoon ${ }^{150}$ in omstandigheden die naar haar aard zijn leven in gevaar brengen en zijn lichaam niet is teruggevonden. In al deze gevallen

146. Ar. 265 Code de procédure civile 1974 (CPC) (B.O. 30 september 1974, p. 1305). Blijkens an. 3 $\mathrm{CPC}$ is de CPC van toepassing daar waar bijzondere regels niet volledig zijn.

147. Aldus ook art. $266 \mathrm{j}^{\circ} 263 \mathrm{CPC}$.

148. Aldus ook art. 266 CPC.

149. Dahir van 10 augustus 1960 , relatif à la déclaration des décès dans certains cas, B.O. 19 augustus 1960 , p. 1561.

150. Althans van een Marokkaan die in of buiten Marokko is verdwenen, of van een buitenlander die verdwenen is hetzij in Marokko, hetzij aan boord van een Marokkaans schip of vliegtuig, dan wel zijn woonplaats of gewone verblijfplaats in Marokko had. 
geeft de rechter een verklaring van overlijden als de vermiste persoon de leeftijd van 80 jaar heeft bereikt ${ }^{151}$. De vermiste persoon wordt als overleden beschouwd vanaf het moment van de rechterlijke uitspraak. De nalatenschap valt pas open en er kan pas tot verdeling onder de erfgenamen worden overgegaan vanaf het moment van de rechterlijke uitspraak (art. 222). Indien later blijkt dat de vermiste persoon nog in leven is dan kan hij de erfdelen terugvorderen voorzover deze zich nog onder de erfgenamen bevinden ${ }^{152}$.

\section{Commoriënten}

Uit art. 224 volgt dat indien meerdere personen die van elkaar zouden erven gelijktijdig zijn overleden en men er niet in slaagt vast te stellen wie eerder is overleden, geen van hen recht heeft op de nalatenschap van de ander, ongeacht of het overlijden tijdens één gebeurtenis plaatsvond of niet ${ }^{153}$.

ad 2. Bestaan van de erfgenaam op het moment van het overlijden van de erflater Hier kunnen zich, evenals bij de vraag naar het overlijden van de erflater, problemen voordoen met betrekking tot de vraag of de erfgenaam nog in leven is, en of hij nog in leven was op het moment van het overlijden van de erflater. Met andere woorden, het gaat ook hier om de vraag naar het overlijden in geval van vermissing en om het geval waarin erflater en erfgenaam gelijktijdig overlijden en niet kan worden vastgesteld wie van hen het eerst overleed. Behalve de vraag of de erfgenaam nog in leven was, kan zich de vraag voordoen of de erfgenaam reeds in leven ís. Deze vraag komt aan de orde wanneer er sprake is van een ongeboren vrucht.

\section{Vermissing van de erfgenaam ${ }^{154}$}

Zolang er bij vermissing geen rechterlijke uitspraak is waarin de erfgenaam als overleden wordt beschouwd, wordt aangenomen dat de erfgenaam nog in leven is. Bij de verdeling van de nalatenschap van de erflater wordt de erfportie van de vermiste erfgenaam gereserveerd totdat er over het bestaan van deze erfgenaam in werkelijkheid of rechtens zekerheid is verkregen (art. 222). De andere erfgenamen nemen ofwel het erfdeel dat zij zouden krijgen als de vermiste persoon de erflater zou hebben overleefd, ofwel het deel dat zij zouden krijgen als de vermiste persoon vóór de erflater was overleden, en wel het kleinste van deze twee ${ }^{\text {iss. }}$ Zodra er (in de in art. 223 genoemde omstandigheden) een rechterlijke uitspraak komt omtrent het overlijden van de

151. Art. $260 \mathrm{CPC}$. In de malikitische rechtsleer werden verschillende opvattingen gehuldigd over de maximale levensduur, variërend van 70 tot 80 jaar, Colomer 1963, 78. Ar. 266 CPC schept hier duidelijkheid.

152. Colomer 1963, 84; Coulson 1971, 197.

153. Deze regel beantwoordt aan de opvatting die hierover in de malikitische rechtsleer wordt gehuldigd. Pesle 1940, 84. Anders: shi'itisch en hanbalitisch recht, waarin de betrokken personen wederkerig elkaars erfgenaam zijn, Coulson 1970, 202.

154. Over de verschillende soonen vermisten: Ammar 1960, 391-399.

155. Coulson 1971, 199. 
erfgenaam, wordt de erfgenaam geacht te zijn overleden op het moment van zijn vermissing ${ }^{156}$. Het erfdeel dat voor de vermiste erfgenaam was gereserveerd wordt nu verdeeld onder de andere erfgenamen van de erflater. De vermiste persoon wordt echter ten aanzien van zijn eigen nalatenschap pas als overleden beschouwd vanaf het moment van de rechterlijke uitspraak. Indien later blijkt dat de vermiste persoon nog in leven is dan kan hij de erfdelen terugvorderen voorzover deze zich nog onder de erfgenamen bevinden.

\section{Commoriënten}

Hiervoor kan worden verwezen naar de bespreking van art. 224 bij het overlijden van de erflater.

\section{De ongeboren vrucht}

Ten aanzien van de ongeboren vrucht geldt dat deze erfgenaam is indien aan twee voorwaarden is voldaan. Vast moet staan dat het kind levend ter wereld is gekomen (art. 227), en het kind moet zijn verwekt vóór het overlijden van de erflater. Art. 226 vereist immers dat de erfgenaam moet bestaan op het moment van het overlijden van de erflater. Of het kind vóór het overlijden van de erflater is verwekt, kan worden vastgesteld door (het moment van) de geboorte of door het verstrijken van de maximale zwangerschapsduur. Er wordt uitgegaan van een minimale zwangerschapsduur van zes maanden en een maximale zwangerschapsduur van (in beginsel) een jaar. De wet geeft niet aan of reeds tot de verdeling van de nalatenschap kan worden overgegaan vóór de geboorte van het kind. Met inachtneming van de opvatting uit de malikitische rechtsleer, welke op grond van art. 297 in acht dient te worden genomen, geldt dat de verdeling van de nalatenschap wordt uitgesteld tot de geboorte van het kind ${ }^{157}$.

ad 3. Kennis omtrent de band op grond waarvan erfrechten worden toegekend Voor erfopvolging dient komen vast te staan dat er sprake is van een band met de erflater op grond waarvan iemand de hoedanigheid van erfgenaam wordt toegekend. Omdat de registratie van afstammingsgegevens en huwelijken in de registers van de burgerlijke stand in Marokko nog niet volmaakt is ${ }^{158}$, wordt bij het opmaken van een

156. Dit moment wordt in de wet niet genoemd. Zie hiervoor Colomer 1968, 145; Coulson 1971, 200 .

157. Coulson 1971, 204; Pesle 1940, 83. In de andere drie sunnitische rechtsscholen wordt de verdeling van de nalatenschap alleen uitgesteld indien de ongeboren vrucht alle erfgenamen zou uitsluiten van de erfenis. Is dit niet het geval, dan nemen de andere erfgenamen ofwel het erfdeel dat zij zouden krijgen als de ongeboren vrucht levend ter wereld komt, ofwel het deel dat zij zouden krijgen als de ongeboren vrucht niet levend ter wereld komt, en wel het kleinste van deze twee. Hierbij dient rekening te worden gehouden met de mogelijkheid dat het kan gaan om een kind van het vrouwelijk of het mannelijk gesiacht en met de mogelijkheid van een meerling.

158. De burgerlijke stand is in Marokko ingevoerd bij dahir van 1915. Een algehele registratieplicht van uitsluitend geboorte en overlijden, werd pas ingevoerd bij een decreet uit 1963. Een geleidelijke invoering vond plaats ondat nog niet overal in Marokko een burgerlijke stand bestond. Zie over een en ander van der Velden 1986, 171-175; van der Velden 1989, 69-91. Thans wordt gewerkt aan een register van huwelijken en huwelijksontbindingen. 
"acte d'hérédité" door "udûl in de regel gebruik gemaakt van de lafif-getuigenis. De "acte d'hérédité" bevat een verklaring van de getuigen van de persoon die is overleden, van diens overlijdensdatum en van de personen van wie zij de afstamming met de erflater dan wel het huwelijk bevestigen ${ }^{159}$. Door de getuigen moet tevens zijn verklaard dat de overledene geen andere erfgenamen nalaat dan de aan hen bekende en door hen genoemde erfgenamen ${ }^{160}$.

\section{Beletselen voor erfopvolging}

De Marokkaanse wet kent de volgende erfbeletselen:

1. geen erfopvolging vindt plaats tussen een moslim en een niet-moslim (art. 228);

2. geen erfrecht komt toe aan hem die de erflater opzettelijk en onrechtmatig heeft gedood (art. 229) (onwaardigheid).

\section{Verschil in godsdienst}

Art. 228 bevat een wederkerig erfbeletsel. Niet alleen kan een niet-moslim niet van een moslim erven, maar ook andersom kan een moslim niet van een niet-moslim erven ${ }^{161}$. Het moment van overlijden van de erflater is het toetsingsmoment ${ }^{162}$.

\section{Onwaardigheid}

Hij die de erflater opzettelijk ${ }^{163}$ en onrechtmatig heeft gedood, erft niet van hem. Opzettelijke doodslag wordt aangenomen als er sprake is geweest van een bewuste daad of nalaten, gericht tegen de persoon, welke hetzij vijandig was hetzij in zichzelf geschikt was tot de dood te leiden ${ }^{164}$. Ten aanzien van hem die de erflater bij vergissing heeft gedood, geldt geen erfbeletsel ${ }^{165}$. Is er bloedgeld betaald, dan behoort dit tot de nalatenschap. Degene die de erflater heeft gedood heeft geen recht op (een deel van) het bloedgeld. Hierbij is niet relevant of hij de erflater opzettelijk dan wel bij vergissing heeft gedood (art. 229). In de Marokkaanse wet wordt niet aangegeven of het erfbeletsel van onwaardigheid ook geldt voor minderjarigen en geestelijk gestoorden. Volgens het malikitische recht is dit wel het geval. Colomer geeft in zijn bespreking van de Marokkaanse wet op dit punt aan van mening te zijn dat voor de vraag of een minderjarige of

159. Lapanne-Joinville 1950, 65; Sarehane 1993, Fasc. 2-2, 15. Mondeling bevestigd door een 'adl in Casablanca.

160. Lapanne-Joinville 1950, 65-66.

161. Khalil ben Ish'ậ, vertaald door Bousquet Tome IV 1962, 90; Colomer 1968, 158; Coulson 1971, 186 193; Pesle 1940, 71; Sarehane 1993, Fasc. 2-2, 6. Het islamitisch geloof gaat over via wettige afstamming (art. 83 CSPS). Zie hierover ook p. 220-221.

162. Colomer 1968, 158; Coulson 1971, 187. Anders: hanbalitisch recht, waarin het moment waarop tot verdeling van de nalatenschap wordt overgegaan bepalend is.

163. Althans "deliberate", Coulson 1971, 177.

164. Dit is de opvatting in de malikitische rechtsschool. In de andere drie sunnitische rechtsscholen wordt opzettelijke doodslag op een andere wijze beoordeeld. Hierover Coulson 1971, 176-181.

165. In andere zin de andere drie sunnitische rechtsscholen, Coulson 1971, 180-181; Tanzil ur-Rahman 1979, 594-595. 
cen geestelijk gestoorde onwaardig kan zijn te erven, bepalend is of de minderjarige respectievelijk de geestelijk gestoorde dader op het moment van de doodslag het oordeel des onderscheids bezat ${ }^{160}$.

Hoewel in de Mudawwanah uitsluitend voor de persoon die de erflater opzettelijk en ongerechtvaardigd heeft gedood is bepaald dat deze andere erfgenamen niet uitsluit van de nalatenschap (art. 229), moet, met inachtneming van de opvatting uit de malikitische rechtsschool (art. 297), hetzelfde worden aangenomen voor degene ten aanzien van wie een erfbeletsel bestaat op grond van verschil in godsdienst. Voor beide groepen geldt bovendien dat zij ook de erfdelen van andere erfgenamen niet kunnen verminderen ${ }^{167}$. Personen ten aanzien van wie een beletsel voor erfopvolging bestaat, kunnen mitsdien geen invloed hebben op het erfrecht van andere erfgenamen.

\section{Het verkrijgen van de hoedanigheid van erfgenaam}

In het intestaat-erfrecht geldt dat erfrechten kunnen voortvloeien uit het huwelijk of uit bloedverwantschap (art. 225).

\section{a. Huwelijk}

Er bestaat erfopvolging tussen echtgenoten indien er sprake is van een geldig en bestaand huwelijk (art. $34 \mathrm{j}^{\circ} 33$ ). Vastgesteld dient derhalve te worden of er tussen de echtgenoten een geldig huwelijk is tot stand gekomen en of dit reeds en nog bestaat op het moment van overlijden van een der echtgenoten.

\section{Geldig huwelijk}

Er is sprake van een geldig huwelijk indien aan de grondslagen en voorwaarden voor de totstandkoming van een geldig huwelijk is voldaan. Deze voorwaarden zijn opgenomen in de art. $4 \mathrm{l} / \mathrm{m} 10$ CSPS. De volgende vereisten gelden: aanbod en aanvaarding ${ }^{168}$ in één zitting (art. 4), de aanwezigheid van twee 'udûl-getuigen die de weder-

166. Colomer 1968, 159-160; Coloner is van mening dat zolang een minderjarige geen oordeel des onderscheids bezit, dit is zolang hij de leeftijd van 12 jaar niet heeft bereikt (art. 138), hij niet onwaardig kan zijn te erven. Ten aanzien van de geestelijk gestoorden onderscheidt hij twee gevallen: 1 . Indien de doodslag heeft plaatsgevonden voordat de rechter een onder curatele-stelling heeft uitgesproken, bestaat er een erfbeletsel, tenzij met zekerheid kan worden gesteld dat hij zich op het moment van de doodslag in een toestand van geestelijke gestoordheid bevond. 2. Indien de doodslag heeft plaatsgevonden nadat de rechter een onder curatele-stelling heeft uitgesproken wordt de dader vermoed de daad te hebben began in een toestand van geestelijke gestoordheid, en bestaat er geen erfbeletsel, tenzij is bewezen dat hij zich op het moment van de doodslag bevond in een toestand van volkomen helderheid. De onwardigheid is voor geestelijk gestoorden en minderjarigen geen beletsel te erven krachtens testament (zie noot 122).

167. Deze opvatting geldt in het algemeen in het islamitische recht. Zie hierover Coutson 1971, 173.

168. De toestemming behoeft niet uitdrukkelijk te worden gedaan, maar kan ook worden afgeleid uit gebaren, Colomer 1963, 134. 
zijdse toestemming vastleggen in de akte (art. 5 lid 2), aanvaarding door de huwelijksvoogd (art. 12) (dit vereiste geldt niet voor de meerderjarige vrouw wier vader overleden is, art. 12 lid 4 ), het vaststellen van een bruidsgave (art. 5 lid 3), beide echtgenoten moeten bij hun volle verstand zijn (art. 6, tenzij art. 7), ze moeten geslachtsrijp zijn (art. 6), de minimumhuwelijksleeftijd van 18 jaar voor de man en respectievelijk 15 jaar voor de vrouw hebben bereikt (art. 8), indien ze minderjarig zijn, dat wil zeggen jonger dan 20 jaar (art. 137) ${ }^{169}$, is de toestemming van de voogd nodig (art. 9), en er moeten geen huwelijksbeletselen zijn (art. 6) ${ }^{170}$. De absolute huwelijksbeletselen zijn opgesomd in art. 25 en betreffen: bloedverwantschap (art. 26), aanverwantschap (art. 27), zoogverwantschap (art. 28), gemeenschap tijdens de 'idda-periode met een andere dan de voormalige echtgenoot, en de vervloeking ( $\left.l i{ }^{\prime} a \hat{n}\right)$. In de malikitische rechtsleer gelden buiten de in art. 25 opgesomde beletselen voorts nog als absolute huwelijksbeletselen de schaking, en het ten gronde richten van een bestaand huwelijk. Niet blijkt dat deze beletselen in het Marokkaanse recht niet zouden gelden ${ }^{171}$. De relatieve huwelijksbeletselen zijn opgesomd in art. 29 en betreffen: polygamie met meer dan vier vrouwen, het polygaam huwelijk met twee vrouwen die, als men zou aannemen dat een van hen een man zou zijn, niet met elkaar zouden mogen trouwen wegens een verboden graad van bloedverwantschap, aanverwantschap of zoogverwantschap ${ }^{172}$, voorts het huwelijk met een vrouw die door de man drie achtereenvolgende keren is verstoten tenzij de vrouw nadien een andere echtgenoot heeft gehad, het huwelijk van een moslimse met een niet-moslim, en, in navolging van de malikitische rechtsleer, het huwelijk van een moslim met een niet-islamitische, christen of joodse vrouw ${ }^{173}$, alsmede het huwelijk van een vrouw die onder de maritale macht van een ander staat, of die zich in de 'idda- of istibrâ' -periode ${ }^{174}$ bevindt. Buiten de in art. 29 genoemde beletselen kent de malikitische rechtsleer nog enkele andere relatieve huwelijksbeletselen zoals het verkeren in een staat van ziekte of het op bedevaart zijn ${ }^{175}$. Ook ten aanzien

169. De wijziging van de meerderjarigheidsgrens van 21 naar 20 jaar heeft plaatsgevonden bij dahir van 11 juni 1992. B.O. 17 juni 1992, p. 266.

170. De in art. 14 opgenomen voorwaarde van gelijkheid van status van de echtelieden tast de geldigheid van het huwelijk niet aan maar geeft de vrouw (en de huwelijksvoogd) het recht om het huwelijk te beeindigen wanneer de status van de man "te laag" is.

171. Coloner 1963, 128; Lapanne-Joinville 1959, 104; Linant de Bellefonds Tome II 1965, 107-120.

172. Uitzondering hierop is het gelijktijdig zijn gehuwd met een vrouw en met de moeder of dochter van de vorige echtgenoot van die vrouw.

173. Colomer 1985, Fasc. 2-1, 18.

174. De 'idda is de wachttijd die een vrouw na de ontbinding van het huwelijk in acht moet nemen (art. 72 79) alvorens een nieuw huwelijk te kunnen aangaan. De istibrâ'-periode had oorspronkelijk betrekking op de periode die een slavin in acht moest nemen na wisseling van haar eigenaars. Volgens Borrmans 1977, 205 noot 62, verwijst de Marokkaanse wetgever hier naar de periode - van 1 menstruatie-cyclus of 1 maand na de laatste gemeenschap - die noodzakelijk in acht moet worden genomen als de vrouw buiten haar huwelijk geslachtsverkeer met een ander heeft gehad en het huwelijk door vervloeking ( $\left(i^{\prime} a ̂ n\right)$, waarbij in dit geval de man zijn echtgenote van overspel heeft beschuldigd, is ontbonden.

175. Colomer 1985, Fasc. 2-1, 19; Linant-de Bellefonds Tome II 1965, 121-151; Pesle 1936, 215. 
van deze beletselen blijkt niet dat de Marokkaanse wet het malikitische recht niet zou willen volgen ${ }^{176}$.

Aan het niet voldaan zijn aan de grondslagen of voorwaarden voor een geldig huwelijk zijn verschillende gevolgen verbonden. Uit art. $32 \mathrm{kan}$ worden afgeleid dat wanneer niet aan het vereiste van aanbod en aanvaarding is voldaan, er geen huwelijk bestaat ${ }^{177}$. In de andere gevallen is een huwelijk niet geldig en moet worden vernietigd. In navolging van het islamitische recht ${ }^{178}$ gaat het Marokkaanse recht ervan uit dat wanneer niet aan een van de grondslagen of voorwaarden voor het huwelijk is voldaan, dit een nietigheidsgrond oplevert. Zodra deze nietigheidsgrond bekend wordt, wordt geconstateerd dat er eigenlijk geen geldig huwelijk is, en het huwelijk moet worden vernietigd. Indien het huwelijksgebrek cen gebrek in de bruidsgave betreft, kan het huwelijk alleen worden vernietigd indien consummatie nog niet heeft plaatsgevonden ${ }^{179}$. Ondanks de vernietiging kunnen door het huwelijk bepaalde rechten en verplichtingen zijn ont$\operatorname{staan}^{180}$.

Eveneens in overeenstemming met het islamitische recht wordt in het Marokkaanse recht onderscheid gemaakt tussen nietigheidsgronden waarover onder de oude rechtsgeleerden eensgezindheid bestaat, en nietigheidsgronden waarover de rechtsgeleerden het niet unaniem eens zijn ${ }^{181}$. Is er sprake van een nietigheidsgrond waarover de rechtsgeleerden het eens zijn ${ }^{182}$, dan is het huwelijk niet geldig. De "echtgenoten" zijn geen erfgenamen van clkaar. Is er sprake van een nietigheidsgrond waarover de rechtsgeleerden niet eensgezind zijn, dan is het huwelijk weliswaar niet geldig, maar de echtgenoten zijn elkaars erfgenamen tot het moment waarop het huwelijk wordt vernietigd (art. 37 lid 2).

Indien niet is voldaan aan de voorwaarde dat het huwelijk is vastgesteld door twee 'udûl-getuigen, kan de rechter op grond van ander wettig bewijsmateriaal het huwelijk

176. Colomer 1963, 132-133; Lapanne-Joinville 1959, 106.

177. Vergelijk ook Buskens 1993, 85; Colomer 1963, 137; Lapanne-Joinville 1959, 111.

178. Hierover o.m. Lapanne-Joinville 1951, 92-102; Lapanne-Joinville, Rescision 1952, 431-450; Linant de Bellefonds Tome II 1965, 152-163.

179. Buskens 1993, 87 .

180. Dit wordt in het islamitische recht overigens niet het geval geacht bij huwelijken die zijn gesloten door jemand wiens verstandelijke vermogens zijn aangetast en door een minderjarige die nog niet met het oordeel des onderscheids handelen kan. In deze gevallen heeft het huwelijk geen enkel gevolg. Aldus Linant de Bellefonds Tome II 1965, 161.

181. Gedoeld wordt hier op de idjmá $:$ consensus onder de erkende rechtsgeleerden uit de figh-scholen over een rechtsregel, zie p. 15. Lapanne-Joinville 1951, 95-99 en Pesle 1936, 226-230, hebben getracht een opsomming te geven van nietigheidsgronden waarover al dan niet unanimiteit onder de rechtsgeleerden bestond. Zie ook Linant de Bellefonds Tome II 1965, 157.

182. In art. 37 wordt hierbij als voorbeeld genoemd het huwelijk dat wegens aanverwantschap is verboden. Ook over een verboden verschil in godsdienst bestaat unanimiteit onder de geleerden. 
vaststellen (art. 5 lid 4) ${ }^{183}$. Een toegestaan bewijsmiddel is de verklaring van twaalf lafif-getuigen ${ }^{184}$. De partijen worden als gehuwd aangemerkt vanaf de door de rechter vastgestelde datum en worden dientengevolge elkaars erfgenamen.

\section{Bestaand huwelijk}

Zodra een geldige huwelijksovereenkomst is gesloten, is er sprake van een bestaand huwelijk. Uit het huwelijk vloeien voor de echtgenoten rechten en plichten jegens elkaar voort, waaronder het recht van erfopvolging. Het antwoord op de vraag of deze rechten en plichten ontstaan direct na de huwelijkssluiting of pas na de consummatie van het huwelijk, moet worden gevonden in de leer van de aangehangen rechtsschool ${ }^{185}$. Volgens de malikitische leer ontstaan erfrechten tussen echtgenoten door de huwelijksovereenkomst, dus reeds vóór de consummatie ${ }^{186}$. Niets wijst erop dat de Marokkaanse wet van deze regel heeft willen afwijken ${ }^{187}$. Naar Marokkaans recht zijn echtgenoten elkanders erfgenaam vanaf de datum van de huwelijkssluiting.

Een huwelijk eindigt door ontbinding ervan. In het Marokkaanse recht wordt onderscheid gemaakt tussen een herroepelijke en een onherroepelijke ontbinding van het huwelijk. Bij een herroepelijke huwelijksontbinding kan het huwelijk binnen de door de vrouw in acht te nemen wachttijd, 'idda, door de man nog worden hersteld. De lengte van deze wachtperiode wordt geregeld in de art. $73 \mathrm{t} / \mathrm{m} \mathrm{78}$, en is in de regel drie maanden, althans drie menstruatie-cycli (art. 73) ${ }^{188}$. Bij een herroepelijke huwelijksontbinding blijven de echtgenoten tijdens de wachttijd elkanders erfgenaam. Verstrijkt de wachttijd zonder dat het huwelijk is hersteld, dan wordt de huwelijksontbinding onherroepelijk. Een onherroepelijke huwelijksontbinding beëindigt de wederzijdse erfrechten onmiddellijk.

Van een herroepelijke huwelijksontbinding is in drie gevallen sprake, namelijk: bij een gerechtelijke echtscheiding wegens het niet nakomen van de onderhoudsplicht door de man (art. $66 \mathrm{j}^{\circ} 53$ ), bij een gerechtelijke echtscheiding wegens de gelofte tot onthouding of wegens het weigeren van omgang door de man (art. 58 en 66), en tot slot bij de eerste en tweede eenzijdige verstotingen vóór de verstoting die door een derde verstoting onherroepelijk wordt (art. $67 \mathrm{j}^{\circ}$ 44). In alle overige gevallen is sprake van een onherroepelijke huwelijksontbinding. Dit geldt derhalve voor de gerechtelijke echtscheiding (tatli $q$ ) wegens een gebrek (art. $55 \mathrm{j}^{\circ} 54$ en 66), de gerechtelijke echtscheiding wegens afwezigheid van de man (art. 57 en 66), de gerechtelijke echtscheiding wegens

183. Art. 5 lid 3 oud.

184. Borrmans 1977,246 . Het instituut van de lafif-getuigenis, en de acceptatie daarvan, komt voor uit 'amal, Lapanne-Joinville 1964, 434-435.

185. Linant de Bellefonds Tome 11 1965, 196.

186. Coulson 1971, 17; Pesle 1936, 198.

187. Colomer 1968, 51-52; Colomer 1985, Fasc. 2-1, 7.

188. Als de vrouw zwanger is, duurt de wachttijd voort tot het moment van de bevalling. Is het huwelijk ontbonden door de dood van de echtgenoot, dan is de wachttijd vier maanden en tien dagen, art. 74. 
schade, darar (art. $66 \mathrm{j}^{\circ} 56$ ), de derde eenzijdige verstoting door de man, talâq (art. $67 \mathrm{j}^{\circ} 44$ ), de verstoting vóór de huwelijksconsummatie (art. 67), de verstoting tegen compensatic, khul' (art. $67 \mathrm{j}^{\prime \prime} 61$ ), de verstoting op grond van een overgedragen verstotingsbevoegdheid, tamlik (art. $67 \mathrm{j}^{\circ} 44$ ), en, na het verstrijken van de 'idda na een herroepelijke huwelijksontbinding. Hoewel de vervloeking, de li 'ân, in de Mudawwanah niet expliciet als echtscheidingsmogelijkheid wordt genoemd, wordt een huwelijk ingeval van li 'ân steeds beëindigd. Bij de li 'ân beschuldigt de man zijn echtgenote van overspel waardoor het huwelijk onmiddellijk en onherroepelijk wordt ontbonden.

\section{b. Bloedverwantschap}

Op grond van bloedverwantschap zijn erfgerechtigd zowel de bloedverwanten in neergaande linie (kinderen, kleinkinderen etc.), in opgaande linie (ouders, grootouders etc.) en in de zijlinic (broers, zussen, neven, nichten, ooms, tantes etc.). Tot in welke graad de erfopvolging plaatsvindt wordt in de volgende paragraaf nader uiteengezet. Bij de erfopvolging wegens bloedverwantschap wordt in art. 225 uitgegaan van een wettige verwantschap. In art. 228 wordt de erfopvolging op grond van bloedverwantschap beperkt in dic zin dat geen erfopvolging plaatsvindt tussen personen tussen wie volgens de wet geen afstamming bestaat, of tussen een uit ontucht geboren kind en de ontuchtige verwekker. De Marokkaanse afstammingsregels zijn een uitwerking van de afstammingsregels uit de shari' $a$. Daar waar in de Marokkaanse wet zaken ongeregeld zijn gelaten, zal moeten worden teruggevallen op de sharî' $a$, in het bijzonder op de leer van de malikitische rechtsschool.

De Marokkaanse wet spreekt van wettige en onwettige verwantschap (art. 83). De erfopvolging is op de wettige verwantschap gebaseerd (art. 83 lid 1). De wettige verwantschap wordt omschreven als die waarin het kind zijn vader volgt in godsdienst en afstamming. De term afstamming (nasab) wordt hier gebruikt om de wettige afstamming ten aanzien van de vader aan te duiden. Onderscheiden kunnen worden de verwantschap ten opzichte van de moeder en de verwantschap ten opzichte van de vader.

\section{Verwantschap ten opzichte van de moeder}

Een onwettige verwantschap wordt ten opzichte van de moeder gelijk gesteld aan een wettige verwantschap (art. 83 lid 2). Het onwettig kind is immers haar kind. Dat betekent dat tussen moeder en kind steeds erfopvolging plaatsvindt en dat het kind ten opzichte van de familie van de vrouw wordt beschouwd als een wettig kind ${ }^{189}$. Dit heeft bijvoorbeeld ook tot gevolg dat, als de moeder komt te overlijden, bij de berekening van het erfdeel van de echtgenoot het bestaan van het onwettig kind in acht wordt genomen ${ }^{(9)}$. 


\section{Verwantschap ten opzichte van de vader}

Voor de afstammingsvraag is niet het tijdstip van geboorte bepalend maar het tijdstip van verwekking. Er kan alleen afstamming bestaan wanneer het kind is verwekt binnen een relatie waarbinnen het hebben van sexuele gemeenschap is gelegitimeerd.

Wanneer het kind "van het bed is" wordt een vermoeden van afstamming aangenomen. Het kind is van het bed niet alleen wanneer het is verwekt binnen een geldig huwelijk maar ook als er sprake is van een huwelijk waaraan een nietigheidsgrond kleeft, of als de "echtgenoten" in de veronderstelling verkeerden dat zij geldig waren gehuwd, terwijl het huwelijk in werkelijkheid niet rechtsgeldig was ${ }^{191}$. Als er geen sprake is van een vermoeden van afstamming kan de afstamming blijkens art. 89 nog worden vastgesteld door een erkenning door de vader (art. 92 e.v.), door de getuigenis van twee 'udûl, en door een testimonium de auditu waarin wordt verklaard dat het zijn kind (het kind van de vader) is, geboren op zijn bed en uit zijn echtgenote. Staat op grond van een van deze middelen de afstamming vast, dan bestaat het recht van erfopvolging. Buiten het concubinaat met slavinnen is het huwelijk de enige relatie waarbinnen sexuele gemeenschap is gelegitimeerd, en mitsdien de enige relatie die tot wettige afstamming kan leiden ${ }^{192}$. De erkenning door de vader, de getuigenis van twee 'udûl, en het testimonium de auditu, dienen derhalve te worden gezien als bewijsmiddelen van het bestaan van een dergelijke legitieme relatie.

De Marokkaanse wet kent hiermee de volgende mogelijkheden om afstamming vast te stellen:

a. Er is sprake van een geldig huwelijk

De afstamming staat vast indien het kind geboren is na zes maanden na het sluiten van de huwelijksovereenkomst en sexueel contact mogelijk is geweest (art. $85 \mathrm{j}^{\circ} 84$ ) tot een jaar ${ }^{193}$ na de beëindiging van het huwelijk (art. 86 lid 2) ${ }^{194}$. Staat de afstamming vast dan bestaat het recht van erfopvolging.

b. Er is sprake van een huwelijk waaraan een nietigheidsgrond kleeft, en dat dus moet worden vernietigd

Indien het een nietigheidsgrond betreft waarover onder de rechtsgeleerden eensgezindheid bestaat, dan staat de afstamming alleen dan vast indien de "echtgenoten" te goeder trouw waren ten aanzien van de geldigheid van hun huwelijk (art. 37 lid 2), mits het

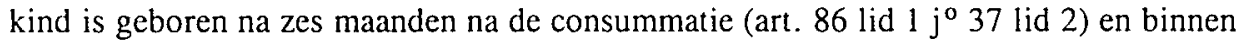

191. Linant de Bellefonds Tome III 1973, 26-30.

192. Lapanne-Joinville 1956, 352.

193. Niet is aangegeven of het hier gaat om een zonnejaar of om een, in de Islam gebruikelijk, maanjaar. Een maanjaar heeft 354 dagen en elf keer in de derig jaar 355 dagen, de Bruijn 1987, 498.

194. Indien na dit jaar nog twijfel over de zwangerschap bestaat kan deze termijn van een jaar worden verlengd (art. 76). 
een jaar na de beëindiging van het huwelijk (art. 86 lid 2). Indien het een nietigheidsgrond betreft waarover onder de rechtsgeleerden geen eensgezindheid bestaat, dan staat de afstamming vast, ongeacht goede of kwade trouw der echtgenoten, mits het kind geboren is na zes maanden na de consummatic (art. 86 lid $1 \mathrm{j}^{\circ} 37 \mathrm{lid} 2$ ) en binnen een jaar na de bcëindiging van het huwelijk (art. 86 lid 2). De afstamming staat vast, ook indien het huwelijk is of wordt vernietigd. Staat de afstamming vast dan bestaat het recht van erfopvolging (aldus ook art. 88).

c. Er is geen sprake van een geldig huwelijk, maar de echtgenoten waren te goeder trouw in de veronderstelling dat er wel een geldig huwelijk bestond

Deze mogelijkheid is onder b reeds besproken. Voor de ongehuwde vrouw die in dwaling gemeenschap heeft gehad is de afstammingsvraag nog eens expliciet in art. 87 geregeld. Uit deze bepaling volgt dat de afstamming vaststaat indien het kind geboren is na zes maanden tot een jaar na de gemeenschap. Staat de afstamming vast dan bestaat het recht van erfopvolging (aldus ook art. 88).

d. Erkenning van een kind door de vader

De erkenning, iqrâr, in de zin waarin deze in het islamitische recht wordt gebruikt, kan niet worden gelijkgesteld aan de betekenis die de erkenning in het Nederlandse recht heeft. Terwijl de erkenning in het Nederlandse recht steeds een erkenning van onwettige kinderen betreft, betreft de erkenning in het islamitische recht de erkenning van het bestaan van legitieme banden van (bloed)verwantschap ${ }^{195}$. Het vooronderstelt een legitieme relatie waarbinnen het kind is verwekt. Erkenning van onwettige kinderen is niet mogelijk. Volgens het islamitische recht is een kind onwettig indien de vaderschap van het kind is ontkend of als het uit ontucht is geboren ${ }^{196}$. De erkenning heeft veeleer een bewijsfunctie, maar creëert op zichzelf geen afstamming. Het instituut van de erkenning wordt van oudsher gebruikt door mannen om door hen bij concubines (slavinnen) verwekte kinderen te erkennen ${ }^{197}$. De erkenning van een kind kan ook van belang zijn als onduidelijkheid of onzekerheid omtrent het bestaan van een huwelijk bestaat. De erkenning van een kind kan zelfs bijvoorbeeld worden toegelaten indien het kind wordt geboren binnen zes maanden na huwelijkssluiting ${ }^{198}$. Een voorwaarde die bij erkenning altijd geldt, is dat de erkenner niet mag vermelden dat het kind binnen een onwettige relatie is verwekt.

Door de erkenning van verwantschap staat de afstamming van de erkenner vast vanaf het moment van de geboorte indien aan de in art. 92 genoemde voorwaarden is voldaan,

195. Buskens 1993, 137; Ibrahim 1979, 196; Lapanne-Joinville 1957, 1.

196. Linant de Bellefonds Tome III 1973, 19.

197. Blanc en Lourde 1983, 163-175; Borrmans 1977, 219; Lapanne-Joinville, Reconnaissance 1952, 153 166; Milliot en Blanc 1987, 410.

198. Ibrahim 1979, 202; Linant de Bellefonds Tome III 1973, 35. Als rechtvaardiging hiervoor gaven de rechtsgeleerden aan dat er bijvoorbeeld vóór de officiële huwelijkssluiting reeds een geheim huwelijk had plaatsgevonden of dat de ouders "in dwaling" gemeenschap hadden gehad. 
te weten: $1^{\circ}$ dat de erkenner van mannelijke kunne is; $2^{\circ}$ dat hij bij zijn volle verstand is; $3^{\circ}$ dat de afstamming van het kind onbekend is; $4^{\circ}$ dat de verklaringen van de erkenner niet door rede of gebruik worden gelogenstraft. Deze laatste voorwaarde bevat onder meer het vereiste dat er tussen de erkenner en het kind een leeftijdsverschil bestaat waarbij verwantschap mogelijk is en het in de malikitische rechtsschool geldende vereiste dat de omstandigheden zodanig zijn dat het plausibel is dat de erkenner de verwekker van het kind kan zijn ${ }^{199}$. De erkenning wordt blijkens art. 95 "bewezen" door een adoulaire akte of door een handgeschreven stuk van de erkenner zelf.

\section{e. De getuigenis van twee 'udâl}

De afstamming kan worden vastgesteld door de getuigenis van twee 'udûl. De getuigen kunnen volstaan met een verklaring inhoudende dat het kind voor wie zij getuigen en wiens afstamming onbekend is, deze man tot vader heeft ${ }^{200}$. De beide getuigen moeten van mannelijke kunne zijn. De regel dat een getuigenis van een man kan worden vervangen door die van twee vrouwen mag hier niet worden toegepast ${ }^{201}$. Bij gebreke van een adoulaire getuigenis wordt in het Marokkaanse recht de verklaring van twaalf lafif-getuigen geaccepteerd ${ }^{202}$. Indien twaalf moslim-getuigen verklaren dat hen bekend is dat een kind het kind is van de vader en is verwekt binnen een wettige relatie, dan kan op grond hiervan de afstamming worden aangenomen.

\section{f. Testimonium de auditu}

Tot slot wordt in art. 89 bepaald dat de afstamming kan worden vastgesteld door een testimonium de auditu. Gedoeld wordt hiermee op het bewijs dat wordt geleverd door twee gekwalificcerde getuigen die verklaren dat het van algemene bekendheid is dat een bepaalde persoon het wettige kind is van een bepaalde andere persoon ${ }^{203}$. Het betreft een indirecte getuigenis: de getuigen hoeven hetgeen zij verklaren niet uit eigen waarneming te kennen.

Het vermoeden van afstamming (mogelijkheden a tot en met c) kan worden weersproken door een ontkenning van het vaderschap. De ontkenning van het vaderschap ${ }^{204}$ geschiedt via een gerechtelijke procedure en dient plaats te vinden zodra de man heeft vernomen dat zijn vrouw zwanger is ${ }^{205}$. Het vermoeden van afstamming kan niet

199. Lapanne-Joinville 1957, 2-3.

200. Linant de Bellefonds Tome III 1973, 75.

201. Linant de Bellefonds Tome III 1973, 75. Anders bij de hanafieten waar in dit geval de getuigenis van een man en twee vrouwen is toegestaan.

202. Lapanne-Joinville 1950, 65.

203. Lapanne-Joinville $1950,67$.

204. Waarbij de zogenaamde li ân-procedure dient te worden gevolgd. Hierover o.m. Ibrahim 1979, 170191; Linant de Bellefonds Tome III 1973, 42-43; Pesle 1940, 75.

205. Over de vaderschapsontkenning o.m. Linant de Bellefonds Tome III 1973, 42-47. Volgens een uitspraak van het Cour suprême (chambre sociale) $n^{\circ} 96$, van 9 februari 1982, GTM 1985, n³ 37, p. 14 , dient de ontkenning van het vaderschap plaats te vinden tijdens de zwangerschap van de vrouw. 
worden weersproken door de getuigenis van twee 'udûl. De afstamming die wordt vastgesteld door erkenning kan wel worden weersproken door de getuigenis van twee 'udûl, hetgeen tot gevolg heeft dat de afstamming met de erkenner teniet wordt gedaan en afstamming komt vast te staan met degene die volgens de getuigenis de werkelijke vader is.

\section{Erkenning van anderen als venvanten}

Naast de erkenning van een kind door de vader regelt de Marokkaanse wet de erkenning van derden als verwanten, zoals de erkenning als kleinkind, als grootouder, als broer of zus, als oom of tante, of als neef of nicht (art. 93). Deze erkenning is niet gericht op het vestigen van juridische verwantschapsbanden maar op vermogensrechtelijke gevolgen. In het islamitische recht komen aan deze personen tot op zekere hoogte ook erfrechten toe. $\mathrm{Zij}$ kunnen in de nalatenschap opkomen als er geen andere erfgenamen $z^{z i j n}{ }^{206}$, en delen met degene die hen heeft erkend het erfdeel dat aan deze laatste toekomt ${ }^{207}$. De erkenning heeft geen gevolgen voor hen die de erkenning niet accepteren. In de malikitische rechtsleer krijgt degene die de derde heeft erkend het deel dat hem zou toekomen als bezat de derde de hoedanigheid waarin hij werd erkend. De erfgenamen die de erkenning niet accepteren, ontvangen het deel waarop zij zonder de derde aanspraak zouden maken ${ }^{208}$. Ter verduidelijking volgen hier twee voorbeelden ${ }^{209}$.

1. Een vader overlijdt en laat twee zonen na. Een van deze twee zonen heeft een derde als broer erkend, welke erkenning door de andere zoon niet is geaccepteerd. Zonder erkenning zouden beide zonen ieder recht hebben op de helft van de nalatenschap. De zoon die de erkenning niet heeft geaccepteerd ontvangt de helft van de nalatenschap. Bij het vaststellen varı de aanspraken van de zoon die de derde als broer heeft erkend, wordt ervan uitgegaan dat de vader drie zonen heeft nagelaten, die ieder recht op eenderde deel zouden hebben. De erkennende zoon maakt nu aanspraak op eenderde deel van de nalatenschap. Dit derde deel gevoegd bij de helft van de andere zoon heeft tot gevolg dat er voor de begunstigde derde eenzesde deel overblijft.

2. De erflater laat als erfgenamen na zijn moeder, een halfzus van vaderszijde en een oom van vaderszijde. De halfzus erkent een derde als volle zus van de erflater. De moeder en de oom erkennen deze derde niet als zus van de erflater. Zonder erkenning zou de verdeling als volgt zijn (zie over de erfdelen p. 61 e.v.):

206. Wil deze regel enige betekenis hebben, dan kan hierbij niet op de Staat als erfgenaam worden gedoeld.

207. Lapanne-Joinville 1959, 124; Linant de Bellefonds Tome III 1973, 48, 66-68.

208. Eenzelfde verdeelsleutel wordt gehanteerd in de hanbalitische rechtsleer. In de hanafitische rechtsleer geldt een andere verdeling. In de shafi' ${ }^{\prime}$ tische rechtsleer heeft de erkenning geen erfrechtelijke gevolgen.

209. Ontleend aan Luciani 1890, 410-411. Het eerste voorbeeld wordt ook gegeven in Linant de Bellefonds Tome III 1973,67. Voor meer voorbeelden, ook als er meerdere erfgenamen de erkenning accepteren, zie Luciani $1890,409-436$. 


$\begin{array}{lll}\text { moeder } & : & 1 / 3 \\ \text { halfzus } & : & 1 / 2 \\ \text { oom } & : & 1 / 6\end{array}$

Met het bestaan van een volle zus zou de verdeling als volgt zijn:

moeder : $1 / 6$

volle zus : $1 / 2$

halfzus : $1 / 6$

oom : $1 / 6$

De erkenning heeft geen gevolgen voor de moeder en de oom. Zij ontvangen mitsdien $1 / 3$ respectievelijk $1 / 6$ deel. De erkenning heeft wel gevolgen voor de halfzus. $\mathrm{Zij}$ ontvangt 1/6 deel. Resteert voor de erkende zus 1/3 deel.

moeder : $1 / 3$

volle zus : $1 / 3$

halfzus : $1 / 6$

oom : $1 / 6$

Hoewel art. 93 in vage bewoordingen is gesteld, lijkt het erop dat de Marokkaanse wetgever het islamitische (malikitische) recht hier heeft willen volgen.

\section{De erfgenamen}

De Marokkaanse wet kent twee soorten erfgenamen: de koranische erfgenamen (de erfgenamen ahl al-farâ'id) en de 'asaba- of agnatische erfgenamen. De koranische erfgenamen zijn verwanten aan wie in de Koran een vastgesteld erfdeel werd toegekend. Tot de koranische erfgenamen behoren: de echtgenote, de echtgenoot, de dochter, de zoonsdochter (en iedere verdere generatie dochters in de agnatische lijn), de moeder, de grootmoeder van beide zijden (en iedere verdere generatie moeders ${ }^{210}$ ), de vader, de grootvader van vaderszijde (en iedere verdere generatie vaders), de (volle) zus, de halfzus van vaderszijde, de halfzus van moederszijde, en de halfbroer van moederszijde. De 'asaba-erfgenamen zijn de erfgenamen uit het pre-islamitische erfrecht, de mannelijke verwanten. Binnen de categorie asaba-erfgenamen worden onderscheiden (art. 245): de 'asaba bi-nafsihi (agnatisch erfgenaam door zichzelf), de 'asaba bi-ghayrihâ (agnatisch erfgenaam door een ander), en de 'asaba ma'a ghayrihâ (agnatisch erfgenaam naast een ander). De Staat wordt in de Mudawwanah niet als erfgenaam genoemd. In navolging van de malikitische rechtsleer ${ }^{211}$ kan worden aangenomen dat de Staat restant-erfgenaam 'asaba van de laatste klasse is ${ }^{212}$. Deze uit de malikitische leer over-

210. De verdere generaties van ascendenten en descendenten worden in de Mudawwanah niet steeds uitdrukkelijk genoemd. Mede met toepassing van art. 297 moet bedoeld zijn dat ook de verdere generaties tot de erfgenamen behoren, Colomer 1968, 49; Coulson 1971, 60; Moulay R'chid 1985, 463. Voor de grootmoeders zie ook: Colomer 1968, 74.

211. Coulson 1971, 49; Coulson 1978, 97; Khalîl ben Ish'âq, vertaald door Bousquet Tome IV 1962, 87; Pesle 1940, 28-29.

212. Borrmans 1977, 229 noot 145 en 255; Colomer 1968, 40, 53-54, 94. 
genomen regel heeft echter weinig betekenis meer nu bij wet van 29 oktober $1962^{213}$ is beslist dat de Staat zich terugtrekt ten behoeve van de koranische erfgenamen. Dit heeft tot gevolg dat de Staat feitelijk alleen kan erven wanneer er noch asaba-erfgenamen noch koranische erfgenamen zijn. In art. 267 Code de procédure civile wordt uitdrukkelijk bepaald dat de Staat pas tot de erfenis kan worden geroepen bij afwezigheid van andere (bekende) erfgenamen.

De koranische en 'asaba-erfgenamen kunnen zijn:

1. Uitsluitend koranische erfgenamen

Tot deze categorie behoren (art. 233): de moeder, de grootmoeder van beide zijden (en iedere verdere generatie moeders), de echtgenote en de halfzus van moederszijde.

2. Erfgenamen die zowel koranisch erfgenaam als 'asaba-erfgenaam ('asaba binafsihi) zijn

Zij kunnen erven als koranisch erfgenaam of als 'asaba-erfgenaam, en wel als 'asaba bi-nafsihi, dan wel in beide hoedanigheden. Tot deze categorie behoren (art. 235): de vader, de grootvader van vaderszijde (en iedere verdere generatie vaders in de agnatische lijn) ${ }^{214}$, de echtgenoot, de zoon van de oom van vaderszijde, en de halfbroer van moederszijde. De laatste drie worden in art. 235 genoemd omdat zij in twee hoedanigheden kunnen erven ${ }^{215}$. Het bezit van twee hoedanigheden leidt tot een cumulatie van erfaanspraken ${ }^{216}$.

3. Koranische erfgenamen die door de aanwezigheid van andere erfgenamen 'asabaerfgenamen worden $\left(t a{ }^{\prime} s i b\right)$, en hierdoor hun erfaanspraken als koranisch erfgenaam verliezen

Indien zij 'asaba-erfgenaam worden, erven zij als 'asaba-erfgenaam, en wel als 'asaba bi-ghayrihâ, of als 'asaba ma'a ghayrihâ. Indien zij geen 'asaba-erfgenaam worden, erven zij als koranisch erfgenaam. Tot deze categorie behoren alleen vrouwen, te weten (art. 236): de dochter, de zoonsdochter, de volle zus en de halfzus van vaderszijde. 'Asaba bi-ghayrihâ worden:

213. Dahir 29 oktober 1962, B.O. 16 november 1962, p. 2665.

214. De reden dat de vader en de grootvader van vaderszijde (en iedere verdere generatie vaders in de agnatische lijn) in beide categorieën kunnen erven is gelegen in het feit dat zij door 'asaba-erfgenamen uit de eerste klasse (afstammelingen in agnatische lijn) als 'asaba-erfgenamen van de nalatenschap zouden worden uitgesloten. Het toekennen van een koranisch erfdeel vormt hierop een correctief, Bousquet en Peltier 1935, 128.

215. De echtgenoot (koranisch erfgenaam) kan tevens neef ('asaba-erfgenaam) van de overleden echtgenote zijn, zie noot 230. De zoon van de oom van vaderszijde (neef, 'asaba-erfgenaam) kan tevens echtgenoot (koranisch erfgenaam) of halfbroer van moederszijde (koranisch erfgenaam) van de overledene zijn, zie noot 230 en 237. De halfbroer van moederszijde (koranisch erfgenaam) kan tevens neef ('asaba-erfgenaam) van de overleden erflater zijn, zie noot 240.

216. Coulson 1971, 164; Lapanne-Joinville 1953, 8; Pesle 1940, 26. 
- $\quad$ de dochter bij aanwezigheid van een zoon;

- $\quad$ de zoonsdochter en iedere verdere generatie dochters in de agnatische $1 \mathrm{ijn}{ }^{217}$ bij aanwezigheid van een zoonszoon (dit kan zijn een broer of een neef van de zoonsdochter) en iedere verdere generatie zoonszonen van gelijke graad, of, bij aanwezigheid van een zoonszoon van verder verwijderde graad als de zoonsdochter niet op andere wijze erft;

- de volle zus bij aanwezigheid van een volle broer;

- de halfzus van vaderszijde bij aanwezigheid van een halfbroer van vaderszijde. 'Asaba ma'a ghayrihâ worden:

- de volle zus en de halfzus van vaderszijde bij aanwezigheid van een dochter of zoonsdochter.

4. Uitsluitend 'asaba-erfgenamen, de 'asaba bi-nafsihi

Tot deze categorie behoren (art. 234): de zoon, de zoonszoon, en iedere verdere generatie zonen in de agnatische lijn, de volle broer, de halfbroer van vaderszijde, de zoon van een broer, en iedere verdere generatie zonen, de oom van vaderszijde, en iedere verdere generatie ooms in de zijlijn van de vader en in de agnatische lijn, en de zoon van deze oom, en iedere verdere generatie zonen.

\section{Rangorde waarin de erfgenamen worden geroepen}

Bij het aanwijzen van de erfgenamen wordt begonnen met de koranische erfgenamen aan wie vastgestelde erfporties toekomen (art. 231). Het restant, of als er geen koranische erfgenamen zijn het geheel, valt toe aan de 'asaba-erfgenamen (art. 232). Bij ontstentenis van 'asaba-erfgenamen valt het restant toe aan de koranische erfgenamen en niet aan de Staat. In de dahir van $1962^{218}$ (art. 1) wordt namelijk bepaald dat wanneer er koranische erfgenamen zijn, de Staat zich als 'asaba-erfgenaam terugtrekt ten behoeve van de koranische erfgenamen. Het deel van de Staat wordt verdeeld onder de koranische erfgenamen naar evenredigheid van hun koranische erfporties ${ }^{219}$. Zijn er 'asabaerfgenamen noch koranische erfgenamen dan komt de nalatenschap toe aan de Staat ${ }^{220}$. Koranische erfgenamen sluiten 'asaba-erfgenamen niet van de erfenis uit,

217. Colomer 1968, 70-71.

218. Zie noot 213.

219. Wanneer er alleen koranische erfgenamen zijn en er blijft na verdeling van de koranische erfporties nog een deel van de nalatenschap over, dan treedt volgens de malikitische rechtsschool de Staat op als restanterfgenaam. In de andere sunnitische rechtsscholen zou in een dergelijk geval volgens de zogenaamde radd-doctrine het restant verdeeld worden onder de koranische erfgenamen en wel naar evenredigheid van hun erfdelen. Alleen de echtgenote blijft buiten deze verdeling. De radd werd in de malikitische leer niet erkend. Door de dahir van 1962 wordt de radd feitelijk ingevoerd, Sarehane 1993, Fasc. 2-2, 4. Onduidelijk is of men de radd-doctrine volledig volgt. Dit is met name van belang voor de vraag of ook de echtgenote meedeelt in het restant.

220. In de meeste islamitische rechtsscholen, de malikitsche uitgezonderd, viel de nalatenschap bij ontstentenis van zowel koranische als 'asaba-erfgenamen toe aan bloedverwanten die niet tot een van deze beide categorieën behoorden, de zogenaamde dhawû al-arhâm. 
ook niet indien deze laatsten in een verdere verwantschapsgraad tot de erflater staan. Mannelijke erfgenamen daarentegen sluiten vrouwelijke verwanten van een verder verwijderde graad wel van de nalatenschap uit ${ }^{221}$. Wat de afstammelingen betreft wordt dit uitgangspunt overigens gedeeltelijk doorbroken via het verplicht testament (zie p. 85-90).

\section{De koranische erfgenamen}

Binnen de groep van koranische erfgenamen is geen rangorde in de erfopvolging aangebracht. Ieder der koranische erfgenamen kan aanspraak maken op een vastgesteld deel. Of zij aanspraak maken op dit deel en wat de omvang hiervan is, wordt door verschillende factoren beïnvloed. De volgende punten dienen hierbij in de gaten te worden gehouden:

sommige koranische erfgenamen kunnen door de aanwezigheid van een andere erfgenaam 'asaba-erfgenaam worden (p. 58-59), waardoor zij als koranisch erfgenaam van hun koranische erfportie zijn uitgesloten. $\mathrm{Zij}$ erven dan nog slechts als 'asaba-erfgenaam ('asaba bi-ghayrihâ of 'asaba ma'a ghayrihâ);

sommige koranische erfgenamen kunnen door bepaalde andere erfgenamen van de erfenis worden uitgesloten (art. $253 \mathrm{j}^{\circ} 255$ );

sommige erfgenamen kunnen nooit van de nalatenschap worden uitgesloten, te weten de zoon, de dochter, de vader, de moeder, de echtgenoot en de echtgenote (art. 254);

- de omvang van de koranische erfporties is mede afhankelijk van het bestaan van bepaalde andere erfgenamen (verminderde uitsluiting, art. $253 \mathrm{j}^{\circ} 239 \mathrm{t} / \mathrm{m} 244$ en 256);

voor een aantal speciale gevallen zijn bijzondere regels gegeven (art. $257 \mathrm{t} / \mathrm{m}$ 265). Deze bijzondere gevallen en de hiervoor geldende regels worden besproken op p. 78 e.v.;

indien een kleinkind van een vooroverleden zoon krachtens verplicht testament verkrijgt, neemt hij de plaats in van de vooroverleden zoon.

\section{De 'asaba-erfgenamen}

Voor de 'asaba-erfgenamen is een rangorde vastgesteld die overeenstemt met de zogenaamde al-Jabarî-regel uit het islamitische recht ${ }^{222}$. Voor de volgorde waarin de 'asaba-erfgenamen tot het restant van de nalatenschap worden geroepen, gelden de volgende regels. De erfgenamen 'asaba bi-nafsihi zijn ondergebracht in vier klassen. Hierbij geldt dat de (mannelijke) erfgenamen uit een hogere klasse de erfgenamen uit een lagere klasse van de erfenis uitsluiten (art. 246). Tot de eerste klasse behoren de erfgenamen uit de filiale lijn, te weten de zonen, zoonszonen, en iedere verdere generatie zonen in de agnatische lijn. Tot de tweede klasse behoren de erfgenamen uit de paternale lijn, te weten de vader, de agnatische grootvader en iedere voorafgaande vader

221. Uitgezonderd de vader die de grootmoeder van moederszijde niet uitsluit van de nalatenschap.

222. Zie over de al-Jabari-regel o.m. Coulson 1971, 33-35. 
in de agnatische lijn, alsmede de volle broers en de halfbroers van vaderszijde. Tot de derde klasse behoren de zonen van de broers en iedere verdere generatie zonen. Tot de vierde klasse behoren de erfgenamen uit de zijlijn van vaderszijde, te weten de volle ooms en halfooms van vaderszijde, de ooms van vaderszijde van diens vader (volle ooms en halfooms van vaderszijde), de ooms van vaderszijde van de agnatische grootvader en iedere voorafgaande generatie ooms, en de zonen van degene die hier vermeld zijn en iedere verdere generatie zonen. Zijn er erfgenamen uit dezelfde klasse, dan sluit degene die in graad het dichtst bij de overledene staat de andere(n) van de erfenis uit (art. 247 lid 1). Zijn er erfgenamen van zowel dezelfde klasse als van dezelfde graad, dan sluit degene wiens kracht van bloedverwantschap met de overledene het sterkst is, de andere(n) van de erfenis uit (art. 247 lid 2).

De erfgenamen 'asaba bi-ghayrihâ (dochter, zoonsdochter) staan in rangorde naast de 'asaba bi-nafsihi van gelijke graad (zoon, zoonszoon) (art. 248) doch hun erfdeel is slechts de helft van het deel van een erfgenaam 'asaba bi-nafsihi.

De erfgenamen 'asaba ma'a ghayrihâ, de volle zus en de halfzus van vaderszijde, komen in de rang te staan van de volle broer respectievelijk de halfbroer van vaderszijde (art. 249).

\section{De erfdelen}

De omvang van de erfdelen van de erfgenamen wordt door de volgende regels bepaald: Voor de koranische erfgenamen geldt dat zij aanspraak maken op een vastgesteld deel van de nalatenschap (de zogenaamde koranische erfportie). De omvang van deze erfporties wordt in sommige gevallen mede bepaald door de aanwezigheid van bepaalde andere erfgenamen (art. 231, $237 \mathrm{t} / \mathrm{m}$ 244, 256, en 213 voor erfgenamen krachtens (anzîl). Wanneer het geheel der koranische etfporties de nalatenschap overschrijdt, dan worden de erfporties pro rata verminderd, door het vergroten van de noemer van de erfbreuk (de zogenaamde 'awl-methode) ${ }^{223}$. Van belang zijn voorts de regels omtrent de uitsluiting van de nalatenschap vanwege de aanwezigheid van andere erfgenamen (art. 246, 247, $252 \mathrm{t} / \mathrm{m} \mathrm{255).}$

Voor de 'asaba-erfgenamen geldt dat hun het restant toekomt. Er geldt een uitsluitingsstelsel (zie p. 60-61, art. 246 en 247). Voor erfgenamen 'asaba bi-nafsihi van gelijke klasse, graad en kracht van bloedverwantschap geldt dat het restant van de nalatenschap gelijkelijk onder hen wordt verdeeld. Voor erfgenamen 'asaba bi-ghayrihâ geldt dat hun portie de helft is van de portie van de man van gelijke graad (art. 248) ${ }^{224}$. Zij delen

223. Ajetunmobi 1988, 209-221; Colomer 1968, 95; Coulson 1971, 46-49; Pesle 1940, 98; Sarehane 1993, Fasc. 2-2, 12.

224. Khalîl ben Ish'âq, vertaald door Bousquet Tome IV 1962,87. Algemeen uitgangspunt is dat aan de man twee keer zoveel toekomt als aan de vrouw. 
in de erfenis tot maximaal hun koranische erfportie 225 . De erfgenamen 'asaba ma' $a$ ghayrihâ hebben recht op het restant als ware zij volle broers respectievelijk halfbroers van vaderszijde (art. 249). Zij delen in de erfenis tot maximaal hun koranische erfportie ${ }^{226}$. Voor alle erfgenamen zijn voorts van belang de speciale regels voor bijzondere gevallen (art. $257 \mathrm{t} / \mathrm{m} \mathrm{265)}$ ). Deze worden afzonderlijk besproken in $\$ 3$. B.6.c.

Met inachtneming van de hierboven gegeven regels wordt in de volgende twee subparagrafen per intestaat-erfgenaam nagegaan wat zijn of haar erfdeel is ${ }^{227}$. In de daarop volgende paragraaf worden de bijzondere gevallen besproken met de speciale regels die voor deze gevallen gelden ${ }^{228}$.

\section{a. Erfdelen van de koranische erfgenamen}

\section{De echigenote}

De echtgenote kan niet van de erfenis worden uitgesloten (art. 254). Zij erft uitsluitend als koranisch erfgenaam (art. 233). Haar erfportie is 1/4 (art. 240 sub 2), of 1/8 wanneer zij samenkomt met een kind of een zoonskind (of iedere verdere generatie kinderen in de agnatische lijn) (art. 240 sub 2, 241 en 256 sub 3). Komen er meerdere echtgenotes samen, dan ontvangen zij ieder een evenredig deel van de erfportie van $1 / 4$ respectievelijk $1 / 8^{229}$.

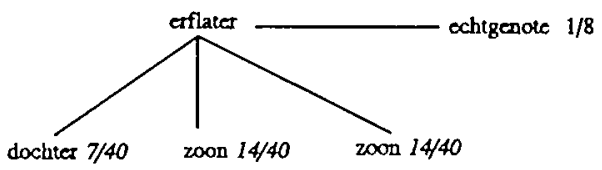

225. Colomer 1968, 97; Coulson 1971, 59.

226. Coulson 1971, 59.

227. In de literatuur over het islamitische erfrecht wordt uitvoerig aandacht besteed aan de positie van de hermafrodiet als erfgenaam. Twee aspecten krijgen hierbij in het bijzonder aandacht. Ten eerste de vraag hoe het doorslaggevende geslacht van een hermafrodiet kan worden vastgesteld. Ten tweede de vraag hoe de erfaanspraken van de hermafrodiet moeten worden berekend als geen doorslaggevend geslacht kan worden bepaald. In de leer van de malikitische rechtsschool geldt dat het erfdeel van een hermafrodiet bedraagt de helft van de som van het erfdeel van de man die hij zou zijn plus het erfdeel van de vrouw die hij zou zijn. In de hanafitische en shafi'itische rechtsschool ontvangt de hermafrodiet wiens doorslaggevend geslacht niet kan worden bepaald hetzij het erfdeel als ware hij een man hetzij het erfdeel als ware hij een vrouw, en wel het kleinste deel van deze twee. Mocht nadien het geslacht wel worden bepaald dan wordt de eerste verdeling ongedaan gemaakt (hanafitische leer) c.q. het bij de eerste verdeling gereserveerde restant alsnog aan de hermafrodiet toegekend (shafi'itische leer). Zie over een en ander o.m. Luciani 1890, 197-201, 438-446; Pesle 1940, 197-212.

228. Bij de erfgenamen zijn uitsluitend de bijzondere gevallen vermeld die van invloed kunnen zijn op zijn of haar erfdeel.

229. Colomer 1968, 79; Coulson 1971, 41; Khalil ben Ish'âq, vertaald door Bousquet Tome IV, 84 . 


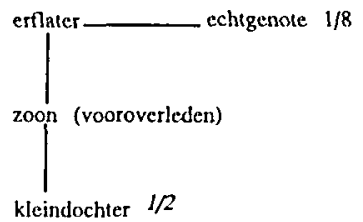

Het restant (3/8) wordt onder de asaba-erfgenamen verdeeld, en als deze er nict zijn, onder de koranische erfgenamen. Zic voor de vrasg of ook de cchigcnote decht in dit restant, noot 219.

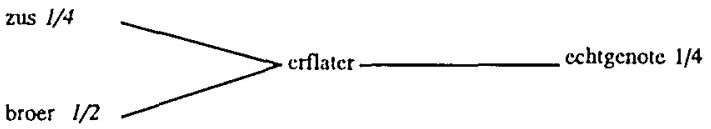

Bijzondere gevallen:

- $\quad$ wanneer zij samenkomt met twee dochters, de vader en de moeder: art. 265 (p. 84-85).

De echtgenoot

De echtgenoot kan niet van de erfenis worden uitgesloten (art. 254). Hij erft uitsluitend als koranisch erfgenaam ${ }^{230}$. Zijn erfportic is $1 / 2$ (art. 239 sub 1), of $1 / 4$ wanneer hij samenkomt met een kind of een zoonskind (of iedere verdere generatie kinderen in de agnatische lijn) (art. 240 sub 1 en 256 sub 2).

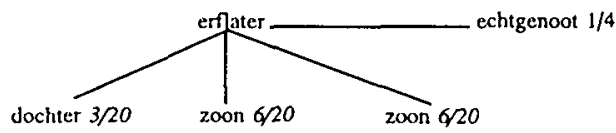

230. Behalve in het geval waarin hij in twee hoedanigheden van de erflater erft. De echtgenoot kan tevens de neef van zijn overleden echtgenote zijn, nu tussen neven en nichten geen huwelijksbeletsel bestaat. Zie hierover Coulson 1971, 164 e.v. Het bezit van twee hoedanigheden leidt tot een cumulatie van erfaanspraken. 


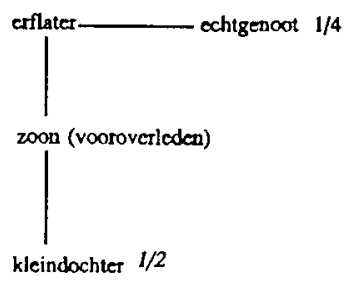

Hot restant (1/4) wondt onder de '2saba-erfgenamen verdocld, an als deze or niet zijn, onder de koranische erfgenamen.

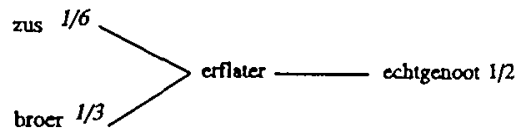

Bijzondere gevallen:

- wanneer hij samenkomt met de moeder, de grootvader, en een volle zus of halfzus van vaderszijde: art. 258 (p. 79-80);

- wanneer hij samenkomt met de moeder, en een volle zus of halfzus van vaderszijde: art. 264 (p. 84).

De dochter

De dochter kan niet van de erfenis worden uitgesloten (art. 254). Bij aanwezigheid van een zoon erft zij als erfgenaam 'asaba bi-ghayrihâ (zie p. 77) en heeft geen recht op haar koranische erfportie. Bij ontstentenis van een zoon treedt zij toe als koranisch erfgenaam. Haar erfportie is $1 / 2$ (art. 239 sub 2), of een evenredig deel van $2 / 3$ wanneer zij samenkomt met een of meer andere dochters (art. 242 sub 1).
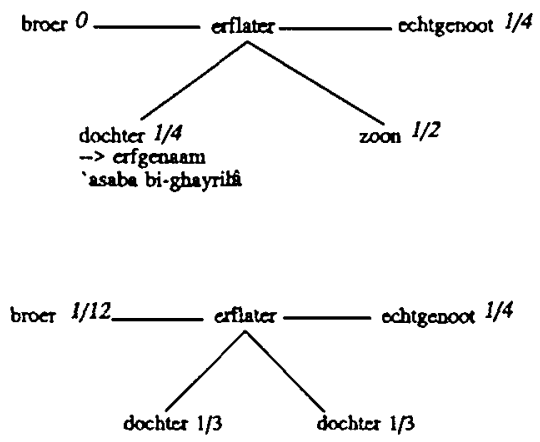
Bijzondere gevallen:

wanneer twee dochters samenkomen met de echtgenote, de vader en de moeder: art. 265 (p. 84-85).

De zoonsdochter (en iedere verdere generatie dochters in de agnatische lijn)

De zoonsdochter wordt uitgesloten van de erfenis door een zoon (art. 255 sub 1). Bij aanwezigheid van een zoonszoon erft zij als erfgenaam 'asaba bi-ghayrihâ (zie p. 77) en heeft geen recht op haar koranische erfportie. Bij ontstentenis van een zoonszoon treedt zij toe als koranisch erfgenaam. Haar erfportie is $1 / 2$ (art. 239 sub 3), 1/6 wanneer zij samenkomt met één dochter (art. 244 sub 3 en art. 256 sub 4), en een evenredig deel van $2 / 3$ wanneer zij samenkomt met een of meer andere zoonsdochters (art. 242 sub 2, art. 256 sub 4). Als koranisch erfgenaam wordt zij de facto van de erfenis uitgesloten door twee dochters. Indien haar vader is overleden en zij als intestaat-erfgenaam niet zou erven heeft zij rechten uit een verplicht testament (zie p. 85-90).
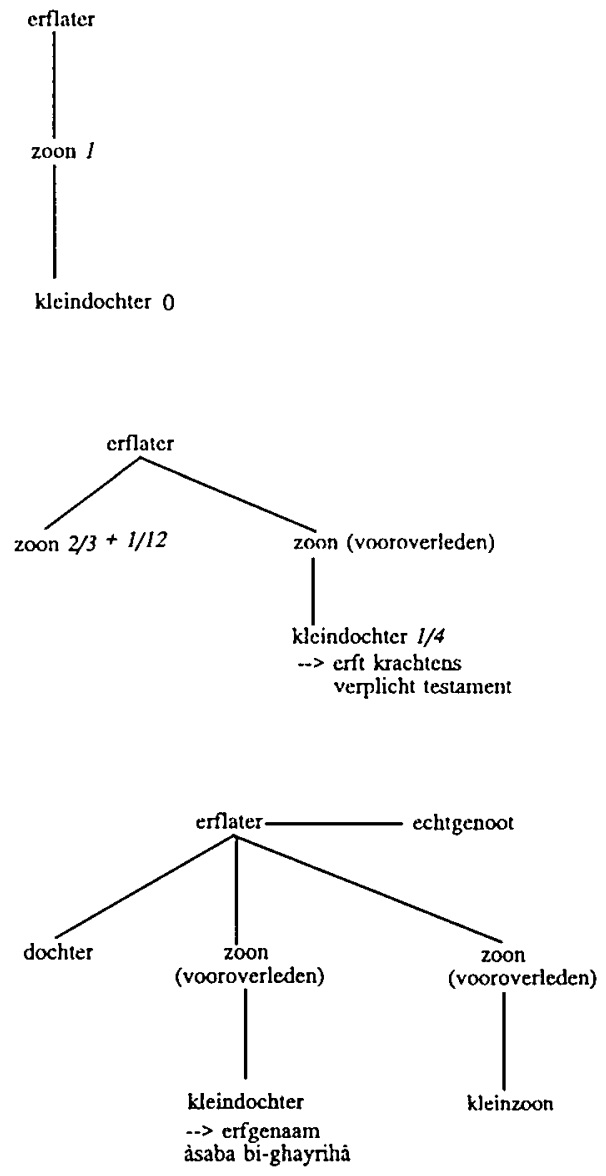


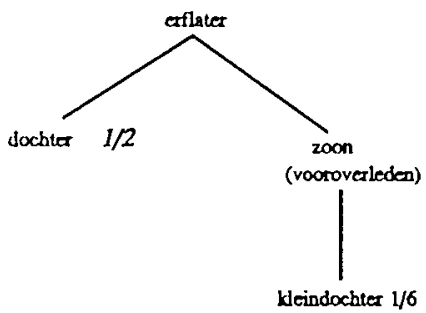

Het restant (1/3) wordt onder de 'asaba-effgenamen verdeeld, en als deze er niet zijn onder de koranische erfgenamen.

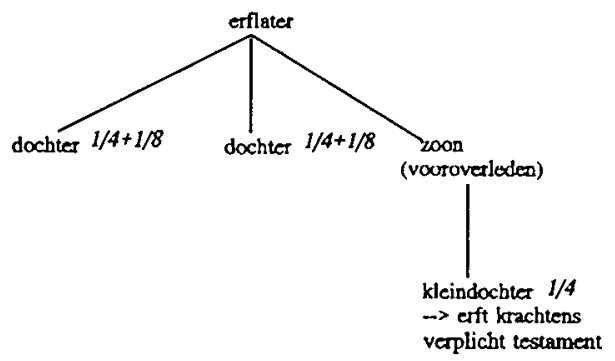

\section{De moeder}

De moeder kan niet van de erfenis worden uitgesloten (art. 254). Zij erft uitsluitend als koranisch erfgenaam (art. 233) ${ }^{231}$. Haar erfportie is 1/3 (art. 243 sub 1), of 1/6 wanneer zij samenkomt met een kind, een zoonskind (of iedere verdere generatie kinderen in de agnatische lijn), of twee of meer (ervende of uitgesloten) broers of zussen (volle, halfvolle van vaderszijde of van moederszijde)(art. 244 sub 2 en 256 sub 1).
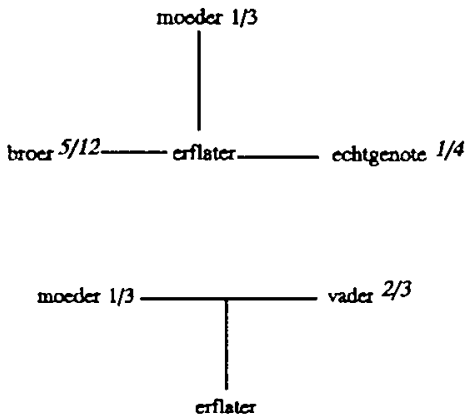

231. Behoudens in het bijzondere geval van art. 263 (zie p. 83-84) waar zij door de aanwezigheid van de vader erft als 'asaba-erfgenaam. 

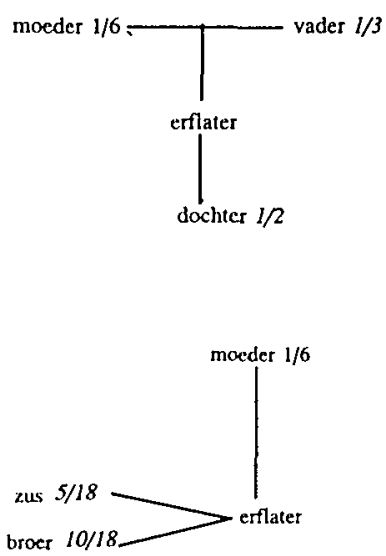

Bijzondere gevallen:

- wanneer zij samenkomt met de echtgenoot, de grootvader, en een volle zus of halfzus van vaderszijde: art. 258 (p. 79-80);

- $\quad$ wanneer zij samenkomt met de echtgenote of de echtgenoot, en de vader: art. 263 (p. 83-84);

- wanneer zij samenkomt met de echtgenoot, een volle zus of halfzus van vaderszijde: art. 264 (p. 84);

- wanneer zij samenkomt met de echtgenote, twee dochters en de vader: art. 265 (p. 84-85).

\section{De vader}

De vader kan niet van de erfenis worden uitgesloten (art. 254). Hij erft zowel als koranisch erfgenaam als erfgenaam 'asaba bi-nafsihi (art. 235). Bij afwezigheid van een kind of een zoonskind (of iedere verdere generatie kinderen in de agnatische lijn) erft hij uitsluitend als 'asaba-erfgenaam (zie p. 73) ${ }^{232}$. Als koranisch erfgenaam is zijn erfportie 1/6 wanneer hij samenkomt met een kind of een zoonskind (of iedere verdere generatie kinderen in de agnatische lijn) (art. 244 sub 1 en 256 sub 6). Vervolgens deelt hij nog in het restant als 'asaba-erfgenaam (art. 250) (zie p. 73).

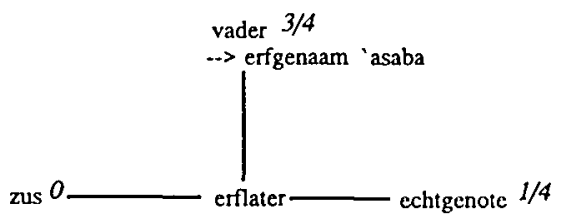



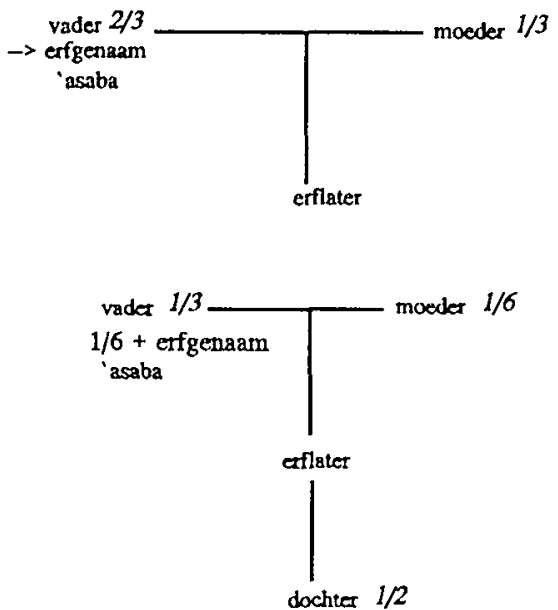

Bijzondere gevallen:

- wanneer hij samenkomt met de echtgenote of de echtgenoot, en de moeder: art. 263 (p. 83-84);

wanneer hij samenkomt met de echtgenote, twee dochters en de moeder: art. 265 (p. 84-85).

De grootmoeder en iedere verdere generatie moeders ${ }^{233}$

De grootmoeder van moederszijde wordt uitgesloten van de erfenis door de moeder (art. 255 sub 12). De grootmoeder van vaderszijde wordt uitgesloten van de erfenis door de vader of de moeder (art. 255 sub 13) ${ }^{234}$. Een grootmoeder wordt uitgesloten van de erfenis door een grootmoeder van moederszijde van een meer nabije graad (art. 255 sub 14) ${ }^{235}$. De grootmoeder erft uitsluitend als koranisch erfgenaam (art. 233). Haar erfportie is 1/6 (art. 244 sub 6), of een evenredig deel van 1/6 wanneer zij samenkomt met een andere grootmoeder van gelijke graad of wanneer een grootmoeder van vaders-

233. Zowel in de agnatische als in de maternale lijn. Wat de verdere generatie moeders van vaderszijde betreft geldt dat in de malikitische rechtsschool slechts erfrecht wordt toegekend aan de moeder van de vader, de moeder van deze moeder en iedere verdere generatie moeders in de maternale lijn. In de hanbalitische rechtsschool komt ook erfrecht toe aan de moeder van de grootvader (en verder iedere verdere generatie moeders in de maternale lijn). In de hanafitische en de shafi'itische rechtsscholen hebben alle grootmoeders en verdere generatie moeders erfrecht, Coulson 1971, 61.

234. In de hanbalitische rechtsschool wordt de grootmoeder van vaderszijde niet door de vader uitgesloten, Coulson 1971, 62.

235. In de hanafitische en de hanbalitische rechtsscholen wordt geen onderscheid gemaakt tussen de grootmoeders uit de paternale en de maternale lijn, Coulson 1971, 61. 
zijde samenkomt met een grootmoeder van moederszijde van een verder verwijderde graad (art. 244 sub 6).

De grootvader van vaderszijde (en iedere verdere generatie vaders in de agnatische lijin) 236

De grootvader van vaderszijde wordt uitgesloten van de erfenis door de vader (art. 255 sub 2). Hij erft zowel als koranisch erfgenaam als erfgenaam 'asaba bi-nafsihi (art. 235). Als koranisch erfgenaam is zijn erfportie 1/6 wanneer hij samenkomt met een kind of een zoonskind (of verdere generatie kinderen in de agnatische lijn) (art. 244 sub 7 en 256 sub 7). Vervolgens deelt hij nog in het restant als asaba-erfgenaam (art. 250) (zie p. 74-75). Zijn erfportie is $1 / 3$ wanneer hij samenkomt met broers en als $1 / 3$ voor hem voordeliger is (dan het deel dat hij ingevolge art. $251 \mathrm{j}^{0} 257$, zie p. 74-75, zou ontvangen) (art. 243 sub 3 ).

Bijzondere gevallen:

- wanneer hij samenkomt met de echtgenoot, de moeder, en een volle zus of halfzus van vaderszijde: art. 258 (p. 79-80);

- wanneer hij samenkomt met de echtgenoot, de moeder, een halfbroer van vaderszijde, en halfbroers of halfzussen van moederszijde: art. 259 (p. 80-81);

- wanneer hij samenkomt met de echtgenoot, de moeder, een volle broer, en halfbroers of halfzussen van moederszijde: art. 260 (p. 81);

wanneer hij samenkomt met de moeder, en een volle zus of halfzus van vaderszijde: art. 261 (p. 82).

De volle zus

De volle zus wordt uitgesloten van de erfenis door de vader, de zoon en de zoonszoon (en iedere verdere generatie zonen in de agnatische lijn) (art. 255 sub 3). Bij aanwezigheid van een volle broer erft zij als erfgenaam 'asaba bi-ghayrihâ (zie p. 77-78) en heeft zij geen recht op haar koranische erfportie. Bij ontstentenis van een broer en aanwezigheid van een dochter of zoonsdochter (en verdere generatie dochters in de agnatische lijn) erft zij als erfgenaam 'asaba ma'a ghayrihâ (zie p. 78) en heeft zij geen recht op haar koranische erfportie. Bij ontstentenis van een volle broer en een dochter of zoonsdochter, treedt zij toe als koranisch erfgenaam. Haar erfportie is $1 / 2$ (art. 239 sub 4), of een evenredig deel van $2 / 3$ wanneer zij samenkomt met een of meer andere volle zussen (art. 242 sub 3).

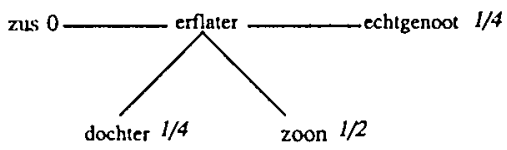

236. De grootvader van moederszijde heeft geen erfrecht. 

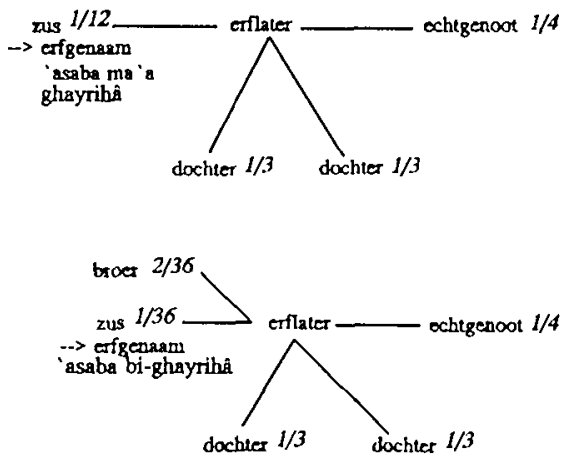

zus $1 / 2$ ochtgenoot $1 / 2$

Bijzondere gevallen:

wanneer zij samenkomt met de grootvader, volle broers, halfbroers en halfzussen van vaderszijde: art. 257 (p. 78-79);

wanneer zij samenkomt met de echtgenoot, de moeder, en de grootvader: art. 258 (p. 79-80);

- $\quad$ wanneer zij samenkomt met de moeder en de grootvader: art. 261 (p. 82);

- wanneer zij samenkomt met de echtgenoot en de moeder: art. 264 (p. 84).

\section{De halfzus van vaderszijde}

De halfzus van vaderszijde wordt uitgesloten van de erfenis door de zoon, de zoonszoon (en iedere verdere generatie zonen in de agnatische lijn), de vader, of een volle broer (art. 255 sub $4 j^{\circ} 255$ sub 3 en 246). Bij aanwezigheid van een halfbroer van vaderszijde erft zij als erfgenaam 'asaba bi-ghayrihâ (zie p. 77-78) en heeft zij geen recht op haar koranische erfportie. Bij ontstentenis van een halfbroer van vaderszijde en aanwezigheid van een dochter of zoonsdochter (en verdere generatie dochters in de agnatische lijn) erft zij als erfgenaam 'asaba ma'a ghayrihâ (zie p. 78) en heeft zij geen recht op haar koranische erfportie. Bij ontstentenis van een halfbroer van vaderszijde, of halfbroer en dochter of zoonsdochter, treedt zij toe als koranisch erfgenaam. Haar erfportie is 1/2 (art. 239 sub 5), 1/6 wanneer zij samenkomt met één volle zus (art. 244 sub 4), en een evenredig deel van $2 / 3$ wanneer zij samenkomt met een of meer andere halfzussen van vaderszijde (art. 242 sub 4). Als koranisch erfgenaam wordt zij de facto van de erfenis uitgesloten door twee volle zussen. 

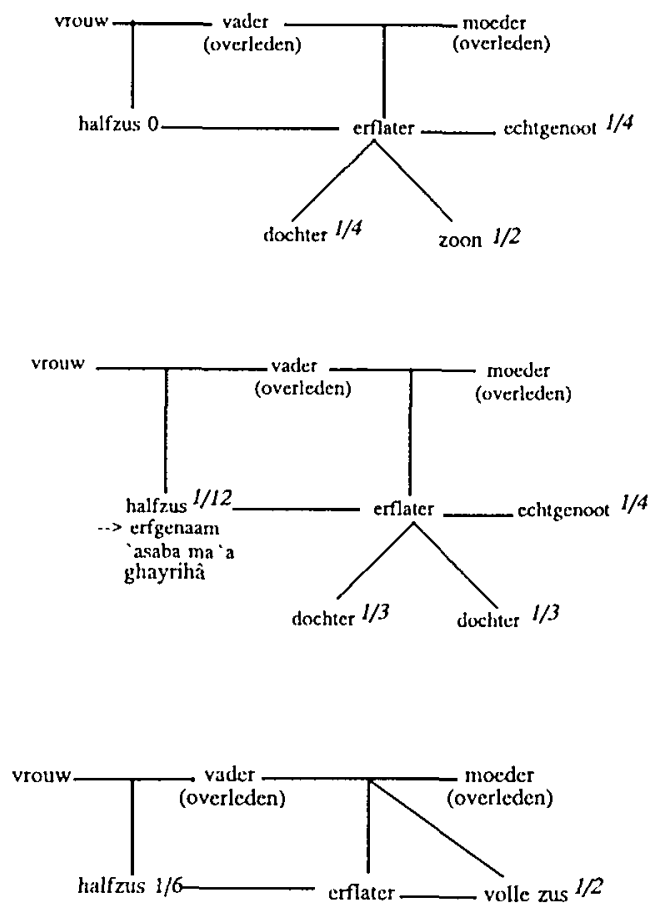

Het tesfam (I/3) wordt onder de 'asaba-tefgenamen verdecld, en als deze er niet zijn, onder de koranische erfgenamen.

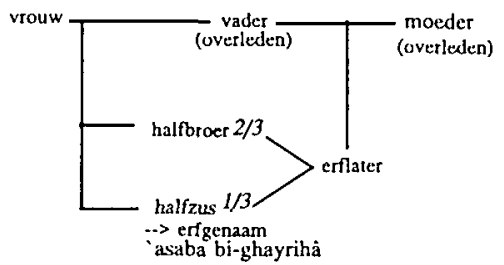

Bijzondere gevallen:

- wanneer zij samenkomt met de grootvader, volle broers en zussen, en halfbroers van vaderszijde: art. 257 (p. 78-79);

wanneer zij samenkomt met de echtgenoot, de moeder, en de grootvader: art. 258 (p. 79-80); 
wanneer zij samenkomt met de moeder en de grootvader: art. 261 (p. 82); wanneer zij samenkomt met de echtgenoot en de moeder: art. 264 (p. 84).

\section{De halfzus van moederszijde}

De halfzus van moederszijde wordt uitgesloten van de erfenis door een kind, een zoonskind (en iedere verdere generatie kinderen in de agnatische lijn), en agnatische ascendenten (art. $255 \mathrm{sub} \mathrm{11).} \mathrm{Zij} \mathrm{erft} \mathrm{uitsluitend} \mathrm{als} \mathrm{koranisch} \mathrm{erfgenaam} \mathrm{(art.} \mathrm{233).} \mathrm{Haar}$ erfportie is 1/6 (art. 244 sub 5), of een evenredig deel van 1/3 wanneer zij samenkomt met een of meer andere halfzussen van moederszijde of halfbroers van moederszijde (art. 243 sub 2).

Bijzondere gevallen:

- wanneer zij samenkomt met de grootvader, de echtgenoot, de moeder, en een volle broer: art. 260 (p. 81);

- wanneer zij samenkomt met de echtgenoot, de moeder of grootmoeder, en volle broers (en volle zussen): art. 262 (p. 82-83).

\section{De halfbroer van moederszijde}

De halfbroer van moederszijde wordt uitgesloten van de erfenis door een kind, een zoonskind (en verdere generatie kinderen in de agnatische lijn), en agnatische ascendenten (art. 255 sub 11). Hij erft uitsluitend als koranisch erfgenaan ${ }^{237}$. Zijn erfportie is 1/6 (art. 244 sub 5), of een evenredig deel van 1/3 wanneer hij samenkomt met een of meer andere halfbroers van moederszijde of halfzussen van moederszijde (art. 243 sub 2).

Bijzondere gevallen:

- wanneer hij samenkomt met de grootvader, de echtgenoot, de moeder, en een volle broer: art. 260 (p. 81);

- $\quad$ wanneer hij samenkomt met de echtgenoot, de moeder of grootmoeder, en volle broers (en volle zussen): art. 262 (p. 82-83).

b. Erfdelen van de 'asaba-erfgenamen

Nadat de koranische erfporties onder de koranische erfgenamen zijn verdeeld, wordt het restant verdeeld onder de 'asaba-erfgenamen.

237. Behalve in het geval waarin hij in twee hoedanigheden van de erflater erven kan. De halfbroer van moederszijde kan tevens neef van de overiedene zijn (Khalil ben Ish'âq, vertaald door Bousquet Tome IV 1962, 86), namelijk wanneer zijn moeder is hertrouwd met de broer van zijn vader, de vader van zijn neef, Coulson 1971, 165 e.v. Het bezit van twee hoedanigheden leide hier tot een cumulatie van erfaanspraken. 


\section{A. 'asaba bi-nafsihi}

\section{Klasse 1}

De zoon

De zoon kan niet van de erfenis worden uitgesloten (art. 254). Hij erft uitsluitend als erfgenaam 'asaba (art. 234). Hij is de eerstgerechtigde van de 'asaba-erfgenamen op het restant van de nalatenschap. Bij aanwezigheid van een of meer andere zonen van gelijke klasse, graad en kracht van bloedverwantschap, wordt de erfenis gelijkelijk onder hen verdeeld (art. 247 lid 3). Bij aanwezigheid van een dochter ("asaba bighayrihâ-erfgenaam), is de portie van de zoon gelijk aan die van twee dochters.

De zoonszoon (en iedere verdere generatie zonen in de agnatische lijn)

$\mathrm{Hij}$ erft uitsluitend als erfgenaam 'asaba (art. 234). De zoonszoon wordt uitgesloten van de erfenis door een zoon (art. 247 lid 1 en 255 sub 1). Komt hij samen met een of meer andere zoonszonen van gelijke klasse, graad en kracht van bloedverwantschap, dan wordt de erfenis gelijkelijk onder hen verdeeld (art. 247 lid 3). Bij aanwezigheid van een zoonsdochter, is de portie van de zoonszoon gelijk aan die van twee zoonsdochters. Indien zijn vader is overleden en hij als intestaat-erfgenaam niet zou erven heeft hij rechten uit cen verplicht testament (zie p. 85-90).

\section{Klasse 2}

\section{De vader}

De vader wordt als 'asaba-erfgenaam uitgesloten van de erfenis door een erfgenaam uit de eerste klasse (art. 246). In dit geval erft hij uitsluitend als koranisch erfgenaam (zie p. 67-68).

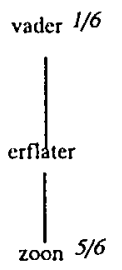

Bijzondere gevallen:

- wanneer hij samenkomt met de echtgenote of de echtgenoot, en de moeder: art. 263 (p. 83-84). 


\section{De agnatisch grootvader}

De agnatisch grootvader wordt als 'asaba-erfgenaam uitgesloten van de erfenis door een erfgenaam uit de eerste klasse (art. 246) en door de vader (art. 247 lid I en 255 sub 2). Bij aanwezigheid van een erfgenaam uit de eerste klasse kan hij uitsluitend als koranisch erfgenaam erven (zie p. 69). Komt hij samen met volle broers en volle zussen en/of halfbroers en halfzussen van vaderszijdc, dan geldt de regeling uit art. 251. Deze komt, met inachtneming van het bepaalde in art. 257 , op het volgende neer ${ }^{238}$ :

1. door aanwezigheid van de grootvader delen de zussen als 'asaba-erfgenamen;

2. alle broers en zussen en de grootvader worden bij elkaar opgeteld;

3. het deel van de grootvader is even groot als het deel van een broer;

4. de portie van een man (dus van de grootvader en van een broer) is gelijk aan die van twee vrouwen (art. 257);

5a. zijn er geen koranische erfgenamen (en geen 'asaba-erfgenamen uit de eerste klasse of de vader), dan ontvangt de grootvader $1 / 3$ van het gehele vermogen, of zijn deel na toepassing van de regels $1 \mathrm{t} / \mathrm{m} 4$.

5b. bij samenkomst met koranische erfgenamen, kan de grootvader kiezen tussen zijn koranische erfportic van $1 / 6$, of $1 / 3$ van het deel van de nalatenschap dat overblijft na verdeling onder koranische erfgenamen, of, als 'asaba-erfgenaam, zijn deel na toepassing van de regels $1 \mathrm{t} / \mathrm{m} 4$.
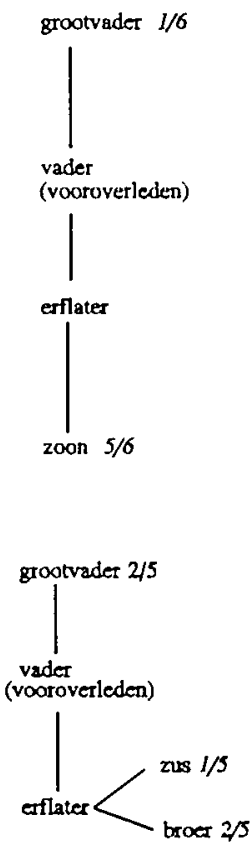


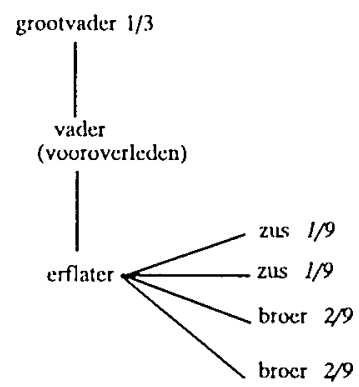

\section{De volle broer}

Hij erft uitsluitend als erfgenaam 'asaba (art. 234). De volle broer wordt uitgesloten van de erfenis door een erfgenaam uit de eerste klasse (art. 246), en door de vader (art. 255 sub 3). Komt hij samen met een of meer andere volle broers van gelijke klasse en graad, dan word de erfenis gelijkelijk onder hen verdeeld (art. 247 lid 3). Bij aanwezigheid van een volle zus, is de portie van de volle broer gelijk aan die van twee volle zussen (art. 248 lid 3).

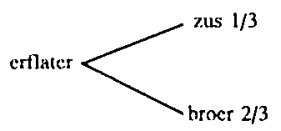

Bijzondere gevallen:

- wanneer hij samenkomt met de grootvader en halfbroers (en halfzussen) van vaderszijde: art. 257 (p. 78-79);

- wanneer hij samenkomt met de grootvader, de echtgenoot, de moeder, en halfbroers of halfzussen van moederszijde: art. 260 (p. 81);

- wanneer hij samenkomt met de echtgenoot, de moeder of grootmoeder, en halfbroers of halfzussen van moederszijde: art. 262 (p. 82-83).

De halfbroer van vaderszijde

Hij erft uitsluitend als erfgenaam 'asaba (art. 234). De halfbroer van vaderszijde wordt uitgesloten van de erfenis door een erfgenaam uit de eerste klasse (art. 246), de vader (art. 255 sub 4), en de volle broer (art. 247 lid 3). Hij wordt níét uitgesloten door een volle zus ${ }^{239}$. Komt hij samen met een of meer andere halfbroers van gelijke klasse en graad, dan wordt de erfenis gelijkelijk onder hen verdeeld (art. 247 lid 3). Bij aan-

239. Uitzondering: indien de volle zus als erfgenaam 'asaba ma'a ghayrihâ erft. Dit is het geval bij aanwezigheid van een dochter of zoonsdochter en afwezigheid van een volle broer. In dit geval sluit zij de halfbroer van vaderszijde wel uit omdat zij dan in de positie erft van een volle broer, Colomer 1968 , 92 . 
wezigheid van een halfzus van vaderszijde, is de portie van de halfbroer van vaderszijde gelijk aan die van twee halfzussen van vaderszijde (art. 248 lid 3).
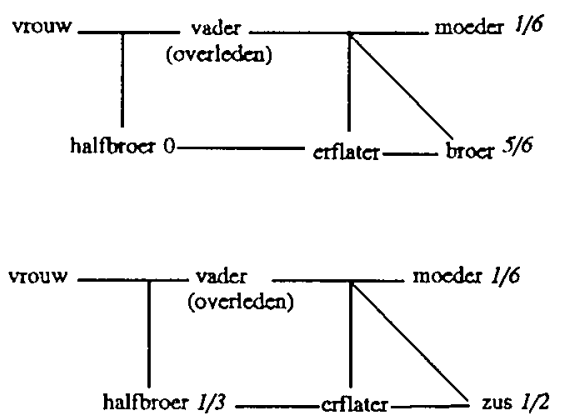

Bijzondere gevallen:

- wanneer hij samenkomt met de grootvader en volle broers of volle zussen van vaderszijde: art. 257 (p. 78-79);

- wanneer hij samenkomt met de grootvader, de echtgenoot, de moeder, en halfbroers of halfzussen van moederszijde: art. 259 (p. 80-81).

Klasse 3

De zonen van de broers (en iedere verdere generatie zonen)

Zij erven uitsluitend als erfgenaam 'asaba. De zonen van de broers worden uitgesloten van de erfenis door een erfgenaam uit de eerste of de tweede klasse (art. 246 en 255 sub 5 en 6). Degene die in graad het dichtst bij de overledene staat sluit de andere(n) van de erfenis uit (art. 247 lid 1). Komt een zoon van een broer samen met een of meer andere zonen van broers van gelijke klasse, graad en kracht van bloedverwantschap, dan wordt de erfenis gelijkelijk onder hen verdeeld (art. 247 lid 3).

Klasse 4

Ooms (volle ooms en halfooms in de zijlijn van de vader) van de overledene, van de vader, van de agnatisch grootvader en iedere voorafgaande generatie ooms

$\mathrm{Zij}$ erven uitsluitend als erfgenaam 'asaba (art. 234). Zij worden uitgesloten van de erfenis door een erfgenaam uit de eerste, tweede of derde klasse (art. 246 en 255 sub 7 en 8). Degene die in graad het dichtst bij de overledene staat sluit de andere(n) van de erfenis uit (art. 247 lid 1). Zijn zij van dezelfde graad, dan sluit degene wiens kracht van bloedverwantschap met de overledene het sterkst is, de andere(n) van de erfenis uit (art. 247 lid 2). Bij gelijke klasse, graad en kracht van bloedverwantschap, wordt de erfenis gelijkelijk onder hen verdeeld (art. 247 lid 3). 


\section{Zonen van de hiervoor genoemde ooms}

$\mathrm{Zij}$ erven uitsluitend als erfgenaam 'asaba (art. 234) ${ }^{240}$. Zij worden uitgesloten van de erfenis door een erfgenaam uit de eerste, tweede of derde klasse (art. 246 en 255 sub 9 en 10). Degene die in graad het dichtst bij de overledene staat sluit de andere(n) van de erfenis uit (art. 247 lid 1). Zijn zij van dezelfde graad, dan sluit degene wiens kracht van bloedverwantschap met de overledene het sterkst is, de andere(n) van de erfenis uit (art. 247 lid 2). Bij gelijke klasse, graad en kracht van bloedverwantschap, wordt de erfenis gelijkelijk onder hen verdeeld (art. 247 lid 3).

\section{B. 'asaba bi-ghayrihâ}

Erfgenamen 'asaba bi-ghayrihâ zijn de dochter bij aanwezigheid van een zoon, de zoonsdochter bij aanwezigheid van een zoonszoon (etcetera), de volle zus bij aanwezigheid van een volle broer, en de halfzus van vaderszijde bij de aanwezigheid van een halfbroer van vaderszijde. Zoals hierboven is vermeld, staan de erfgenamen 'asaba bighayrihâ in rangorde gelijk aan ofwel naast de 'asaba bi-hafsihi van gelijke graad (art. 248) (zie voor de dochter p. 73; voor de zoonsdochter (en iedere verdere generatie dochters in de agnatische lijn) p. 73; voor de volle zus p. 75; voor de halfzus van vaderszijde p. 75-76). Het erfdeel van de 'asaba bi-ghayrihâ is de helft van de portie van de man van gelijke graad. De 'asaba bi-ghayrihâ delen in de erfenis tot maximaal hun koranische erfportie.
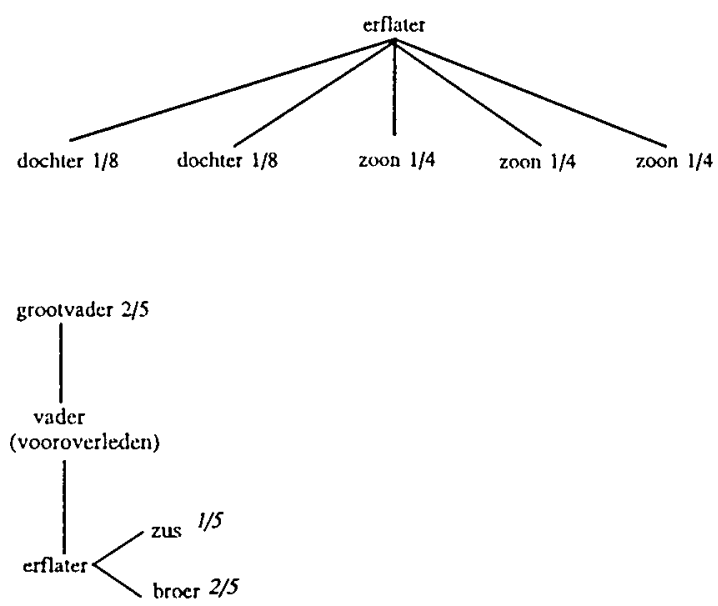

240. Behalve in het geval waarin hij in twee hoedanigheden van de erflater erven kan. De neef kan tevens echtgenoot zijn van de overleden echtgenote, nu tussen neven en nichten geen huwelijksbeletsel bestaat. Voorts kan een neef halfbroer van moederszijde van de overledene zijn, namelijk wanneer zijn moeder henrouwt met de broer van zijn vader, de vader van zijn neef, Coulson 1971, 165 e.v. Het bezit van twee hoedanigheden leidt hier tot een cumulatie van erfaanspraken. 
Bijzondere gevallen:

Voor de volle zus:

- wanneer zij samenkomt met (een volle broer,) de grootvader en halfbroers van vaderszijde (en halfzussen van vaderszijde): art. 257 (p. 78-79);

wanneer zij samenkomt met (een volle broer,) de echtgenoot, de moeder, en halfbroers of -zussen van moederszijde: art. 260 (p. 81);

wanneer zij samenkomt met (een volle broer, ) de echtgenoot, de moeder of grootmoeder, en halfbroers of -zussen van moederszijde: art. 262 (p. 82-83).

Voor de halfzus van vaderszijde:

wanneer zij samenkomt met (een halfbroer van vaderszijde,) de grootvader en volle broers of zussen: art. 257 (p. 78-79);

wanneer zij samenkomt met (een halfbroer van vaderszijde,) de echtgenoot, de moeder, en halfbroers of halfzussen van moederszijde: art. 259 (p. 80-81).

C. 'asaba ma'a ghayrihâ

Erfgenamen 'asaba ma'a ghayrihâ zijn de volle zus en de halfzus van vaderszijde bij aanwezigheid van een dochter of zoonsdochter. Zoals hierboven is vermeld, komen de erfgenamen 'asaba ma'a ghayrihâ, de volle zus en de halfzus van vaderszijde, in de rang te staan van de volle broer respectievelijk de halfbroer van vaderszijde (art. 249). De erfgenamen 'asaba ma'a ghayrihâ hebben recht op het restant als ware zij volle broer respectievelijk halfbroer van vaderszijde (zie voor de volle zus p. 75; voor de halfzus van vaderszijde p. 75-76). Zij delen in de erfenis tot maximaal hun koranische erfportie.

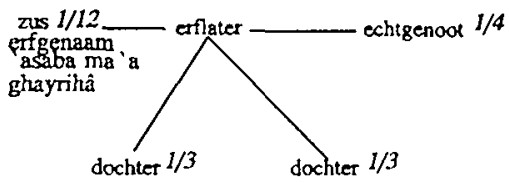

c. Bijzondere gevallen

Art. 257 Het geval van de Optelling, ofwel het geval van de $M u^{\prime} a \hat{d} d a h^{241}$

Samenkomen: grootvader, volle broers en zussen, halfbroers en halfzussen van vaderszijde.

241. De voor dit geval gegeven regel geldt in de malikitische, de shafi'itische en de hanbalitische leer, maar wordt verworpen in de hanafitische leer. In de hanafitische rechtsschool sluit de grootvader alle broers en zussen van de erfenis uit, Coulson 1971, 80-85, i.h.b. 85; Pesle 1940, 49-52. 
Komen volle broers (en volle zussen) samen met halfbroers van vaderszijde (en halfzussen van vaderszijde), dan worden alle broers en zussen en de grootvader bij elkaar opgeteld. De grootvader ontvangt hetzelfde deel als een broer. De portie van een man is gelijk aan die van twee vrouwen. Als echter $1 / 3$ van de nalatenschap voor de grootvader voordeliger is, neemt hij (op grond van art. 251) 1/3 deel. Volle broers sluiten vervolgens halfbroers en halfzussen van vaderszijde van de erfenis uit.

Is er slechts één volle zus die samenkomt met halfbroers (en halfzussen) van vaderszijde, dan worden de delen van de broers en zussen en van de grootvader bij elkaar opgeteld. De grootvader ontvangt hetzelfde deel als cen halfbroer. De volle zus neemt haar volledige koranische erfportic. De rest wordt verdeeld tussen de halfbroers en halfzussen van vaderszijde en de grootvader, zodanig dat de portie van een man gelijk is aan die van twee vrouwen. Als echter $1 / 3$ van de nalatenschap voor de grootvader voordeliger is, neemt hij (op grond van art. 251) 1/3 deel.

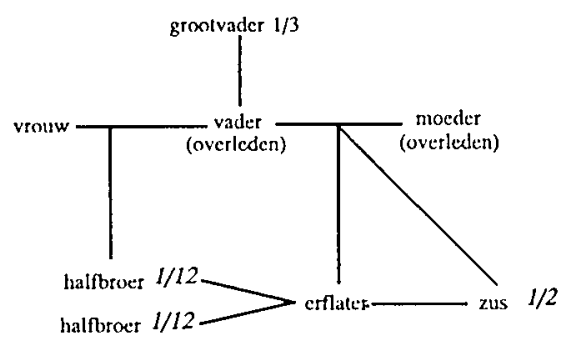

Art. 258 Het geval van de Akdariyya en de Gharrâ, ${ }^{242}$

Samenkomen: de echtgenoot, de moeder, de grootvader, en een volle zus of halfzus van vaderszijde.

De echtgenoot zou recht hebben op $1 / 2$; de moeder op $1 / 3$. De erfporties van de grootvader $(1 / 6)$ en van de zus (1/2) worden opgeteld en het totaal wordt tussen hen beiden verdeeld, zodanig dat de portie van de man (de grootvader) gelijk is aan die van twee vrouwen (zussen). Dat wil zeggen: voor de grootvader $2 / 3$ van $4 / 6(1 / 6+1 / 2)=8 / 18$ en voor de zus $1 / 3$ van $4 / 6(1 / 6+1 / 2)=4 / 18$. Omdat de erfporties het geheel der nalatenschap overschrijden wordt de noemer van $1 / 6$ vergroot tot $1 / 9$ (met de grootste gemene deler 27).

242. De voor dit geval gegeven regel geldt in de malikitische (Khalil ben Ish'âq, vertaald door Bousquet Tome IV 1962, 85-86), de shafi' itische en de hanbalitische leer, doch niet in de hanafitische leer. Colomer 1968, 119-121; Coulson 1971, 88-90; Pesle 1940, 56-60. 
Resultaat van de regel:

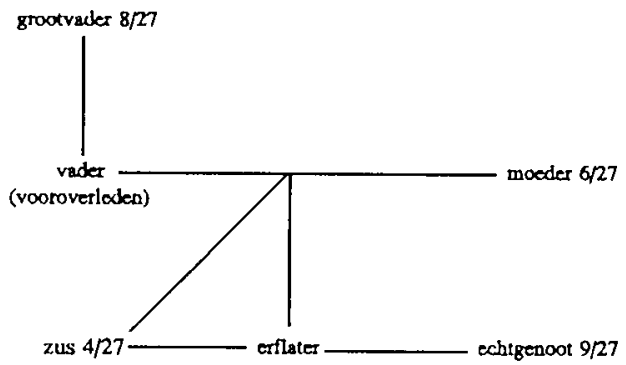

De voor dit geval gegeven regel is een verbijzondering van de regeling uit art. 251 voor het geval waarin ook koranische erfgenamen aanwezig zijn, en de 'awl, de vermindering van erfporties door het vergroten van de noemer, wordt toegepast. Door de regel uit art. 251 maakt de grootvader de zus tot erfgenaam 'asaba bi-ghayrihâ. Als de grootvader zijn koranische erfportie van $1 / 6$ neemt, zou er na de verdeling onder de koranische erfgenamen niets voor de zus overblijven.

\section{Art. 259 Het geval al-Mâlikiyyah ${ }^{243}$}

De grootvader komt samen met: de echtgenoot, de moeder, een halfbroer (en halfzus) van vaderszijde, en halfbroers of halfzussen van moederszijde.

echtgenoot

moeder

grootvader

halfbroer van vaderszijde

halfbroers en halfzussen van moederszijde 0

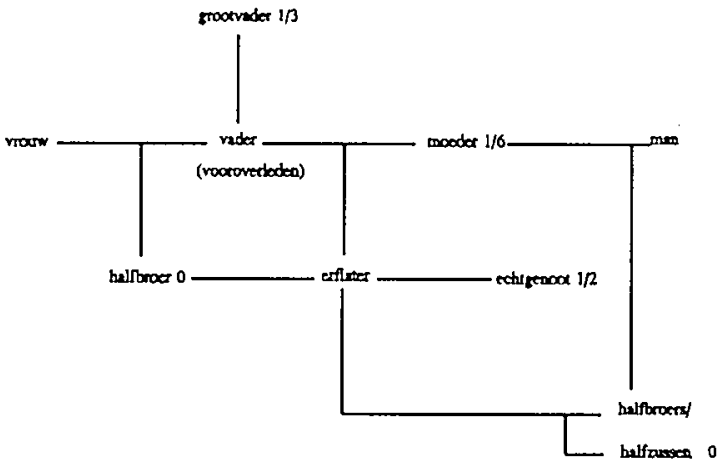

243. De voor dit geval gegeven regel geldt alleen in de malikitische leer, Colomer 1968, 121-122; Coulson $1971,87-88$. 
Zonder de in art. 259 neergelegde regel zou de grootvader de halfbroers en halfzussen van moederszijde van de erfenis hebben uitgesloten. De grootvader en de halfbroer van vaderszijde zouden ieder $1 / 6$ hebben gekregen. Reden voor het formuleren van de regel is geweest dat bij afwezigheid van de grootvader de halfbroers en halfzussen van moederszijde niet van de erfenis zouden zijn uitgesloten en hun koranische erfportie zouden hebben gekregen waardoor voor de halfbroers en halfzussen van vaderszijde niets meer zou resteren. De regel voorkomt dat halfbroers van vaderszijde hun erfrecht alleen op grond van de aanwezigheid van de grootvader krijgen.

Art. 260 Het geval analoog aan al-Mâlikiyyah ${ }^{244}$

De grootvader komt samen met: de echtgenoot, de moeder, een volle broer (en volle zus), en halfbroers of halfzussen van moederszijde.

echtgenoot

moeder

grootvader

volle broer
$1 / 2$ (koranische erfportie wordt niet gewijzigd)

$1 / 6$ (koranische erfportie wordt niet gewijzigd)

$1 / 3$ (de rest na verdeling van de koranische porties)

halfbroers en halfzussen van moederszijde 0

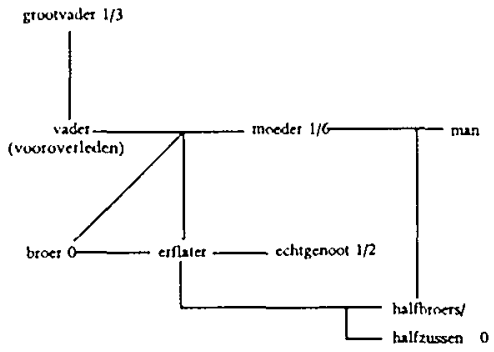

Wanneer, bij afwezigheid van de grootvader, volle broers door de aanwezigheid van halfbroers of halfzussen van de erfenis zouden zijn uitgesloten, delen de volle broers op grond van art. 262 met de halfbroers en halfzussen van moederszijde. De volle broer zou dan evenveel ontvangen als de halfbroer van moederszijde. De regel voorkomt dat volle broers hun erfrecht alleen op grond van de aanwezigheid van de grootvader krijgen door hen ook in dit geval de status van halfbroer van moederszijde te geven, die door de grootvader wordt uitgesloten.

244. De voor dit geval gegeven regel geldt alleen in de malikitische leer, Colomer 1968, 122: Coulson $1971,87-88$. 
Art. 261 Het geval van de Verscheurden, ofwel het geval van de Khuraqâ, ${ }^{245}$

Samenkomen: de moeder, de grootvader, een volle zus of halfzus van vaderszijde.

Het erfdeel van de moeder is $1 / 3$ (of $1 / 6$ bij meerdere zussen) (koranische erfportie wordt niet gewijzigd). Wat overblijft delen de grootvader en de zussen zodanig dat de portie van de man (de grootvader) gelijk is aan die van twee vrouwen (zussen) ${ }^{246}$.

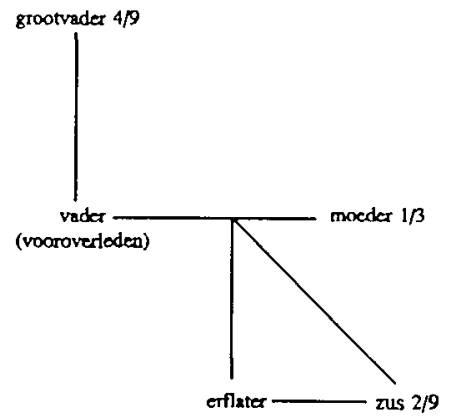

Zonder deze regeling zouden de zussen en grootvader als koranische erfgenamen erven met een erfportie van respectievelijk voor de zus $1 / 2$ (of meerdere zussen samen $2 / 3$ ), voor de grootvader $1 / 3$, en zouden de noemers moeten worden vergroot door middel van de 'awl.

Art. 262 Het geval van de Onderlinge Verdeling, ofwel het geval van de Himâriyya of de Mushtaraka ${ }^{247}$

Samenkomen: de echtgenoot, de moeder of grootmoeder, halfbroers en halfzussen van moederszijde, en volle broers en volle zussen.

echtgenoot $1 / 2$ (koranische erfportie wordt niet gewijzigd).

moeder $\quad 1 / 6$ (koranische erfportie wordt niet gewijzigd).

Het overblijvende deel (1/3) wordt, zonder onderscheid naar geslacht, gelijkelijk verdeeld onder de volle broers en de volle zussen, de halfbroers en halfzussen van moederszijde.

245. Colomer 1968, 127-128; Coulson 1971, 79-80; Pesle 1940, 55.

246. Deze regel geld niet in de hanafitische leer, Coulson 1971,80 .

247. De voor dit geval gegeven regel geldt in de malikitische (Khalîl ben Ish'âq, vertaald door Bousquet Tome IV 1962, 86) en de shafi'itische rechtsscholen. De Himâriyya-regel wordt door de hanafieten en de hanbalieten verworpen, Colomer 1968, 128-129; Coulson 1971, 73-77; Pesle 1940, 55. 


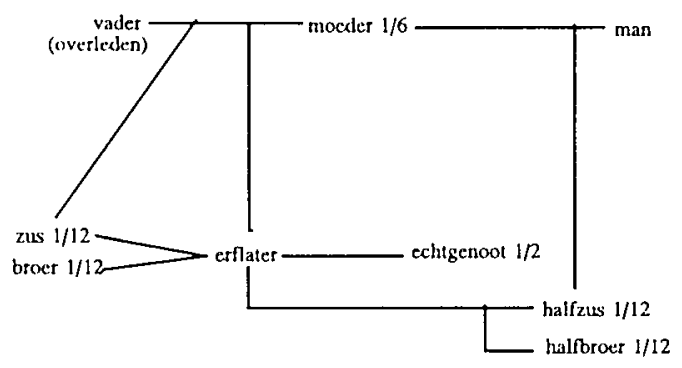

Zonder deze regeling zouden de halfbroers en halfzussen van moederszijde hun koranische erfporties krijgen, en zou er niets meer overblijven voor de volle broers en de volle zussen. Zij zouden dan feitelijk door de halfbroers en halfzussen van moederszijde van de erfenis zijn uitgesloten.

Art. 263 Het geval van de Twee Misleiders, ofwel het geval van de 'Umariyyatan of de Gharrawâni ${ }^{2+8}$

Hierin worden twee gevallen onderscheiden:

1. Samenkomen: de echtgenote, de vader en de moeder.

Het erfdeel van de echtgenote is $1 / 4$ (koranische erfportie wordt niet gewijzigd). Van wat overblijft krijgt de moeder $1 / 3(=1 / 4$ van het geheel $)$ en de vader de rest $(=1 / 2$ van het geheel).

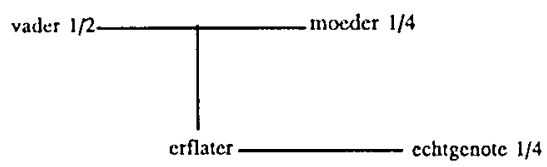

Zonder deze regeling zou de erfportie van de moeder $1 / 3$ zijn en zou de vader het restant $(=5 / 12)$ krijgen. De regel is ingegeven vanuit de gedachte dat de portie van de man gelijk is aan die van twee vrouwen. De moeder deelt nu in het restant met de vader. 
2. Samenkomen: de echtgenoot, de vader en de moeder.

Het erfdeel van de echtgenoot is $1 / 2$ (koranische erfportie wordt niet gewijzigd). Van wat overblijft krijgt de moeder $1 / 3(=1 / 6$ van het geheel $)$ en de vader de rest $(=1 / 3$ van het geheel).

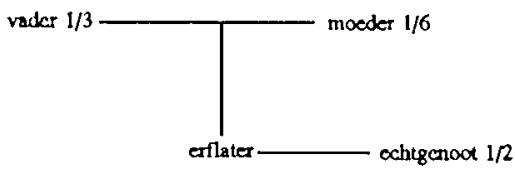

Zonder deze regeling zou de erfportie van de moeder $1 / 3$ zijn en zou de vader het restant $(=1 / 6)$ krijgen. De regel is ingegeven vanuit de gedachte dat de portie van de man gelijk is aan die van twee vrouwen. De moeder deelt nu in het restant met de vader.

Art. 264 Het geval van de wederzijdse vervloeking, ofwel het geval van Umm al-furûkh of van de Mubâhala ${ }^{249}$

Samenkomen: een echtgenoot, de moeder, een volle zus of halfzus van vaderszijde.

Omdat de koranische erfporties het geheel der nalatenschap overschrijden wordt de noemer van $1 / 6$ vergroot tot $1 / 8$.

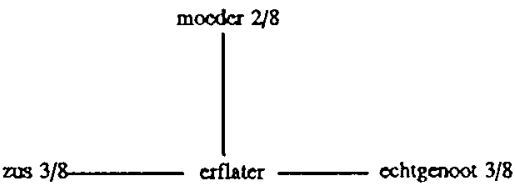

Art. 265 Het geval van de Spreekstoel, ofwel het geval van de Minbariyya ${ }^{250}$

Samenkomen: de echtgenote, twee dochters, de vader en de moeder.

Omdat de koranische erfporties het geheel der nalatenschap overschrijden wordt de noemer van $1 / 24$ vergroot tot $1 / 27$.

249. Colomer 1968, 130-131; Coulson 1971, 69; Khalîl ben Ish'âq, vertaald door Bousquet Tome IV 1962 , 87.

250. Colomer 1968, 131; Coulson 1971, 47-49; Pesle 1940, 105. 


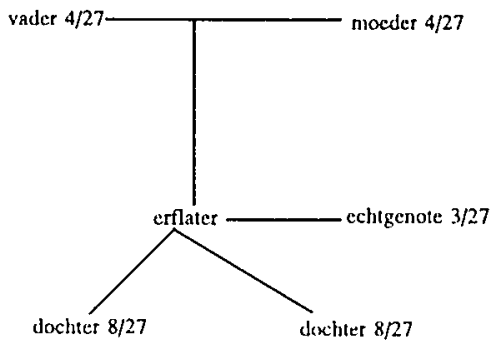

\section{d. Het verplicht testament}

In het islamitische recht is de figuur van de plaatsvervulling van erfgenamen bij vooroverlijden van een andere erfgenaam onbekend. Wel kent het islamitische recht de tanzîl, waarbij iemand die geen wettig erfgenaam is, in de plaats kan worden gesteld van een erfgenaam door wie hij met de erflater verbonden kan zijn ${ }^{251}$. De tanzil heeft in de Mudawwanah een plaats gekregen in de art. 212 e.v. en is besproken op p. 42-43 (aanwijzing van erfgenamen). Omdat de tanzil niet voldoende beantwoordde aan de matschappelijke verlangens ${ }^{252}$ is in de wetgeving van verschillende islamitische landen het verplicht testament ingevoerd. De invoering van dit verplicht testament is de belangrijkste hervorming geweest van het islamitische erfrecht. In Marokko is het verplicht testament geregeld in de art. 266 e.v. van de Mudawwanah.

In art. 266 wordt bepaald dat wanneer iemand overlijdt en kleinkinderen nalaat die kinderen zijn van een zoon die vóór of gelijktijdig met de erflater is overleden, een testament ten voordele van deze kleinkinderen verplicht is (onder de in de navolgende artikelen gestelde voorwaarden). Dat betekent niet dat de erflater verplicht is een testament voor deze kleinkinderen te maken, maar dat deze kleinkinderen zullen erven als ware er een testament waarin de plaatsvervulling was geregeld. Een dergelijk "fictief testament" is onderworpen aan de in de art. 266 tot en met 269 gegeven regels. Feitelijk bevatten deze bepalingen een regeling voor de plaatsvervulling. Uit de art. $266 \mathrm{j}^{\mathrm{o}} 269$ volgt dat een verplicht testament alleen geldt ten behoeve van de kinderen van de (vooroverleden) zoon, de kinderen van de zoonszoon en iedere verdere generatie kinderen

251. Colomer 1968, 134; Coulson 1971, 92.

252. Het zou onbillijk worden gevonden dat een kind van een vooroverleden zoon door de aanwezigheid van een andere zoon van de erflater van de nalatenschap zou worden uitgesloten. Ook heeft men in verschillende landen getracht de positie van kleinkinderen in het erfrecht te verbeteren ten koste van erfaanspraken van mannelijke verwanten in de zijlinie. Een dergelijke verandering zou tegemoet moeten komen aan de veranderende visie op het gezin, Coulson 1971, 143-144; Coulson 1983, 27-29. 
in de agnatische lijn, en niet die van een vooroverleden dochter ${ }^{253}$. Onder kinderen zijn hier zowel de vrouwelijke als de mannelijke afstammelingen te verstaan.

De omvang van het verplicht testament is gelijk aan het deel dat hun (groot)vader zou hebben gekregen indien hij de erflater zou hebben overleefd, doch mag in totaal het derde deel van de nalatenschap niet overschrijden (art. 267). De portie van een man is gelijk aan die van twee vrouwen (art. 269). Anders dan uit de bewoordingen van art. 267 volgt, zouden echter volgens het Arabisch commentaar bij de Mudawwanah van Shabûn, de afstammelingen van de vooroverleden zoon niet het erfdeel ontvangen dat hun vooroverleden vader zou hebben gekregen, met een maximum van eenderde, maar het erfdeel dat ze zouden krijgen van het erfdeel dat hun vader zou hebben ontvangen als hij de erflater had overleefd ${ }^{254}$. Deze opvatting is tot op zekere hoogte bevestigd in een uitspraak van het Cour suprême waaruit volgt dat als de vooroverleden zoon alleen een dochter nalaat, zij slechts aanspraak heeft op de helft van het erfdeel van haar vooroverleden vader (met een maximum van eenderde deel van de nalatenschap) ${ }^{255}$. Als de vooroverleden zoon alleen twee of meer dochters zou hebben nagelaten, dan zouden deze slechts aanspraak maken op tweederde deel van het erfdeel dat hun vooroverleden vader zou hebben ontvangen (met een maximum van eenderde deel van de nalatenschap).

In drie gevallen hebben de kleinkinderen geen recht op cen verplicht testament, te weten (art. 268):

1. als zij zelf erven;

2. als de erflater ten voordele van hen heeft getesteerd;

3. als de erflater hen gedurende hun leven iets heeft geschonken dat gelijk is aan de omvang van het deel waarop zij krachtens verplicht testament recht hebben.

Als hun minder is getesteerd of geschonken dan het deel waarop zij krachtens verplicht testament recht hebben moet dit worden aangevuld; als hun meer is vermaakt, kunnen zij slechts aanspraak maken op het meerdere indien de andere erfgenamen hiervoor hun toestemming geven of hebben gegeven.

Omdat (achter)kleinkinderen geen recht op een verplicht testament hebben als zij zelf erven (zie punt 1) dient eerst te worden nagegaan of zij zelf volgens de intestaat-erfopvolgingsregels in hun hoedanigheid van (achter)kleinkind zouden erven. Is dit het geval, dan ontvangen zij het deel dat zij volgens de intestaat-erfopvolgingsregels zouden erven en niet een recht uit verplicht testament, zelfs niet indien hun wettig erfdeel kleiner (of groter) is dan het deel waarop zij krachtens verplicht testament recht zouden hebben.

253. De reden voor dit onderscheid is hierin gelegen dat kinderen van een dochter ook niet zouden erven wanneer alle kinderen van de erflater zouden zijn overleden.

254. Arabisch commentaar bij de Mudawwanah van Shabûn, p. 459-461.

255. Cour suprême 28 mei 1985. aldus Sarehane 1993, Fasc. 2-2, 14. 
Erven zij volgens de intestaat-erfopvolgingsregels niet, dan erven zij als legatarissen krachtens verplicht testament.

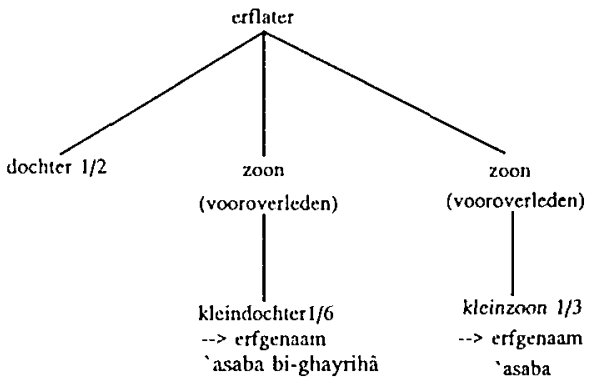

De kleindochter en kleinzoon erven krachtens de intestaterfopvolgingsregels reeds als erfgenamen 'asabât. Zij verkrijgen mitsdien niet uit hoofde van verplicht testament.

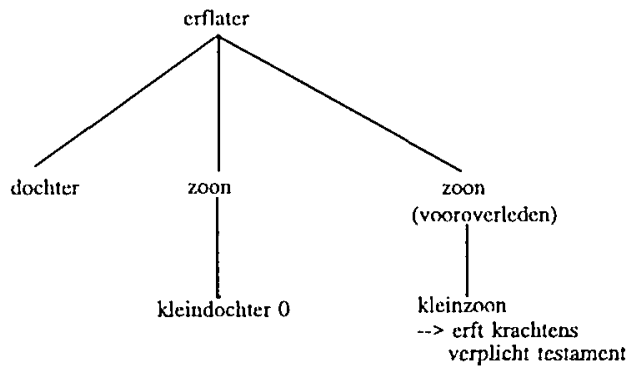

De kleindochter en kleinzoon worden op grond van de intestaat-erfopvolgingsregels van de nalatenschap uitgesloten door de aanwezigheid van een zoon. Zij verkrijgen dus niet reeds krachtens het intestaat-erfrecht. De kleinzoon verkrijgt dan uit hoofde van verplicht testament.

Verschillende zaken die de uitvoering van het verplicht testament betreffen zijn in de Mudawwanah ongeregeld gebleven. Het plaatsen van de regels omtrent het verplicht testament in het Boek dat over de wettige erfopvolging gaat, doet vermoeden dat het verplicht testament de regels van het intestaat-erfrecht volgt. Zo wordt bijvoorbeeld in art. 266 bij de kinderen en kleinkinderen gedoeld op de wettige verwantschap, terwijl bij testament ook ten behoeve van onwettige verwanten kan worden beschikt. Voorts is bij het verplicht testament de portie van een man gelijk aan die van twee vrouwen terwijl in de testamentaire regeling geen onderscheid wordt gemaakt naar geslacht. Onduidelijk is overigens welke regels uit het intestaat-erfrecht op het verplicht testament van toepassing zijn ${ }^{256}$.

256. Zo wordt door Chafi 1991, 265, gesteld dat onwaardigheid van de vooroverieden zoon niet in de weg staat aan een erfopvolging krachtens verplicht testament door de kleinkinderen, omdat onwaardigheid persoonsgebonden is. 
Ongeregeld is ook wat er moet gebeuren wanneer de erflater een testament ten behoeve van derden heeft gemaakt. Testamentair mag niet over meer dan eenderde deel van de nalatenschap worden beschikt. Ook het verplicht testament strekt zich uit tot maximaal eenderde deel van de nalatenschap. Moeten beide "testamenten" nu worden samengevoegd zodat zij samen zich tot maximaal dit derde deel kunnen uitstrekken? En zo ja, hoe dient dan de rangorde te zijn tussen degenen dic rechten ontlenen aan het verplicht testament enerzijds en degenen dic rechten ontlenen aan het testament van de erflater anderzijds? Met een verwijzing naar de Egyptische regeling van het verplicht testament, welke de Marokkaanse regeling heeft geïnspireerd, wordt door sommige auteurs wel verdedigd dat degenen die rechten ontlenen aan een verplicht testament voorgaan boven de legatarissen, waarbij zij gezamenlijk niet meer mogen ontvangen dan eenderde deel van de nalatenschap ${ }^{257}$. Anderen leiden uit het zwijgen van de Marokkaanse wetgever juist af dat er geen sprake is van voorrang van de ene groep boven de andere ${ }^{258}$. Ook voor gevallen waarin de erflater geen testament heeft gemaakt laat de wetgever ongeregeld hoe de volgorde in de verdeling dient te zijn. Er kunnen ten minste twee manieren worden onderscheiden. De eerste methode (A) is dat eerst het verplicht testament wordt uitgevoerd, waarbij bij de berekening van de omvang wordt nagegaan wat degene in wiens plaats wordt getreden zou hebben ontvangen als hij nog in leven ware geweest, met een maximum van eenderde deel van de te verdelen nalatenschap. Vervolgens wordt het restant verdeeld onder de andere erfgenamen volgens de intestaat-erfopvolgingsregels, bij welke berekening de erfgenaam krachtens verplicht testament geen rol meer speelt. De tweede methode (B) is dat het verplicht testament niet eerder maar gelijktijdig met de intestaat-erfopvolgingsregels wordt uitgevoerd. De erfdelen, ook die van hen die erven uit hoofde van het verplicht testament, worden vastgesteld aan de hand van de wettige erfopvolgingsregels, waarbij de omvang van het erfdeel van degene die krachtens verplicht testament erft, niet meer mag zijn dan eenderde deel van de nalatenschap ${ }^{259}$.

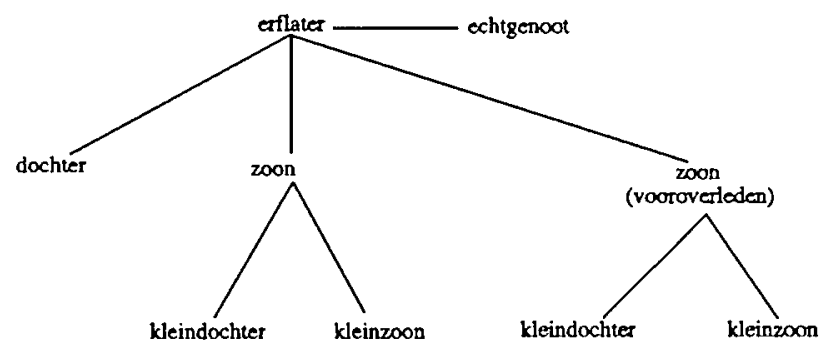

257. O.m. Colomer 1968, 149. Coulson, Law of succession 1978, 232 geeft aan dat het verplicht testament (absolute) voorrang heeft boven een ander testament.

258. O.m. Chafi 1991, 276-277.

259. Colomer spreekt zijn voorkeur uit voor de eerste methode (A) en verwerpt de tweede methode (B), Colomer 1968, 150-152. Ook uit het Arabisch commentaar bij de Mudawwanah van Shabûn, p. 459461. volgt dat de eerste methode zou moeten worden gehanteerd. Een beschrijving van mogelijke verdeelmethoden wordt ook gegeven in Coulson 1971, 146-150. 
De kleinkinderen kunnen alleen uit hoofde van verplicht testament verkrijgen als zij niet erven op grond van de regels van het intestaat-erfrecht. De in het schema opgenomen kleinkinderen worden alle vier van de nalatenschap uitgesloten door de aanwezigheid van een zoon van de erflater. De kinderen van deze zoon verkrijgen niet krachtens verplicht testament omdat hun vader nog in leven is. De kinderen van de vooroverleden zoon verkrijgen wel krachtens verplicht testament. Dit geldt zowel voor de kleindochter als voor de kleinzoon.

Bij toepassing van methode A zou eerst het verplicht testament moeten worden uitgevoerd. Om het erfdeel krachtens verplicht testament vast te stellen moeten de wettelijke erfopvolgingsregels worden toegepast als ware de vooroverleden vader nog in leven. De echtgenoot zou $1 / 4$ deel ontvangen. Het restant, $3 / 4$ deel zou moeten worden verdeeld onder de 'asaba-erfgenamen. De erfportie van de zoon is twee keer zo groot als dat van de dochter. De dochter heeft dan recht op $1 / 5 \times 3 / 4(=3 / 20)$, en de zonen hebben ieder recht op $2 / 5 \times 3 / 4(=6 / 20)$. Het erfdeel dat krachtens verplicht testament moet worden verdeeld is dus $6 / 20$. Hiervan krijgt de kleindochter $1 / 3$ deel $(=1 / 3 \times 6 / 20=1 / 10)$, en de kleinzoon $2 / 3$ deel $(2 / 3 \times 6 / 20=2 / 10)$. Het restant na de uitvoering van het verplicht testament is 14/20. Dit wordt onder de wettige erfgenamen verdeeld. De erfgenamen krachtens verplicht testament worden hierbij buiten beschouwing gelaten. De echtgenoot, koranisch erfgenaam, heeft aanspraak op $1 / 4 \times 14 / 20(=7 / 40)$. Het restant $(=3 / 4 \times 14 / 20=21 / 40)$ gaat naar de 'asaba-erfgenamen. De dochter ontvangt $1 / 3 \times 21 / 40(=7 / 40)$, en de zoon ontvangt $2 / 3 \times 21 / 40(=14 / 40)$.

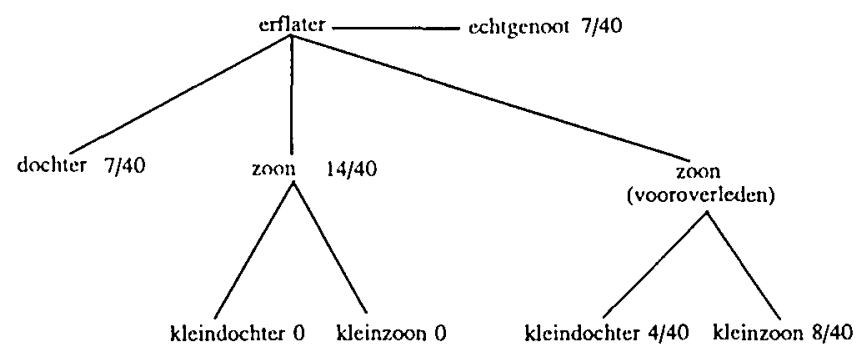

Bij toepassing van methode B worden alle erfdelen volgens de wettelijke erfopvolgingsregels vastgesteld, waarbij ervan wordt uitgegaan dat de kleinkinderen delen in het erfdeel van de vooroverleden zoon. De echtgenoot zou $1 / 4$ deel ontvangen. Het restant, $3 / 4$ deel zou moeten worden verdeeld onder de 'asaba-erfgenamen. De erfportie van de zoon is twee keer zo groot als die van de dochter. De dochter heeft dan recht op $1 / 5$ $\times 3 / 4(=3 / 20)$, en de zonen hebben ieder recht op $2 / 5 \times 3 / 4(=6 / 20)$. Het erfdeel dat krachtens verplicht testament moet worden verdeeld, is dus $6 / 20$. Hiervan krijgt de kleindochter $1 / 3$ deel $(=1 / 3 \times 6 / 20=1 / 10)$, en de kleinzoon $2 / 3$ deel $(2 / 3 \times 6 / 20=$ $2 / 10)$. 


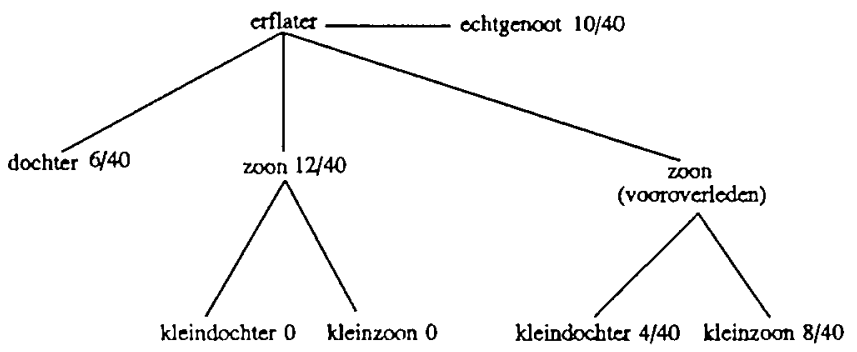

Vergelijken we beide methoden dan zien we dat het voor degenen die erven krachtens verplicht testament in dit geval geen verschil makt welke methode wordt gehanteerd. Voor de andere erfgenamen leiden de methoden daarentegen niet tot dezelfde resultaten.

\section{DE AFWIKKELING VAN DE NALATENSCHAP}

De afwikkeling van de nalatenschap is geregeld in het negende en tiende hoofdstuk van Boek 6 van de Mudawwanah. In het negende hoofdstuk is de vereffening van de nalatenschap geregeld, in het tiende hoofdstuk de levering en verdeling van de nalatenschap. Een uitvoerige regeling van de afwikkeling van de nalatenschap wordt ook gegeven in de CPC (art. 221 tot en met 268). Voor zover bepalingen in bijzondere wetten (in casu de Mudawwanah) zijn te vinden, prevaleren deze. De bepalingen uit de CPC vullen deze aan (vgl, art. 3 en 221 CPC). Hieronder worden de hoofdlijnen van de wijze waarop een nalatenschap naar Marokkaans recht wordt afgewikkeld uiteengezet, waarbij in beginsel uitsluitend wordt verwezen naar de bepalingen uit de Mudawwanah.

\section{Maatregelen die aan de vereffening vooraf gaan}

Voorafgaande aan de vereffening van de nalatenschap kan een aantal maatregelen worden getroffen. De rechter moet, indien nodig, alle conservatoire maatregelen treffen tot het behoud van de nalatenschap, alsmede kan hij tot verzegeling en bewaargeving van waardevolle zaken bevelen (art. 270 en 271). Er wordt een vereffenaar aangewezen. Deze kan bij testament door de erflater zijn aangewezen (art. 195). Bij gebreke hiervan kunnen de erfgenamen een vereffenaar aanwijzen. Kunnen zij hierover geen overeenstemming bereiken, dan wijst de rechter een vereffenaar aan (art. 273). Indien mogelijk wijst hij een van de erfgenamen als vereffenaar aan.

\section{Opmaken van een "acte d'hérédité"}

Het opmaken van een "acte d'hérédité" is niet uitdrukkelijk in de CSPS geregeld. Praktijk is dat deze akte wordt opgemaakt door twee "udûl en wordt gehomologeerd door de rechter. De 'adl maakt hierbij gebruik van de lafif-getuigenis ${ }^{260}$. 


\section{Vereffening van de nalatenschap}

De vereffenaar is verplicht een boedelbeschrijving op te maken (art. 280), en te presenteren (art. 281), van alle zaken, vorderingen en schulden van de erflater. Schenkingen door de erflater gedurende zijn leven gedaan - met uitzondering van die welke zijn gedaan tijdens zijn sterfbed, laatste ziekte ${ }^{261}$-, worden noch ingebracht, noch ingekort. De boedelbeschrijving wordt opgemaakt ten overstaan van twee 'udût.

Gedurende de vereffening is de vereffenaar verplicht de noodzakelijke beheersdaden te verrichten, opeisbare vorderingen te innen, en vertegenwoordigt hij de nalatenschap in rechtszaken (art. 283). De vereffenaar kan tot betaling van de opeisbare schulden ${ }^{262}$ van de nalatenschap overgaan wanneer hij hiervoor de toestemming van de rechter en van de erfgenamen heeft verkregen (art. 285). Alleen ten aanzien van schulden waarover een geschil bestaat dient een definitieve beslissing te worden afgewacht alvorens tot vereffening kan worden overgegaan (art. 285, laatste volzin). Bij de betaling van de schulden houdt de vereffenaar de in art. 218 gegeven volgorde aan. Dat wil zeggen dat hij eerst de schulden voldoet die rusten op tot de nalatenschap behorende zaken. Vervolgens voldoet hij de begrafeniskosten, en ten derde betaalt hij de overige schulden. De vereffenaar betaalt de schulden van de nalatenschap met wat uit haar vorderingen voortkomt en met wat zich aan geld en waarde van roerende goederen in de nalatenschap bevindt. Als dat alles niet voldoende is, dan met wat voldoende is van de waarde van de onroerende zaken van de nalatenschap. De roerende en onroerende zaken van de nalatenschap worden bij openbare verkoop verkocht, behalve indien de erfgenamen zijn overeengekomen dat zij deze zelf op zich nemen, tegen een prijs welke door een deskundige is vastgesteld, of middels een onderlinge verkoop (art. 287). Voor schulden die niet door de vereffenaar worden voldaan, kan ieder der erfgenamen slechts gehouden worden tot een bedrag of tot dat deel dat hij uit de nalatenschap heeft ontvangen. Nadat de schulden zijn vereffend neemt de vereffenaar de uitvoering van de testamenten op zich (art. 288) (p. 34 e.v.).

\section{Levering van de nalatenschap}

Art. 289 bepaalt dat nadat aan de verplichtingen van de nalatenschap is voldaan, alle erfgenamen krijgen, ieder overeenkomstig zijn wettig deel, wat er is overgebleven. Het Marokkaanse recht kent niet de saisine. Door het overlijden van de erflater treden de erfgenamen niet in de rechten van de erflater, doch hebben een recht op "overdracht" van het nalatenschapsvermogen. Zolang de nalatenschap niet is vereffend, mogen de erfgenamen niet over het vermogen van de nalatenschap beschikken, behalve indien een

261. Zie noot 56 .

262. Hiermee lijkt het Marokkaanse recht af te wijken van het islamitische recht, waarin alle schulden van een erflater direct opeisbaar worden bij diens overlijden. Sommige schrijvers menen dat de Marokkaanse wetgever in de Mudawwanah geen afwijking van het islamitische recht heeft beoogd, en dus dat met het overlijden van de erflater al diens schulden opeisbaar zouden zijn geworden, Colomer 1968, 164; Milliot en Blane 1987, 515-516. 
dringende noodzaak hiertoe dwingt (art. 272). Pas ná de vereffening van de nalatenschap, dus nadat de schulden, lasten en testamenten zijn voldaan, gaan de rechten op de erfgenamen over en worden zij eigenaar van de resterende activa van de nalatenschap. Een en ander kan worden afgeleid uit de art. 289 lid 1, hierboven aangehaald, en art. 219 dat luidt: "De erfopvolging is de overgang van een recht vanwege het overlijden van de eigenaar ervan, na de vereffening van de nalatenschap, aan de wettige rechthebbende $(\ldots)^{\prime 263}$. Verwerping van de erfenis is niet mogelijk.

\section{Verdeling van de nalatenschap}

De verdeling kan op twee manieren worden vastgesteld:

a. door middel van onderlinge overeenstemming tussen de erfgenamen;

b. door middel van een rechterlijke uitspraak. De verdeling kan bij rechterlijke uitspraak worden vastgesteld als de erfgenamen onderling geen overeenstemming bereiken, er een erfgenaam afwezig is, of er een erfgenaam onbekwaam is aan een onderlinge overeenkomst mee te werken. De verdeling van de nalatenschap geschiedt volgens de wettelijk vastgestelde beginselen van verdeling (art. 294), zoals beschreven in § 3.B.

\section{SUCCESSIERECHTEN}

Over de goederen die uit een nalatenschap worden verkregen zijn geen successierechten verschuldigd. In 1968 werd bij wet het heffen van een dergelijke belasting ingesteld, doch deze wet is ruim acht maanden later reeds afgeschaft omdat hij niet te verenigen was met de beginselen van het islamitische recht ${ }^{26-}$. Er dienen uitsluitend registratierechten te worden betaald. Deze rechten bedragen ${ }^{265}$ :

voor afstammelingen en bloedverwanten in opgaande linie, en voor de langstlevende echtgenoot: $0,5 \%$ van het erfdeel;

voor bloedverwanten in de zijlinie: $1 \%$ van het erfdeel; voor anderen ${ }^{26 x}: 4 \%$ van het erfdeel.

264. Talbi $1984,258$.

265. Imâm 1976, 376. Volgens mondelinge informatie waren deze cijfers in 1995 nog dezelfde.

266. De belangrijkste categorie "anderen" wordt gevormd door de legatarissen. 
Hoofdstuk 3

\section{Bevoegdheden van diplomatieke vertegenwoordigers}

\section{en consulaire ambtenaren}

De basis voor consulaire betrekkingen alsmede de bevoegdheden van consulaire ambtenaren is het Verdrag van Wenen inzake consulaire betrekkingen ${ }^{267}$. Wat Marokko betreft zijn de bevoegdheden van de Marokkaanse diplomatieke vertegenwoordigers en consulaire ambtenaren geregeld in de dahir van 20 oktober $1969^{268}$, waarvan de invoering is geregeld bij decreet van 29 januari $1970^{269}$. Op grond van art. 2 van de dahir van 1969 kunnen diplomatieke vertegenwoordigers en consulaire ambtenaren door middel van een besluit van de Marokkaanse Minister van Buitenlandse Zaken en de Minister van Justitie worden bekleed met de functie van 'adl. In deze hoedanigheid kunnen zij bevoegdheden uitoefenen voorzover de Staat van vestiging zich hiertegen niet verzet (art. 2 dahir 1969) ${ }^{270}$. Deze ambtenaren zijn geaccrediteerd bij de in Nederland gevestigde Marokkaanse consulaten ${ }^{271}$. Op de Marokkaanse Ambassade te 's-Gravenhage is een ambtenaar werkzaam die is bekleed met de functie van rechter voor adoulaire zaken. De adoulaire rechter is belast met het toezicht op en de contrôle van de 'udûl, het homologeren van de adoulaire akten ${ }^{272}$ en de registratie van deze akten ${ }^{273}$. De bevoegdheden van 'udûl in het algemeen zijn geregeld in een dahir van 6 mei 1982 en uitgewerkt in een decreet van 18 april $1983^{274}$. De specifieke taken

267. Verdrag van Wenen inzake Consulaire Betrekkingen 24 april 1963, Trb. 1965, 40. Zowel Nederland als Marokko zijn partij bij dit Verdrag.

268. Dahir 20 oktober 1969, B.O. 17 december 1969, p. 1543.

269. Décret 29 januari 1970, B.O. 4 februari 1970, rectificatie: B.O. 8 april 1970, p. 540.

270. Aldus ook art. 5 sub $f$ van het Verdrag van Wenen inzake Consulaire Betrekkingen.

271. Te weten in Amsterdam, Rotterdam en 's-Hertogenbosch.

272. Iedere adoulaire akte dient te worden gehomologeerd door een adoulaire rechter (art. 30 dahir 1982, zie noot 274).

273. Buskens 1993, 215.

274. Dahir 6 mei 1982, B.O. 27 april 1983 (Arabisch); Décret 18 april 1983, B.O. 27 april 1983 (Arabisch). Voor een bespreking van deze regelgeving: Buskens 1991, 9-23; Buskens 1993, 186-237. De dahir is laatstelijk gewijzigd bij decreet van 18 mei 1995. 
van 'udul op het gebied van het familierecht en erfrecht zijn te vinden in de Mudawwanah. Op het gebied van het familierecht kunnen consulaire ambtenaren die de functie van 'udîl bezitten bijvoorbeeld betrokken worden bij de sluiting van huwelijken en de ontbinding van huwelijken ${ }^{275}$. Een bespreking van deze bevoegdheden en de vraag naar de erkenning hiervan in Nederland komen in hoofdstuk 5 aan de orde.

In het onderhavige hoofdstuk wordt nader ingegaan op de bevoegdheden van Marokkaanse consulaire ambtenaren en diplomatieke vertegenwoordigers op het gebied van het erfrecht. Op grond van art. 3 van de dahir van 1969 zijn zij belast met het beschermen van de belangen van Marokkaanse onderdanen in nalatenschappen in Nederland, in overeenstemming met het in Nederland geldende recht ${ }^{276}$. Naast de mogelijkheid om als getuigen op te treden bij het opmaken van een testament is vooral hun rol bij de afwikkeling van nalatenschappen van Marokkaanse onderdanen van belang. Ten behoeve van de liquidatic kunnen de erfgenamen van een Marokkaanse erflater aan een consulaire ambtenaar een volmacht verlenen hen bij de liquidatie te vertegenwoordigen ${ }^{27}$. Om tegemoet te komen aan problemen die kunnen ontstaan bij de afwikkeling van Marokkaanse nalatenschappen in het buitenland, in casu in Nederland, en ter vereenvoudiging van de te volgen liquidatieprocedure, is in de jaren zestig een commissie gecreëerd bestaande uit vertegenwoordigers van het Marokkaanse Ministerie van Buitenlandse Zaken, Financiële Zaken en Justitie, hetgeen geresulteerd heeft in het vaststellen van een circulaire in 1966 waarin de te volgen procedure bij het overlijden van Marokkanen in Nederland wordt uiteengezet ${ }^{278}$. Deze procedure komt kort samengevat op het volgende neer. De diplomatieke vertegenwoordiger of consulaire ambtenaar treft onmiddellijk alle conservatoire maatregelen om eventuele aanspraken van de erfgenamen te verzekeren. Hij vraagt de erfgenamen een volmacht om hen bij de liquidatie te vertegenwoordigen. Hij zendt een voorlopig rapport naar het Marokkaanse Ministerie van Buitenlandse Zaken waarin de gegevens van de erflater en de inhoud van de nalatenschap aangegeven zijn. De aan de overledene toebehorende zaken, zoals horloge, armband, ring, familiesouvenirs en dergelijke, worden gebracht onder de bescherming van het Marokkaanse Ministerie van Buitenlandse Zaken aan de vertegenwoordiger van de Koning nabij de rechtbank waar de erfgenamen wonen. De liquide middelen van de erflater alsmede de inkomsten die uit de nalatenschap worden verkregen (bijvoorbeeld door verkoop van goederen), worden door de verantwoordelijke vertegenwoordiger ${ }^{279}$ geregistreerd. De activa en passiva worden opgenomen in de maandelijkse overdrachten van de verantwoordelijke vertegenwoordiger. Deze laatste

275. Over de adoulaire bevoegdheden op het gebied van het familierecht: Buskens 1992, 23-34; Buskens 1993, 186-237.

276. Vgl. ook art. 5 sub g van het Verdrag van Wenen inzake Consulaire Betrekkingen.

277. Deze volmacht wordt opgemaakt in de vorm van een adoulaire akte, en wordt gehomologeerd door de rechter van de Marokkaanse Ambassade.

278. Circulaire du Ministère des Affaires Etrangères 11 augustus 1966, Note $n^{\circ} 33 / \mathrm{c}$.

279. Bij Koninklijk Decreet van 18 maart 1966, $\mathrm{n}^{\circ} 799-65$ is een centraal boekhoudkundig bureau voor diplomatieke en consulaire vestigingen ingesteld. 
neemt op zich de overdracht door de tussenpersoon van de Rijkskas ter bewaring en beheer, die het bedrag inschrijft in de geschriften van de nalatenschap en die het saldo ter beschikking houdt van de liquidateur. Het dossier wordt overgedragen aan de vertegenwoordiger van de Koning, onder bescherming van het Marokkaanse Ministerie van Buitenlandse Zaken en het Marokkaanse Ministerie van Justitie, zodat de aangewezen overheidsambtenaar, in samenwerking met de Marokkaanse notariële rechtbank de rechten van de rechthebbenden op de nalatenschap kan voldoen.

Uit enkele dossiers die ik heb ingezien ${ }^{280}$ blijkt dat van de hier beschreven procedure in het bijzonder gebruik wordt gemaakt wanneer zich vermogen in Marokko bevindt en de erfgenamen, of een deel van de erfgenamen, zich in Nederland bevinden. De in Nederland woonachtige erfgenamen gaven hierbij in hun aan het consulaat verleende volmacht steeds aan wie van de erfgenamen het zich in Marokko bevindende vermogen zou moeten worden toebedeeld. Nadat door de Marokkaanse vertegenwoordigers in Nederland de gegevens van de erflater en de gegevens over de inhoud van de nalatenschap aan de desbetreffende Marokkaanse autoriteiten waren gezonden, werd door een Marokkaanse rechtbank op basis van een getuigenverklaring van twee 'udûl, een akte van verdeling ("acte d'hérédité") opgemaakt. Deze akte werd vervolgens weer naar Nederland gezonden voor het tekenen van accoord door de erfgenamen. 

Hoofdstuk 4

\section{Nederlands internationaal erfrecht}

\section{$\S 1$. Inleiding}

Wanneer een in Nederland woonachtige Marokkaan(se) komt te overlijden, heeft alleen al het bezit van de vreemde Marokkaanse nationaliteit tot gevolg dat men te maken krijgt met regels van Nederlands internationaal privaatrecht. Aan de hand van de Nederlandse conflictregel zal moeten worden vastgesteld welk recht de erfopvolging beheerst. Voor in Nederland woonachtige Marokkanen die tevens de Nederlandse nationaliteit bezitten geldt dat zij, behoudens de gevallen waarin zij een rechtskeuze hebben gedaan voor een buitenlands rechtsstelsel, zijn onderworpen aan het Nederlandse erfrecht. Voor monopatride Marokkanen geldt dat hetzij het Marokkaanse erfrecht hetzij het Nederlandse erfrecht toepasselijk wordt verklaard. In uitzonderlijke gevallen kan zelfs het recht van een derde Staat van toepassing zijn. Een bespreking van de verwijzingsregel vindt plaats in $\$ 4$. In dit boek is ervoor gekozen om alleen de gevallen waarin de erfopvolging door Marokkaans recht wordt beheerst nader te analyseren. Bij een aantal van de problemen waarop men hierbij kan stuiten, wordt in dit hoofdstuk nader stilgestaan. Twee onderwerpen die om uitgebreide aandacht vragen worden afzonderlijk besproken in de hoofdstukken vijf en zes. Dit zijn de voorvraag en de exceptie van de openbare orde. De regels van erfopvolging worden uitgevoerd bij de afwikkeling van de nalatenschap. Onderzocht zal worden of het recht dat de erfopvolging beheerst en het recht dat de afwikkeling beheerst op elkaar aansluiten of dat er sprake is van een zekere kortsluiting. In het laatste geval zou een aanpassing of afstemming kunnen plaatsvinden, met als mogelijk gevolg dat de toepasselijke erfwet niet meer onverkort wordt toegepast.

\section{§ 2. Bevoegdheid van de Nederlandse rechter}

De autoriteit in Nederland die zich bij uitstek bezighoudt met erfrechtelijke aangelegenheden is de notaris. Voor hem gelden geen regels die zijn competentie in IPR-zaken bepalen. In het kader van de erfopvolging zal de Nederlandse rechter pas worden inge- 
schakeld als er een geschil optreedt of als er procesrechtelijke maatregelen worden gewenst.

Bij gebreke van een Verdrag ${ }^{281}$ wordt de internationale bevoegdheid van de Nederlandse rechter in erfrechtzaken afgeleid uit de relatieve competentieregels van het interne recht. Ten tijde van dit schrijven is een wetsvoorstel aanhangig waarin met dit systeem wordt gebroken ${ }^{282}$. Voorgesteld wordt in de eerste titel van het Wetboek van Burgerlijke Rechtsvordering aparte bepalingen op te nemen waarin de rechtsmacht van de Nederlandse rechter in internationale zaken wordt geregeld. Ondertussen wordt in het kader van de Europese Gemeenschap gewerkt aan een Verdrag betreffende de rechterlijke bevoegdheid en tenuitvoerlegging van beslissingen in familiezaken (Verdrag van Brussel II). Aanvankelijk voorzag een voorontwerp van de "Europese Groep" 283 in een bevoegdheidsregeling voor erfrechtzaken. De Raad van de Europese Unie heeft haar werkzaamheden beperkt tot een aantal familierechtelijke onderwerpen ${ }^{284}$. Het nicuwe Verdrag zal derhalve geen regeling bevatten voor de competentie in erfrechtzaken.

\section{A. HUIDIG RECHT}

De hoofdregel voor de bevoegdheid van de rechter in erfrechtzaken is neergelegd in art. 126 lid 12 Rv. Deze bepaling bevat een uitzondering op de algemene bevoegdheidsregel van art. $126 \mathrm{Rv}$.

Art. 126 lid 12 luidt:

"In zaken betreffende een nalatenschap:

$1^{\circ}$ wegens onderlinge vorderingen der erfgenamen tot aan de totstandkoming van de verdeling en wegens vorderingen tot vernietiging, ontbinding of ongedaanmaking van een verdeling;

281. De toepasselijkheid van het Verdrag betreffende de rechterlijke bevoegdheid en de tenuitvoerlegging van beslissingen in burgerlijke en handelszaken (EEX), wordt in art. 1 aanhef en sub 1 EEX uitgesloten. Hetzelfde geldt voor het EVEX. Voons kan gewezen worden op het Verdrag tussen Nederland en België betreffende de territoriale rechterlijke bevoegdheid, betreffende het faillissement en betreffende het gezag en de tenuitvoerlegging van rechterlijke beslissingen van 1925. Buiten het feit dat dit Verdrag alleen van toepassing is wanneer Belgie en Nederland bij de zaak betrokken zijn, dient de bevoegdheid van de Nederlandse rechter in overeenstemming met de strekking en de aard van dit Verdrag te worden beoordeeld aan de hand van de nationale bevoegdheidsregels, in het bijzonder art. 126 lid 12 Rv, aldus Struycken 1993, 353.

282. Wetsvoorstel 1995-1996 nr. 24651 tot aanpassing van het Wetboek van Burgerlijke Rechtsvordering in verband met de herziening van de rechterlijke organisatie. Uitvoerig hierover: NIPR speciale aflevering 1996. De voorgestelde bepalingen uit het voorontwerp van deze wet betreffende de internationale rechtsmacht werden besproken door o.m. Kokkini-Iatridou en Boele-Woelki 1993, 319-364.

283. Een groep van Europese IPR-specialisten die $0 . \mathrm{m}$. voorstellen doet op het gebied van de interactie tussen Gemeenschapsrecht en internationaal privaatrecht (Sumampouw 1995, 1). Het voorontwerp van de Europese Groep is gepubliceerd in NIPR 1995, 5-8.

284. Van der Velden 1995, 3. 
$2^{\circ}$ wegens vorderingen, door de schuldeisers van de erflater vóór de totstandkoming van de verdeling ingesteld;

$3^{\circ}$ wegens vorderingen betrekkelijk tot een uiterste wilsbeschikking;

voor de rechter van het sterfhuis."

Op grond van deze bepaling is derhalve bevoegd de rechter van het sterfhuis van de erflater. Waar het sterfhuis is gelegen, is geregeld in art. 1:13 BW. Hierin wordt bepaald dat het sterfhuis van de overledene daar is waar hij zijn laatste woonplaats heeft gehad. Betekent dit nu dat de Nederlandse rechter niet bevoegd is wanneer een erflater zijn sterfhuis buiten Nederland heeft? Of kan, nu de bijzondere regeling uit het twaalfde lid geen bevoegdheid voor de Nederlandse rechter creëert, worden teruggevallen op de algemene bevoegdheidsregels uit art. $126 \mathrm{Rv}$ ? Nadat in enkele uitspraken van lagere rechters deze laatste vraag in positieve zin werd beantwoord, heeft de Hoge Raad de kwestie in 1984 tot op zekere hoogte beslecht ${ }^{285}$. Het ging in deze zaak om een vordering tot scheiding en deling van een nalatenschap waarin zich in Nederland gelegen onrocrend goed bevond, terwijl de erflater zijn laatste woonplaats buiten Nederland had. De Hoge Raad overwoog dat de vraag of en zo ja in welke gevallen aan de Nederlandse rechter rechtsmacht toekomt ten aanzien van een vordering tot scheiding en deling van de nalatenschap wanneer de erfenis is opengevallen buiten Nederland, in die zin moet worden beantwoord "dat in geval de erflater zijn laatste woonplaats buiten Nederland had, ten aanzien van cen vordering tot scheiding en deling van de nalatenschap aan de Nederlandse rechter rechtsmacht toekomt indien hier te lande tot de nalatenschap behorend onroerend goed is gelegen dan wel de verweerder hicr zijn laatste woonplaats heeft" ${ }^{286}$. Uit deze beslissing is als algemene regel in erfrechtzaken afgeleid dat

285. HR 26 oktober 1984, NJ 1985, 696.

286. De Hoge Raad verwijst hier naar het destijds nog geldende art. 126 sub $10 \mathrm{Rv}$. Deze bepaling luidde: "In zaken van gemengden aard behoudens hetgeen in dit arikel volgt ten aanzien van zaken van erfenis, voor den regter onder wiens regtsgebied het onroerend goed gelegen is, of voor dien alwaar de verweerder zijn woonplaats heeft, ter keuze van den aanlegger". De regel voor de rechtsmacht in erfrechtzaken was neergelegd in ant. 126 sub $12 \mathrm{Rv}$, watan bevoegd werd verklaard de rechter binnen wiens rechtsgebied de erfenis was opengevalletl. Art. $126 \mathrm{Rv}$ is gewijzigd bij Wet van 7 mei 1986, S. 295, in werking treding 1 januari 1992. De motivering van de Hoge Raad voor de vermelde beslissing was als volgt: nadat de Hoge Raad had overwogen dat hier sprake was van een gemengde zaak in de zin van art. 129 (oud), waarvoor de hoofdregel is neergelegd in art. 126 sub $10 \mathrm{Rv}$, overwoog de Hoge Raad: "Op deze hoofdregel maken echter de voorschriften van art. 126 onder $10 \mathrm{e}$ en 12e, in onderling verband, een uitzondering voor de onder $12 \mathrm{e}$ nader aangeduide "zaken van erfenis": voor deze laatste zaken wordt - zowel om redenen van doeimatigheid als ter voorkoming van tegenstrijdige beslissingen door het voorschrift van art. 126 onder $12 \mathrm{e}$ als betrekkelijk bevoegd aangewezen de rechter van erflaters laatste woonplaats. Overeenkomstig de aard van de onderhavige bepalingen nopens de betrekkelijke bevoegdheid ziet ook dit voorschrift echter enkel op de Nederlandse rechter. Ligt erflaters laatste woonplaats buiten Nederland, dan kan het derhalve geen toepassing vinden. Niet aannemelijk is dat het voorschrift zou beogen "uitsluiting van rechtsmacht binnen Nederland, zoo vaak de erflater daarbuiten is overleden" (...), al ware het slechts omdat alsdan, ook in geval alle betrokkenen hier te lande woonachtige Nederlanders zijn en de gehele nalatenschap in Nederland ligt, het enkele feit dat erflater zijn laatste woonplaats buiten Nederland had, zou meebrengen dat betrokkenen voor bij de 
wanneer geen bevoegdheid kan worden ontleend aan de bijzondere regel van art. 126 lid $12 \mathrm{Rv}$, de bevoegdheid op grond van een der andere leden van art. $126 \mathrm{Rv}$ kan worden aangenomen ${ }^{287}$. Voor verzoekschriftprocedures geldt art. $429 \mathrm{c} \mathrm{Rv}$. Voorts bevatten boek $4 \mathrm{BW}$ en de art. $658 \mathrm{c.v}$. Rv een aantal specifieke bepalingen waarin aan de Nederlandse rechter bepaalde bevoegdheden in erfrechtelijke aangelegenheden worden toegekend. De gronden waarop de rechter zijn bevoegdheid kan baseren lopen in deze bepalingen uiteen: soms wordt de rechter van het sterfhuis aangewezen (bijv. in art. 4:989 en 4:1070 BW), soms de rechter van de plaats waar het vermogen zich geheel of grotendeels bevindt (bijv. in art. 672 lid $1 \mathrm{Rv}$ ), soms wordt aangesloten bij de bevoegdheidsregel van art. 126 lid $12 \mathrm{Rv}$, soms is bevoegd de rechter van de plaats waar de gevraagde handeling moet worden verricht (bijv. in art. 658 lid $1 \mathrm{Rv}$ ), en soms ontbreekt een bevoegdheidsgrond in de bepaling ${ }^{288}$.

\section{Forum non conveniens}

In verzoekschriftprocedures is de forum non conveniens-leer algemeen geaccepteerd in art. 429c lid $15 \mathrm{Rv}$. Wanneer de wet haar uitdrukkelijk uitsluit, mag de forum non conveniens-regel niet worden tocgepast ${ }^{289}$. Heersende opvatting is dat zij in dagvaardingsprocedures niet kan worden erkend ${ }^{200}$. In erfrechtzaken is de situatie op dit punt niet geheel duidelijk. Het belang om in erfrechtzaken tegenstrijdige beslissingen te voorkomen kan het in uitzonderlijke omstandigheden wenselijk maken dat de forum non conveniens-regel wordt geaccepteerd ${ }^{291}$.

\section{Forum necessitatis}

De forum necessitatis-leer wordt over het algemeen zowel in verzoekschrift-als in dagvaardingsprocedures geaccepteerd. Kan de Nederlandse rechter in erfrechtzaken geen rechtsmacht ontlenen aan een geschreven regel, dan kan hij niettemin kennis nemen van

$286 . \rightarrow$

afwikkeling en verdeling der nalatenschap rijzende geschillen in Nederland geen bevoegde rechter zouden vinden. Het ligt mede daarom veeleer in de rede ervan uit te gaan dat als de in art. 126 onder $12 \mathrm{e}$ vervatte uitzondering op de hoofdregel van art. 126 onder $10 \mathrm{e}$ geen toepassing kan vinden, die hoofregel haar werking herneemt."

287. Verheul en Feteris 1986, 165-167; MvT bij wet van 7 mei 1986, Stb. 295 (zie noot 286), TwK 1980$1981,16593,3$, p. 15.

288. Voor een uitgebreidere bespreking zij verwezen naar Verheul en Feteris 1986, 166-174.

289. Zie bijvoorbeeld in art. 814 lid 2 Rv.

290. Strikwerda $1995,248-249$.

291. Aldus ook de Hoge Raad in zijn arrest van 1984 (zie noot 285). In dit arrest overwoog de Hoge Raad ten overvloede dat ook indien aan de bevoegdheidsvoorwaarden is voldaan, "de mede aan het voorschrift van art. 126 onder $12 \mathrm{e}$ ten grondslag liggende, in internationale gevallen des te sterker sprekende gedachte dat het in "zaken van erfenis" van belang is tegenstrijdige beslissingen te voorkomen", kan "meebrengen dat niettemin in bijzondere gevallen, waarin de vordering onvoldoende aanknoping heeft met de rechtssfeer van Nederland, aan de Nederlandse rechter geen rechtsmacht toekomt. "Een enkele schrijver leidde hieruit af dat hiermee de forum non conveniens-regel in het erfrecht was geintroduceerd, van der Velden 1985, 243-244; Verheul 1986, 479; Verheul en Feteris 1986, 165. Kritisch hierover Schultsz in zijn noot bij het arrest. 
een zaak wanncer er geen andere buitenlandse rechter bevoegd is, er sprake is van een zodanige verbondenheid met de Nederlandse rechtssfeer dat procederen in het buitenland bezwaarlijk van partijen kan worden gevergd, of met zijn beslissing een Nederlands maatschappelijk belang wordt gediend ${ }^{292}$.

\section{Forumkeuze}

Sinds de uitspraak van de Hoge Raad in het Piscator-arrest ${ }^{293}$ wordt algemeen aangenomen dat, onder de voorwaarden die in dit arrest worden gesteld, de Nederlandse rechter zijn bevoegdheid kan ontlenen aan een door partijen gedane forumkeuze ${ }^{294}$. De voorwaarden die in dit arrest worden gesteld zijn: 1. dat er geen verdrags- of wetsbepaling is, waarin de rechtsmacht van de Nederlandse rechter specifiek is geregeld en welke zich tegen een forumkeuzebevoegdheid verzet; 2 . dat het gaat om een geschil over een zaak die ter vrije bepaling van partijen staat; 3 . dat voor het doen van een forumkeuze een redelijk belang niet ontbreekt. Gezien de tweede voorwaarde, het geschil moet gaan om een zaak die ter vrije bepaling van partijen staat, wordt een forumkeuze in de meeste familierechtelijke aangelegenheden niet aanvaard. Wat het erfrecht betreft zou cen forumkeuze echter zonder veel bezwaar kunnen worden toegela$\operatorname{ten}^{295}$.

\section{Wet conflictenrecht erfopvolging (WCEO)}

Naast de hierboven genoemde algemene bevoegdheidsregel (bevoegd is de rechter van het sterfhuis) en bijzondere bevoegdheidsgronden, bevat art. 5 WCEo (waarop op p. 130 en 136 nog wordt teruggekomen) een competentiescheppende bepaling, in het bijzonder voor gevallen waarin de nalatenschap in het buitenland is opengevallen en zich vermogensbestanddelen uit de nalatenschap in Nederland bevinden. Op grond van art. 5 lid 2 WCEo is de Nederlandse rechter bevoegd om voorzieningen te treffen teneinde te waarborgen dat de op grond van de in Nederland geldende verwijzingsregel toepasselijke erfwet wordt toegepast ten aanzien van in Nederland gelegen vermogensbestanddelen. Hij kan bevelen dat in verband daarmee zekerheden worden gesteld.

\section{B. VOORSTEL VAN WET}

Volgens het wetsvoorstel tot aanpassing van het Wetboek van Burgerlijke Rechtsvordering ${ }^{296}$ kan de Nederlandse rechter in internationale erfrechtzaken rechtsmacht ontlenen aan de algemene bevoegdheidsregels en daarnaast aan een bijzondere bevoegdheidsregel. De algemene bevoegdheidsregel in dagvaardingsprocedures is neergelegd in art. 1.1.2, waarin rechtsmacht aan de Nederlandse rechter wordt toegekend indien de ver-

292. Joppe, Vademecum 1980, 26-28; Lemaire 1968, 294-299; Strikwerda 1995, 249.

293. HR 1 februari 1985 , NJ $1985,698$.

294. Strikwerda 1995, 242-243.

295. Aldus Verheul en Feteris 1986, 90

296. Zie noot 282. 
weerder zijn woonplaats of zijn gewone verblijfplaats in Nederland heeft. De algemene bevoegdheidsregel voor verzoekschriftprocedures is neergelegd in art. 1.1.3. De alternatieve bevoegdheidsregel voor nalatenschappen is te vinden in art. 1.1.5 sub $\mathrm{f}$. Volgens deze bepaling heeft de Nederlandse rechter (voorts) rechtsmacht indien de erflater zijn laatste woonplaats of gewone verblijfplaats in Nederland had.

\section{Forum non conveniens}

In het wetsvoorstel ontbreekt een algemene forum non conveniens-regel ${ }^{297}$.

\section{Forum necessitatis}

In het wetsvoorstel wordt de forum necessitatis-regel in een afzonderlijke bepaling geregeld (art. 1.1.8). De voorgestelde bepaling luidt: "Komt de Nederlandse rechter niet op grond van de artikelen 1.1.2 tot en met 1.1.7 rechtsmacht toe, dan heeft hij niettemin rechtsmacht indien: a. het een rechtsbetrekking betreft die ter vrije bepaling van partijen staat en de gedaagde of belanghebbende in de procedure is verschenen niet uitsluitend of mede met het doel de rechtsmacht van de Nederlandse rechter te betwisten, tenzij voor rechtsmacht van de Nederlandse rechter geen redelijk belang aanwezig is, b. een gerechtelijke procedure buiten Nederland onmogelijk blijkt, of c. een zaak die bij dagvaarding moet worden ingeleid voldoende met de rechtssfeer van Nederland verbonden is en het onaanvaardbaar is van de eiser te vergen dat hij de zaak aan het oordeel van cen rechter van cen vreemde staat onderwerpt."

\section{Forumkeuze}

In het voorstel wordt de forumkeuze aanvaard in art. 1.1.7 lid 1.

\section{$\S 3$. Verwijzingscategorieën}

Het internationaal erfrecht is niet ondergebracht in één verwijzingscategorie, maar kent meerdere categorieën voor de verschillende onderdelen die in een erfrechtelijke kwestie de revue passeren. Er is een verwijzingscategorie voor de erfopvolging, een verwijzingscategorie voor de vorm van een uiterste wil, en een verwijzingscategorie voor de afwikkeling van de nalatenschap. Recentelijk heeft de IPR-wetgever voor de vereffening respectievelijk de verdeling van de nalatenschap twee conflictregels geformuleerd. Ook de bekwaamheid om bij uiterste wil te beschikken kan in het erfrecht als afzonderlijke

297. In de Memorie van Toelichting wordt als argument voor het ontbreken van een algemene forum non conveniens-regel aangevoerd dat de aanknopingspunten zoals deze in het wetsvoorstel zijn geformuleerd dermate substantieel zijn dat er naar de mening van de wetgever geen behoefte meer is aan een algemene forum non conveniens-bepaling voor verzoekschriftprocedures. TwK 1995-1996, 24651,3 , p. 65. Deze voorgestelde wijziging ten opzichte van het huidige art. $429 \mathrm{c} \mathrm{lid} 15 \mathrm{Rv}$ is in de literatuur kritisch ontvangen door Kokkini-Iatridou en Boele-Woelki 1993, 333-337; Boele Woelki, discussie 1996 (zie noot 282), 132-134; Koppenol-Laforce, Rechtsmacht 1994, 5-10; Vlas 1994, 68-69. Over het wijzigingsvoorstel zie voorts: Leijnse-Kolk 1996, 113-117: Strikwerda 1996, 98-104. 
verwijzingscategorie worden beschouwd. Een en ander resulteert in een bespreking van de conflictregels voor de volgende onderwerpen:

- paragraaf 4: de erfopvolging;

- paragraaf 5: de vorm van de uiterste wil;

- paragraaf 6: de bekwaamheid om bij uiterste wil te beschikken;

- paragraaf 7: de afwikkeling van de nalatenschap, onder te verdelen in de vereffening van de nalatenschap en de verdeling van de nalatenschap.

Bij deze "hoofdcategorieën" kan nog een drietal andere verwijzingscategorieën een rol spelen ${ }^{298}$, namelijk het procesrecht, dat met name aan de orde is bij de vereffening van de nalatenschap, en dat naar Nederlands IPR wordt beheerst door de lex fori; de vorm van handelingen, bijvoorbeeld bij een aantal vereffeningshandelingen of bij het maken van een ouderlijke boedelverdeling, welke vorm naar Nederlands IPR in ieder geval geldig is wanneer is voldaan aan de voorschriften van de lex loci actus (art. 10 Wet $A B$ ), maar welke geldigheid in beginsel eveneens kan worden vastgesteld aan de hand van de lex causae of mogelijk zelfs aan de hand van een ander bij de rechtsverhouding betrokken rechtsstelsel ${ }^{2 * *)}$; en de zakelijke rechten, bijvoorbeeld wanneer eigendom niet overgaat door het overlijden van de erflater maar pas na een leveringshandeling. De zakelijke rechten worden in het algemeen beheerst door de lex rei sitae.

Omdat iedere verwijzingscategorie een eigen conflictregel kent, kunnen in één erfrechtelijke zaak verschillende rechtsstelsels van toepassing zijn. Op zichzelf behoeft het naast elkaar toepasselijk zijn van verschillende rechtsstelsels geen probleem te zijn, mits de onderwerpen die door de verschillende rechtsstelsels geregeld worden ook materieel van elkaar gescheiden kunnen worden. Juist op dit punt knelt het in het erfrecht. In het materiële recht zijn de verschillende onderwerpen vaak aan elkaar gekoppeld, of beïnvloeden elkaar over en weer: sommige vereffeningshandelingen, zoals de verwerping van de nalatenschap, beïnvloeden direct de erfopvolging, de vorm van een uiterste wil kan zijn gekoppeld aan de inhoud ervan, etcetera. Een belangrijk discussiepunt in het Nederlands internationaal erfrecht is geweest de vraag of voor de afwikkeling van de nalatenschap een bijzondere verwijzingsregel moest gelden of dat deze zou moeten worden onderworpen aan de op grond van de verwijzingsregel inzake de erfopvolging toepasselijke erfwet ${ }^{300}$. De vraag werd ook expliciet gesteld in het preadvies van Westbroek en de Lange bij het Erfrechtverdrag ${ }^{301}$ alsmede bij de vraag naar de goed-

298. En verder nog de verwijzingscategorieën waarmee men te maken kan krijgen als er voorvragen rijzen. Deze worden besproken in hoofdstuk 5 .

299. Uitvoerig over de vorm van (authentieke) akten in het internationaal privaatrecht: Lubbers 1976,61-81, 91-94.

300. Meijers reeds in 1936, 636, 641-642. Voor een overzicht van deze discussie kan worden verwezen naar ten Wolde 1995, 12-21. Deze discussie zou, aldus ten Wolde 1995, 13, reeds zijn aangezwengeld door Hijmans in een in 1928 gegeven college voor de Ring Amsterdam van de Broederschap der Notarissen in Nederland.

301. Westbroek 1990, 103 en de Lange 1990, 159-171. 
keuring van dit Verdrag ${ }^{3 / 2}$ en het tot stand brengen van de Wet conflictenrecht erfopvolging ${ }^{303}$. Het naast elkaar bestaan van twee verwijzingscategorieën voor de erfopvolging respectievelijk de afwikkeling van de nalatenschap heeft als probleem dat hiermee de in het materieel recht doorgaans bestaande samenhang tussen erfopvolging en erfafwikkeling wordt doorbroken en de in het materieel recht onafscheidelijk gekoppelde zaken van elkaar gescheiden worden, en kunnen worden onderworpen aan twee verschillende rechtsstelsels. Het probleem treedt met name op wanneer het ene rechtsstelsel, zoals het Nederlandse, de saisine kent, en het andere rechtsstelsel niet. Er kan dan kortsluiting ontstaan bijvoorbeeld ten aanzien van de mogelijkheid van verwerping of de aansprakelijkheid voor schulden van de erflater. Een dergelijke kortsluiting kan worden voorkomen of achteraf worden gecorrigeerd door middel van een correctie van de verwijzingsregels of een aanpassing van het verwijzingsresultaat ${ }^{304}$. Zoals verderop in dit hoofdstuk zal blijken, heeft de Nederlandse wetgever ervoor gekozen om in het erfrecht de verschillende verwijzingscategorieën naast elkaar te handhaven. De mogelijkheid van een zekere vorm van aanpassing bij een kortsluiting tussen erfopvolging en afwikkeling wordt slechts voor twee omstandigheden expliciet geregeld ${ }^{305}$.

\section{Kwalificatie}

De vraag welke onderwerpen behoren tot een verwijzingscategorie, is een kwalificatievraag. Valt de aansprakelijkheid voor schulden van de erflater in de categorie erfopvolging of in de categorie vereffening? Heersende leer is dat het kwalificeren van rechtsfeiten, rechtsverhoudingen en rechtsinstellingen, buiten de gevallen waarin een verdragsautonome kwalificatic wordt verlangd, geschiedt aan de hand van de internationaal privaatrechtelijke begrippen van de lex fori ${ }^{306}$. Is eenmaal vastgesteld welke conflictregel van toepassing is, en verwijst deze naar een vreemd rechtsstelsel, dan kan het zijn dat dit vreemde recht materiële regels bevat die in de lex causae bij een ander onderwerp thuishoren dan dat van de verwijzingscategorie, of omgekeerd, materiële regels kent die volgens de lex causae wel tot het onderwerp van de verwijzingscategorie valien, doch die niet onder de verwijzingscategorie zouden worden gerekend. In het algemeen is men van mening dat deze secundaire kwalificatie de primaire kwalificatie volgt ${ }^{307}$. In steeds meer IPR-regels, ook in het internationaal erfrecht, wordt een opsomming gegeven van onderwerpen die tot de desbetreffende verwijzingscategorie behoren.

302. Rapport van de Staatscommissie voor het internationaal privaatrecht aan de Staatssecretaris van Justitie, juni 1992.

303. TwK 1993-1994, 23857,3, p. 3-4.

304. Niet alleen bij verwijzingscategorieën binnen het erfrech zelf, maar ook in de verhouding tussen venwijzingscategorieën uit het erfrecht en het huwelijksvermogensrecht c.q. de onderhoudsverplichtingen, kunnen korsluitingen ontstaan warop door middel van aanpassing kan worden gereageerd. Hierop wordt teruggekomen in hoofdstuk 6.

305. Zie de op p. 136 te bespreken artikelen 4 lid 2 en 5 lid 2 van de Wet conflictenrecht erfopvolging.

306. Cohen Henriquez, IPR-trends 1980, 45-46; Lemaire 1968, 339-342; Strikwerda 1995, 64. En voor het erfrecht in het bijzonder: Joppe, Vademecum 1980, 11, 16. 


\section{$\S 4$. Erfopvolging: de toepasselijke erfwet}

Op 1 oktober 1996 is de Wet conflictenrecht erfopvolging (WCEo) ${ }^{308}$ in werking getreden. Wat het toepasselijke recht op de erfopvolging betreft wordt in het eerste artikel van deze wet verwezen naar de conflictregels uit het Erfrechtverdrag ${ }^{309}$. Dit Verdrag is door Nederland goedgekeurd, doch nog niet in werking getreden. Voor inwerkingtreding is namelijk de bekrachtiging, aanvaarding of goedkeuring van drie Staten nodig (art. 28 lid 1 Erfrechtverdrag). Ten tijde van de afronding van het onderhavige bock (april 1997) heeft alleen Nederland het Verdrag nog goedgekeurd ${ }^{310}$. De inwerkingtreding van de WCEo brengt met zich mee dat de oude verwijzingsregel van Nederlands internationaal erfrecht die gold vóór de inwerkingtreding van het Verdrag haar betekenis vrijwel geheel heeft verloren. Het oude verwijzingsrecht zal met name nog van belang kunnen zijn in lopende geschillen of toekomstige geschillen omtrent vóór de inwerkingtreding van het Erfrechtverdrag opengevallen nalatenschappen, en wanneer onder vigeur van de oude conflictregel rechten zijn verkregen die ook na de inwerkingtreding van het Erfrechtverdrag moeten worden gerespecteerd (droits acquis). Niet alleen vanwege deze betekenis die nog aan de oude verwijzingsregel moet worden toegekend, maar ook om de ontwikkeling in het Nederlandse internationale erfrecht te schetsen, wordt hieronder ook de oude regeling nog beknopt uiteengezet.

\section{A. OUDE CONFLICTENRECHT INZAKE DE ERFOPVOLGING}

De verwijzingsregel voor de erfopvolging vond haar grondslag in het ongeschreven recht, in het bijzonder in de Nederlandse jurisprudentie en het oude ontwerp voor een cenvormige Benelux-IPR-wet ${ }^{311}$. Hoofdregel was dat de erfopvolging werd beheerst door het recht van de Staat waarvan de erflater de nationaliteit bezat op het tijdstip van zijn overlijden ${ }^{312}$. Bezat de erflater op het tijdstip van zijn overlijden meerdere nationaliteiten dan werd aangenomen dat aangeknoopt diende te worden bij de effectieve nationaliteit ${ }^{313}$. Bij staatloosheid gold het recht van de laatste gewone verblijfplaats van de erflater ${ }^{314}$. In twee gevallen was het denkbaar dat de hoofdregel niet werd

308. Regeling van het conflictenrecht inzake de erfopvolging alsmede de vereffening en de verdeling van de nalatenschap, Stb. 1996, 457.

309. 's-Gravenhage 1 augustus 1989, Trb. 1994, 49; Nederlandse vertaling Trb. 1994, 168.

310. Goedkeuringswet Stb. 1996, 456.

311. In 1969 sloten Nederland, België en Luxemburg een Verdrag tot invoering van een eenvormige wet betreffende het internationaal privaatrecht (E.W.)(gewijzigde versie van de E.W. van 1951), Trb. 1969, 167. Uit art. 9 E.W.-ontwerp volgde dat het nationale recht van de erflater ten tijde van diens overlijden de erfopvolging beheerste. Bij de intrekking van het E.W.-ontwerp werd gezegd dat art. 9 als ongeschreven recht moest worden beschouwd.

312. Deze in de lagere rechispraak en literatuur gebezigde opvatting werd bevestigd in HR 16 maart 1990, NJ 1991, 575.

313. Van der Ploeg 1979, 212; ten Wolde 1996, 30, 32.

314. Ten Wolde $1996,35$. 
toegepast, namelijk ten eerste als de erflater op het tijdstip van zijn overlijden geen reële banden van betekenis meer had met zijn nationaliteitsland. Deze uitzondering werd met name in de lagere rechtspraak toegepast ${ }^{315}$ en werd onder schrijvers doorgaans geaccepteerd $^{316}$. De Hoge Raad heeft zich hierover nimmer ondubbelzinnig uitgelaten. Een tweede uitzondering kon gelden als de erflater een rechtskeuze had uitgebracht. Onder het oude recht was omstreden of een dergelijke conflictenrechtelijke rechtskeuze in het internationaal erfrecht moest worden geaccepteerd. Op beide punten wordt hieronder nader ingegaan.

\section{Ontbreken van reële banden met het nationaliteitsland}

Aangenomen werd dat de mogelijkheid om af te wijken van de nationaliteit als aanknopingsfactor als de erflater ten tijde van zijn overlijden geen reële banden meer had met zijn nationaliteitsland, voor het ecrst werd geopend in de uitspraak inzake de Estlandse nalatenschap ${ }^{317}$. Het ging in deze zaak om een als Nederlander in Nederland geboren man die, op enkele maanden na, zijn gehele leven in Nederland of de Nederlandse koloniën had gewoond, en dic vervolgens in 1942 in Nederland overleed. In 1933 had de man zich tot Estlander laten naturaliseren. Met Estland had hij geen andere banden dan die van naturalisatic, het verlengen van het Estlandse paspoort, en het zo nu en dan geven van een gift voor een goed doel ten voordele van Estland. Na zijn naturalisatie had de man bij testament een van zijn kinderen benoemd als enig en algemeen erfgenaam. In geschil was of de erfopvolging moest worden beheerst door het recht van Estland, als het nationale recht van de erflater ten tijde van zijn overlijden, of door Nederlands recht, nu immers met Estland geen reële banden van betekenis bestonden. In het laatste geval zou namelijk de legitieme portie van tenminste één ander kind dienen te worden gerespecteerd. Het Gerechtshof Amsterdam, rechtsprekende in hoger beroep, had aan het nationaliteitscriterium geen doorslaggevende betekenis toegekend. Het Hof overwoog "dat namelijk de (...) feiten en omstandigheden in dit geval het Nederlandsche recht bestempelen tot dat recht, bij welks toepassing de rechtstoestand van de nalatenschap het beste past bij de opvattingen omtrent zeden, recht en gebruiken van den kring, waartoe de overledene behoorde (...)". In het cassatiemiddel werd de toepasselijkheid van Nederlands recht in het bijzonder bestreden met een verwijzing naar de toepasselijkheid van de art. 6 en 9 Wet AB en de art. 960 en 961 (oud) BW. De Hoge Raad kon dit middel verwerpen door te overwegen dat in deze wetsbepalingen geen conflictregel voor het recht dat de erfopvolging beheerst kon worden gelezen. Over de overweging van het Hof op grond waarvan de toepasselijkheid van Nederlands recht gerechtvaardigd zou zijn, behoefde de Hoge Raad zich niet meer uit te laten. Vervolgens gaat de Rechtbank Utrecht in zijn vonnis inzake de Turkse te Vleuten ${ }^{318}$ nog verder dan het Hof Amsterdam door het nationaliteitscriterium als uitgangspunt geheel te verlaten. De

315. Voor een bespreking van deze rechtspraak zij verwezen naar ten Wolde 1996, 17-22.

316. Voor een overzicht van opvatingen in de literatuur: ten Wolde 1996, 22-24.

317. HR 21 maar 1947, NJ 1947, 382.

318. Rb Utrecht 12 november 1954 , NJ 1955, 372. 
Rechtbank overwoog: "dat het ongeschreven Ned. Internationaal Privaatrecht m.b.t. het erfrecht geen algemeen geldende regel bevat, doch volgens dat recht de vraag of op het erfrecht het nationaliteits- dan wel het domicilie-beginsel moet worden toegepast van geval tot geval dient te worden beantwoord met dien verstande dat de vererving wordt beheerst door dat recht, hetwelk het meest strookte en zich het nauwste aanpaste bij de maatschappelijke en rechtsopvattingen, zeden en gebruiken van de kring waartoe de overledene behoorde en wilde behoren". De IPR-regel zoals deze door de Rechtbank Utrecht was geformuleerd kreeg echter geen erkenning. Uit de rechtspraak die ná dit vonnis is gewezen, blijkt dat het nationaliteitscriterium als uitgangspunt gehandhaafd bleef $^{319}$. Alleen op grond van zwaarwegende omstandigheden kon van deze hoofdregel worden afgeweken. Dergelijke zwaarwegende omstandigheden konden met name aanwezig zijn als er geen reële banden van betekenis met het nationaliteitsland meer waren. Of deze er nog waren moest worden beoordeeld naar de feiten en omstandigheden van het concrete geval. Indien reële banden met het nationaliteitsland van de erflater ontbraken, en voor toepassing van het nationale recht mitsdien geen rechtvaardiging meer bestond, moest vervolgens de vraag worden beantwoord, aan de hand van welk aanknopingspunt het toepasselijke recht dan moest worden vastgesteld. Zowel in de rechtspraak als in de literatuur bestond de neiging aan te knopen bij het recht van het laatste domicilie van de erflater ${ }^{320}$.

\section{Rechtskeuze}

Zoals gezegd was onder het oude recht omstreden of een rechtskeuze in het internationaal erfrecht werd erkend. De rechtspraak was terughoudend op dit punt. In de literatuur daarentegen werd steeds meer geneigd naar het accepteren van een rechtskeu$\mathrm{ze}^{321}$. De argumenten die tegen het accepteren van een rechtskcuze werden aangevoerd waren encrzijds van inhoudelijke aard, met name vroeg men zich af of het toelaatbaar was om dwingende rechtsregels - in Nederland met name de legitieme portie betreffende - te omzeilen, en anderzijds van methodologische aard: past het toelaten van een rechtskeuze wel binnen de IPR-methodologie? Sommigen beschouwden de rechtskeuze als verlegenheidsoplossing, te gebruiken als steunargument wanneer nationaliteitsaanknoping om de een of andere reden problematisch was. Argumenten die vóór het

319. Rb Rotterdam o februari 1967. NJ 1967, 480; Rb Middelburg 12 juni 1974, NJ 1977, 326; Hof 's-Gravenhage 26 maart 1980, AK 12.167; HR 16 maart 1990, NJ 1991, 575.

320. Zie o.m. HR 21 maan 1947, NJ 1947, 382; Rb Utrecht 12 november 1954, NJ 1955, 372; Hof Leeuwarden 3 maart 1954, NJ 1954, 328; Rb Rotterdam 6 februari 1967, NJ 1967, 480; en duidelijker nog: Rb Middelburg 12 juni 1974, NJ 1977, 326. Cohen Henriquez, IPR-trends 1980, 123-124; Cohen Henriquez 1977, 6; Cohen Henriquez, Vervreemding 1989, 549; Cohen Henriquez, Grepen 1989, 4042; Joppe, Vademecum 1980, 36; Mostermans 1988, 720; Strikwerda 1995, 166; ten Wolde 1996, 16.

321. Als voorstanders kunnen worden genoemd: Cohen Henriquez, IPR-trends 1980, 136; Cohen Henriquez 1977, 7; Cohen Henriquez 1985, 239; Cohen Henriquez, Grepen 1989, 45; Heyning \& Marck, Eén zwaluw 1993, 284; Jessurun d'Oliveira 1974, 20a-20b; Joppe, Vademecum 1980, 44; Joppe 1992, 182; Joppe 1996, 91; de Lange 1990, 166; Mostermans 1988, 717-718; ten Wolde, Rechtskeuze 1992, 728. Tegenstander: Bervoets 1974, 43. Een aantal argumenten voor en tegen het toelaten van de rechtskeuze in het erfrecht is ook te vinden in Struycken 1974, 385-387. 
accepteren van een rechiskeuze werden aangevoerd betroffen het afnemend belang van dwingende regels in het erfrecht, het belang van de beschikkingsvrijheid, het belang van de rechtszekerheid, het feit dat ook op andere terreinen de rechtskeuze stecds meer veld won, en uiteraard het naderende Erfrechtverdrag ${ }^{322}$. Voorzover men van mening was dat een rechtskeuze in het erfrecht kon worden geaccepteerd, werd in het algemeen aangenomen dat deze was beperkt tot een keuze voor het nationale recht of voor het domiciliaire recht ${ }^{323}$. Dit kon betreffen zowel de nationaliteit c.q. het domicilie ten tijde van het overlijden als de nationaliteit c.q. het domicilie ten tijde van het doen van de rechtskeuze. Sommige schrijvers achtten ook een partiële rechtskeuze voor de lex rei sitae denkbaar ${ }^{324}$. Een materiële rechtskeuze werd in het algemeen wel toelaatbaar geacht $^{325}$.

\section{B. ERFREChTVERDRAG EN WET CONFLICTENRECHT ERFOPVOLGING}

Omdat het Erfrechtverdrag ${ }^{326}$ naar verwachting binnen afzienbare tijd in werking zal treden, en aangezien de inmiddels al wel in werking getreden Wet conflictenrecht erfopvolging (WCEo) ${ }^{327}$ verwijst naar de regels uit het Verdrag, is een afzonderlijke bespreking van het Erfrechtverdrag niet van belang. Bij de behandeling van de regels uit het Erfrechtverdrag en de WCEo zal nader worden stilgestaan bij enkele specifieke punten die aan de orde kunnen zijn als de erfopvolging door Marokkaans recht wordt beheerst. Dit gebeurt onder de kopjes "Marokkaanse erflaters".

\section{Toepassingsbereik}

\section{Intertemporeel toepassingsgebied}

$\mathrm{Na}$ de inwerkingtreding zal het Erfrechtverdrag in Nederland van toepassing zijn op personen die overlijden na de datum van inwerkingtreding (art. 22 lid 1). Indien de erflater echter voorafgaande aan de inwerkingtreding van het Verdrag een rechtskeuze heeft uitgebracht, wordt deze rechtskeuze als geldig beschouwd indien is voldaan aan de geldigheidsvereisten die in art. 5 van het Verdrag worden gesteld (art. 22 lid 2), en bij een rechtskeuze in een overeenkomst van erfopvolging indien is voldaan aan de

322. Sommige auteurs waren in het begin van de jaren negentig van mening dat op het Erfrechtverdrag reeds geanticipeerd kon worden, Hensen, Reactie 1993, 495; Joppe 1992, 182; ten Wolde 1992, 728.

323. Aldus o.m. Bos 1989, 469; Cohen Henriquez, IPR-trends 1980, 136; Cohen Henriquez 1977, 7; Cohen Henriquez, Grepen 1989, 45; Mostermans 1988, 720.

324. O.m. Strikwerda $1987,152$.

325. Ten Wolde 1996, 44.

326. 's-Gravenhage 1 augustus 1989, Trb. 1994, 49; Nederlandse veraling Trb. 1994, 168. Het Verdrag wordt besproken door o.m.: Droz 1989, 213-216; Heyning en Marck 1995, 195-198; Joppe 1992. 179-198; Lagarde 1989, 249-275; van Loon 1989, 48-58; Scoles 1994, 85-123; Strikwerda 1987, 149. 152; Struycken 1993, 351-356; Westbroek 1989,457-461; Westbroek 1990,83-157; ten Wolde 1996, 229-329.

327. Regeling van het conflictenrecht inzake de erfopvolging alsmede de vereffening en de verdefing van de nalatenschap, Stb. 1996, 457. 
bepalingen van art. 11 (art. 22 lid 3). Voor de Wet conflictenrecht erfopvolging (WCEo) geldt eenzelfde regel: de Wet is van toepassing op de erfopvolging van personen die na de inwerkingtreding van de Wet - op 1 oktober 1996 - overlijden (art. 7 lid 1). Voor rechtskeuzes die zijn uitgebracht voorafgaande aan de inwerkingtreding van de WCEo geldt dat een dergelijke aanwijzing geldig is indien zij voldoet aan de bepalingen van art. 5 van het Verdrag (art. 7 lid 2) dan wel, bij een rechtskeuze in een overeenkomst van erfopvolging, indien is voldaan aan de bepalingen van art. 11 van het Verdrag (art. 7 lid 3). Een vóór de inwerking treding van de Wet gedane rechtskeuze kan niet als ongeldig worden beschouwd op de enkele grond dat de wet deze toen niet regelde (art. 7 lid 4 ).

\section{Formeel toepassingsgebied}

Het Erfrechtverdrag is van toepassing zelfs als het toepasselijke recht dat van een nietVerdragsluitende Staat is (art. 2). Met andere woorden: het Verdrag stelt geen reciprociteitseis. De WCEo stelt geen beperkingen aan het formeel toepassingsgebied.

\section{Materieel toepassingsgebied}

Wat de verwijzingsregel voor de erfopvolging betreft wordt in art. 1 WCEo verwezen naar de toepasselijkheid van de bepalingen uit het Erfrechtverdrag. Wat de erfopvolging betreft conformeert de WCEo zich dus aan het materieel toepassingsgebied van het Verdrag. De WCEo kent voorts afzonderlijke conflictregels voor de vereffening en de verdeling van nalatenschappen ${ }^{328}$.

Het is zaak te onderscheiden welke onderwerpen door de verwijzingsregel inzake de erfopvolging worden beheerst en welke hiervan zijn afgescheiden en aan andere conflictregels zijn onderworpen. Dit is te meer van belang omdat het erfrecht verschillende raakvlakken heeft met andere onderwerpen, zoals het huwelijksvermogensrecht, schenkingen en dergelijke, en tevens omdat er binnen het erfrecht vaak sprake is van een vloeiende lijn tussen de erfopvolging en de afwikkeling van de nalatenschap. Voor een belangrijk deel kan het materieel toepassingsgebied worden afgeleid uit het Erfrechtverdrag zelf. In art. I van het Verdrag wordt aangegeven welke onderwerpen buiten de toepassing van het Verdrag vallen. In art. 7 wordt aangegeven welke onderwerpen binnen de toepassing van het Verdrag vallen. Onderwerpen die buiten de toepassing van het Verdrag vallen zijn (art. 1 lid 2):

a. de vorm van uiterste wilsbeschikkingen;

b. de bekwaamheid om bij uiterste wil te beschikken;

c. vragen die het huwelijksvermogensregime betreffen;

d. rechten en goederen, in het leven geroepen of overgedragen op andere wijze dan door erfopvolging, zoals aan verschillende personen gemeenschappelijke eigendom 
welke overgaat op de langstlevende, pensioenregelingen, verzekeringsovereenkomsten of regelingen van soortgelijke aard ${ }^{329}$.

In art. 7 lid 2 worden de onderwerpen genoemd die worden beheerst door het door de verwijzingsregel van het Verdrag aangewezen recht. Het betreft hier een enuntiatieve opsomming. Het derde lid van art. 7 biedt Verdragsluitende Staten immers de mogelijkheid om ook op onderwerpen die niet in het tweede lid worden genoemd maar die volgens het recht van die desbetreffende Staat onder de erfopvolging vallen, het ingevolge het Verdrag toepasselijke recht toe te passen. Dit dient dan te geschieden via het eigen conflictenrecht van een Staat. In de literatuur is de vraag gesteld of de door art. 1 van de toepasselijkheid van het Verdrag uitgesloten onderwerpen middels het derde lid van art. 7 toch weer onder de tocpasselijkheid van de verwijzingsregel van het Verdrag konden worden gebracht ${ }^{330}$. Het toelichtend rapport van Waters geeft op deze vraag een tegenstrijdig antwoord ${ }^{331}$. Anders dan een meerderheid van de Staatscommissie voor IPR ${ }^{332}$ acht Westbroek het juister om art. 1 op te vatten als een dwingendrechtelijke negatieve begrenzing ${ }^{333}$.

In het tweede lid van art. 7 worden de onderwerpen genoemd die in ieder geval wel worden beheerst door het ingevolge het Verdrag toepasselijke recht. In het eerste lid van art. 7 wordt bepaald dat dit recht, behoudens een materiële rechtskeuze (zie hierna p. 116) de vererving van de gehele nalatenschap beheerst, ongeacht waar de goederen zich bevinden. Dit recht behecrst:

a.1 de aanwijzing van de erfgenamen en legatarissen, de bepaling van de onderscheiden erfdelen en de verplichtingen die hun door de erflater zijn opgelegd

Deze clausule heeft betrekking op de vragen wie erfgenamen en legatarissen zijn, op welk deel van de nalatenschap zij recht hebben en onder welke voorwaarden zij dit recht hebben. Uit de regel dat de aanwijzing van de erfgenamen wordt beheerst door het door

329. Het bepaalde onder d) is opgenomen ten gerieve van de common law-landen, teneinde rechten en goederen die door middel van zogenaamde "will institutes" onder levenden in het leven zijn geroepen, buiten de conflictregels van het Verdrag te houden. Westbroek 1990, 133 omschrijft de "will institutes" ais bij leven getroffen beschikkingen, die niet bij testament gemaakt behoeven te worden, maar wel de strekking hebben de financiële positie van de nabestaanden te regelen. Een voorbeeld van een dergelijk "will institute" is de onder levenden gevestigde trust, aldus Waters, Explanatory Report 1988, par. 46. Een aantal Marokkaanse familie-ahbâs, die onder levenden zijn gevestigd, zal door deze bepaling van de toepassing van het Erfrechtverdrag worden uitgezonderd.

330. Westbroek 1990, 103-104.

331. In par. 36 wordt aangegeven dat een Verdragsstaat op grond van het derde lid van ant. 7 via haar eigen conflictregels de verdragsregel ook kan toepassen op de in art. 1 uitgesloten onderwerpen. In par. 74 laatste alinea wordt aangegeven dat deze onderwerpen niét via art. 7 lid 3 onder de erfwet kunnen worden gebracht.

332. Rapport Staatscommissie IPR 1992, par. 6.

333. Westbroek $1990,104$. 
de verdragsregel aangewezen erfrecht, kan nict worden afgeleid dat dit recht tevens van toepassing is op de voorvragen aan de hand waarvan dient te worden vastgesteld of men de door de toepasselijke erfwet vereiste hoedanigheid van erfgenaam heeft. De vraag hoe deze voorvragen kunnen worden beoordeeld, komt uitvoerig aan de orde in het vijfde hoofdstuk van dit boek.

Bij de afbakening en invulling van de onderscheiden erfdelen kunnen zich problemen voordoen wanneer de lex rei sitae zich opdringt. Dit zal met name het geval zijn wanneer zich nalatenschapsvermogen bevindt in cen land dat niet is aangesloten bij het Erfrechtverdrag en dit land de zaken aan een ander recht onderwerpt dan het recht dat op grond van het Erfrechtverdrag als toepasselijk wordt aangewezen. In de WCEo wordt dit probleem behandeld in het kader van de vereffening (art. 2 WCEO). De erfdelen worden uitsluitend vastgesteld aan de hand van de toepasselijke erfwet, zonder dat rekening wordt gehouden met de vraag of zij in verband met de lex rei sitae geëffectueerd kunnen worden.

\section{Marokkaanse erflaters}

In art. 18 van de Marokkaanse IPR-wet (DCC, waarover hoofdstuk $7 \S 1$ ) wordt uitgegaan van een eenheid van de nalatenschap. Aangeknoopt wordt bij het nationale recht van de erflater. De erfopvolging van cen Marokkaanse erflater ten aanzien van vermogen dat zich in Marokko bevindt, wordt mitsdien beheerst door het Marokkaanse recht, niet op grond van de lex rei sitae maar op grond van een aanknoping aan de nationaliteit.

a.2 andere rechten op de nalatenschap die ontstaan als gevolg van het overlijden, daaronder begrepen toewijzingen uit de nalatenschap door een rechterlijke of een andere autoriteit ten gunste van personen die de erflater na stonden

Hier gaat het vooral om de mogelijkheid die in sommige landen bestaat dat de rechter of cen andere autoriteit gedeelten van de nalatenschap toewijst aan personen die nauw met de erflater verbonden waren ${ }^{334}$. Wat het Nederlandse recht betreft kan bijvoorbeeld worden gedacht aan de onderhoudsverplichting die een erflater ten opzichte van zijn onwettige niet erkende kinderen heeft (art. 1:406 lid 5 BW).

b. de onterving en de uitsluiting wegens onwaardigheid

c. de inbreng en de inkorting van schenkingen en makingen alsmede de wijze waarop deze bij de berekening van de erfdelen worden verwerkt

Problemen ontstaan wanneer op het moment dat de schenkingen of makingen werden gedaan, een conflictregel gold op grond waarvan een ander recht de erfopvolging zou 
beheersen dan het recht dat bij het overlijden daadwerkelijk van toepassing is, of wanneer in het toepasselijke recht materiële wijzigingen zijn opgetreden, en hierdoor de inbreng en inkorting van de schenking of making anders zou worden gewaardeerd.

\section{Marokkaanse erflaters}

Naar Marokkaans recht zijn schenkingen tijdens leven gedaan, met uitzondering van schenkingen gedaan op het sterfbed, onbeperkt toegestaan zonder dat deze behoeven te worden ingebracht of ingekort bij het overlijden van de schenker. Wanneer een Marokkaan in Nederland tijdens zijn leven vóór de inwerkingtreding van het Erfrechtverdrag of de WCEo een deel van zijn vermogen heeft geschonken aan een toekomstig erfgenaam, zou volgens de op dat moment geldende verwijzingsregel zijn erfopvolging in principe worden beheerst door het Marokkaanse recht. Er zou geen inbreng of inkorting plaatsvinden. Indien de Marokkaan ná de inwerkingtreding van het Verdrag of de WCEo zou komen te overlijden, kan het zijn dat zijn erfopvolging wordt beheerst door Nederlands recht. De gedane schenking zou dan moeten worden ingebracht en ingekort. Hetzelfde probleem treedt overigens op wanneer de Marokkaan zich na de schenking (onvoorzien) zou laten naturaliseren, en op grond van zijn gewijzigde nationaliteit Nederlands recht op de erfopvolging zou worden toegepast. De vraag is of de rechten verkregen onder de erfwet die van toepassing zou zijn op grond van de ten tijde van de schenking geldende verwijzingsregel, kunnen worden gerespecteerd. In de literatuur wordt er de voorkeur aan gegeven om deze rechten als "droits acquis" te respecteren, met als gevolg dat de schenking niet behoeft te worden ingebracht of ingekort ${ }^{335}$, mits, zo voegt een enkele schrijver eraan toc, de begiftigde erop mocht vertrouwen dat de schenking bij het overlijden van de schenker niet zou behoeven te worden ingebracht ${ }^{336}$. Bij schenkingen die zijn gedaan op het sterfbed van de erflater geldt naar Marokkaans recht dat deze nietig zijn voorzover ze het derde deel van het vermogen van de erflater overschrijden of zijn gedaan aan wettige erfgenamen, tenzij de (andere) erfgenamen hierin toestemmen ${ }^{337}$. Voor zover gedane schenkingen nietig zijn, behoort het geschonken vermogen nog tot het nalatenschapsvermogen van de erflater. Voor het geldig geschonkene geldt dat dit niet behoeft te worden ingebracht of ingekort. In één geval dienen naar Marokkaans recht gedane makingen tijdens het leven wel te worden ingebracht, namelijk wanneer bij het vooroverlijden van een zoon van de erflater aan een kleinkind, dat zou erven op grond van het verplicht testament (zie p. 85-90), meer is vermaakt dan het deel waarop het kleinkind krachtens verplicht testament recht zou hebben, en de andere erfgenamen voor het verkrijgen van dit meerdere geen toestemming hebben gegeven.

335. Joppe, Vademecum 1980, 55, 76; van der Ploeg 1961, 28-29; ten Wolde 1996, 97-98, 292. Voor Duitsland o.m. Scheuermann 1969, 116.

336. Scheuermann 1969, 116; ten Wolde 1996, 97-98, 292.

337. Zijn er op het sterfbed meerdere schenkingen gedaan die in totaal eenderde van het vermogen overschrijden, dan worde het geldig geschonken deel (van eenderde) verdeeld in chronologische volgorde waarin de schenkingen zijn gedaan. 
Heeft de erflater tijdens zijn leven een hubus gevestigd ten behoeve van erfgenamen, dan behoeft hiermee naar Marokkaans recht bij de berekening van de erfdelen geen rekening te worden gehouden. Alleen de testamentaire hubus en de hubus die is gevestigd op het sterfbed van de erflater is gebonden aan de ultra vires doctrine. Deze is niet geldig indien zij is gevestigd ten behoeve van erfgenamen of wanneer deze eenderde van de nalatenschap overschrijdt, behoudens de toestemming van de (andere) erfgenamen. Voor de mogelijkheid cen hubus te erkennen zij verwezen naar $\$ 9$.

Een ander onderwerp ten aanzien waarvan in de literatuur is aangegeven dat dit mogelijk onder art. 7 lid 2 sub c zou kunnen worden gebracht is de verrekening. Wanneer de volgens de erfwet vastgestelde erfdelen niet kunnen worden gerealiseerd omdat er sprake is van aanknopingsovermacht, hetgeen tot benadeling van erfgerechtigden leidt, heeft de benadeelde erfgenaam recht op verrekening. De verrekening geschiedt ten laste van de in het buitenland bevoordeelde erfgenaam. Volgens Westbroek bestaat er tussen inbreng en inkorting enerzijds en de verrekening anderzijds zoveel gelijkenis dat er geen reden is hiertussen onderscheid te maken, en zou de verrekening op grond van het in lid 2 onder $c$ gestelde door de erfwet moeten worden beheerst. Mocht deze opvatting niet worden gedeeld dan zou hij de verrekening onder lid 2 sub a willen doen laten vallen, hetgeen leidt tot hetzelfde resultaat ${ }^{338}$. In art. 2 lid 2 van de WCEo, waarin de verrekeningsmogelijkheid wordt crkend, wordt echter expliciet aangegeven dat deze ter gelegenheid van de vereffening van de nalatenschap plaatsvindt, en uitsluitend wanneer de benadeelde gerechtigde hierom vraagt. Hiermee valt de verrekening buiten art. 7 lid 2 sub $c$.

d. het beschikbare deel, de wettelijke erfdelen en andere beperkingen van de bevoegdheid om bij uiterste wil te beschikken

Deze bepaling heeft betrekking op de testeervrijheid en de beperkingen die hieraan kunnen worden gesteld ${ }^{339}$.

\section{Marokkaanse erflaters}

Naar Marokkaans recht is het deel waarover beschikt kan worden beperkt tot maximaal eenderde deel van de nalatenschap dat resteert nadat de begrafeniskosten en de schulden van de erflater zijn voldaan, behoudens instemming van de erfgenamen ab intestaat. Of en in hoeverre de beperking van de bevoegdheid om bij uiterste wil te beschikken verenigbaar is met de Nederlandse openbare orde, wordt uitvoerig besproken in hoofdstuk $6^{340}$.

338. Westbroek 1990, 124.

339. Waters, Explanatory Repon 1988, par. 79.

340. Goederen die voorwerp zijn van een hubus behoren naar Marokkaans recht niet meer tot het vermogen van de erflater, en daardoor evenmin tot het beschikbare deel. Voor de erkenning van de hubus zij verwezen naar $\$ 9$. 
e. de materiële geldigheid van testamentaire beschikkingen

Marokkaanse erflaters

Voor een bespreking van de inhoudelijke geldigheid van een testament naar Marokkaans recht, kan worden verwezen naar $\$ 3$. A van hoofdstuk 2 .

\section{Lid 3}

De Verdragsluitende Staten kunnen op grond van het derde lid van art. 7 onderwerpen die niet in het tweede lid zijn genoemd, onder de erfwet brengen. Onderwerpen die in het tweede lid bijvoorbeeld niet worden genoemd zijn de verwerping en aanvaarding van nalatenschappen en de aansprakelijkheid voor schulden. Blijkens de Wet conflictenrecht erfopvolging heeft de Nederlandse wetgever er voor gekozen om deze onderwerpen onder te brengen in een aparte verwijzingsregel inzake de vereffening van de nalatenschap. Hiermee worden zij afgescheiden van de erfwet en beheerst door het recht dat op de vereffening van toepassing is. In $\$ 7$ wordt ingegaan op de consequenties hiervan.

\section{De verwijzingsregel}

De objectieve verwijzingsregel is te vinden in art. 3. Anders dan onder het oude recht wordt in het Erfrechtverdrag ook de rechtskeuze uitdrukkelijk geaccepteerd (art. 5). Op grond van deze twee bepalingen wordt de erfopvolging beheerst door:

- het recht waarvoor een rechtskeuze is uitgebracht; bij gebreke van een rechtskeuze:

- door het op grond van de objectieve verwijzingsregel toepasselijke recht. Het ingevolge art. 3 of 5 toepasselijke recht beheerst de vererving van de gehele nalatenschap (eenheidsstelsel, art. 7 lid 1) ${ }^{341}$.

\section{a. Rechtskeuze}

Het Verdrag kent zowel een conflictenrechtelijke rechtskeuze (art. 5) als een materieelrechtelijke rechtskeuze (art. 6).

De conflictenrechtelijke rechtskeuze betreft een keuze voor het toepasselijke recht op de vererving van de gehele nalatenschap (art. 5 lid 1). Een partiële rechtskeuze wordt in het Verdrag niet erkend. Deze kan ook niet uit het vierde lid van art. 5 worden afgeleid, waarin staat "tenzij de erflater uitdrukkelijk anders heeft bepaald, wordt voor de toepassing van dit artikel de aanwijzing van het toepasselijke recht geacht betrekking te hebben op de vererving van de gehele nalatenschap (...)". De clausule "tenzij de

341. Op dit eenheidsstelsel wordt door enkele verdragsbepalingen een inbreuk toegelaten. Verwezen zij naar de art. 4, 5 lid 2, 6, 15, 18 en 24. Deze bepalingen komen in de hierna te bespreken paragrafen aan de orde. 
crflater uitdrukkelijk anders heeft bepaald", impliceert een verwijzing naar art. $6^{342}$, waarin de mogelijkheid wordt geboden om ten aanzien van bepaalde goederen een materiële rechtskeuze uit te brengen. In art. 5 lid 1 wordt de rechtskeuze beperkt tot een keuze voor:

- het recht van de Staat waarvan de erflater de nationaliteit bezat op het tijdstip van de aanwijzing of op het tijdstip van zijn overlijden;

- het recht van de Staat waar de erflater zijn gewone verblijfplaats had op het tijdstip van de aanwijzing of op het tijdstip van zijn overlijden.

In art. 24 lid I sub c wordt aan de Verdragsluitende Staten de mogelijkheid geboden een voorbehoud te maken ten aanzien van de erkenning van een rechtskeuze "gedaan door een persoon die op het tijdstip van zijn overlijden niet of niet meer de nationaliteit bezat van de Staat waarvan hij het recht had aangewezen of daar niet of niet meer zijn gewone verblijfplaats had, maar op dat tijdstip de nationaliteit bezat van de Staat die het voorbehoud heeft gemaakt en daar zijn gewone verblijfplaats had". Nederland heeft dit voorbehoud niet gemaakt.

Het tweede lid van art. 5 bevat een bepaling over de vorm waarin de rechtskeuze moet worden gedaan. Deze moet worden uitgedrukt in een verklaring dic, wat de vorm betreft, voldoet aan de vereisten voor uiterste wilsbeschikkingen. Aangezien het toepasselijk recht voor de uiterste wilsbeschikking voor Nederland is geregeld in het Haags Testamentsvormenverdrag (zie $\$ 5$ ), dient de rechtskeuze te voldoen aan de vormvereisten van het ingevolge het Testamentsvormenverdrag toepasselijke recht. De tweede zin in het tweede lid, inhoudende dat het bestaan en de materiële geldigheid van de aanwijzingshandeling worden beheerst door het bij de rechtskeuze aangewezen recht, dient aldus te worden verstaan dat niet aan de hand van het aangewezen recht wordt bepaald of een rechtskeuze mogelijk is en of deze qua inhoud geldig is - dat gebeurt immers aan de hand van het Erfrechtverdrag zelf (te toetsen aan art. 5 lid 1) - maar of de rechtskeuze volgens het aangewezen recht al dan niet aantastbaar is (bijvoorbeeld op grond van een wilsgebrek) ${ }^{343}$. Zou het bestaan van de rechtskeuze of de materiële geldigheid ervan volgens dit recht zijn aangetast, dan wordt de erfopvolging niet (langer) beheerst door het door de erflater aangewezen recht, maar is het door de objectieve verwijzingsregel aangewezen recht toepasselijk.

Op grond van art. 24 lid 1 aanhef en sub d kan een Verdragsluitende Staat een voorbehoud maken ten aanzien van de erkenning van een rechtskeuze, wanneer dit geschiedt ter bescherming van de (dwingendrechtelijke) legitieme van de langstlevende echtgenoot en de kinderen in zijn recht, het recht van deze Staat op grond van de objectieve verwijzingsregel toepasselijk zou zijn, en de te beschermen echtgenoot of het kind zijn gewone verblijfplaats heeft in dan wel de nationaliteit bezit van deze Staat. Nederland heeft dit voorbehoud niet gemaakt.

343. Waters, Explanatory Report 1988, par. 66; Westbroek 1990, 117. 


\section{De materieelrechtelijke rechtskeuze}

In het Verdrag wordt uitgegaan van een eenheid van de nalatenschap: het op grond van het Verdrag toepasselijke recht beheerst de vererving van zowel roerende als onroerende goederen. Op dit uitgangspunt kan een inbreuk worden gemaakt door gebruikmaking van de in art. 6 toegelaten materieelrechtelijke rechtskeuze. Ingevolge deze bepaling kan het recht van één of meer Staten worden aangewezen als het recht dat de vererving van bepaalde goederen in zijn nalatenschap beheerst. Een dergelijke rechtskeuze kan echter dwingende bepalingen van het ingevolge de verwijzingsregel uit het Verdrag toepasselijke recht niet opzij zetten.

\section{Marokkaanse erflaters}

Indien Marokkaans recht de erfopvolging beheerst, en de erflater zou bijvoorbeeld ten aanzien van zijn vermogen in Nederland hebben gekozen voor de toepassing van Nederlands recht, dan kan dit slechts voorzover het Marokkaanse dwingende recht hicraan niet in de weg staat. Dat betekent dat een dergelijke aanwijzing slechts mogelijk is tot maximaal eenderde van de nalatenschap en niet ten behoeve van wettige erfgenamen (behoudens toestemming van de andere erfgenamen). Zou Nederlands recht de erfopvolging beheersen, en de erflater zou ingevolge art. 6 ten aanzien van zijn in Marokko gelegen vermogen kiezen voor de toepasselijkheid van Marokkaans recht, dan is dit slechts toelaatbaar voorzover de Nederlandse dwingende bepalingen, in het bijzonder de bepalingen omtrent de legitieme, zich hiertegen niet verzetten.

\section{b. De objectieve verwijzingsregel}

De objectieve verwijzingsregel is neergelegd in art. 3. Hierin worden drie situaties onderscheiden:

1. op het tijdstip van zijn overlijden had de erflater zijn gewone verblijfplaats in de Staat waarvan hij de nationaliteit bezat. Het recht van de Staat van de gewone verblijfplaats beheerst dan de erfopvolging. (art. 3 lid 1);

2. op het tijdstip van zijn overlijden had de erflater gedurende ten minste vijf jaren onmiddellijk voorafgaande aan zijn overlijden zijn verblijfplaats in eenzelfde Staat. Het recht van de Staat van die laatste gewone verblijfplaats beheerst dan de erfopvolging. Echter, in uitzonderlijke omstandigheden, wanneer de erflater ten tijde van zijn overlijden kennelijk nauwere banden had met de Staat waarvan hij op dat moment de nationaliteit bezat, beheerst het recht van de Staat waarvan hij die nationaliteit bezat de erfopvolging. (art. 3 lid 2);

3. op het tijdstip van zijn overlijden had de erflater minder dan vijf jaren onmiddellijk voorafgaande aan zijn overlijden verblijfplaats in eenzelfde Staat. Het recht van de Staat waarvan de erflater op het tijdstip van zijn overlijden de nationaliteit bezat, beheerst dan de erfopvolging. Echter, indien hij op dat tijdstip nauwere banden had met een andere Staat, beheerst het recht van laatstgenoemde Staat de erfopvolging. (art. 3 lid 3); 


\section{Aanknopingsfactoren}

Uit de verwijzingsregels blijkt dat er drie aanknopingsfactoren zijn aan de hand waarvan het tocpasselijke recht dient te worden bepaald, te weten de nationaliteit, de gewone verblijfplaats, en de nauwere banden.

\section{Nationaliteit}

Of iemand de nationaliteit van een bepaalde Staat bezit wordt vastgesteld aan de hand van het nationaliteitsrecht van de desbetreffende Staat. Mochten bij de toepassing van dit recht voorvragen rijzen, bijvoorbeeld naar het bestaan van familierechtelijke betrekkingen, dan dienen deze eveneens te worden beantwoord aan de hand van het recht van deze Staat ${ }^{344}$. De nationaliteit als aanknopingsfactor kan problematisch worden indien de erflater geen reële banden (meer) had met deze nationaliteit (de zgn. verwaterde nationaliteit), een meervoudige nationaliteit bezat, of geen nationaliteit bezat. In het Verdrag zelf worden deze kwesties niet opgelost. Blijkens de verdragsgeschiedenis heeft men het probleem van de staatloosheid en meervoudige nationaliteit willen overlaten aan het forumland ${ }^{345}$.

Bezat de erflater slechts één nationaliteit, en had hij geen werkelijke banden van betekenis meer met (het land van) deze nationaliteit, dan kan aan dit "verwaterd" zijn van de nationaliteit alleen betekenis worden toegekend in de in art. 3 lid 3 genoemde situatie. Noch bij de toepassing van art. 5 omtrent de rechtskeuze, noch bij de toepassing van de objectieve verwijzingsregels uit art. 3 leden 1 en 2, vindt een realiteitstoets plaats. Bezat de erflater meerdere nationaliteiten, dan geldt wat de rechtskeuze betreft dat een keuze voor ieder der nationale rechtsstelsels is toegestaan ${ }^{346}$. Bij de toepassing van de objectieve verwijzingsregel is bij cen meervoudige nationaliteit in de situatie van het eerste lid van art. 3 alleen relevant de nationaliteit van de Staat waar de erflater tevens zijn laatste gewone verblijfplaats bezat. Een effectiviteitstoets vindt hier niet plaats ${ }^{347}$. Voor de in het tweede en derde lid van ant. 3 beschreven situaties daarentegen wordt aangenomen dat, voorzover wordt verwezen naar de nationaliteit als aanknopingsfactor, er in de geest van het Verdrag wel cen effectiviteitstoets dient plaats te vinden, en derhalve alleen de effectieve nationaliteit hier in aanmerking kan worden genomen ${ }^{348}$. Indien overigens een van deze nationaliteiten de nationaliteit is van het land waar de erflater zijn laatste gewone verblijfplaats had, is het eerste lid van art. 3 van toepassing. Bij staatloosheid zal een rechtskeuze alleen kunnen worden uitgebracht voor het recht van de Staat waar de erflater zijn gewone verblijfplaats had (op het tijdstip van het

344. De Groot, losbiadige PFR, Nationaliteitswetgeving, p. Nat.Inl.-83.

345. Waters, Explanatory Report 1988, par. 51.

346. Waters, Explanatory Repon 1988, par. 61.

347. MvT goedkeuringswet bij het Erfrechtverdrag. TwK 1993-1994, 23863 (1510), 3, p. 6. Kritisch hierover ten Wolde 1996, 247 (en 259).

348. Westbroek 1990, 111-112. MvT goedkeuringswet bij het Erfrechtverdrag. TwK 1993-1994, 23863 (R 1510), 3, p. 6, waar gesproken wordt over "een toetsing die verwant is aan de toepassing van het beginsel van de effectieve nationaliteit". 
uitbrengen van de rechtskeuze dan wel ten tijde van zijn overlijden) ${ }^{349}$. Bij de toepasselijkheid van de objectieve verwijzingsregel kan de in het eerste lid genoemde situatie zich niet voordoen. In de in het tweede lid beschreven situatie kan alleen het recht van de Staat van de laatste gewone verblijfplaats van toepassing zijn. Alleen in de in het derde lid beschreven situatie zou de staatloosheid derhalve een probleem kunnen opleveren. Hier zijn twee opties denkbaar: toepasselijk is het recht van de Staat van de gewone verblijfplaats, tenzij de erflater op het tijdstip van zijn overlijden nauwere banden met een andere Staat bezat, of toepasselijk is het recht van de Staat waarmee de erflater op het tijdstip van zijn overlijden de nauwste banden had. Beide mogelijkheden zullen overigens in principe tot eenzelfde resultaat moeten leiden.

\section{Marokkaanse erflaters}

Wat de Marokkaanse erflaters betreft geldt op dit moment dat er een toename is van Marokkanen die bipatride zijn. Door een naturalisatie tot Nederlander(se) verliezen zij in de regel hun Marokkaanse nationaliteit niet. Bezat een erflater ten tijde van zijn overlijden zowel de Nederlandse als de Marokkaanse nationaliteit, en had hij zijn laatste gewone verblijfplaats in Nederland, dan wordt op grond van art. 3 lid 1 de erfopvolging beheerst door Nederlands recht. De vraag naar de effectieve nationaliteit zal nog kunnen spelen wanneer de erflater die zijn laatste gewone verblijfplaats in Nederland had, naast de Marokkaanse nog een andere niet-Nederlandse nationaliteit bezat.

\section{Gewone verblijfplaats}

Het begrip "gewone verblijfplaats" wordt in het Verdrag niet nader gedefinicerd. Het begrip dient verdragsautonoom te worden uitgelegd, hetgeen betekent dat de betekenis ervan dient te worden vastgesteld aan de hand van de bedoeling van het Verdrag ${ }^{350}$. Uit de geschiedenis van de totstandkoming van het Verdrag blijkt dat het moeilijk was overeenstemming te bereiken over de wijze waarop de gewone verblijfplaats kan worden vastgesteld. Uiteindelijk wordt in het rapport Waters geconcludeerd dat hiervoor een aantal elementen dienen te worden gewogen ${ }^{351}$. Over het begrip "gewone verblijfplaats" wordt in dit rapport het volgende opgemeld: "Essentially it is the place of belonging of the de cujus. A person can only have one habitual residence, because it is the centre of his living, the place with which he is most closely associated in his pattern of life. For the purpose of determining this place, his family and personal ties are particularly important elements. Intention appears to play a more muted role as an element in habitual residence than it traditionally has done in domicile (...). It is a regular physical presence, enduring for some time, and a clearly stronger association than 'ordinary' or 'simple' residence (cursief SR)(...). However, the manifest hopes and plans of the de cujus (cursief SR) are also elements that may be legitimately considered by the person who would have to know which State is the habitual residence."

349. MvT goedkeuringswet bij het Haags Erfrechtverdrag, TwK 1993-1994, 23863 (R 1510), 3, p. 9.

350. Westbroek 1990, 110.

351. Waters, Explanatory Report 1988, par. 51. 


\section{Nauwere banden}

Bij de vraag of de erflater nauwere banden had met een ander land dan dat van zijn nationaliteit dient, aldus de wordingsgeschiedenis van het Verdrag, eveneens een aantal elementen te worden gewogen, te weten "his nationality, the location of his immediate family, his personal ties, the nature and location of his employment or business, the permanence of his place of residence (his apparent home), the principle situs of his personal assets, and his journeying and the reasons for the same" 35?. Zowel economische als culturele, persoonlijke en emotionele factoren kunnen derhalve een rol spelen bij het bepalen van de nauwere verbondenheid met een Staat. Het geven van een opsomming van alle factoren die hierbij in aanmerking kunnen worden genomen, betekent overigens geenszins dat de toepassing van deze verdragsbepaling eenvoudig is. Zo zal het heel wel denkbaar zijn dat een Marokkaanse erflater die reeds een aantal jaren in Nederland verblijft, met heel zijn familie, en wiens gehele vermogen zich in Nederland bevindt, en die in Nederland werkzaam is, vanwege een emotionele binding met Marokko of een binding met de Islam, toch nauwere banden heeft met zijn nationaliteitsland dan met Nederland. Per concreet geval zal moeten worden vastgesteld of er cen nauwere band bestaat met Nederland dan met het nationaliteitsland. Bij de bepaling van de verbondenheid met Nederland kunnen inlichtingen van nabestaanden een rol spelen ${ }^{353}$.

\section{Art. 3 lid 2: uitzonderlijke omstandigheden en kennelijk nauwere banden}

Bij een onafgebroken laatste verblijf in Nederland van vijf jaren of langer wordt de erfopvolging door Nederlands recht beheerst. Echter, in uitzonderlijke omstandigheden, wanneer de erflater ten tijde van zijn overlijden kennelijk nauwere banden had met de Staat waarvan hij op dat moment de nationaliteit bezat, beheerst het recht van de Staat waarvan hij die nationaliteit bezat de erfopvolging. Bij een onderzoek of deze uitzondering zich voordoet, zou aan drie voorwaarden moeten zijn voldaan, te weten: de erflater had ten tijde van zijn overlijden nauwere banden met zijn nationaliteitsland dan met Nederland; de erflater bezat deze nauwere banden kennelijk; en er moet sprake zijn van uitzonderlijke omstandigheden.

Wat de eerste voorwaarde betreft zij verwezen naar hetgeen hierboven over de "nauwere banden" is vermeld. Anders dan in het derde lid van art. 3 wordt in het tweede lid verlangd dat hij deze nauwere banden kennelijk bezat. Een nauwere binding met het nationaliteitsland dan met het verblijfsland moet manifest zijn. Dit zou wellicht zodanig kunnen worden uitgelegd dat er geen twijfel over bestaat dat de banden met het ene land nauwer zijn dan met het andere. Dit behoeft overigens niet weg te nemen dat die nauwere betrokkenheid enkel kan zijn gegrond op een emotionele of culturele binding met het nationaliteitsland, terwijl objectief waarneembare feiten op een band met het land van verblijf zouden wijzen. Tenslotte moet volgens de verdragstekst sprake zijn van 
uitzonderlijke omstandigheden. Uit de wordingsgeschiedenis van het Verdrag kan worden opgemaakt dat het begrip "uitzonderlijke omstandigheden" is opgenomen om aan te geven dat afwijking van het recht van de laatste gewone verblijfplaats alleen bij uitzondering kan geschieden ${ }^{354}$. In het rapport Waters wordt gesproken van een "escape clause, to be used in genuinely unusual circumstances" 355 . De vraag is natuurlijk wanneer er sprake is van uitzonderlijke omstandigheden. Kennelijk is een kennelijk nauwere band met het nationaliteitsland niet voldoende voor een toepassing van het nationale recht. Tijdens de debatten van de Haagse Conferentie werd het voorbeeld ter sprake gebracht van een Engelsman die zich voor een aantal jaren had verbonden in Saoedi-Arabië werkzaam te zijn, en daar - waarschijnlijk op jonge leeftijd - overleed. Westbroek leidt uit dit voorbeeld af dat het begrip uitzonderlijke omstandigheden in de zin van het Verdrag kan worden uitgelegd als "omstandigheden die buiten het verwachtingspatroon vallen, waaruit volgt dat bijvoorbeeld de leeftijd waarop de erflater overlijdt en de reden van zijn verblijf in een bepaald land een rol zullen kunnen spelen" ${ }^{356}$. In een andere bijdrage merkt Westbroek bij ditzelfde voorbeeld op dat de Conferentie buitengewone omstandigheden kennelijk aanneemt als de betrokken erflater vrij jong overleed en hierop niet had gerekend, terwijl hij ook geen deel had aan de sterk verschillende cultuur ${ }^{357}$. Een deel van de Marokkaanse bevolking in Nederland zal nog sterke banden hebben met de Marokkaanse cultuur en de islamitische godsdienst, en daarmee mogelijk ook met het Marokkaanse islamitische erfrecht. Uitzonderlijk zal dit derhalve niet zijn. Betekent dit nu ook dat er in deze gevallen geen sprake is van uitzonderlijke omstandigheden? ${ }^{358}$ Of kunnen de uitzonderlijke omstandigheden juist wel (mede) zijn gelegen in een culturele, emotionele of religieuze verbondenheid? In de literatuur lijkt men niet erg geneigd te zijn enkel op grond van een culturele verbondenheid uitzonderlijke omstandigheden te willen aannemen, maar lijkt men deze te willen zien in combinatie met de reden voor het verblijf in een bepaald land en de leeftijd waarop de erflater overlijdt ${ }^{359}$. Of er sprake zal zijn van uitzonderlijke omstan-

354. Zitting van 4 maart 1988, proces-verbaal nr. 3, minutes nr. 3, Proceedings p. 359-363. Met de restrictieve formulering heeft men beoogd de rechtszekerheid te dienen, Mostermans 1989, 423-425.

355. Waters, Explanatory Report 1988, par. 53.

356. Westbroek 1990, 91.

357. Westbroek $1989,459$.

358. Vergelijk in dit verband Cohen Henriquez, Vervreemding 1989, 550, die zich afvraagt of de uitzonderingsclausule van art. 3 lid 2 Erfrechtverdrag ook toepasbaar is op bepaalde bevolkingsgroepen, bijvoorbeeld de Marokkaanse groep in Nederland. Zijn conclusie is dat, voor zover hij hierover heeft gelezen, de Marokkaanse groep in het algemeen niet vervreemd is van Marokko, deze groep in Nederland derhalve geen uitzonderlijk verschijnsel is, en er derhalve in het algemeen geen sprake is om hier uitzonderlijke omstandigheden aan te nemen. Naar aanleiding hiervan merkt Westbroek 1990, 91 op dat niettemin onder uitzonderlijke omstandigheden toepassing van de uitzondering op leden van zo'n groep denkbaar is. Naar aanleiding van deze reactie wijst Cohen Henriquez op de bezwaren die aan de (te) flexibele norm van de uitzonderingsclausule kleven, Cohen Henriquez 1990, 535.

359. Westbroek 1989, 459; ten Wolde 1990, 140. 
digheden zal per individueel geval moeten worden bekeken ${ }^{360}$. Door de in de literatuur gegeven uitleg voegt het vereiste van "uitzonderlijke omstandigheden" substantieel iets toe aan het vereiste van "kennelijk nauwere banden". Een emotionele, culturele en religicuze verbondenheid zal in deze visie m.i. regelmatig kunnen leiden tot het aannemen van kennelijk nauwere banden met een ander land, doch niet snel tot het aannemen van uitzonderlijke omstandigheden. Uitzonderlijke omstandigheden zullen dan immers niet snel kunnen worden aangenomen als een hele groep zich op een dergelijke verbondenheid kan beroepen, en deze verbondenheid mitsdien ook voor de erflater, die tot deze groep "behoort", nict uitzonderlijk is. De vraag of iemand behoort tot een bepaalde groep waarvan de "leden" zich misschien bijna allemaal op een bepaalde culturele verbondenheid kunnen beroepen, is m.i. echter niet relevant. Bij een beoordeling van de omstandigheden in cen concreet geval, behoren de omstandigheden van anderen geen rol te spelen. Het dient er m.i. niet zozeer om te gaan dat een bepaalde situatie verrassend is ${ }^{361}$, maar of $\mathrm{er}$ in cen concreet geval sprake is van dusdanige omstandigheden dat hier bij wijze van uitzondering van de hoofdregel behoort te worden afgeweken.

\section{c. Overige bepalingen}

\section{Renvoi}

Volgens art. 17 wordt in het Verdrag onder recht verstaan, de interne rechtsregels van een Staat. Renvoi wordt, behoudens één uitzondering, niet geaccepteerd. De ene uitzondering, geregeld in art. 4, betreft het accepteren van een doorverwijzing wanneer het ingevolge art. 3 toepasselijke recht het recht is van een niet-Verdragsluitende Staat, en het IPR van die Staat ten aanzien van het geheel of een gedeelte van de nalatenschap verwijst naar het recht van cen andere niet-Verdragsluitende Staat die zijn eigen recht zou toepassen. In dat geval is het recht van die andere Staat van toepassing. De doorverwijzing wordt niet geaccepteerd bij de toepasselijkheid van een ingevolge een rechtskeuze aangewezen rechtsstelsel. Omdat ook een doorverwijzing voor een gedeelte van de nalatenschap wordt geaccepteerd, kan het zijn dat de erfopvolging door verschillende rechtsstelsels wordt beheerst, hetgeen een inbreuk zou vormen op het eenheidsbeginsel. Volgens art. 24 lid 1 sub b kunnen Verdragsstaten een voorbehoud maken ten aanzien van de toepasbaarheid van art. 4 . Het voorbehoud bij art. 4 is door Nederland niet gemaakt.

360. In het verslag van de vaste commissie van Justitie, TwK 1995-1996, $23857,7, \mathrm{p}$. 4, is hierover het volgende te lezen: "Of een afwijking van de hoofdregel gerechtvaardigd is, zal van geval tor geval moeten worden nagegaan. Van "uitzonderlijke omstandigheden" zal bij een groep of een categorie van personen geen sprake kunnen zijn. In elk individueel geval zal moeten worden beoordeeld of er sprake was van een duidelijke en sterke binding met het andere land. Daarbij dient niet alleen op de economische verbondenheid te worden gelet, maar ook op culturele en emotionele banden. Met name zal moeten worden onderzocht om welke reden een erflater heeft verkozen in een bepaald land te verblijven en wat in zijn geval als uitzonderlijk kan worden beschouwd. Daarbij kan de leeftijd waarop de erflater overlijd, een rol spelen."

361. In deze zin Westbroek 1989, 459; ten Wolde 1990, 333. 


\section{Marokkaanse erflaters}

Indien de erfopvolging van een Marokkaanse erflater op grond van de verwijzingsregel van art. 3 dient te worden beheerst door Marokkaans recht, zal er in de regel geen sprake zijn van een doorverwijzing. Marokko is weliswaar geen Verdragsstaat, doch het Marokkaans IPR knoopt aan bij de nationaliteit van de erflater ${ }^{362}$ en gaat in het erfrecht, evenals Nederland, uit van een eenheid van vermogen ${ }^{363}$.

\section{Openbare orde}

Het Verdrag kent een algemene openbare orde-clausule, neergelegd in art. 18. Deze bepaling luidt: "De tocpassing van een door dit Verdrag aangewezen recht kan slechts worden geweigerd indien deze kennelijk in strijd zou zijn met de openbare orde".

\section{Marokkaanse erflaters}

Gezien de spanningen die bestaan tussen het Marokkaanse erfrecht en in Nederland geldende fundamentele rechtsbeginselen, zal wanneer de verwijzingsregel Marokkaans recht als toepasselijk aanwijst, regelmatig de vraag gesteld moeten worden of de exceptie van de openbare orde behoort te worden ingeroepen. Aan deze problematiek is hoofdstuk 6 gewijd.

\section{Voorrangsregels}

In het Verdrag is geen algemene voorziening omtrent voorrangsregels opgenomen. Wel laat het Verdrag op een aantal plaatsen ruimte tot het onverlet laten van dwingende bepalingen van een niet door de verwijzingsregel aangewezen rechtsstelsel (zie art. 6, art. 5 lid 2, via het voorbehoud van art. 24 lid 1 aanhef en sub d, en art. 15).

\section{Diversen}

\section{Overeenkomsten inzake erfopvolging}

In hoofdstuk III, art. 8 tot en met 12, worden de overeenkomsten van erfopvolging behandeld. In art. 8 wordt een overeenkomst inzake erfopvolging omschreven als een schriftelijke of uit wederkerige testamentaire beschikkingen voortvloeiende overeenkomst die, met of zonder tegenprestatie, rechten op de toekomstige nalatenschap van één of meer personen die partij zijn bij een zodanige overeenkomst, in het leven roept, wijzigt of doet vervallen. Wat het toepasselijk recht betreft wordt in de art. 9 en 10

362. Voor moslims geldt dat de nationaliteit wijkt voor de islamitische religie. Iedere moslim is, ongeacht zijn nationaliteit, onderworpen aan de Marokkaanse Mudawwanah. Meer hierover in $\S 2$ van hoofdstuk 5 .

363. Art. 4 zou dan alleen van toepassing zijn ten aanzien van een Marokkaanse erflater die onmiddellijk voorafgaande aan zijn overlijden minder dan vijf jaren in Nederland verbleef, en op het tijdstip van zijn overlijden nauwere banden had - bijvoorbeeld door langdurig verblijf - met een andere nietVerdragsstaat, welke rechtsstelsel op grond van art. 3 lid 3 van toepassing zou zijn, en het IPR van dit rechtsstelsel voor het geheel of een gedeelte van de nalatenschap verwijst naar weer een ander stelsel dat zijn eigen recht zou toepassen. 
verwezen naar de verwijzingsregels uit art. 3 en 5 lid 1 . In art. 11 wordt voorzien in de mogelijkheid tot het doen van een rechtskeuze. Ingevolge art. 24 lid 1 aanhef en sub a kunnen Verdragsstaten een voorbehoud maken ten aanzien van de toepasselijkheid van het Verdrag op de overeenkomsten inzake erfopvolging. Nederland heeft van deze mogelijkheid geen gebruik gemaakt.

\section{Marokkaanse erflaters}

In het Marokkaanse erfrecht is de overeenkomst van erfopvolging onbekend.

Hoofdstuk IV bevat de algemene bepalingen (art. 13 tot en met 24), waarvan die over de renvoi (art. 17), openbare orde (art. 18), het intertemporeel recht (art. 22) en voorbehouden (art. 24) hiervóór reeds aan de orde zijn gesteld.

\section{Commoriënten}

Art. 13 geeft een materieelrechtelijke oplossing voor conflictenrechtelijke problemen bij commoriënten. Het artikel luidt: "Wanneer twce of meer personen wier erfopvolging door verschillende rechtsstelsels wordt beheerst, overlijden onder omstandigheden waaronder onzeker is in welke volgorde zij zijn overleden, en wanneer deze situatie in dic rechtsstelsels op uiteenlopende wijze is geregeld of in het geheel niet is geregeld, heeft gcen van de overleden personen rechten ten aanzien van de nalatenschap van de ander of anderen".

\section{Marokkaanse erflaters}

Voor zover het situaties betreft waarin de toepasselijke rechtsstelsels uitsluitend de Nederlandse en Marokkaanse zijn, zal een beroep op art. 13 niet nodig zijn nu in beide stelsels bij commoriënten de betrokken personen geen rechten op elkanders nalatenschap hebben ${ }^{364}$.

Trusts, stichtingen en soortgelijke instellingen die bij uiterste wil in het leven zijn geroepen

Art. 14 bevat een regeling voor trusts, stichtingen en soortgelijke instellingen die in het leven zijn geroepen bij uiterste wilsbeschikking. Ingevolge art. 14 belet de toepassing van het ingevolge het Verdrag toepasselijke recht op de erfopvolging niet, dat op deze instellingen een ander recht wordt toegepast. Omgekeerd belet de toepassing van het op deze instelling betrekking hebbende recht niet, dat op de erfopvolging het ingevolge het Verdrag toepasselijke recht wordt toegepast.

\section{Marokkaanse erflaters}

Op grond van deze bepaling belet de toepassing van de erfwet niet dat op een naar Marokkaans recht gevestigde testamentaire hubus, Marokkaans recht wordt toegepast.

364. Voor de Marokkaanse regeling op dit punt zij verwezen naar p. 45. Voor Nederland: art. 4:878 en 4:94I BW. 
Zie voor de beoordeling van de geldigheid en erkenning van de Marokkaanse hubus en over de verhouding tussen hubus-recht en erfrecht $\$ 9$.

\section{Bijzondere erfrechtregimes}

Art. 15: Het ingevolge het Verdrag toepasselijke recht maakt geen inbreuk op bijzondere erfrechtregimes waaraan bepaalde onroerende goederen, ondernemingen of andere bijzondere categorieën goederen in de Staat waar zij zich bevinden zijn onderworpen uit hoofde van hun economische of maatschappelijke bestemming, dan wel hun belang voor de familie.

\section{Marokkaanse erflaters}

Wat Marokko betreft is van belang dat buitenlanders geen eigendom kunnen verwerven van "terres agricoles", landbouwgrond die zich geheel of gedeeltelijk bevindt buiten de omgeving van de steden. Op grond van een dahir van $1975^{365}$ kan de eigendom van deze landbouwgrond alleen worden verkregen door de Marokkaanse Staat, Marokkaanse natuurlijke personen, Marokkaanse publiekrechtelijke rechtspersonen, Marokkaanse agrarische coöperatieve verenigingen en Marokkaanse verenigingen van personen ${ }^{366}$. De regeling is een vervolg op oudere wetgeving op grond waarvan buitenlanders na de onafhankelijkheid van Marokko de aan hen toebehorende landbouwgrond moesten overdragen aan de Marokkaanse Staat. Van een specifieke erfrechtregeling is geen sprake, behalve waar het betreft de "terres agricoles" die tot het privé-domein van de Marokkaanse Staat behoren. Ten aanzien hiervan is bepaald dat de grond die is toebedeeld aan landbouwers slechts kan overgaan op één erfgenaam ${ }^{367}$.

\section{de Staat}

Art. 16: wanneer er volgens het ingevolge het Verdrag toepasselijke recht geen erfgenaam of legataris is uit hoofde van een uiterste wilsbeschikking, noch een natuurlijke persoon die wettelijk crfgenaam is, belet de toepassing van het aldus bepaalde recht niet dat een Staat of een daartoc door die Staat aangewezen instantic zich de goederen uit de nalatenschap die zich op zijn grondgebied bevindt, tocëigent.

\section{Marokkaanse erflaters}

Naar Marokkaans erfrecht is de Staat restant-erfgenaam. Hij treedt als erfgenaam op wanneer er geen (andere) erfgenamen zijn ${ }^{368}$. Wanneer een Marokkaanse erflater met goederen in Nederland overlijdt zonder erfgenamen - anders dan de Staat - na te laten, en de erfopvolging door Marokkaans recht zou worden beheerst, heeft naar Marokkaans recht de Marokkaanse Staat aanspraak op de goederen die zich in Nederland bevinden. Art. 16 van het Verdrag geeft nu niettemin de bevoegdheid aan de Nederlandse Staat

365. Dahir van 23 april 1975, B.O. 21 mei 1975, p. 656.

366. Hierover Decroux 1977, 280; Decroux 1981, 158.

367. Dahir van 29 december 1972. Hierover Decroux 1977, 300.

368. Zie hierover p. 57-58. 
om zich deze goederen toe te eigenen ${ }^{369}$. Joppe is van mening dat de Nederlandse Staat uit internationale loyaliteit van zijn bevoegdheid uit art. 16 geen gebruik zou moeten maken wannecr de erfgerechtigde vreemde Staat haar aanspraak op hier te lande bevindende goederen geldend zou willen maken ${ }^{370}$. Westbroek geeft hierbij aan dat het gaat om een bevoegdheid, waarvan de Staat de uitoefening op gronden ontleend aan zijn commune IPR, onder omstandigheden achterwege behoort te laten ${ }^{371}$.

\section{Onderaanknoping}

De art. 19 tot en met 21 bevatten bepalingen over onderaanknoping en interregionaal recht. Ten aanzien van Marokko is art. 20 van belang waarin de onderaanknoping wordt geregeld bij interpersoneel recht. Wanneer bij het overlijden van een Marokkaanse erflater in Nederland Marokkaans recht als toepasselijk wordt aangewezen, moet immers, nu in Marokko voor de verschillende bevolkingsgroepen verschillende regels gelden (zie p. 19), nog worden vastgesteld of de erflater moslim was, jood was of een andere overtuiging aanhing. Art. 20 luidt: "Wanneer een Staat ter zake van erfopvolging twee of meer rechtsstelsels heeft die van toepassing zijn op verschillende categorieën van personen, wordt ter bepaling van het volgens dit Verdrag toepasselijke recht elke verwijzing naar het recht van een zodanige Staat beschouwd als een verwijzing naar het rechtsstelsel dat wordt aangewezen door de regels die in die Staat van kracht zijn. Bij gebreke van dergelijke regels wordt de verwijzing beschouwd als verwijzing naar het rechtsstelsel waarmee de erflater de nauwste banden had." In het kader van dit boek is van belang dat bij een verwijzing naar Marokkaans recht op Marokkaanse moslimerflaters het op het islamitische recht gebaseerde erfrecht uit de Mudawwanah van tocpassing is.

\section{Verhouding tot andere verdragen}

In art. 23 wordt de verhouding tussen het Erfrechtverdrag en andere internationale regelingen (instrumenten) geregeld.

\section{$\S 5$. Vorm van de uiterste wil}

De regel van Nederlands internationaal privaatrecht aan de hand waarvan wordt bepaald of een uiterste wil naar de vorm geldig is, is neergelegd in het Verdrag inzake de wetsconflicten betreffende de vorm van testamentaire beschikkingen van 5 oktober 1961 (Haags Testamentsvormenverdrag) ${ }^{372}$. Dit Verdrag is voor Nederland in werking getreden op 1 augustus 1982.

369. Waters, Explanatory Report 1988, par. 116.

370. Joppe, Vademecum 1980, 57.

371. Westbroek 1990, 148.

372. Trb. 1980,54 


\section{A. TOEPASSINGSBEREIK}

\section{Intertemporeel toepassingsgebied}

Volgens art. 8 is het Verdrag van tocpassing in alle gevallen waarin de erflater is overleden na de inwerkingtreding van het Verdrag. In art. 2 van de Uitvoeringswet ${ }^{373}$ wordt hieraan nog toegevoegd dat deze van toepassing is, ook indien de testamentaire beschikking vóór de inwerkingtreding van de wet (eveneens op 1 augustus 1982) is gemaakt.

\section{Formeel toepassingsgebied}

Het Verdrag stelt geen reciprociteitseis. Het is van toepassing ook indien de nationaliteit van de betrokkenen of het ingevolge het Verdrag toepasselijke recht niet dat van een Verdragsluitende Staat is (art. 6). Marokko is overigens geen partij bij het Verdrag.

\section{Materieel toepassingsgebied}

Het Haags Testamentsvormenverdrag beheerst de formele geldigheid van testamentaire beschikkingen. De uitdrukking "testamentaire beschikkingen" beperkt zich niet tot testamenten maar omvat elke uiterste wilsbeschikking ${ }^{374}$. Onder testamentaire beschikkingen vallen ook de herroeping bij testament van een vroegere testamentaire beschikking (art. 2), en het gemeenschappelijk testament (art. 4). Tot de vormvoorschriften worden voor de toepassing van het Verdrag ook gerekend: voorschriften, die op grond van leeftijd, nationaliteit ${ }^{375}$ of andere persoonlijke hoedanigheden van de testateur de voor testamentaire beschikkingen toelaatbare vormen beperken, alsmede de hoedanigheden, die de voor de geldigheid van een testamentaire beschikking vereiste getuigen moeten bezitten (art. 5). De handelingsbekwaamheid om bij uiterste wil te beschikken behoort niet tot de vormvoorschriften en is in het Verdrag niet geregeld. In Nederland pleegt men deze vraag zelfstandig, dus aan de hand van het eigen IPR, te beantwoorden (zie hierna, §6). Het Verdrag is voorts van toepassing op testamentaire bepalingen die niet van erfrechtelijke aard zijn. Nederland heeft immers het voorbehoud van art. 12 niet gemaakt. Zo zal het Verdrag bijvoorbeeld van toepassing zijn op de formele geldigheid van een testamentaire adoptie.

373. Wet van 10 maart 1982 tot uitvoering van het op 5 oktober 1961 te 's-Gravenhage tot stand gekomen Verdrag inzake de wetsconflicten betreffende de vorm van testamentaire beschikkingen, Stb. 1982, 88.

374. Batiffol, Explanatory Report 1961, p. 160: TwK 1979-1980, 16 334, 2-3, p. 4.

375. In art. 1 van de Uitvoeringswet is bepaald dat art. $992 \mathrm{BW}$ (oud) bij de inwerkingtreding van het Verdrag zou komen te vervallen. Hiermee zijn twee vormen van onderscheid die vóór de inwerkingtreding nog werden gemaakt opgeheven, te weten: het onderscheid tussen testamentaire beschikkingen van Nederlanders in binnenland en buitenland, en het onderscheid tussen testamentaire beschikkingen van Nederlanders en niet-Nederlanders in het buitenland. 


\section{B. DE VERWIJZINGSREGEL}

De verwijzingsregel is te vinden in art. 1 van het Verdrag. De verwijzingsregel in dit artikel kent een facultatief samengestelde aänknopingsfactor. Dat wil zeggen dat een testamentaire beschikking wat de vorm betreft geldig is indien zij voidoet aan de vereisten van cen rechtsstelsel waarnaar door ceén van de in de verwijzingsregel genoemde aanknopingspunten, ongeacht welke, wordt verwezen. Een testamentaire beschikking is wat de vorm betreft geldig, indien zij beantwoordt aan de eisen van het interne recht:

a van de plaats waar de testateur beschikte;

b van cen Staat waarvan de testateur de nationaliteit bezat op het ogenblik waarop hij beschikte of op het ogenblik van zijn overlijden;

c van de plaats waar de testateur zijn woonplaats had op het ogenblik waarop hij beschikte of op het ogenblik van zijn overlijden;

d van de plaats waar de testateur zijn gewoon verblijf had op het ogenblik waarop hij beschikte of op het ogenblik van zijn overlijden;

c Voor onroerende goederen geldt bovendien nog als een extra aanknopingspunt: de plaats van ligging van het onroerend goed.

Bovendien staat het Verdragsluitende Staten op grond van art. 3 vrij om bij wetgeving gunstigere regels voor de erkenning van de vorm van testamentaire beschikkingen te stellen.

Nederland heeft ten aanzien van de door Nederlanders gemaakte mondelinge testamenten het door art. 10 van het Verdrag toegelaten voorbehoud gemaakt: een mondelinge testamentaire beschikking welke, behoudens buitengewone omstandigheden, is gemaakt door een Nederlander die niet tevens een andere nationaliteit bezat, wordt in Nederland niet erkend ${ }^{376}$.

\section{Nationaliteit}

Indien de erflater meerdere nationaliteiten bezat hetzij op het ogenblik waarop hij beschikte hetzij op het ogenblik van zijn overlijden, wordt geen effectiviteitstoets gehanteerd. Elk van deze nationaliteiten wordt als aanknopingsfactor in aanmerking genomen ${ }^{377}$. Dit kan worden afgeleid uit de bewoordingen van art. 1 lid 1 aanhef en sub b, waarin gesproken wordt over een Staat en niet over de Staat ${ }^{378}$.

\section{Woonplaats}

In het derde lid van art. 1 wordt aangegeven dat de vraag of de erflater woonplaats ("domicile") had op een bepaalde plaats wordt beheerst door het recht van die plaats. $V$ an de in art. 9 opgenomen mogelijkheid om ten aanzien van deze bepaling een voorbe- 
houd te maken teneinde de woonplaats te beoordelen aan de hand van de lex fori, is door Nederland geen gebruik gemaakt.

\section{Gewoon verblijf}

Het begrip "gewoon verblijf" is een verdragsautonoom begrip, en heeft voornamelijk cen feitelijkc inhoud ${ }^{379}$. Deze aanknopingsfactor is nog naast de woonplaats opgenomen om kwalificatieproblemen (het begrip "domicile" heeft in common law landen een andere betekenis dan in civil law landen) en hinkende testamenten zoveel mogelijk te voorkomen ${ }^{380}$.

\section{Openbare orde}

Art. 7 behelst een algemene openbare orde-clausule: de toepassing van een door dit Verdrag aangewezen recht kan slechts terzijde worden gesteld, indien deze toepassing kennelijk onverenigbaar is met de openbare orde.

\section{$\S 6$. Bekwaamheid om bij uiterste wil te beschikken}

De vraag naar de bekwaamheid om bij uiterste wil te beschikken behoort naar Nederlands IPR niet tot de verwijzingscategorie inzake de testamentsvorm. Evenmin wordt deze beheerst door de erfwet, welke ook op de innerlijke geldigheid van een uiterste wil van toepassing is. De vraag naar de handelingsbckwaamheid rijst als deelvraag, en wordt zelfstandig beoordeeld aan de hand van art. 6 Wet AB. Dat wil zeggen dat deze wordt beheerst door het nationale recht van de betrokkene ten tijde van het maken van zijn uiterste wil ${ }^{381}$. In het algemeen wordt op de regel dat de handelingsbekwaamheid wordt beoordeeld door het nationalc recht van de betrokkene een uitzondering gemaakt door de zogenaamde Lizardi-regel: iemand die volgens zijn nationale recht handelingsonbekwaam is kan zich daarop niet beroepen indien hij volgens het recht van het land waar hij handelt als handelingsbekwaam zou worden aangemerkt en de wederpartij van de handelingsonbekwaamheid niet op de hoogte was, noch behoorde te zijn $^{382}$. Het ligt niet voor de hand om de Lizardi-regel toe te passen bij het beschikken bij uiterste wil. Het specifieke karakter van de bevoegdheid om bij uiterste wil te beschikken maken, gezien de aard en strekking van de Lizardi-regel, een toepassing van dit beschermingsbeginsel niet wenselijk ${ }^{383}$. Bij een meervoudige nationaliteit zal ter beoordeling van de handelingsbekwaamheid een effectiviteitstoets kunnen plaatsvinden.

379. TwK 1979-1980, 16 334, 2-3, p. 6. Vergelijk ook hetgeen over de gewone verblijfplaats is opgemerkt op p. 118.

380. Breemhaar 1981, 869; Droz 1979, 279; Kisch 1961, 48

381. Joppe, Vademecum 1980, 61; van der Ploeg 1961, 56-58; Strikwerda 1995, 165; Vonken, losbladige PFR Titel 13: Minderjarigheid, IPR, 38-48; Westbroek 1990, 107; ten Wolde 1996, 68.

382. Strikwerda 1995, 113.

383. Aldus ook Vonken, losbladige PFR, Titel 13: Minderjarigheid, IPR, 52-62, die voorts verwijst naar het Duitse en Zwitserse IPR waar de beschermingsregel in dergelijke gevallen buiten toepassing wordt gesteld. 


\section{§ 7. Afwikkeling van de nalatenschap}

Evenals bij de erfopvolging zal bij de behandeling van het Nederlandse IPR dat voor de afwikkeling van de nalatenschap geldt nader worden stilgestaan bij enkele specifieke punten die aan de orde kunnen zijn als de erfopvolging door Marokkaans recht wordt behcerst. Dit gebeurt ook hier onder de kopjes "Marokkaanse erflaters".

\section{A. WET CONFLICTENRECHT ERFOPVOLGING}

Anders dan het Erfrechtverdrag, bevat de Wet conflictenrecht erfopvolging wel conflictregels voor de afwikkeling van de nalatenschap. Hiermee is voor het Nederlandse internationale erfrecht tevens voor een belangrijk deel duidelijk gemaakt welke onderwerpen worden beheerst door de erfwet en welke hiervan zijn afgescheiden (vergelijk art. 7 lid 3 Erfrechtverdrag).

De wet is van toepassing op de erfopvolging van personen die na het tijdstip van inwerkingtreding van de wet overlijden (art. 7 lid 1 WCEO). De wet bevat geen aparte regel van intertemporeel recht voor de afwikkeling van de nalatenschap, hetgeen betekent dat ook ten aanzien van de afwikkeling het tijdstip van overlijden van de erflater geldt. Is de erflater vóór de inwerkingtreding van de wet overleden, maar moet met de afwikkeling van zijn nalatenschap nog een begin worden gemaakt, dan zou hierop het oude IPR moeten worden toegepast. In de parlementaire geschiedenis wordt dit probleem niet aangeroerd. Ook de doctrine laat zich hierover nict uit.

\section{Vereffening van de nalatenschap}

Voor de vereffening van de nalatenschap is een eenzijdige conflictregel neergelegd in art. 4 WCEO: de vereffening van de nalatenschap wordt door het Nederlandse recht beheerst indien de erflater zijn laatste gewone verblijfplaats in Nederland had. Voor gevallen waarin de erflater zijn laatste gewone verblijfplaats buiten Nederland had, ontbreekt een conflictregel, hetgeen praktisch met name betekenis heeft wanneer zich vermogensbestanddelen in Nederland bevinden ${ }^{384}$. Het argument dat werd aangevoerd voor het opstellen van een eenzijdige regel was dat een verwijzingsregel voor de vereffening van een in het buitenland opengevallen nalatenschap haar doel zou missen, omdat bij de afwikkeling doorgaans plaatselijke autoriteiten betrokken zijn, die gebonden zijn aan hun eigen regels van internationaal privaatrecht ${ }^{385}$ en de erkenning van buiten Nederland vereffende nalatenschappen niet afhankelijk zou moeten zijn van het daarop toegepaste recht ${ }^{386}$. Tegen het gevaar dat bij een vereffening volgens een ander recht

384. Over de eenzijdigheid van de conflictenregel laat zich kritisch uit: ten Wolde 1995, 47-48; ten Wolde 1996, 298.

385. TwK 1993-1994, 23 857, 3, p. 4.

386. Rappon Staatscommissie IPR 1992, par. 7.4.4. 
dan het Nederlandse, het ingevolge het Erfrechtverdrag toepasselijke recht op de erfopvolging niet wordt nageleefd met betrekking tot in Nederland gelegen vermogensbestanddelen uit de nalatenschap, waakt art. 5 lid 2 WCEo, althans deze bepaling biedt de mogelijkheid hiertegen te waken. Op grond van dit artikel is, onverminderd de bevoegdheid van de President in kort geding, de rechter bevoegd om te waarborgen dat op de vererving van in Nederland gelegen vermogen het ingevolge het Erfrechtverdrag toepasselijke recht wordt toegepast. Hij kan bevelen dat daartoe zekerheden worden gesteld.

\section{Materieel toepassingsgebied}

In de tweede zin van art. 4 WCEo wordt iets gezegd over de onderwerpen die onder de conflictregel vallen: in het bijzonder zijn van toepassing de Nederlandse voorschriften inzake de gehoudenheid van de door de erfwet aangewezen erfgenamen voor de schulden van de erflater en de voorwaarden waaronder zij hun gehoudenheid kunnen uitsluiten of beperken. De aansprakelijkheid voor de schulden van de nalatenschap, alsmede de bevoegdheid om die aansprakelijkheid te beperken of uit te sluiten (door middel van verwerping of beneficiaire aanvaarding) zijn derhalve onderworpen aan de verwijzingsregel inzake de vereffening. Uit de Memorie van Toelichting bij deze bepaling blijkt dat het in de rede ligt om ook de vraag naar de al dan niet onmiddellijke overgang van de rechten jegens de nalatenschap op de erfgenaam, te beantwoorden naar Nederlands recht indien de laatste gewone verblijfplaats van de erflater in Nederland was gelegen ${ }^{387}$. De gevolgen van de uitsluiting of de beperking van de aansprakelijkheid zouden daarentegen moeten worden beheerst door de erfwet ${ }^{388}$. Verder vallen onder de verwijzingsregel die onderwerpen die zonder twijfel tot de vereffening behoren, zoals het beheer van de boedel, het treffen van conservatoire maatregelen, de wijze van inbreng etcetera ${ }^{389}$.

Marokkaanse erflaters

Als Marokkaans recht de erfopvolging beheerst en de vereffening van de nalatenschap op grond van art. 4 lid 1 WCEo door Nederlands recht wordt geregeld, is een aantal factoren van belang. Naar Marokkaans recht is er geen sprake van saisine. De Marokkaanse regels van erfopvolging bij versterf hebben slechts betrekking op dat deel van het nalatenschapsvermogen dat resteert nadat de schulden zijn voldaan en een eventueel testament is uitgevoerd. Bij de vereffening naar Nederlands recht wordt uitgegaan van het volledige nalatenschapsvermogen. Anders dan in het Marokkaanse erfrecht treden de erfgenamen dan ook in de schulden van de erflater. Hieraan kan tegemoet worden gekomen door gebruikmaking van de in het Nederlandse recht bestaande mogelijkheid de erfenis beneficiair te aanvaarden of te verwerpen. De in het IPR door de wetgever

387. TwK $1993-1994,23857,3$, p. 5 .

388. TwK 1993-1994, 23857,3, p. 5.

389. Voor een opsomming kan worden verwezen naar Vaste Commissie van Justitie, TwK 1995-1996, 23 857,7, p. 10. 
voorgestelde constructie om de gevolgen van de aanvaarding of verwerping te onderwerpen aan de erfwet leidt tot moeilijkheden. Omdat naar Marokkaans erfrecht de schulden niet overgaan op de erfgenamen, ontbreekt in het versterf-erfrecht een regeling over de aanvaarding en verwerping. Deze zijn zelfs niet toegestaan ${ }^{390}$. Zou een erfgenaam beneficiair aanvaarden, dan zullen de gevolgen hiervan geen probleem opleveren. Een beneficiaire aanvaarding naar Nederlands recht leidt immers tot een situatie die ook in het Marokkaanse crfrecht zou worden bereikt: de erfgenaam is niet verder gehouden tot betaling van schulden en lasten dan ten belope van zijn erfdeel, en hij is niet met zijn privé-vermogen aansprakelijk. Zou een erfgenaam daarentegen de erfenis verwerpen, en zouden de gevolgen hiervan naar Marokkaans recht moeten worden beoordeeld, dan rijst een probleem omdat deze gevolgen in het Marokkaanse erfrecht niet zijn geregeld. Dit kan tot lastige vragen leiden, met name met betrekking tot het bepalen van de erfdelen van de erfgenamen: moet hierbij met het bestaan van de verwerpende erfgenaam wel of geen rekening worden gehouden? In het Marokkaanse recht zal deze vraag veelvuldig rijzen, omdat de erfaanspraken van erfgenamen heel vaak afhankelijk worden gesteld van de aanwezigheid van bepaalde andere erfgenamen. Enkele voorbeelden kunnen dit illustreren.

- Bepaalde verwanten worden door de aanwezigheid van bepaalde erfgenamen van de nalatenschap uitgesloten. Een zoonsdochter wordt uitgesloten door een zoon, een grootmoeder kan worden uitgesloten door de vader of moeder, een zus wordt uitgesloten door een zoon, zoonszoon of de vader, 'asaba-erfgenamen worden uitgesloten door 'asaba-erfgenamen uit een meer nabije klasse, etcetera. Moet nu, indien er erfgenamen zijn wier aanwezigheid tot uitsluiting van andere verwanten zou leiden, en die de erfenis verwerpen, worden gedaan alsof deze erfgenamen niet bestaan zodat de verwanten die eigenlijk zouden worden uitgesloten alsnog hun erfdeel ontvangen, of vallen deze laatsten buiten de nalatenschap?

- De omvang van de koranische erfporties wordt veelal bepaald door de aanwezigheid van andere erfgenamen. De erfportie van de echtgenoot(ote) of moeder is groter als er geen kinderen zijn dan als er wel kinderen zijn, de erfportic van een kleindochter is groter als er geen dochter is dan als er wel een dochter is, etcetera. Moet nu, indien er erfgenamen zijn wier bestaan de omvang van de erfdelen van andere erfgenamen kunnen beïnvloeden, en die tot verwerping van de erfenis overgaan, worden gedaan alsof zij niet bestaan met als gevolg dat de erfdelen van de andere koranische erfgenamen groter zijn dan zij bij hun aanwezigheid zouden zijn, of juist niet?

- $\quad$ Sommige koranische erfgenamen worden door de aanwezigheid van andere erfgenamen "geconverteerd" in "asaba-erfgenamen. Dit geldt bijvoorbeeld voor de dochter als er een zoon is, en voor de zus als er een broer is. Moet nu, wanneer de mannelijke erfgenaam de erfenis verwerpt, de desbetreffende vrouwelijke erfgenaam haar koranische portie krijgen, of ontvangt zij dat deel dat zij als

390. De aanvaarding en venwerping door legatarissen van een bij uiterste wil gedane making, zijn in het Marokkaanse erfrecht wel geregeld. 
'asaba bi ghayrihâ-erfgenaam zou krijgen (met tevens als gevolg dat zij 'asabaerfgenamen uit een lagere klasse uitsluit van de nalatenschap)?

Kunnen kleinkinderen erven krachtens verplicht testament wanneer hun vader niet is vooroverleden maar de erfenis verwerpt?

Kan een verwant die erfgenaam ab intestaat zou zijn wettig erfdeel verwerpen om vervolgens krachtens testament te erven? Met andere woorden kan een testament dat naar Marokkaans recht niet kan worden gemaakt ten behoeve van een wettig erfgenaam niettemin geldig zijn wanneer de erfgenaam zijn wettelijke erfaanspraken verwerpt? Voor deze erfgenaam kan dit interessant zijn omdat de testamentaire making groter kan zijn dan het wettelijk erfdeel.

Het moge duidelijk zijn dat het oplossen van deze problemen theoretisch tot grote moeilijkheden kan leiden. Er zal een zekere aanpassing moeten plaatsvinden. Bij een aanpassing van verwijzingsregels kan prioriteit worden gegeven aan een van de toepasselijke verwijzingsregels, of er kan een nicuwe verwijzingscategorie worden geïntroduceerd. Bij cen aanpassing van het verwijzingsresultaat, wordt het resultaat waartoe de toepassing van verschillende verwijzingsregels heeft geleid, gecorrigeerd ${ }^{391}$.

Is er sprake van een verwerping door een wettige erfgenaam dan zullen bij het beoordelen van de gevolgen hiervan problemen ontstaan. Bij de behandeling van de opties waarvoor zou kunnen worden gekozen, waarbij volledigheid niet wordt gepretendeerd, zal worden uitgegaan van het voorbeeld waarin een erflater als potentiële erfgenamen nalaat: zijn echtgenote, een zus en een broer, een dochter en een zoon. De zoon heeft zelf nog een dochter en een zoon. De zoon van de erflater wenst zijn erfdeel te verwerpen.

1. Omdat er een kortsluiting ontstaat als de verwerping wordt onderworpen aan Nederlands recht en de gevolgen hiervan aan het Marokkaanse recht, zou overwogen kunnen worden om de verwerping aan de erfwet, dat wil zeggen aan Marokkaans recht te onderwerpen. De verwerping zou dan niet zijn toegestaan. Erfrechtelijk zou de verdeling als volgt zijn:

echigenote : $1 / 8$

dochter : $\quad 7 / 24$

zoon: : $14 / 24$

kleindochter : 0

kleinzoon : 0

zus $\quad: 0$

broer : : 0

391. Zie voor een overzicht van de wijzen waarop in dergelijke gevallen de correctie kan plaatsvinden: Lemaire 1968, 357-358 (materieelrechtelijke aanpassing); Offerhaus 1963, 27-39 (185-197): Strikwerda 1995, 70. 
Een alternatief zou in dit geval kunnen zijn om binnen het Marokkaanse erfrecht te handelen als ware de zoon overleden. Alsdan zou de dochter de helft ontvangen, de kleinzoon $1 / 4$ en de kleindochter $1 / 8$.

2. Zouden de gevolgen van verwerping worden onderworpen aan de wet die de afwikkeling beheerst, dat wil zeggen aan Nederlands recht, dan zou de verwerpende erfgenaam worden beschouwd als niet bestaand. Een dergelijke keuze kan een serieuze aantasting van het Marokkaanse versterf-erfrecht betekenen, hetgeen moge blijken uit het volgende overzicht ${ }^{392}$.

$\begin{array}{lll}\text { echtgenote } & : & 1 / 8 \\ \text { dochter } & : & 1 / 2 \\ \text { zoon } & : & - \\ \text { kleindochter } & : & 1 / 8 \\ \text { kleinzoon } & : & 1 / 4 \\ \text { zus } & : & 0 \\ \text { broer } & : & 0\end{array}$

3.a. Een derde mogelijkheid is om te zoeken naar een materieelrechtelijke correctie. Een eerste manier is om het erfdeel van de zoon naar evenredigheid te verdelen onder de crfgenamen als ware ook de zoon erfgenaam.

$\begin{array}{lll}\text { echtgenote } & : & 9 / 30 \\ \text { dochter } & : & 21 / 30 \\ \text { zoon } & : & - \\ \text { kleindochter } & : & 0 \\ \text { kleinzoon } & : & 0 \\ \text { zus } & : & 0 \\ \text { broer } & : & 0\end{array}$

3.b. Een tweede manier is om het erfdeel van de zoon te verdelen onder de 'asabaerfgenamen als ware de zoon erfgenaam. Argument voor een dergelijke verdeling zou zijn dat de koranische erfgenamen een vastgesteld deel ontvangen.

$\begin{array}{lll}\text { echtgenote } & : & 1 / 8 \\ \text { dochter } & : & 7 / 24 \\ \text { zoon } & : & - \\ \text { kleindochter } & : & 0 \\ \text { kleinzoon } & : & 0 \\ \text { zus } & : & 7 / 36 \\ \text { broer } & : & 14 / 36\end{array}$

Indachtig het gegeven dat het bij de afwikkeling gaat om het realiseren van de erfopvolging volgens de toepasselijke erfwet, zou mijn voorkeur uitgaan naar de eerste optie,

392. Van een ontoelaatbare aantasting van het Marokkaanse erfrecht zou in het bijzonder sprake zijn als een verwerpende erfgenaam, ten behoeve van wie naar Marokkaans recht ongeldig was beschikt, bij de intestaat-verdeling als niet bestaand wordt beschouwd, met als gevolg dat hij geen wettig erfgenaam is, dat mitsdien ten behoeve van hem rechtsgeldig kan worden beschikt, en hij als legataris in de nalatenschap deelt. 
waarin de verwerping door een erfgenaam niet wordt geaccepteerd ${ }^{393}$. De erfgenaam die had willen verwerpen kan (vervolgens) afstand doen van zijn erfdeel ten behoeve van andere erfgenamen. Praktisch zal het overigens veelal zo kunnen gaan dat een erfgenaam die geen prijs stelt op zijn erfdeel of die zijn erfdeel ten goede wil laten komen aan andere erfgenamen accoord gaat met een andere verdeling dan de wettelijk vastgestelde.

Een ander aspect dat bij een afwikkeling naar Nederlands recht de aandacht verdient is dat het Marokkaanse erfrecht rechtsfiguren kent die in het Nederlandse recht onbekend zijn. De saisine uit het Nederlandse recht betreft alleen de erfgenamen (erfgenamen ab intestaat of erfgenamen krachtens testament); legatarissen zijn geen opvolgers onder algemene titel. Zij zijn niet aansprakelijk voor lasten of schulden van de nalatenschap. De kwalificatie als erfgenaam of legataris is derhalve essentieel. Bij de toepassing van Marokkaans erfrecht hebben de rechtsfiguren van de tanzil (zie p. 42-43) en het verplicht testament (zie p. 85-90) raakvlakken met zowel het testamentair erfrecht als met het intestaat erfrecht. Naar Marokkaans recht worden degenen die verkrijgen krachtens tanzil aangemerkt als legatarissen. Het ligt voor de hand deze kwalificatie bij de toepassing van Marokkaans recht in Nederland te volgen. Terwijl de tanzill moet worden uitgevoerd vóór de regels van wettige erfopvolging, bestaat hierover bij het verplicht testament geen zekerheid (zie p. 88-90). De tanzil wordt beheerst door de regels van het testament. Op het verplicht testament zijn zowel een aantal regels van het testament als een aantal regels van de wettige erfopvolging van toepassing. Degene die verkrijgt krachtens verplicht testament kan noch worden gelijkgesteld aan cen erfgenaam noch aan een legataris ${ }^{394}$. Niet geregeld is of degene die kan verkrijgen krachtens verplicht testament, zijn aanspraken moet aanvaarden ${ }^{395}$. In het kader van de vraag of zij naar Nederlands recht aansprakelijk zijn voor de schulden van de nalatenschap, neig ik ertoe hen te kwalificeren als erfgenaam omdat zij treden in de rechten van een (vooroverleden) erfgenaam. Omdat zij niet meer kunnen ontvangen dan eenderde deel van de nalatenschap, terwijl de erfgenaam in wiens plaats de begunstigde treedt tot meer gerechtigd zou kunnen zijn, zou de aansprakelijkheid het verworven "legaat" niet mogen overtreffen.

\section{Näherberechtigung en retorsie}

De wetgever heeft ervoor gekozen om de Näherberechtigung en retorsie te regelen bij de vereffening van de nalatenschap. Dat betekent dat in het kader van de erfopvolging geen rekening wordt gehouden met het feit dat bepaalde aanspraken op in het buitenland

393. Bovendien moet worden gewaakt tegen een oneigenlijk gebruik van de verwerping, in die zin dat juist vrouwen zich genoopt kunnen voelen hun erfdeel te verwerpen. In dit verband kan worden gerefereerd aan de in noot 65 opgenomen literatuur.

394. Hierover Chafi 1991, 276-278.

395. Gezien het verplichte karakter van het verplichte testament ligt het overigens niet voor de hand dat een dergelijke eis gesteld kan worden. 
gelegen goederen niet geldend kunnen worden gemaakt omdat een ander recht hieraan in de weg staat. Blijken de op grond van de toepasselijke erfwet bestaande aanspraken om deze reden niet te kunnen worden geëffectueerd, dan kan dit in de vereffeningsfase, als de benadeelde hierom vraagt, gecorrigeerd worden. De regeling hieromtrent is te vinden in art. 2 WCEo, welke bepaling luidt:

" 1 . Indien een der gerechtigden in een te vereffenen nalatenschap ten opzichte van een andere gerechtigde wordt benadeeld door de toepassing op een buitenslands gelegen goed van een krachtens het internationaal privaatrecht van het land van ligging aangewezen recht, worden de goederen, aldus overeenkomstig dat recht door die andere gerechtigde of door derden verkregen, als geldig verkregen erkend.

2. De benadeelde gerechtigde kan echter vorderen dat ter gelegenheid van de vereffening van de nalatenschap tussen hem en de bevoordeelde gerechtigde een verrekening plaatsvindt tot ten hoogste het ondervonden nadeel. Verrekening is uitsluitend mogelijk met betrekking tot goederen van de nalatenschap dan wel door vermindering van een last.

3. In de voorgaande leden wordt onder gerechtigde verstaan een erfgenaam, legataris of een lastbevoordeelde."

Marokkaanse erflaters

In dit verband kan er reeds op worden gewezen dat een erfopvolging en erfafwikkeling van een nalatenschap van een Marokkaanse erflater, in Marokko, en daarmee op in Marokko gelegen vermogen, alleen geaccepteerd kunnen worden wanneer het Marokkaanse recht volledig is gerespecteerd. De tenuitvoerlegging van beslissingen in Marokko is onderwerp van hoofdstuk 7.

\section{Bevoegdheden vereffenaar}

Op grond van art. 5 lid 1 WCEo worden de taak en de bevoegdheden van een door de erflater aangewezen vereffenaar beheerst door het Nederlandse recht indien de erflater zijn laatste gewone verblijfplaats in Nederland had. Ook hier kunnen vragen rijzen wanneer bij in het buitenland opengevallen nalatenschappen zich vermogensbestanddelen uit de nalatenschap in Nederland bevinden. Volgens de Memorie van Toelichting is niet gekozen voor een regel die de vereffenaar dwingt op de in Nederland gelegen bestanddelen het volgens het Verdrag toepasselijke recht toe te passen, omdat het niet goed verdedigbaar wordt geacht dat het naar Nederlands IPR toepasselijke recht zich steeds doorzet als het gaat om een in het buitenland opengevallen nalatenschap, en bovendien zou een daartoe strekkende bepaling in strijd zijn met het Verdrag inzake het internationaal beheer over nalatenschappen van $1973^{3 \%}$. Dit laatste Verdrag ${ }^{397}$, dat voor Nederland nog niet in werking is getreden, heeft tot doel het instellen van een internationaal certificaat, waarin wordt aangegeven wie bevoegd is tot het beheer van een

397. Verdrag van 2 oktober 1973, Trb. 1974, 83. Uitvoerig hierover: de Vos 1975, 394-429. 
roerende nalatenschap en welke bevoegdheden deze beheerder heeft, teneinde de toegang tot zich in andere Staten bevindende goederen mogelijk te maken. Dit in een Verdragsluitende Staat opgemaakt certificaat dient onder de in het Verdrag gestelde voorwaarden in Verdragsluitende Staten te worden erkend. De in het tweede lid van art. 5 opgenomen voorziening biedt de mogelijkheid te waarborgen dat op in Nederland gelegen vermogen het ingevolge het Erfrechtverdrag tocpasselijke recht wordt in acht genomen.

\section{Verdeling van de nalatenschap}

Bij de verdeling van een nalatenschap zijn juridisch twee aspecten aan te wijzen: de afspraak die wordt gemaakt over de verdeling van de goederen (activa en passiva) (de verbintenisrechtelijke kant), en de goederenrechtelijke kant ${ }^{398}$. In de WCEo wordt met beide aspecten rekening gehouden. Ingevolge het tweede lid van art. 4 WCEo wordt de wijze waarop de verdeling van de nalatenschap tot stand wordt gebracht, beheerst door het Nederlandse recht indien de erflater zijn laatste woonplaats in Nederland had, tenzij de deelgenoten gezamenlijk het recht van een ander land aanwijzen. Hieraan wordt toegevoegd dat met de eisen van het goederenrecht van de plaats van ligging der activa rekening wordt gehouden. Uit de parlementaire geschiedenis blijkt dat het hier bepalingen van dwingend recht betreft die gestalte geven aan het gesloten systeem van goederenrecht ter plaatse en aan de toepassing waarvan bij de verdeling van de nalatenschap niet kan worden ontkomen, en waarmee derhalve rekening dient te worden gehouden ${ }^{39 \%}$.

\section{$\S 8$. Erkenning van consulaire werkzaamheden}

Omdat in dit boek alleen aan de orde zijn Marokkaanse nalatenschappen die in Nederland openvallen, vindt geen bespreking plaats van de vraag naar erkenning van beslissingen, handelingen en bevoegdheden bij in het buitenland opengevallen nalatenschappen. De mogelijkheid voor een in Nederland verblijvende erflater of voor erfgenamen van een erflater die zijn laatste gewone verblijfplaats in Nederland had, om gebruik te maken van bevoegdheden van Marokkaanse consulaire vertegenwoordigers in erfrechtzaken, alsmede de nauwe betrokkenheid van de Nederlandse rechtssfeer in dergelijke situaties, vormen de aanleiding om niettemin de vraag of en in hoeverre dergelijke bevoegdheden in Nederland moeten worden erkend te bespreken ${ }^{400}$.

398. Ten Wolde 1995, 31-45; ten Wolde 1996, 304-306.

399. Nota van de Minister naar aanleiding van vragen van een regeringsfractie, TwK 1994-1995, 23857 , 6. p. 2.

400. Een bespreking van de erkenning van beslissingen van Marokkaanse rechters of van de bevoegdheden van vereffenaars uit Marokko, wanneer deze autoriteiten of personen door een in Nederland verblijvende erflater of door erfgenamen van een erflater die zijn laatste gewone verblijfplaats in Nederland had worden ingeschakeld, blijft achterwege. Het onderwerp van dit boek is beperkt tot beslissingen die in Nederland worden genomen en handelingen die in Nederland worden verricht. 
Gezien het groot aantal consulaten in Nederland en de aanzienlijke bevoegdheden van consulaire ambtenaren op het gebied van het familierecht en erfrecht, is het opmerkelijk dat binnen het IPR een algemene regel voor de erkenning of geldigheid van op het consulaat tot stand gekomen beslissingen of rechtsverhoudingen ontbreekt. Wat het familierecht betreft is alleen voor consulaire huwelijken in een regeling voorzien ${ }^{401}$. In art. 9 lid 2 van het Huwelijksverdrag van $1978^{402}$ wordt bepaald dat het huwelijk dat ten overstaan van een diplomaticke of consulaire ambtenaar overeenkomstig diens recht is voltrokken als rechtsgeldig wordt beschouwd, mits deze huwelijksvoltrekking in de Staat waar het huwelijk is voltrokken niet verboden is. In navolging hiervan is in de Wet conflictenrecht huwelijk (WCH) een bepaling, art. 4, opgenomen waaruit volgt dat een huwelijk wat de vorm betreft ook rechtsgeldig kan worden gesloten door buitenlandse diplomatieke vertegenwoordigers of consulaire ambtenaren, en in art. 5 lid 2 een regeling voor de erkenning van buiten Nederland voltrokken "diplomatieke" of consulaire huwelijken. Wat de huwelijksontbinding betreft is door de Hoge Raad bepaald dat in Nederland de Nederlandse rechters exclusief bevoegd zijn huwelijken te ontbinden ${ }^{403}$. Een huwelijksontbinding die op cen consulaat in Nederland is tot stand gebracht wordt derhalve in Nederland niet erkend. Een IPR-regeling omtrent de erkenning van handelingen van diplomatiek personeel of consulaire ambtenaren in nalatenschapskwesties ontbreekt. In het algemeen hebben IPR-regels inzake de erkenning, naar hun bewoordingen alleen betrekking op buiten Nederland ofwel in een andere Staat gegeven beslissingen of ontstane rechtsverhoudingen, en niet op die welke zijn totstandgebracht door een autoriteit van een andere Staat in Nederland. Voor de vraag naar de erkenning of geldigheid van consulaire werkzaamheden zal derhalve veelal moeten worden teruggevallen op regels en beginselen van het internationaal publiekrecht. Aan de erkenning van consulaire werkzaamheden worden dan twee eisen gesteld:

1. de diplomatieke of consulaire autoriteiten moeten volgens Verdrag of eigen nationale wetgeving tot de werkzaamheden bevoegd zijn; en

2. de Staat waar de diplomatieke vertegenwoordiging of het consulaat is gevestigd moet zich niet tegen de werkzaamheden verzetten. Dit vloeit voort uit de soevereiniteit van Staten. De Staat van vestiging is, behoudens Verdrag, niet verplicht om tegen zijn wil op zijn territoir de werkzaamheden van buitenlandse ambtenaren te

401. Voorts kende het oude Vooguijverdrag van 1902 in an. 2 aan diplomatieke en consulaire ambtenaren de bevoegdheid toe om overeenkomstig het recht van de Staat waarvan de minderjarige onderdaan was, in de voogdij te voorzien van een minderjarige onderdaan van de zendstaat die zijn gewoon verblijf in den vreemde had, voor wie geen voogdijregeling was getroffen, en alleen wanneer de Staat waar de minderjarige zijn gewone verblijf had zich daartegen niet verzette. Het Haags Kinderbeschermingsverdrag van 1961 kent een dergelijke voorziening niet. Ook in het nieuwe Verdrag inzake de bevoegdheid, het toepasselijke recht, de erkenning en tenuitvoerlegging, en samenwerking op het gebied van ouderlijke verantwoordelijkheden en maatregelen van kinderbescherming, ontbreekt een specifieke bepaling over de erkenning van bevoegdheden van diplomatieke en consulaire vertegenwoordigers.

402. Verdrag inzake de voltrekking en de erkenning van de geldigheid van huwelijken, 's-Gravenhage 14 maar 1978, Trb. 1987, 137, in werking getreden voor Nederland op 1 mei 1991

403. HR 31 oktober 1986, NJ 1987, 924 
dulden ${ }^{4(4)}$. Ingevolge het volkenrecht $k$ an een Staat geen overheidshandelingen verrichten op het territoir van een andere Staat, als deze Staat zich daartegen verzet ${ }^{405}$.

De consulaire ambtenaren zijn bevoegd de belangen van eigen onderdanen, Marokkaanse onderdanen derhalve, te beschermen. Zij zijn hiertoe volgens hun eigen recht ook bevoegd als de betrokkene naast de Marokkaanse nationaliteit nog een andere nationaliteit bezit. Voor hen is alleen de Marokkaanse nationaliteit van belang. Het is echter minder vanzelfsprekend dat in Nederland consulaire handelingen worden erkend wanneer de erflater (of de te beschermen erfgenaam) naast de Marokkaanse tevens de Nederlandse nationaliteit bezit. Lange tijd werd in Nederland de regel gehanteerd dat een consulair huwelijk waarbij een Nederlander was betrokken, in Nederland niet werd erkend ${ }^{406}$. Deze regel is door de wetgever in de parlementaire geschiedenis bij de WCH bevestigd ${ }^{407}$ en werd veelal ook in de rechtspraak nageleefd ${ }^{408}$. In 1996 heeft de Hoge Raad echter beslist dat een consulair huwelijk waarbij een partij is betrokken die naast de nationaliteit van de zendstaat tevens de Nederlandse nationaliteit bezit, in Nederland wel kan worden erkend ${ }^{4(x)}$. De Hoge Raad besliste in dit arrest dat uitsluitend zwaarwegende redenen kunnen leiden tot de conclusie dat de geldigheid van een dergelijk huwelijk niet zou worden erkend. Het bezit van de Nederlandse nationaliteit van een der aanstaande echtgenoten, terwijl de betrokkene tevens de nationaliteit van de zendstaat bezat, werd door de Hoge Raad niet als een dergelijke zwaarwegende reden beschouwd. Hiermee is de gedachte dat de Nederlandse Staat de bevoegdheid en handelingen van diplomatieke vertegenwoordigers of consulaire ambtenaren kan weigeren te erkennen omdat er een Nederlandse partij in het geding is, aan het wankelen gebracht. Deze bevoegdheid zou alleen nog onverkort gelden als er een Nederlander betrokken is die niet tevens de nationaliteit van de zendstaat bezit.

\section{A. ERKENNING VAN EEN CONSULAIRE AFWIKKELING VAN DE NALATENSCHAP}

Erkenning van de benoeming van de vereffenaar of executeur

Bij de totstandkoming van de Wet conflictenrecht erfopvolging (WCEo) is door de wetgever aangegeven dat een regeling voor de erkenning van de benoeming van een vereffenaar of executeur in het Nederlandse IPR niet nodig was omdat over de geldigheid van een dergelijke benoeming geen twijfel mogelijk zou zijn ${ }^{410}$. Niettemin is Nederland niet verplicht de benoeming van een consulair ambtenaar als vereffenaar te

404. Kosters/Dubbink 1962, 876 .

405. Kosters/Dubbink 1962, 389.

406. Reeds Kosters/Dubbink 1962, 876.

407. TwK 1987-1988, 20507,3, p. 7.

408. Recentelijk is deze regel nog toegepast door de Centrale Raad van Beroep, CRvB 22 maar 1995, RSV 1996, nr. 27.

409. HR 13 december 1996, RvdW 1997, 2.

410. TwK 1993-1994, 23857,3 , p. 5. 
crkennen. De vestigingsstaat moet de benocming immers toclaten ${ }^{411}$ en kan hieraan voorwaarden stellen.

Erkenning van de bevoegdheden van de vereffenaar of executeur

Nederland is niet verplicht om de bevocgdheden van een consulair ambtenaar in de afwikkeling van een nalatenschap van een erflater die zijn laatste gewone verblijfplaats in Nederland had te erkennen. Een argument om deze bevoegdheden niet te erkennen kan zijn gelegen in de bescherming van belangen van erfgenamen, legatarissen en schuldeisers van de erflater. In dit opzicht kan een parallel worden getrokken met de consulaire huwelijksontbinding, waar voor de regel dat in Nederland de Nederlandse rechter exclusief bevoegd is tot huwelijksontbinding, de rechtszekerheid en de bescherming van de belangen van de echtgenoten en de kinderen, een rol hebben gespeeld. Wordt erkenning niet uitgesloten ${ }^{412}$, dan is Nederland vrij om hieraan voorwaarden te stellen. De genomen maatregelen zullen bijvoorbecld niet mogen botsen met door de Nederlandse rechter bevolen maatregelen. Verder is denkbaar dat wordt verlangd dat de vereffening en verdeling geschiedt met inachtneming van het ingevolge het Erfrechtverdrag toepasselijke recht, en dat er geen sprake is van strijd met de Nederlandse openbare orde.

Of cen afwikkeling overeenkomstig de in de circulaire van de Marokkaanse overheid van 1966 voorgeschreven procedure (zie p. 94-95) in Nederland moet worden geaccepteerd, zal m.i. afhankelijk moeten zijn van de concrete omstandigheden van het geval. Wordt deze procedure gevolgd om de verdeling van vermogen dat zich in Marokko bevindt te vereenvoudigen, dan zal tegen erkenning ervan m.i. geen bezwaar bestaan. Wel zou degene die is benadeeld doordat het Nederlandse IPR niet in acht is genomen, wanneer hij niet met de verdeling accoord is gegaan, een verrekeningsrecht op vermogen in Nederland moeten kunnen krijgen. Betreft de afwikkeling daarentegen (tevens) nalatenschapsgoederen die zich in Nederland bevinden, dan zal de procedure m.i. niet behoeven te worden geaccepteerd. Erkenning onder voorwaarden zoals hierboven zijn beschreven zou mogelijk zijn. Mochten de erfgenamen accoord gaan met de afwikkeling, dan bestaat m.i. tegen erkenning ervan geen bezwaar.

Worden er door consulaire ambtenaren in het kader van de afwikkeling activiteiten verricht die in Nederland niet worden geaccepteerd, dan biedt art. 5 lid 2 WCEo de mogelijkheid om in Nederland gelegen vermogen te "beschermen". De Nederlandse rechter kan waarborgen, bijvoorbeeld door zekerheden te stellen, dat op de vererving van in Nederland gelegen vermogensbestanddelen uit de nalatenschap het ingevolge het Erfrechtverdrag toepasselijke recht wordt toegepast. Wordt men geconfronteerd met het

411. Vgl. Kosters/Dubbink 1962, 892.

412. In dit verband is het interessant te lezen dat Rigaux 1957, 256-257, aangeeft dat, anders dan bij notariële akten en akten van de burgerlijke stand, de erkenning van bevoegdheden betreffende de afwikkeling van een nalatenschap exclusief behoort tot het verdragenrecht. 
feit dat in het kader van de afwikkeling vermogensbestanddelen uit Nederland zijn weggehaald en naar Marokko zijn gebracht, dan behoeft een benadeelde erfgenaam of legataris niet zijn toevlucht te nemen tot de verrekeningsmogelijkheid die art. 2 lid 2 WCEo hem biedt, maar heeft hij van rechtswege een vordering op de bevoorrechte erfgenaam. Of de benadeelde erfgenaam (of legataris) is en wat de omvang van zijn nadeel is, kan worden beantwoord naar het ingevolge het Erfrechtverdrag toepasselijke recht. Procesrechtelijke mogelijkheden om deze aanspraken op goederen die zich in Marokko bevinden te realiseren zullen veelal beperkt zijn, omdat Marokko de aanspraken niet zal erkennen. De benadeelde kan dan gebruik maken van andere mogelijkheden en middelen, zoals verrekening, beslag op vermogen van de bevoorrechte in Nederland en dergelijke.

\section{§ 9. Het Haags Trustverdrag en de Marokkaanse hubus}

In hoofdstuk 2 is uitvoerig stilgestaan bij de Marokkaanse hubus. Hier werd ook aangegeven dat de hubus in Marokko nog een levend instituut is. Dat betekent dat men bij de erfopvolging en afwikkeling van de nalatenschap van Marokkaanse erflaters, ook in Nederland, geconfronteerd kan worden met het instituut van de hubus. Het kan zijn dat een Marokkaanse erflater zijn vermogen of een deel hiervan tot hubus-zaken heeft bestemd. Wordt de hubus erkend, dan behoren de hubus-zaken niet meer tot het vermogen van de erflater. Als de erflater zelf begunstigde is van een hubus, dan zijn de rechten die hij hieraan ontleent (het recht op de opbrengsten uit de hubus-zaken) onderworpen aan de hubus-regeling. Deze gaan over op de (verdere) begunstigden van de hubus ${ }^{413}$. De geldigheid en de gevolgen van een hubus vallen niet onder de erfwet, zelfs niet als deze pas door het overlijden uitvoerbaar wordt. Een tijdens leven gevestigde hubus zal in dat geval immers op grond van art. 1 lid 2 sub d Erfrechtverdrag buiten de erfwet vallen; voor de testamentaire hubus geldt op grond van art. 14 Erfrechtverdrag dat de erfwet niet belet dat hierop een ander recht wordt toegepast. In deze paragraaf wordt ingegaan op de erfrechtelijke gevolgen van de hubus. Alvorens deze consequenties te bespreken dient te worden onderzocht hoe de geldigheid en de erkenning van een hubus in Nederland dient te worden beoordeeld. Vanwege de gelijkenis met de trust, rijst de vraag of een hubus als trust in de zin van het Trustverdrag kan worden gekwalificeerd. In dat geval zouden namelijk zowel de geldigheid als de erkenning ervan worden beoordeeld aan de hand van het op 1 februari 1996 voor Nederland in werking

413. Tenzij er sprake is van een tijdelijke hubus, welke eindigt met het overlijden van de erflater. Alsdan keert de eigendom hiervan terug bij de insteller of diens erfgenamen, tenzij anders is bepaald in de vestigingshandeling. 
getreden Haags Trustverdrag ${ }^{41.4}$ en de op dezelfde datum in werking getreden Wet conflictenrecht trusts (WCT) ${ }^{415}$.

\section{A. HET HaAgs TRUSTVERdRAG}

Omdat in de WCT zowel de vraag wat onder een trust in de zin van de Wet wordt verstaan als voor de vraag naar het toepasselijk recht en de erkenning van trusts, wordt verwezen naar het Haags Trustverdrag (in art. 1 resp. 2 WCT), vindt er geen afzonderlijke bespreking van de WCT plaats.

\section{Toepassingsbereik}

\section{Intertemporeel toepassingsgebied}

Het Verdrag is van toepassing op trusts ongeacht het tijdstip waarop zij in het leven geroepen zijn (art. 22) ${ }^{416}$. Verdragstaten kunnen zich het recht voorbehouden het Verdrag niet toe te passen op trusts die in het leven zijn geroepen voor het tijdstip waarop het Verdrag voor die Staat in werking is getreden. Nederland heeft een dergelijk voorbehoud niet gemaakt.

\section{Formeel toepassingsgebied}

Het Verdrag stelt geen reciprociteitseis. Wel kan een Verdragsluitende Staat zich het recht voorbehouden de bepalingen inzake de erkenning van trusts ex art. 11 tot en met 14 slechts toe te passen op trusts waarvan de geldigheid beheerst wordt door het recht van een Verdragsluitende Staat (art. 21). Nederland heeft dit voorbehoud niet gemaakt. Marokko is geen partij bij het Verdrag.

414. Verdrag inzake het recht dat toepasselijk is op trusts en inzake de erkenning van trusts, Trb. 1985,141; Nederlandse vertaling Trb. 1996. 9. Het Trustverdrag wordt besproken door 0.m. Akkermans 1995. 701-705; van Boeschoten 1994, 1-44; Bouckaert 1995, 244-245; Cohen Henriquez 1986, 272-274; Cohen Henriquez 1987, 49-51; Duynstee 1993, 370-376; Gaillard en Trautman 1987, 307-340; van der Grinten 1993, 225-229; Joppe, Het Haags Trustverdrag 1996, 181-190; Joppe, Estate planning 1996, 85-97; Kleijn 1994, 209-216; Knigge 1994, 57-62; van Kooten 1993, 637-643; KoppenolLaforce 1985, 22-23; Koppenol-Laforce 1988, 95-115; Koppenol-Laforce, To trust 1994, 737-738; Koppenol-Laforce 1997; Koppenol-Laforce en Vlas 1995, 27-33; Snijders 1993, 23 I-243; Steenhoff 1996, 9-12; Uniken Venema 1985, 117-120; Uniken Venema 1993, 447-453; Verhagen 1996, 69-123; Vlas 1996, 19; Vriesendorp 1994, 45-106.

415. Wet houdende wettelijke bepalingen in verband met de aanvaarding van het op 1 juli 1985 te 'sGravenhage tot stand gekomen Verdrag inzake het recht dat van toepassing is op trusts en inzake de erkeming van trusts, Stb. 1995, 508 .

416. Vóór de inwerkingtreding van de WCT en het Trustverdrag werd door een aantal schrijvers reeds de opvatting gehuldigd dat er weinig op tegen was om het Trustverdrag anticiperend toe te passen, Joppe 1992, 193; Koppenol-Laforce 1988, 96; ten Wolde, Noot 1992, 59. 


\section{Materieel toepassingsgebied}

In de art. 2 en 3 van het Verdrag wordt aangegeven wanneer een rechtsfiguur kan worden aangemerkt als een trust die valt onder het toepassingsgebied van het Verdrag. Volgens art. 2 heeft de term trust betrekking op de rechtsbetrekkingen die - bij rechtshandeling onder de levenden of terzake des doods - in het leven worden geroepen door cen persoon, de insteller, wanneer goederen onder de macht/controle van een trustee worden gebracht ten behoeve van een begunstigde of voor een bepaald doel. Hieraan wordt toegevoegd dat een trust de volgende kenmerken heeft: a) de goederen van de trust vormen een afgescheiden vermogen en zijn geen deel van het vermogen van de trustec; b) de rechtstitel met betrekking tot de goederen van de trust staat ten name van de trustce of ten name van een ander voor rekening van de trustee; c) de trustee heeft de bevoegdheid en de plicht, terzake waarvan hij verantwoording schuldig is, om in overeenstemming met de bepalingen van de trust en de bijzondere verplichtingen, waaraan hij van rechtswege is onderworpen, de goederen van de trust te besturen en te beheren of er over te beschikken. Uit art. 3 volgt dat het Verdrag alleen die trusts betreft die door een wilsuiting in het leven zijn geroepen, en waarvan het bestaan blijkt door middel van een geschrift ${ }^{417}$.

Het Trustverdrag is tot stand gekomen met het oog op de Anglo-Amerikaanse trust. Aanvankelijk was de gedachte dat het Trustverdrag alleen op deze trusts betrekking zou hebben. Tijdens de vijftiende zitting van de Haagse Conferentie werd echter duidelijk dat ook aan de Anglo-Amerikaanse trust analoge instituten onder het Trustverdrag zouden vallen. Indien een rechtsfiguur voldoet aan de in art. 2 genoemde kenmerken van een trust, waarbij een verdragsautonome kwalificatie plaatsvindt, kan deze als trust in de zin van het Trustverdrag worden aangemerkt. In het rapport van von Overbeck wordt onderscheid gemaakt tussen rechtsfiguren die structureel analoog zijn aan de trust en rechtsfiguren die alleen functioncel analoog aan de trust zijn. De eerste rechtsfiguren zouden wel, de tweede rechtsfiguren zouden niet onder het Trustverdrag vallen ${ }^{4 / 8}$.

\section{Toepasselijk recht}

Hoofdstuk II van het Verdrag (art. 6 tot en met 10) bevat bepalingen over het toepasselijke recht. De trust wordt beheerst door het door de insteller gekozen recht (art. 6), tenzij dit recht de trust niet kent (art. 6 lid 2), en bij gebreke van een rechtskeuze door het recht waarmee de trust het nauwst verbonden is (art. 7). In art. 8 wordt bepaald welke onderwerpen door het toepasselijke recht worden beheerst. Dit zijn: de geldigheid, de uitlegging en de rechtsgevolgen van de trust, alsmede het bestuur over de trust. In art. 8 wordt voorts een niet limitatieve opsomming gegeven van onderwerpen die hiertoe in ieder geval gerekend moeten worden.

417. Uniken Venema 1993, 366.

418. Von Overbeck, Explanatory Repor 1984, par. 13. 


\section{Erkenning}

Aan de erkenning van trusts is het derde hoofdstuk van het Verdrag (art. 11 tot en met 14) gewijd. Ook in het vierde hoofdstuk, bevattende algemene bepalingen, zijn regels te vinden die direct de erkenning van trusts betreffen. In art. 11 wordt vooropgesteld dat een trust die in het leven is geroepen overeenkomstig het als toepasselijk aangewezen recht, erkend wordt als trust. In het artikel wordt voorts aangegeven wat deze erkenning minimaal impliceert. Buiten de in art. Il zelf genoemde te erkennen gevolgen, worden de gevolgen bepaald door het recht dat op de trust van toepassing is. Het Verdrag kent echter enkele bepalingen dic aan een gehele of gedeeltelijke erkenning van de trust in de weg kunnen staat, te weten de art. 13, 15, 16, 18 en 19.

In art. 13 is bepaald dat geen Staat is gehouden een trust te erkennen waarvan de kenmerkende elementen, afgezien van de keuze voor het toepasselijke recht, de plaats van bestuur van de trust en de gewone verblijfplaats van de trustee, nauwer verbonden zijn met Staten die de rechtsfiguur of de betrokken vorm van trust niet erkennen. Bij art. 13 is vooral gedacht aan de mogelijkheid om bij fraus legis erkenning aan de trust te onthouden. Door het instellen van een trust zou men zich namelijk kunnen onttrekken aan dwingende bepalingen van bijvoorbeeld het nationale recht of recht van de verblijfplaats van de insteller of van het recht van het land waar het trustvermogen zich bevindt, teneinde zich te onttrekken aan regels van erfopvolging, faillissement, de greep van de fiscus of andere schuldeisers ${ }^{419}$. Elementen waarmee bij de toepassing van art. 13 rekening kan worden gehouden zijn de plaats waar de trustgoederen zich bevinden, de verblijfplaats van de insteller, de verblijfplaats van de begunstigden, de nationaliteit van de insteller, en de nationaliteit van de begunstigden ${ }^{420}$. Hierbij dient een weging van de verschillende factoren plaats te vinden ${ }^{421}$.

Art. 15 laat de toepassing van dwingende bepalingen uit de toepasselijke rechtsstelsels op betrokken rechtsgebieden onverlet. Het eerste lid van art. 15 luidt: "Het Verdrag laat onverlet de toepassing van bepalingen van het recht dat is aangewezen door de verwijzingsregels van het land van de rechter, in zoverre van deze bepalingen niet door een wilsuiting kan worden afgeweken, met name wanneer zij betreffen:
a. de bescherming van minderjarigen en andere handelingsonbekwamen;
b. de persoonlijke en vermogensrechtelijke gevolgen van het huwelijk;
c. de erfopvolging krachtens testament of wet, in het bijzonder het wettelijk erfdeel;
d. de eigendomsoverdracht en de zekerheidsrechten;
e. de bescherming van schuldeisers in geval van insolventie;

419. TwK 1992-1993, 23 027, 3, p. 8; de Jong 1993, 340; Knigge 1994, 61-62.

420. TwK 1992-1993, 23 027, 3, p. 8.

421. Koppenol-Laforce 1994, 738; TwK 1992-1993, 23 027,3, p. 8 waar gesproken wordt van een belangenafweging, waarbij wordt aangegeven dat de plaats waar het vermogen is gelegen vooral van belang lijkt te zijn. 
f. de bescherming van derden te goeder trouw in andere opzichten Het betreft hier een niet limitatieve opsomming.

Het handhaven van deze dwingendrechtelijke bepalingen kan tot gevolg hebben dat van de erkenning van de trust en de rechtsgevolgen ervan ex art. 11 weinig overblijft. In de Memoric van Toclichting bij de WCT wordt in dit verband opgemerkt dat de rechter aan het erkenningsbeginsel van art. 11 de ruimst mogelijke werking zal moeten verlenen en zich ten aanzien van de tocpassing van art. 15 lid 1 in beginsel terughoudend zal moeten opstellen ${ }^{422}$. Zulks, aldus de Memorie van Toelichting, vloeit voort uit het Verdrag zelf, dat er in de eerste plaats op gericht is de erkenning van trusts te bevorderen, maar ook uit de omstandigheid dat de Nederlandse wetgever aan de aanvaarding van het Verdrag zijn goedkeuring hecht en daarmee blijk geeft het door het Verdrag nagestreefde docl te onderschrijven. In verband hiermee is de wetgever entoe overgegaan om in art. 4 WCT een regel op te nemen waarin wordt bepaald dat Nederlandse bepalingen inzake eigendomsoverdracht, zekerheidsrechten (art. 15 lid 1 sub d Verdrag) of de bescherming van schuldeisers in geval van insolventie (art. 15 lid 1 sub e Verdrag) de in art. 11 van het Verdrag omschreven rechtsgevolgen van de erkenning van een trust onverlet laten. Ten aanzien van de onder a tot en met $c$, en onder $f$ opgenomen bepalingen (en eventuele niet expliciet genoemde bepalingen) zal de Nederlandse rechter van geval tot geval moeten beoordelen wat de verhouding is tussen art. 15 en art. 11 , zulks indachtig de doelstelling van het Verdrag. In de literatuur is men het met deze relativering van art. 15 niet altijd eens, en wordt wel aangenomen dat een trust de dwingende regels van het door het forum aangewezen recht niet opzij kán zetten ${ }^{423}$.

Indien een rechtsfiguur is aan te merken als een trust in de zin van het Verdrag, doch deze niet wordt erkend op grond van het eerste lid van art. 15, dient de rechter te proberen op andere wijze aan het doel van de trust gevolg te geven (art. 15 lid 2). Hierbij kan hij, door middel van aanpassing, zijn toevlucht nemen tot enigszins vergelijkbare in Nederland wel tocgestane rechtsfiguren ${ }^{424}$.

422. TwK 1992-1993, 23027,3 , p. 17.

423. Duynstee 1993, 373. Duynstee verwijst hierbij naar par. 105 van het Explanatory Report van Von Overbeck waaruit volgt dat het duidelijk de bedoeling is dat de gevolgen van art. 11 geheel worden beperkt door art. 15. In noot 17 op p. 373 geeft hij aan niet overtuigd te zijn door de opvatting van de Staatssecretaris. Overigens geeft hij aan wel teleurgesteld te zijn door art. 15 lid I van het Verdrag en had liever gezien dat de rechtsgevolgen van art. 11 buiten de werkingssfeer van art. 15 waren gelaten. Zie voorts Uniken Venema 1985, 118.

424. Over de aanpassing en kwalificatie van een trust vóór de inwerkingtreding van de WCT: van Boeschoten 1993, 219; Cohen Henriquez 1986, 239, 270-271; Dyer en van Loon 1983, 56-59; van der Grinten 1993, 225-226; Joppe 1987, 197; Kleijn 1994, 215; Koppenol-Laforce en Vlas 1995, 32; Offerhaus 1963, 174-176. Analogieën zouden bijvoorbeeld kunnen worden gezocht in de fiduciaire eigendom (o.m. Hijmans van den Bergh 1962,262), bewind, lastgeving, fideicommis, vruchtgebruik-constructies, en de stichting. Zit over de Nederlandse eigendom ten titel van beheer en de verhouding met de trust: Uniken Venema en Eisma 1990. 
Op grond van art. 16 worden voorrangsregels van de lex fori en van derde Staten gerespecteerd. Met betrekking tot het accepteren van de voorrangsregels van derde Staten was het mogelijk een voorbehoud te maken, doch Nederland heeft van deze mogelijkheid geen gebruik gemaakt.

Op grond van art. 18, kan erkenning van een trust achterwege blijven bij klaarblijkelijke onverenigbaarheid met de openbare orde.

Art. 19 tenslotte bepaalt dat het Verdrag de bevoegdheden van de Staten op belastinggebied onverlet laat. Iedere Verdragsstaat bepaalt mitsdien autonoom welke (eigen) fiscale regels op de trust worden toegepast ${ }^{425}$.

\section{B. IS DE MAROKKAANSE HUBUS EEN TRUST?}

De Marokkaanse hubus kan als trust in de zin van het Trustverdrag worden aangemerkt indien zij voldoet aan de kenmerken en vereisten die worden gesteld in de art. 2 en 3 van het Verdrag. Alvorens dit na te gaan, wordt de hubus hier beknopt in herinnering gebracht. Bij de Marokkaanse hubus gaat het om een handeling waarbij goederen aan het handelsverkeer worden onttrokken en de opbrengst van deze goederen wordt bestemd voor een door de insteller aangewezen goed doel of begunstigde personen (met als uiteindelijke bestemming: een goed docl). De goederen verlaten het vermogen van de insteller, althans zijn niet meer te zijner vrije beschikking. Een beheerder, dic is aangewezen door de insteller, en bij gebreke hiervan door de rechter, draagt zorg voor de uitvoering van de vestigingshandeling hetgeen inhoudt dat hij zorg draagt voor de goederen, deze exploiteert en ervoor zorgt dat de opbrengsten van de hubus-goederen terecht komen bij het aangewezen goede doel of de aangewezen begunstigden. Bij de familie hubus in Marokko wordt dit beheer in de regel door de begunstigden zelf uitgeoefend. De overeenkomsten met de trust springen in het oog. Bij beide rechtsfiguren is er sprake van een rechtshandeling van de insteller waardoor de goederen het vermogen van de insteller verlaten en deze goederen of de opbrengsten ervan zijn bestemd voor derde begunstigden of voor een goed doel. $\mathrm{Er}$ is een beheerder/tussenpersoon belast met het beheer van de goederen, welke goederen van diens privé-vermogen zijn afgescheiden. De beheerder is verplicht zijn taken uit te voeren in overeenstemming met het in de vestigingshandeling van de trust respectievelijk hubus bepaalde (en met het recht). Er ontstaan rechtsbetrekkingen tussen de beheerder enerzijds en de begunstigden anderzijds met betrekking tot de goederen. Het enige kenmerk van een trust in de zin van het

425. TwK 1992-1993, 23 027, 3. Op p. 12 van de Memorie van Toelichting worden hiervoor enkele inhoudelijke aanwijzingen gegeven. Voor de coördinatie van de fiscale behandeling van de trust kan o.m. worden verwezen naar een beleidspublicatic van de staatssecretaris van financiën, opgenomen in TwK 1994-1995, 23054 ( $R$ 1464), 10, p. 10. Voor een bespreking van consequenties van het Trustverdrag voor het belastingrecht kan voorts worden verwezen naar Sonneveldt 1993, 377-382. 
Trustverdrag dat problematisch lijkt te kunnen zijn, is de titel $^{426}$ in de zin van art. 2 van het Trustverdrag die de trustee moet bezitten met betrekking tot de goederen. In het voorbereidend rapport van Dyer en van Loon van 1982 bij het Trustverdrag wezen de rapporteurs op het verschil tussen een beheerder van een waqf en een trustee: anders dan een trustee heeft de beheerder van een waqf geen eigendom ("ownership") over de goederen die hij beheert ${ }^{427}$. Inmiddels is wel duidelijk dat er geen sprake behoeft te zijn van een absoluut eigendomsrecht in de betekenis die hieraan in de civil-law-landen wordt gegeven. De titel van een trustee van een Anglo-Amerikaanse trust gaat namelijk ook niet zo ver ${ }^{428}$. Wat de titel dan wel moet inhouden is niet geheel duidelijk. De trustee van een Anglo-Amerikaanse trust heeft veelal niet een formele zakenrechtelijke titel met betrekking tot de goederen. Dyer spreckt van een 'fiction of "legal" title' ${ }^{229}$. De trustee moet in enigerlei vorm gerechtigd zijn tot de trustgoederen ${ }^{430}$. Bij de Marokkaanse hubus wordt aan de beheerder geen eigendom overgedragen. De eigendom blijft waarschijnlijk bij de insteller. Dit eigendomsrecht heeft noch inhoud noch gevolgen meer. Wat er na zijn dood met de eigendomsaanspraken gebeurt is derhalve niet meer relevant ${ }^{431}$. Als de hubus wordt ontbonden, herleeft het eigendomsrecht, en komt dit toe aan de erfgenamen van de insteller. Zolang de hubus in stand is zijn vooral de positie van de beheerder en van de begunstigden van belang. De Marokkaanse publieke hubus wordt beheerd onder verantwoordelijkheid van het Ministerie van Habous, die voor de uitvoering ervan nazzirs benoemt. Er is een veelheid van regelgeving die de verplichtingen en bevoegdheden van deze nâzirs regelt. Het beheer van de familie hubus is doorgaans in handen van de begunstigden zelf. Dit staat overigens niet in de weg aan het zijn van een trust in de zin van het Trustverdrag (art. 2 lid 3). Volgens deze bepaling is het niet noodzakelijkerwijs onverenigbaar met het bestaan van een trust dat de trustee bepaalde (cursief SR) rechten als begunstigde heeft ${ }^{432}$. Betreffen de hubus-zaken geregistreerd onroerend goed, dan hebben de begunstigden, of de begunstigde intermediair, van een familie hubus, evenals andere zakelijk gerechtigden, de mogelijkheid een speciale titel te verkrijgen welke wordt opgenomen in de registers (de "livres fonciers"). Zij zijn de rechthebbende van (het vruchtgenot van) het hubusvermogen. De beheerder van een familie hubus als zodanig heeft vooral bevoegdheden, verplichtingen en verantwoordelijkheden, doch geen ("zakenrechtelijke") titel met

426. In de originele Engelse en Franse versie wordt gesproken van een "title" respectievelijk "titre". De Nederlandse veraling van de verdragstekst spreekt over "rechtstitel".

427. Dyer en van Loon, Preliminary Report 1982, par. 56.

428. Zie over de functie van een trustee van een Anglo-Amerikaanse trust o.m. van Boeschoten 1994, 5-6; Dyer 1983, i.h.b. 5-13; van Loon 1983, 48-54; Uniken Venema 1985, 93-96; Waters 1995, i.h.b. 221 $225,428-435$.

429. Dyer $1983,10$.

430. Uniken Venema 1985, 93.

431. Voor de verschillende opvattingen over de eigendom van een hubus of waqf zij verwezen naar de noten 70 en 71.

432. In het rapport van von Overbeck, par. 47, wordt overigens aangegeven dat van de in het derde lid van art. 2 genoemde mogelijkheden in de praktijk zelden gebruik wordt gemaakt. 
betrekking tot de goederen. De vraag is of de bevoegdheden, verplichtingen en verantwoordelijkheden van de beheerder van een hubus (eventueel in verhouding tot die van de insteller, de begunstigden, en derden) zodanig zijn dat zij hem voldoende macht over de goederen geven die hem een titel opleveren in de zin van art. 2 van het Trustverdrag. Indien niet de "fictieve" titel, die een trustee wel maar een nâzir niet bezit, maar de verhouding waarin de beheerder tot de goederen staat, en de inhoud van de bevoegdheden en verantwoordelijkheden die uit deze verhouding voortvloeien doorslaggevend mochten zijn voor het al dan niet bezitten van de vereiste titel, dan kan worden geconstateerd dat er grote gelijkenissen bestaan tussen de positie van een trustee en die van cen nâzir van een islamitische waqf ${ }^{433}$. Bij de Marokkaanse publieke hubus, die is bestemd voor een bepaald doel en niet is gevestigd ten behoeve van aangewezen begunstigden, zal de beheerder "de sterkste papieren" ${ }^{434}$ met betrekking tot de goederen hebben. Ten aanzien van de Marokkaanse familie hubus, waarbij de nâzir in de regel tevens begunstigde is, ofwel éen, enkele of alle begunstigden tevens beheerders zijn, is overigens de vraag of de nâzir zich nog voldoende onderscheidt van de begunstigden. Nader onderzoek zou nodig zijn naar de "zakenrechtelijke" bevoegdheden welke de persoon die formeel de nâzir van cen familie hubus is, met betrekking tot de hubus goederen bezit. Het begrip trust in de zin van het Trustverdrag moet verdragsautonoom worden gekwalificeerd. Het ontbreken van voldoende duidelijke richtlijnen om tot een dergelijke kwalificatie te kunnen komen en het ontbreken van een internationale rechter die de uitleg van de verdragsbepalingen kan vaststellen maken het bijna onvermijdelijk dat de Verdragstaten op hun eigen wijze de verdragsautonome kwalificatie kunnen gaan bepalen.

\section{ERKENNING VAN DE MAROKKAANSE hUBUS}

Mocht de Marokkaanse hubus worden gekwalificeerd als een trust in de zin van het Trustverdrag dan kan deze worden erkend onder de in het Verdrag gestelde voorwaarden. Is dit niet het geval, dan zal de vraag naar de erkenning ervan op andere wijze moeten worden beoordeeld. Bij gebreke van zowel geschreven als ongeschreven erkenningsregels zijn hierbij ten minste twee wegen denkbaar. De eerste is dat erkenning van de hubus en van de (erfrechtelijke) gevolgen ervan plaatsvindt met een beroep op het fait accompli-beginsel en het beginsel van de "droits acquis" ${ }^{435}{ }^{436}$. Deze mogelijk-

433. Cattan 1984, 212 betoogt dat een analyse van de verschillen tussen de trust en de waqf, waaronder het verschil in titel van de beheerder met betrekking tot de goederen, slechts de grote gelijkenis tussen de beide rechtsfiguren bevestigt. Ook Kneller $1966,52,58$, betoogt dat er sprake is noch van een functioneel noch van een formeel onderscheid tussen de trust en de wagf.

434. Aldus Koppenol-Laforce 1997, par. 2.4.1. Uniken Venema 1985, 93, spreekt van het toekomen aan de trustee van een 'better title' dan aan degene die deze titel betwist of de goederen onder zich heeft.

435. Hierover Joppe, Overgangsrecht in het internationaal privaatrecht en het fait accompli 1987. Voorstander om de rechten van een beneficiary van een trust als verworven rechten te (kunnen) erkennen is van Loon 1983, 75-76. Ten aanzien van deze rechten zal dan wel een aanpassing moeten plaatsvinden aan 
heid staat met name open wanneer de hubus buiten de Nederlandse rechtssfeer is gevestigd en bij de betrokkenen legitieme verwachtingen bestaan ten aanzien van de geldigheid crvan. Een tweede mogelijkheid is om een aanpassingsconstructie te gebruiken door de hubus te kwalificeren als een instituut dat het Nederlandse IPR wel kent, en waarmee de hubus zoveel mogelijk overeenkomsten vertoont. Vervolgens dienen de vreemde elementen te worden gewrongen in het keurslijf van de wel bekende rechtsfiguur ${ }^{437}$. In beide gevallen kan overigens erkenning aan de hubus worden onthouden bij strijd met de Nederlandse openbare orde. Een weigering op grond van fraus legis behoort eveneens tot de mogelijkheden, zij het dat dit leerstuk in Nederland niet populair is en slechts in uitzonderlijke gevallen wordt gehanteerd. Als er sprake is van fraus legis wordt vaak de voorkeur gegeven aan cen beroep op de openbare orde.

Indien de hubus mocht worden aangemerkt als een trust in de zin van het Trustverdrag is de erkenning hiervan en van de gevolgen onderworpen aan de in het Trustverdrag en de WCT gestelde voorwaarden. Mocht de hubus niet kunnen worden gekwalificeerd als een trust in de zin van het Trustverdrag, dan zou ik, indachtig het fait accompli-beginsel, een analoge toepassing van het Trustverdrag willen bepleiten. Met het oog hierop zou dan een aanpassing van de WCT wenselijk zijn. De hubus zou dan worden beheerst door het door de insteller gekozen recht, en bij gebreke van een rechtskeuze door het recht waarmee de hubus het nauwst verbonden is. Is de hubus volgens dit recht rechtsgeldig tot stand gekomen, dan kan zij worden erkend. De erkenning van een rechtsgeldig tot stand gekomen hubus zou dan kunnen worden geweigerd:

a. indien de hubus nauwer is verbonden met Staten die de hubus niet kennen (dan met Staten die de hubus wel kennen);

b. indien en voorzover dwingende bepalingen van het toepasselijke recht op andere rechtsgebieden zich hiertegen verzetten;

c. indien voorrangsregels van de lex fori zich hiertegen verzetten;

d. bij klaarblijkelijke onverenigbaarheid met de openbare orde.

het systeem van erkende rechten van het Nederlandse zakenrecht, van Loon 1983, 76. Kritisch over de mogelijkheid van een dergelijke erkenning: Uniken Venema 1985, 117.

436. Een andere, m.i. juridisch minder fraaie, weg waarlangs erkenning van de hubus in het kader van het erfrecht zou kumen worden bereikt wanneer Marokkaans recht de erfopvolging beheerst, is de vraag naar de geldigheid van de hubus te beschouwen als een deelvraag bij de erfopvolging, en erkenning hiervan afhankelijk te stellen van de geldigheid van de hubus volgens het toepasselijke erfrecht. Een aanbeveling in deze zin voor trusts, fideïcommis en dergelijke, werd gedaan door de Internationale Vereniging voor het Latijns Notariaat in 1969, Lubbers 1970, 136.

437. Zoals de fiduciaire eigendom, het bewind, lastgeving, bewind, fideïcommis, vruchtgebruik-constructies, en de stichting, zie noot 424. Enkele Nederlandse trustachtige figuren worden besproken in Hayton 1996. 
ad a. nauwere verbondenheid met andere Staten

Voor de betekenis hiervan in het kader van het erfrecht zij verwezen naar hetgeen bij art. 13 van het Trustverdrag is opgemerkt. Afhankelijk van de omstandigheden is bijvoorbeeld denkbaar dat aan een hubus die is gevestigd door een in Nederland woonachtige Marokkaanse erflater waarbij de hubus-goederen zich in Nederland bevinden, op grond van deze regel erkenning wordt onthouden.

ad b. dwingende bepalingen van het toepasselijke recht op andere rechtsgebieden dienen onverlet te worden gelaten.

Wat de persoonlijke gevolgen van het huwelijk betreft, geldt dat wanneer een gehuwde man of vrouw wiens echtgenoot(ote) in Nederland zijn gewone verblijfplaats heeft, zijn vermogen geheel of gedecltelijk tot hubus-vermogen wil bestemmen, hiervoor op grond van art. 1:88 sub a BW de toestemming van de andere echtgenoot behoeft. Op grond van art. 3 Wet conflictenrecht huwelijksbetrekkingen is hierop immers Nederlands recht van toepassing, als zijnde het recht van de gewone verblijfplaats van de echtgenoot wiens toestemming al dan niet is vereist. Ontbreekt een dergelijke toestemming, dan kan de echtgenoot wiens toestemming nodig was de hubus laten vernietigen. Wat de vermogensrechtelijke gevolgen betreft geldt dat wanneer volgens het toepasselijke recht een gemeenschap van goederen bestaat, slechts over dat deel waarvan men eigenaar is kan worden beschikt.

Wat de bescherming van dwingendrechtelijke erfrechtbepalingen betreft, geldt dat indien de erfopvolging door Marokkaans recht wordt beheerst, de hubus, die en voorzover deze naar Marokkaans recht geldig is, volledig kan worden erkend. Het is toegestaan een hubus te vestigen waarbij de regels van erfopvolging volledig worden gepasseerd. Alleen de testamentaire hubus is onderworpen aan de beperkingen die aan een testament zijn gesteld. Indien daarentegen de erfopvolging door Nederlands recht zou worden beheerst, wordt de toepassing van de dwingendrechtelijke Nederlandse bepalingen, in het bijzonder de bepalingen omtrent de legitieme, onverlet gelaten. De hubus behoeft niet te worden erkend voorzover deze een aantasting van de dwingende Nederlandse erfrechtbepalingen tot gevolg zou hebben. Zouden de hubus-goederen zich in dit geval in Marokko bevinden, dan zal toepassing van de Nederlandse dwingendrechtelijke bepalingen waarmee een inbreuk zou worden gemaakt op de hubus-situatie, niet te realiseren zijn. Het niet of niet geheel erkennen van de hubus heeft dan feitelijk alleen zin als er een verrekeningsmogelijkheid of andere verhaalsmogelijkheid bestaat.

Wat de zekerheidsrechten en vorderingen van schuldeisers in geval van insolventie betreft, is van belang dat wanneer een hubus naar Marokkaans recht is gevestigd, de hubus-goederen aan het handelsverkeer zijn onttrokken, en derhalve op geen enkele wijze meer als verhaalsobject kunnen dienen. Indien de vordering van een schuldeiser bijvoorbeeld door Nederlands recht wordt beheerst of er naar Nederlands recht een zekerheidsrecht is gevestigd op een goed dat onderwerp wordt van een hubus, kan de schuldeiser zijn vordering of recht niet meer uitoefenen ten aanzien van hubus-goederen. 
Door de tocpassing van dwingendrechtelijke Nederlandse bepalingen op dit punt onverlet te laten kan aan dit nadeel voor schuldeisers het hoofd worden geboden. In art. 4 WCT is ervoor gekozen om juist de rechtsgevolgen van de erkenning van een trust te laten prevaleren ten koste van Nederlandse bepalingen inzake de eigendomsoverdracht, zekerheidsrechten of de bescherming van schuldeisers.

ad d. de openbare orde verzet zich tegen erkenning van de hubus of de gevolgen ervan Door het vestigen van een hubus kunnen de regels van erfopvolging worden omzeild. In de praktijk wordt niet zelden juist om deze reden een hubus in het leven geroepen. Het omzeilen van de islamitische regels van erfopvolging wordt wel gezien als een bezwaar dat, samen met andere aan de hubus klevende bezwaren ${ }^{438}$, in een aantal islamitische Staten reden heeft gevormd tot het afschaffen van de familic-hubus. Het inroepen van de exceptic van de openbare orde is bijvoorbeeld denkbaar wanneer een familie-hubus is gevestigd teneinde vrouwelijke afstammelingen uit te sluiten van aanspraken op het nalatenschapsvermogen. Ook hier geldt dat, wanneer de hubus-goederen zich in Marokko bevinden, het weigeren van erkenning alleen praktische betekenis heeft als er een verrekeningsmogelijkheid of andere verhaalsmogelijkheid bestaat. 
Hoofdstuk 5

\section{Voorvragen}

\section{$\S 1$. De voorvraag}

De voorvraag werd lange tijd niet als een afzonderlijk probleem gezien, maar behandeld bij andere IPR-leerstukken en technieken, zoals de kwalificatie, aanpassing en het leerstuk van de "droits acquis". Het zijn met name Duitse IPR-specialisten in de jaren dertig geweest die de voorvraag voor het eerst beschouwden als een zelfstandig probleem waarvoor een eigen theorie kon worden ontwikkeld ${ }^{439}$.

In dit hoofdstuk wordt uitgegaan van het bestaan van een voorvraag wanneer bij de toepassing van het ingevolge een verwijzingsregel aangewezen recht (de lex causae) een andere conflictenrechtelijke vraag rijst. De verwijzingsregel waar het hier om gaat is die inzake de erfopvolging. De vraag naar de erfopvolging is dan de hoofdvraag. Het toepasselijke recht wordt middels de verwijzing in de WCEo vastgesteld op grond van het Erfrechtverdrag. Bij een Marokkaanse erflater zal dit in de regel leiden tot de toepasselijkheid van hetzij Marokkaans hetzij Nederlands erfrecht. In deze verhandeling wordt uitgegaan van gevallen waarin Marokkaans recht de hoofdvraag, de vraag naar de erfopvolging derhalve, beheerst. Als voorvragen worden in dit hoofdstuk niet beschouwd:

a. deelvragen: vragen die zelfstandig rijzen, dus niet bij de toepassing van de regels van erfopvolging, en welke tot een andere verwijzingscategorie dan die van de erfopvolging behoren. Deze deelvragen zijn in beginsel aan een eigen conflictregel onderworpen ${ }^{440}$. Voorbeelden van dergelijke deelvragen zijn de vraag naar de

439. In het bijzonder W. Wengler, Die Vorfrage im Kollisionsrecht, Rabelsz. 1934, 148-251, G. Melchior, Die Grundlagen des deutschen internationalen Privatrechts, Berlin/Leipzig 1932, 245-265, en Raape 1934, 485-495. Zie over deze ontwikkeling ook Schmidt 1992, 342-367.

440. Een afwijking is mogelijk wanneer de deeivraag en hoofdvraag een zo nauwe samenhang vertonen dat zij niet los van elkaar kunnen worden beoordeeld. Dit kan bijvoorbeeld het geval zijn als de gevolgen van het huwelijksvermogensregime bij het overlijden van een echtgenoot worden geregeld in het erfrecht, of als de vorm van een uiterste wil is gekoppeld aan de inhoud ervan. 
formele geldigheid van een testament, de bekwaamheid om bij uiterste wil te beschikken, en de vraag wat er behoort tot het nalatenschapsvermogen van de erflater. Een aantal van deze deelvragen die ook tot het erfrecht behoren, is vanuit Nederlands internationaal privaatrechtelijk perspectief in het vierde hoofdstuk aan de orde geweest. Een vraag die in veel nalatenschappen ook zal rijzen en die directe gevolgen heeft of kan hebben voor het erfrecht, is de vraag naar het huwelijksvermogensregime in gevallen waarin de erflater op het moment van zijn overlijden gehuwd was. Aan deze vraag wordt apart aandacht geschonken in $\$ 7$;

b. kwalificatievragen die rijzen bij de aanknopingsfactor van de toepasselijke verwijzingsregel. Voor een bespreking van de aanknopingsfactoren bij de erfopvolging en de kwalificatievragen die hierbij kunnen rijzen zij verwezen naar het vorige hoofdstuk;

c. materieclrechtelijke kwalificatievragen dic rijzen bij de toepassing van het aangewezen recht; rechtsverhoudingen of instituten moeten worden ingepast in het begrippensysteem van de lex causac.

Indien op de hoofdvraag, de vraag naar de erfopvolging, volgens de Nederlandse verwijzingsregel het Marokkaanse erfrecht toepasselijk is, kunnen bij de toepassing hiervan prealabele rechtsvragen rijzen. Het erfrecht is bij uitstek een onderwerp waarbij dergelijke vragen rijzen. De hoedanigheid van erfgenaam is immers in de regel gekoppeld aan de familierechtelijke verhouding waarin iemand tot de erflater staat, en het bestaan of de geldigheid van deze familierechtelijke verhouding kan in het ene rechtsstelsel anders worden gewaardeerd dan in een ander stelsel ${ }^{441}$. In het Marokkaanse erfrecht geldt dat erfopvolging kan plaatsvinden op grond van het bestaan van een geldig huwelijk en op grond van wettige bloedverwantschap (zie hoofdstuk 2 3.B.3). Bij de voorvragen gaat het in dit hoofdstuk om het vaststellen van het al dan niet bestaan van een rechtsverhouding of rechtsfeit op het moment van het overlijden van de erflater. De vier voorvragen die zich kunnen opdringen zijn:

1. was er sprake van een geldig huwelijk met de erflater?

2. was het huwelijk met de erflater ontbonden door een geldige huwelijksontbinding?

3. was er sprake van wettige bloedverwantschap met de erflater?

4. was er sprake van wettige verwantschap met de erflater op grond van adoptie?

Vanaf het moment dat het leerstuk van de voorvraag een zelfstandige betekenis heeft gekregen hebben zich twee theorieën ontwikkeld die een oplossing voor het voorvraagprobleem hebben willen geven. Dit zijn de theorie van de afhankelijke aanknoping en

441. Over de familierechtelijke vragen die bij de erfopvolging kunnen rijzen gaat reeds Raape 1934, 505517 uitvoerig in. Hij behandelt dit aspect overigens niet bij de voorvraag maar bij de aanpassing. De familierechtelijke voorvragen bij de erfopvolging worden ook uitvoerig besproken door Wengler 1966 , 165-215. 
de theoric van de zelfstandige aanknoping ${ }^{442}$. In de theorie van de afhankelijke aanknoping wordt de voorvraag beantwoord aan de hand van het rechtsstelsel, inclusief het conflictenrecht, dat ook de hoofdvraag bcheerst. In de theorie van de zelfstandige aanknoping wordt de voorvraag, los van de hoofdvraag, beantwoord aan de hand van het cigen (conflicten)recht van het forum.

Voor de theorie van de afhankelijke aanknoping kan een aantal argumenten van uiteenlopende aard worden aangevoerd: het IPR van het forum zou zijn uitgespeeld als de rechtsverhouding - de hoofdvraag - wordt verwezen naar een vreemd rechtsstelsel; wanneer voor de hoofdvraag wordt verwezen naar vreemd recht, dient de Nederlandse rechter dit recht toe te passen op de wijze waarop de vreemde rechter dit zou toepassen; met een afhankelijke beoordeling is de internationale beslissingsharmonie gediend (althans indien volgens het conflictenrecht van de lex causae ook het eigen recht de voorvraag zou behcersen); erkenning in het land waarvan het recht de hoofdvraag beheerst zal op minder problemen stuiten; er is sprake van een samenhang tussen hoofdvraag en voorvraag; bij een afhankelijke beoordeling wordt het vreemde recht volledig gerespecteerd. Tegen een afhankelijke beoordeling wordt met name aangevoerd dat de geldigheid of het bestaan van eenzelfde rechtsverhouding of rechtsfeit binnen één Staat verschillend kan worden beoordeeld, namelijk afhankelijk wordt gesteld van de context waarbinnen de vraag rijst (inbreuk op de interne beslissingsharmonie). Tegen dit nadeel kan weer worden aangevoerd dat bij een afhankelijke beoordeling niet de geldigheid of het bestaan van de rechtsverhouding of het rechtsfeit verschillend worden beoordeeld, maar dat slechts de hieraan verbonden rechtsgevolgen worden bepaald door het op de hoofdvraag toepasselijke vreemde recht ${ }^{443}$.

Argumenten die voor de theorie van de zelfstandige aanknoping kunnen worden aangevoerd $^{444}$ zijn dat de voorvraag juist niet kan worden geacht te worden beheerst door het recht dat de hoofdvraag beheerst, maar een zelfstandige rechtsverhouding of rechtsfeit betreft die is onderworpen aan de hiervoor geldende forale conflictregels; bij het totstandbrengen van een conflictregel zijn prealabele vragen niet in de overwegingen betrokken; een rechtsverhouding of rechtsfeit moet binnen één Staat steeds op eenzelfde wijze worden beoordeeld en niet afhankelijk worden gesteld van de kwestie waarin de (voor)vraag rijst: hiermee is het belang van de interne beslissingsharmonie gediend. Indien een keuze zou moeten worden gemaakt tussen beide theorieën, dan moet het bij deze keuze m.i. niet gaan om de vraag welke doeleinden men met de ene of de andere theorie wenst te bereiken, maar om de vraag of de voorvraag al dan niet behoort tot het

442. Van Hoogstraten 1962, 209-225; Kokkini-Iatridou en Frohn 1987, 371 e.v.; Lemaire 1968, 343-350; Schmidt 1992, 368-438 (spreekt over een lex fori- respectievelijk lex causae-benadering); Strikwerda 1995, 73-74; Voskuil 1963, 1-15, i.h.b. 2-3; Voskuil 1985, 102-104. Zie voons over de voorvraagproblematiek Lequette 1994, 102-121; Nova 1966, 557-569.

443. Aldus ook Voskuil 1963, 5 e.v., die zich in Nederland onomwonden als een van de weinige voorstanders van de aftankelijke aanknoping profileert.

444. Van Hoogstraten 1962, 217 e.v.; Lemaire 1968, 346 e.v. 
domein van het op de hoofdvraag toepasselijk verklaarde (vreemde) recht, en als dit het geval is op welke grond de voorvraag dan mogelijk toch naar het IPR van het forum kan worden toegetrokken. Bij een verwijzingsregel die uitgaat van een blinde verwijzing, behoort de voorvraag in beginsel m.i. tot de lex causae die op de hoofdvraag van toepassing is. Beantwoording van de voorvraag is dan - zoals Voskuil ook aangeeft slechts een vorm van (conflictenrechtelijke) kwalificatie; begrippen waarvan dat vreemde recht zich bedient, ontlenen hun inhoud aan dát recht ${ }^{445}$. Hiervan uitgaande kan de toepassing van het vreemde recht, ook op de voorvraag, alleen nog achterwege blijven door gebruik te maken van een correctiemiddel, waarvan de gebruikelijke zijn het inroepen van de exceptie van de openbare orde, of het respect voor verworven rechten, het fait accompli, of het gebruik maken van een aanpassingsconstructie. Het gebruik van dergelijke correctiemiddelen, het accepteren van alternatieve verwijzingsregels, het gebrek aan eenduidigheid over IPR-methoden, en andere factoren, hebben de blindheid van de verwijzingsregel aan het wankelen gebracht. Tegen dat licht zou ook de theorie van de zelfstandige aanknoping, waarin de forale conflictregels in feite kunnen worden beschouwd als conflictenrechtelijke voorrangsregels, kunnen worden verklaard. Aanhangers van beide theorieën achten overigens, ook buiten de toelaatbaarheid van correcticmiddelen, uitzonderingen op de door hen aangehangen theorieën toegestaan.

Voor sommige gevallen is de voorvraag-problematiek geregeld in het geschreven conflictenrecht (Verdrag ${ }^{446}$ of IPR-wet). De regeling kan zijn gegeven in de verwijzingsregels die de hoofdvraag regelen of in de verwijzingsregels die het onderwerp van de voorvraag regelen. Een voorbeeld van het eerste geval is te vinden in art. 1 laatste volzin van de Wet conflictenrecht namen luidende: "Uitsluitend voor de vaststelling van de geslachtsnamen en de voornaam worden de omstandigheden waarvan deze afhangen beoordeeld naar dat recht" (afhankelijke aanknoping van de voorvraag). Een voorbeeld van het tweede geval geeft art. 7 van de Wet conflictenrecht huweiijk, luidende: "De artikelen 5 en 6 zijn van toepassing, ongeacht of over de erkenning van de rechtsgeldigheid van een huwelijk als hoofdvraag, dan wel als voorvraag in verband met een andere vraag wordt beslist" (zelfstandige aanknoping van de voorvraag). Waar een geschreven regeling ontbreekt, dient te worden teruggevallen op het ongeschreven recht. In rechtspraak en literatuur is een voorkeur te bespeuren voor de zelfstandige beoordeling van de voorvraag ${ }^{447}$, zij het dat hierop uitzonderingen dan wel correcties mogelijk worden geacht. Voor deze opvatting wordt wel steun gezocht in het Weber-Staat-arrest ${ }^{448}$. In dit arrest, waar het ging om twee opvolgende eigendomsverkrijgingen, was de Hoge Raad van mening dat de vraag naar de eerste eigendomsverkrijging onafhankelijk kon

445. Voskuil 1963, 6.

446. Een overzicht van de regeling van de voorvraag in Verdragen worủt gegeven door Kokkini-Iatridou en Frohn 1988, 75-125.

447. Ook in enkele andere landen lijkt een tendens waarneembaar naar een zelfstandige beoordeling van de voorvraag. Zie o.m. voor Duitsland: Winkler von Mohrenfels 1987, 21; voor Frankrijk: Cour de cassation (1 re chambre civile) 22 april 1986, Clunet 1986, 1025 e.v., met noot Sinay-Cytermann.

448. HR 28 mei 1965, NJ 1966, 119. 
rijzen van de vraag naar de tweede eigendomsverkrijging. De Hoge Raad stelde hier een zelfstandige aanknoping voorop ${ }^{449}$. Wel achtte hij afhankelijke aanknoping mogelijk indien de samenhang tussen hoofdvraag en voorvraag daartoe zou dwingen. Volgens Strikwerda ${ }^{451}$ dient bij de vraag of van een zodanige samenhang sprake is vermoedelijk aan twee soorten van gevallen te worden gedacht: "Aan de ene kant de gevallen waarin de rechtsverhoudingen die het onderwerp van onderscheidenlijk de hoofdvraag en de voorvraag vormen zo nauw samenhangen dat een gescheiden conflictenrechtelijke behandeling tot materieel onaanvaardbare resultaten leidt, aan de andere kant de gevalIen waarin de hoofdvraag en de voorvraag zo nauw verbonden zijn met het rechtsstelsel dat de hoofdvraag beheerst, dat Nederland niet of nauwelijks belang heeft bij toepassing van zijn conflictregel op de voorvraag".

Kokkini-Iatridou en Frohn wijzen erop dat zowel de theorie van de afhankelijke aanknoping als de theoric van de zelfstandige aanknoping moeilijk verenigbaar zijn met de moderne materiële tendensen op het gebied van het internationaal privaatrecht ${ }^{451}$. In het licht van deze tendensen ontwikkelen zij een nieuwe theorie die zij wel aanduiden als de vergelijkende methode. In deze theorie, die volgens hen in de Nederlandse rechtspraak en doctrine feitelijk al wordt toegepast, gaat het om een afweging van het concrete materiële resultaal dat bij toepassing van het recht dat de hoofdvraag beheerst dan wel het recht dat toepasselijk zou zijn op grond van de forale conflictregel zou worden bereikt. Bij het materiële resultaat spelen de legitieme verwachtingen van partijen (en mogelijk van derden) een essentiële rol. Wanneer de verwachtingen van partijen (en van mogelijke derden) met betrekking tot het voorwerp van de voorvraag samenvallen en de relevante materiële regels tot tegenstrijdige resultaten leiden, zouden die regels dienen te worden toegepast die het meest aan de verwachtingen beantwoorden. Bij nietovereenstemmende verwachtingen zou cerst dienen te worden nagegaan of via een aanpassingsconstructie tot een oplossing kan worden gekomen. Is dit niet het geval dan zou er een belangenafweging moeten plaatsvinden, en zou toepasselijk moeten zijn het recht dat de prevalerende belangen het beste dient. Ook bij deze methode zou een correctie zijn toegestaan wanneer het leidt tot een schending van fundamentele beginselen van het forumland. Correctie is dan mogelijk via een beroep op de openbare orde of het respect voor verkregen rechten ${ }^{452}$.

449. In andere zin: Deelen 1971, 396, volgens wie de overwegingen van de Hoge Raad in het Weber-Staatarrest niet in de eerste plaats wezen op een zelfstandige beoordeling van de voorvraag maar op een beoordeling van geval tot geval.

450. Strikwerda 1995, 74. In vergelijkbare zin Lemaire 1968, 349-350: Vonken, Het internationale huwelijksrecht II 1992, 7.

451. Kokkini-Iatridou en Frohn 1987, 415.

452. De grens bij de toepassing van de rechtsvergelijkende methode dient volgens Kokkini-Iatridou en Frohn te worden gevonden in de bescherming van de belangen en de grondbeginselen van de forumstaat. Dat het respect voor in den vreemde verkregen rechten, zoveel zulks mogelijk is, als een rechtsbeginsel van de Nederlandse rechtsorde geldt, wordt onder meer betoogd door van Brakel 1953, 114-115. 
In de hierna volgende paragrafen 3 tot en met 6 wordt ervan uitgegaan dat de hoofdvraag naar de erfopvolging wordt beheerst door Marokkaans recht. Voor iedere voorvraag wordt nagegaan op welke wijze deze, met inachtneming van de huidige opvattingen over de voorvraagproblemaktiek, kan worden behandeld. Omdat bij de zelfstandige of afhankelijke aanknoping de voorvraag wordt beoordeeld aan de hand van het Nederlandse respectievelijk het Marokkaanse IPR (of het Marokkaanse interne recht), zullen hierbij de bij deze voorvragen behorende conflict- en erkenningsregels van zowel het Nederlandse als Marokkaanse recht worden uiteengezet. Op de mogelijkheid om het resultaat van een afhankelijke of zelfstandige aanknoping te corrigeren met een beroep op de openbare orde, wordt in deze paragrafen niet uitvoerig ingegaan. Dit onderwerp wordt behandeld in hoofdstuk 6 (p. 233 c.v.). De voorvragen die aan de orde worden gesteld zijn de vraag naar het bestaan van een geldig huwelijk met de erflater $(\$ 3)$, de vraag naar de geldigheid van een huwelijksontbinding $(\$ 4)$, de vraag naar de afstamming $(\$ 5)$ en de adoptic $(\$ 6)$.

\section{§ 2. Marokkaans IPR betreffende het personeel statuut}

De betekenis van "het personeel statuut" in het Marokkaanse IPR is ruim. Hieronder vallen niet alleen het persoonlijk statuut (handelingsbekwaamheid en dergelijke) en familiebetrekkingen (huwelijk, huwelijksontbinding, afstamming en dergelijke), maar ook vermogensrechtelijke betrekkingen binnen de familie, zoals het huwelijksvermogensrecht, erfrecht, en schenkingen ${ }^{453}$. Omdat men bij de voorvragen geconfronteerd kan worden met het Marokkaanse IPR is het m.i. op zijn plaats om enige aandacht te schenken aan algemene beginselen en uitgangspunten van dit Marokkaanse IPR waar het het personeel statuut betreft.

De geschreven conflictregels van het Marokkaanse IPR zijn, behoudens in enkele Verdragen ${ }^{454}$, te vinden in de "Dahir sur la condition civile des Français et des étrangers" van 12 augustus 1913 (DCC) ${ }^{455}$. Hoofdregel is dat het personeel statuut wordt beheerst door het nationale recht. Deze regel, waarvan wordt aangenomen dat zij is neergelegd in art. $3 \mathrm{DCC}$, vormt het uitgangspunt voor oplossingen in alle gevallen betreffende het personen- en familierecht en het erfrecht. Voor een aantal onderwerpen, te weten het huwelijk, de huwelijksontbinding, het huwelijksvermogensrecht en het erf-

453. Sarehane en Lahlou-Rachdi 1994, Fasc. 4, 12.

454. Marokko heeft IPR-Verdragen gesloten met Frankrijk, België, Libië, Algerije, Tunesië, Senegal, Italië, Roemenië en Polen. Stand van zaken 1994, Sarehane en Lahlou-Rachdi 1994, Fasc. 4, 21 . Uitvoerig over het IPR-Verdrag dat is gesloten tussen Frankrijk en Marokko (La Convention franco-marocaine du 10 août 1981 relative au statut des personnes et de la famille et à la coopération judiciaire): Decroux 1985, 49-101; Monéger 1984, 29-69, 267-288. Wat de Verdragen van de Haagse Conferentie betreft is Marokko slechts partij bij het Verdrag betreffende de burgerlijke rechtsvordering 1954. Door Marokko zijn voorts ondertekend: Het Verdrag inzake de toegang tot de rechter in internationale gevallen 1980, en het nieuwe Kinderbeschermingsverdrag 1996. 
recht, kent de DCC afzonderlijke regels waarin de nationaliteit als aanknopingsfactor geldt. De DCC dateert uit de tijd dat Marokko nog onder Frans protectoraat viel. Na de onafhankelijkheid van Marokko in 1956 hebben zich ontwikkelingen voorgedaan die hun invloed op het Marokkaanse IPR hebben doen gelden. Wat het personeel statuut betreft kunnen met name drie vernieuwingen worden geconstateerd: een toenemende invloed van de islamitische godsdienst; een groter zelfbewustzijn voor de eigen Marokkaanse identiteit en waarden; invoering van de verblijfplaats en woonplaats als (subsidiaire) aanknopingsfactoren. Deze laatste vernieuwing is met name gerealiseerd in enkele Verdragen waarbij Marokko partij is.

De hier genoemde ontwikkelingen, en met name de eerste twee, hebben voor het Marokkaanse internationale personen-, familie- en erfrecht met zich meegebracht dat de regel dat het personeel statuut wordt beheerst door het nationale recht weliswaar nog wel geldt, maar dat hierbij de volgende punten in aanmerking moeten worden genomen: 1. er wordt voorrang gegeven aan de islamitische godsdienst boven het nationale recht ${ }^{456}$. In concreto betekent dit dat wanneer iemand moslim is, hij in Marokko - van rechtswege - wordt onderworpen aan het Marokkaanse islamitische recht zoals dit is neergelegd in de Mudawwanah. De nationaliteit van betrokkene(n) is hierbij niet meer van belang ${ }^{457}$. De Marokkaanse Mudawwanah wordt zelfs toegepast op moslims die de nationaliteit van een andere "islamitische Staat" bezitten. De oorzaak voor de regel dat aan de islamitische godsdienst voorrang wordt gegeven boven het nationale recht is een dahir van $1959^{458}$. Volgens deze dahir worden geschillen die het personeel statuut en erfrecht van buitenlandse moslims betreffen onderworpen aan de shari' $a$ rechters. De regel is zodanig uitgelegd dat het Marokkaanse recht, de Mudawwanah, van toepassing is altijd wanneer een of meerdere partijen moslim zijn ${ }^{459}$. Aan deze opvatting is men ook na de wijziging van de rechterlijke organisatie ${ }^{460}$ blijven vasthouden;

456. Sarehane en Lahlou-Rachdi 1994, Fasc. 4, 8-9. Zie verder: Bourely 1962, 465; Deprez 1981, 142; Deprez 1988, 132; Moulay R'chid, Grandes lignes 1991, 41-42; Moulay R'chid 1992, 148, 161-163.

457. Sarehane en Lahlou-Rachdi 1994, Fasc 4, 8-9. Zie verder: Bourely 1962, 465-466; Bourely 1964, 7; Decroux 1981, 163; Moulay R'chid 1992, 161. De regel vormt een probleem in gevallen die worden beheerst door een Verdrag waarbij Marokko partij is en waarin wordt aangeknoopt aan de nationaliteit als de betrokkene een vreemde nationaliteit bezit en tevens moslim is. De regel uit het Verdrag zou hier moeten prevaleren. Niettemin heeft het Cour suprème in een arrest van 5 juli 1974 in een geval dat viel onder het toepassingsbereik van het Marokko-Algerije Verdrag van 1963 waarin de nationaliteit als aanknopingsfactor gold, het Marokkaanse islamitische recht toegepast om de geldigheid te beoordelen van een testament dat was opgemaakt door een buitenlandse moslim.

458. Dahir 24 april 1959, B.O. 1959, p. 734 e.v. (aanvulling op de dahir van 4 april 1959) relatif à l'organisation judiciaire et le fonctionnement des juridictions de droit commun.

459. Sarehane en Lahlou-Rachdi 1994, Fasc. 4, 9, 12. Zie verder: Deprez 1981, 142; Moulay R'chid 1992. $159-160$.

460. Waarbij het instituut van de religieuze rechters werd afgeschaft, dahir 15 juli en 28 september 1974 , B.O. 1974 , p. 1305 
2. er wordt voorrang gegeven aan de Marokkaanse nationaliteit boven een andere nationaliteit $^{461}$. In concreto betekent dit dat wanneer bij een (rechts)verhouding, bijvoorbeeld een huwelijk, een der betrokkenen de Marokkaanse nationaliteit bezit en tevens moslim is, de Marokkaanse Mudawwanah de gehele verhouding beheerst, ongeacht een eventueel bezit van een vreemde nationaliteit bij de andere partij. Ook betekent dit dat bij bipatride Marokkanen de Marokkaanse nationaliteit de doorslag geeft.

Gelet op nationaliteit en godsdienst komen deze twee punten op het volgende neer. Het personeel statuut van Marokkanen wordt beheerst door het Marokkaanse recht. Voor de Marokkaanse moslims is dit de op het islamitische recht gebaseerde Mudawwanah, voor de Marokkaanse joden het joodse recht en voor Marokkanen die noch moslim noch jood zijn eveneens de Mudawwanah, met uitzondering van de regels betreffende de polygamie, melkverwantschap en verstoting ${ }^{462}$. Het personeel statuut van buitenlanders wordt beheerst door de Marokkaanse Mudawwanah als zij moslim zijn, en door hun nationale recht als zij geen moslim zijn. Indien de Marokkaanse rechter niet bekend is met het vreemde nationale recht, past hij (in de praktijk) de lex fori toe, dat wil zeggen het Marokkaanse recht uit de Mudawwanah, met uitzondering van de regels betreffende de polygamie, melkverwantschap en verstoting ${ }^{463}$. Op het personeel statuut van staatlozen en vluchtelingen wordt eveneens de lex fori toegepast ${ }^{46-}$. Zijn $\mathrm{zij}$ moslim, dan is dit het recht uit de Mudawwanah; zijn zij geen moslim dan wordt de Marokkaanse Mudawwanah toegepast, met uitzondering van de regels betreffende de polygamie, melkverwantschap en verstoting ${ }^{465}$;

3. De toenemende waardering voor eigen (islamitische) waarden heeft het belang van de lex fori vergroot ${ }^{466}$. Dit heeft tot gevolg gehad dat op het personeel statuut van buitenlanders het nationale recht niet absoluut en onverkort meer van toepassing is. Het belang van de lex fori komt eveneens tot uiting in de toenemende tendens te kwalificeren lege fori ${ }^{467}$, de mogelijkheid tot het accepteren van renvoi, over welk onderwerp geen unanimiteit bestaat ${ }^{468}$, en in een ruimere toepassing van de exceptie van de openbare orde ${ }^{469}$. Sinds circa 1960 wordt uitge-

461. Sarehane en Lahlou-Rachdi 1994, Fasc. 4, 8-9. Zie verder: Bourely 1962, 467; Decroux 1981, $162-$ 163; Moulay R'chid, Grandes lignes 1991, 39-40; Moulay R'chid 1992, 148, 156-158, 159-160.

462. Art. 3 Code de la nationalité. Zie p. 19-20.

463. Sarehane en Lahlou-Rachdi 1994, Fasc. 4, 8.

464. Sarehane en Lahlou-Rachdi wijzen erop dat deze oplossing strijdig is met die uit het Vluchtelingenverdrag van Genève van 1951 en het Verdrag van New York betreffende staatlozen, waarin wordt aangeknoopt bij het recht van het domicilie. en bij gebreke hiervan bij het recht van de verblijfplaats, en bij gebreke hiervan bij de lex fori. Marokko is wel partij bij het Vluchtelingenverdrag, doch niet bij het Staatlozenverdrag, Sarehane en Lahlou-Rachdi 1994, Fasc. 4, 12. Uitvoerig hierover: Sarehane 1989.

465. Moulay R'chid 1992, 163; Sarehane en Lahlou-Rachdi 1994, Fasc. 4, 8, 12.

466. Aldus ook Messaoudi 1992, 954.

467. Sarehane en Lahlou-Rachdi 1994, Fasc. 4, 8 en de hier gegeven referenties, 10 en de hier genoemde rechispraak en literatuur.

468. Sarehane en Lahlou-Rachdi 1994, Fasc. 4, 8, 10.

469. Sarehane en Lahlou-Rachdi 1994, Fasc. 4, 7-8. 
gaan van een openbare orde die is gebaseerd op fundamentele normen en waarden van de Islam en van de Marokkaanse gemeenschap ${ }^{470}$.

\section{§ 3. Huwelijk}

\section{A. HUWELIJK ALS VOORVRAAG}

Op de vraag naar welk recht de geldigheid van een huwelijk als voorvraag moet worden beoordeeld, geven het Verdrag inzake de voltrekking en de erkenning van de geldigheid van huwelijken van $1978^{471}$ en de in verband hiermee ingevoerde Wet conflictenrecht huwelijk (WCH) ${ }^{472}$ een antwoord in art. 12 van het Verdrag respectievelijk art. 7 van de Wet. Het Verdrag en de WCH zijn van toepassing op huwelijken die zijn voltrokken na de inwerkingtreding van het Verdrag op 1 mei $1991^{473}$ respectievelijk na de inwerkingtreding van de Wet op 1 januari 1990 (art. 8 WCH). In art. 7 WCH wordt gekozen voor een zelfstandige aanknoping van de voorvraag: de bepalingen uit de Wet inzake de erkenning van buiten Nederland gesloten huwelijken zijn van toepassing, ongeacht of over de erkenning van de rechtsgeldigheid van een huwelijk als hoofdvraag, dan wel als voorvraag in verband met een andere vraag wordt beslist. Art. 12 van het Verdrag kent in het eerste lid dezelfde regeling. Het tweede lid van dit artikel laat echter een uitzondering op deze regel toe namelijk voor die gevallen waarin de hoofdvraag volgens de verwijzingsregels van de Staat waar deze moet worden beantwoord, door het recht van een niet-Verdragsluitende Staat wordt beheerst. Dat betekent, nu Marokko geen partij is bij het Huwelijksverdrag, dat wanneer op grond van de Nederlandse verwijzingsregel Marokkaans recht toepasselijk is op de hoofdvraag inzake de erfopvolging, op grond van art. 12 lid 2 van het Verdrag de van de in het eerste lid voorgeschreven zelfstandige aanknoping kan worden afgeweken. De bewoordingen van het tweede lid "niettemin behoeven deze regels niet te worden toegepast" geven de vrijheid te bepalen op welke wijze de voorvraag dan kan worden beoordeeld: een zelfstandige aanknoping blijft mogelijk maar ook een afhankelijke aanknoping is toegestaan of het zoeken naar een oplossing die leidt tot een materieel aanvaardbaar resultaat ${ }^{474}$. De Nederlandse wetgever heeft van deze vrijheid geen gebruik gemaakt en het tweede lid van art. 12

470. Sarehane en Lahlou-Rachdi 1994, Fasc. 4, 10.

471. 's-Gravenhage 14 maart 1978, Trb. 1987, 137, voor Nedertand in werking getreden op 1 mej 1991.

472. Wet van 7 september 1989 , houdende regeling van het conflictenrecht inzake het huwelijk, i.v.m. de bekrachtiging van het Verdrag van 's-Gravenhage van 14 maart 1978 inzake de voltrekking en de erkenning van de geldigheid van huwelijken, in werking getreden op 1 januari 1990, Stb. 392, 419.

473. Nederland heeft het voorbehoud van het tweede lid van art. 15 van het Verdrag gemaakt, d.w.z. dat de regels inzake de erkenning van de geldigheid van huwelijken van het Verdrag niet worden toegepast op huwelijken die zijn voltrokken voór het tijdstip waarop het Verdrag voor het Koninkrijk in werking is getreden (art. 2 Goedkeuringswet van 7 september 1989, Stb. 391).

474. Aldus ook Vonken. Het internationale huwelijksrecht II 1992, 7, die in het tweede lid van art. 12 een nogelijkheid ziet om als "correctif d'équité" te fungeren. Anders: van Rijn van Alkemade 1977, 483 (zie ook noot 476). Voor een overzicht van opvattingen: Kokkini-latridou en Frohn 1988, 89-90. 
niet overgenomen in de WCH. De reden hiervoor kan zijn dat Nederland de erkenningsregels uit het Verdrag tot de zijne heeft gemaakt, en er derhalve geen reden meer zou zijn voor een beroep op het tweede lid van art. 12 van het Verdrag ${ }^{475}$. De doctrine daarentegen gaat er van uit dat de rechter in een concreet geval de volledige vrijheid heeft om met een beroep op art. 12 lid 2 van het Verdrag art. 7 WCH te passeren ${ }^{476}$. Wanneer een wet afwijkt van een Verdrag, gaat de Verdragsregeling immers voor (art. 94 Gr.w.).

Ecn leemte die de voorvraag-regeling van zowel het Verdrag als de $\mathrm{WCH}$ vertoont is dat deze zich beperkt tot de buiten Nederland tot stand gekomen huwelijken. Ook in de parlementaire behandeling van de WCH en de goedkeuringswet bij het Huwelijksverdrag gaat men hier uitsluitend uit van buitenlandse huwelijken ${ }^{477}$. Over de vraag hoe de geldigheid van een in Nederland gesloten huwelijk moet worden beoordeeld indien deze vraag als voorvraag rijst, wordt gezwegen. Gezien de strekking van art. $7 \mathrm{WCH}$ en art. 12 van het Huwelijksverdrag, namelijk dat moet worden voorkomen dat een huwelijk in de ene context wel en in een andere niet als rechtsgeldig wordt beschouwd ${ }^{478}$, ligt het voor de hand dat de wetgever ook hier de voorvraag zelfstandig wil beoordelen. Indien deze zienswijze juist is, dan volgt hieruit duidelijk dat de wetgever de voorvraag ziet als een zelfstandig problcem, en niet zozeer als een probleem dat zijn oorsprong vindt in het vreemde recht dat de hoofdvraag beheerst. De kwestie is van belang indien het in Nederland gesloten huwelijk niet wordt erkend in de Staat waarvan het rechtsstelsel de hoofdvraag beheerst.

Voor huwelijken die vóór de inwerkingtreding van de WCH zijn gesloten moet worden teruggevallen op de heersende leer van vóór de inwerkingtreding. In de literatuur en rechtspraak bestond aangaande de voorvraag naar het huwelijk in erfrechtkwesties een voorkeur voor een zelfstandige aanknoping ${ }^{479}$.

475. De wetgever lijkt er van uit te zijn gegaan dat het tweede lid van art. 12 is opgenomen omdat er mogelijk Verdragstaten zijn die in overeenstemming met de in hun Staat geldende algemene beginselen van internationaal privaatrecht rekening wensen te houden met het recht van niet-Verdragsstaten, TwK 1987-1988, 20504 (R 1348), 3, 32. Aldus ook Malmström, Explanatory Report 1977, par. 25; Böhmer and Dyer 1976, 125-126, 136-137.

476. Kokkini-Iatridou en Frohn 1987, 375 (net verwijzing naar het Explanatory Report); Kokkini-Iatridou en Frohn 1988, 89; Verheul 1991, 123; Vonken, Het internationale huwelijksrecht Il 1992, 7. Voorzichtiger: van Rijn van Alkemade die in 1977, 483 nog aangaf dat het op zijn minst onduidelijk is hoe het tweede lid van art. 12 moet worden toegepast, en in 1989, 224 aangaf dat hij hoopte dat het gebruik van art. 12 lid 2 zou meevallen.

477. TwK 1987-1988, 20507,3, p. 9-10 resp TwK 1987-1988, 20504 (R 1348), 3, p. 29-33.

478. TwK 1987-1988, 20 507, 3, p. 9-10 en TwK 1987-1988, 20504 (R 1348), 3, p. 29-31.

479. Cohen-Henriquez, IPR-trends 1980, 51-52; Joppe, Vademecum 1980, 52-54, 21; Kokkini-latridou en Frohn 1987, 372; van der Ploeg 1961, $52-53$ (die de zelfstandige aanknoping overigens als correctie op de afhankelijke aanknoping ziet). 


\section{B. NEDERLANDS INTERNATIONAAL HUWELIJKSRECHT}

Een regeling voor het recht dat de huwelijksvoltrekking in Nederland beheerst en de erkenning van buiten Nederland gesloten huwelijken is neergelegd in de WCH en het Huwelijksverdrag van 1978.

\section{Huwelijksvoltrekking in Nederland}

Volgens art. 2 WCH (vergelijk art. 3 van het Verdrag) wordt de huwelijksbevoegdheid bcheerst:

a. voor ieder der aanstaande echtgenoten, door Nederlands recht, indien een van hen de Nederlandse nationaliteit bezit of in Nederland zijn gewone verblijfplaats heeft, of

b. voor ieder der aanstaande echtgenoten, door het recht waarvan hij de nationaliteit bezit. Bezit een aanstaande echtgenoot meer dan één nationaliteit, dan geldt het recht van de Staat waarvan de betrokkene de nationaliteit bezit, waarmee hij alle omstandigheden in aanmerking genomen, de sterkste band heeft.

Een huwelijk kan in Nederland niet worden voltrokken indien voltrekking onverenigbaar met de openbare orde zou zijn (art. 3 lid 1 WCH en art. 5 van het Verdrag). Hiervan is onder meer sprake wanneer de vrije toestemming van een der aanstaande echtgenoten ontbreekt ${ }^{480}$, en ingeval van bigamie ${ }^{481}$. Wanneer het nationale recht van een der aanstaande echtgenoten een huwelijksbeletsel kent dat in strijd is met de Nederlandse openbare orde, kan op die grond de huwelijksvoltrekking niet worden geweigerd (art. 3 lid $2 \mathrm{WCH})$.

Wat de vorm betreft kan het huwelijk slechts rechtsgeldig worden voltrokken door de ambtenaar van de burgerlijke stand, met inachtneming van de vormvoorschriften van het Nederlandse recht (art. $4 \mathrm{WCH}$, vergelijk art. 2 van het Verdrag). Een uitzondering geldt voor huwelijken die in Nederland op een buitenlands consulaat of Ambassade worden gesloten. Deze huwelijken komen voor erkenning in aanmerking indien de ambtenaar van het consulaat of de Ambassade volgens het recht van zijn Staat daartoe bevoegd is, de aanstaande echtgenoten de nationaliteit van de zendstaat bezitten, geen

480. De vrije toestemming van beide aanstaande echtgenoten werd voor een wettig huwelijk reeds vereist in art. 1 van het Verdrag inzake de huwelijkstoestemning, de minimum-leeftijd waarop een huwelijk mag worden aangegaan en de registratie van huwelijken, New York 10 december 1962, Trb. 1964. 165 (Nederlandse vertaling), voor Nederland in werking getreden op 30 september 1965.

481. In art. 3 lid 1 van de $\mathrm{WCH}$ is een niet limitatieve opsomming gegeven van gevalten waarin sprake is van strijd met de openbare orde. 
der aanstaande echtgenoten uitsluitend de Nederlandse nationaliteit bezit ${ }^{482}$, en de ambtenaar het recht van de Staat die hem heeft aangesteld in acht heeft genomen ${ }^{483}$.

\section{Erkenning van buiten Nederland gesloten huwelijken}

Een buiten Nederland gesloten huwelijk wordt in Nederland erkend indien het ingevolge het recht van de Staat waar het is voltrokken rechtsgeldig is of rechtsgeldig is geworden (art. 5 lid $1 \mathrm{WCH}$, vergelijk art. 9 van het Verdrag). Een huwelijk wordt vermoed rechtsgeldig te zijn, indien een huwelijksverklaring is afgegeven door een bevoegde autoriteit (art. 5 lid 4 WCH, art. 10 van het Verdrag). Een buiten Nederland gesloten huwelijk wordt niet crkend, indien erkenning onverenigbaar zou zijn met de openbare orde (art. $6 \mathrm{WCH}$, art. 14 van het Verdrag) ${ }^{4 k 4}$.

Uit de algemene bepalingen van het Verdrag (Hoofdstuk III) kunnen nog worden vermeld:

Art. 20 "Wanneer een Staat terzake van het huwelijk twee of meer rechtsstelsels kent die worden toegepast op verschillende categorieën personen, wordt iedere verwijzing naar het recht van die Staat opgevat als cen verwijzing naar het rechtsstelsel, door de in dic Staat van kracht zijnde regels aangewezen".

Art. 21 "(1) Het Verdrag laat onverlet de toepassing van enig Verdrag dat bepalingen bevat over de voltrekking of de erkenning van de geldigheid van huwelijken, waarbij cen Verdragsluitende Staat partij is op het tijdstip dat dit Verdrag voor die Staat in werking treedt". ${ }^{485}$

482. Uit een uitspraak van de Hoge Raad van 13 december 1996, RvdW 1997, 2 volgt dat een consulaire huwelijkssluiting watrbij een der echtgenoten de Nederlandse nationaliteit bezat ten tijde van de huwelijkssluiting en daarnaast de nationaliteit van de zendstaat in Nederland voor erkenning in aanmerking kan komen. Wetgeving over de erkenning van consulaire huwelijken waarbij een Nederiander is betrokken, is in voorbereiding.

483. TwK 1987-1988, 20 507, 3, p. 7.

484. Het Verdrag bevat voorts een bepaling waarin gronden worden genoemd waarop de erkenning van de geldigheid van een buiten een Verdragstaat gesloten huwelijk mag worden geweigerd (art. 11). Dit arikel luidt, voor zover van belang: "(1) Een Verdragsluitende Staat kan slechts weigeren de geldigheid van een huwelijk te erkennen indien, volgens het recht van die Staat, een der echtgenoten op het (ijdstip van dat huwelijk:

1. reeds gehuwd was; of

(...)

5. niet vrijelijk zijn toestemming tot het huwelijk had gegeven.

(2) Niettemin kan in het onder 1 van het vorige lid bedoelde geval de erkenning niet worden geweigerd indien het huwelijk later geldig is geworden door de ontbinding of de nietigverklaring van het eerdere huwelijk". Voor de samenhang tussen de weigeringsgronden van de WCH en het Verdrag kan worden gewezen op art. 13, dat luidt: "Dit Verdrag verzet er zich niet tegen dat in een Verdragsluitende Staat rechtsregels worden toegepast welke voor de erkenning van in het buitenland gesloten huwelijken gunstiger zijn".

485. Voor Nederland $k a n$ in dit verband worden gewezen op het Verdrag van 1962, zie noot 480, en de Overeenkomst strekkende tot het vergemakkelijken van huwelijkssluiting in het buitenland, Parijs 10 september 1964, Trb. 1968, 89, voor Nederland in werking getreden op 29 mei 1968. 
Voor huwelijken die zijn voltrokken vóór de inwerkingtreding van de WCH op 1 januari 1990, blijven de ongeschreven regels van Nederlands IPR die tot dit tijdstip golden, van toepassing. Volgens de ongeschreven regels die tot 1990 golden werd de huwelijksbevoegdheid van elk der aanstaande echtgenoten beheerst door diens nationale recht. De vorm werd beheerst door het recht van de Staat waar het huwelijk werd gesloten. Voor huwelijken dic op cen buitenlands consulaat of Ambassade in Nederland werden gesloten gold dat zij konden worden erkend onder de hierboven onder I genoemde voorwaarden. De erkenning van de geldigheid van een huwelijk kon worden geweigerd bij strijd met de Nederlandse openbare orde ${ }^{486}$.

\section{MAROKKAANS INTERNATIONAAL HUWELIJKSRECHT}

\section{Huwelijksvoltrekking in Marokko}

Voor huwelijken die in Marokko worden gesloten gelden de volgende verwijzingsregels:

De vraag aan de hand van welk recht de huwelijksbevoegdheid van de aanstaande echtgenoten dient te worden beoordeeld, wordt beantwoord in art. 8 DCC: "Le droit de contracter mariage est réglé par la loi nationale de chacun des futurs époux." De verwijzingsregel voor de vorm van het huwelijk wordt gegeven in art. 11 DCC: "Les Français et les étrangers ne peuvent se marier que suivant les formes admises par leur loi nationale ou suivant celles qui seront déterminées ultérieurement pour l'ćtat civil dans le Protectorat français." Voor gemengde huwelijken waarbij een der echtgenoten de Marokkaanse nationaliteit bezit geldt een dahir van $1960^{487}$. Deze dahir bevat vier artikelen waarvan de eerste drie luiden:

art. 1: "Les mariages entre Marocains et étrangères d'une part. et Marocaines et étrangers d'autre part, dans la mesurc où ils ne sont pas interdits par le statut personnel du conjoint marocain, peuvent être célébrés, à la demande des conjoints, par l'officier de l'état civil conformément aux dispositions du dahir du 24 chaoual 1333 (4 septembre 1915) (...)."

art. 2: "Toutefois, la célébration du mariage en la forme de l'état civil est subordonnée à la consécration préalable de l'union dans les conditions de fond et de forme prévues par le statut personnel du conjoint marocain."

486. Tot 1 juni 1979 gold overigens nog het Haags Huwelijksverdrag van 12 juni 1902, Stb. 1904, ur, 121, opzegging: Trb. 1977, 57. Het Verdrag was van toepassing op huwelijken gesloten op het grondgebied van een Verdragsluitende Stat tussen personen van wie er ten minste éen tot een Verdragsluitende Stat behoorde. De huwelijksbevoegdheid werd beoordeeld naar het nationale recht (art. 1). De vorm werd beoordeeld naar de lex loci celebrationis (art. 5), zij het dat een huwelijk dat wat de vorm betreft nietig was volgens de lex loci celebrationis, in andere landen als geldig kon worden erkend indien voldaan was aan de vormvereisten van beider nationale wet (art. 7). Huwelijken die waren gesloten ten overstaan van een diplomatieke of consulaire ambtenaar overeenkomstig diens wetgeving werden als geldig erkend, indien geen der partijen behoorde tot de Staat waar het huwelijk gesloten werd, en indien deze Staat zich er niet tegen verzette (art. 6).

487. Dahir relatif à la célébration, suivant les formes déterminées pour l'état civil, des mariages entre Marocains et étrangères ou Marocaines et étrangers, 4 maart 1960, B.O. 25 mars 1960, p. 689. 
art. 3: "Les mariages visés à l'article premier et célébrés par l'officier de l'état civil antéricurement à la date de publication du présent dahir seront considérés comme valables si les conditions de fond et de forme prévues par le statut personnel du conjoint marocain ont été respectées et si ces mariages ne sont pas interdits par ce statut."

De toepassing van vreemd recht kan achterwege blijven bij strijd met de Marokkaanse openbare orde. Van deze mogelijkheid wordt niet snel gebruik gemaakt ${ }^{488}$.

Voor twee Marokkanen ${ }^{489}$ die in Marokko in het huwelijk treden geldt, als de verhouding een internationaal karakter heeft, op grond van art. $8 \mathrm{DCC}$ dat voldaan moet zijn aan de materiële huwelijksvereisten van het Marokkaanse recht, zijnde het nationale recht van de aanstaande echtgenoten, alsmede op grond van art. 11 DCC dat voldaan moet zijn aan de vormvoorschriften van het Marokkaanse nationale recht.

Voor twee (niet-islamitische) buitenlanders die in Marokko in het huwelijk treden geldt op grond van art. 8 DCC dat voldaan moet zijn aan de materiële huwelijksvereisten van het gemeenschappelijk nationaal recht, en bij gebreke van een gemeenschappelijk nationaal recht, dat voor ieder der aanstaande echtgenoten is voldaan aan de materiële huwelijksvereisten van het recht van de Staat waarvan hij de nationaliteit bezit ${ }^{490}$. Bezit een der echtgenoten meer dan één nationaliteit, dan stelt de aangezochte rechter op grond van art. 4 DCC het toepasselijke personeel statuut vast ${ }^{491}$. Wat de vorm betreft geldt op grond van art. 11 DCC dat voldaan moet zijn aan de vormvoorschriften ofwel van het (interne) nationale recht van de aanstaande echtgenoten ofwel van het plaatselijke recht voor de burgerlijke stand. Hoewel deze regel de indruk wekt dat aan de betrokkenen de keuze wordt gelaten voor de toepasselijkheid van een der beide rechtsstelsels, lijkt deze bepaling aldus te worden uitgelegd dat primair geldt dat moet zijn voldaan aan de vormvoorschriften van het nationale recht van de aanstaande echtgenoten, en subsidiair dat een burgerlijke stand-huwelijk kan worden gesloten mits dit door het nationale recht van de aanstaande echtgenoten wordt toegelaten ${ }^{492}$. Wanneer volgens dit recht een burgerlijke stand-huwelijk niet is toegestaan, kan ook worden gekozen voor een andere vorm die is toegestaan volgens het recht van het land waar het huwelijk wordt gesloten ${ }^{493}$.

488. Deprez, Un aspect inattendu 1975, 48; Moulay R'chid, Grandes lignes 1991, 151.

489. Waar in deze verhandeling over Marokkanen wordt gesproken wordt steeds uitsluitend gedoeld op Marokkanse moslims.

490. Decroux 1963, 165-166; Deprez, Un aspect inattendu 1975, 48-49; Sarehane en Lahlou-Rachdi, 1994. Fasc. $4,13$.

491. Decroux 1963, 181; Moulay R'chid 1992, 151.

492. Deprez, Un aspect inattendu 1975, 30, 45-46; Sarehane en Lahlou-Rachdi 1994, Fasc. $4,14$.

493. Sarehane en Lahlou-Rachdi, 1994, Fasc. 4, 14. 
Voor gemengde huwelijken waarbij een der aanstaande echtgenoten de Marokkaanse nationaliteit bezit geldt zowel voor de materiële huwelijksvereisten als voor de vormvereisten de hierboven besproken dahir van 1960. Volgens art. 1 van deze wet is op verzoek van de echtgenoten een burgerlijke stand-huwelijk mogelijk indien dit niet wordt verboden door het personeel statuut van de Marokkaanse echtgenoot. Bovendien geldt op grond van art. 2 dat een burgerlijke stand-huwelijk moet zijn voorafgegaan door een huwelijk in de vorm van het Marokkaanse recht waarbij de Marokkaanse materiële huwelijksvoorschriften zijn nageleefd. Aan het huwelijk naar Marokkaans recht wordt voorrang gegeven boven het huwelijk voor de ambtenaar van de burgerlijke stand. Het burgerlijke stand-huwelijk is in de Marokkaanse IPR-wetgeving uitsluitend opgenomen om het huwelijk ook geldig te doen zijn in de Staat waarvan de niet-Marokkaanse echtgenoot de nationaliteit bezit ${ }^{494}$. Voor de niet-Marokkaanse echtgenoot zou op grond van art. $8 \mathrm{DCC}$ voldaan moeten zijn aan de materiële huwelijksvereisten van zijn nationale recht. Respect voor dit vreemde recht is overigens niet gegarandeerd ${ }^{495}$. Voor gemengde huwelijken dic zijn gesloten ten overstaan van de ambtenaar van de burgerlijke stand vóór de publicatic van de wet van 1960, wordt in art. 3 van deze wet bepaald dat deze als geldig worden erkend indien aan de vormvoorschriften en materiële voorwaarden van het Marokkaanse recht is voldaan en het huwelijk niet was verboden door het personcel statuut van de Marokkaanse echtgenoot.

\section{Erkenning van buiten Marokko gesloten huwelijken}

Voor de erkenning van huwelijken die buiten Marokko zijn gesloten gelden de volgende regels:

Huwelijken tussen twee Marokkanen zijn onderworpen aan het personeel statuut van de echtgenoten. Dat betekent dat zowel voldaan moet zijn aan de Marokkaanse materiële huwelijksvereisten als aan de Marokkaanse vormvereisten ${ }^{496}$. Dit komt er feitelijk op neer dat een huwelijk tussen twee Marokkanen in een land dat niet de Marokkaanse (adoulaire) vorm van huwelijkssluiting kent, alleen kan worden gesloten op een Marokkaans consulaat of Marokkaanse Ambassade. Op grond van een decreet van 29 januari $1970^{497}$ in samenhang met de dahir van 1969 betreffende de bevoegdheden van diplomatieke en consulaire vertegenwoordigers van Marokko in het buitenland, kunnen deze vertegenwoordigers door een besluit van de Minister bekleed zijn met de functie van ' $a d l$, en kunnen zij rechtsgeldige huwelijksakten opmaken in die gevallen waarin in Marokko een dergelijke akte in adoulaire vorm geldig opgemaakt kan worden ${ }^{498}$. Huwelijken tussen twee Marokkanen die buiten Marokko uitsluitend voor de ambtenaar

494. Deprez, Un aspect inattendu 1975,66 .

495. Moulay R'chid 1992, 157; Sarehane en Lahlou-Rachdi 1994, Fasc. 4, 13. Zo wordt een tweede huwelijk van een Marokkaanse man die reeds is gehuwd met een buitenlandse vrouw wier nationale recht polygamie verbiedt, als geldig beschouwd.

496. Sarehane en Lahou-Rachdi 1994, Fasc. 4, 14.

497. Décret 29 januari 1970, B.O. 4 februari 1970, p. 258.

498. Deprez, Un aspect inattendu $1975,32,36-37$. 
van de burgerlijke stand zijn gesloten worden in Marokko niet erkend ${ }^{499}$. In dergelijke gevallen kan via cen eenvoudige consulaire procedure een huwelijk naar Marokkaans recht worden vastgesteld, zodat de geldigheid ervan ook in Marokko word geaccepteerd. Volstaan kan worden met het overleggen van de huwelijksakte van de burgerlijke stand, een uittreksel uit de Gemeentelijke Basisadministratie waaruit blijkt dat echtgenoten ongehuwd waren vór de sluiting van het burgerlijke stand-huwelijk, het paspoort van beide echtgenoten, en twee pasfoto's. Op basis hiervan wordt een consulaire adoulaire huwelijksakte ("acte de mariage") opgemaakt, gehomologeerd door de adoulaire rechter van de Marokkaanse Ambassade, waarin wordt vastgesteld dat de echtelieden een burgerlijk huwelijk hebben gesloten en verder voldoen aan de vereisten die het Marokkaanse recht aan de huwelijkssluiting stelt. Het huwelijk wordt in beginsel vastgesteld vanaf de datum van de burgerlijke huwelijkssluiting ${ }^{500}$. Als er geen burgerlijk huwelijk is gesloten of er kan geen bewijs van een huwelijk worden overgelegd, dan kan het bestaan van een huwelijk worden vastgesteld met behulp van de zogenaamde lafifgetuigenis ${ }^{501}$. Twaalf moslim getuigen ${ }^{502}$ verklaren ten overstaan van twee 'udûl op het consulaat dat hen bekend is dat de betrokken man en vrouw elkaars echtgenoten zijn sedert een bepaalde datum, en dat zij nict zijn gescheiden. Er wordt een akte opgemaakt welke wordt ondertekend door de desbetreffende laftf-getuigen, twee 'udîl en de adoulaire rechter van de Marokkaanse Ambassade. Deze akte staat in Nederland wel bekend onder de naam "reconnaissance matrimoniale". De procedure kan bijvoorbeeld worden gevolgd om buitenechtelijke relaties te wettigen (zelfs nog na het overlijden van een van de partners), als er een burgerlijke stand-huwelijk heeft plaatsgevonden maar cen van de echtgenoten is inmiddels overleden ${ }^{503}$, of als het huwelijk moet worden vastgesteld vóór het burgerlijke stand-huwelijk. Naast de consulaire procedure bestaat uiteraard altijd de mogelijkheid om een huwelijk te sluiten of het bestaan van een huwelijk te laten vaststellen in Marokko.

Voor huwelijken tussen twee (niet-islamitische) buitenlanders gelden geen bijzondere erkenningsregels. Deze huwelijken zullen in ieder geval kunnen worden erkend indien is voldaan aan de verwijzingsregels van de artikelen 8 en 11 DCC en er geen sprake is van strijd met de Marokkaanse openbare orde.

Voor gemengde huwelijken waarbij een der aanstaande echtgenoten de Marokkaanse nationaliteit bezit, bestaat evenmin een aparte conflictregel. Hoewel de dahir van 1960 geschreven is voor huwelijkssluitingen binnen Marokko, wordt aangenomen dat deze wet ook moet worden aangewend ter vaststelling van de geldigheid van buiten Marokko

499. Decroux 1963, 371; Sarehane en Lahlou-Rachdi 1994, Fasc. 4, 14.

500. Met dank aan M. Hajji, juridisch attaché en (adoulaire) rechter bij de Marokkaanse Ambassade te 'sGravenhage, voor de door hem verstrekte informatie.

501. Hierover: Borrmans 1977, 246; Decroux 1963, 195; Decroux 1981, 162. Zie ook noot 138

502. Volgens M. Hajji zou ook kunnen worden volstaan met zes getuigen als deze familieleden van de betrokkene(n) zijn.

503. Aldus M. Hajji, mondelinge informatie. 
tot stand gekomen gemengde huwelijken ${ }^{504}$. Dat betekent dat een gemengd huwelijk waarbij een Marokkaanse echtgenoot betrokken is en dat is gesloten in een land dat niet de Marokkaanse (adoulaire) vorm van huwelijkssluiting kent, alleen als geldig kan worden beschouwd als de geldigheid van dit huwelijk tevens is vastgesteld op het Marokkaanse consulaat of de Marokkaanse Ambassade en de Marokkaanse materiële huwelijksvereisten en vormvoorschriften in acht zijn genomen, of in Marokko een huwelijk wordt gesloten of vastgesteld. Een huwelijk tussen een (Marokkaanse) islamitische vrouw en een (buitenlandse) niet-islamitische man wordt in Marokko niet erkend reeds omdat niet aan de materiële huwelijksvereisten van het Marokkaanse recht is voldaan ${ }^{505}$. Gemengde huwelijken die uitsluitend ten overstaan van de ambtenaar van de burgerlijke stand zijn gesloten, worden niet erkend. De geldigheid ervan kan wel op het consulaat worden vastgesteld volgens de hierboven beschreven procedure. Deze mogelijkheid bestaat niet voor burgerlijke huwelijken tussen een islamitische vrouw en een niet-islamitische man. Ook buitenechtelijke relaties kunnen volgens de hierboven weergegeven procedure met behulp van de lafif-getuigenis als een naar Marokkaans recht geldig huwelijk worden vastgesteld.

\section{VOORBEELDEN}

\section{Voorbeeld 1}

Een Marokkaanse man, sedert 1991 in Nederland woonachtig, en een Nederlandse vrouw zijn in 1992 in Nederland gehuwd ten overstaan van de ambtenaar van de burgerlijke stand. Een consulaire huwelijkssluiting of huwelijksbevestiging heeft niet plaatsgevonden. De echtgenoten hebben onafgebroken verblijf in Nederland gehad. Volgens het Nederlandse conflictenrecht is het huwelijk rechtsgeldig gesloten. In Marokko wordt het huwelijk niet erkend. Zou de man als eerste overlijden en zou zijn erfopvolging door Marokkaans recht worden beheerst, dan rijst de vraag hoe de geldigheid van het huwelijk moet worden beoordeeld, aannemende dat de geldigheid van het huwelijk naar Marokkaans recht ook na het overlijden van de man niet is vastgesteld. Hoewel art. 7 WCH letterlijk genomen niet van toepassing is op gevallen waarin de huwelijkssluiting in Nederland heeft plaatsgevonden, kan op grond van de hierachter liggende gedachte de bepaling analoog worden toegepast. Dat zou betekenen dat de vraag naar de geldigheid van het huwelijk zelfstandig zou moeten worden beoordeeld. Het huwelijk is dan geldig, en de vrouw is erfgenaam van de man ${ }^{500}$. Art. $7 \mathrm{WCH}$ is echter niet verenigbaar met het tweede lid van art. 12 van het Huwelijksverdrag, dat in dit geval een afwijking van de zelfstandige aanknoping mogelijk maakt, aannemende dat ook hier een

504. Decroux 1968, 896; Decroux 1981, 162; Sarehane en Lahlou-Rachdi 1994, Fasc. 4, 14.

505. Aldus ook Moulay R'chid $1988,73$.

506. Indien de vrouw geen moslim is zou naar Marokkaans recht het verschil in godsdienst nog aan erfopvolging in de weg staan. M.i. dient een verschil in godsdienst als erfbeletsel echter wegens strijd met de openbare orde buiten toepassing te worden gelaten (hierover p. 221). Is de vrouw moslim, dan kan zij hiervan (kosteloos) ten overstaan van twee consulaire 'ud̂̉l een verklaring afleggen. Zij wordt als moslim aangemerkt vanaf het moment dat zij verklaar moslim te zijn. 
analoge toepassing mogelijk is. Voor een afwijking van de regel van een zelfstandige aanknoping kan reden bestaan indien de hoofdvraag en voorvraag zo nauw samenhangen dat een gescheiden conflictenrechtelijke behandeling onaanvaardbaar is, of wanneer de hoofdvraag en voorvraag zo nauw verbonden zijn met het rechtsstelsel dat de hoofdvraag beheerst dat de Nederlandse rechtsorde niet of nauwelijks belang heeft bij toepassing van zijn IPR op de voorvraag (criteria ontleend aan het Weber-Staat-arrest), of wanneer een zelfstandige aanknoping leidt tot een materieel onaanvaardbaar resultaat (rechtsvergelijkende methode), in welk geval tevens een correctie op de gekozen aanknoping denkbaar zou zijn. De eerste twee omstandigheden, die een afwijking van een zelfstandige aanknoping kunnen rechtvaardigen, lijken zich hier niet voor te doen. $\mathrm{Bij}$ de vraag of er sprake is van een materieel onaanvaardbaar resultaat zouden de legitieme verwachtingen een grote rol spelen. De verwachtingen zouden dan met name betrekking hebben op het al dan niet bestaan van een geldig huwelijk. Zelfs indien de echtgenoten of een van hen wisten dat het huwelijk naar Marokkaans recht niet rechtsgeldig was, behoeft hieraan m.i. geen doorslaggevende betekenis te worden toegekend, nu ook voor de echtgenoten buiten twijfel was dat het huwelijk in Nederland rechtsgeldig was. Er is dan onvoldoende reden om af te wijken van een zelfstandige aanknoping. Het huwelijk kan ook bij toepassing van Marokkaans erfrecht als rechtsgeldig worden beschouwd, en de vrouw is erfgenaam ${ }^{507}$.

\section{Voorbeeld 2}

Een in Nederland woonachtige Marokkaanse man, gehuwd met een Nederlandse vrouw, sluit in Marokko een tweede huwelijk met een aldaar woonachtige Marokkaanse vrouw. Tussen de Nederlandse vrouw en de Marokkaanse man heeft zowel een huwelijk plaatsgevonden op het Marokkaanse consulaat als ten overstaan van de Nederlandse ambtenaar van de burgerlijke stand. Zowel naar Nederlands als naar Marokkaans recht is hier sprake van een geldig huwelijk. Het tweede huwelijk met de Marokkaanse vrouw is naar Marokkaans recht eveneens geldig. In Nederland zal dit huwelijk waarschijnlijk niet worden erkend wegens strijd met de openbare orde, nu de eerste echtgenote de Nederlandse nationaliteit bezit en er voldoende sprake is van een betrokkenheid met de Nederlandse rechtssfeer ${ }^{508}$. De man heeft bij testament een rechtskeuze uitgebracht voor de toepasselijkheid van Marokkaans erfrecht. Is de tweede echtgenote erfgenaam wanneer de man in Nederland komt te overlijden? Op grond van art. 7 WCH zou de vraag naar de geldigheid van het (tweede) huwelijk, die rijst als voorvraag bij de erfopvolging, zelfstandig moeten worden aangeknoopt, dat wil zeggen moeten worden beoordeeld aan de hand van het Nederlandse conflictenrecht. Wanneer erkenning van dit huwelijk wordt geweigerd wegens strijd met de openbare orde, wordt de Marokkaanse vrouw niet als echtgenote aangemerkt, en is zij ook bij toepassing van het Marokkaanse erfrecht geen

507. Mits een verschil in godsdienst niet aan erfopvolging in de weg staat. Zie noot 506.

508. Aldus ook Vonken, Reflexwerking 1993, 169-170. Vgl. Cohen Henriquez, Polygamie 1990, 171; de Groot en Rutten 1996, 22-23; Mattheussens-Kroon 1993, 12; Verheul 1991, 124; Vonken, Het internationale huwelijksrecht II 1992, 5. 
erfgenaam. Ook hier laat art. 12 lid 2 van het Huwelijksverdrag de mogelijkheid open om van een zelfstandige aanknoping af te wijken. Voor een afwijking van de regel van een zelfstandige aanknoping kan reden bestaan indien de hoofdvraag en voorvraag zo nauw samenhangen dat een gescheiden conflictenrechtelijke behandeling onaanvaardbaar is, of wanneer de hoofdvraag en voorvraag zo nauw verbonden zijn met het rechtsstelsel dat de hoofdvraag beheerst dat de Nederlandse rechtsorde niet of nauwelijks belang heeft bij toepassing van zijn IPR op de voorvraag (criteria ontleend aan het WeberStaat-arrest), of wanneer een zelfstandige aanknoping leidt tot een materieel onaanvaardbaar resultaat (rechtsvergelijkende methode), in welk geval tevens een correctie op de gekozen aanknoping denkbaar zou zijn. Een belangrijk verschil tussen dit voorbeeld en het ecrste voorbeeld is dat in het eerste voorbeeld het huwelijk in Nederland is gesloten en in het onderhavige voorbeeld het huwelijk in Marokko is gesloten. De verbondenheid van het huwelijk met Marokko (de voorvraag) is derhalve groter dan in het eerste voorbeeld. Deze verbondenheid is echter niet zo groot dat de Nederlandse rechtsorde geen belang meer heeft bij toepassing van het eigen conflictenrecht op de voorvraag, te meer niet omdat juist vanwege deze betrokkenheid het huwelijk niet zou zijn erkend. De eerste twee uitzonderingen zijn hier m.i. dan ook niet van toepassing. Bij de vraag of er sprake is van een materieel onaanvaardbaar resultaat zouden de legitieme verwachtingen een grote rol spelen. De erflater zal rekening moeten of kunnen hebben gehouden met het weigeren van erkenning van zijn tweede huwelijk in Nederland. De vraag is of hij ook had kunnen verwachten dat bij het uitbrengen van een geldige rechtskeuze voor de toepasselijkheid van Marokkaans erfrecht en daarmee wetende dat Marokkaans recht zijn erfopvolging zou gaan beheersen, zijn tweede vrouw ook in het kader van het erfrecht niet als echtgenote zou worden erkend. Het belang van de in Nederland woonachtige eerste echtgenote, die in dit geval de Nederlandse nationaliteit bezit, die bij een afhankelijke aanknoping van de voorvraag de helft van het vermogen verloren ziet gaan aan een echtgenote die in Nederland niet als echtgenote wordt erkend, kan het wenselijk maken de voorvraag naar het bestaan van een geldig huwelijk zelfstandig te beoordelen. De tweede echtgenote zou dan geen erfgenaam zijn ${ }^{509}$.

\section{Voorbeeld 3}

Ten overstaan van de Nederlandse ambtenaar van de burgerlijke stand is het huwelijk voltrokken tussen een Marokkaanse islamitische vrouw en een Nederlandse niet-islamitische man. Naar Nederlands recht is hier sprake van een geldig huwelijk. Naar Marokkaans recht is dit geen geldig huwelijk en de geldigheid ervan kan ook niet worden vastgesteld omdat het verschil in godsdienst een huwelijksbeletsel cplevert. Is de man erfgenaam als de vrouw in Nederland komt te overlijden en haar erfopvolging door Marokkaans recht wordt beheerst? Er is hier dunkt mij, evenals in het eerste voorbeeld, geen reden om af te wijken van het uitgangspunt dat de vraag naar de geldigheid van het huwelijk in het kader van de erfopvolging zelfstandig wordt beoordeeld. Dat bete-

509. Overigens zou de Nederlandse echtgenote, als zij geen moslim is, alleen erven indien het verschil in godsdienst als erfbeletsel buiten toepassing word gelaten. Zie ook noot 506. 
kent dat in Nederland de man als erfgenaam van de vrouw zou moeten worden aangemerkt.

\section{$\S 4$. Huwelijksontbinding}

\section{A. HUWELIJKSONTBINDING ALS VOORVRAAG}

Op de vraag naar de geldigheid van een huwelijksontbinding als voorvraag bij de hoofdvraag naar de erfopvolging, is noch in de conflictregels inzake de huwelijksontbinding noch in die van de erfopvolging een antwoord te vinden ${ }^{510}$. De literatuur op dit punt is schaars en lijkt te neigen naar een zelfstandige aanknoping van de voorvraag ${ }^{511}$.

\section{B. NEDERLANDS INTERNATIONAAL HUWELIJKSONTBINDINGSRECHT}

De Wet conflictenrecht echtscheiding (WCE) ${ }^{512}$ is van toepassing op huwelijksontbindingen die zijn tot stand gekomen na de inwerkingtreding van de wet (art. 4) op 10 april 1981.

\section{Huwelijksontbinding in Nederland}

Art. 1 geeft de verwijzingsregel voor echtscheidingsprocedures voor de Nederlandse rechter. De bepaling luidt:

"(1) Of ontbinding van het huwelijk of scheiding van tafel en bed kan worden gevorderd of verzocht en op welke gronden wordt bepaald

a. indien partijen een gemeenschappelijk nationaal recht hebben: door dat recht;

b. indien een gemeenschappelijk nationaal recht ontbreekt: door het recht van het land waarin partijen hun gewone verblijfplaats hebben;

510. De vraag naar de geldigheid van een huwelijksontbinding als voorvraag bij de vraag of een nieuw huwelijk kan worden gestoten is geregeld in ant. 9 Verdrag inzake de erkenning van beslissingen betreffende de huwelijksband 1967 (Luxemburg 8 september 1967, voor Nederland in werking getreden op 30 juli 1981, Trb. 1981, 141) en in ant. 11 van het Verdrag inzake de erkenning van echtscheidingen en scheidingen van afel en bed 1970 ('s-Gravenhage 1 juni 1970, voor Nederland in werking getreden op 22 augustus 1981, Trb. 1981, 142), waar de vraag naar de geldigheid van de huwelijksontbinding zelfstandig wordt aangeknoopt. Aangezien deze Verdragen een reciprociteitseis kennen en Marokko bij deze Verdragen geen partij is, hebben de bepalingen uit deze Verdragen geen rechtstreekse betekenis. Het inmiddels buiten werking getreden Haagse Huwelijksverdrag van 1902 gebood een afhankelijke beantwoording van de voorvraag. Deze regel werd in de rechtspraak niet steeds nageleefd of werd omzeild. Zie hierover Kokkini-latridou en Frohn 1987, 387-388.

511. Joppe, Vademecum 1980, 54, 21.

512. Wet van 25 maart 1981, houdende regeling van het conflictenrecht inzake ontbinding van het huwelijk en scheiding van tafel en bed en de erkenning daarvan, in verband met de bekrachtiging van de Verdragen van Luxemburg en 's-Gravenhage inzake erkenning van beslissingen betreffende de huwelijksband, onderscheidenlijk de erkenning van echtscheidingen en scheidingen van tafel en bed, in werking getreden op 10 april 1981 , Stb. 166. 
c. indien partijen geen gemeenschappelijk nationaal recht hebben en niet in hetzelfde land hun gewone verblijfplaats hebben: door Nederlands recht.

(2) Voor de toepassing van het voorgaande lid wordt met het ontbreken van een gemeenschappelijk nationaal recht gelijk gesteld het geval dat voor één van de partijen een werkelijke matschappelijke band met het land der gemeenschappelijke nationaliteit kennelijk ontbreckt. In dat geval wordt het gemeenschappelijke nationale recht nochtans toegepast, indien door partijen gezamenlijk een keuze voor dit recht is gedaan of een dergelijke keuze van éen van de partijen onweersproken is gebleven.

(3) Bezit cen partij de nationaliteit van meer dan één land dan geldt als zijn nationale recht het recht van dat land waarvan hij de nationaliteit bezit, waarmede hij alle omstandigheden in aanmerking genomen de sterkste band heeft.

(4) Ongeacht de voorgaande leden wordt Nederlands recht toegepast, indien door partijen gezamenlijk een keuze voor dit recht is gedaan of een dergelijke keuze van één van de partijen onweersproken is gebleven."

II. Erkenning van buiten Nederland tot stand gekomen huwelijksontbindingen Voor de erkemning van buiten het Koninkrijk tot stand gekomen huwelijksontbindingen gelden de art. 2 en 3 . Op grond van art. 2 wordt een buiten het Koninkrijk verkregen huwelijksontbinding in Nederland erkend indien (lid 1) zij is verkregen na een behoorlijke rechtspleging, en is tot stand gekomen door een beslissing van een rechter of andere autoriteit aan wic daartoe rechtsmacht toekwam, of (lid 2) indien aan een of meer van deze voorwaarden niet is voldaan maar duidelijk blijkt dat de wederpartij in de buitenlandsc procedure uitdrukkelijk of stilzwijgend hetzij tijdens die procedure heeft ingestemd met, hetzij zich na die procedure heeft neergelegd bij de huwelijksontbinding. Op grond van art. 3 wordt een buiten het Koninkrijk uitsluitend door een eenzijdige verklaring van de man tot stand gekomen huwelijksontbinding in Nederland niet erkend, tenzij:

a. de ontbinding van het huwelijk in deze vorm overeenstemt met de personele wet van de man;

b. de ontbinding ter plaatse waar zij geschiedde rechtsgevolg heeft; en

c. duidelijk blijkt dat de vrouw uitdrukkelijk of stilzwijgend met de ontbinding van het huwelijk heeft ingestemd of zich daarbij heeft neergelegd.

Er was een wetsvoorstel aanhangig gemaakt waarin werd voorgesteld om de onder c genoemde eis niet langer te stellen indien deze vorm van huwelijksontbinding overeenstemt met de nationale wet van de vrouw en de vrouw op het tijdstip van de verstoting haar gewone verblijfplaats had in een Staat die de verstoting als vorm van huwelijksontbinding kent ${ }^{513}$. Dit wetsvoorstel is echter op 23 april 1997 door de Minister ingetrokken. 
Huwelijksontbindingen die op een buitenlands consulaat in Nederland zijn verkregen vallen niet onder de werking van de WCE. Zij worden in Nederland niet erkend ${ }^{5 / 4}$.

\section{MAROKKAANS INTERNATIONAAL HUWELIJKSONTBINDINGSRECHT}

\section{Huwelijksontbinding in Marokko}

\section{Materiële vereisten}

De vraag of het huwelijk kan worden ontbonden wordt beheerst door de verwijzingsregel van art. 9 DCC welke luidt: "Les Français et les étrangers ont le droit de demander le divorce ou la séparation de corps, aux conditions fixées par leur loi nationale." De vraag of het huwelijk kan worden ontbonden en op welke gronden wordt mitsdien bepaald door het nationale recht van de echtgenoten. Bij het ontbreken van een gemeenschappelijk nationaal recht worden beide nationale rechtsstelsels cumulatief toegepast ${ }^{515}$. De DCC laat ongeregeid de gevallen waarin het nationale recht van een der echtgenoten de huwelijksontbinding niet toelaat, en het nationale recht van de andere echtgenoot de huwelijksontbinding wel toelaat. De doctrine is verdeeld over het alsdan toe te passen recht ${ }^{516}$. Bezit een der echtgenoten of bezitten beide echtgenoten de Marokkaanse nationaliteit, dan wordt de huwelijksontbinding volledig door Marokkaans recht beheerst ${ }^{517}$. Deze regel geldt ook als een of beide echtgenoten moslim zijn, ongeacht hun nationaliteit. Vreemd echtscheidingsrecht kan buiten toepassing worden gelaten bij strijd met de Marokkaanse openbare orde.

514. IIR 31 oktober 1986, NJ 1986, 702. Op grond van afspraken die (in 1995) zijn gemaakt tussen het Marokkaanse Ministerie van Justitie, het Nederlandse Ministerie van Justitie en de Marokkaanse Ambassade te 's-Gravenhage, vinden op de Marokkaanse diplomatieke of consulaire vertegenwoordigingen geen huwelijksontbindingen plaats als de huwelijksontbinding niet eerst door de Nederlandse rechter is uitgesproken. ( $\mathrm{Na}$ de wijziging van de Marokkaanse CSPS in september 1993 die tot gevolg had dat een verstoting alleen nog met toestemming van de rechter kon worden uitgesproken, hebben de Marokkaanse consulaire ambtenaren zich enkele maanden niet bevoegd geacht mee te werken aan consulaire verstotingen. Na een circulaire van januari 1994, betreffende de uitvoering van de in september 1993 in de CSPS doorgevoerde wijzigingen, is de bevoegdheid van consulaire ambtenaren bij verstotingen enige tijd niet geheel duidelijk geweest. Zie hierover: Jordens-Cotran 1995,4$)$.

515. Decroux 1963, 220.

516. In oudere rechtspraak werd een verzoek tot huwelijksontbinding toegewezen indien dit mogelijk was volgens het nationale recht van de verzoekende echtgenoot. Dit had dan tot gevolg dat alleen de verzoekende echtgenoot als gescheiden werd aangemerkt, maar de andere echtgenoot nog als gehuwd, Sarehane en Lahlou-Rachdi 1994, Fasc. 4, 16. Sarehane en Lahlou-Rachdi geven voorts aan dat - in verband met het respect voor beide nationaliteiten - een terugvallen op een der beide nationale rechtsstelsels, op het domiciliair recht of op de lex fori nog niet mogelijk is. Volgens hen zou een aantal schrijvers toepasselijk achten het nationale recht van die echtgenoot dat tevens het domiciliaire recht is, en bij gebreke hiervan het nationale recht van de man. Moulay $R^{\prime}$ chid 1992,153 is daarentegen van mening dat kan worden tenggevallen op het domiciliare recht of de lex fori.

517. Decroux 1981, 163; Deprez, Un aspect inattendu 1975, 67; Moulay R'chid 1992, 159; Sarehane en Lahlou-Rachdi 1994. Fasc. 4, 16-17. 


\section{Formele vereisten}

De procedurele vereisten worden onderworpen aan de lex fori (art. $212 \mathrm{t} / \mathrm{m} 216$ Code de procédure civile, CPC).

\section{Erkenning van buiten Marokko tot stand gekomen huwelijksontbindingen}

Een buiten Marokko tot stand gekomen huwelijksontbinding komt in Marokko voor erkenning in aanmerking onder de in art. 430 en 431 CPC gestelde voorwaarden. Voor een bespreking van deze artikelen wordt verwezen naar hoofdstuk 7 . Er vind geen conflictenrechtelijke toetsing plaats. Weigering van erkenning vindt alleen plaats bij strijd met de Marokkaanse openbare orde. Wanneer geen der echtgenoten de Marokkaanse nationaliteit bezit, zal de openbare orde niet snel worden ingeroepen. Tussen het Marokkaanse Ministerie van Justitie, het Nederlandse Ministerie van Justitie en de Marokkaanse vertegenwoordigingen in Nederland zijn inmiddels afspraken gemaakt over de erkenningsmogelijkheden in Marokko van echtscheidingsvonnissen van Nederlandse rechters. Wanneer de Nederlandse rechter de echtscheiding heeft uitgesproken, kan op cen Marokkaans consulaat door twee 'udül een akte van huwelijksontbinding worden opgemaakt ("acte de répudiation") indien aan twee voorwaarden is voldaan. De eerste voorwaarde is dat er een definitief echtscheidingsvonnis van de Nederlandse rechter $^{518}$ is en de echtscheiding is ingeschreven in de registers van de burgerlijke stand. De tweede voorwaarde is dat beide partijen met de echtscheiding accoord gaan. Er wordt een adoulaire "acte de répudiation" opgemaakt die wordt gehomologeerd door de adoulaire rechter van de Marokkaanse Ambassade. Gaat een van de partijen niet accoord met de echtscheiding, dan kan de voorgaande procedure niet worden gevolgd. De belanghebbende kan tenuitvoerlegging van het Nederlandse vonnis bij de Marokkaanse rechter verzocken (exeduaturprocedure). De tenuitvoerlegging wordt beoordeeld op basis van de art. $430 \mathrm{en} 431$ CPC. Erkenning en tenuitvoerlegging van het Nederlandse echtscheidingsvonnis in Marokko is volgens de gemaakte afspraken mogelijk wanneer de echtscheiding is uitgesproken op basis van feiten die ook naar Marokkaans recht tot een huwelijksontbinding kunnen leiden. Ten behoeve van de exequaturprocedure in Marokko kan de rechter van de Marokkaanse Ambassade vaststellen of de echtscheiding door de Nederlandse rechter is uitgesproken op basis van feiten die ook naar Marokkaans recht tot een huwelijksontbinding kunnen leiden.

\section{VOORBEELDEN}

\section{Voorbeeld la}

Een Marokkaanse vrouw is in 1990 door haar Marokkaanse echtgenoot op het Marokkaans consulaat in Nederland (onherroepelijk) verstoten, welke verstoting door de Marokkaanse Rechtbank is gehomologeerd. Ten tijde van de verstoting hadden beide

518. Het echtscheidingsvonnis moet worden gelegaliseerd door de Rechtbank die het vonnis heeft gewezen, door de Nederlandse Minister van Justitie, en de Nederlandse Minister van Bujtenlandse Zaken, en de vertaling van het vonnis nat het A rabisch door de Marokkaanse vertegenwoordiger op de Ambassade. 
echtgenoten hun gewone verblijfplaats in Nederland. Naar Marokkaans recht was het huwelijk rechtsgeldig ontbonden. De huwelijksontbinding werd echter in Nederland niet erkend, zodat volgens het Nederlandse conflictenrecht het huwelijk nog in stand was. Stel dat een der echtgenoten zou overlijden en de erfopvolging zou worden beheerst door Marokkaans recht, zouden de (ex) echigenoten dan elkaars erfgenaam zijn? Een geschreven regel voor de beantwoording van de voorvraag naar de geldigheid van de huwelijksontbinding ontbreckt. In de literatuur bestaat een voorkeur voor een zelfstandige aanknoping. Dat zou betekenen dat er geen sprake is van een geldige huwelijksontbinding en dat de echtgenoten elkaars erfgenaam zijn. Is er reden om te kiezen voor een andere benadering? Hiervoor zal met name aanleiding bestaan wanneer de hoofdvraag en voorvraag zo nauw samenhangen dat een gescheiden conflictenrechtelijke behandeling onaanvaardbaar is, of wanneer de hoofdvraag en voorvraag zo nauw verbonden zijn met het rechtsstelsel dat de hoofdvraag beheerst dat de Nederlandse rechtsorde niet of nauwelijks belang heeft bij toepassing van zijn IPR op de voorvraag (criteria ontleend aan het Weber-Staat-arrest), of wanneer een zelfstandige aanknoping leidt tot een materieel onaanvaardbaar resultaat (rechtsvergelijkende methode), in welk geval tevens een correctie op de gekozen aanknoping denkbaar zou zijn. De eerste twee uitzonderingen lijken zich hier niet voor te doen. Bij de vraag wat materiecl onaanvaardbaar is, kan rekening worden gehouden met de legitieme verwachtingen van de betrokkenen. Wisten zij of kon van hen worden verwacht dat zij op de hoogte waren van het feit dat de consulaire huwelijksontbinding in Nederland niet rechtsgeldig was? Indien dit het geval is, kan hierin een argument worden gevonden voor het "handhaven" van een zelfstandige aanknoping. Anderzijds kan het zijn dat zij legitieme verwachtingen hadden ten aanzien van de toepasselijkhcid van het Marokkaans recht op de erfopvolging, waarbij nict vanzelfsprekend de geldigheid van de huwelijksontbinding door een ander dan het Marokkaanse recht zou worden beheerst. Als de relatie recds enige tijd is beëindigd en er geen enkele persoonlijke betrokkenheid tussen de (ex)echtgenoten meer bestaat, is het maar de vraag of het toekennen van erfrechten materieel wel aanvaardbaar is.

\section{Voorbeeld $1 b$}

In dit tweede voorbeeld is eveneens sprake van een in 1990 plaatsgevonden consulaire huwelijksontbinding tussen Marokkaanse echtgenoten. Enige tijd na deze huwelijksontbinding treedt de man in Marokko in het huwelijk met een andere Marokkaanse vrouw. Dit tweede huwelijk wordt in Nederland erkend. De man overlijdt en we nemen aan dat zijn erfopvolging wordt beheerst door Marokkaans recht. De behandeling van de voorvraag of er met de eerste echtgenote nog een huwelijk bestaat dient op dezelfde wijze te geschieden als in het vorige voorbeeld, met dat verschil dat een zelfstandige aanknoping van de voorvraag, met als gevolg dat ook de eerste echtgenote nog erfgenaam is, wellicht eerder zal leiden tot een materieel onaanvaardbaar resultaat.

\section{Voorbeeld $1 \mathrm{C}$}

Ook hier is sprake van een in 1990 plaatsgevonden consulaire huwelijksontbinding tussen Marokkaanse echtgenoten. Nu is het niet de man maar de vrouw die enige tijd 
later in Marokko cen tweede huwelijk aangaat met een andere Marokkaanse man. In Marokko is dit tweede huwelijk rechtsgeldig. Indien bij de vraag naar de erkenning van dit huwelijk in Nederland de vraag naar de huwelijksontbinding zelfstandig zou worden beoordceld, zou naar Marokkaans recht dit tweede huwelijk niet mogelijk zijn, en zou erkenning van de geldigheid ervan kunnen worden onthouden op grond van art. 5 WCH. De vrouw overlijdt en we nemen aan dat haar erfopvolging wordt beheerst door Marokkaans recht. Een zelfstandige beoordeling van de voorvraag naar de geldigheid van de huwelijksontbinding leidt ertoe dat de cerste echtgenoot erfgenaam is nu deze huwelijksontbinding in Nederland niet wordt erkend. Of de tweede echtgenoot zal erven hangt af van de beoordeling van de voorvraag naar de geldigheid van dit huwelijk (zie $\$ 5)$. Een afhankelijke aanknoping van de voorvraag naar het nog bestaan van het eerste huwelijk zou ertoe leiden dat de eerste echtgenoot geen erfgenaam meer is nu de verstoting naar Marokkaans recht een einde aan het huwelijk heeft gemaakt. Hoe de voorvraag kan worden beoordeeld is uiteengezet in de vorige twee voorbeelden onder a en $b$.

\section{Voorbeeld 2}

Een hoogbejaarde vermogende Marokkaanse man brengt zijn laatste levensdagen door met zijn Marokkaanse vrouw in Nederland. Vóór dit laatste huwelijk was hij maar liefst vier maal eerder gehuwd geweest met respectievelijk een (altijd in Frankrijk gewoond hebbende) Marokkaanse, tweemaal een Nederlandse en een Tunesische vrouw, welke huwelijken hij allevier door een eenzijdige verstoting heeft ontbonden. De erfopvolging van de man wordt beheerst door Marokkaans recht. Bij het overlijden van de man komen buiten de huidige echtgenote, ook alle vier de vroegere echtgenotes op stellende dat zij nooit hebben ingestemd met de verstoting en nog als echtgenotes van de erflater moeten worden aangemerkt. Op grond van art. 3 WCE zou geen van deze verstotingen in Nederland worden erkend. Bij een zelfstandige beoordeling van de voorvragen naar de geldigheid van de huwelijksontbindingen zouden alle vroegere echtgenotes nog erfgenamen zijn. Bij een afhankelijke aanknoping zouden de vier vorige echtgenotes geen erfgenamen zijn. Van geen enkele verstoting kan worden gezegd dat deze uitsluitend met de Marokkaanse rechtssfeer is verbonden. Enkele verstotingen hebben geen enkele betrokkenheid met de Nederlandse rechtssfeer. Voorzover het toekennen van erfaanspraken aan een of meer van de vroegere echtgenotes onwenselijk wordt geacht, kan een dergelijk resultaat niet enkel worden bereikt door toepassing van de zelfstandige of afhankelijke aanknoping van de voorvraag. Alsdan zal het resultaat moeten worden gecorrigeerd met bijvoorbeeld een beroep op "droits acquis", het fait accompli-leerstuk of de openbare orde.

\section{Voorbeeld $3 a$}

De Nederlandse rechter spreekt tussen Marokkaanse echtgenoten de echtscheiding uit op grond van duurzame ontwrichting van het huwelijk. Uit de overwegingen van de Rechtbank kan worden afgeleid dat er sprake is geweest van feiten die ook naar Marokkaans recht een echtscheiding mogelijk maken. Op verzoek van partijen is op basis van het Nederlandse echtscheidingsvonnis op het Marokkaanse consulaat in Nederland de 
huwelijksontbinding naar Marokkaans recht vastgesteld. Nu er zowel naar Nederlands als naar Marokkaans recht sprake is van een geldige huwelijksontbinding, zal bij het overlijden van een der ex-echtgenoten de andere partij geen erfgenaam zijn.

\section{Voorbeeld $3 b$}

De Nederlandse rechter spreekt tussen Marokkaanse echtgenoten de echtscheiding uit op grond van duurzame ontwrichting van het huwelijk. In Nederland is dit een geldige huwelijksontbinding. De man had zich tegen deze echtscheiding verzet. Een exequaturprocedure in Marokko heeft (nog) niet plaatsgevonden. Een der ex-echtgenoten overlijdt en we nemen aan dat de erfopvolging wordt beheerst door Marokkaans recht. Bij een zelfstandige beoordeling van de voorvraag naar de huwelijksontbinding zou de langstlevende echtgenoot niet erven, bij een afhankelijke aanknoping zou hij wel erven. Er bestaat een voorkeur voor cen zelfstandige aanknoping. Een keuze voor een andere beoordeling is met name gerechtvaardigd wanneer de hoofdvraag er voorvraag zo nauw samenhangen dat een gescheiden conflictenrechtelijke behandeling onaanvaardbaar is, of wanneer de hoofdvraag en voorvraag zo nauw verbonden zijn met het rechtsstelsel dat de hoofdvraag beheerst dat de Nederlandse rechtsorde niet of nauwelijks belang heeft bij toepassing van zijn IPR op de voorvraag, of wanneer een zelfstandige aanknoping leidt tot een matericel onaanvaardbaar resultaat, in welk geval tevens een correctie op de gekozen aanknoping denkbaar zou zijn. Geen der genoemde omstandigheden lijkt zich hier voor te doen. Een zelfstandige aanknoping ligt het meest voor de hand. De overlevende ex-echtgenoot zal geen erfgenaam zijn.

\section{$\S 5$. Afstamming}

\section{A. AFSTAMMING ALS VOORVRAAG}

Op de vraag naar de afstamming als voorvraag bij de hoofdvraag naar de erfopvolging geven noch het (ongeschreven) conflictenrecht inzake de afstamming noch het conflictenrecht inzake de erfopvolging een antwoord. Enkele rechterlijke uitspraken op dit punt wijzen in de richting van een zelfstandige aanknoping ${ }^{519}$. Ook in de literatuur bestaat een voorkeur voor een zelfstandige aanknoping ${ }^{520}$. Soms is de vraag naar de afstamming op haar beurt weer afhankelijk van de vraag naar het bestaan van een geldig huwelijk. In dat geval zijn drie opties denkbaar: 1. de vraag naar het bestaan van een geldig huwelijk wordt geabsorbeerd door het recht dat de afstamming beheerst; 2 . de vraag naar het bestaan van een geldig huwelijk komt op als voorvraag bij de afstamming; 3 . de vraag naar het bestaan van een geldig huwelijk wordt als voorvraag bij de erfopvolging gezien en trekt de afstammingsvraag naar zich toe, absorbeert de afstam-

519. Hof Amsterdam 24 januari 1913, NJ 1913, p. 593; HR 21 maart 1947, NJ 1947, 382 (Estlandse nalatenschap). In andere zin: Hof Amsterdam 11 juli 1946, NJ 1947, 66 (Estlandse nalatenschap) en Hof 's-Gravenhage 12 november 1965, NJ 1967, 154.

520. Joppe, Vademecum 1980, 52-53; van der Ploeg 1961, 53-54; Vonken 1987, 430-433, i.h.b. 431. 
mingsvraag. Het gering aantal schrijvers dat zich over deze vraag uillaat opteert voor de derde mogelijkheid ${ }^{521}$.

De voorvraag naar de afstamming behoeft niet aitijd betrekking te hebben op familierechtelijke betrekkingen met de erflater (bijvoorbeeld vader - kind), maar kan ook familierechtelijke betrekkingen met verwanten van de erflater betreffen (bijvoorbeeld broer - kind van broer, of kind - kleinkind).

\section{B. NEDERLANDS INTERNATIONAAI. AFSTAMMINGSRECHT}

\section{Afstamming in Nederland}

In Nederland geldt geen algemene geschreven conflictregel waarin is geregeld welk recht de afstamming beheerst. Volgens een ongeschreven regel van Nederlands IPR worden de familierechtelijke betrekkingen met een wettig kind in beginsel beheerst door het nationale recht van de vader, en familierechtelijke betrekkingen met een onwettig kind in beginsel door het nationale recht van degene met wie de familierechtelijke betrekking moet worden vastgesteld ${ }^{522}$. Bij de beoordeling of tussen een buitenlandse man en een kind familierechtelijke betrekkingen kunnen worden vastgesteld, is in de rechtspraak een ontwikkeling waar te nemen, waarin de regel om het nationale recht van de man toe te passen, stecds vaker uitzondering lijdt ten gunste van de toepassing van Nederlands recht, wanneer er voldoende aanknopingspunten met de Nederlandse rechtssfeer kunnen worden aangenomen en toepassing van Nederlands recht in het belang van het kind wordt geacht. Een relativering van het nationaliteitsbeginsel vind met name plaats bij de ontkenning van het vaderschap en de erkenning van kinderen ${ }^{523}$.

Op p. 165-167 werd gesproken over de mogelijkheid die ouders hebben om een huwelijk op het Marokkaans consulaat in Nederland te laten vaststellen. Niet zelden wordt in de praktijk van deze mogelijkheid gebruik gemaakt om kinderen die zijn geboren voordat cen naar Marokkaans recht geldige huwelijkssluiting heeft plaatsgevonden of als een bewijs van een naar Marokkaans recht geldig of bestaand huwelijk ontbreekt, de status van wettig kind te geven. Gaat het hierbij om cen zogenaamde "reconnaissance matrimoniale" waarbij de akte is opgemaakt op basis van een lafif-getuigenis, dan hebben deze getuigen niet alleen verklaard dat de man en vrouw elkaars echtgenoten zijn vanaf een bepaalde datum, maar ook dat hen bekend is dat de desbetreffende kinderen de kinderen van deze ouders zijn. Het huwelijk is dan vastgesteld vanaf het moment dat er sprake zou zijn geweest van een huwelijk, en de kinderen zijn dientengevolge staande het huwelijk verwekt en hebben naar Marokkaans recht de status van wettig kind. Nederlands beleid is dat de wettige status van de kinderen wanneer deze is ontleend aan cen "reconnaissance matrimoniale" in Nederland wordt geaccepteerd indien

523. Strikwerda 1995, 126. 
tussen de ouders een naar Nederlands IPR geldig huwelijk is gesloten, ongeacht of dit is geschied vóór of na de geboorte van de kinderen. Indien een van de ouders de Nederlandse nationaliteit bezit dient een burgerlijke stand-huwelijk te zijn (of worden) gesloten $^{524}$. Voorts moet uit bescheiden van een Marokkaanse autoriteit blijken dat het kind naar Marokkaans recht een wettig kind is ${ }^{525}$. Gaat het om een door de Marokkaanse rechter uitgesproken "reconnaissance matrimoniale" ten aanzien van partijen dic in Marokko een relatie onderhiclden, dan komt deze in beginsel voor erkenning in aanmerking ${ }^{526}$.

Er zijn twee internationale overeenkomsten waarbij Nederland partij is en waarin twee specifieke afstammingsbanden worden geregeld. De eerste is de Overeenkomst betreffende de vaststelling van de familierechtelijke betrekkingen tussen het onwettige kind en zijn moeder ${ }^{527}$, en ten tweede de Overeenkomst inzake wettiging door huwelijk ${ }^{528}$. In het eerste Verdrag wordt aangegeven op welke wijze de familierechtelijke betrekkingen tussen een moeder en een onwettig kind dienen te worden vastgesteld. Het tweede Verdrag, dat geen reciprociteitseis stelt (art. 5), bepaalt wanneer een wettiging door huwelijk als geldig moet worden beschouwd, en op welke wijze deze geldigheid (administratief) moet worden gerealiseerd.

\section{MAROKKAANS INTERNATIONAAL AFSTAMMINGSRECHT}

Het Marokkaanse recht kent voor de afstamming geen verwijzingsregel in de DCC. Omdat de vraag naar de afstamming het personeel statuut van het kind betreft, wordt aangeknoopt bij het nationale recht ${ }^{5 \%}$. In vroegere rechterlijke uitspraken werd wel gekozen voor het nationale recht van het kind ${ }^{530}$. Deze opvatting is echter bekritiseerd $^{531}$. Van een eensluidende opvatting is derhalve geen sprake. Duidelijk is we] dat wanneer het gaat om het vestigen van familierechtelijke betrekkingen met onwettige kinderen, en een der partijen bezit de Marokkaanse nationaliteit, Marokkaans recht dient te worden toegepast, en in deze gevallen, wanneer de familierechtelijke betrekkingen met het onwettig kind buiten Marokko zijn gevestigd, erkenning hiervan wordt geweigerd wegens strijd met de Marokkaanse openbare orde ${ }^{532}$.

524. Permanente adviescommissie voor de burgerlijke stand HPS 1991, 2, p. 35.

525. Aldus HR 18 december 1987 , NJ 1988, 830.

526. Permanente adviesconmissie voor de burgerlijke stand, zie noot 524, 35.

527. Brussel 12 september 1962, voor Nederland in werking getreden op 23 april 1964, Trb. $1964,76$.

528. Rome 10 september 1970, voor Nederland in werking getreden op 31 juli 1977. Trb. 1977, 114.

529. Sarehane en Lahlou-Rachdi 1994, Fasc. 4, 18. Zie verder: Moulay R'chid 1992, 153-154.

530. Decroux 1963, 311; Sarehane en Lahlou-Rachdi 1994, Fasc. 4, 18-19.

531. Zie hierover Decroux 1963, 312.

532. Decroux 1963, 312; Deprez 1978, 77-78, 80; Sarehane en Lahlou-Rachdi 1994, Fasc. 4, $10,18,19$. Indien het gaat om het vestigen van familierechtelijke betrekkingen met onwettige kinderen of de erkenning van deze kinderen terwijl geen der partijen de Marokkaanse nationaliteit bezit noch moslim is, is niet geheel zeker of de Marokkaanse openbare orde zich hiertegen zal verzetten. Deprez 1981, 139, en Moulay R'chid, Grandes lignes 1991, 24-25, achten dit zeker niet uitgesloten. 


\section{VOORBEELDEN}

\section{Voorbeeld I}

Een Nederlandse vrouw en een Marokkaanse man hebben een buitenechtelijke relatie. Uit deze relatic wordt een kind geboren. Bij de geboorte wordt het kind door de vader naar Nederlands recht erkend. Op vordering van de Nederlandse rechter heeft de ambtenaar van de burgerlijke stand de erkenning geaccepteerd omdat de nauwe verbondenheid van de man met de Nederlandse samenleving en het ontbreken van reële banden met Marokko dienden te leiden tot een afwijking van de nationaliteit als aanknopingsfactor. Door de erkenning zijn familierechtelijke betrekkingen ontstaan tussen vader en kind. $\mathrm{Er}$ is echter geen sprake van wettige afstamming. De familierechtelijke betrekkingen worden in Marokko niet erkend ${ }^{533}$. De man overlijdt en we nemen aan dat zijn erfopvolging door Marokkaans recht wordt beheerst. Om te kunnen erven moet men naar Marokkaans recht wettig bloedverwant van de erfgenaam zijn. Noch bij een zelfstandige noch bij een afhankelijke aanknoping van de voorvraag naar de afstamming bezit een erkend kind de status van wettig bloedverwant. Het behandelen van de voorvraag heeft derhalve alleen zin wanneer het in het Marokkaanse recht gemaakte onderscheid tussen wettige en onwettige natuurlijke kinderen buiten toepassing wordt gelaten wegens strijd met de Nederlandse openbare orde. In beginsel zal m.i. een dergelijke strijd vaak aangenomen kunnen worden (hicrover: hoofdstuk $6 \$ 3$.A.2). Er bestaat geen geschreven regel voor de behandeling van deze voorvraag. In de literatuur bestaat de voorkeur voor een zelfstandige aanknoping. Er zijn familierechtelijke betrekkingen gevestigd. Bij het buiten toepassing laten van het onderscheid tussen wettige en natuurlijke kinderen zou het kind erfgenaam zijn ${ }^{534}$. Bij een keuze voor een afhankelijke aanknoping van de voorvraag zouden er in het kader van het erfrecht geen familierechtelijke betrekkingen tussen vader en kind worden aangenomen en zou het kind niet de status hebben van erfgenaam. De vraag of dit resultaat in strijd komt met de Nederlandse openbare orde wordt behandeld in hoofdstuk $6 \S 3$. A.2.

\section{Voorbeeld $2 a$}

Een Marokkaanse man en een Nederlandse vrouw zijn in 1992 in Nederland gehuwd ten overstaan van de ambtenaar van de burgerlijke stand. Uit het huwelijk zijn twee kinderen geboren. Het huwelijk is naar Nederlands recht rechtsgeldig tot stand gekomen; de kinderen zijn - bij een zelfstandige beoordeling van de voorvraag naar de geldigheid van het huwelijk - naar Nederlands recht wettige kinderen. Zolang het huwelijk naar Marokkaans recht niet is vastgesteld wordt het naar Marokkaans recht niet

533. Wettige verwantschap naar Marokkaans recht zou in dit geval overigens kunnen worden vastgesteld op basis van een naar Marokkaans recht toegestane bewijsmethode. Een van deze methoden betreft de lafif-getuigenis. Als gevolg hiervan wordt naar Marokkaans recht ook een huwelijk tussen de ouders aangenomen.

534. Mits het mostim is of, als het dit niet is (opvolging in het islamitisch geloof vindt plaats door middel van afstamming), het verschil in godsdienst als erfbeletsel wegens strijd met de openbare orde buiten toepassing wordt gelaten. Dit laatste zou m.i. dienen te gebeuren (p. 221). 
erkend. Als noch het huwelijk van de ouders noch de afstamming van de kinderen is vastgesteld zullen de kinderen niet als wettige kinderen van de vader worden aangemerkt. De vader overlijdt en we nemen aan dat zijn erfopvolging wordt beheerst door Marokkaans recht. De behandeling van de voorvraag naar de afstamming kent hier als complicerende factor dat deze afhankelijk is van het al dan niet aannemen van de geldigheid van het huwelijk. Op p. 176 is aangegeven op welke wijze hierbij te werk zou kunnen worden gegaan. Hier werden drie opties genoemd, te weten: 1. de vraag naar het bestaan van een geldig huwelijk wordt geabsorbeerd door het recht dat de afstamming beheerst; 2 . de vraag naar het bestaan van een geldig huwelijk komt op als voorvraag bij de afstamming; 3 . de vraag naar het bestaan van een geldig huwelijk wordt als voorvraag bij de erfopvolging gezien en trekt de afstammingsvraag naar zich toe, absorbeert de afstammingsvraag. Welke werkwijze ook wordt gevolgd, deze leidt er in casu steeds toe dat áls de geldigheid van het huwelijk zelfstandig wordt beoordeeld (hetzij als voorvraag bij de afstamming, hetzij als voorvraag bij het erfrecht) deze steeds leidt tot de vaststelling dat de kinderen wettige kinderen zijn, en derhalve erfgenamen van de vader ${ }^{535}$. Andersom zou een afhankelijke beoordeling van het huwelijk (hetzij geabsorbeerd door het recht dat de afstamming beheerst (in deze casus het Marokkaanse rechi), hetzij als voorvraag bij de afstammingsvraag, hetzij als voorvraag bij de erfopvolging, steeds ertoe leiden dat de kinderen als onwettig worden aangemerkt. Als onwettige kinderen zouden zij niet erven ${ }^{536}$. Of de geldigheid van het huwelijk zelfstandig dan wel afhankelijk dient te worden beoordeeld is als voorvraag bij de erfopvolging (optie 3 ) besproken in $\$ 3$. Als voorvraag bij de afstamming (optie 2 ) kan voor een afhankelijke aanknoping worden aangevoerd de samenhang tussen het huwelijk en de afstamming, die juist ook in optic 1 tot uitdrukking word gebracht, maar tegen een afhankelijke aanknoping kunnen worden aangevoerd de betrokkenheid van de Nederlandse rechtssfeer en het materieel te bereiken resultaat. Voor een afhankelijke aanknoping laat art. 12 lid 2 van het Huwelijksverdrag ruimte wanneer de vraag naar de afstamming word beheerst door het recht van een niet-Verdragsluitende Staat, zoals Marokko.

\section{Voorbeeld $2 b$}

De Marokkaanse man en Nederlandse vrouw uit voorbeeld 2a laten het huwelijk "bevestigen" op het Marokkaanse consulaat. Blijkens een aldaar verkregen akte worden de echtgenoten naar Marokkaans recht als gehuwd aangemerkt vanaf de datum van het burgerlijke stand-huwelijk. De kinderen zijn dan geboren (meer dan zes maanden) na de huwelijkssluiting en zijn naar Marokkaans recht wettige kinderen. Nu zowel naar Marokkaans recht als naar Nederlands recht sprake is van een geldig huwelijk en de

535. Zijn de kinderen geen moslim omdat naar Marokkaans recht de afstamming niet wordt aangenomen, dan erven zij alleen als het verschil in godsdienst als erfbeletsel wegens strijd met de openbare orde buiten toepassing wordt gelaten. Zie noot 534 .

536. Tenzij de openbare orde aan een dergelijk resultaat in de weg zou staan (p. 218-219). 
wettige afstamming van de kinderen vaststaat, bestaat erfopvolging tussen de ouders en de kinderen ${ }^{537}$.

\section{Voorbeeld 3}

Een in Nederland woonachtige Marokkaanse man, gehuwd met een Nederlandse vrouw, sluit in Marokko een tweede huwelijk met een aldaar woonachtige Marokkaanse vrouw. Uit dit tweede huwelijk zijn vier kinderen geboren. Het eerste huwelijk is zowel in Nederland als in Marokko geldig. Het tweede huwelijk is in Marokko geldig, doch wordt in Nederland mogelijk niet erkend (zie p. 168). De man overlijdt en de erfopvolging wordt beheerst door Marokkaans recht. Zouden de vier kinderen uit het tweede huwelijk zijn erfgenamen zijn? Hicr is evenals in het voorbeeld onder 2 a een complicerende factor dat de voorvraag naar de afstamming mede wordt bepaald door het al dan niet bestaan van een geldig huwelijk. De conclusie bij dit voorbeeld was, en dit gaat ook hier op, dat de afstammingsvraag, en daarmee de vraag of de kinderen erfgenamen zijn, afhankelijk is van het feit of de vraag naar de geldigheid van het huwelijk afhankelijk of zelfstandig wordt beoordeeld. Bij een zelfstandige beoordeling, waarbij de geldigheid van het huwelijk nict zou worden erkend, zou ook de afstamming niet vaststaan ${ }^{538}$. In het op p. 168-169 besproken tweede voorbeeld waar deze vraag voor het onderhavige geval aan de orde is gesteld, werd een voorzichtige voorkeur uitgesproken voor cen zelfstandige aanknoping van deze voorvraag, hetgeen betekende dat de tweede echtgenote in het kader van het erfrecht niet als echtgenote werd beschouwd. Kan de vraag naar de geldigheid van het huwelijk nu anders worden beoordeeld als het gaat om de afstammingsvraag met betrekking tot de kinderen? Voor een bevestigende beantwoording van deze vraag kan cen aantal argumenten worden aangevoerd: de samenhang tussen afstamming en huwelijk makkt een afhankelijke aanknoping of absorptie in de afstammingsvraag wenselijk, bij het vestigen van de afstammingsbanden was de Nederlandse rechtssfeer niet betrokken, en wellicht is het minder onaanvaardbaar dat de kinderen uit het tweede huwelijk wel maar de tweede echtgenote geen aanspraak maken op de nalatenschap van de man. De vraag naar de geldigheid van het huwelijk zou dan ten aanzien van de tweede echtgenote als voorvraag bij de erfopvolging zelfstandig kunnen worden beoordeeld, maar ten aanzien van de kinderen bij de voorvraag naar de afstamming afhankelijk kunnen worden beoordeeld of worden geabsorbeerd in de (voorvraag naar de) afstamming. Een andere mogelijkheid die tot hetzelfde resultaat leidt zou zijn om de voorvraag naar het huwelijk ook ten opzichte van de kinderen zelfstandig te beoordelen, maar de aanspraken van de kinderen te erkennen als "droits acquis".

537. Door de gevestigde afstammingsbanden zijn de kinderen hun vader ook gevolgd in het islamitisch geloof.

538. Tenzij de vader de kinderen in Nederland naar Nederlands recht zou hebben erkend. 


\section{§6. Adoptie}

\section{A. ADOPTIE ALS VOORVRAAG}

Van de voorvragen heeft de adoptie onder de schrijvers misschien wel de meeste hersenbrecksels gekost. Zowel de adoptieprocedure als de gevolgen van een adoptic kunnen per land sterk verschillen. Dit levert weer problemen op bij de vraag naar erkenning van buitenlandse adoptics. Als gevolg hiervan moeten adopties vaak worden gekwalificeerd als een begrip dat bekend is in het rechtsstelsel dat de hoofdivraag beheerst.

Er is geen geschreven conflictregel waarin wordt bepaald hoe de voorvraag naar de (gevolgen van) adoptie moet worden aangeknoopt als deze vraag rijst bij de hoofdvraag naar de erfopvolging. In de literatuur wordt op dit punt ook geen uitsluitsel gegeven ${ }^{539}$. Zowel de zelfstandige als de afhankelijke aanknoping stuiten op problemen wanneer de adoptie is uitgesproken (of is erkend) volgens een recht dat aan de adoptie andere gevolgen verbindt dan hieraan worden toegekend in het rechtsstelsel dat de erfopvolging behecrst.

\section{B. NEDERLANDS INTERNATIONAAL ADOPTIERECHT}

\section{Adoptic in Nederland}

Voor adoptieverzoeken die aan de Nederlandse rechter worden voorgelegd bestaat omtrent het toepasselijke recht geen geschreven verwijzingsregel ${ }^{540}$. Aanvankelijk was de gedachte dat deze verzocken slechts konden worden toegewezen indien was voldaan aan zowel het nationale recht van de adoptiefouders als aan het nationale recht van het te adopteren kind. Dit cumulatiestelsel wordt in de rechtspraak vaak niet meer nageleefd. Er is sprake van een grote variëteit in de rechtspraak met betrekking tot het tocpasselijke recht. Onderscheid kan worden gemaakt tussen gevallen waarin Nederlanders en gevallen waarin geen Nederlanders bij de adoptie betrokken zijn. Voorts speelt een rol of $\mathrm{er}$ al dan niet in het buitenland reeds een adoptie heeft plaatsgevonden. Indien bij een adoptieverzoek een of meer Nederlanders zijn betrokken en er nog geen adoptie in het buitenland heeft plaatsgevonden, zal het verzoek in de regel in ieder geval aan

539. Zie bijvoorbeeld Goudsmit 1961, 7; Jessunn d'Oliveira 1987, 107; Joppe, Vademecum 1980, 53; Kokkini-Iatridou 1990, 113-122; Schultsz 1960, 25-28. Schultsz 1961, 73 is voorstander van een afhankelijke aanknoping. Dat hij zelf betwijfelt of dit in alle gevallen tot de juiste oplossing leidt, blijkt uit een door hem op p. 80 gestelde vraag (warover meer in noot 552). Voorstander van een afhankelijke aanknoping is ook Openti Badan 1983, 373-374, war hij overigens wijst op het belang om het recht van erfopvolging in geval van adoptie te bezien in samenhang met het familierecht.

540. Het Verdrag inzake de bevoegdheid der autoriteiten, het toepasselijke recht en de erkenning van beslissingen inzake adoptie, Verdrag van 15 november 1965 , Recueil des Conventions de la Conférence de la Haye, 1951-1988, pp. 64 e.v., Trb. 1968, 101, in werking getreden op 23 oktober 1978, geldt niet voor Nederland. Naar verwachting zal dit Verdrag voor Nederland ook niet in werking treden. 
de adoptievoorwaarden uit het Nederlandse recht worden getoetst ${ }^{541}$. De vraag of en in hoeverre ook het vreemde nationale recht van een der betrokkenen wordt toegepast, wordt in de rechtsprak op uiteenlopende wijze beantwoord. Naarmate de verbondenheid met de Nederlandse rechtssfeer groter is (bijvoorbeeld door woonplaats van adoptanten en adoptiefkind), lijkt aan het vreemde recht minder betekenis behoeven te worden toegekend. Een uitzondering geldt wellicht nog voor de vraag of de toestemming van de natuurlijke ouders nodig is. Heeft er reeds een adoptie in het buitenland plaatsgevonden, en zijn hierbij Nederlanders betrokken, dan blijkt in de praktijk dat nog een adoptieprocedure in Nederland wordt verlangd ${ }^{542}$. Wel kunnen aan de buitenlandse adoptic gevolgen worden toegekend die van invloed zijn op de voorwaarden waaraan moet zijn voldaan wil het adoptieverzoek in Nederland kunnen worden toegewezen. Bezit geen der betrokkenen de Nederlandse nationaliteit, dan wordt aan het vreemde recht in de regel cen grotere waarde tocgekend. Voor het (tevens) toepassen van het Nederlandse recht bestaat met name aanleiding indien er sprake is van een verwaterde nationaliteit of een grote betrokkenheid met de Nederlandse rechtssfeer.

\section{Erkenning van buiten Nederland uitgesproken adoptics}

Voor erkenning van een in het buitenland uitgesproken adoptie geldt dat moet zijn voldaan aan de voorwaarden die in het algemeen aan erkenning van buitenlandse beslissingen worden gesteld, te weten: de adoptie moet zijn uitgesproken door een bevoegde autoriteit, er moet een behoorlijke procedure zijn gevolgd, en erkenning mag niet in strijd met de Nederlandse openbare orde zijn. Lange tijd vond daarnaast ook nog een conflictenrechtelijke toetsing plaats. De eis van een conflictenrechtelijke toetsing wordt niet altijd meer onverkort gehandhaafd. De rechtspraak vertoont een zeer gevarieerd beeld van voorwaarden die de onderscheiden rechters stellen aan de erkenning van een buitenlandse adoptie waarbij Nederlanders betrokken zijn. Indien bij de buitenlandse adoptie geen Nederlanders zijn betrokken, lijkt de erkenning op minder bezwaren te stuiten, in ieder geval indien de betrokkenen eenzelfde buitenlandse nationaliteit bezitten ${ }^{543}$. Heeft de buitenlandse adoptic niet tot gevolg dat het adoptiefkind de status van wettig kind van de adoptiefouders krijgt, dan wordt de adoptie in de regel niet erkend. Gaat het om een zwakke adoptie, dan kunnen de gevolgen hiervan wel betekenis hebben in een nieuwe adoptieprocedure.

Inmiddels is het Verdrag inzake de internationale samenwerking en de bescherming van kinderen op het gebied van interlandelijke adopties tot stand gebracht ${ }^{544}$. Nederland

541. Zij het dat een mitigatie van een enkele voorwaarden mogelijk is, zie Rb 's-Gravenhage 25 maart 1987. NJ $1988,502$.

542. Vonken, losbladige PFR. Titel 12: Adoptie. IPR, 115.

543. Vonken, losbladige PFR, Titel 12: Adoptie, IPR, 132-136.

544. 's-Gravenhage 29 mei 1993, Trb. 1993, 197; 1996, 94 (Nederlandse veraling). Inwerkingtreding 1 mei 1995. Nederland bereidt de goedkeuring van het Verdrag voor, TwK 24810 (R 1577). Voor een bespreking van het Verdrag kan worden verwezen naar van Loon, Adoption 1993, 326-374. 
bereidt de goedkeuring van dit Verdrag voor ${ }^{545}$. Het Verdrag bevat in de art. 23 tot en met 27 een socpele erkenningsregeling voor interlandelijke adopties. Volgens art. 23 lid 1 dient een adoptie die is uitgesproken door een bevoegde autoriteit in overeenstemming met het Verdrag (de vereisten worden gegeven in de art. 4 en 5) in de andere Verdragsluitende Staten van rechtswege te worden erkend. Marokko is geen partij bij dit Verdrag. Op interlandelijke adopties "tussen" Marokko en Nederland is dit Verdrag derhalve niet van toepassing (art. 2). De gevolgen die met de erkenning van een adoptie worden geaccepteerd worden genoemd in de art. 26 en 27 . Erkenning mag alleen worden geweigerd bij kennelijke strijd met de openbare orde, met inachtneming van het belang van het kind (art. 24).

\section{MAROKKAANS inTERnAtIONAAL ADOPTIERECHT}

\section{Adoptie in Marokko}

De adoptie waarbij familierechtelijke betrekkingen worden gevestigd is in het Marokkaanse recht niet mogelijk (art. 83 lid 3 CSPS). Wel kent het Marokkaanse recht de adoptic bij gratificatie of testament. Een op deze wijze "geadopteerd" kind erft naar Marokkaans recht volgens de regels van het testament (zie p. 42-43) ${ }^{546}$. Het Marokkaanse IPR kent geen geschreven conflictregel voor de adoptie. Regel is dat de adoptie wordt beheerst door het nationale recht, te weten het gemeenschappelijke nationale recht van de adoptanten en geadopteerde ${ }^{547}$. Bij het ontbreken van een gemeenschappelijke nationaliteit, worden de verschillende nationale rechtsstelsels cumulatief toegepast ${ }^{548}$. Bezit een der adoptanten of het te adopteren kind de Marokkaanse nationaliteit of is een der betrokkenen moslim, dan is adoptie niet mogelijk.

Indien (niet-islamitische) buitenlanders in Marokko een (niet-islamitisch) kind willen adopteren, en volgens hun nationale rechtsstelsel(s) is hiervoor geen rechterlijke tussenkomst vereist, dan zal de adoptic op een buitenlands consulaat in Marokko kunnen plaatsvinden ${ }^{549}$. Wordt een adoptieverzoek aan de Marokkaanse rechter voorgelegd, en is volgens het toepasselijke vreemde recht de tussenkomst van de rechter vereist, dan zal de Marokkaanse rechter het verzoek kunnen afwijzen ${ }^{550}$.

545. TwK 1995-1996, 24810 (R 1577). Tevens is een wet ter uitvoering van het Adoptieverdrag in voorbereiding. TwK 1995-1996, 24811.

546. Verder kent de Marokkaanse praktijk een soort pleegouderschap, de kafâla. De kafäla is geregeld in een dahir van 10 september 1993, B.O. 15 september 1993, p. 479. Deze rechtsfiguur kan worden aangewend ten behoeve van kinderen tot 18 jaar die hetzij vondeling zijn, hetzij wees, hetzij ouders hebben die buiten hun wil niet in staat zijn de bescherming en opvoeding van de kinderen te verzekeren, hetzij gescheiden ouders hebben die de verantwoordelijkheid om het kind te beschermen en op het "juiste pad" te leiden niet op zich nemen.

547. Decroux 1963, 305; Deprez 1978, 74; Sarehane en Lahlou-Rachdi 1994, Fasc. 4, 19.

548. Decroux 1963, 306; Sarehane en Lahlou-Rachdi 1994, Fasc, 4, 19.

549. Deprez 1978, 75.

550. Deprez 1978, 75; Sarehane en Lahlou-Rachdi 1994, Fasc. 4, 10, 19. 


\section{Erkenning van buiten Marokko uitgesproken adopties}

Een in het buitenland tot stand gekomen adoptie komt in Marokko voor erkenning in aanmerking, doch nict wanneer een der adoptanten of het kind de Marokkaanse nationaliteit bezit of moslim is.

\section{VOORBEELDEN}

Een in Nederland woonachtige Nederlandse vrouw en haar Marokkaanse echtgenoot verzocken de Nederlandse rechter om de adoptie van een in Nederland woonachtig Marokkaans kind uit te spreken. De rechter heeft het verzoek toegewezen met inachtneming van uitsluitend het Nederlandse recht. De adoptie wordt in Marokko niet erkend. De man overlijdt en we nemen aan dat zijn erfopvolging wordt beheerst door Marokkaans recht. Zou het adopticfkind zijn erfgenaam zijn? Naar Marokkaans erfrecht moet sprake zijn van wettige bloedverwantschap. Zelfs als de wettige afstamming van het kind ook in het kader van de erfopvolging wordt aangenomen (middels cen zelfstandige beoordeling van de voorvraag naar de afstamming) dan nog staat het vereiste van bloedverwantschap aan erfopvolging in de weg ${ }^{551}$. De vraag naar de erfrechtelijke gevolgen van een adoptie behoort eigenlijk niet tot de voorvraag van de adoptie maar tot de hoofdvraag zelf. Een constructie waarbij de erfrechtelijke gevolgen van cen adoptie niet zonder meer worden beheerst door de erfwet maar worden gekoppeld aan de adoptie krijgt echter in de literatuur ook enige bijval. Alsdan zouden de erfrechtelijke gevolgen van de adoptic kunnen worden beoordeeld hetzij aan de hand van het recht, inclusief het conflictenrecht, van het forumland, hetzij aan de hand van het recht waarnaar de adoptie is uitgesproken ${ }^{552}$, hetzij aan de hand van het recht dat de erfopvolging beheerst. In de onderhavige casus zouden de eerste twee mogelijkheden tot hetzelfde resultaat Ieiden: de adoptic heeft tot gevolg dat adoptanten en adoptiefkind elkaars erfgenaam worden. De derde optie heeft tot gevolg dat naar Marokkaans recht moet worden beoordeeld of uit de onderhavige adoptie erfaanspraken voortvloeien. Hoewel de adoptie met wettige afstamming als gevolg in Marokko niet zou worden erkend, is het niet ondenkbaar om deze, middels een aanpassingsconstructie, te kwalificeren als een adoptie bij wijze van gratificatie (art. 83 CSPS) ${ }^{553}$. Het adoptiefkind kan dan maximaal eenderde deel van de nalatenschap ontvangen.

551. Het vereiste van bloedverwantschap zou misschien, in het bijzonder als er sprake was van een gezinsleven met de erflater, wegens strijd met de openbare orde buiten toepassing kunnen worden gelaten (hierover p. 228-229).

552. Deze opvatting lijkt te worden gehuldigd door Joppe, Vademecum 1980, 53. Schultsz 1961, 78 , betwijfelt de juistheid van een dergelijke opvatting, doch stelt op p. 80 de door hem niet beantwoorde vraag of een kind dat volgens het recht waarnaar het is geadopteerd de status van wettig kind verkrijgt. bij de toepassing van een erfwet die aan adoptiefkinderen geen erfrecht toekent, moet worden behandeld als een wettig kind of als een adoptiefkind.

553. Er is hier sprake van een materieelrechtelijke aanpassing of substitutie, Vonken, Substitutie 1992, 3-6. 


\section{§ 7. Huwelijksvermogensregime}

\section{A. HUWELIJKSVERMOGENSREGIME ALS VOORAFGAANDE VRAAG}

Indien een erflater op het tijdstip van zijn overlijden gehuwd was, kan het huwelijksvermogensregime gevolgen hebben voor de omvang van het nalatenschapsvermogen van de erflater. Ervan uitgaande dat een eventueel bestaande gemeenschap wordt ontbonden door het overlijden van de erflater, gaat de vraag naar het huwelijksvermogensrecht vooraf aan de vraag naar de erfopvolging ${ }^{554}$. Deze vraag wordt dan zelfstandig, dus aan de hand van het Nederlandse IPR, beoordeeld. Bevinden zich goederen in het buitenland, dan zal aan de hand van het IPR van het land van ligging moeten worden bekeken of het in Nederland aangewezen recht zich kan doorzetten. In deze paragraaf wordt uitsluitend ten aanzien van in Marokko gelegen vermogensbestanddelen nagegaan hoe het Marokkaanse IPR op dit punt luidt.

\section{B. NEDERI_ANDS INTIERNATIONAAL HUWELIJKSVERMOGENSRECHT}

Wanneer in Nederland moet worden bepaald welk recht het huwelijksvermogensregime beheerst kan in beginsel worden uitgegaan van de conflictregel die gold op het moment van huwelijkssluiting. Dit uitgangspunt wordt doorbroken door verwijzingsregels waaraan terugwerkende kracht is toegekend. In Nederland hebben sinds het begin van deze ceuw een aantal conflictregels gegolden: de verwijzingsregels uit het Haags Huwelijksgevolgenverdrag van $1905^{555}$ (tot 23 augustus 1977); voor huwelijken die niet onder het Verdrag van 1905 vielen, de ongeschreven verwijzingsregel zoals deze was geformuleerd in het Clemens-Klein-arrest ${ }^{556}$, welke verwijzingsregel vanaf de jaren zestig aan betekenis heeft ingeboct; na 10 december 1976, de verwijzingsregel uit het Chelouche van Leer-arrest ${ }^{557}$ (tot 1 september 1992); en vanaf 1 september 1992 de verwij-

554. Erfrecht en huwelijksvermogensrecht kunnen niet altijd worden geschejden. In sommige rechtsstelsels is de huwelijksvermogensrechelijke positie bij het overlijden van een der echtgenoten geregeld in het erfrecht, of in de erfrechtelijke positie van de langstlevende echtgenoot kan zijn voorzien in de regeling van het huwelijksgoederenrecht. Ook kan een beschikken bij uiterste wil door een derde ten behoeve van een der echtgenoten gevolgen hebben voor het huwelijksvermogen. Zie over deze laatste problematiek bijvoorbeeld Hof Amsterdam 21 november 1991, NIPR 1992, 57, warover Joppe 1988, 647-648. In dergelijke gevallen zal een aanpassing plaatsvinden. Veruer kan nog worden gewezen op de samenloop van erfrecht en huwelijksvermogensrecht als in huwelijkse voorwaarden een erfrechtelijke making is opgenomen, en deze making moet worden gekwalificeerd (zie Joppe, Rechtspraakoverzicht 1980), 228).

555. Verdrag betreffende de wetsconflicten met betrekking tot de gevolgen van het huwelijk ten opzichte van de rechten en verplichtingen der echtgenoten in hun persoonlijke betrekkingen en ten opzichte van hun goederen, 's-Gravenhage 17 juli 1905, Stb. 1912, 285. In werking getreden voor Nederland op 23 augustus 1912.

556. HR 17 mei 1929, NJ 1929, 1279.

557. HR 10 december 1976, NJ 1977, 275. 
zingsregels uit het Haags Huwelijksvermogensverdrag van $1978^{558}$ en de Wet conflictenrecht huwelijksvermogensregime (WCHv) ${ }^{559}$.

Het huwelijksvermogensregime in een huwelijk tussen echtgenoten die ten tijde van de huwelijkssluiting beiden de Marokkaanse nationaliteit bezaten wordt, behoudens de gevallen waarin een rechtskeuze (hierover later meer) is gedaan, in beginsel beheerst door Marokkaans recht. Indien het echtpaar na de huwelijkssluiting meer dan tien jaar gewone verblijfplaats in Nederland heeft gehad en het huwelijk is gesloten na 1 september 1992, dan zal, behoudens een gedane rechtskeuze of gemaakte huwelijkse voorwaarden, na deze tien jaar het Nederlandse huwelijksvermogensrecht (in beginsel zonder terugwerkende kracht) van toepassing zijn (art. 7 lid 2 sub 2 en 8 Haags Huwelijksvermogensverdrag 1978).

Bezat slechts één van de echtgenoten ten tijde van de huwelijkssluiting de Marokkaanse nationaliteit dan zal, behoudens de gevallen waarin een rechtskeuze is gedaan, veelal het huwelijksvermogensrecht van het land van het eerste huwelijksdomicilie c.q. het recht van het eerste gemeenschappelijk gewone verblijfland van toepassing zijn. Dit zal niet het geval behoeven te zijn in de volgende omstandigheden:

het huwelijk valt onder het toepassingsgebied van het Haags Huwelijksgevolgenverdrag van 1905. Dan is immers in de regel het nationale recht van de man toepasselijk. Het zal niet vaak voorkomen dat een gemengd huwelijk waarbij een der echtgenoten de Marokkaanse nationaliteit bezit onder de werking van dit Verdrag valt. Een huwelijk valt onder het toepassingsbereik van het Verdrag van 1905 indien aan drie voorwaarden is voldaan: 1) het huwelijk is gesloten vóor 23 augustus $1977^{5(x)}$;2) de art. 2 tot en met 9 van het Verdrag moeten verwijzen naar het recht van een Verdragstaat. Bij ontbreken van huwelijkse voorwaarden betekent dit dat de man de nationaliteit van een Verdragsluitende Staat moet bezitten. Marokko was geen partij bij het Verdrag. Dit Verdrag zal derhalve niet van toepassing zijn als de man de Marokkaanse nationaliteit bezit. Bezit de vrouw de Marokkaanse nationaliteit, dan moet de man de nationaliteit van een Verdragstaat bezitten; 3) het moet niet zo zijn dat het huwelijk waarbij een eigen onderdaan is betrokken geen verband houdt met een der andere Verdragstaten door de plaats van huwelijksvoltrekking of nationaliteit der echtgenoten vóór of na de huwelijks-

558. Verdrag inzake het recht dat van toepassing is op het huwelijksvermogensregime, 's-Gravenhage 14 maart 1978. Trb. 1988, 130. Voor Nederland in werking getreden op 1 september 1992.

559. Wet van 20 november 1991 , houdende regeling van het conflictenrecht inzake het huwelijksvermogensregime en de vermogensrechtelijke betrekkingen van de echtgenoten ten opzichte van derden, mede in verband met de bekrachtiging van het op 14 maar 1978 ie 's-Gravenhage tot stand gekomen Verdrag inzake het recht dat van toepassing is op het huwelijksvermogensregime, Stb. 1991, 628, inwerkingtreding: 1 september 1992.

560. De datum waarop het Verdrag van 1905 voor Nederland buiten werking is getreden, Trb. 1977, 59. De conflictregels uit het Verdrag dienen ook ná de buitenwerkingtreding ervan te worden toegepast op huwelijken die tijojens de gelding van het Verdrag zijn gesloten, HR 27 maart 1981, NJ 1981, 335. 
sluiting ${ }^{561}$. Bezit de man de Nederlandse nationaliteit dan zal voor de toepasselijkheid van het Verdrag van 1905 veelal vereist zijn dat het huwelijk is voltrokken in een andere Verdragstaat;

- bij huwelijken die niet vallen onder het toepassingsbereik van het Verdrag van 1905, als er geen eerste huwelijksdomicilie respectievelijk eerste gemeenschappelijk gewone verblijfland is. Alsdan is toepasselijk het recht waarmee de nauwste verbondenheid bestaat (verwijzingsregel uit het Cheouche van Leer-arrest dan wel art. 4 Huwelijksvermogensverdrag 1978);

indien het echtpaar na het huwelijk meer dan tien jaar gewone verblijfplaats in Nederland heeft gehad en het huwelijk is gesloten na 1 september 1992, dan zal, behoudens een gedane rechtskeuze of gemaakte huwelijkse voorwaarden, na deze tien jaar het Nederlandse huwelijksvermogensrecht (in beginsel zonder terugwerkende kracht) van toepassing zijn ongeacht aan welk recht het huwelijksvermogensregime voor die tijd was onderworpen (art. 7 en 8 Haags Huwelijksvermogensverdrag 1978);

het huwelijk valt in beginsel onder de in het Chelouche van I-eer-arrest geformuleerde verwijzingsregel, maar er zijn gronden voor het toepassen van een conflictenrechtelijke dan wel matericelrechtelijke correctie. In het arrest van 7 april 1989 (Sabah) ${ }^{562}$, kent de Hoge Raad aan de verwijzingsregel uit het Chelouche van Leer-arrest terugwerkende kracht toe. De Hoge Raad formuleerde een algemene uitzondering op de toepasselijkheid van de verwijzingsregel uit het Chelouche van Leer-arrest: bijzondere omstandigheden kunnen aanleiding geven om van de in het Chelouche van Leer-arrest gegeven verwijzingsregel af te wijken. Van dergelijke bijzondere omstandigheden zou, aldus de Hoge Raad, met name sprake zijn "indien blijkt dat de echtgenoten op goede gronden (bijvoorbeeld ingewonnen advies) zijn uitgegaan van andere collisieregels inzake het huwelijksvermogensregime dan die van voormeld arrest, dientengevolge hebben aangenomen en redelijkerwijs hebben mogen aannemen dat hun huwelijksvermogensregime werd beheerst door een ander recht dan daarop ingevolge de in dat arrest geformuleerde regels van toepassing zou zijn, en hun vermogensrechtelijke voorzieningen op dat recht hebben afgestemd". Aangenomen werd nu dat de onaanvaardbaarheidsexceptie uit het Chelouche van Leer-arrest was opgegaan in de Sabah-exceptie. Enkele jaren na het Sabah-arrest echter deed de Hoge Raad een uitspraak waarin hij de in het Sabah-arrest geformuleerde uitzondering niet toepast hoewel aan alle voorwaarden die hierin worden gesteld leek te zijn voldaan (Zimbabwe of Rhodesiëarrest ${ }^{563}$. De Hoge Raad koos in dit arrest niet voor een conflictenrechtelijke maar voor een materieelrechtelijke correctie. In de literatuur werd deze redeneer- 
wijze fel bekritiseerd ${ }^{564}$. In welke omstandigheden een correctie op de Chelouche van Leer-verwijzingsregel, hetzij matericelrechtelijk hetzij conflictenrechtelijk, kan worden aangenomen is nu niet meer duidelijk ${ }^{565}$. Uit de rechtspraak van de Hoge Raad ${ }^{5(x)}$ blijkt dat in gevallen waarin de echtgenoten worden overvallen door een (Nederlandse) gemeenschap van goederen, de Hoge Raad bereid is te onderzocken of er ruimte is voor een correctic op de Chelouche van Lecr-verwijzingsregel.

\section{Rechtskeuze}

Is door de echtgenoten vóór of staande het huwelijk een recht aangewezen dat hun huwelijksvermogensregime beheerst, dan geldt het volgende: een rechtskeuze die is uitgebracht na 1 september 1992 en die beantwoordt aan de vereisten van art. 3 of 6 en art. 13 Haags Huwelijksvermogensverdrag 1978 is geldig en bepaalt het toepasselijke recht (art. 21 Huwelijksvermogensverdrag en art. 12 lid 3 WCHv). Een rechtskeuze welke is gedaan vóó 1 september 1992 kan niet als ongeldig worden beschouwd op de enkele grond dat de wet een zodanige aanwijzing toen niet regelde (art. $13 \mathrm{WCHv}$ ). Dit geldt niet voor een rechtskeuze die is gedaan vóór 23 augustus 1977 door echtgenoten of aanstaande echtgenoten wier huwelijk viel onder het Haags Huwelijksverdrag van $1905^{567}$ (art. $13 \mathrm{WCHv}$ ).

564. Th.M. de Boer 1994, 617-619; Th.M. de Boer in zijn noot bij het Hong Kong-arrest, HR 16 september 1994, NJ 1995, 169; Hensen, Internationaal privaatrecht 1993, 148; ten Woide 1994, 120. Ook Strikwerda kiest in zijn conclusie voor het Zimbabwe-arrest in verband met de internationaliteit van het geval niet voor een materieelrechtelijke maar voor een conflictenrechtelijke correctie.

565. Joppe 1995, 295, is van mening dat uit het Zimbabwe-arrest de conclusie kan worden getrokken dat de Sabah-exceptie niet meer als een algemene exceptie kan gelden. Daarentegen lijkt wel weer ruimte te worden geboden voor de Chelouche van Leer-exceptie (aldus ook Strikwerda in zijn conclusie voor het Hong Kong-arrest). in zijn noot bij het Hong Kong-arrest geeft de Boer aan dat de zienswijze van de Hoge Raad in het Zimbabwe-arrest erop duidt "dat de Hoge Raad de conflictenrechtelijke exceptie(s) reserveert voor gevallen waarin echtgenoten zich geconfronteerd zien met een ander huwelijksvermogensregime dan waarin zij meenden gehuwd te zijn, (1) hetzij omdat zij zich niet bewust waren van een wijziging in het Nederlandse conflictenrecht (...), (2) hetzij omdat zij zich om andere redenen een verkeerde voorstelling van het toepasselijke recht en het tussen hen geldende regime hebben gemaakt (bijvoorbeeld omdat zij uitgingen van een buitenlandse conflictregel), terwijl het door de Nederlandse conflictregel aangewezen recht (...) geen mogelijkheden kent om het materiële resultaat te corrigeren." In het cerste geval zou gebruik kunnen worden gemaakt van de Sabah-exceptie; in het tweede geval van de Chelouche van Leer-exceptie. Volgens de Boer zou de Hong Kong beslissing suggereren dat er voor een beroep op de Chelouche van Leer-exceptie nog plaats is indien de Nederlandse conflictregel verwijst naar een wettelijk stelsel waarmee geen van beide echtgenoten, gelet op ieders nationaliteit en/of woonplaats vóór het huwelijk, bekend was.

566. Chelouche van Leer-arrest, Sabah-arrest, Zimbabwe-arrest en Hong Kong-arrest.

567. Onder het Haags Huwelijksgevolgenverdrag bestond een beperkte mogelijkheid tot het doen van een rechtskeuze voor een recht dat de gevolgen van de huwelijkse voorwarden beheerst. 


\section{Näherberechigung en retorsie}

In de WCHv is een regeling opgenomen voor gevallen van Näherberechtigung (art. 6 WCHv). Deze luidt: "Heeft een der echtgenoten, door de toepassing op een buitenlands gelegen vermogensbestandjeel van een krachtens het internationaal privaatrecht van het land van ligging aangewezen recht, ten opzichte van de andere echtgenoot een voordeel genoten dat hem niet zou zijn toegekomen indien het op grond van de bepalingen van het in artikel I van deze wet vermelde Verdrag aangewezen recht zou zijn toegepast, dan kan die andere echtgenoot daarvan verrekening of vergoeding vorderen bij de in verband met de beëindiging of wijziging van het huwelijksvermogensregime tussen de echtgenoten plaats vindende afrekening". Vóó l september 1992 bestond geen geschreven regeling voor verrekening in geval van Näherberechtigung. In de praktijk gold echter reeds wel de verrekeningsmogelijkheid ${ }^{568}$.

\section{Rechtsbetrekkingen met derden}

Aspecten die de rechtsbetrekkingen met derden betreffen worden voor huwelijken die zijn gesloten na 1 september 1992 geregeld in art. 8 lid 2 en art. 9 van het Verdrag en de art. 3 tot en met 5 , en art. 7 WCHv ${ }^{569}$. Vóór 1 september 1992 was de derdenbescherming niet geregeld. In de literatuur wordt ervoor gepleit de art. 3 tot en met 5 WCHv met terugwerkende kracht toe te passen, ook op onder het commune IPR gesloten huwelijken, en in ieder geval op rechtshandelingen die na de inwerkingtreding van de WCHv zijn aangegaan ${ }^{570}$.

\section{MAROKKAANS INTERNATIONAAL HUWELIJKSVERMOGENSRECHT}

In de DCC worden onderscheiden de gevallen waarin een "contrat de mariage" (huwelijksovereenkomst, "huwelijkse voorwaarden") is overeengekomen (art. 12 en 14) en gevallen waarin een huwelijksovereenkomst ontbreekt (art. 15) ${ }^{571}$. Is er een huwelijksovereenkomst, dan wordt de formele geldigheid hiervan beoordeeld aan de hand van het nationale recht van ieder der echtgenoten ten tijde van het sluiten van het contract (art. 12 DCC). De innerlijke geldigheid en de gevolgen van de huwelijksovereenkomst worden beheerst door het nationale recht van de man ten tijde van de huwelijksvoltrekking, wanneer de overeenkomst vóór (of ten tijde van) de huwelijksvoltrekking is gesloten, en door het nationale recht van beide echtgenoten wanneer de huwelijksovereenkomst tijdens het huwelijk is gesloten (art. 14 lid 1 DCC). Wanneer een der echtge-

568. Joppe 1990, 71; Joppe, losbladige PFR, Titel 7: Huwelijksvermogensrecht, IPR, 464

569. De derdenbescherming bij huishoudelijke schulden en rechtshandelingen waarvoor toestemming van de andere echtgenoot nodig is, vallen niet onder het huwelijksvermogensrecht. Hiervoor gelden de art. 2 en 3 Wet conflictenrecht huwelijksbetrekkingen, WCHb.

570. Joppe 1990, 71; Joppe, losbladige PFR, Titel 7: Huwelijksvernogensrecht, IPR, 219-220.

571. De art. 12, 14 en 15 zijn letterlijk overgenomen uit het Haags Huwelijksgevolgenverdrag van 1905. Dit Verdrag, dat op 23 augustus 1912 in werking trad, werd overigens door Frankrijk reeds met ingang van 23 augustus 1917 opgezegd. 
noten moslim is worden de gevolgen beheerst door het Marokkaanse recht ${ }^{572}$. Het recht dat de innerlijke geldigheid en gevolgen beheerst beslist eveneens of en in welke mate de echtgenoten de vrijheid bezitten om in de huwelijkse voorwaarden een rechtskeuze te doen. De aangewezen wet bepaalt dan de gevolgen van de huwelijkse voorwaarden (art. 14 lid 2 DCC). Wanneer een der echtgenoten moslim is kunnen zij geen rechtskeuze uitbrengen voor een vreemd recht. Bij het ontbreken van een huwelijksovereenkomst wordt het huwelijksgoederenregime beheerst door het interne nationale recht van de man ten tijde van de huwelijksvoltrekking. Zowel roerende als onroerende goederen zijn onderworpen aan deze regel. Het nationale recht van de man ten tijde van de huwelijksvoltrekking blijft van toepassing ook als de man nadien van nationaliteit verandert, of als het nationale recht nadien verandert ${ }^{573}$. De Marokkaanse rechter dient de verwijzingsregel van art. 15 toe te passen ongeacht waar het huwelijk is gesloten ${ }^{574}$. Wanneer een der echtgenoten moslim is wordt het huwelijksvermogensregime beheerst door het Marokkaanse recht ${ }^{575}$.

\section{VOORBEELDEN}

\section{Voorbeeld 1}

Een Marokkaans echtpaar dat in Marokko is gehuwd, is direct na de huwelijkssluiting naar Nederland gekomen. In Nederland wordt bij huwelijkse voorwaarden het Nederlands recht - gemeenschap van goederen - aangewezen als toepasselijk recht op het huwelijksvermogensregime. De rechtskeuze kan in het kader van het Nederlandse IPR worden geaccepteerd. Tijdens het huwelijk wordt door de man een huis in Nederland gekocht. Ander vermogen van enige betekenis is er niet. Uit het huwelijk zijn twee kinderen geboren. Wanneer de man of vrouw overlijdt wordt de huwelijksgoederengemeenschap ontbonden. Bij toepassing van het Marokkaanse erfrecht in Nederland dient crvan te worden uitgegaan dat slechts de helft van (de waarde van) het huis tot het nalatenschapsvermogen behoort. Deze helft wordt verdeeld onder de erfgenamen (langstlevende echtgenoot, kinderen en eventuele andere erfgenamen). De andere helft valt buiten het nalatenschapsvermogen en is eigendom van de langstlevende echtgenoot. Zou het huis in Marokko zijn gelegen, dan kan men te maken krijgen met Näherberechtigung. Op grond van het Marokkaanse IPR zou de rechtskcuze voor Nederlands recht niet worden geaccepteerd, en zou Marokkaans recht het huwelijksgoederenregime beheersen. Het huis zou volledig eigendom zijn van de man. De vrouw die hierdoor wordt benadeeld heeft een verrekeningsrecht (art. $6 \mathrm{WCHv}$ ). Bij het overlijden van de man zou zij dit verrekeningsrecht hebben plus haar aandeel in de erfenis.

572. Sarehane en Lahlou-Rachdi 1994, Fasc. 4, 16.

573. Decroux 1963, 205-206; Sarchane en Lahlou-Rachdi 1994, Fasc. 4, 15.

574. Decroux 1963, 208-210; Sarehane en Lahlou-Rachdi 1994, Fasc. 4, 15. In de lagere rechtspraak treft men wel de opvatting aan dat an. 15 DCC alleen van toepassing is indien het huwelijk in Marokko is gesloten of het eerste huwelijksdomicilie zich in Marokko bevindt. Een dergelijke opvatting wordt door de tekst van art. 15 echter niet gerechtvaardigd, aldus Sarehane en Lahlou-Rachdi 1994, Fasc. 4, 15.

575. Sarehane en Lahlou-Rachdi 1994, Fasc. 4, 16. 


\section{Voorbeeld 2}

Een Marokkaanse man en een Nederlandse vrouw zijn in Nederland in 1979 gehuwd. Er zijn geen huwelijkse voorwaarden gemaakt. Het eerste huwelijksdomicilie bevindt zich in Nederland. De man overlijdt. Als hoofdregel geldt de verwijzingsregel uit het Chelouche van Leer-arrest. Er is geen aaniciding om hiervan af te wijken. Nu noch een rechtskeuze is gedaan noch sprake is van een gemeenschappelijke nationaliteit, wordt het huwelijksvermogensregime beheerst door Nederlands recht. Er is sprake van een gemeenschap van goederen. Deze gemeenschap wordt door de dood van de man ontbonden. Slechts de helft van deze gemeenschap behoort tot het nalatenschapsvermogen van de man. De andere helft behoort toe aan de Nederlandse echtgenote. Zou het (huwelijks)vermogen geheel of gedechelijk in Marokko zijn gelegen, dan krijgt men met Näherberechtigung te maken. In dat geval zou de echtgenoot die door het Marokkaanse huwelijksvermogensregime wordt benadeeld een vordering tot verrekening hebben (art. 6 WCHv). 
Hoofdstuk 6

\section{De openbare orde}

\section{$\S$ 1. Inleiding}

De toepassing van vreemd recht kan achterwege blijven als deze leidt tot onverenigbaarheid met de Nederlandse openbare orde. Het Erfrechtverdrag, waarvan de bepalingen omtrent het toc tc passen recht in de Wet conflictenrecht erfopvolging indirect toepasselijk zijn verklaard, kent in art. 18 een bepaling omtrent de openbare orde. Volgens art. 18 van het Erfrechtverdrag kan de toepassing van een door het Verdrag aangewezen recht slechts worden geweigerd indien deze kennelijk in strijd is met de openbare orde. De exceptie van de openbare orde kan worden ingeroepen niet alleen tegen de toepasselijkheid van het door de objectieve verwijzingsregel aangewezen recht maar ook tegen het door de erflater gekozen of het overeengekomen recht. Met het begrip "kennelijk" heeft men willen aangeven dat Staten de openbare orde-exceptie niet lichtvaardig kunnen gebruiken ${ }^{576}$. Een ruim gebruik van art. 18 zou immers de doelstellingen van het Verdrag frustreren ${ }^{577}$. Ook de Nederlandse wetgever onderstreept de grote terughoudendheid die bij art. 18 in acht moet worden genomen: "Het Verdrag gaat immers uit van de toelaatbaarheid van de tocpassing van vreemd recht, en daarmee van regels van erfrecht die van de Nederlandse afwijken" ${ }^{578}$. Art. 18 verwijst naar de openbare orde van het forumland. Ieder land kan dit begrip op eigen wijze invullen. In paragraaf 2 wordt een korte uiteenzetting gegeven van het internationaal privaatrechtelijke openbare orde begrip in Nederland in het algemeen. Wat deze kan betekenen bij de toepasselijkheid van Marokkaans erfrecht, wordt met name in paragraaf 3 uiteengezet.

576. Waters, Explanatory Repor 1988, par. 121.

577. Waters, Explanatory Report 1988, par. 121.

578. Vaste Commissie van Justitie, TwK 1995-1996, 23 857, 7, p. 13. 


\section{$\S 2$. De openbare orde}

\section{A. BEGRIPSOMSCHRIJVING}

Ter onderscheiding van het interne of nationale openbare orde begrip duidt men de openbare orde in het IPR wel aan als de internationale openbare orde. Met dit begrip wordt hier dan niet gedoeld op de volkenrechtelijke openbare orde, waarvoor eveneens het begrip internationale openbare orde wordt gebruikt, maar op de openbare orde die geldt voor internationaal privaatrechtelijke rechtsverhoudingen. Deze openbare orde wordt per land ingekleurd. Het spreekt welhaast vanzelf dat aan het begrip openbare orde geen vastomlijnde betekenis kan worden gegeven. Slechts in globale bewoordingen kan worden aangegeven wat hieronder moet worden verstaan. Het moet hierbij gaan om fundamentele beginselen ofwel grondslagen van de Nederlandse rechtsorde ${ }^{579}$, beginselen die aan het Nederlandse positieve recht ten grondslag liggen ${ }^{580}$. Hierbij kan het gaan om geschreven en ongeschreven, en om nationale of internationale beginselen.

De openbare orde kan in het IPR verschillende functies vervullen. De cerste twee functies vervult zij in het conflictenrecht bij de vraag naar het toe te passen recht. Het betreft hier de openbare orde in positieve zin en de openbare orde in negatieve zin. Een derde functie vervult de openbare orde bij de vraag naar de erkenning van in het buitenland tot stand gekomen of beëindigde rechtsverhoudingen en van buitenlandse rechterlijke beslissingen. Het is de tweede betekenis die in dit hoofdstuk centraal staat: de openbare orde in negatieve zin die een rol kan spelen bij de vraag naar de doorzetting van het aangewezen vreemde recht. Het door een verwijzingsregel aangewezen toepasselijke recht wordt dan niet toegepast indien en voorzover er sprake is van kennelijke strijd met de Nederlandse openbare orde. In dit verband wordt gesproken van de exceptie van de openbare orde.

\section{B. DE EXCEPTIE VAN DE OPENBARE ORDE}

De exceptie van de openbare orde kan worden ingeroepen indien de toepassing van vreemd recht in strijd komt met de openbare orde. Voor het inroepen van de exceptie van de openbare orde moet het door de verwijzingsregel aangewezen recht het recht van een vreemde Staat zijn. De toepassing van dit recht moet in strijd zijn met een fundamenteel beginsel van de Nederlandse rechtsorde, en er moet sprake zijn van voldoende betrokkenheid met de Nederlandse rechtssfeer ("Binnenbeziehung"). Art. 18 van het Erfrechtverdrag verlangt voorts dat er sprake is van kennelijke strijd met de Nederlandse

579. Strikwerda 1995, 76.

580. Voor een bespreking van de openbare orde kan worden verwezen naar de diverse IPR-handboeken, zoals van Brakel 1953, 83 c.v.; Hijmans 1937, 209 e.v.; Kosters/Dubbink 1962, 327 e.v.; Lemaire 1968, 390 e.v.: Strikwerda 1995, 75 e.v., en voorts in het bijzonder naar Kollewijn 1917. 
openbare orde. Tot slot is het wenselijk als de exceptie van de openbare orde alleen wordt ingeroepen wanneer dit in de gegeven omstandigheden gerechtvaardigd is gezien de in het geding zijnde belangen. Aan de exceptie van de openbare orde kunnen op deze manier verschillende aspecten worden onderscheiden, die hieronder achtereenvolgens nader zullen worden bekeken.

\section{Toepasselijkheid van vreemd recht}

De exceptie van de openbare orde kan pas ter sprake komen wanneer aan de hand van de verwijzingsregel is vastgesteld dat een vreemd rechtsstelsel de rechtsverhouding beheerst. Alsdan kan strijd met de openbare orde tot gevolg hebben dat het aangewezen recht geheel of gedeeltelijk buiten toepassing moet blijven. De openbare orde speelt in deze visie dus geen rol bij het toepassen van de verwijzingsregel zelf, noch geeft de openbare orde zelf aan op welke wijze een eventueel ontstane leemte moet worden ingevuld.

\section{Fundamentele rechtsbeginselen}

\section{Nationale fundamentele rechtsbeginselen}

Voor nationale normen en waarden geldt dat in algemene zin geen kenmerken kunnen worden gegeven om vast te stellen of zij fundamenteel zijn. De in de Grondwet neergelegde beginselen zullen veelal een dergelijk karakter bezitten. Verder is in de rechtspraak van de Hoge Raad aan enkele Nederlandse nationale beginselen of regels een fundamentele betekenis toegekend in die zin dat een schending ervan als een inbreuk op de Nederlandse openbare orde wordt aangemerkt (bijvoorbeeld in art. 1:33 BW). Voor het overige kan alleen worden afgegaan op een heersende rechtsovertuiging, waarvoor aanwijzingen kunnen worden gevonden in literatuur, rechtspraak, gewoonten en dergelijke.

\section{Internationale fundamentele rechtsbeginselen}

Bij de vraag naar internationale fundamentele rechtsbeginselen kan in ieder geval gedacht worden aan mensenrechten. Een grote rol kan ook worden toegekend aan geschreven of ongeschreven rechtsbeginselen die aan de formulering van mensenrechten ten grondslag liggen, welke soms zijn te vinden in de preambules bij Verdragen, en aan andere volkenrechtelijke normen. Een aantal fundamentele rechten is neergelegd in Verdragen. Gaat het om mensenrechten dic in internationaal verband zijn geformuleerd, dan betreft het internationale normen, volkenrechtelijke normen die, indien Nederland partij is bii het desbetreffende Verdrag en het om rechtstreeks werkende bepalingen gaat, ook tot regels van de nationale Nederlandse rechtsorde behoren. Enkele internationaal aarivaarde menseniechten hebben in het Nederlandse IPR expliciete erkenning gekregen. Zo worden w'egens strijd met de openbare orde in Nederland geen huwelijken voltrokken als de vrije toestemming van een der aanstaande echtgenoten ontbreekt of als de aanstaande echtgenoten de leeftijd van vijftien jaren nog niet hebben bereikt (art. 
3 Wet conflictenrecht huwelijk) ${ }^{581}$. Mensenrechten zijn vaak gebaseerd op of geven uiting aan rechtsbeginselen met een hoog "ethisch" gehalte ${ }^{582}$. Wanneer bij de toepassing van vreemd recht cen mensenrecht wordt geschonden bestaat er om deze reden reeds aanleiding te onderzoeken of de openbare orde in het geding is ${ }^{583}$. Het is dan vooral het in een mensenrecht besloten beginsel dat in het kader van de openbare orde een rol speelt.

\section{Strijd met een fundamenteel rechtsbeginsel}

Als wordt vastgesteld dat vreemd recht de rechtsverhouding beheerst en bij de toepassing hiervan rechtsbeginselen dreigen te worden veronachtzaamd, is er aanleiding om te onderzocken of de Nederlandse openbare orde in het geding is. De toepassing van vreemd recht kan op twee manieren leiden tot strijd met de openbare orde. De eerste is dat de inhoud of strekking van het als toepasselijk aangewezen vreemde recht op zichzelf reeds, dus ongeacht de omstandigheden van het geval, in strijd komt met de Nederlandse openbare orde. In de literatuur wordt in dit verband ook wel gesproken over het buitengrenscriterium ${ }^{584}$ of van cen beoordeling in abstracto ${ }^{585}$. De tweede is dat de resultaten van tocpassing van het vreemde recht in strijd met de Nederlandse openbare orde komen. Hier spreckt men wel van het binnengrenscriterium of een beoordeling in concreto: vreemd recht wordt niet alleen op inhoud of strekking beoordeeld, maar het gaat juist om de vraag of de toepassing van het vreemde recht in een concreet geval strijd met de openbare orde oplevert.

\section{Inhoud of strekking van vreemd recht is in strijd met de openbare orde}

Om te kunnen bepalen of het vreemde recht enkel op grond van zijn inhoud of strekking reeds in strijd met de Nederlandse openbare orde komt, behoeft enkel de inhoud of strekking van het vreemde recht te worden onderzocht. Niet van belang is of de Nederlandse rechtssfeer bij de rechtsverhouding betrokken is, noch spelen de concrete omstandigheden van het geval een rol. De inhoud of strekking van het vreemde recht is op zichzelf reeds onaanvaardbaar.

581. Vergelijk de an. 1 en 2 van het Verdrag inzake de huwelijkstoestemming, de leeftijd waarop een huwelijk mag worden aangegaan en de registratie van huwelijken, New York 1962, Trb. 1964, 55. alsmede art. 16 lid 2 Universele Verklaring van de Rechten van de Mens.

582. Verheul $1978,10-11$.

583. Goldman 1969, 455 geeft in dit verband aan dat zeker de mensenrechtenbepalingen die direct tot doel hebben de bescherming van individuele rechten uitermate geschikt zijn om de inhoud van de IPRopenbare orde te ontwikkelen. Kort na de vaststelling van de Universele Verklaring van de Rechten van de Mens in 1948, wees Lerebours-Pigeonnière 1950, 255-270, i.h.b. 270, reeds op het belang van de internationaal aanvaarde mensenrechten voor de nationale IPR-openbare orde.

584. Kosters/Dubbink 1962, 344-345; Strikwerda 1995, 76-78.

585. Kokkini-Iatridou en Boele-Woelki 1992, 503-504. 


\section{Toepassing van vreemd recht is in strijd met de openbare orde}

In het merendeel van de gevallen waarin de openbare orde een rol speelt gaat het om de vraag of de toepassing van het vreemde recht in Nederland aanvaardbaar is. Toepassing van vreemd recht moet in de concrete omstandigheden leiden tot onaanvaardbare resultaten. Hoewel de inhoud of strekking van het vreemde recht zelf in theorie niet strijdig behoeft te zijn met Nederlandse normen en waarden, zal in de praktijk de inhoud en strekking van het vreemde recht veelal bepalend zijn.

Om te beginnen zal een afwijking van een Nederlandse norm, en wel van een fundamentele Nederlandse norm worden geconstateerd. De neiging om bij een voldoende betrokkenheid van de Nederlandse rechtssfeer de openbare orde-exceptie te gaan inroepen zal groot zijn. Enige waakzaamheid is echter geboden. De vreemde regel die in strijd is met cen Nederlands fundamenteel beginsel maakt onderdeel uit van een geheel van regels en kan niet los worden gezien van de (rechts)cultuur van het land waarbinnen zij geldt. Het kan zijn dat de regel kan worden gerechtvaardigd door de ruimere context van regels uit hetzelfde rechtsstelsel. Zo is het bijvoorbeeld denkbaar dat het geheel ontbreken van een recht op alimentatie van een gewezen echtgenoot, binnen datzelfde buitenlandse rechtsstelsel wordt gecompenseerd door een regeling in het huwelijksvermogensrecht. Er kan alleen dan een afwijking van de Nederlandse openbare orde worden aangenomen indien ofwel de vreemde regel met inachtneming van het geheel van regels waarvan zij deel uitmaakt, nog steeds afwijkt van de Nederlandse norm, ofwel indien de compenserende regels uit het vreemde recht krachtens de Nederlandse verwijzingsregel niet van toepassing zijn. In het laatste geval kan overigens via aanpassing worden voorkomen dat uitsluitend de met de openbare orde strijdige regels toepasselijk zijn. De aanpassing kan hicruit bestaan dat of wel beide onderwerpen bij een van de twee van toepassing zijnde verwijzingsregels worden ondergebracht of worden ondergebracht in een nieuwe verwijzingsregel (conflictenrechtelijke correctie), ofwel dat de verwijzingsresultaten worden aangepast (materieelrechtelijke correctie) ${ }^{586}$. Regels kunnen ook hun rechtvaardiging vinden in de maatschappelijke context, de cultuur waarvoor zij geschreven zijn. Indien dergelijke regels in Nederland zouden moeten worden toegepast, verandert de maatschappelijke context. De in de vreemde maatschappelijke context gelegen rechtvaardiging is dan niet meer automatisch aanwezig. Nagegaan zal moeten worden of de in het buitenland bestaande rechtvaardiging voor de regels ook in de Nederlandse maatschappij aanvaardbaar is.

\section{Binnenbeziehung}

Indien toepassing van vreemd recht reeds op grond van zijn onaanvaardbare inhoud achterwege behoort te blijven, behoeft niet te worden onderzocht of het geval voldoende aanknopingspunten met de Nederlandse rechtssfeer heeft. De vreemde regel komt dan al niet door het buitengrenscriterium heen. Indien echter toepassing van het vreemde recht op grond van zijn toepassingsresultaten in Nederland leidt tot strijd met fundamen- 
tele Nederlandse beginselen, dan wordt een betrokkenheid met de Nederlandse rechtssfeer wel verlangd. Naarmate de betrokkenheid met de Nederlandse rechtssfeer geringer is (en de verbondenheid met het vreemde land essentiëler is), is er minder reden om het vreemde recht buiten toepassing te laten ${ }^{587}$. Anderzijds geldt dat naarmate de geschonden norm fundamenteler is en aan een handhaving ervan meer waarde wordt gehecht, een geringere betrokkenheid van de Nederlandse rechtssfeer zal kunnen worden verlangd ${ }^{588}$.

\section{Belangenafweging}

Is er, wanneer er sprake is van strijd met een fundamenteel rechtsbeginsel, nog ruimte voor een belangenafweging? Kunnen de belangen dic de verwijzingsregel beoogt te dienen of andere (fundamentele) belangen nog van invloed zijn op de beslissing of de openbare orde-exceptic al dan niet zal worden ingeroepen? Ik zou deze vraag bevestigend willen beantwoorden. Enerzijds kunnen er belangen in het geding zijn die bij de "crkenning" van het beginsel niet in ogenschouw zijn genomen. Anderzijds is er in de regel ruimte voor een beperking van het beginsel op grond van de bescherming van zwaarwegendere belangen (of beginselen). Wel geldt ook hier dat naarmate het geschonden beginsel fundamenteler is, hieraan in de belangenafweging een zwaarder gewicht wordt toegekend.

\section{GEVOlgen VAN EEN BEROEP OP DE EXCEPTIE VAN DE OPENBARE ORDE}

Met het buiten toepassing laten van een bepaling uit het vreemde recht wegens strijd met de openbare orde is nog geen antwoord gegeven op de vraag welke regel dan wél moet worden toegepast. Er kunnen verschillende situaties worden onderscheiden:

1. slechts die bepalingen uit het vreemde recht waarvan de toepassing strijd oplevert met de openbare orde blijven buiten toepassing. Voor het overige blijft het vreemde recht gehandhaafd. Ontstaat er door het buiten toepassing laten van vreemde regels een leemte, dan moet deze worden ingevuld;

2. de bepalingen uit het vreemde recht waarvan de toepassing strijd oplevert met de openbare orde zijn zo nauw verbonden of vertonen een zodanige samenhang met andere bepalingen uit het vreemde recht dat het vreemde recht in gekorte vorm bezwaarlijk meer kan worden toegepast. Het in beginsel toepasselijke vreemde recht blijft in zijn geheel (of voor een groter gedeelte) buiten toepassing. Er moet worden vastgesteld welk recht dan van toepassing is;

3. het in beginsel toepasselijke vreemde recht blijft geheel wegens strijd met de openbare orde buiten toepassing. Ook hier moet worden vastgesteld welk recht de rechtsverhouding dan beheerst. 


\section{Vreemd recht blijft gedeettelijk buiten toepassing}

Indien door het buiten tocpassing laten van een of meerdere regels uit het vreemde recht geen leemte ontstaat, behoeft geen nadere voorziening getroffen te worden. Het vreemde recht wordt in gekorte vorm toegepast. Vaak zal door het buiten toepassing laten van cen of meerdere regels wel een lecmte ontstaan. Deze leemte dient te worden ingevuld. De vraag is op welke wijze dit dient te geschieden. In de literatuur is men vrijwel unaniem van mening dat het niet gerechtvaardigd is aan te nemen dat deze leemte zonder meer door de lex fori moet worden ingevuld ${ }^{589}$. Over de vraag hoe de leemte dan wel moet worden ingevuld lopen de meningen enigszins uiteen. Een enkele auteur geeft aan dat eerst moet worden gekeken of er Nederlandse regels van openbare orde in positieve zin zijn ${ }^{50)}$. Dit is in zoverre juist dat regels van Nederlandse openbare orde in positieve zin tot resultaat kunnen hebben dat de leemte wordt opgevuld, maar deze regels zetten zich altijd door ongeacht het tocpasselijke recht, dus ook ongeacht of er door het buiten toepassing laten van vreemde regels een leemte ontstaat of niet. In de literatuur overheerst de opvatting dat bij het ontstaan van een leemte binnen het toepasselijke vreemde recht zelf naar een mogelijke oplossing moet worden gezocht ${ }^{591}$. De inbreuk op het vreemde recht dient immers zo beperkt mogelijk te blijven. Te verwachten is echter dat in het vreemde recht niet vaak een oplossing gevonden zal worden. De volgens het vreemde recht toepasselijke regel blijft immers buiten toepassing. Het vreemde recht zou dan een alternatieve regel of een andere toepasselijke niet met de openbare orde strijdige regel moeten bevatten. Indien in het vreemde recht geen afdoende oplossing kan worden gevonden, zijn er verschillende mogelijkheden om de lecmte op te vullen. Kollewijn gaf in zijn beroemde werk uit 1917 aan dat de zedelijkheidseisen waaraan het vreemde recht had moeten voldoen tevens de oplossing moeten geven ${ }^{592}$. Deze benaderingswijze is $\mathrm{m} . \mathrm{i}$. de meest zuivere. Indien de toepassing van cen regel uit een vreemd rechtsstelsel waarin aan iemand een bepaald recht wordt geweigerd buiten toepassing blijft wegens strijd met een Nederlands fundamenteel rechtsbeginsel, zal ditzelfde rechtsbeginsel doorgaans verlangen dat aan de betrokkene dit recht wel wordt toegekend ${ }^{593}$. Niettemin worden door latere schrijvers andere benaderingswijzen verdedigd. Zo komt men de opvatting tegen dat moet worden gezocht naar het recht dat het beste past bij de concrete omstandigheden en de daarin gelegen

589. O.m. van Brakel 1953, 95; Hijmans 1937, 211; Kollewijn 1917, 74-75; Kosters/Dubbink 1962, 350; Lemaire 1968, 397. Volgens Hijmans zou het accepteren van de regel dat een leemte die ontstaat door het buiten toepassing laten van vreemd recht wordt opgevuld door de lex fori neerkomen op de verouderde opvatting dat de toepassing van vreemd recht als uitzondering wordt beschouwd, Hijmans 1937 , 235.

590. Van Brakel 1953, 96: Kosters/Dubbink 1962, 350.

591. Van Brakel 1953, 97; Kosters/Dubbink 1962, 350; Lemaire 1968, 397; ten Wolde 1996, 100. Een enkele keer wordt in een Nederlandse conflictregel zelf al rekening gehouden met een mogelijk onaanvaardbaar resultaat. Zo kent het Alimentatieverdrag van 1973 alternatieve conflictregels als het in eerste instantie aangewezen recht aan de onderhoudsgerechtigde geen onderhoudsaanspraken toekent.

592. Kollewijn 1917, 75.

593. Zie in deze zin bijvoorbeekl Pres. Rechtbank 's-Hentogenbosch 24 oktober 1991, NIPR 1992, 81. 
aanknopingspunten van het internationale geval ${ }^{594}$, of dat de lex fori moet worden toegepast ${ }^{595}$. Uit de weinige rechtspraak die hierover bestaat is ook geen zekerheid te verkrijgen.

Soms kan het invullen van een leemte met behulp van een regel of beginsel uit een ander rechtsstelsel tot gevolg hebben dat toepassing van de nog wel toepasselijke bepalingen uit het vreemde recht tot een resultaat leidt dat door de vreemde regel niet is gewild. Het kan wenselijk zijn dat het materiële resultaat wordt aangepast. In extreme gevallen zal dit tot gevolg kunnen hebben dat het toepasselijke buitenlandse rechtsstelsel met de voor haar wezensvreemde elementen bezwaarlijk nog kan worden toegepast.

\section{Vreend recht blijft geheel buiten toepassing}

Blijft vreemd recht in zijn geheel buiten toepassing, dan zal een ander rechtsstelsel als toepasselijk moeten worden aangewezen. De conflictregel is uitgewerkt en geeft, behalve wanneer zij een facultatief samengestelde aanknopingsfactor bevat, geen alternatief. De rechtstoepasser zal hier zelf recht moeten vinden. Een grondslag waarop hij zich kan baseren ontbreekt. Verschillende alternatieven zijn denkbaar: er kan worden teruggevallen op de lex fori, er kan worden aangesloten bij het recht van de Staat van de nauwste verbondenheid, of er wordt van een andere aanknopingsfactor uitgegaan. Voor dit laatste zou met name gekozen kunnen worden wanneer er reden is de effectiviteit van het in de verwijzingsregel geldende aanknopingspunt te relativeren.

\section{§ 3. Marokkaans erfrecht en de openbare orde}

\section{A. INLEIDING}

Het Marokkaanse familie- en erfrecht is, zoals in het tweede hoofdstuk werd aangegeven, een getrouwe weergave van het islamitische recht in zijn malikitische versie. Bij de totstandkoming van de Mudawwanah werd slechts op een gering aantal punten van het malikitische recht afgeweken. In 1993 zijn op het gebied van het familierecht, met name ter verbetering van de positic van de vrouw, enkele hervormingen doorgevoerd ${ }^{59}$. De wijzigingen hebben geen betrekking op het erfrecht. Op dit gebied zijn voorlopig geen hervormingen te verwachten. Het streven van een aanzienlijk aantal Marokkanen naar een juridische gelijkheid van man en vrouw geldt weliswaar algemeen, maar een gelijke positie van man en vrouw in het erfrecht lijkt vooralsnog,

594. Vgl. Hijmans 1937, 211, 235.

595. Kosters/Dubbink 1962, 350-351; Lemaire 1968, 397. Aldus ook Rechtbank Breda 9 juni 1992, NIPR 1993, 412. Zie ook noot 610 .

596. Dahir van 10 september $1993, n^{\circ} 1.93 .347$ tot wijziging van enkele bepalingen uit de Code de statut personnel. Zie voor hervormingen terzake voorzieningen bij huwelijksontbinding voorts dahir van 10 september 1993, $\mathrm{n}^{\circ} 1.93 .346$ tot wijziging van enkele bepalingen uit de Code de procédure civile. Voor een bespreking van de wijzigingen zie men Buskens 1995, 59-96; Jordens-Cotran 1993, 211-217. 
om in de woorden van Moulay R'chid te spreken, een utopie ${ }^{597}$. Een belangrijke oorzaak hiervoor lijkt te zijn dat de erfrechtelijke positie van de vrouw in de praktijk vaak nog slechter is dan in de Mudawwanah ${ }^{598}$. Teneinde vermogen binnen de familie te houden kunnen allerlei middelen worden aangewend om de vrouw haar aanspraken te ontnemen ${ }^{5(x)}$. Er kan een hubus worden gevestigd ten behoeve van mannelijke afstammelingen, vermogen kan tijdens het leven worden weggeschorken, de vrouw kan onder druk afstand van haar aanspraken doen. Het doen van schenkingen tijdens leven of het vestigen van een hubus is extra aantrekkelijk omdat het Marokkaanse erfrecht geen inbrengverplichting kent. Op deze wijze zouden overigens ook vrouwelijke erfgenamen kunnen worden bevoordeeld. Een andere factor die aan een hervorming van het erfrecht in de weg staat is het religieuze karakter van dit recht. In landen waar het islamitische recht het geldende recht is wordt het religieuze karakter ervan immers nog vaak als argument gebruikt tegen een aanpassing van het recht aan maatschappelijke ontwikkelingen. Het Nederlandse erfrecht daarentegen is mensenwerk. Het recht kan zich gemakkelijker aanpassen aan maatschappelijke ontwikkelingen en aan hetgeen in de maatschappij als rechtvaardig wordt beschouwd.

Het Marokkaanse erfrecht verschilt niet alleen qua systeem van het Nederlandse erfrecht, maar ook de uitgangspunten waarop de regels zijn gebaseerd, wijken vaak af van de gedachten die aan het Nederlandse erfrecht ten grondslag liggen. Hierdoor wijken de regels ook inhoudelijk sterk af van de Nederlandse. Het inroepen van de exceptie van de openbare orde zal mogelijk zijn wanneer het Marokkaanse recht of de toepassing ervan in strijd komt met fundamentele beginselen van de Nederlandse rechtsorde. Er is ecn aantal beginselen waarmee het Marokkaanse erfrecht op gespannen voet staat. Deze beginselen zouden kunnen worden onderscheiden in algemene beginselen, in het bijzonder het verbod van discriminatie naar geslacht, godsdienst en geboorte $(\$ 1$ tot en met $\S 3$ ), en beginselen die specifiek voor het (Nederlandse) erfrecht gelden $\$ 4)$.

Een aantal van deze beginselen is te vinden in mensenrechtenverdragen. In verband met het familie- en erfrecht kan in het bijzonder worden gewezen op het Europees Verdrag tot bescherming van de Rechten van de Mens en de fundamentele vrijheden (EVRM), het Internationaal Verdrag inzake burgerrechten en politieke rechten (IVBPR), het Verdrag inzake de uitbanning van alle vormen van discriminatie van Vrouwen (Vrouwenverdrag), en het Verdrag inzake de Rechten van het Kind. Marokko is partij bij het IVBPR ${ }^{600}$, bij het Vrouwenverdrag ${ }^{61}$, en bij het Verdrag inzake de Rechten van

597. Moulay R'chid 1985, 470: "Réformer dans le contexte actuel le droit positif dans ce sens est chimérique".

598. Janous 1981, 125-127: Modisk-Touiti 1987, 100-101: Moulay R'chid 1985, 466-769.

599. Zic p. 25-26. Voor Marokko, zie ook: Chafi 1989, 211 en de op deze pagina in noot 41 aangehaalde literatuur.

600. Ratificatie: 3 mei 1979.

601. Toetreding: 21 juni 1993. 
het Kind ${ }^{(2) 2}$. Bij het IVBPR zijn door Marokko geen voorbehouden gemaakt. Bij het Vrouwenverdrag zijn voorbehouden gemaakt bij art. 9 lid 2 (gelijke rechten van vrouwen en mannen wat de nationaliteit van hun kinderen betreft), ant. 16 (gelijke rechten van yrouwen en mannen inzake huwelijk en familiebetrekkingen), en art. 29 lid 1 (arbitrage). Tevens heeft Marokko verklaard slechts bereid te zijn art. 2 van het Vrouwenverdrag toe te passen voorzover de hierin genoemde voorzieningen niet in strijd met de sharî $a$ komen, alsmede verklaard zich aan art. 15 lid 4 alleen gebonden te achten voorzover de hicrin opgenomen voorziening, in het bijzonder die met betrekking tot het recht van de vrouw haar woonplaats te kiezen, niet onverenigbaar is met de art. 34 en 36 CSPS $^{(x) 3}$. Wat het Verdrag inzake de Rechten van het Kind betreft, is uitsluitend cen voorbehoud gemaakt bij art. 14. In Marokko is niet uitdrukkelijk gekozen voor het monistische stelsel waarin het internationale recht voorrang heeft boven het nationale recht. Wel wordt in de preambule bij de herziene Grondwet van 1992 de gebondenheid van Marokko aan universeel aanvaarde mensenrechten bevestigd. Voor zover deze mensenrechten echter onverenigbaar zijn met de shari ${ }^{\prime} a$, is deze gebondenheid niet vanzelfsprekend nu de shari 'a van openbare orde wordt geacht en in art. 6 van de Grondwet wordt bepaald dat de Islam de Staatsgodsdienst is. De hierboven genoemde voorbehouden bij mensenrechtenverdragen zijn door Marokko gemaakt met een beroep op de shari'a. Hicrmee wordt door Marokko prioriteit verleend aan het islamitische recht. De islamitische openbare orde, gecombineerd met de grote waarde die wordt gehecht aan de soevereiniteit van de Staat, vormen een obstakel voor een volledige verwezenlijking van de internationaal aanvaarde mensenrechten in Marokko ${ }^{64}$.

\section{Onderscheid naar geslacht}

\section{a. Gelijkheidsbeginsel: verbod van discriminatie naar geslacht}

Het Marokkaanse erfrecht bevat meerdere regels die direct of indirect onderscheid maken tussen de erfaanspraken van mannen en vrouwen. Het beginsel van gelijkheid tussen man en vrouw is in Nederland cen fundamenteel beginsel. Ook bij de toepasselijkheid van een buitenlands rechtsstelsel dient dit beginsel in acht te worden genomen ${ }^{605}$. Een algemeen verbod van discriminatie naar geslacht is neergelegd in de Grondwet (art. 1) en in Verdragen (zoals art. 26 IVBPR, het Vrouwenverdrag, en in verband met andere verdragsbepalingen, in art. 14 EVRM en in art. 2 IVESCR), alsme-

602. Ratificatie: 21 juni 1993.

603. Voor de bezwaren die Nederland heeft geuit tegen de door Marokko afgelegde verklaringen en gemakkte voorbehouden, zij verwezen naar p. 271.

604. Ihraï 1994, 206.

605. In dit verband kan worden gewezen op de parlementaire geschiedenis bij de totstandkoming van de Wet conflictenrecht huwelijksbetrekkingen. Hierin werd aangegeven dat buitenlandse regelingen waarin vrouwen worden gediscrimineerd wegens strijd met grondrechten en mensenrechten, en mitsdien ook wegens strijd met de openbare orde, buiten toepassing behoren te worden gelaten, TwK 1991-1992, 21328,9, p. 4 (nota naar aanleiding van het eindverslag). 
de in art. 2 Universele Verklaring van de Rechten van de Mens. Een verbod van discriminatic naar geslacht ten aanzien van kinderen is neergelegd in art. 2 Verdrag inzake de Rechten van het Kind. Een verbod van discriminatic tussen echtgenoten is te vinden in art. 16 lid 1 Universele Verklaring van de Rechten van de Mens, art. 5 Zevende Protocol EVRM, en in art. 23 lid 4 IVBPR. Ook binnen de lidstaten van de Raad van Europa wordt aan het gelijkheidsbeginsel grote betekenis toegekend. Dit blijkt onder meer uit de rechtspraak van het Europese Hof voor de Rechten van de Mens (EHRM) met betrekking tot art. 14 EVRM waarin het Hof aangeeft dat "It can be said that the advancement of the equality of the sexes is today a major goal in the member States of the Council of Europe. This means that very weighty reasons would have to be advanced before a difference of treatment on the ground of sex could be regarded as compatible with the Convention" ${ }^{6 x}$. Er is geen bepaling waarin het recht van erfopvolging zonder onderscheid naar geslacht met zoveel woorden wordt toegekend. Naast de verboden van discriminatie naar geslacht kunnen ook houvast bieden de rechten die samenhangen met het recht op respect voor het gezinsleven ex art. 8 EVRM ten aanzien waarvan volgens art. 14 EVRM niet mag worden gediscrimineerd naar geslacht, art. 23 IVBPR, en het eigendomsrecht, in algemene zin neergelegd in art. 17 Universele Verklaring van de Rechten van de Mens, art. 1 Eerste Protocol EVRM, het gelijke recht van echtgenoten om eigendom te verwerven in art. 16 lid 1 aanhef en sub h Vrouwenverdrag, en het recht van echtgenoten op gelijke rechten en verantwoordelijkheden van civielrechtelijke aard ingevolge art. 5 Zevende Protocol EVRM. Dit protocol is door Nederland wel ondertekend, zodat een zekere reflexwerking van de bepaling mogelijk is, doch niet geratificeerd. Dubbink heeft in 1992 de Nederlandse regering geadviseerd om niet tot ratificatie ervan over te gaan ${ }^{607}$. De mogelijkheid om de toepassing van de regels uit het Marokkaanse erfrecht die onderscheid maken naar geslacht rechtstreeks te toetsen aan verdragsbepalingen wordt besproken in paragraaf 4 van dit hoofdstuk. De algemene discriminatieverboden strekken zich in beginsel ook tot het erfrecht uit. Dat betekent dat wanneer in het erfrecht op enigerlei wijze onderscheid wordt gemaakt naar geslacht, er in beginsel sprake is van een schending van het verbod onderscheid te maken naar geslacht, tenzij voor het maken van het onderscheid een rechivaardiging bestaat. Steeds zal dus moeten worden onderzocht of een dergelijke rechtvaardiging aanwezig is. De discriminatieverboden waarop slechts een beroep kan worden gedaan in combinatie met een ander beginsel gelden niet algemeen, maar strekken zich slechts uit tot de rechten of belangen die het andere beginsel beoogt te beschermen. Kunnen aan dat andere beginsel erfaanspraken worden ontleend, dan mag op grond van het discriminatieverbod geen onderscheid worden gemaakt in erfaanspraken, tenzij hiervoor een rechtvaardiging bestaat.

Het maken van onderscheid naar geslacht in het erfrecht wordt in de doctrine regelmatig genoemd als voorbeeld bij uitstek van een geval waarin sprake is van strijd met de

606. EHRM 28 mei 1985, Publ. EHRM Serie A vol. 94, Abdulazziz, Cabales and Balkandali, par. 78.

607. Het advies is gepubliceerd in NJCM 1995, 439-461. 
Nederlandse openbare orde ${ }^{(1) x}$. Niet zelden wordt hierbij verwezen naar het islamitische erfrecht, of zelfs specifick naar het Marokkaanse erfrecht ${ }^{6 * 0)}$. In de Nederlandse rechtspraak zijn opvallend weinig uitspraken te vinden waarin vreemd recht wegens strijd met het gelijkheidsbeginsel in strijd met de openbare orde werd geacht ${ }^{610}$. Een blik in enkele andere West-Europese landen leert dat ook daar de toepassing van vreemd recht dat discrimineert naar geslacht wegens strijd met de openbare orde buiten toepassing kan worden gelaten ${ }^{611}$.

\section{b. Is het Marokkaanse erfrecht in strijd met het verbod van discriminatie naar geslacht?}

Het Marokkaanse erfrecht maakt op verschillende punten onderscheid tussen de positie van de vrouw en die van de man. Een van de meest in het oog springende regels is die waarin wordt bepaald dat de erfportie van de vrouw slechts de helft is van die van de man die in gelijke graad en rang tot de erflater staat. Deze regel is op verschillende plaatsen in de Marokkaanse wet terug te vinden. Ten eerste bij de vrouwelijke koranische crfgenamen die door middel van $t a$ 'sîb (conversie) 'asaba-erfgenamen worden (art. 248) en alsdan slechts aanspraak maken op een erfportie die de helft is van de erfportie van de mannelijke erfgenaam. Dit geldt voor de dochter als er een zoon is, de zoonsdochter als er een zoonszoon is, voor iedere verdere generatie dochters in de agnatische

608. Dubbink 1996, 54-55; Joppe, Vademecum 1980, 19; Westbroek 1990, 92, 149; ten Wolde 1996, 100 (onder voorbehoud van de concrete omstandigheden van het geval).

609. Cohen Henriquez, Vervreemding 1989, 550; Hensen 1989, 112; Hensen, Marokkaanse erflaters 1993 , 8.

610. Een voorbeeld van een geval uit de rechtspraak warin het Marokkaanse echtscheidingsrech wegens strijd met het gelijkheidsbeginsel tussen man en vrouw buiten toepassing werd gelaten is de uitspraak van de Rechtbank Breda9 juni 1992, NIPR 1993, 412 (In beroep volgde het Hof 's-Hertogenbosch overigens een andere weg om tot toepassing van Nederlands recht te komen).

611. Het maken van onderscheid nar geslacht wordt in het algemeen strijdig met de Franse openbare orde geacht, Audit 1991, 260). Het maken van onderscheid naar geslacht in het erfrecht wordt in strijd geacht met de Franse openbare orde, Boulanger 1981, 120, en 132 waar wordt aangegeven dat het weinig twijfel lijdt dat een erfrecht dat onderscheid maakt tussen de erfaanspraken van de echtgenoot en echtgenote in strijd met de Franse openbare orde is. Ferid-Firsching, Internationales Erbrecht, p. 13. Het maken van onderscheid in het islamitische erfrecht naar geslacht wordi ook strijdig geacht met de Duitse openbare orde, Krüger 1992, 121, waar hij aangeeft dat wanneer de vrouwelijke erfgenamen in Duitsland leven of er op andere wijze sprake is van voldoende "Binnenbeziehung", de islamitische regel die vrouwen discrimineert strijd oplever met de Duitse openbare orde. Ter ondersteuning van zijn opvatting verwijst hij naar IPG $1983, n^{\circ} 32 \mathrm{en} \mathrm{IPG} \mathrm{1987-88,} \mathrm{n}^{\circ} 43$, maar geeft overigens aan dat hierover nog niet in hoogste instantie is beslist. Ook Lorenz 1993, 148 e.v. acht hier strijd met de openbare orde aanwezig. Pauli onderscheidt twee categorieën: de eerste categorie betreft de ongelijke positie van de weduwe en weduwnaar. Hier neemt hij een hypothetisch ongelijke behandeling aan, aangezien de echtgenote en echtgenoot niet gelijktijdig in de nalatenschap kunnen opkomen. In concreto is er volgens hem dan geen sprake van een discriminerend toepassingsresultaat. Toepassing van de Marokkaanse regels ten aanzien van de langstlevende echtgenoot acht hij derhalve niet bezwaarlijk en niet in strijd met de openbare orde, Pauli 1994, 171-174, 181. De tweede categorie betreft het maken van onderscheid naar geslacht tussen afstammelingen. Ten aanzien van deze categorie neemt Pauli wel een schending aan van de openbare orde, Pauli 1994, 170-171, 181. 
lijn als er een kleinzoon in agnatische lijn is, voor de volle zus als er een volle broer is, en voor de halfzus van vaderszijde als er een halfbroer van vaderszijde is. De regel is voorts geïncorporeerd in de koranische erfporties zelf: de erfportie van de langstlevende echtgenote is $1 / 4$ (of $1 / 8$ ), terwijl de crfportie van de langstlevende echtgenoot $1 / 2$ (of 1/4) is; de erfportie van de grootmoeder is $1 / 6$, terwijl die van de grootvader $1 / 3$ is. Dit verschil in koranische erfporties tussen man en vrouw is overigens niet gemaakt bij de halfbroer van moederszijde en de halfzus van moederszijde, die beiden in beginsel tot $1 / 6$ deel gerechtigd zijn, noch bij de erfporties van de vader en de moeder, die beiden als koranisch erfgenaam in ieder geval aanspraak maken op 1/6 deel. De vader kan, anders dan de moeder, bovendien nog erven als 'asaba-erfgenaam. Een andere regel waarin het onderscheid tussen man en vrouw tot uiting komt is de regel dat mannelijke erfgenamen de vrouwelijke erfgenamen die in een verder verwijderde verwantschapsgraad tot de crflater staan van de erfenis uitsluiten. Een uitzondering geldt voor de grootmoeder van moederszijde die niet door de vader wordt uitgesloten. Andersom worden mannelijke erfgenamen niet van de erfenis uitgesloten door een vrouwelijke erfgenaam die in een nauwere verwantschapsgraad tot de erflater staat. Ook komt het onderscheid tot uiting in het feit dat wanneer iemand nict in opgaande, neergaande of zijlinie rechtstreeks met de erflater verbonden is, hij alleen nog erfgenaam kan zijn door verwantschap via een mannelijke lijn. De enige uitzondering op deze regel betreft de grootmoeder van moederszijde. Voorts komt het onderscheid tot uiting in het verplicht testament: bij vooroverlijden van een zoon erven de kinderen van de vooroverleden zoon krachtens verplicht testament. Bij vooroverlijden van een dochter is dit niet het geval: de regeling van het verplicht testament geldt niet voor de kinderen van een vooroverleden dochter. Een volgend onderscheid dat uit de Marokkaanse wet voortvloeit is dat de kring van de mannelijke agnatische erfgenamen groter is dan de kring van de vrouwen die tot de groep koranische erfgenamen behoren. Dit heeft tot gevolg dat een mannelijk familielid wel crfgenaam kan zijn terwijl een vrouwelijk familielid die in eenzelfde verwantschapsgraad tot de erflater staat geen erfgenaam is. Zo kan een oom erfgenaam zijn, maar een tante niet. Veel van de hierboven genoemde verschillen worden veroorzaakt door het hoofdonderscheid dat in het Marokkaanse erfrecht wordt gemaakt in twee groepen erfgenamen, te weten tussen enerzijds de in graad beperkte groep koranische erfgenamen onder wie zowel mannelijke als vrouwelijke erfgenamen, en anderzijds de in graad oneindige groep van mannelijke agnatische erfgenamen. Dit hoofdonderscheid heeft tevens gevolgen voor de omvang van de erfaanspraken. Voor de koranische erfgenamen gelden vastgestelde erfporties, terwijl de agnatische erfgenamen onbeperkt in de nalatenschap kunnen delen. Bovendien leidt dit hoofdonderscheid in combinatie met andere Marokkaansrechtelijke regels, bijvoorbeeld de $t a$ 'sîb-regel, tot een ongelijke behandeling van man en vrouw.

In een aantal van deze regels wordt direct onderscheid gemaakt naar geslacht, zoals de regel dat de erfportie van een man twee keer zo groot is als die van een vrouw, en de regel dat mannelijke verwanten vrouwelijke verwanten van een verder verwijderde graad van de nalatenschap uitsluiten terwijl dit andersom niet het geval is. Sommige verschil- 
Ien tussen man en vrouw zijn het resultaat van toepassing van een regel waarin geen direct onderscheid naar geslacht wordt gemaakt, met name de "kloving" tussen koranische en 'asaba-erfgenamen, maar waarvan de toepassing leidt tot een onderscheid naar geslacht. In deze gevallen kan sprake zijn van een indirecte discriminatie.

\section{Rechtvaardiging voor het onderscheid?}

De regels waarin direct onderscheid wordt gemaakt naar geslacht zijn op zichzelf onverenigbar met het in Nederland geldende gelijkheidsbeginsel tussen rnan en vrouw. Het kan echter zijn dat de regels elders in het Marokkaanse recht worden gecompenseerd, of dat zij in Marokko hun rechtvaardiging vinden in de maatschappelijke context waarbinnen zij gelden. In het eerste geval is het van belang na te gaan of in Nederland niet alleen de regel dic onderscheid maakt van toepassing is maar ook de "compenserende" regel. Behoort de compenserende regel tot de regels van erfopvolging, dan is ook deze van tocpassing, en behoeft er geen sprake meer te zijn van strijd met het gelijkheidsbeginsel, althans bestaat er mogelijk voor de ongelijkheid een rechtvaardiging. Behoort de compenserende regel echter tot een andere verwijzingscategorie, dan hangt de toepasselijkheid hiervan af van ecn andere conflictregel. Verwijst deze ook naar Marokkaans recht, dan kan hierin de compensatic zijn gelegen. Wijst deze andere verwijzingsregel een ander dan het Marokkaanse recht als toepasselijk aan, dan kunnen ofwel beide verwijzingsregels worden doorgezet, ofwel er zou een aanpassing van de verwijzingsregels of de verwijzingsresultaten kunnen plaatsvinden. Wordt het onderscheid naar geslacht verklaard door de maatschappelijke context of rechtsopvattingen, dan zou bij de vraag naar de toepassing van de regel in Nederland moeten worden nagegaan of deze verklaring hier te lande het onderscheid naar geslacht rechtvaardigt.

Voor een juiste waardering van de Marokkaanse erfrechtelijke bepalingen waarin het onderscheid tussen mannen en vrouwen tot uiting komt, is het derhalve van belang deze in hun juridische en maatschappelijke context te bezien. De erfrechtelijke regels zijn overgenomen uit het islamitische recht. Zij zijn neergelegd in en afgeleid uit de Koran (en Hadith), en hiermee gebaseerd op de openbaringen van Allah zelf. Uitgaande van de onaantastbaarheid van Allah's wil, zou deze verklaring afdoende moeten zijn voor het gemaakte onderscheid. Niettemin hebben latere islamitische rechtsgeleerden gezocht naar een rationele verklaring. Van belang is zich te realiseren dat in de pre-islamitische tijd de vrouw in de regel helemaal geen erfrechten had. De Islam heeft in dit gewoonterecht een belangrijke verandering gebracht. Het toekennen van erfrechten aan vrouwen was in die tijd bepaald revolutionair. Hervormingsgezinde of modernistische schrijvers geven als reden hiervoor dat Mohammed zelf reeds streefde naar een meer gelijkwaardige positie van man en vrouw ${ }^{612}$. Een andere opvatting die wordt verdedigd om het erfdeel van de vrouw te verklaren is dat men aan de vrouw een soort reserve heeft willen geven voor het geval zij niet zou trouwen of bij het overlijden van haar echtge- 
noot met haar gezin onbemiddeld achter zou blijven ${ }^{6 / 3}$. Een laatste opvatting, die zeker niet als de heersende kan worden beschouwd en ook in de Marokkaanse wetgeving niet is overgenomen, is dat de regeling in de Koran waarbij ook aan vrouwen erfrechten worden toegekend niet als algemeen geldende regeling moet worden gezien maar als een regel die slechts voor uitzonderingsgevallen geldt ${ }^{614}$.

Ter verklaring van de verschillen tussen de omvang van de erfaanspraken van een man en dic van een vrouw worden verschillende argumenten aangevoerd. Uit de pre-islamitische stammenmaatschappij stam nog het niet geheel verdwenen idee dat alleen de man, vanwege zijn fysicke kracht en zijn moed, in staat en verantwoordelijk is voor de bescherming van het vermogen van de familic. Ook wordt het van belang geacht om vermogen zoveel mogelijk binnen de familie (in de mannelijke lijn) te houden, hetgeen niet is gegarandeerd als aan vrouwen erfaanspraken worden toegekend. Door een huwelijk met iemand van buiten de familie zal zij namelijk vaak tot een andere familie, de schoonfamilie, gaan behoren. Een andere reden betreft het verschil in maatschappelijke verantwoordelijkheden van de man en vrouw binnen het gezin: de man dient zijn vrouw en kinderen te onderhouden ${ }^{6.5}$. De taken van de vrouw liggen binnenshuis. Dit verschil in maatschappelijke verantwoordelijkheden uit zich ook in een verschil in financiële verantwoordelijkheden. Op de man rusten financiële verplichtingen die de vrouw niet heeft. Hierbij word gedoeld op de verplichting van de man om in het levensonderhoud te voorzien van zijn vrouw en kinderen en in de kosten van de huishouding, en op de verplichting van de man om zijn vrouw een bruidsgave te betalen ${ }^{616}$. Met name dit verschil in financiële verantwoordelijkheden wordt de laatste jaren vaak als belangrijkste argument naar voren gebracht om het verschil in erfaanspraken van man en vrouw te rechtvaardigen ${ }^{617}$.

Voor een aantal van de hier genoemde argumenten geldt dat hierin de verklaring voor het onderscheid in erfporties tussen man en vrouw gezocht wordt in de maatschappelijke context. In de Marokkaanse wetgeving wordt uitgegaan van een verschil in maatschappelijke posities: de vrouw bouwt zelf geen vermogen door arbeid op; haar taken liggen binnenshuis ${ }^{618}$. De man brengt het geld op tafel door het verrichten van arbeid

613. Kernkamp 1935, 87.

614. Powers 1986, 21-109, in het bijzonder 53-86.

615. Kernkamp 1935, 100, 107. Zie ook de oorzaken genoemd door Brugman 1969.91 en Lapanne-Joinville 1953, 4.

616. Voor een bespreking van dit argument zie Borrmans 1977, 237; Bousquet 1951, 6; Brugman 1969 , 91; Kernkamp 1935, 86, 107; Lapanne-Joinville 1953, 4; Moulay R'chid 1985, 465.

617. Uit een door Strijp verricht onderzoek naar opvattingen van Marokkanen in Nederland over de betekenis die het Marokkaanse erfrecht voor hen heeft, blijkt dat verschillende van de ondervraagden dit argument als verklaring noemen en accepteren voor de ongelijke verdeling in het Marokkaanse islamitische erfrecht tussen man en vrouw. Strijp 1997.

618. Kritisch hierover: Moulay R'chid 1986, 175-179. 
buitenshuis. Gezien de ontwikkelingen die in Marokko hebben plaatsgevonden ${ }^{619}$ snijden bovengenoemde argumenten in hun algemeenheid geen hout meer. Een aanzienlijk percentage van de Marokkaanse vrouwen heeft arbeid buitenshuis en daarmee eigen inkomsten, die zij ook besteedt aan het huishouden.

Te onderzoeken zijn dan nog de argumenten volgens welke de rechtvaardiging voor het onderscheid in het erfrecht moet worden gevonden in andere regels uit het Marokkaanse recht, in het bijzonder het huwelijksvermogensrecht en de regels betreffende financiële verplichtingen.

\section{Huwelijksvermogensrecht}

Een compensatic kan niet worden gevonden in het Marokkaanse huwelijksvermogensrecht. Het Marokkaanse recht kent geen gemeenschap van goederen. De enige bepalingen die betrekking hebben op het vermogen van echtgenoten zijn de art. 35 en 39 CSPS. Uit art. 35 aanhef en sub 4 volgt dat de vrouw het recht heeft te beschikken over haar eigen vermogen. In art. 39 wordt een regeling gegeven voor de eigendomsverdeling van roerende zaken die zich in de echtelijke woning bevinden indien de echtgenoten over de eigendom hiervan van mening verschillen, en voor de eigendomsverdeling van handelszaken.

\section{Verschil in financiële verplichtingen}

Kan een compensatic worden gevonden in de regels die alleen de man en niet de vrouw financiële verplichtingen opleggen? Onderscheiden kunnen worden de onderhoudsverplichtingen en de verplichting tot het betalen van een bruidsgave.

\section{Bruidsgave naar Marokkaans recht}

Wat de bruidsgave betreft geldt in het Marokkaanse recht dat het vaststellen hiervan bij de huwelijksovereenkomst een vereiste is voor het tot stand komen van een geldig huwelijk (art. 5 CSPS). De bruidsgave moet worden betaald door de man aan zijn echtgenote. Vaak wordt bij de huwelijkssluiting cen gedeelte van de bruidsgave betaald. De bruidsgave moet gcheel of gedeeltelijk zijn voldaan bij de consummatie van het huwelijk (art. 20 lid 2 CSPS), dat wil zeggen bij de huwelijksvoltrekking door het plaatsvinden van gemeenschap in afzondering of enkel door afzondering waarbij gemeenschap mogelijk is. De bruidsgave is volledig opeisbaar bij het overlijden van de echtgenoot of bij de consummatie van het huwelijk (art. 20 lid 3 CSPS) ${ }^{620}$. De bruidsgave kan eveneens worden gevorderd bij de ontbinding van het huwelijk (art. 22 CSPS). De omvang van de bruidsgave wordt in de huwelijksovereenkomst bepaald. $\mathrm{Zij}$ is noch aan een minimum noch aan een maximum gebonden (art. 17 lid 2). Is geen bruidsgave overeengekomen, dan heeft de vrouw recht op een bruidsgave die voor haar

619. Hierover: Moulay R'chid 1985.

620. In art. 22 CSPS worden enkele gevallen genoemd waarin de vrouw geen recht heeft op, of slechts recht heeft op de helft van de bruidsgave. 
passend is. Passend is die bruidsgave die een vrouw van haar sociale klasse, leeftijd, schoonheid, afkomst en dergelijke normaliter zou krijgen ${ }^{621}$. Uit art. 16 CSPS blijkt dat de bruidsgave is wat de bruidegom verschaft aan vermogensbestanddelen waaruit de wens blijkt dat hij een huwelijk wil sluiten teneinde een gezin te stichten en in een verhouding met wederzijdse liefde wil leven.

\section{Onderhoudsverplichtingen naar Marokkaans recht}

Wat de onderhoudsverplichtingen betreft geeft de Marokkaanse wet de volgende regeling: op grond van de art. $115 \mathrm{cn} 117$ CSPS is de man verplicht te voorzien in het onderhoud van zijn echtgenote. Haar recht op dit onderhoud is ook nog eens neergelegd in art. 35 lid 1 CSPS ${ }^{622}$. Dit onderhoud omvat, in billijke mate en volgens wat naar gewoonte en gebruik als noodzakelijk beschouwd wordt, huisvesting, voeding, kleding en verpleging (art. $118 \mathrm{CSPS}$, aldus ook art. 35 CSPS). Bij het bepalen van de omvang van de onderhoudsverplichting wordt rekening gehouden met de inkomsten van de echtgenoot, de omstandigheden van de echtgenote, de hoogte van de prijzen, dit alles met inachtneming van het gemiddelde (art. 119 lid 1 CSPS). Op de vrouw rust geen verplichting om in het onderhoud van haar echtgenoot te voorzien. De man is voorts op grond van de art. 124 en 126 CSPS verplicht in het levensonderhoud van zijn kinderen te voorzien. Dit onderhoud omvat onder meer voeding, kleding, huisvesting, en onderwijs, overeenkomstig de situatie van de onderhoudsplichtige en de gebruiken van de gemeenschap waarin zij leven (art. 127 CSPS). De vrouw is jegens haar kinderen pas onderhoudsplichtig als de vader niet tot onderhoud van de kinderen in staat is en de vrouw rijk is (art. 129 CSPS). Een specifieke bepaling waarin de moeder wordt verplicht in het levensonderhoud van haar kinderen te voorzien na het overlijden van de vader, ontbreekt. Het onderhoud van een dochter duurt voort totdat haar echtgenoot verplicht is in haar onderhoud te voorzien, en jegens een zoon duurt het voort totdat hij geslachtsrijp is, bij zijn volle verstand, en in staat is inkomsten te verwerven. Ook de kinderen zijn, overeenkomstig hun welvaart, jegens hun beide ouders onderhoudsplichtig (art. 124 en 125 CSPS).

Gezien deze regelingen kan worden geconcludeerd dat op de man naar Marokkaans recht inderdaad meer financiële verplichtingen rusten dan op de vrouw. De man moet aan zijn echtgenote een bruidsgave betalen. De man is verplicht in het levensonderhoud van zijn echtgenote en kinderen te voorzien. Betekent dit nu ook dat hierin een afdoende verklaring is gelegen voor het in het erfrecht gemaakte onderscheid ten aanzien van de erfporties van man en vrouw? In dit verband kan nog eens worden herhaald dat in de Marokkaanse wetgeving wordt uitgegaan van een bepaalde uit het islamitische recht

621. Zie hierover Linant de Bellefonds Tome II 1965, 213-215. Vanwege de gecompliceerde wijze waarop de omvang van de bruidsgave dan dient te worden bepaald, komt het zelden voor dat deze niet in de huwelijksovereenkomst wordt afgesproken, aldus Linant de Bellefonds Tome II 1965, 215.

622. In art. 123 en 122 lid 3 CSPC worden enkele omstandigheden genoemod waarin de onderhoudsverplichting van de man jegens zijn echtgenote kan worden opgeschort respectievelijk eindigt. 
overgenomen rolverdeling tussen man en vrouw, waardoor mede een verschil in rechtspositic is te verklaren. De reden om financiële verplichtingen op te leggen aan de man en niet aan de vrouw vloeit m.i. ongetwijfeld voort uit de gedachte dat de man degene is die inkomsten verwerft door arbeid en de vrouw haar taken binnenshuis vervult. Deze gedachte, waarin wordt uitgegaan van een patriarchale samenleving ${ }^{623}$, komt in meerdere bepalingen van de Mudawwanah tot uitdrukking: bij de rechten en plichten van de echtgenoten jegens elkaar (art. $33 \mathrm{t} / \mathrm{m} \mathrm{36}$ ); bij de regel die aan de vrouw die in het huwelijk treedt de mogelijkheid biedt om in de huwelijksovereenkomst te bedingen dat zij arbeid buitenshuis verrichten kan (art. 38) (zij heeft dit recht dus niet automa(isch); bij de onderhoudsverplichting van een vader jegens zijn dochter welke voortduurt totdat haar echtgenoot verplicht is in haar onderhoud te voorzien, terwijl deze jegens zijn zoon voortduurt totdat deze in staat is inkomsten te verwerven (art. 126 lid 2) etcetera.

Is het verschil in financiële verplichtingen hiermee een afdoende en acceptabele verklaring voor het onderscheid dat in het erfrecht wordt gemaakt tussen de erfrechten van mannen en vrouwen? Een afdoende verklaring is het in ieder geval niet ten aanzien van die vrouwen die zelf in hun levensonderhoud (en dat van haar kinderen) mocten voorzien, die geen echtgenoot noch andere familieleden (meer) hebben die juridisch verplicht kunnen worden in haar levensonderhoud te voorzien. Juist bij het wegvallen, het overlijden, van echtgenoot of vader is de kans groot dat een vrouw voor zichzelf en haar gezin zal moeten gaan zorgen. Juist dan zou zij wel behoefte hebben aan financiële middelen. Ook zullen er achtergebleven mannen zijn die geen familieleden hebben of zullen krijgen jegens wie zij financiële verplichtingen hebben. Bij de vraag of de verklaring ook een rechtvaardige is, kan men mede in beschouwing nemen de vraag of de verdeling van de onderhoudsverplichtingen wel legitiem is. Zoals eerder is vermeld, is de Marokkaanse wetgever er vanuit gegaan dat in gezinssituaties het de man is die inkomsten inbrengt. In de praktijk echter blijken veel Marokkaanse vrouwen te werken, en hun inkomsten uit arbeid, maar ook andere inkomsten, aan te wenden voor het levensonderhoud van het gezin. De Marokkaanse regeling omtrent de onderhoudsverplichtingen is in deze gevallen geen afspiegeling van de praktijk. Over de gerechtvaardigdheid van het verschil tussen man en vrouw, mede met het oog op de verdeling van de onderhoudsverplichtingen, bestaat in Marokko noch in theorie noch in de praktijk unanimiteit ${ }^{624}$. Voorts blijkt niet (expliciet) dat de Marokkaanse wetgever een koppeling heeft willen leggen tussen de financiële verplichtingen enerzijds en erfrechtaanspraken anderzijds. Zo wordt bijvoorbeeld geen verband gelegd tussen de omvang van de onderhoudsverplichtingen en bruidsgave enerzijds en de omvang van de erfdelen anderzijds. In art. 125 CSPS wordt zelfs uitdrukkelijk bepaald dat de onderhoudsplicht van kinderen jegens hun ouders niet wordt omgeslagen overeenkomstig hun erfdeel maar overeenkomstig hun welvaart. Het Marokkaanse erfrecht is een codificatie van het malikitische islamiti-

624. Voor een breed onderzoek zie Moulay R'chid 1985. 
sche familierecht, en hierbij is het onderscheid tussen man en vrouw simpelweg gehandhaafd.

Bovendien zou, zelfs als het verschil in erfaanspraken tussen man en vrouw zou kunnen worden verklaard door het verschil in financiële verplichtingen, hierop in Nederland alleen een beroep kunnen worden gedaan als het Marokkaanse recht ook op deze onderwerpen in Nederland moet worden toegepast (of erkend). Dit zou dan voor iedere erfgenaam moeten worden vastgesteld ${ }^{625}$. Op het moment van overlijden staan de onderhoudsverplichtingen dan wel onderhoudsrechten die de erfgenamen hebben of zullen krijgen lang nict altijd vast ${ }^{626}$. Of en wanneer Marokkaans recht de onderhoudsverplichtingen beheerst, zal in Nederland mocten worden beoordeeld aan de hand van de Nederlandse conflictregels ${ }^{627}$. De naar Marokkaans recht bestaande verplichting tot het betalen van een bruidsgave wordt overigens in het algemeen niet strijdig met de Nederlandse openbare orde geacht ${ }^{628}$. Evenmin pleegt men het Marokkaanse recht inzake de onderhoudsverplichtingen wegens strijd met de openbare orde buiten toepassing te laten ${ }^{629}$.

625. Aldus voor Duitsland ook: Krüger 1992, 121, waar hij stelt dat het verschil in financiële verplichtingen tussen man en vrouw in Dutsland niet kan worden aangemerkt als een geldig argument voor het onderscheid in het erfrecht, omdat dit argument in Duitsland niet opgaat.

626. Pauli neeme op grond van deze onzekerheid aan dat hierin geen rechtvaardiging kan worden gevonden voor het verschil in behandeling ussen mannelijke en vrouwelijke erfgenamen. In uitzonderlijke omstandigheden waarin de financiële verplichtingen of rechten wel vast staan, is hij van mening dat hiermee wel rekening kan worden gehouden, Pauli 1994, 174-177.

627. Wat de verplichting tot het betalen van een bruidsgave betreft rijst een kwalificatie-probleem. Wat de vermogensrechtelijke aspecten van de bruidsgave betreft zou aansluiting kunnen worden gezocht bij de verwijzingsregels inzake de huwelijksbetrekkingen, het huwelijksvermogensregime, de onderhoudsverplichtingen of de overeenkonst. Zie over dit probleem: de Groot 1979, 364-367; Hebler 1988, 9597; Heldrich 1983, 64-65. De Rechtbank 's-Gravenhage heeft in een vonnis van 24 januari 1996, NIPR 1996, 69, een overeenkomst tot het betalen van een bruidsschat, waarvan betaling was uitgesteld tot de ontbinding van het huwelijk (door echtscheiding of overlijden), gekwalificeerd als een overeenkomst tot het betalen van een bijdrage in het levensonderhoud van de vrouw.

War de onderhoudsverplichting betreft zij verwezen naar de Haagse Alimentatieverdragen. Hoofdregel ter bepaling van het toepasselijk recht is dat het recht van het land van de gewone verbliffplats van de onderhoudsgerechtigde de onderhoudsverplichting beheerst (art. 4 Alimentatieverdrag 1973). Uitvoeriger over een en ander: Rutten 1995, 145-151.

628. Zie Rb Amsterdam 27 januari 1988, NIPR 1989, 203; Rb 's-Gravenhage 10 juli 1989, NIPR 1989. 399; Kantonrechter Beetsterzwag 7 augustus 1990, NIPR 1990, 446; Rb 's-Gravenhage 24 januari 1996, NIPR 1996, 69.

629. Vergelijk bijvoorbeeld de uitspraken van Rb Breda 16 december 1988, NIPR 1989, 206 en Rb Arnhem 8 augustus 1995, NIPR 1995, 496, waarin de vraag aan de orde was of het ontbreken van een onderhoudsverplichting jegens de vrouw na een huwelijksontbinding naar Marokkaans recht van belang was voor de mogelijkheid van een gemeente om verhaal uit te oefenen op de ex-echtgenoot voor aan de vrouw verleende bijstand. In de eerste uitspraak leidde het ontbreken van een alimentatieverplichting ertoe dat ook geen bijstand kon worden verhaald; in de tweede uitspraak werd verhaal wel mogelijk geacht, waarbij de Rechtbank overwoog dat het sociaal recht hier derogeerde aan het privaatrecht. In een beslissing van 21 februari 1997. RvdW 1997, 56c, heeft de Hoge Raad overigens geaccepteerd dat 
Conclusie uit een en ander is dat de argumenten die worden aangevoerd om het onderscheid tussen man en vrouw te rechtvaardigen, in de regel in Nederland niet zullen behoeven te worden geaccepteerd.

\section{Schenkingen}

Naast de mogelijkheid dat in het recht zelf een compensatie is te vinden die de ongelijkheid in het erfrecht kan rechtvaardigen, bestaat de mogelijkheid dat de erflater zelf in de praktijk de compensatie regelt. Zo is het voor een vader mogelijk om schenkingen aan zijn dochters te doen opdat zijn vermogen na zijn overlijden, bij toepassing van het Marokkaanse erfrecht, toch gelijk onder de zonen en dochters is verdeeld. Kan een dergelijke compensatie worden geaccepteerd? Vooreerst zal dan moeten vaststaan dat de schenking niet behoeft te worden ingebracht ${ }^{630}$. Ik ben geneigd de vraag ontkennend tc beantwoorden. Zou een man namelijk aan zijn zonen schenkingen hebben gedaan, dan is van een door de vader gewenste compensatie geen sprake. Het is mocilijk denkbaar om hier, anders dan via een inbrengverplichting, niettemin tot compensatie over te gaan.

\section{c. Conclusic}

Mijn conclusie is dat voor het in het Marokkaanse erfrecht gemaakte onderscheid tussen man en vrouw onvoldoende rechtvaardiging bestaat, en derhalve dat toepassing van dit recht strijd zal opleveren met een fundamenteel beginsel van de Nederlandse rechtsorde. Zoals ik op p. 204-206 heb aangegeven, komt dit onderscheid in tal van Marokkaanse bepalingen tot uiting. Deze bepalingen of regels bezitten niet allemaal eenzelfde karakter. Sommige regels zijn direct discriminerend, andere zijn niet direct discriminerend maar de toepassing ervan leidt tot een discriminerend resultaat. Bij deze laatste regels is sprake van een indirecte discriminatie. Soms betreft de regeling een onderscheid tussen verwanten die in een zeer nabije graad tot de erflater staan, een andere keer gaat het om een onderscheid tussen verre verwanten. Ten aanzien van geen enkele van deze regels zou ik willen aannemen dat deze op zichzelf reeds zo verwerpelijk zijn dat de toepassingsresultaten ervan in concreto niet meer relevant zijn. Ik kom tot deze conclusie omdat in de vorige paragraaf slechts is onderzocht of er een objectieve rechtvaardiging voor het onderscheid bestaat en niet is gekeken naar de toepassingsresultaten. Buiten beschouwing is gelaten de vraag naar het bestaan van een subjectieve rechtvaardiging. Hiermee doel ik met name op de subjectieve wil van de erflater (en die van de nabestaanden). Indien alle erfgenamen, in overeenstemming met een veronderstelde wil van de erflater, accoord gaan met een verdeling die er bijvoorbeeld toe leidt dat zonen twee keer zoveel ontvangen als dochters, zou een enigszins terughoudende opstelling

$629, \rightarrow$

de koppeling van echtscheidingsrecht en alimentatierecht kan worden doorbroken door het uitbrengen van een keuze voor het recht dat de alimentatie beheerst.

630. Zie hierover p. 112. 
van de Nederlandse autoriteiten op zijn plaats zijn. Het gelijkheidsbeginsel dat met name dient ter bescherming van vrouwen, behoeft niet tegen de wil van de (vrouwelijke) erfgenamen aan hen te worden opgedrongen ${ }^{631}$.

Ervan uitgaande dat het Marokkaanse recht bij toetsing aan de openbare orde door het zogenaamde buitengrenscriterium heen komt, dan geldt dat naarmate het geschonden beginsel fundamenteler is, de openbare orde eerder zal kunnen worden ingeroepen, en er minder betrokkenheid met de Nederlandse rechtssfeer wordt verlangd. Naarmate het geschonden beginsel minder fundamenteel is, zal de openbare orde minder snel kunnen worden gebruikt, en zal een grotere betrokkenheid met de Nederlandse rechtssfeer mogen worden verlangd. Bij het verbod van ongelijke behandeling naar geslacht gaat het in principe om een zeer fundamenteel beginsel. De meest ernstige schending hiervan zou ik willen aannemen wanneer er een regel moet worden toegepast die direct discrimineert naar geslacht. De erflater laat bijvoorbeeld een zoon en een dochter na of een broer en een zus. De regel dat de zoon respectievelijk de broer twee keer zoveel als een dochter respectievelijk een zus krijgt is direct discriminerend. Als er sprake is van indirect discriminerende regels kunnen andere belangen ook een rol gaan spelen. Laat ik als voorbeeld nemen het in het Marokkaanse recht gemaakte onderscheid tussen koranische en 'asaba-erfgenamen. Wanneer een crflater een dochter en een broer nalaat, heeft de dochter als koranisch erfgenaam aanspraak op de ene helft van de nalatenschap en de broer, als 'asaba-erfgenaam recht op de andere helft. Zou de erflater een zoon en een broer nalaten, dan zou de gehele nalatenschap gaan naar de zoon als 'asabaerfgenaam en zou de broer niets ontvangen. Moet in het ecrste geval worden geaccepteerd dat de dochter slechts de helft krijgt, terwijl zij als zij een zoon was geweest recht op de gehele nalatenschap zou hebben gehad? Naar Marokkaans recht wordt een dochter als er ook een zoon is, geplaatst in dezelfde categorie als de zoon. Is er geen zoon, dan heeft zij een eigen positic, namelijk als koranisch erfgenaam. Op zichzelf acht ik onvoldoende reden aanwezig om een dergelijke regel principieel te verwerpen ${ }^{632}$. In een concreet geval kan dit tot gevolg hebben dat een dochter minder ontvangt dan het deel waarop zij als zoon aanspraak zou maken. Het is ook mogelijk dat zij aanspraak maakt op een groter deel dan zij als zoon zou ontvangen. Als een erflaatster haar echtgenoot, moeder en twee dochters nalaat, heeft ieder van de dochters recht op 4/13 deel van de nalatenschap. Laat zij haar echtgenoot, moeder en twee zonen na, dan heeft ieder der zonen slechts aanspraak op 7/24 deel van de nalatenschap. Moet de ongelijkheid naar geslacht steeds worden veroordeeld, ook wanneer deze zich in concreto tussen de erfge-

631. De vrouw kan verschillende redenen hebben om zich te conformeren aan de Marokkaanse islamitische regels van erfopvolging. Er kan sprake zijn van een volledig vrijwillige onderwerping aan dit recht. Het kan echter ook zijn dat de omstandigheden waarin zij verkeert haar hientoe bewegen. In de praktijk blijken vrouwen zelfs vaak afstand te doen van haar erfaanspraken, bijvoorbeeld omdat zij de loyaliteit van hun mannelijke familieleden niet willen of kunnen verliezen. Hierover van den Berg-Eldering 1978, 109; Moors 1996, 69-84; Moors 1997; Strijp 1997. Zie ook de noten 64, 65, 598 en 599.

632. Interessant is overigens dat in de Tunesische en Iraakse regelgeving een dochter wel de broers en zussen en verdere verwanten in de zijlinie van de nalatenschap uitsluit. 
namen niet manifesteert en haar grondslag niet in een direct discriminerende regel vindt? Ik zou niet willen uitsluiten dat zich gevallen kunnen voordoen waarin bij een belangenafweging aan het respect voor het Marokkaanse recht, waarin het onderscheid tussen koranische en 'asaba-erfgenamen van essentiële betekenis is, meer waarde wordt toegekend dan aan het gelijkheidsbeginsel dat zich in de concrete omstandigheid slechts indirect manifesteert. Het buiten toepassing laten van het in het Marokkaanse erfrecht gemaakte onderscheid tussen koranische en asaba-erfgenamen daar waar dit leidt tot een indirect onderscheid naar geslacht, althans de toepassing ervan zou to gevolg hebben dat aan het Marokkaanse erfrecht nauwelijks nog serieuze betekenis wordt gehecht. Het onderscheid komt niet enkel tot uiting ten aanzien van dochters en zonen, maar ook ten aanzien van kleindochters en kleinzonen, zussen en broers, en tot op zekere hoogte ten aanzien van de vader en moeder, en de grootvader en de grootmoeder. Ik zou derhalve terughoudend zijn met een verwerping van dit onderscheid.

Daar waar binnen de categorie van koranische erfgenamen onderscheid wordt gemaakt naar geslacht, zoals dit met name gebeurt ten aanzien van de echtgenote en de echtgenoot, gaat het bovenstaande niet op. Hier is m.i. namelijk wel sprake van een direct onderscheid. Ook meen ik dat het voorgaande niet opgaat voor de ongelijkheid tussen halfbroers en halfzussen van moederszijde (koranische erfgenamen) enerzijds en de halfbroers en halfzussen van vaderszijde ('asaba-erfgenamen) anderzijds, in die gevallen waarin de broers en zussen van moederszijde niet maar de broers en zussen van vaderszijde wel zouden erven en beiden in de nalatenschap opkomen.

Resumerend kan worden gezegd dat in het Marokkaanse erfrecht op een aanzienlijk aantal punten direct of indirect onderscheid wordt gemaakt naar geslacht. Een objectieve rechtvaardiging voor dit onderscheid acht ik nict aanwezig. Noch een verschil in maatschappelijke positie noch een verschil in financiële verantwoordelijkheden behoort in Nederland als rechtvaardiging te worden geaccepteerd. Niettemin is nict uitgesloten dat in concrete omstandigheden de toepassing van discriminerende regels moet worden aanvaard. Hierbij zou acht kunnen worden geslagen op de aard en strekking van de discriminerende regel. Is deze direct of indirect discriminerend? Bij een indirect onderscheid in de hierboven beschreven zin kunnen de concrete omstandigheden een grotere rol spelen en het uitgangspunt dat het vreemde recht wordt gerespecteerd een groter gewicht in de schaal leggen dan wanneer het om een direct onderscheid gaat.

\section{Onderscheid naar geboorte}

\section{a. Gelijkheidsbeginsel: verbod van discriminatie naar geboorte}

In het Marokkaanse recht kan erfopvolging op grond van bloedverwantschap alleen bestaan als er sprake is van wettige verwantschap. Het Marokkaanse erfrecht maakt hiermee wat de erfaanspraken van kinderen (en vice versa) betreft onderscheid naar geboorte. Heeft een kind de status van onwettig kind dan kan hierin naar Marokkaans 
recht geen verandering meer worden gebracht. Kan het verbod dat geen erfopvolging plaatsvindt bij onwettige afstamming worden beschouwd als een schending van een fundamenteel beginsel van de Nederlandse rechtsorde?

Ecn algemeen verbod van discriminatie naar geboorte is neergelegd in de Grondwet (art. 1) en Verdragen (art. 26 IVBPR, en, in verband met andere verdragsrechten in art. 2 Verdrag inzake de Rechten van het Kind, art. 2 en art. 24 IVBPR, art. 14 EVRM, en art. 2 IVESCR), alsmede in art. 2 Universele Verklaring van de Rechten van de Mens. Er is geen bepaling waarin het recht van erfopvolging zonder onderscheid naar geboorte met zoveel woorden wordt toegekend. De algemene discriminatieverboden dienen zich in beginsel ook tot het erfrecht uit te strekken. Dat betekent dat wanneer in het erfrecht op enigerlei wijze onderscheid wordt gemaakt naar geboorte, er in beginsel sprake is van een schending van dit verbod, tenzij voor het maken van het onderscheid een rechtvaardigingsgrond bestaat. Van groot belang zijn ook de rechten die samenhangen met het recht op respect voor het gezinsleven in de zin van art. 8 EVRM ten aanzien waarvan volgens art. 14 EVRM niet mag worden gediscrimineerd naar geboorte. Uit rechtspraak van het EHRM volgt dat aan art. 8 EVRM op zichzelf niet reeds erfaanspraken kumnen worden ontleend ${ }^{633}$. Wel geeft het Hof aan dat erfrechtelijke aangelegenheden nauw zijn verbonden met het gezinsleven. Indien tussen personen met wic de erflater een gezinsleven had onderscheid wordt gemaakt naar geboorte, kan dit een geschilpunt opleveren in verband met art. 14 bezien in samenhang met art. 8 EVRM. Als er sprake was van een gezinsleven met de erflater, levert het maken van onderscheid naar geboorte tussen de verschillende gezinsleden in beginsel een schending op van art. $14 \mathrm{j}^{\circ} 8 \mathrm{EVRM}$. Dit is niet het geval wanneer het maken van onderscheid naar geboorte gerechtvaardigd is. Na de uitspraak van het EHRM in de zaak Marckx, is in de Nederlandse wetgeving het destijds in het erfrecht nog bestaande onderscheid tussen wettige en natuurlijke - erkende - kinderen opgeheven, in die zin dat wettige en natuurlijke afstamming in het erfrecht werden gelijkgesteld. Criterium is geworden het bestaan van familierechtelijke betrekkingen (art. 4:879 BW). In art. 1:406 lid 5 BW wordt ook aan niet-erkende kinderen een zekere "erfaanspraak" jegens hun biologische vader toegekend, welke het kind kan vorderen van de erfgenamen van de vader (vergelijk ook art. 4.2A.2.5 NBW). De vraag of het onthouden van erfaanspraken wegens het ontbreken van familierechtelijke betrekkingen in strijd is met art. $14 \mathrm{j}^{\circ} 8 \mathrm{EVRM}$ als er wél sprake is van biologisch ouderschap en van een gezinsleven, is recentelijk enkele malen voorgelegd aan de Hoge Raad. In een uitspraak uit 1988 had het Gemeenschappelijk Hof van Justitie van de Nederlandse Antillen en Aruba nog beslist dat het onthouden van erfaanspraken aan een niet erkend kind dat met de erflater een gezinsleven had gehad, geen strijd opleverde met art. $14 \mathrm{j}^{\circ} 8$ EVRM $^{634}$. Het laten prevaleren van duidelijkheid boven gelijkheid vormde naar het oordeel van dit Hof een voldoende en

633. EHRM 13 juni 1979, Publ. EHRM Serie A vol. 31, Marckx. Uitvoeriger over deze uitspraak p. 261 262.

634. Gemeenschappelijk Hof van Justitie Nederlandse Antillen en Aruba 22 november 1988, NJ 1989, 566. 
objectieve rechtvaardiging voor het gemaakte onderscheid naar geboorte. Mede onder invloed van de rechtspraak van het EHRM, is door de Nederlandse rechter enkele keren impliciet gewezen op cen mogelijke onverenigbaarheid van het Nederlandse recht op dit punt met art. $14 \mathrm{j}^{\circ} 8 \mathrm{EVRM}$, doch uiteindelijk heeft de Hoge Raad geoordeeld dat het de taak van de rechter te buiten gaat om de erfrechtelijke gevolgen van een eventuele onverenigbaarheid vast te stellen ${ }^{635}$. In zijn uitspraak van $1997^{636}$ maakt de Hoge Raad duidelijk dat het uitsluiten van erfgenaamschap op de enkele grond van het onwettig karakter van de afstamming, discriminatoir zal zijn. De Hoge Raad geeft hierbij aan dat er momenteel echter wordt gewerkt aan een herziening van het afstammingsrecht waarbij ook de erfrechtelijke positie van het onwettige kind aan de orde is. Wat de afstamming betreft is hierbij van belang dat uit de rechtspraak van het EHRM ${ }^{637}$ en die van de Hoge Raad ${ }^{6.38}$ volgt dat in situatics waarin sprake is van een gezinsleven de wetgeving niet in de weg mag staan aan het vestigen van juridische afstammingsbanden. Uit de voorstellen tot herziening van het Nederlandse afstammingsrecht kan, aldus nog steeds de Hoge Raad, worden afgeleid dat het ontbreken in het Nederlandse recht van een regel dat het onwettige niet erkende kind erfgenaam van zijn verwekker is, niet enkel berust op het onwettige karakter van de afstamming, maar "op de moeilijkheid in het kader van de ondernomen wetgeving tot een verantwoorde afweging van alle bij het afstammingsrecht betrokken belangen te komen". Ook in de literatuur gaan geluiden op voor een erkenning van erfaanspraken van onwettige kinderen ${ }^{639}$. Veranderende opvattingen over het afstammingsrecht en de daaruit voortvloeiende gevolgen zullen mogelijk consequenties hebben voor de regel dat erfaanspraken alleen bestaan als er sprake is van wettige verwantschap of bij erkenning.

Een beroep op het verbod van discriminatie naar geboorte, eventueel gecombineerd met een beroep op het respect voor het gezinsleven, dient (uit zijn aard) niet alleen open te staan voor diegenen die rechtstreeks door geboorte of gezinsverband met de erflater betrokken zijn, maar ook voor degenen die door geboorte of gezinsleven zijn verbonden met een erfgenaam van de erflater ${ }^{(N)}$.

Mij zijn geen Nederlandse rechterlijke uitspraken bekend waarin buitenlands erfrecht buiten toepassing werd gelaten wegens een verboden onderscheid naar geboorte. Litera-

635. HR 24 februari 1995, NJ 1995, 468 en HR 17 januari 1997, RvdW 1997, 23 c.

636. Zie noot 635 .

637. Zie m.n. EHRM 18 december 1986, Publ. EHRM Serie A vol. 112, Johnston (waarover uitvoeriger op p. 262-263) en EHRM 27 oktober 1994, Publ. EHRM Serie A vol. 297-c, Kroon.

638. HR 18 mei 1990, NJ 1991, 374.

639. Zie m.n. J. de Boer 1991, 67-70; J. de Boer 1993, 6-7, 23; J. de Boer 1995, noot bij HR 24 februari 1995, NJ 1995, 468. Zie ook de Hondt en Holtrust 1996, 753.

640. Zie het Marckx-artest (noot 633) voor de erfopvolging ten opzichte van verwanten van moederszijde, en het arrest Vermeire (EHRM 29 oktober 1991. Publ. EHRM Serie A vol. 214-C waarover uitvoeriger op p. 264) voor de erfopvolging ten opzichte van de grootouders. 
tuur hierover is schaars ${ }^{\text {twl }}$. In enkele landen om ons heen wordt het maken van onderscheid naar geboorte in het erfrecht als strijdig met de openbare orde aangemerkt ${ }^{6+2}$.

b. Is het Marokkaanse erfrecht in strijd met het verbod van discriminatie naar geboorte?

Volgens art. 225 CSPS is bloedverwantschap een grond voor erfopvolging. Gedoeld wordt hier op de wettig erkende bloedverwantschap. Art. 228 CSPS bepaalt uitdrukkelijk dat geen erfopvolging plaatsvindt tussen iemand wiens afstamming volgens de wet niet wordt erkend, of tussen een uit ontucht geboren kind en de ontuchtige verwekker. De verwantschapsregels of afstammingsregels zijn te vinden in de hoofdstukken 1 en 2 van Bock 3 CSPS (art. $83 \mathrm{t} / \mathrm{m} \mathrm{96}$ ), waarin tevens is bepaald dat de erfopvolging is gebaseerd op wettige verwantschap (zie in het bijzonder art. 83 lid 1). Zonder wettige verwantschap is er geen erfopvolging. Bovendien kan onwettige verwantschap niet door middel van wettiging, erkenning, adoptie of anderszins tot een wettige worden gemaakt. Zolang echter niet is komen vast te staan dat het kind onwettig is, bestaan er naar Marokkaans recht nog verschillende mogelijkheden om de wettige afstamming vast te stellen ${ }^{(43}$. In de verhouding tot de moeder wordt onwettige verwantschap gelijkgesteld met wettige verwantschap (art. 83 lid 2 CSPS). Tussen een kind en zijn moeder bestaat altijd recht van erfopvolging. In de verhouding tussen vader en kind (en hun ascendenten respectievelijk descendenten) daarentegen is wettige verwantschap vereist. Mitsdien wordt in het Marokkaanse erfrecht onderscheid gemaakt naar geboo'te. Of er sprake is van wettige verwantschap is afhankelijk van de wijze waarop de voorvraag naar de afstamming in het kader van de erfopvolging wordt beoordeeld. Deze voorvraag is besproken in hoofdstuk $5 \S 5$. In de onderhavige paragraaf gaat het er uitsluitend om of het onderscheid naar geboorte strijdig moet worden geacht met een fundamenteel Nederlands rechtsbeginsel.

\section{Rechtvaardiging voor het onderscheid?}

Het verbod van erfopvolging tussen personen tussen wie geen wettige verwantschap bestaat houdt verband met de wens om vermogen binnen de wettig erkende familie te houden, en hangt hiermee direct samen met het in het islamitische en Marokkaanse recht

641. Ten Wolde geeft aan dat de erfrechtelijke discriminatie van buitenechtelijke kinderen mogelijk in strijd kan zijn met de Nederlandse openbare orde, ten Wolde 1996, 100.

642. Zie voor Duitsland: Lorenz 1993, 148. Voor Frankrijk: Boulanger 1981, 122; Ferid-Firsching, Internationales Erbrech, Frankreich, p. 13): "Seit dem G v 3.1.1972" (het tijdstip waarop de positie van huwelijkse en buitenechtelijke kinderen in het Franse erfrecht werd gelijkgesteld, SR) "erscheint es wahrscheinlich (obwohl Entscheidungen, soweit ersichtlich, noch nicht vorliegen), daßs (...) eine ausländische Regelung, die dem nichtehel Kind gar keine oder nur allzu geringe Erbrechte gewähr als mit dem franz ordre public unvereinbar angesehen wird".

643. Zie hierover p. 53-55 en, in het bijzonder voor de mogelijkheden in Nederiand, p. 165-167 en p. 177 178. 
geldende uitgangspunt dat het huwelijk ${ }^{(x+4}$ de enige relatie is waarbinnen sexuele gemeenschap gelegitimeerd is ${ }^{1+5}$. Aan onwettige verhoudingen kunnen noch rechten noch plichten worden ontleend. Ook aan het gehele familierecht ligt dit uitgangspunt ten grondslag. Naar Marokkaans recht is het in het erfrecht gemaakte onderscheid tussen wettige en onwettige kinderen hiermee genoegzaam gerechtvaardigd.

Ook in het Nederlandse stelsel van intestaat-erfopvolging is een van de uitgangspunten het vermogen van de erflater zoveel mogelijk binnen de familie te houden. Op dit punt kan derhalve moeilijk van een onverenigbaarheid met Nederlandse beginselen worden gesproken. Het is dan met name de vraag of het erkennen van het huwelijk als enige legitieme relatie waarbinnen juridisch erkende verwantschapsbanden kunnen worden gecreëerd, in Nederland acceptabel is. In dat verband is de rechtspraak van het EHRM van belang waaruit volgt dat, als er sprake is van een gezinsleven, de status van onwettige kinderen zoveel mogelijk dient te worden gelijkgesteld aan die van wettige kinderen, alsook de gewijzigde opvattingen in Nederland ten aanzien van gezinsvormen waarbinnen juridische afstammingsbanden kunnen worden gevestigd. Het aanvaarden van erfopvolging wclke is beperkt tot binnen een huwelijk ontstane verwantschapsbanden, zal in de regel een niet te aanvaarden schending van het beginsel van gelijkheid naar geboorte opleveren. In een aantal gevallen zal een handhaving van dit onderscheid bovendien niet beantwoorden aan de verwachtingen en wensen van de erflater. Gaat het bijvoorbeeld om een Marokkaanse erflater die zijn kind naar Nederlands recht heeft erkend, waardoor naar Nederlands recht familicrechtelijke betrekkingen zijn ontstaan, dan behoort hij niet vervolgens te worden achtervolgd met een rechtsstelsel waaraan hij zich niet conformeren kan.

\section{c. Conclusie}

Gezien het in Nederland geldende verbod van discriminatie naar geboorte en het respect voor het gezinsleven, en gezien de strekking van deze beginselen, zal in de regel cen rechtvaardiging ontbreken voor het in het Marokkaanse erfrecht gemaakte onderscheid naar geboorte. Wannecr er zowel sprake is van familierechtelijke betrekkingen als van een gezinsleven ${ }^{6} 6$ behoeft het onderscheid niet te worden geaccepteerd. Wanneer er sprake is noch van familierechtelijke betrekkingen noch van een gezinsleven, zal het onderscheid in beginsel kunnen worden geaccepteerd. Het toekennen van erfaanspraken enkel op grond van het bestaan van bloedverwantschap is geen beginsel van de Nederlandse rechtsorde. Is er naast bloedverwantschap sprake van bijkomende omstandighe-

644. En het concubinaat met slaven. Omdat het concubinaat met slaven een verouderd instituut is en in Marokko is afgeschaft, Sarehane 1993. Fasc. 2-2, 6, wordt hieraan verder geen aandacht besteed.

645. Volgens Lapanne-Joinville 1959,102, is de verklaring voor de erkenning van het huwelijk als enige legitieme relatie voor het hebben van sexuele gemeenschap gelegen in een patriarchale familiestructuur.

646. Als er sprake is van familierechtelijke betrekkingen zal overigens in beginsel een gezinsleven worden aangenomen, HR 22 oktober 1993, NJ 1994, 153. 
den, zoals het bestaan van ouderlijk gezag en onderhoudsverplichtingen, dan zal er m.i. slechts in uitzonderlijke omstandigheden moeten worden nagegaan of het ontbreken van familierechtelijke betrekkingen een relevante rechtvaardiging oplevert voor het onderscheid naar geboorte. Bestaan er geen familierechtelijke betrekkingen maar was er wel sprake van een gezinsleven, dan is een schending van een fundamenteel beginsel niet uitgesloten. De ontwikkelingen hebben zich op dit punt nog niet volledig uitgekristalliseerd. Schending van een fundamenteel beginsel lijkt in ieder geval te kunnen worden aangenomen als de verklaring voor een onderscheid naar geboorte enkel is gelegen in de onwettigheid van de afstamming. Welke gronden of belangen wel een rechtvaardiging zullen kunnen opleveren is nog niet duidelijk. Zijn er pogingen gedaan om familierechtelijke betrekkingen te vestigen, maar zonder succes omdat het volgens het Nederlandse IPR toepasselijke recht hieraan in de weg stond, dan zal de in het IPR geldende verwijzingsregel de rechtvaardiging voor het onderscheid kunnen vormen. Het ligt dan niet voor de hand om hiertegen de exceptic van de openbare orde in te roepen. Dat een dergelijk geval mogelijk onverenigbaar is met art. 8 EVRM zal in $\$ 4$ worden aangetoond.

\section{Onderscheid naar godsdienst}

a. Gelijkheidsbeginsel: verbod van discriminatic naar godsdienst

Het Marokkaanse erfrecht verbiedt erfopvolging tussen moslims en niet-moslims (art. 228 CSPS) en maakt hiermee onderscheid naar godsdienst. Het verbod van discriminatie naar godsdienst is een fundamenteel beginsel en als zodanig ook neergelegd in de discriminatieverboden van art. 1 Grondwet, en in Verdragen (art. 26 IVBPR, en, in verband met andere verdragsrechten in art. 14 EVRM, en art. 2 IVESCR), alsmede in art. 2 Universele Verklaring van de Rechten van de Mens. Ten aanzien van art. 14 EVRM heeft het EHRM in de zaak Hoffmann beslist dat een onderscheid dat "essentially" is gebaseerd op een verschil in godsdienst alleen, niet acceptabel is ${ }^{647}$.

In de literatuur is weinig te vinden over het maken van onderscheid naar godsdienst in het erfrecht. De enkele auteurs die zich hierover uitdrukkelijk uitlaten zijn van mening dat regels waarin een verschil in godsdienst als erfbeletsel geldt, in strijd komen met de Nederlandse openbare orde ${ }^{648}$. Dat een verschil in godsdienst als huwelijksbeletsel strijdig is met de openbare orde lijkt algemeen geaccepteerd te zijn ${ }^{649}$. Ook in andere

647. EHRM 23 juni 1993, Publ. EHRM Serie A vol. 255, par. 36. Uitvoeriger over deze uitspraak p. 269.

648. Hensen, Marokkaanse erflaters 1993, 8; Joppe, Vademecum 1980, 19; Meijers 1936, 635 (waar hij het voorbeeld aanhaalt dat iemand vanwege zijn behoren tot een geestelijke orde onbevoegd zou zijn te erven, welk erfbeletsel wegens strijd met de openbare orde niet zou behoeven te worden geaccepteerd); ten Wolde 1996, 100 (onder voorbehoud van de concrete omstandigheden van het geval).

649. Dit wordt als voorbeeld genoemd in de parlementaire geschiedenis bij art. 3 lid 2 Wet conflictenrecht huwelijk, TwK 1987-1988, 20 507, 3, p. 7. 
West-Europese landen wordt het maken van onderscheid naar godsdienst in strijd met de openbare orde bevonden ${ }^{650}$.

b. Is het Marokkaanse erfrecht in strijd met het verbod van discriminatie naar godsdienst?

Art. 228 CSPS bepaalt dat geen erfopvolging plaatsvindt tussen een moslim en een nietmoslim. Dit erfbeletsel werkt wederzijds: niet-moslims erven niet van moslims, maar moslims erven ook niet van niet-moslims.

\section{Rechtvaardiging voor het onderscheid?}

De regel dat niet-moslims niet kunnen erven van moslims is overgenomen uit het islamitische recht. De grond, en daarmee de naar Marokkaans recht bestaande rechtvaardiging voor het onderscheid is hierin gelegen dat de regels van het Marokkaanse islamitische erfrecht erop zijn gericht om vermogen binnen de mosiimgemeenschap te houden ${ }^{651}$, hetgeen met zich meebrengt dat alleen aan islamitische familieleden erfaanspraken worden toegekend. Deze gedachte komt voort uit een bepaalde vorm van loyaliteit aan de islamitische gemeenschap.

De vraag of het verschil in godsdienst als erfbeletsel kan worden geaccepteerd zal zich ten aanzien van directe verwanten in Nederland vaak voordoen bij gemengde huwelijken, huwelijken tussen moslims en niet-moslims. Bij een huwelijk tussen een Marokkaanse islamitische man en een nict-islamitische vrouw zou bij het overlijden van de man voor de vrouw cen erfbeletsel gelden. Bij een huwelijk tussen een Marokkaanse islamitische vrouw en een niet-islamitische man, zou niet alleen het huwelijk naar Marokkaans recht niet geldig zijn, maar bestaat bij het overlijden van de vrouw bovendien een erfbeletsel voor de man ${ }^{652}$.

Voor de kinderen geldt dat wanneer de afstamming vaststaat met hun islamitische vader ${ }^{653}$, zij moslim zijn (art. 83 lid 1 CSPS). Volgens het tweede lid van art. 83 kan bij onwettige afstamming het islamitisch geloof niet via de vader aan de kinderen wor-

650. Het maken van onderscheid naar godsdienst in het erfrecht wordt strijdig geacht met de Franse openbare orde, Audit 1991, 260, 263; Batiffol/Lagarde 1993, 592; Boulanger 1981, 103-104.

Ook in Duitsland wordt een dergelijk onderscheid strijdig geacht met de openbare orde: Krüger 1992 , 121. IPG 1967-1968, Nr. 59 (Köln); IPG 1983, Nr. 32 (Göttingen); Lorenz 1993, 148; OLG Hamm 29 april 1992, besproken door Dörner 1994, 33-37; Pauli 1994, 178.

651. Coulson 1971, 186.

652. De vraag naar de acceptatie van dit erfbeletsel komt in dit geval alleen op als de geldigheid van het huwelijk in het kader van de erfopvolging wordt aangenomen (of als de man tevens als neef zou kunnen erven). De geldigheid van het huwelijk wordt aangenomen als de voorvraag naar het huwelijk zelfstandig, dus naar Nederlands (conflicten)recht, wordt beoordeeld. Hierover hoofdstuk $5 \S 3$.

653. Hierover p. 53-55. 
den doorgegeven ${ }^{6.54}$. Op grond hiervan zouden kinderen die zijn geboren uit een buitenechtelijke relatie tussen een Nederlandse vrouw en een islamitische Marokkaanse man, geen moslim zijn, tenzij naar Marokkaans recht de wettige afstamming wordt vastgesteld. Onwettige afstamming wordt daarentegen ten opzichte van de moeder gelijkgesteld met een wettige afstamming, inclusief de gevolgen hiervan, dat wil zeggen inclusief het volgen in de godsdienst van de moeder ${ }^{655}{ }^{656}$.

\section{c. Conclusie}

Omdat voor het in het Marokkaanse erfrecht gemaakte onderscheid naar godsdienst naar mijn mening geen rechtvaardiging bestaat die in Nederland zou moeten worden geaccepteerd, en het verbod van discriminatie op grond van godsdienst als een fundamenteel beginsel van de Nederlandse rechtsorde geldt, zal art. 228 CSPS met een beroep op de openbare orde buiten toepassing kunnen blijven.

\section{Afwijkingen van grondslagen van het Nederlandse erfrecht}

In de vorige paragrafen is onderzocht of enkele in Nederland aanvaarde algemene fundamentele beginselen ook in het erfrecht dienen te worden gerespecteerd, en in het bijzonder bij de toepassing van het Marokkaanse erfrecht. In deze paragraaf gaat het niet alleen om de vraag of $\mathrm{en}$ in hoeverre het Marokkaanse erfrecht onverenigbaar is met algemene fundamentele beginselen, maar of het onverenigbaar is met aan het $\mathrm{Ne}$ derlandse erfrecht ten grondslag liggende uitgangspunten en beginselen, en of deze laatste van zo fundamentele aard zijn dat cen schending ervan strijd met de Nederlandse openbare orde oplevert.

Het Nederlandse erfrecht bevat wat de erfopvolging betreft voornamelijk regels van regelend recht. Dwingend zijn onder meer de bepalingen omtrent de legitieme, voorschriften betreffende fideïcommissen, en de voorwaarde dat de erfgenaam moet bestaan op het moment dat de nalatenschap openvalt. De testeervrijheid en daarmee de keuze voor regelend recht vloeien voort uit de ontwikkeling van de individuele eigendom ${ }^{657}$ : eigendom is niet langer het goed van een bepaalde gemeenschap. Een ieder heeft het

654. De Franse tekst van art. 83 is op dit punt duidelijker dan de op de Arabische tekst gebaseerde Nederlandse vertaling. De eerste zin hiervan luidt: "La filiation non légitime ne crée aucun lien de parenté vis-à-vis du père et ne produit, d'une façon générale, aucun des effets énumérés ci-dessus."

655. Ook op dit punt is de Franse tekst van art. 83 lid 2 CSPS duidelijker dan de Nederlandse vertaling. De tweede zin van dit artikellid luidt: "Par contre, cette filiation entraine vis-à-vis de la mère les mêrmes effets que la filiation légitime, en raison du lien naturel unissant l'enfant à sa mère."

656. Volgens Lapanne-Joinville, Filiation 1952, 257 zou het islamitisch geloof in de regel niet van de moeder kunnen worden verkregen. Een natuurlijk kind zou zelf voor het islamitisch geloof kunnen kiezen zodra hij het oordeel des onderscheids bezit. Art. 83 CSPS biedt voor deze opvatting geen steun.

657. Asser/van der Ploeg/Perrick 1996, 7. 
vrije genot en de vrije beschikking over zijn eigendom. Dat er toch bepalingen van dwingend recht zijn houdt verband met de bescherming van belangen die de overheid tot haar zorg rekent. Dit kunnen zijn algemene belangen of de persoonlijke belangen van erflater, en die van verwanten van de erflater en van derden. Bij de invulling van zowel het dwingend recht als het regelend recht spelen de maatschappelijke samenleving en de binnen deze samenleving bestaande rechtsopvattingen een grote rol. Centraal in het erfrecht staat het familieverband ${ }^{658}$. De erfopvolging vindt binnen de eigen kring plaats. Bij de vraag hoe deze kring wordt samengesteld en welke prioriteiten hierbinnen gelden, spelen maatschappelijke opvattingen weer een belangrijke rol ${ }^{659}$. Tegenwoordig wordt deze kring in de cerste plaats gevormd door het gezin. De ontwikkelingen ten aanzien van nieuwe gezinsvormen hebben reeds tot gevolg gehad dat wettige en natuurlijke kinderen in het erfrecht zijn gelijkgesteld. Wat de prioriteiten binnen het eigen gezin betreft hebben ook de ontwikkelingen in opvattingen over de positic van de langstlevende echtgenoot hun invloed doen gelden. In 1923 werd de langstlevende echtgenoot geplaatst in de eerste groep van erfgenamen. Tot die tijd nam deze een plaats in na de bloedverwanten in de twaalfde graad. Volgens de huidige regels is erfopvolging slechts tot en met de zesde graad mogelijk. De wetgever beraadt zich op dit moment over de wijze waarop de positie van de langstlevende echtgenoot in het versterf-erfrecht kan worden versterkt ${ }^{(x)}$.

Het Marokkaanse erfrecht bevat voornamelijk dwingend recht. De testeervrijheid is beperkt tot eenderde deel van de nalatenschap en ook binnen die testeervrijheid is men aan voorwaarden gebonden. Het Marokkaanse erfrecht is direct gebaseerd op het islamitische erfrecht. Het doordringen van maatschappelijke ontwikkelingen binnen dit op de godsdienst gebasecrde recht geschiedt slechts mondjesmaat. Bij een aanpassing van de regels aan maatschappelijke ontwikkelingen worden de religieuze uitgangspunten zoveel mogelijk gerespecteerd. In het Marokkaanse erfrecht hebben maatschappelijke ontwikkelingen, voor zover hiervan op dit terrein al sprake zou zijn, nauwelijks tot enige wijziging aanleiding gegeven. De Marokkaanse regels van erfopvolging zijn in navolging van het islamitische erfrecht cr op gericht een materiële voorziening te geven aan familieleden die met de erflater verbonden waren door wederzijdse banden en verantwoordelijkheden die zijn gebaseerd op bloedverwantschap ${ }^{(6)}$. Het vermogen dient binnen de familie (in agnatische lijn) te blijven ${ }^{62: 2}$ en wordt binnen de moslimgemeenschap gehouden. In de regels van erfopvolging wordt nog uitgegaan van een familie of gezin in ruime zin. In de loop van de tijd heeft het begrip "gezin" of "familie" een ontwikkeling doorgemaakt, en is vaak niet langer sprake van een "extended family" maar van

658. Asser/van der Ploeg/Perrick 1996, 7.

659. Asser/van der Ploeg/Perrick 1996, 7-9.

660. TwK 24665.

661. Coulson 1971, 1 .

662. Coulson 1983, 26. 
een "nuclear family" ${ }^{x}, 3$. Anders dan in het Nederlandse erfrecht waar het gezin centraal staat, is dit in het Marokkaanse recht de familie, de moslimfamilie. Voorts staat het huwelijk centraal. Van een ontwikkeling waarbij naast het huwelijk andere samenlevingsvormen worden getolereerd is geen sprake. In het versterf-erfrecht is geen plaats om rekening te houden met de wil van de crflater, als men al niet is uitgegaan van een veronderstelde wil van iedere Marokkaan zich te conformeren aan de regels van de Islam zoals deze in de Mudawwanah zijn verwoord.

Deze verschillen in uitgangspunten tussen het Nederlandse en Marokkaanse erfrecht hebben geresulteerd in een vrij groot aantal verschillen tussen beide rechtsstelsels. Niet iedere afwijking van het Nederlandse erfrecht leidt tot onverenigbaarheid met de openbare orde. Voorzover de aan het Nederlandse erfrecht ten grondslag liggende uitgangspunten geen algemene fundamentele waarden zijn zal hun betekenis en waarde en de handhaving ervan in de concrete omstandigheden moeten worden bepaald. Zonder te pretenderen uitputtend te zijn, zal in het navolgende een aantal grondslagen van het Nederlandse erfrecht worden nagelopen en worden bezien of de hiervan afwijkende Marokkaanse regels de toets van de openbare orde kunnen doorstaan.

\section{a. Testeervrijheid; dwingend recht en regelend recht}

Het Marokkaanse erfrecht bevat voornamelijk dwingend recht en beperkt de vrijheid van de erflater om over zijn eigen vermogen te beschikken zowel wat het deel betreft waarover vrij kan worden beschikt als de personen ten behoeve van wie kan worden beschikt. Behoudens toestemming van de (andere) erfgenamen mag niet worden beschikt over meer dan eenderde deel van het vermogen (dat resteert nadat de nalatenschapsschulden en begrafeniskosten zijn voldaan) en er mag niet worden beschikt ten behoeve van wettige erfgenamen. Alleen zij die niet als wettig erfgenaam erven kunnen van de testamentaire beschikkingsmogelijkheid de vruchten plukken. Ten aanzien van de wettige erfgenamen is men gebonden aan de regels van de Mudawwanah.

In het Nederlandse erfrecht wordt enerzijds uitgegaan van de vrijheid om over het eigen vermogen te beschikken, hetgeen resulteert in regels van regelend recht, maar anderzijds worden bepaalde belangen beschermd, hetgeen resulteert in een aantal regels van dwingend recht. Hoe belangrijk zijn het respect voor de beschikkingsvrijheid enerzijds en de bescherming van bepaalde belangen anderzijds? De beschikkingsvrijheid staat in nauw verband met het eigendomsrecht. Dit recht geniet zowel in het nationale recht als in Verdragen bescherming. Een van die verdragsbepalingen is art. 1 Eerste Protocol EVRM. Ten aanzien van deze bepaling heeft het EHRM beslist dat het recht om over zijn eigendommen te beschikken een traditioneel en fundamenteel aspect van het eigen- 
domsrecht inhoudt ${ }^{(x+}$. Op grond van het tweede lid van dit artikel heeft een Staat echter het recht om "die wetten toe te passen die hij noodzakelijk oordeelt om het gebruik van eigendom te reguleren in overeenstemming met het algemeen belang of om de betaling van belastingen of andere heffingen of boeten te verzekeren". De fiscale aspecten daargelaten kan een Staat derhalve beperkingen aan de beschikkingsvrijheid stellen voorzover een dergelijke regulering in overeenstemming is met het algemeen belang. Volgens rechtspraak van het EHRM moet er sprake zijn van een redelijk evenwicht tussen eisen die in het algemeen belang worden gesteld en eisen die het te beschermen individueel belang stelt ${ }^{665}$. Met het oog op het algemeen belang kunnen zowel aan de omvang als aan de inhoud van de testeervrijheid beperkingen worden gesteld. Met dit algemeen belang lijkt typisch te worden verwezen naar het algemeen (nationaal) belang van ieder der Verdragstaten. Ook buiten Verdragen wordt in het Nederlandse materiële recht aan het eigendomsrecht, en daarmee aan de vrijheid om over eigen eigendom te beschikken, een fundamentele betekenis toekend (zie art. 5:1 BW: eigendom is het meest omvattende recht dat een persoon op een zaak kan hebben). Maar ook dit eigendomsrecht is niet onbeperkt. Zo kan bijvoorbeeld ingevolge de Onteigeningswet ten behoeve van een algemeen belang privé-eigendom worden onteigend. Het privaatrecht beperkt het vrije genot van de eigendom onder meer voorzover dit in strijd komt met rechten van anderen of indien hiermee op wettelijke voorschriften en regels van ongeschreven recht gegronde beperkingen buiten acht worden gelaten (art. 5:1 lid 2 BW). In het erfrecht wordt de beschikkingsvrijheid met name beperkt door de legitieme van de kinderen. De Nederlandse wetgever is van mening dat het niet aannemelijk is dat het beperken van de testeervrijheid door de dwingende regels omtrent de legitieme portie in strijd is met art. 1 Eerste Protocol bij het EVRM ${ }^{(x \times)}$.

De vraag is in hoeverre, met het oog op de bescherming van welke belangen, in het erfrecht een inbreuk op het eigendomsrecht, op de vrijheid om over eigen vermogen te beschikken, is toegelaten. Kan het hier siechts gaan om belangen welke het Nederlandse erfrecht beoogt te beschermen of ook om belangen die het ingevolge de IPR-verwijzingsregel toepasselijke recht beoogt te beschermen? Nagegaan zal moeten worden welke belangen het vreemde recht beoogt te beschermen, en of dit belangen zijn die ook in Nederland gerespecteerd dienen te worden. Gaat het bijvoorbeeld om het beschermen van cen belang van de vreemde Staat maar is deze Staat bij de erfafwikkeling op geen enkele wijze betrokken, dan is er weinig grond om dit belang in Nederland te respecteren. Gaat het om belangen die hun grondslag vinden in maatschappelijke (familie)structuren van het vreemde land, dan is de vraag in hoeverre in Nederland ruimte moet zijn voor het respect voor sommige familiestructuren, en wellicht, in concrete situaties, of de erflater zich al dan niet bewoog binnen dat familieverband. In dit verband kan nog

664. EHRM 13 juni 1979, Publ. EHRM Serie A vol. 31, par. 63, Marckx, met verwijzing naar EHRM 7 december 1976, Publ. EHRM Serie A vol. 24, par. 62. Handyside.

665. EHRM 23 september 1982, Publ. EHRM Serie A vol. 52, Sporrong en Lönnroth, par. 73.

666. TwK 1992-1993, 17141,12, p. 43. 
worden opgemerkt dat het nict voor de hand ligt om de Nederlandse regeling omtrent de legitieme porties te beschouwen als van openbare orde. Niet alleen is deze legitieme afgestemd op opvattingen over het "gezin" naar Nederlandse maatstaven en laat dus geen ruimte voor buitenlandse maatschappelijke opvattingen, ook staat de legitieme in de Nederlandse literatuur zo zeer ter discussie dat moeilijk kan worden volgehouden dat deze zich zelfs in internationale verhoudingen zou moeten opdringen. Weliswaar hebben enkele schrijvers zich ten aanzien van het toestaan van een rechtskeuze in het internationaal erfrecht terughoudend opgesteld omdat hiermee de legitieme zou kunnen worden omzeild, uiteindelijk is er niettemin ongeclausuleerd ${ }^{667}$ mee accoord gegaan dat in het Erfrechtverdrag de rechtskeuze uitdrukkelijk werd erkend.

Het recht om vrij over zijn vermogen te beschikken kan ook in verband worden gebracht met het recht op respect voor het gezinsleven. In dit verband heeft het Europese Hof in de zaak Marckx ${ }^{608}$ opgemerkt: "Matters of intestate succession - and of disposition - between near relatives prove to be intimately connected with family life. Family life does not include only social, moral or cultural relations (...); it also comprises interests of a material kind, as is shown by, amongst other things, the obligations in respect of maintenance and the position occupied in the domestic legal systems of the majority of the Contracting States by the institution of the reserved portion of an estate (...). Whilst inheritance rights are not normally exercised until the estate-owner's death, that is at a time when family life undergoes a change or even comes to an end, this does not mean that no issue concerning such rights may arise before the death: the distribution of the estate may be settled, and in practice fairly often is settled, by the making of a will or of a gift on account of a future inheritance (...); it therefore represents a feature of family life that cannot be disregarded."

Wordt bij toepassing van het Marokkaanse erfrecht een onaanvaardbare inbreuk gemaakt op het eigendomsrecht of op het recht op respect voor het gezinsleven?

De regel dat de beschikkingsvrijheid is beperkt tot maximaal cenderde deel van het nalatenschapsvermogen vindt zijn directe grondslag in het islamitische recht ${ }^{609}$ en dient ter bescherming van de erfaanspraken van de wettige erfgenamen, terwijl hij toch

667. In art. 24 lid 1 sub d Erfrechtverdrag wordt Verdragstaten de mogetijkheid geboden een voorbehoud te maken ten aanzien van de erkenning van een rechtskeuze welke tot gevolg zou hebben dat de in het eigen recht geldende legitieme porties niet zouden worden gerespecteerd. Nederland heeft dit voorbehoud niet gemaakt.

668. Zic noot 633, Marckx, par. 52.

669. In vroegere Koranverzen werd een ieder die vermogen naliet nog voorgeschreven een (testamentaire) beschikking te maken ten behoeve van ouders en nabije verwanten, en ten behoeve van de echegenote een beschikking te maken voor een jaar onderhoud. Deze verzen worden geacht te zijn vervallen door latere Koranverzen waarin de regels van "intestaat" erfopvolging worden gelezen. De vraag welke mogelijkheden nog bestonden om bij uiterste wil te beschikken of welke beperkingen aan de beschikkingsvrijheid waren gesteld bleef in de Koran onbeantwoord. Het antwoord hierop zou zijn gegeven in de Sumna, Coulson 1971, 213-214. 
de mogelijkheid biedt voor de erflater om een beschikking te maken ten behoeve van hetgeen hij als een morele of persoonlijke plicht of weldaad beschouwt ${ }^{670}$. De regel dat binnen deze ruimte van eenderde deel niet mag worden beschikt ten behoeve van wettige erfgenamen, vindt eveneens zijn directe grondslag in het islamitische recht. Hierbij is overigens wel van belang dat vaststaat dat de versterferfgenamen, behoudens hun instemming met een afwijking hiervan, aanspraak maken op tweederde deel van het nalatenschapsvermogen. Aldus wordt gegarandeerd dat het vermogen grotendeels binnen de cigen (moslim)familic blijft. Beide beperkingen die aan de testeervrijheid zijn gesteld zijn derhalve onlosmakelijk verbonden. Aan het Marokkaanse erfrecht zou volledig afbreuk worden gedaan als de eerste beperking niet zou worden gerespecteerd, en de tweede wel, dat, met andere woorden, de volledige nalatenschap aan een vreemde zou kunnen worden vermaakt.

In principe kan binnen de testeervrijheid worden beschikt ten behoeve van wie men wil, mits dit geen wettig erfgenaam is. Soms is dit echter niet geheel zeker. Zo heeft het Marokkaanse Cour suprême twee tegengestelde uitspraken gedaan in zaken waarin de erflater testamentair had beschikt ten behoeve van zijn concubine ${ }^{671}$. In de ene uitspraak verklaarde het Cour suprême een testament van een Italiaanse man dat was opgemaakt ten behoeve van zijn joodse Marokkaanse concubine geldig ${ }^{672}$. In het andere geval verklaarde het Cour suprême een testament van een Franse man dat was opgemaakt ten behoeve van zijn Franse concubine nictig omdat een dergelijk testament immoreel was, nu buitenechtelijke relaties moesten worden beschouwd als zijnde strijdig met de Marokkaanse openbare orde ${ }^{673}$. Moet deze eventuele strijd met de Marokkaanse openbare orde in Nederland bij de toepasselijkheid van Marokkaans recht worden geaccepteerd? Ik zou menen dat een dergelijke beperking een ontoclaatbare inbreuk op de beschikkingsvrijheid, en in ieder geval ook een inbreuk op het gezinsleven, maakt. De erflater heeft immers zelf, in afwijking van de Marokkaanse normen, gekozen voor een buitenechtelijke relatie, en zijn uiterste wil moet dan ook worden gerespecteerd. $\mathrm{Er}$ is m.i. geen enkel te beschermen (algemeen) belang dat deze inbreuk zou rechtvaardigen.

Hoewel het Marokkaanse recht niet met zoveel woorden de legitieme portie kent, hebben de dwingende regels van het versterf-erfrecht tot gevolg dat voor een vrij groot aantal erfgenamen een bepaalde erfaanspraak in beginsel is gegarandeerd. Dit geldt niet alleen voor de directe afstammelingen, maar ook bijvoorbeeld voor de langstlevende echtgenoot, de ouders en andere verwanten. Een dergelijke in het Marokkaanse recht gemaakte regeling behoort $\mathrm{m} . \mathrm{i}$. in beginsel te worden gerespecteerd. In Nederland is gekozen voor een bescherming van het gezin in enge zin, in het Marokkaanse recht voor

670. Coulson 1971, 214: Coulson 1983, 26.

671. Zie ook p. 287.

672. Cour suprême (chambre administrative) 23 februari 1977.

673. Cour suprême (1 re chambre civile) 14 september 1977. 
de bescherming van een ruimere familie. Er kunnen zich echter situaties voordoen waarin de gevolgen van de toepassing van deze regels leiden tot onaanvaardbare resultaten. Zou een Marokkaanse erflater alleen een achterneef in ver verwijderde graad nalaten, die naar Marokkaans recht aanspraak op het gehele nalatenschapsvermogen zou maken, en zou deze erflater over meer dan eenderde deel van zijn vermogen hebben beschikt ten behoeve van een liefdadige instelling of ten behoeve van zijn ongehuwde partner, dan lijkt mij aannemelijk dat de beperking die aan de testeervrijheid is gesteld met een beroep op de openbare orde kan worden genegeerd, omdat aan de opvatting dat het vermogen binnen de familie zou blijven in dit geval geen reële betekenis kan worden gehecht, en het beschermen van het belang van een verre achterneef niet geacht kan worden te behoren tot die belangen die cen inbreuk op de beschikkingsvrijheid rechtvaardigen kunnen. Zou de erflater niet alleen een verre achterneef nalaten maar ook nog een langstlevende echtgenoot of zus, die beiden slechts een beperkte aanspraak op de nalatenschap hebben, en die de erflater bij testament extra begunstigt, dan zouden niet alleen de beperking te beschikken over maximaal eenderde van het vermogen maar ook de beperking om niet te beschikken ten behoeve van wettige erfgenamen, in mijn ogen tot onaanvaardbare resultaten leiden. De gedachte om het vermogen binnen de familie te houden lijkt met een dergelijk testament eerder te zijn gediend dan te zijn geschonden. De bescherming van de beschikkingsvrijheid en de belangen van de nabije verwanten zouden zwaarder moeten wegen dan het belang van de verre neef en het respect voor het Marokkaanse recht. Zou een erflater bij uiterste wil een verdeling hebben vastgesteld die volledig beantwoordt aan de Marokkaanse versterf-erfrechtregeling, bijvoorbeeld om te voorkomen dat de regels van het Marokkaanse intestaat-erfrecht in Nederland wegens strijd met de openbare orde buiten toepassing worden gelaten, dan is cen dergelijk testament naar Marokkaans recht weliswaar niet geldig, doch het beantwoordt wel volledig aan de doelstellingen van het Marokkaanse erfrecht. Aan de argumenten die de beperking van de beschikkingsvrijheid in het Marokkaanse erfrecht moeten verklaren komt hier geen waarde toe. Aangezien er m.i. ook geen beginsel van Nederlandse openbare orde is dat zich tegen de erkenning van een dergelijk testament verzet, neig ik ertoe de geldigheid van dit testament in Nederland te accepteren.

Het gaat er om dat in concrete gevallen wordt beoordeeld of en in hoeverre het respect voor het Marokkaanse erfrecht en het respect voor de belangen die het Marokkaanse recht beoogt te beschermen, een rechtvaardiging kunnen zijn voor een aantasting van de beschikkingsvrijheid, de uiterste wil van de erflater, en, afhankelijk van de omstandigheden, van het recht op bescherming van het gezinsleven. Hierbij zou in beginsel het dwingendrechtelijke Marokkaanse versterf-erfrecht moeten worden geaccepteerd. Aan een respect voor het Marokkaanse versterf-erfrecht zal m.i. minder gewicht behoeven te worden toegekend naarmate de verwantschapsband met de erflater verder verwijderd is en van een familieleven met de erflater geen sprake meer is. Dit zal zich met name kunnen voordoen ten aanzien van 'asaba-erfgenamen. In ieder geval zou gerespecteerd moeten worden de regel dat bepaalde erfgenamen, te weten de dochter, de zoon, de 
moeder, de vader, de echtgenote en de echtgenoot, niet van de nalatenschap kunnen worden uitgesloten (art. 254 CSPS).

b. Het verkrijgen van de hoedanigheid van erfgenaam

Naar Marokkaans recht kan men erven op grond van een huwelijk of op grond van bloedverwantschap.

\section{Huwelijk}

Het vereiste van een huwelijk geldt ook in Nederland, en levert derhalve geen problemen op: de openbare orde-exceptie kan hier vanzelfsprekend niet worden ingeroepen. Eenzelfde opvatting kan worden ingenomen wanneer de erflater met meerdere echtgenotes was gehuwd. Ook in het buitenland wordt aangenomen dat dan alle echtgenotes erfgerechtigd zijn ${ }^{674}$. Dat in Marokko en Nederland verschillend kan worden gedacht over het bestaan van een geldig huwelijk, is geen vraag van materieel recht maar een conflictenrechtelijk probleem, dat, in het kader van de openbare orde-exceptie, wordt besproken in $\$ 5$.

\section{Bloedverwantschap}

In het Nederlandse erfrecht wordt niet uitgegaan van bloedverwantschap maar - vooralsnog - van het bestaan van familierechtelijke betrekkingen (art. 4:879 lid 1 BW). Is het in alle omstandigheden aanvaardbaar dat tussen ouders en kinderen (en hun ascendenten respecticvelijk afstammelingen) geen erfopvolging mogelijk is als tussen hen geen bloedverwantschap bestaat? Noch in de Grondwet noch in Verdragen wordt het maken van onderscheid op grond van bloedverwantschap expliciet verboden. Uit de rechtspraak van het EHRM met betrekking tot art. 8 EVRM blijkt dat juist de bloedverwantschap vaak van fundamentele betekenis zal zijn voor het recht van erfopvolging ${ }^{675}$. Deze rechtspraak sluit overigens niet uit dat in bepaalde gevallen bij het ontbreken van bloedverwantschap eveneens een recht van erfopvolging zou moeten worden aangenomen ${ }^{676}$. Een beginsel waaraan grote waarde wordt gehecht is het respect voor het gezinsleven, en wat de erfaanspraken betreft, gecombineerd met het bestaan van familierechtelijke betrekkingen. Via adoptie en via erkenning van niet eigen kinderen, alsmede via kunstmatige donorinseminatie, kunnen familierechtelijke betrekkingen worden gevestigd tussen personen die niet door bloedverwantschap met elkaar zijn verbonden. Als er ook nog sprake is geweest van een gezinsleven met de erflater (of als familierechte-

674. Voor Frankrijk: Audit 1991, 268; P. Mercier 1972, 33: de La Pradelle 1992, 71; Cass.Civ. 1, 3 januari 1980. RCDIP 1980, $331 \mathrm{~m} . \mathrm{nt}$. Batiffol/Clunet 1980, $327 \mathrm{~m} . \mathrm{nt}$. Simon Depitre; Paris 8 november 1983, RCDIP 1984, 476. Voor Engeland: Cheshire 1992, 623: P. Mercier 1972, 50. België: Rigaux 1993, 657-658.

675. Aldus J. de Boer 1990, 42.

676. Wat Frankrijk betreft is Boulanger van mening dat "il semble que l'ordre public interviendrait plus facilement à l'encontre de lois (...) si elles sont fondées uniquement sur les liens du sang", Boulanger $1981,120$. 
lijke betrekkingen zijn gevestigd met een erfgenaam van de erflater, een gezinsleven met dic erfgenaam), is er, bij voldoende betrokkenheid met de Nederlandse rechtssfeer, veel voor te zeggen om ook niet-bloedverwanten erfaanspraken te verlenen. Daar staat tegenover dat aan het vereiste van bloedverwantschap in het Marokkaanse recht - in het licht van het familierecht begrijpelijkerwijs - veel waarde wordt gehecht ${ }^{67}$, terwijl dit recht bovendien de mogelijkheid kent om door middel van adoptie bij wijze van gratificatie (art. 83 lid 3 CSPS) of door middel van tanzill (art. 212 e.v. CSPS, zie p. 42-43) niet-bloedverwanten als erfgenamen aan te wijzen. Zij kunnen opkomen in de nalatenschap tot maximaal cenderde deel. Naast de eventueel bestaande mogelijkheid om het vereiste van bloedverwantschap te pareren met een beroep op de openbare orde, zijn er ook andere mogelijkheden die kunnen leiden tot een resultaat waarbij erfaanspraken bestaan tussen adoptiefouder(s) en adoptiefkind. Deze mogelijkheden werden besproken op p. $185-186$.

\section{c. Kring der erfgenamen}

In deze paragraaf wordt de vraag aan de orde gesteld of de graad tot waarin naar Marokkaans recht kan worden geërfd de openbare orde-toets zal kunnen doorstaan. Dat de kring der erfgenamen uit het Marokkaanse erfrecht in Nederland tot problemen kan leiden moge blijken uit cen zaak die heeft geleid tot een uitspraak van het Hof 's-Hertogenbosch van $19911^{678}$. Een makelaar bemiddelde, op verzock van de echtgenote van de overledene, bij de verkoop van een in Nederland gelegen woonhuis dat behoorde tot de nalatenschap van een Marokkaanse erflater. Het woonhuis werd verkocht. De makelaar had zich niet gerealiseerd dat er een ander erfrecht dan het Nederlandse toepasselijk zou zijn, en dat er mitsdien buiten de echtgenote en de kinderen ook andere erfgenamen konden zijn. Inderdaad bleken zich nog andere erfgenamen in het buitenland te bevinden ${ }^{679}$, die naar Marokkaans recht eveneens tot de erfgenamen behoorden. Van hen had de makelaar geen volmacht voor de verkoop van het woonhuis gekregen. Dientengevolge kon de eigendomsoverdracht van de woning niet op het overeengekomen tijdstip plaatsvinden, waarvoor de makelaar aansprakelijk werd gesteld.

In het Marokkaanse recht wordt, althans wat de mannelijke verwanten in mannelijke linie betreft ${ }^{680}$, geen grens gesteld aan de graad van verwantschap in welke men tot

677. Het gaat hierbij in het Marokkaanse recht om "wettige bloedverwantschap". Hiervan is sprake als het huwelijk van de ouders is vastgesteld en het kind is geboren meer dan zes maanden na de huwelijkssluiting en binnen een jaar na een huwelijksontbinding, en als de afstamming is vastgesteld. Hierover p. 52-56, p. 165-167 en p. 177-178. Het gaat hier om een juridische werkelijkheid en niet om een biologische werkelijkheid.

678. Hof 's-Hertogenbosch 5 maan 1991. TvC 1991, p. 230-232/NIPR 1991, 402, waarover Stille 1996. 57 e.v.

679. Uit het dossier van de advocaat van een van de procespartijen bleek dat de moeder en een broer van de erflater nog in leven waren.

680. Het op dit punt gemaakte onderscheid tussen man en vrouw is reeds aan de orde gesteld in $\S 1$. 
de erflater moet staan. In Nederland is een grens gesteld bij de zesde graad. Hiermee wordt de voorkeur gegeven de Staat te laten opkomen in de nalatenschap boven het tockennen van erfaanspraken aan een onbekende, en wordt voorkomen dat onbekenden worden geconfronteerd met schulden van een hun onbekende erflater ${ }^{681}$. Het is ook uit praktisch oogpunt wenselijk dat er een grens wordt gesteld. Dat de keuze voor de Staat boven cen erfgenaam die in een zeer ver verwijderde graad tot de erflater staat, is gebaseerd op een fundamentecl beginsel, of zelf als een fundamenteel beginsel geldt, lijkt mij nict aannemelijk ${ }^{6.82}$. Een dergelijke keuze zal enerzijds uit praktische overwegingen voortkomen en anderzijds uit de gedachte dat er weinig grond is om een ver verwijderd familielid in de nalatenschap te laten opkomen. Bevat de nalatenschap meer schulden dan activa, dan kan het argument dat onbekenden kunnen worden geconfronteerd met schulden van de erflater voor het Marokkaanse erfrecht geen rol spelen omdat hierin slechts sprake is van een overgang van activa en erfgenamen nooit gehouden kunnen worden aan schulden die hun positieve erfdeel zouden overschrijden. Omdat in het kader van het Nederlandse IPR de aansprakelijkheid voor schulden valt onder de afwikkeling van de nalatenschap, welke bij een nalatenschap die in Nederland openvalt door Nederlands recht zal worden beheerst, kunnen echter ook bij toepassing van Marokkaans recht op de erfopvolging, de erfgenamen met schulden van de erflater worden belast. Aan het hierboven aangehaalde argument kan dan weer wel betekenis worden gehecht. Het argument geldt des te sterker, omdat erfgenamen van een Marokkaanse erflater er in het algemeen geen rekening mee zullen behocven te houden dat zij met schulden van een erflater worden belast. Deze erfgenamen zullen de erfenis beneficiair kunnen aanvaarden of kunnen verwerpen. Op p. 133-134 heb ik gesuggereerd dat als de gevolgen van cen verwerping door de erfwet worden beheerst, en de erfwet regelt deze gevolgen niet omdat het de verwerping niet kent, het wellicht beter is de verwerping niet toe te laten. Zou dit tot gevolg hebben dat voor een erfgenaam de passiva de activa overtreffen dan zal dit tot onaanvaardbare resultaten kunnen leiden. Onbekende erfgenamen kunnen met schulden van de erflater worden geconfronteerd, terwijl er van een daadwerkelijk respect voor het Marokkaanse erfrecht toch al geen sprake is wanneer wordt aangenomen dat erfgenamen treden in de schulden van de erflater. Overtreffen daarentegen de activa van de nalatenschap de passiva, dan levert de graad tot waarin naar Marokkaans recht kan worden geërfd naar mijn mening geen strijd op met een fundamenteel beginsel.

681. Door het heffen van successiebelasting komt overigens een belangrijk deel van het vermogen van de erflater ten goede aan de Staat, Asser/van der Ploeg/Perrick 1996, 8.

682. In enigszins andere zin voor Frankrijk: Boulanger 1981, 119 waar hij het volgende aangeeft: hoewel er naar zijn weten geen enkele Franse uitspraak is, zal de openbare orde zich er vermoedelijk tegen verzetten dat een vreemd recht wordt toegepast dat geen limiet in graden kent, zoals het islamitische erfrecht, en volgens welk de nalatenschap kan toekomen aan zeer ver verwijderde verwanten. Een erfrecht dat erfrechten toekent tot de $17 \mathrm{e}$ of $18 \mathrm{e}$ graad wordt volgens hem niet a priori buiten toepassing verklaard. 
De graad tot waarin naar Marokkaans recht kan worden geërfd kan tevens ter discussie worden gesteld als een erfgenaam in een zeer ver verwijderde graad in de nalatenschap optreedt terwijl er tevens koranische erfgenamen zijn die altijd wel in een vrij nabije graad met de erflater zijn verbonden ${ }^{683}$. Dit wordt niet alleen veroorzaakt door de regel dat geen grens is gesteld aan de verwantschapsgraad maar ook door de splitsing tussen koranische erfgenamen en 'asaba-erfgenamen waarbij de koranische erfgenamen, anders dan de asaba-erfgenamen, vastgestelde porties toekomen. Dit aspect wordt daarom besproken in de volgende paragraaf.

\section{d. Onderscheid tussen koranische en 'asaba-erfgenamen}

Het Marokkaanse recht onderscheidt globaal gesteld twee categorieën: de koranische erfgenamen en de 'asaba-erfgenamen. Uit de nalatenschap worden eerst de koranische erfporties voldaan. De 'asaba-erfgenamen delen vervolgens in het restant. Voor de koranische erfgenamen wordt de omvang van de vastgestelde erfportie mede bepaald door de al dan nict aanwezigheid van cen erfgenaam die in een nauwere graad van bloedverwantschap tot de erflater staat. Voor de 'asaba-erfgenamen geldt, evenals in het Nederlandse recht dat erfgenamen die in een nauwere verwantschapsgraad tot de crflater staan de verder verwijderde bloedverwanten van de erfopvolging uitsluiten. Evenals in het Nederlandse recht wordt in het Marokkaanse recht aan de bloedverwantschap in rechte neergaande linie voorrang gegeven boven bloedverwantschap in de zijlinie, en gaan volle bloedverwanten in de zijlinie boven halve bloedverwanten. Zowel in het Nederlandse als in het Marokkaanse recht speelt bij de rangorde waarin de erfgenamen tot de nalatenschap worden geroepen de verwantschapsgraad waarin men tot de erflater staat een belangrijke rol. Op detailpunten zijn hier verschillen te constateren. Het belangrijkste verschilpunt betreft echter het gemaakte onderscheid tussen de twee categorieën erfgenamen in het Marokkaanse recht en het hiermee verband houdende feit dat voor de ene categorie vastgestelde erfporties gelden terwijl de andere categorie deelt in het restant. Dit onderscheid kan bovendien met zich meebrengen dat het erfdeel van cen nauwe verwant die tot de koranische erfgenamen behoort heel klein kan zijn in verhouding tot het erfdeel van een verre verwant die tot de 'asaba-erfgenamen behoort. Een voorbeeld ter illustratie: de erflater laat één dochter na en een verre neef. De dochter heeft naar Marokkaans recht aanspraak op de helft van de nalatenschap. De andere helft gaat naar de verre neef van de erflater.

In de Marokkaanse Mudawwanah is de tweedeling rechtstreeks overgenomen uit het islamitische recht, en hieraan komt een fundamentele betekenis toe. De koranische erfgenamen hebben per definitie een andere erfrechtelijke positie dan de 'asaba-erfgenamen. Gezien de veranderingen in de gezinsstructuur zoals deze zich ook op verschillende plaatsen in Marokko manifesteren, en gezien de gedachte om het vermogen zoveel

683. Koranische erfgenamen in opgaande en neergaande linie kunnen ook tot in oneindige graad erven. De mogelijkheid dat zij in een ver verwijuerde graad tot de erflater staan is echter niet reëel. 
mogelijk binnen de familie te houden ${ }^{6 \times 4}$, zal het m.i. in de meeste gevallen wenselijk zijn het resultaat waartoe in het genoemde voorbeeld wordt gekomen, niet te accepteren.

De gemaakte tweedeling implicecrt op twee punten het maken van onderscheid naar geslacht. Ten eerste behoren tot de koranische erfgenamen voornamelijk vrouwelijke verwanten van de erflater, terwijl tot de 'asaba-erfgenamen, althans de 'asaba-bi-nafsihî erfgenamen, uitsluitend mannelijke verwanten behoren. Ten tweede is de kring van vrouwelijke (koranische) erfgenamen qua omvang aanzienlijk beperkter dan de kring der mannelijke ('asaba-) erfgenamen. Het eerste onderscheid, namelijk dat vrouwelijke verwanten behoren tot een andere erfcategorie dan mannelijke verwanten, is niet zo absoluut als het op het eerste gezicht lijkt. Een aantal vrouwelijke erfgenamen die tot de koranische erfgenamen behoren, valt immers onder de categorie van 'asaba-erfgenamen wanneer zich onder de nabestaanden mannelijke erfgenamen bevinden die tot de erflater in dezelfde verwantschapsgraad staan ( $\left(a{ }^{\prime} s i b\right)$. In die gevallen is er geen sprake meer van een tweedeling. Omdat het onderscheid tussen koranische en 'asaba-erfgenamen voor een belangrijk deel een onderscheid tussen mannen en vrouwen impliceert, is zij eerder reeds aan de orde gesteld, met name op p. 213-214. Aldaar heb ik ook getracht gemotiveerd aan te geven dat het niet altijd wenselijk zal zijn om de regeling wegens strijd met de openbare orde buiten toepassing te laten.

\section{c. Omvang van de erfdelen}

Bij de vraag of de omvang van de erfdelen die naar Marokkaans recht wordt vastgesteld de toets aan de openbare orde kan doorstaan gaat het er niet alleen om of een bepaalde persoon wel een aanvaardbaar deel van de nalatenschap krijgt, maar (vooral) ook of er sprake is van cen aanvaardbare verdeling tussen de erfgenamen. Welk deel een erfgenaam zal ontvangen wordt bepaald door zijn erfrechtelijke positie als koranisch erfgenaam of als 'asaba-erfgenaam. De verhouding van erfporties tussen de erfgenamen onderling wordt bepaald door de tweedeling in koranische erfgenamen en 'asaba-erfgenamen, de verdeling van de koranische porties, de man - vrouw verhouding, en de rangorde bij de 'asaba-erfgenamen. De rangorde bij 'asaba-erfgenamen wordt bepaald door de verwantschapsgraad in welke zij tot de erflater staan, en is in de vorige paragraaf aan de orde geweest. Hierbij is geen sprake van strijd met enig fundamenteel beginsel van de Nederlandse openbare orde. Aan de man - vrouw verhouding in het Marokkaanse erfrecht en de strijd met het gelijkheidsbeginsel is geheel $\S 1$ gewijd. De tweedeling in koranische erfgenamen en 'asaba-erfgenamen en de gevolgen die zij kan hebben voor de verhouding tussen vrouwelijke en mannelijke verwanten, is ook reeds in de vorige paragraaf aan de orde gesteld. Resteert nog slechts de vraag of de verdeling van de koranische erfporties in Nederland aanvaardbaar is. Is het aanvaardbaar dat de

684. Ook het verplicht testament (p. 85-90) is ingevoerd met het oog op het houden van vermogen binnen de "nuclear family" in plaats van binnen de "extended family", zie noot 252. 
echtgenote een achtste deel ${ }^{685}$ ontvangt en de kinderen, ongeacht het aantal, de rest, terwijl de echtgenote in Nederland in dit opzicht gelijkgesteld wordt aan een kind? Is het aanvaardbaar dat het erfdeel van de moeder groter is dan dat van de echtgenote (als er ook kinderen zijn)? Is het aanvaardbaar dat de vader de zussen van de nalatenschap uitsluit? Wat het erfdeel van de langstlevende echtgenoot betreft is er geen enkel fundamenteel beginsel waaruit de omvang van haar erfdeel, eventucel in relatie tot die van de andere erfgenamen betreft, kan worden afgeleid. Bij de andere familieleden gaat het om een keuze voor een bepaalde verdeling binnen de familie. Ook hier kan men m.i. niet van een fundamenteel beginsel spreken. Derhalve behoort de in het Marokkaanse erfrecht gekozen verdeling naar mijn mening (in beginsel) te worden gerespecteerd.

\section{f. Overige afwijkingen}

Bij een tocpassing van het Marokkaanse erfrecht zal men stuiten op een aantal aspecten waarop het Marokkaanse erfrecht afwijkt van het Nederlandse. De voorwaarden en beletselen voor erfopvolging blijken op meerdere punten van detail anders te zijn, de plaatsvervulling is anders geregeld etcetera. Slechts wanneer er achter de Nederlandse regeling cen fundamentele gedachte schuilgaat waarvan de schending onaanvaardbaar zou zijn, zal er reden zijn te onderzoeken of de openbare orde in het geding is.

\section{Voorvragen en openbare orde}

In het Marokkaanse erfrecht kan erfopvolging bestaan op grond van een geldig en bestaand huwelijk en op grond van wettige bloedverwantschap. Bij de toepasselijkheid van Marokkaans erfrecht rijzen de vraag naar de geldigheid en het bestaan van een huwelijk en die naar de afstamming als voorvragen. In hoofdstuk 5 is aangegeven op welke wijze deze voorvragen kunnen of moeten worden behandeld. In deze paragraaf zal worden onderzocht of en in hoeverre bij een afhankelijke aanknoping van de voorvraag het resultaat kan worden gecorrigecrd met een beroep op de openbare orde ${ }^{686}$. Met andere woorden: onderzocht zal worden of de toepassing van Marokkaans recht, inclusief het Marokkaanse IPR, op de voorvraag leidt tot een onaanvaardbaar resultaat in de erfopvolging. Deze benaderingswijze verschilt in zoverre van de in hoofdstuk 5 beschreven aanpak dat in hoofdstuk 5 is onderzocht welke methode (de zelfstandige

685. Op deze plaats wordt er, misschien ten onrechte, van uitgegaan dat het deel van de echtgenote zoals dit naar Marokkaans recht is vastgesteld, wordt geaccepterd. Als haar deel met een beroep op het gelijkheidsbeginsel wordt gewijzigd, komt hiervoor het gewijzigde deel in de plaats.

686. De Hoge Raad heeft deze procedure gevolgd in het arrest inzake de Estlandse nalatenschap, HR 21 maart 1947. NJ 1947, 382: de voorvraag naar de afstamming in het kader van de erfopvolging werd volgens de Hoge Raad beoordeeld door Estlands recht, terwijl de vraag naar de erfopvolging werd beheerst door Nederlands recht. Ondat toepassing van Estlands recht zou leiden tot wettige afstamming terwijl naar Nederlands recht sprake was van een overspelig kind, werd het resultaat dat het kind erfgenaam zou zijn buiten toepassing gelaten wegens strijd met de Nederlandse openbare orde. Zie hierover Dubbink 1949, 137-138. 
aanknoping, afhankelijke aanknoping of de rechtsvergelijkende methode) kon of moest worden aangewend, terwijl het er hier om gaat of, áls is gekozen voor een afhankelijke beoordeling van de voorvraag, het resultaat $k a n$ worden gecorrigeerd met een beroep op de openbare orde. Het resultaat dat hiermee wordt bereikt zal vaak ook kunnen worden verkregen door de voorvraag te behandelen via de rechtsvergelijkende methode. Niettemin is het zinvol om ook de procedure van afhankelijke aanknoping met correctiemogelijkheid te behandelen, te meer omdat de rechtsvergelijkende methode nog geen uitdrukkelijke erkenning heeft gekregen. Bij een afhankelijke aanknoping van de voorvraag worden de vraag naar de geldigheid of het bestaan van een huwelijk of de afstammingsvraag beoordecld naar Marokkaans recht, inclusief het Marokkaanse IPR. Wanneer dit het geval is, is in het vorige hoofdstuk besproken. In beginsel bespreek ik hieronder alleen die familierechtelijke verhoudingen die als voorvraag bij een afhankelijke beoordcling tot een ander resultaat kunnen leiden dan bij een zelfstandige beoordeling.

\section{Geldigheid van het huwelijk}

Polygamie

Naar Marokkaans recht kan een man rechtsgeldig gelijktijdig met maximaal vier vrouwen zijn gehuwd. In Nederland komen polygame huwelijken voor erkenning in aanmerking indien ze rechtsgeldig zijn of rechtsgeldig zijn geworden ingevolge het recht van de Staat waar zij zijn voltrokken (art. 5 lid $1 \mathrm{WCH}$ ), en erkenning niet onverenigbaar met de Nederlandse openbare orde is (art. $6 \mathrm{WCH})^{687}$. Worden polygame huwelijken in Nederland erkend, dan wordt ook de geldigheid van deze huwelijken naar Marokkaans recht in Nederland geaccepteerd. Wordt erkenning van polygamie geweigerd wegens strijd met de openbare orde, dan zal dezelfde openbare orde zich m.i. in beginsel verzetten tegen een beoordeling van de geldigheid van deze huwelijken naar Marokkaans recht.

Huwelijken waaraan een nietigheidsgrond kleeft

Als een huwelijk nietig is wegens een gebrek waarover de rechtsscholen het eens zijn ${ }^{688}$, dan is het huwelijk nietig ab initio ${ }^{689}$. Wanneer het echter een grond betreft waarover de rechtsscholen niet unaniem zijn, moet het huwelijk worden vernietigd. De cchtgenoten blijven elkaars erfgenamen tot het moment waarop het huwelijk wordt vernietigd. Het ligt voor de hand om in ieder geval in het kader van het erfrecht de geldigheid van het huwelijk aan te nemen zolang op de ongeldigheid geen beroep is

687. Zie over de erkenning van polygame huwelijken en de weigering van erkenning ervan wegens strijd met de openbare orde, p. 168.

688. Zie p. 50

689. De geldigheid van een dergelijk huwelijk behoeft dan in Nederland ook niet te worden erkend. Zowel naar Nederlands IPR als naar Marokkaans recht is dan geen sprake van een geldig huwelijk, zodat toepassing van Marokkaans recht op de voorvraag hier kan worden geaccepteerd. 
gedaan. De rechten van erfopvolging kunnen als zogenaamde "droits acquis" worden gerespecteerd.

\section{Consulaire huwelijken}

Huwelijken die zijn gesloten op cen Marokkaans consulaat in Nederland, zijn in Marokko rechtsgeldig als het Marokkaanse recht in acht is genomen. Deze huwelijken komen in Nederland voor erkenning in aanmerking als zij zijn gesloten ten overstaan van cen bevoegde autoriteit, er geen (monopatride) Nederlandse partij bij betrokken is, en het Marokkaanse recht in acht is genomen. Bij erkenning kan de geldigheid naar Marokkaans recht worden geaccepteerd. Wordt erkenning geweigerd, in het bijzonder omdat een der aanstaande echtgenoten de Nederlandse nationaliteit bezit (en niet tevens de Marokkaanse nationaliteit ${ }^{(6)}$ ), dan zou ik willen verdedigen dat de openbare orde zich verzet tegen een beoordeling van de geldigheid van het huwelijk naar Marokkaans recht. De weigering om een dergelijk huwelijk te erkennen berust immers op een volkenrechtelijk uitgangspunt.

Huwelijken die (retro-actief) worden vastgesteld op grond van art. 5 lid 4 Mudawwanah Naar Marokkaans recht zijn deze huwelijken geldig vanaf de retro-actief vastgestelde datum. In beginsel komen dergelijke huwelijken in Nederland voor erkenning in aanmerking behalve wanneer het gaat om een consulaire vaststelling van het huwelijk in Nederland en er een Nederlandse partij bij was betrokken of wanneer erkenning kan worden geweigerd met een beroep op de Nederlandse openbare orde ${ }^{691}$. Bij een erkenning kan cen beoordeling van de geldigheid naar Marokkaans recht worden geaccepteerd. Betreft het een consulaire vaststelling waarvan de erkenning reeds kan worden geweigerd omdat een der aanstaande echtgenoten de Nederlandse nationaliteit bezit, dan kan m.i. ook hier met een verwijzing naar het volkenrecht, worden aangevoerd dat de Nederlandse openbare orde zich verzet tegen een beoordeling van de geldigheid van het huwelijk naar Marokkaans recht. Wordt erkenning geweigerd met een beroep op de openbare orde, dan zal dezelfde openbare orde zich er m.i. tegen verzetten dat de geldigheid van het huwelijk naar Marokkaans recht wordt beoordeeld.

\section{Burgerlijke stand-huwelijken}

Een huwelijk waarbij ten minste een der aanstaande echtgenoten de Marokkaanse nationaliteit bezit en dat enkel is gesloten ten overstaan van een ambtenaar van de burgerlijke stand, wordt in Marokko niet erkend. In Nederland zal sprake zijn van een geldig huwelijk ${ }^{692}$. Kan een beoordeling van de geldigheid van het huwelijk naar Marokkaans recht hier worden gepareerd met een beroep op de Nederlandse openbare orde?

690. HR 13 december 1996, RvdW 1997, 2 waarover uitvoeriger op p. 138.

691. Zie ook p. 161-162.

692. Bij een huwelijkssluiting ten overstaan van de Nederlandse ambtenaar van de burgerlijke stand is dit zonder meer het geval. Bij een huwelijkssluiting ten overstaan van een ambtenaar van de burgerlijke stand in het buitenland, zal erkenning in de regel op grond van art. 5 lid 1 WCH plaatsvinden. 
Uit het vorige hoofdstuk kan worden afgeleid dat een afhankelijke beoordeling van de voorvraag naar de geldigheid van het huwelijk niet vanzelfsprekend is, maar zou moeten worden gerechtvaardigd. In gevallen als de onderhavige zal deze rechtvaardiging veelal zijn gelegen in een onvoldoende betrokkenheid van de Nederlandse rechtssfeer. Bij een geringe betrokkenheid ligt het in beginsel niet voor de hand de openbare orde-exceptie in te roepen. We hebben echter ook geconstateerd dat naarmate het beginsel dat bij toepassing van vreemd recht, in dit geval een beoordeling van de voorvraag naar Marokkaans recht, geschonden wordt, fundamenteler is, er een geringere betrokkenheid met de Nederlandse rechtssfeer kan worden verlangd. De beginselen die met een afhankelijke beoordeling van de voorvraag worden geschonden kunnen zijn het respect voor het gezinsleven en het beginsel van gelijke rechten van echtgenoten, zoals dit is verwoord in art. 16 van het Vrouwenverdrag, art. 23 lid 4 IVBPR, en in art. 5 van het Zevende Protocol bij het EVRM. Dit laatste beginsel is in het geding wanneer de vraag naar de geldigheid van het huwelijk bij de erfopvolging van de echtgenoten verschillend zou worden beoordeeld.

\section{Huwelijksontbinding naar Marokkaans recht}

Huwelijksontbinding in Marokko

Een huwelijksontbinding dic in Marokko naar Marokkaans recht rechtsgeldig tot stand is gekomen, en in Nederland wordt erkend, levert geen problemen op. Een afhankelijke aanknoping van de voorvraag naar het bestaan van een huwelijk leidt niet tot een onaanvaardbaar resultaat. Wordt een dergelijke huwelijksontbinding in Nederland niet erkend op grond van een beginsel van openbare orde, dan zal ditzelfde beginsel, bij voldoende betrokkenheid met de Nederlandse rechtssfeer, zich ertegen kunnen verzetten dat de geldigheid van de huwelijksontbinding in het kader van het erfrecht naar Marokkaans recht wordt beoordeeld. Als beginselen van openbare orde zou ik in dit verband bijvoorbeeld willen aanmerken het respect voor de verdedigingsrechten van partijen in een gerechtelijke procedure, het toewijzen van een echtscheiding op een grond die in strijd is met een fundamenteel beginsel ${ }^{693}$, en het beschermingsbeginsel dat ten grondslag ligt aan het vereiste dat bij een verstoting de instemming van de vrouw wordt verlangd dan wel dat zij zich bij de verstoting neerlegt (art. 3 lid 3 WCE).

\section{Consulaire huwelijksontbinding}

Een huwelijksontbinding die uitsluitend tot stand komt op een Marokkaans consulaat in Nederland ${ }^{64}$, wordt in Nederland niet erkend omdat in Nederland de Nederlandse rechter exclusief bevoegd is tot het ontbinden van huwelijken. Het gaat hier om een beginsel van openbare orde, dat ook zou moeten kunnen worden ingeroepen tegen een

693. Hierbij kan bijvoorbeeld worden gedacht aan de geloofsafval als grond voor de huwelijksontbinding. Deze grond is in strijd met het verbod van discriminatie naar godsdienst.

694. Hetgeen in ieder geval sinds 1995 niet meer gebeurt als de echtscheiding niet eerst door de Nederlandse rechter is uirgesproken, zie noot 514 . 
gedaan. De rechten van erfopvolging kunnen als zogenaamde "droits acquis" worden gerespecteerd.

\section{Consulaire huwelijken}

Huwelijken die zijn gesloten op een Marokkaans consulaat in Nederland, zijn in Marokko rechtsgeldig als het Marokkaanse recht in acht is genomen. Deze huwelijken komen in Nederland voor erkenning in aanmerking als zij zijn gesloten ten overstaan van een bevoegde autoriteit, er geen (monopatride) Nederlandse partij bij betrokken is, en het Marokkaanse recht in acht is genomen. Bij erkenning kan de geldigheid naar Marokkaans recht worden geaccepteerd. Wordt erkenning geweigerd, in het bijzonder omdat een der aanstaande echtgenoten de Nederlandse nationaliteit bezit (en niet tevens de Marokkaanse nationaliteit ${ }^{\left({ }^{(1)}\right)}$ ), dan zou ik willen verdedigen dat de openbare orde zich verzet tegen een beoordeling van de geldigheid van het huwelijk naar Marokkaans recht. De weigering om een dergelijk huwelijk te erkennen berust immers op een volkenrechtelijk uitgangspunt.

Huwelijken die (retro-actief) worden vastgesteld op grond van art. 5 lid 4 Mudawwanah Naar Marokkaans recht zijn deze huwelijken geldig vanaf de retro-actief vastgestelde datum. In beginsel komen dergelijke huwelijken in Nederland voor erkenning in aanmerking behalve wanneer het gaat om een consulaire vaststelling van het huwelijk in Nederland en er een Nederlandse partij bij was betrokken of wanneer erkenning kan worden geweigerd met een beroep op de Nederlandse openbare orde ${ }^{691}$. Bij een erkenning kan een beoordeling van de geidigheid naar Marokkaans recht worden geaccepteerd. Betreft het een consulaire vaststelling waarvan de erkenning reeds kan worden geweigerd omdat een der aanstaande echtgenoten de Nederlandse nationaliteit bezit, dan kan m.i. ook hier met een verwijzing naar het volkenrecht, worden aangevoerd dat de Nederlandse openbare orde zich verzet tegen een beoordeling van de geldigheid van het huwelijk naar Marokkaans recht. Wordt erkenning geweigerd met een beroep op de openbare orde, dan zal dezelfde openbare orde zich er m.i. tegen verzetten dat de geldigheid van het huwelijk naar Marokkaans recht wordt beoordeeld.

\section{Burgerlijke stand-huwelijken}

Een huwelijk waarbij ten minste een der aanstaande echtgenoten de Marokkaanse nationaliteit bezit en dat enkel is gesloten ten overstaan van een ambtenaar van de burgerlijke stand, wordt in Marokko niet erkend. In Nederland zal sprake zijn van een geldig huwelijk ${ }^{692}$. Kan een beoordeling van de geldigheid van het huwelijk naar Marokkaans recht hier worden gepareerd met een beroep op de Nederlandse openbare orde?

690. HR 13 december 1996, RvdW 1997, 2 waarover uitvoeriger op p. 138.

691. Zie ook p. 161-162.

692. Bij een huwelijkssiuiting ten overstaan van de Nederlandse ambtenaar van de burgerlijke stand is dit zonder meer het geval. Bij een huwelijkssluiting ten overstaan van een ambtenaar van de burgerlijke stand in het buitenland, zal erkenning in de regel op grond van art. 5 lid 1 WCH plaatsvinden. 
beoordeling van de eventuele geldigheid van de huwelijksontbinding naar Marokkaans recht.

Huwelijksontbinding door de Nederlandse rechter

Een huwelijksontbinding welke is uitgesproken door de Nederlandse rechter, maakt in Nederland een einde aan het huwelijk, doch behoeft in Marokko niet altijd te worden erkend. Wordt de huwelijksontbinding in Marokko niet erkend, en wordt de voorvraag naar het bestaan van een huwelijk afhankelijk aangeknoopt, dan is het gevolg dat het huwclijk in het kader van het erfrecht geacht wordt nog te bestaan. Kan de toepassing van Marokkaans recht worden geweigerd met een beroep op de openbare orde? Ook hier geldt dat wanneer voor een afhankelijke aanknoping is gekozen vanwege het ontbreken van een verbondenheid met de Nederlandse rechtssfeer, de Nederlandse openbare orde-exceptie in beginsel niet zou moeten kunnen worden ingeroepen. Wordt principieel voor cen afhankelijke aanknoping gekozen, en is er wel sprake van een voldoende verbondenheid met de Nederlandse rechtssfeer, dan zou m.i. moeten worden onderzocht of een beoordeling van de voorvraag naar Marokkaans recht leidt tot matericel onaanvaardbare resultaten. Hierbij is dan in ieder geval rekening te houden met de legitieme verwachtingen van de partijen.

\section{Tegengestelde belangen en de openbare orde-exceptie}

In de voorgaande twee "subparagrafen" is meerdere malen aangegeven dat het beginsel dat zich verzet tegen de erkenning van een naar Marokkaans recht tot stand gekomen of beëindigde rechtsverhouding, zich eveneens zou moeten kunnen verzetten tegen een beoordeling van deze rechtsverhouding in het kader van het erfrecht. Bij een afhankelijke aanknoping van de voorvraag wordt de voorvraag immers door het toepasselijke recht op de hoofdvraag geabsorbeerd, cn levert de toepassing van dit recht een schending op van een openbare orde beginsel. De vraag is of het wenselijk is om een schending van een dergelijk beginsel in alle omstandigheden te bestraffen met het inroepen van de openbare orde-exceptie, en hierbij andere beginselen te negeren. Aan zowel het Nederlandse als het Marokkaanse erfrecht ligt de gedachte ten grondslag het vermogen te laten toekomen aan hen die tot het gezin of de familie van de erfiater behoren. Ook wordt waarde toegekend aan de wil van de erflater. Deze wil kan met name relevant zijn als juridisch erkende verwantschapsbanden doorslaggevend zijn, en de geldigheid hiervan door Marokkaans recht en Nederlands recht verschillend wordt beoordeeld. Deze uitgangspunten of beginselen kunnen in strijd komen met de beginselen die aan een erkenning van de geldigheid of ongeldigheid van een bepaalde familierechtelijke rechtsverhouding in de weg staan. Het niet erkennen van een consulaire verstoting op grond van de exclusiviteit van de Nederlandse rechter of het niet erkennen van een polygaam huwelijk op grond van het monogamiebeginsel kunnen in botsing komen met het respect voor het gezinsleven en het respect voor de wil van de erflater. In mijn ogen dienen bij de vraag of de openbare orde-exceptie moet worden ingeroepen ook deze belangen te worden meegewogen. Wat het resultaat zal zijn, kan slechts in de concrete omstandigheden van het geval worden beoordeeld. 


\section{Afstamming naar Marokkaans recht}

Het gaat in deze paragraaf enkel om het vaststellen van de verwantschap van een kind ten opzichte van zijn vader en vice versa. Tussen moeder en kind wordt naar Marokkaans recht de onwettige verwantschap aan een wettige verwantschap gelijkgesteld. In het kader van de openbare orde-vraag, en in het bijzonder het verbod van discriminatie naar geboorte, zal het bestaan van een gezinsleven gecombineerd met het bestaan van familierechtelijke betrekkingen een belangrijke rol spelen. Uit rechtspraak van het EHRM over art. 8 EVRM kan worden afgeleid dat wanneer er sprake is van een gezinsleven en er sprake is van bloedverwantschap, gestreefd zou moeten worden naar een juridische gelijkstelling van wettige en onwettige kinderen. De Hoge Raad heeft hierbij aangegeven dat uit art. 8 EVRM in beginsel het recht voortvloeit tot het vestigen van familierechtelijke betrekkingen met de kinderen met wie men een gezinsleven heeft ${ }^{695}$. Volgens de ongeschreven verwijzingsregel van Nederlands IPR worden de familierechtelijke betrekkingen tussen een "vader" en kind in beginsel vastgesteld aan de hand van het nationale recht van de man. Er bestaat ten aanzien van buitenlandse mannen een neiging om hiervan af te wijken wanneer voldoende aanknopingspunten met de Nederlandse rechtssfeer bestaan en het belang van het kind hiermee is gediend. In de voorstellen tot herziening van het internationaal afstammingsrechi wordt meer waarde gchecht aan aanknopingspunten die het gehele gezin betreffen, en wordt de mogelijkheid tot het vestigen van familierechtelijke betrekkingen aanzienlijk uitgebreid. Op tal van punten wordt hierin gewerkt met getrapte verwijzingsladders, die tot gevolg hebben dat wanneer volgens het ene recht het vestigen van familierechtelijke betrekkingen niet mogelijk is, kan worden uitgeweken naar een ander rechtsstelsel. Aldus bestaat ook in het IPR de neiging tegemoet te komen aan de wens om bij het bestaan van een gezinsleven, familierechtelijke betrekkingen te kunnen vestigen. Vanuit dit perspectief dient m.i. ook de voorvraag te worden bezien. Wanneer er sprake is van een gezinsleven zou er naar gestreefd moeten worden de voorvraag zodanig te behandelen dat deze zoveel mogelijk leidt tot het bestaan van familierechtelijke betrekkingen. Het belang van het kind kan geacht worden hiermee te zijn gediend. Dat betekent dat wanneer gekozen wordt voor een afhankelijke aanknoping van de voorvraag, en de vraag naar de afstamming derhalve wordt beheerst door het Marokkaanse recht, inclusief het Marokkaanse IPR, de vraag of de toepasselijkheid hiervan de openbare orde toets kan doorstaan, vooral wordt bepaald door de vraag of er sprake is van een gezinsleven en zo ja of er volgens dit Marokkaanse recht familierechtelijke betrekkingen bestaan die tot erfopvolging kunnen leiden. In een groot aantal gevallen zou deze problematiek kunnen spelen. Hieronder passeren elf situaties de revue.

\section{Binnen zes maanden na de huwelijkssluiting geboren kinderen}

Naar Marokkaans recht zijn dit onwettige kinderen. Er bestaat geen mogelijkheid om wettige afstamming aan te nemen. Is er sprake is van een gezinsleven, dan leidt een afhankelijke aanknoping tot een resultaat dat op gespannen voet staat met het verbod van 
discriminatie naar geboorte jegens personen die met de erflater een gezinsleven hadden. Zou echter in dit geval ook een zelfstandige beoordeling van de voorvraag leiden tot onwettigheid (het Nederlands IPR knoopt immers nu nog in beginsel aan bij het nationale recht van de vader) dan zal bij een afhankelijke beoordeling strijd met de openbare orde niet (snel) kunnen worden aangenomen.

2. Meer dan 306 dagen (art. 1:197 BW) en minder dan een jaar (art. 86 lid 2 CSPS) na de huwelijksontbinding geboren kinderen

Naar Marokkaans recht zijn dit wettige kinderen ${ }^{696}$. In beginsel zal de openbare orde zich niet tegen een dergelijk resultaat verzetten.

3. Kinderen geboren binnen cen huwelijk waaraan een nietigheidsgrond kleeft Naar Marokkaans recht staat de afstamming van de kinderen vast, mits zij zijn geboren meer dan zes maanden na de huwelijkssluiting of binnen een jaar na een eventuele huwclijksontbinding. Er is geen reden om dit niet te accepteren.

4. Kinderen geboren uit een huwelijk waarvan de echtgenoten te goeder trouw in de onjuiste veronderstelling verkeerden dat het geldig was

Naar Marokkaans recht staat de afstamming van de kinderen vast, mits zij zijn geboren meer dan zes maanden en binnen een jaar nadat sexuele gemeenschap heeft plaatsgevonden. In beginsel kan dit worden gerespecteerd.

5. Kinderen waarvan de afstamming naar Marokkaans recht is erkend Een erkenning naar Marokkaans recht, iqrâr, veronderstelt de aanwezigheid van een legitieme relatie. Door deze vorm van erkenning komt de wettige afstamming vast te staan. Wanneer een Marokkaanse man tot deze erkenning is overgegaan, zal deze in Nederland kunnen worden geaccepteerd. Een afhankelijke aanknoping van de voorvraag zal geen strijd met de openbare orde opleveren.

\section{Kinderen geboren uit cen consulair huwelijk}

Naar Marokkaans recht is hier sprake van een geldig huwelijk en zijn de uit zo'n huwelijk geboren kinderen, mits geboren na zes maanden na de huwelijkssluiting en binnen een jaar na cen eventuele huwelijksontbinding, wettige kinderen. Wordt het huwelijk in Nederland erkend, dan zijn ook de kinderen wettig. Wordt het huwelijk in Nederland niet erkend, in het bijzonder omdat een der echtgenoten ten tijde van de huwelijkssluiting de Nederlandse nationaliteit bezat, dan zou een afhankelijke aanknoping van de voorvraag naar de afstamming, waarbij de vraag naar de geldigheid van het huwelijk wordt geabsorbeerd, ertoe leiden dat wettige afstamming wordt aangenomen van kinderen die zijn geboren uit een naar Nederlands IPR ongeldig huwelijk. Mij lijkt een

696. Hierbij wordt er uiteraard vanuit gegaan dat deze kinderen niet in familierechtelijke betrekkingen tot een andere man staan. 
dergelijk resultaat, mede gezien het respect voor het gezinsleven, in de regel niet onaanvaardbaar.

7. Kinderen geboren uit een retro-actief vastgesteld huwelijk

Naar Marokkaans recht is hier sprake van een geldig huwelijk met terugwerkende kracht en zijn de uit dit huwelijk geboren kinderen, mits geboren na zes maanden na de huwelijkssluiting en binnen een jaar na een eventuele huwelijksontbinding, wettige kinderen. In Nederland wordt de afstamming lang niet altijd aangenomen (zie p. 177-178). Wordt het huwelijk in Nederland erkend, dan zijn ook de kinderen wettig. Wordt het huwelijk in Nederland niet erkend, dan zou een afhankelijke aanknoping van de voorvraag naar de afstamming, waarbij de vraag naar de geldigheid van het huwelijk wordt geabsorbeerd, ertoe leiden dat wettige afstamming wordt aangenomen van kinderen die zijn geboren uit een naar Nederlands IPR ongeldig huwelijk. Mij lijkt ook hier een dergelijk resultaat, mede gezien het respect voor het gezinsleven, niet onaanvaardbaar.

\section{Kinderen geboren uit polygame huwelijken}

Indien een Marokkaanse man naar Marokkaans recht rechtsgeldig is gehuwd met twee (of meer) echtgenoten, dan zijn kinderen die uit deze huwelijken zijn geboren naar Marokkaans recht wettige kinderen. Wordt het tweede (of verdere) huwelijk in Nederland erkend, dan wordt ook de wettige status van de uit dit huwelijk geboren kinderen erkend. Wordt het tweede (of verdere) huwelijk in Nederland niet erkend, dan zou een afhankelijke aanknoping van de voorvraag naar de afstamming, indien de vraag naar de geldigheid van het huwelijk hierin zou worden geabsorbeerd, ertoe leiden dat in het kader van de erfopvolging de kinderen geacht worden de status van wettig kind te hebben. Een zelfstandige beoordeling van de voorvraag naar de afstamming zou, indien de vraag naar de geldigheid van het huwelijk hierbij door het Nederlandse conflictenrecht zou worden beoordeeld, ertoe leiden dat de kinderen niet de status van wettige kinderen bezitten. Er is sprake van een botsing tussen enerzijds het respect voor het monogamiebeginsel en de belangen van de eerste echtgenote en haar kinderen, en anderzijds het respect voor een mogelijk gezinsleven en het verbod van discriminatie naar geboorte, dat dient ter bescherming van de kinderen uit het tweede huwelijk. Prioriteit voor de belangen van de kinderen zal naar mijn mening geen strijd opleveren met de openbare orde. Het monogamiebeginsel beschermt de gehuwde vrouw tegen een tweede huwelijk van haar echtgenoot, doch kan niet voorkomen dat de echtgenoot kinderen verwekt bij een andere vrouw ${ }^{697}$.

697. In dit verband kan nog worden gewezen op de uitspraak van de Hoge Raad van 3 april 1992, NJ 1993. 296, waarin de Hoge Raad overwoog dat de in het Nederlandse recht bestaande onmogelijkheid voor een gehuwde man om een kind van een andere vrouw te erkennen, in strijd is met art. 8 EVRM. Ook het wetsvoorstel inzake de herziening van het afstammingsrecht schept de mogelijkheid voor een gehuwde man om buitenechtelijke kinderen te erkennen. 
9. Kinderen geboren uit een burgerlijke stand-huwelijk

Is een huwelijk waarbij een der aanstaande echtgenoten de Marokkaanse nationaliteit bezit uitsluitend ten overstaan van de ambtenaar van de burgerlijke stand gesloten, dan zal dit naar Marokkaans recht niet worden erkend ${ }^{698}$. De binnen dit huwelijk geboren kinderen bezitten naar Marokkaans recht niet zonder meer de status van wettig kind. Wordt de voorvraag naar de afstamming afhankelijk beoordeeld, en trekt deze de vraag naar de geldigheid van het huwelijk met zich mee, dan zouden tussen de vader en kinderen geen erfaanspraken bestaan. Gezien het respect voor het gezinsleven en het verbod van discriminatie naar geboorte, zou hier, bij voldoende betrokkenheid van de Nederlandse rechtssfeer, het inroepen van de openbare orde tegen een afhankelijke aanknoping toclaatbaar moeten zijn.

\section{Buitenechtelijke naar Nederlands recht erkende kinderen}

Een erkenning naar Nederlands recht door een Marokkaanse man of van een Marokkaans kind, zal in Marokko wegens strijd met de Marokkaanse openbare orde in de regel niet worden geaccepteerd ${ }^{6(x)}$. Er ontstaat geen wettige verwantschap. Een athankelijke aanknoping van de voorvraag naar de afstamming zal ertoe leiden dat tussen de vader en het kind geen recht van erfopvolging bestaat. Een afhankelijke aanknoping levert een schending op van het verbod van discriminatie naar geboorte jegens personen die met de erflater een gezinsleven hadden ${ }^{7(x)}$. Heeft een Marokkaanse man naar Nederlands recht een kind erkend, dan zal deze erkenning zijn toegestaan wegens de nauwe verbondenheid van betrokkenen met Nederland en het belang van het kind. Daarbij komt nog dat een Marokkaanse man die naar Nederlands recht een buitenechtelijk kind erkent en hicrbij de buitenechtelijke relatic erkent zich niet conformeert aan de Marokkaansrechtelijke waarden op dit punt. Voor een afhankelijke beoordeling van de voorvraag naar de afstamming zal mitsdien niet snel grond aanwezig zijn. Als deze afhankelijke beoordeling niettemin zou zijn "geboden" dan zou deze met cen beroep op de openbare orde achterwege moeten kunnen blijven.

\section{Voorhuwelijkse, naar Nederlands recht gewettigde kinderen}

De wettige status van een voorhuwelijks kind die is verkregen door een opvolgend huwelijk en cen erkenning naar Nederlands recht, wordt in Marokko niet geaccepteerd $^{701}$. Wordt de wettige status naar Marokkaans IPR niet erkend, dan heeft een

698. Overigens kan de geldigheid van een dergelijk huwelijk op eenvoudige wijze worden vastgesteld via een consulaire procedure, mits voldaan wordt aan de huwelijksvereisten van het Marokkaanse recht. Zie voor deze mogelijkheden p. 165-167.

699. Voor de mogelijkheid om in dergelijke gevallen de afstamming naar Marokkaans recht vast te stellen zij verwezen naar p. 177-178.

700. Het TGI Paris 23 avril 1979, RCDIP 1980, 83, m.nt. Lagarde, heeft de openbare orde-exceptie opgeworpen tegen het islamitisch verbod om buitenechtelijke kinderen te erkennen.

701. In dergelijke gevallen kan, in het bijzonder middels een lafif-getuigenis, worden vastgesteld dat partijen als echtgenoten samenwonen vanaf een datum die meer dan zes maanden voor de geboont van het kind ligt. Alsdan wordt de wettige status van het kind ook naar Marokkaans recht aangenomen. 
afhankelijke aanknoping van de voorvraag naar de afstamming tot gevolg dat geen erfopvolging bestaat tussen de vader en het kind. Dit levert een schending op van het verbod van discriminatic naar geboorte jegens personen die, bij het bestaan hebben van een gezinsleven, met de erflater een gezinsleven hadden. In beginsel behoeft een dergelijke schending niet te worden geaccepteerd.

\section{Betekenis van het religieuze karakter van het Marokkaanse erfrecht en van de islami- tische godsdienst van de erflater}

In deze paragraaf zal worden onderzocht of het religieuze karakter van het Marokkaanse erfrecht dan wel de islamitische geloofsovertuiging van de erflater van invloed is op de beslissing over het al dan niet inroepen van de openbare orde tegen de toepassing van dit recht. De eveneens zeer interessante vraag of de godsdienst cen rol speelt bij de keuze van de aanknopingsfactor en mitsdien bij het vaststellen van het toepasselijke recht, laat ik hier, gezien het onderwerp van behandeling, achterwege ${ }^{702}$. Een enkele opmerking wil ik hierbij nog wel maken. Wanneer op grond van de primaire verwijzingsregel van het Erfrechtverdrag wordt geconcludeerd tot de toepasselijkheid van Marokkaans recht, dient (middels art. 20 Erfrechtverdrag) nog een nadere aanknoping plaats te vinden. Marokko kent namelijk voor het personeel statuut en erfrecht twee rechtsstelsels die van tocpassing zijn op verschillende categorieën van personen. Omdat het in deze verhandeling gaat om Marokkaanse erflaters die moslim zijn, wordt op grond van hun moslim zijn het voor moslims geldende in de Mudawwanah gecodificeerde (islamitische) erfrecht toepasselijk verklaard. Men zou zich kunnen afvragen of door deze onderaanknoping het religieuze karakter van het toepasselijke recht reeds is erkend. Mij zou dit te ver gaan. De onderaanknoping is te beschouwen als een formele stap die moet worden genomen om het toepassclijke recht vast te stellen. De Marokkaanse Mudawwanah wordt tocpasselijk verklaard omdat dit het formeel geldende recht voor deze bevolkingsgroep is, en niet omdat het een religicuze oorsprong heeft ${ }^{703}$.

Dat het Marokkaanse recht als zodanig een religieus karakter heeft is in het kader van de openbare orde toetsing niet of nauwelijks van belang. Wat wel van belang kan zijn is dat de erflater een islamitische (levens)overtuiging en godsdienst bezit welke bij een onverkorte toepassing van het Marokkaanse recht worden gerespecteerd. Niet wenselijk is het dat aan het enkele moslim zijn van de erflater de consequentie wordt verbonden dat cen respect voor zijn godsdienst een respect voor alle op de Islam gebaseerde regels van erfopvolging betekent. Respect voor het islamitische erfrecht als zijnde een belichaming van de godsdienst of levensovertuiging van de erflater behoeft alleen dan in ogenschouw te worden genomen als de handhaving van deze erfopvolgingsregels voor de

702. Zie over deze vraag uitvoerig: Elgeddawy 1971.

703. Aldus ook Gannagé 1979, 359. Volgens Elgeddawy 1971, 130, wordt dit in seculiere Staten als heersende opvatting beschouwd. 
betrokken erflater cen morele of religieuze waarde heeft ${ }^{704}$. Of dit het geval is zal uit de concrete omstandigheden van het geval moeten worden afgeleid. Stel dat het in een concreet geval aannemelijk is dat het voor de erflater van belang is dat zijn nalatenschap zal worden verdeeld volgens de regels van het islamitische (lees i.c.: Marokkaanse) recht, welke waarde moet hieraan dan worden toegekend? Uit de Nederlandse rechtspraak blijkt dat het niet is uitgesloten om ter verkrijging van bepaalde familierechtelijke rechten een beroep op de Islam te doen, maar dat voor het antwoord op de vraag of aan dit beroep wordt tegemoet gekomen, een belangenafweging dient plaats te vinden ${ }^{705}$. De godsdienst, levensovertuiging of cultuur is namelijk niet het enige belang dat respect verdient. Ook de rechten en vrijheden van anderen of algemene belangen behoren tot de te beschermen belangen. Aan een aantal hiervan zal een hogere waarde worden toegekend dan aan het respecteren van de godsdienst. Wat hieruit volgt is dat wanneer de godsdienst, levensovertuiging of andere persoonlijke waarde van de erflater in het geding is, of hierop ecn beroep wordt gedaan, hieraan niet ongemotiveerd voorbij zou mogen worden gegaan. Concreet betekent dit dat bij het inroepen van de exceptic van de openbare orde in dergelijke gevalten m.i. niet zou kunnen worden volstaan met het argument dat de toepassing van vreemd recht strijd oplevert met een fundamenteel beginsel van de Nederlandse rechtsorde.

\section{Betekenis van de rechtskeuze voor de openbare orde-exceptie}

In de vorige paragrafen 1 tot en met 6 is onderzocht of en in hoeverre het Marokkaanse erfrecht wegens strijd met de Nederlandse openbare orde buiten toepassing zou moeten blijven. Hierbij is geen aandacht besteed aan de vraag welke aanknopingsfactor tot de toepasselijkheid van het Marokkaanse erfrecht heeft geleid. De exceptie van de openbare orde kan worden ingeroepen zowel wanneer het Marokkaanse erfrecht toepasselijk is verklaard op grond van de objecticve verwijzingsregel als wanneer dit recht toepasselijk is verklaard op grond van een uitgebrachte rechtskeuze. De vraag is of in het laatste geval een meer terughoudende opstelling niet op zijn plaats is. Als een erflater een keuze heeft uitgebracht voor de toepasselijkheid van Marokkaans recht, betreft het weliswaar een conflictenrechtelijke rechtskeuze, doch heel vaak zal de erflater de bedoeling hebben gehad dat zijn nalatenschap wordt verdeeld overeenkomstig de materiële regels uit het Marokkaanse recht. Deze verdeling kan hij naar Marokkaans recht bij

704. Over de objectieve en subjectieve benadering van de godsdienstvrijheid, en de wijze waarop de Nederlandse rechter deze beoordeelt, leze men Labuschagne 1997.

705. HR 1 juli 1982, NJ 1983, 201, waarin een islamitische vader zich onder meer met een beroep op art. 27 IVBPR verzette tegen een verzoek tot onderoezichtstelling van zijn 17-jarige van huis weggelopen dochter. Het meisje was van huis weggelopen omdat zij zich niet kon verenigen met de opvoedingsnormen die haar vader, met een beroep op de Islam, hanteerde. De Hoge Raad overwoog dat er geen sprake was van een schending van art. 27 IVBPR omdat het daarin neergelegde recht om zijn eigen cultuur te beleven en zijn eigen godsdienst te betijden en in de praktijk toe te passen niet zodanig mag worden uitgeoefend, dat de rechten van vrijheden van anderen, in casu van de dochter, dreigen te worden aangetast. 
uiterste wil alleen realiseren als de erfgenamen hiermee instemmen. Is dit niet het geval dan wordt de erflater bij de toepasselijkheid van Marokkaans recht immers gehinderd door de beperkingen dat niet mag worden beschikt ten behoeve van wettige erfgenamen en niet mag worden beschikt over meer dan eenderde deel van het vermogen. Neemt de testateur de naar Marokkaans recht geldende beperkingen aan de beschikkingsvrijheid niet in acht, en wordt de innerlijke geldigheid van het testament beoordeeld naar Marokkaans recht, dan zou de geldigheid van zijn testament in Nederland alleen kunnen worden geaccepteerd als de beschikkingsbeperkingen strijdig worden geacht met de Nederlandse openbare orde ${ }^{7(x)}$. Een verdeling van het nalatenschapsvermogen die beantwoordt aan het Marokkaans recht, kan niet worden bereikt door de tocpassing van Nederlands recht. Wel zal een erflater bij toepasselijkheid van Nederlands recht bij uiterste wil vaak een verdeling kunnen regelen die in de buurt komt van een verdeling volgens het Marokkaanse intestaat-erfrecht. Hij dient dan slechts rekening te houden met de Nederlandse dwingendrechtelijke regeling omtrent de legitieme. Als zou worden geaccepteerd dat de naar Marokkaans recht geldende beperkingen aan de beschikkingsvrijheid in Nederland niet worden erkend wegens strijd met de openbare orde, of als in cen concrect geval bij de toepasselijkheid van Nederlands recht ecn resultaat zou worden bereikt dat een verdeling naar Marokkaans recht benadert, bestaat in feite de mogelijkheid dat een verdeling word bereikt die min of meer beantwoordt aan die van het Marokkaanse intestaat-erfrecht. Het treffen van een materiële regeling bij uiterste wil (dan wel het uitbrengen van een keuze voor Nederlands recht) is dan te prefereren boven het enkel uitbrengen van een rechtskeuze voor Marokkaans recht. Het aanwijzen van Marokkaans recht is immers (theoretisch) niet meer dan een aanwijzing van het toepasselijke recht. De Nederlandse autoriteiten zijn verantwoordelijk voor de toepasselijkheid van dit recht. Bij het uitvoeren van een uiterste wil waarin een materiële verdeling wordt vastgesteld, wordt daarentegen "slechts" de wil van de erflater uitgevoerd.

Aangezien de toetsing van vreemd recht aan de openbare orde, ook als dit recht op grond van een hiervoor uitgebrachte keuze toepasselijk is, niet zonder reden is, zou ik, niet geheel zonder twijfel ${ }^{707}$, in gevallen waar de mogelijkheid bestaat een resultaat te bereiken dat beantwoordt aan het Marokkaanse wettelijk erfrecht hetzij door het treffen van een materiële verdelingsregeling hetzij door toepassing van Nederlands recht, en waarin niettemin is volstaan met het uitbrengen van een rechtskeuze voor Marokkaans recht, het standpunt willen verdedigen dat Nederlandse autoriteiten bij het uitvoeren of beoordelen van een uiterste wil waarin een rechtskeuze voor Marokkaans recht is gedaan, de toepassing van het Marokkaanse recht op dezelfde wijze moeten toctsen aan de Nederlandse openbare orde als in gevallen waarin geen rechtskeuze is

706. Zie hierover p. 227

707. Welke twijfel met name worde veroorzaakt door het feit dat ik niet kan beoordelen of van het Nederlands notariaat verwacht kan worden de verschillende mogelijkheden en consequenties hiervan te overziten. 
uitgebracht en Marokkaans recht toepasselijk is op grond van de objectieve verwijzingsregel.

\section{B. Gevolgen van EEN beroep op de openbare orde}

Wannecr in een concreet geval wordt vastgesteld dat toepassing van bepaalde Marokkaanse regels een onaanvaardbare strijd oplevert met de Nederlandse openbare orde zal bij het inroepen van de exceptie van de openbare orde in veel gevallen een leemte ontstaan die door een andere regel of andere regels moet worden ingevuld. De wijzen waarop dit kan geschieden zijn uiteengezet op p. 198-200. In de onderstaande bespreking is ervoor gekozen om de volgende drie - door mij voorgestane - uitgangs-punten in acht te nemen:

1. de bepalingen en beginselen van het Marokkaanse recht die niet strijdig worden geacht met de openbare orde dienen zoveel mogelijk te worden gerespecteerd;

2. het beginsel waarvan de schending tot een verwerping van het vreemde recht heeft geleid, zal eveneens de oplossing moeten geven;

3. wanneer met behulp van dit beginsel in het concrete geval geen oplossing kan worden gevonden, zullen regels uit een ander rechtsstelsel de leemte kunnen vullen. Dit kunnen regels zijn uit het recht dat het beste past bij de omstandigheden van het internationale geval of die van de lex fori. Bij nalatenschappen die in Nederland openvallen zal dit in de regel neerkomen op een toepasselijkheid van regels uit het Nederlandse erfrecht.

De wijze waarop een ontstane leemte wordt ingevuld zal per geval kunnen verschillen. Hieronder wordt een aantal voorbeelden gegeven en zal worden onderzocht tot welk resultaat zou worden gekomen bij inachtneming van bovenstaande uitgangspunten. Hierbij is ervan uitgegaan dat het Marokkaanse recht op het desbetreffende punt wegens strijd met de openbare orde buiten toepassing blijft. Voor de vraag of en wanneer dit daadwerkelijk het geval zal zijn is, raadplege men $\$ 3$.A van dit hoofdstuk.

\section{Voorbeelden}

1. De erflater laat als erfgenamen na een dochter, een zoon en zijn vader. Naar Marokkaans recht zou de verdeling als volgt zijn:

$\begin{array}{lc}\text { vader } & 1 / 6 \\ \text { dochter } & 5 / 18 \\ \text { zoon } & 10 / 18\end{array}$

Stel dat alleen de regel dat het erfdeel van een man twee keer zo groot is als dat van een vrouw wegens strijd met de openbare orde buiten toepassing wordt gelaten. Respect voor het Marokkaanse recht brengt mee dat het erfdeel van de vader gehandhaafd blijft. Het gelijkheidsbeginsel verlangt dat de dochter en de zoon recht hebben op een gelijk deel.

Dit leidt tot het volgende resultaat: vader 
dochter

zoon

Bij respect voor het erfdeel van de vader zou bij toepassing van Nederlands recht tot hetzelfde resultaat worden gekomen.

2. De erflater laat als erfgenamen na de echtgenote, een dochter, en een zoon. Naar Marokkaans recht zou de verdeling als volgt zijn:

$\begin{array}{lc}\text { echtgenote } & 1 / 8 \\ \text { dochter } & 7 / 24 \\ \text { zoon } & 14 / 24\end{array}$

Stel dat de regels waarin cen onderscheid naar geslacht wordt gemaakı wegens strijd met de openbare orde buiten toepassing worden gelaten. Het gelijkheidsbeginsel verlangt dat de dochter en de zoon recht hebben op een gelijk deel, en dat de erfportie van de langstlevende echtgenote even groot behoort te zijn als het erfdeel van de langstlevende echtgenoot zou zijn. Uit het gelijkheidsbeginsel volgt echter niet hoe groot dat erfdeel van de echtgenote dan zou moeten zijn: dient hierbij het erfdeel van de man of dat van de vrouw als norm gehanteerd te worden ${ }^{708}$ ? Het niet direct terugvallen op het eigen Nederlandse recht, maar een zo groot mogelijk respect voor het Marokkaanse recht maakt het m.i. wenselijk dat wordt uitgegaan van de norm van de man ${ }^{7(k)}$, mede omdat anders wanneer de echtgenote als eerste zou overlijden aan de man een erfdecl zou moeten worden toegekend dat kleiner is dan het deel waarop hij naar Marokkaans recht aanspraak zou maken. In dat geval zou de verdeling als volgt zijn:

$\begin{array}{ll}\text { echtgenote } & 1 / 4 \\ \text { dochter } & 3 / 8 \\ \text { zoon } & 3 / 8\end{array}$

Zou de leemte die ontstaat door het buiten toepassing laten van de naar geslacht discriminerende regels wegens schending van het gelijkheidsbeginsel worden ingevuld door Nederlands recht dan zou de verdeling als volgt zijn:

echtgenote

$1 / 3$

dochter

zoon

3. De erflater laat als nabestaanden na een dochter en een broer. Naar Marokkaans recht zou de verdeling als volgt zijn:

dochter

$1 / 2$

broer

$1 / 2$

In $\$ 3$. A. 1 in het bijzonder op p. 213-214, is de vraag aan de orde gesteld of het gelijkheidsbeginsel zou moeten vergen dat het erfdeel van de dochter zo groot zou moeten zijn als dat van een zoon in gelijke omstandigheden zou zijn geweest. Ik heb me nogal terughoudend ten aanzien van een positieve beantwoording van deze vraag opgesteld.

708. Zie over deze problematiek uitvoerig: Lorenz 1993, 148-151.

709. Aldus ook Lorenz $1993,150$. 
Zou het gelijkheidsbeginsel een dergelijke gelijkheid verlangen, dan rijst ook hier de vraag of de erfrechtelijke positic van een zoon, namelijk die van 'asaba-erfgenaam, of dic van een dochter, koranisch erfgenaam, als uitgangspunt moet worden genomen. De tweede optie lijkt mij uitgesloten omdat door een zoon als koranisch erfgenaam aan te merken een fundamentele inbreuk wordt gemaakt op het Marokkaanse erfrechtstelsel. Het plaatsen van de dochter in de categorie van 'asaba-erfgenamen verdient ook geen schoonheidsprijs, maar is te prefereren boven een beoordeling naar Nederlands recht, ondat hicrmec de erfdelen van eventuele andere koranische erfgenamen kunnen worden gerespectecrd. Het gevolg van een en ander zou zijn dat de dochter, als zogenaamde asaba-erfgenaam uit de eerste categoric, aanspraak op de gehele nalatenschap zou hebben, en dat de broer niets zou ontvangen. Hetzelfde resultaat zou worden bereikt bij toepassing van Nederlands recht.

4. De erflater laat als enige nabestaanden drie dochters van een (vooroverleden) dochter na. Naar Marokkaans recht zouden zij geen erfaanspraken hebben en zou de gehele nalatenschap toekomen aan de Staat. Zou het niet om drie dochters van een dochter gaan maar om dric dochters van een zoon, dan zou de gehele nalatenschap aan de kleindochters toevallen ${ }^{711}$. Zou de regel die onderscheid maakt tussen kinderen van een zoon en kinderen van een dochter een verboden discriminatie opleveren, dan verlangt hetzelfde gelijkheidsbeginsel dat de dochters van een dochter het deel zouden ontvangen waarop zoonsdochters aanspraak zouden maken. Zij zouden, ieder voor een gelijk deel, aanspraak op de gehele nalatenschap hebben. Bij tocpassing van Nederlands recht zou hetzelfde resultaat worden bereikt.

5. De erflater laat als erfgenamen zijn moeder en zijn vader na. Naar Marokkaans recht zou de verdeling als volgt zijn:

moeder $\quad 1 / 3$ (koranisch erfgenaam)

vader $\quad 2 / 3$ ('asaba-erfgenaam)

Het gelijkheidsbeginsel verlangt dat de moeder en de vader recht hebben op eenzelfde erfdeel, dus beiden aanspraak maken op 1/2. Bij toepassing van Nederlands recht zou hetzelfde resultaat worden bereikt.

6. De erflater laat een erfgenaam na voor wie een erfbeletsel geldt, bijvoorbeeld een niet-moslim of een onwettig kind. Laat een erflater een niet-islamitische echtgenote na, een wettige zoon, en een buitenechtelijke zoon die hij heeft erkend, dan zou naar Marokkaans recht de verdeling als volgt zijn:

echtgenote 0

wettige zoon 1

onwettige zoon 0

710. Hun gezamenlijke koranische erfportie zou $2 / 3$ zijn. Op grond van de dahir van 1962 (zie p. 59), zou ook het restant onder hen worden verdeeld. 
Levert het onderscheid naar godsdienst of geboorte een verboden discriminatie op, dan verlangt ditzelfde gelijkheidsbeginsel dat het ontbreken van de islamitische geloofsovertuiging dan wel het ontbreken van wettige verwantschap niet aan erfopvolging in de weg staat. De verwanten zijn wel erfgenamen "als ware zij moslim" respectievelijk als ware hij wettig kind ${ }^{71}$. Er ontstaat geen leemte. In dat geval zou de verdeling als volgı zijn:

$\begin{array}{ll}\text { echtgenote } & 1 / 8 \\ \text { wettige zoon } & 7 / 16 \\ \text { onwettige zoon } & 7 / 16\end{array}$

Na correctie van het erfdeel van de echtgenote op grond van het gelijkheidsbeginsel (zie onder voorbeeld 2) zou de verdeling als volgt zijn:

$\begin{array}{ll}\text { echtgenote } & 1 / 4 \\ \text { wettige zoon } & 3 / 8 \\ \text { onwettige zoon } & 3 / 8 \\ \text { Bij toepassing van Nederlands recht zou de verdeling zijn: } \\ \text { echtgenote } & 1 / 3 \\ \text { wettige zoon } & 1 / 3 \\ \text { onwettige zoon } & 1 / 3\end{array}$

7. De erflater heeft bij uiterste wil beschikt ten behoeve van een wettig erfgenaam (tot maximaal eenderde deel van de nalatenschap). Naar Marokkaans recht zou dit niet mogelijk zijn zonder toestemming van de andere erfgenamen. Zou deze beperking een onaanvaardbare inbreuk op de beschikkingsvrijheid opleveren, dan zullen deze beginselen in de regel verlangen dat een dergelijke uiterste wil rechtsgeldig is.

8. De erflater heeft bij uiterste wil beschikt of wenst te beschikken over meer dan cenderde deel van zijn vermogen. Naar Marokkaans recht zou dit niet mogelijk zijn zonder toestemming van de erfgenamen. Zou deze beperking een onaanvaardbare inbreuk op de beschikkingsvrijheid zijn ${ }^{712}$, dan rijst de vraag over welk deel de erflater kan beschikken, en, als dit niet de gehele nalatenschap is, hoe het deel waarover niet kan worden beschikt dient te worden verdeeld. Het antwoord op de eerste vraag zal m.i. worden bepaald door het resultaat van een belangenafweging, waarbij enerzijds de belangen van de erflater (respect voor zijn beschikkingsvrijheid en uiterste wil) en mogelijk de belangen van de personen die met de erflater een gezinsleven hadden een rol spelen, en anderzijds de belangen die met een respect voor het Marokkaanse erfrecht worden gediend (in het bijzonder belangen van de versterf-erfgenamen, waarbij er

711. M.i, behoort het verschil in godsdienst als erfbeletsel ook buiten toepassing te worden gelaten wanneer de niet-moslim erfgenaam naar Nederlands recht geen erfgenaam zou zijn. Dit kan zich bijvoorbeeld voordoen als de vader van de erflater geen moslim is. In mijn visie is toepassing van de lex fori namelijk pas aan de orde als het Marokkaanse recht of het geschonden beginsel geen oplossing bieden. In andere zin Pauli 1994, 179-180.

712. Zie hierover p. 225-228. 
rekening mee is te houden dat er erfgenamen zijn die niet van de nalatenschap kunnen worden uitgesloten). Bij een beoordcling van de belangen van de versterf-erfgenamen is de vraag of voor hen een soort legitieme portie bestaat waarop zij aanspraak hebben. Het probleem hierbij is dat voor hen die uitsluitend als koranische erfgenamen erven wel cen vaststaand crfdeel geldt, maar dat zij die als 'asaba-erfgenamen erven, delen in het restant. De omvang van hun erfdecl is niet vastgesteld. Het komt mij onwenselijk voor dat de koranische erfporties volledig als legitieme porties zouden worden gerespecteerd, en de erfdelen van 'asaba-erfgenamen op andere wijze worden beoordeeld, bijvoorbceld door een analoge toepassing van de Nederlandse regeling van de legitieme portic. De verhouding tussen de erfaanspraken van koranische en 'asaba-erfgenamen die in het Marokkaanse recht bestaat, zou hiermee volledig worden doorbroken. Dit brengt mij tevens tot een antwoord op de tweede vraag naar de verdeling van het deel van de nalatenschap waarover niet rechtsgeldig kan worden beschikt: respect voor het Marokkaanse erfrecht dient m.i. met zich mee te brengen dat dit deel wordt verdeeld overeenkomstig de regeling van het Marokkaanse erfrecht. Dit heeft een evenredige vermindering tot gevolg van de naar Marokkaans recht vastgestelde erfdelen, welk resultaat ook zou zijn bercikt bij een toepassing van de in het Marokkaanse recht geacceptecrde 'awlmethode.

\section{$\S 4$. Toetsing aan Verdragen}

\section{A. BETEKENIS VAN MENSENRECHTEN IN HET IPR}

In $\$ 2$ is de mogelijkheid besproken om bij het inroepen van de exceptie van de openbare orde een beroep op in Verdragen verwoorde beginselen te doen, in die zin dat wanneer de verwijzingsregel verwijst naar vreemd recht, de tocpassing hiervan achterwege zou kunnen blijven met een beroep op de openbare orde omdat de inhoud of toepassing van het vreemde recht in strijd met volkenrechtelijke beginselen komt. In het Nederlandse IPR leidt niet iedere schending van een verdragsbepaling a priori tot een ontoelaatbare schending van de Nederlandse internationaal privaatrechtelijke openbarc orde. Het Nederlandse IPR kent niet, zoals bijvoorbeeld het Duitse IPR een verwijzing naar grondrechten kent ${ }^{713}$, een verwijzing naar internationale beginselen in de zin dat bij een schending van grondrechten of mensenrechten de openbare orde geacht wordt te zijn geschonden. Wel zal, en dat is ook cerder reeds aangegeven, wanneer een verdragsrecht in het geding is, hierin aanleiding moeten worden gevonden om te onder-

713. Art. 6 EGBGB luidt: "Eine Rechtsnorm eines anderen States ist nicht anzuwenden, wenn ihre Anwendung zu einem Ergebnis führ, das mit wesentlichen Gundsätzen des deutschen Rechts offensichtlich unvereinbar ist. Sie ist insbesondere nicht anzuwenden, wenn die Anwendung mit den Grundrechten unvereinbar ist". Gebleken is dat in Duitsland op deze bepaling veelvuldig een beroep is gedaan, met als gevolg dat een aantal conflictregels en de toepassing van buitenlands recht regelmatig buiten toepassing zijn gebleven. Voor een beschrijving van deze ontwikkelingen kan worden verwezen naar Kreuzer 1995, 153-183 en Damm 1993. 
zocken of de openbare orde in het geding is. In het kader van deze openbare orde vraag is het zaak om na te gaan wat het verdragsbeginsel inhoudt. Naast een dergelijke beoordeling van een verdragsrecht in het kader van de openbare orde toetsing, rijst de vraag of ter afwering van vreemd recht, niet ook rechtstreeks een beroep op het verdragsrecht zelf kan worden gedaan. De bescherming van fundamentele mensenrechten behoort, zeker in een democratische samenleving, niet alleen voor eigen maar ook voor vreemde staatsburgers te gelden. In het IPR zou dit betekenen dat wanneer de toepassing van cen als toepasselijk aangewezen recht als zodanig strijd oplevert met een verdragsbepaling, deze toepassing achterwege behoort te blijven ${ }^{714}$. Deze gedachte die in de ons omringende landen, in het bijzonder in Duitsland en Frankrijk, al sedert enkele jaren niet alleen in de literatuur maar ook reeds in de rechtspraak de aandacht krijgt ${ }^{715}$, is vrij recent ook in de Nederlandse literatuur doorgedrongen ${ }^{716}$, waarin dan ook dankbaar gebruik wordt gemaakt van het in onze buurlanden verrichte onderzock.

De bespreking van de verdragsbepalingen in de onderhavige paragraaf dient in de eerste plaats om tc onderzoeken of een rechtstreeks beroep op deze bepaling in internationale erfrechtzaken mogelijk is. Daarnaast is een bespreking van de verdragsbepalingen zinvol met het oog op het belang dat mensenrechten kunnen hebben in het kader van de exceptic van de openbare orde ${ }^{717}$, welk belang in de derde paragraaf al zoveel mogelijk is aangegeven.

Een probleem dat zich voordoet bij een rechtstreekse toetsing aan verdragsbepalingen is dat hicrin geen, of althans niet uitdrukkelijk, rekening wordt gehouden met de typische IPR-aspecten van het geval. Op deze specifieke aspecten, die, zoals zal blijken, bij de toepassing van verdragsbepalingen voor extra hindernissen zorgen, ga ik hieronder in. $\mathrm{Ik}$ wil beginnen met het aanstippen van een aantal zaken waarop men bedacht moet zijn bij een beroep op een verdragsbepaling in zaken die worden gerekend tot het IPR.

(1) Allereerst dient het tocpassingsbereik van het Verdrag zich ook uit te strekken tot internationaal privaatrechtelijke gevallen.

(2) Vervolgens dienen de verdragsbepalingen waarop men zich wil beroepen voor de burger rechtstreekse werking te hebben.

(3) Men zou zich verder kunnen afvragen of op een (rechtstreeks werkende) verdragsbepaling direct een beroep kan worden gedaan, met voorbijgaan aan de regels van het IPR. De Nederlandse rechter mag bij het toepassen van een vreemd rechtsstelsel geen beslissing geven die een schending van een mensenrechtenverdragsbepa-

714. O.m. Bystricky 1979, 67; Lemaire 1968, 410-415; P. Mayer 1991, 664-665.

715. Zie von Bar 1994, 191-212, alsmede de Diskussion zu den Referaten Bryde, von Bar, Geimer, 1994, 277-309; Ehricke 1993, 113-118; Engel 1989, 3-51; Hammje 1994; Jayme 1991/1992 en P. Mayer 1991. Over de invloed van het Europees gemeenschapsrecht in het algemeen op de nationale openbare orde, kan worden verwezen naar o.m. Jayme 1995; Martiny 1991.

716. Dubbink 1996; van Loon, Wisselwerking 1993; Vonken, Reflexwerking 1993.

717. Zie over deze dubbele rol van messenrecuten in het 1PR: Cohen 1989, 451-483, i.h.b. 480-483; Engel 1989, i.h.b. 49: Lequette 1995, 315; Vonken, Reflexwerking 1993, i.h.b. 182. 
ling oplevert. Een dergelijke toetsing heeft echter alleen zin in gevallen waarin aan de verdragsbepaling zelf zelfstandige materiële rechten kunnen worden ontleend ${ }^{718}$. In IPR-gevallen kan dan namelijk niet worden getoetst aan een verdragsrecht zolang niet is vastgesteld aan welk rechtsstelsel de zaak is onderworpen. Aan het IPR zal dientengevolge veelal niet voorbij kunnen worden gegaan.

(4) Dienen verdragsbepalingen in gevallen met een internationaal karakter dezelfde betekenis te hebben als in gevallen die geen vreemde elementen bevatten? Is er bijvoorbecld bij het respect voor het gezinsleven ruimte om rekening te houden met de opvattingen die niet-Nederlanders kunnen hebben over wat een gezin is, of moet bij de interpretatie worden uitgegaan van een gezin waarover consensus binnen de Verdragstaten bestaat, eventueel aangevuld met leefvormen die in de Verdragstaat als gezin gelden? En dient rekening te worden gehouden met het mogelijk gegeven dat in het aangewezen rechtsstelsel het desbetreffende mensenrecht niet geldt of dat dit rechtsstelsel hieraan verdergaande beperkingen stelt dan in de Verdragstaat wordt gedaan? De vraag naar de relevantie van het internationale karakter rijst allereerst reeds bij een toetsing van de conflictregel aan verdragsbepalingen, en vervolgens, wanneer is vastgesteld dat een vreemd recht de rechtsverhouding beheerst, bij de toetsing van de toepassing van dit vreemde recht aan verdragsbepalingen. Op beide punten ga ik onder 5 en 6 nader in.

(5) De vraag kan rijzen of een conflictregel waarin de nationaliteit bepalend is voor het toepasselijke recht, een toetsing aan het discriminatieverbod zal doorstaan ${ }^{719}$. Dit onderscheid kan namelijk tot gevolg hebben ten eerste dat de inhoud van een verdragsrecht voor een buitenlander een andere is dan voor een eigen onderdaan, en ten tweede dat buitenlanders kunnen worden onderworpen aan een rechtsstelsel dat een verdergaande beperking van het verdragsrecht kent dan

718. Vergelijk ook Goldman 1969, 459.

719. Hierover o.m. Fischer 1991, 157-182; Roth 1991, 642 e.v.; Ubertazzi 1977, 339-414, i.h.b. 380-394. Als een conflictregel wordt getoetst aan een in ten Verdrag neergelegd discriminatieverbod, dan is dit mogelijk wanneer de conflictrege! van een lagere rang is dan het mensenrechtenverdrag. Gaat het om een ongeschreven conflictregel van het IPR of een conflictregel die is opgenomen in een nationale wet, hetgeen momenteel bij de erfopvolging nog het geval is, dan kan formeel een toetsing aan het verdragsrecht plaatsvinden omdat deze van hogere orde is. Is de conflictregel daarentegen neergelegd in een Verdrag dan zou een verdragsconflict kunnen ontstaan. Noch IPR-Verdragen noch mensenrechtenverdragen bevatten bepalingen ter oplossing van conflicten tussen beide typen Verdragen. Een algemene regeling over de verhouding tussen Verdragen die op hetzelfde onderwerp betrekking hebben, wordt gegeven in art. 30 van het Weens Verdragenverdrag. Een eenduidige oplossing voor verdragsconflicten is er echter niet (over de verhouding tussen mensenrechtenverdragen en andere Verdragen zie $0 . \mathrm{m}$. Alkema 1995, 70-74; Heringa 1988, 1187-1191: Mus 1996). Gaat het om een schending van mensenrechten die behoren tot het ius cogens, dan zullen deze prevaleren. Is dit niet het geval dan hebben de mensenrechten niet zonder meer voorrang. In 1990 heeft de Hoge Raad een uitspraak gedaan waarin werd beslist dat een EVRM-verdragsrecht aan een toepassing van een uitleveringsverdrag in de weg stond, HR 29 mei 1990, NJ 1991, 467. 
het eigen rechtsstelsel ${ }^{720}$. IPR-gevallen verschillen in zoverre van interne gevallen dat in IPR-zaken niet op voorhand vaststaat welk rechtsstelsel van toepassing is. Juist het feit dat er meerdere landen zijn betrokken, bijvoorbeeld door nationaliteit, woonplaats of anderszins, geeft het geval een internationaal karakter. Bij de vraag aan welk rechtsstelsel een zaak dient te worden onderworpen kunnen diverse overwegingen en belangen een rol hebben gespeeld: de nauwste verbondenheid met de rechtsverhouding, het begunstigingsbeginsel, het beschermingsbeginsel, de internationale beslissingsharmonie etcetera. Tegenwoordig wordt wel aangenomen dat het IPR niet slechts conflictenrechtelijke belangen behoort te dienen, maar tot op zekere hoogte oog behoort te hebben voor materiële belangen ${ }^{721}$. Het primaire doel van het IPR is immers, aldus Strikwerda, een doelmatige en rechtvaardige regeling van het door rechtsverscheidenheid gecompliceerde rechtsverkeer ${ }^{722}$. In de argumenten die bij een verwijzingsregel hebben geleid tot de keuze van een bepaalde aanknopingsfactor, moet dan ook de rechtvaardiging worden gezocht voor een verschil in behandeling van interne en internationale gevallen. In het internationale erfrecht is gezocht naar die aanknopingsfactor die in het algemeen op de nauwste verbondenheid zou wijzen en bovendien in een groot aantal landen op erkenning kon rekenen ${ }^{723}$. Wanneer bij de keuze voor een aanknopingsfactor alle relevante, zowel conflictenrechtelijke als materieelrechtelijke belangen in het afwegingsproces zijn betrokken, zal de verwijzingsregel die het resultaat is van deze belangenafweging, in het algemeen niet gauw als discriminerend kunnen worden aangemerkt ${ }^{724}$. Een verwijzingsregel gaat echter uit van een abstracte doclmatigheid en rechtvaardigheid. Dit betekent dat in concrete gevallen een belangenafweging heel wel tot een andere aanknopingsfactor zou hebben kunnen leiden dan die welke bij een abstracte benadering is gekozen ${ }^{725}$. Het Nederlandse IPR biedt, althans bij gesloten geschreven verwijzingsregels, (nog) geen moge-

720. Interessant is een uitspraak van de Franse Cour d'appel de Paris (1 re chambre civile) 14 juni 1994 , RCDIP 1995, 308 e.v. met lezenswardige noot van Y. Lequette. In deze uitspraak geeft het Hof aan dat bij de bescherming van mensenrechten ten aanzien van in Frankrijk wonende personen, op grond van art. $1 \mathrm{j}^{\circ} 14$ EVRM geen verschil mag worden gemaakt naar nationaliteit. De toepassing van het nationale recht van de betrokkene zou leiden tot een beslissing die op zichzelf een schending van een verodragsrecht zou betekenen.

721. Voor Nederland: Th. de Boer 1993; van Loon, Wisselwerking 1993, 136; Strikwerda 1986, 3-27; Vonken, Reflexwerking 1993, 157; Vonken, Rechtsverfijningen 1993, 302.

722. Strikwerda 1995, 20.

723. Waters, Explanatory Report 1988, par. 25 en 26.

724. Van Loon, Wisselwerking 1993, 138. Vergelijk in dit verband ook Engel 1989, 25-27, die op p. 27 over de verhouding tussen het IPR en de "margin of appreciation" van an. 14 EVRM het volgende opmerkt: "Daß die Vertragsstaaten diese margin schon dadurch verließen, daß sie überhaupt ein IPR bzw. IZVR schaffen, wird man nicht ernstlich annehmen können. Vielmehr ist die potentielle Verweisung auf ausländisches Privatrecht der einzig praktikable Weg, um der Vielfalt der Lebensverhältnisse uberall in der Weft gerecht zu werden und zugleich im Interesse der Betroffenen den Ehescheidungseinklang zu fördern $(\ldots) "$.

725. Aldus ook, in andere bewoordingen: Vonken, Rechtsverfijningen 1993, 305, 307. 
lijkheid om in deze gevallen van de verwijzingsregel af te wijken. Onaanvaardbare resultaten worden niet via de verwijzingsregel maar via exceptie-clausules opgelost. In een in 1992 verspreide eerste tekst voor een algemene wet voor het internationale privaatrecht (IPR-Schets) ${ }^{726}$ werd in art. 8 voorgesteld om een verwijzingsregel of een recht waarnaar de verwijzingsregel verwijst buiten toepassing te laten indien toepassing leidt tot een resultaat dat kennelijk onverenigbaar is met de openbare orde. In cen tweede tussen haakjes geplaatste zin wordt voorgesteld om het aangewezen recht of de verwijzingsregel ook buiten toepassing te laten indien de uitkomst in de gegeven omstandigheden naar maatstaven van redelijkheid en billijkheid onaanvaardbaar zou zijn ${ }^{727}$. Met name deze tweede zin van de voorgestelde bepaling is opgevat als een uitwerking van een algemene ontsnappingsclausule die een afwijking van de primaire verwijzingsregel mogelijk maakt. Hiermec is de discussie over het al dan niet opnemen van een exceptieclausule bij de verwijzingsregel weer nicuw leven ingeblazen ${ }^{728}$. Een antal auteurs geeft inmiddels aan voorstander te zijn van het opnemen van een ontsnappingsclausu$1 \mathrm{e}^{729}$, doch kan zich niet vinden in de in de IPR-Schets voorgestelde invulling hiervan door de redelijkheid en billijkheid ${ }^{730}$. M.i. zou in een concrete situatie waarin onvoldoende rechtvaardiging bestaat voor de gebezigde aanknopingsfactor, en deze aanknopingsfactor een grond betreft ten aanzien waarvan volgens een discriminatieverbod geen onderscheid mag worden gemaakt, hetgeen in het bijzonder het geval is bij de nationaliteit, de verwijzingsregel ook nu reeds wegens strijd met dit discriminatieverbod buiten toepassing moeten kunnen blijven ${ }^{731}$.

726. Schets van een algemene wet betreffende het internationaal privaatrecht, Ministerie van Justitie, Stafafdeling wetgeving privaatrecht.

727. Het plaatsen tussen haakjes heeft volgens het Ministerie van Justitie tot doel om hierover discussie uit te lokken, aldus van Rijn van Alkemade tijdens een discussie op de studiedag over de IPR-Schets, waarvan verslag in: NIPR 1994, speciale aflevering, p. 87.

728. Uitvoerig over de exceptieclausules: Kokkini-Iatridou en Frohn 1989.

729. Th.M. de Boer 1990, 105; Hooimeijer 1996, 229: Kokkini-Iatridou en Boele-Woelki 1992, 511-512; Kokkini-Iatridou en Frohn 1989, 263; Polak 1990, 46; Vonken, Rechtsverfijningen 1993, 310-311; Vonken. Artikelen 1993, 625.

730. Th.M de Boer, discussie 1994 (zie noot 727), 90); Joppe, discussie 1994 (zie noot 727), 88; KokkiniLatridou en Boele-Woelki 1994, 512; Polak 1994, 20; Roelvink, discussie 1994 (zie noot 727), 227; Schultsz 1994, 32-33; Strikwerda 1993, 166; Vonken, Artikelen 1993, 625-626; Vonken, discussie 1994 (zie noot 727), 89: Vonken, Rechtsverfijningen 1993, 299 e.v. Positief over de voorgestelde exceptie-clausule: Roelvink 1993, 219-230. Voor argumenten voor en tegen een dergelijke exceptieclausule en over de reikwijdte ervan zie ook: von Overbeck 1994, 36-43. Zie voorts over de exceptieclausules: Boele-Woelki 1994, 235-271. Voorstanders van de doorwerking van de Nederlandse redelijkheid en billijkheid in internationale verhoudingen: van Rijn van Alkemade 1991, 109; Vlas 1989, 11.

731. Volgens Engel 1989, 28 bestaat er voor een onderscheid in behandeling op een door art. 14 EVRM verboden grond alleen dan een objectieve en redelijke rechtvaardiging als het IPR leidt tot de toepassing van een recht dat nauwer is betrokken bij de zaak dan het eigen recht. Hoewel ik geneigd ben aan de nauwste betrokkenheid de grootste waarde te hechten, dienen m.i. ook andere belangen zoals de internationale beslissingsharmonie in het afwegingsproces te worden betrokken. Hierbij ga ik er we! van uit dat bij een beoordeling van de nauwste verbondenheid. deze andere conflictenrechtelijke 
(6) In verdragsbepalingen wordt vaak aan de Verdragstaten de mogelijkheid gegeven om de grenzen van het verdragsrecht nader af te bakenen; aan Verdragstaten wordt cen zogenaamde "margin of appreciation" gelaten. Deze marge is echter niet altijd erg groot. Schokkenbroek heeft in zijn onderzoek naar de toetsing aan de beperkingsclausules bij Europese vrijheidsrechten van het EVRM geconstateerd dat uit de rechtspraak van het EHRM en de Nederlandse Hoge Raad blijkt dat de omvang van de bcoordelingsmarge door verschillende factoren wordt beïnvloed $^{732}$. Hij noemt een zestal factoren, te weten:

a. het bestaan van een Europese consensus. Als geen Europese consensus bestaat, is de "margin of appreciation" groter; is deze er wel, dan zou het al dan niet volgen van deze Europese consensus door de desbetreffende Verdragstaat van belang zijn;

b. de beperkingsgrond die aan de orde is. Gaat het bijvoorbeeld om een op grond van de bescherming van de goede zeden gestelde beperking, dan is de beoordelingsmarge groot; Verdragstaten hebben een ruime vrijheid te bepalen wat de goede zeden in hun land inhouden;

c. de vraag of het recht dat is of dreigt te worden geschonden bchoort tot de kern van het verdragsrecht. Is dit het geval dan is de "margin of appreciation" gering;

d. de aard van het verdragsrecht. Betreft dit bijvoorbeeld een essentiële grondslag van een democratische samenleving, dan zal de "margin of appreciation" gering zijn;

e. zaken die het sociaal economisch beleid van de Staat betreffen laten een ruime beoordelingsmarge aan de Verdragstaten;

f. indien de beperking wordt ingegeven teneinde een noodsituatie het hoofd te bieden, dan is de "margin of appreciation" ruim.

Of er voor Verdragstaten nog een "margin of appreciation" bestaat en wat de omvang hiervan is, kan derhalve niet uitsluitend uit de desbetreffende verdragsbepaling zelf worden afgeleid. De rechtspraak, in het bijzonder die van het EHRM, heeft aan deze beoordelingsmarge beperkingen gesteld. Mocht er voor een Verdragstaat een beoordelingsmarge resteren, dan kan de vraag worden gesteld of in gevallen waarin op grond van een Nederlandse conflictregel buitenlands recht wordt aangewezen, deze marge moet worden ingevuld naar Nederlandse maatsta-

belangen niet inbegrepen zijn, maar dat de nauwste betrokkenheid uitsluitend betrekking heeft op de betrokkenheid die partijen zelf met een bepaalde rechtssfeer hebben (subjectieve feitelijk-geografische verbondenheid). Het kan bijvoorbeeld best zijn dat het vreemde recht een minder vergaande beperking op een verdragsrecht toelaat dan het eigen recht, en dat in dergelijke gevallen de "begunstiging" van betrokkene door de toepassing van het vreemde recht gecombineerd met de hiermee bereikte internationale beslissingsharmonie, voldoende rechivaardiging biedt voor het onderscheid. Ook Engel gaat er overigens van uit dat bij een toetsing aan het discriminatieverbod, de aanknopingsfactor het voorwerp van onderzoek is.

732. Schokkenbroek 1996, i.h.b. 205-209. 
ven of naar de maatstaven van het toepasselijke vreemde recht. Als op grond van een verwijzing tot de toepasselijkheid van een vreemd rechtsstelsel wordt geconcludeerd behoort m.i. in beginsel ook de "margin of appreciation" door de regels uit dit vreemde stelsel te worden bepaald, zolang zij de Nederlandse openbare orde-toets kunnen doorstaan. Naarmate het geval echter sterker betrokken is met de Nederlandse rechtsorde en de betrokkenen nauwer verbonden zijn met de Nederlandse normen en waarden, en een internationale beslissingsharmonie voor de betrokkene geen waarde heeft, is er m.i. reden om de "margin of appreciation" meer door de eigen Nederlandse opvattingen te bepalen. Aan het internationale karakter van het geval komt dan immers minder of geen betekenis meer toe.

(7) Kunnen autoriteiten van een Verdragstaat buitenlands recht toetsen aan verdragsbepalingen? Iedere Staat is soeverein bij het maken van zijn eigen wetten. Een Staat kan niet door middel van een toetsing van het recht van een andere Staat aan een Verdrag, de geldigheid van dit recht aantasten. Wat wel kan is dat autoriteiten die op grond van een verwijzingsregel buitenlands recht zouden moeten toepassen, de toepassing van dit recht in een concreet geval toetsen aan een verdragsbepaling. Toepassing blijft dan achterwege wanneer deze op zichzelf zou leiden tot een schending van deze bepaling. Bij het wel toepassen van dit recht zou namelijk een beslissing worden genomen die op zichzelf in strijd met een verdragsregel is ${ }^{733}$. Het is deze toetsingsmogelijkheid, en uitsluitend deze mogelijkheid, die ik hier verder aan de orde wil stellen.

\section{B. VERDRAGSBEPALINGEN DIE VOOR DE ERFOPVOLGING VAN BELANG KUNNEN ZIJN}

De verdragsbepalingen die in het kader van de erfopvolging een rol kunnen spelen zijn tc onderscheiden in bepalingen waaraan mogelijk erfaanspraken kunnen worden ontleend en bepalingen die iemand de vrijheid geven om over zijn eigendom te beschikken. In het kader van de openbare orde-bespreking zijn in $\S 3$ de relevante verdragsbepalingen reeds de revue gepasseerd. Genoemd werden zowel de bepalingen die een algemeen discriminatieverbod bevatten als de bepalingen waaraan direct of indirect erfaanspraken zouden kunnen worden ontleend ${ }^{734}$ dan wel waarin de beschikkingsvrijheid werd gegarandeerd.

Er zijn drie verdragsbepalingen ten aanzien waarvan onderzocht zal worden of, in gevallen waarin Marokkaans recht de erfopvolging beheerst, een rechtstreeks beroep hierop mogelijk is en tot welk resultaat dit dan zou leiden. Dit zijn wat de rechten van

733. Aldus ook P. Mayer 1991, 654-655.

734. Een verdragsbepaling die in $\$ 3$ niet werd genoemd en waaraan wel een rechtstreeks recht van erfopvolging kan worden ontleend is art. 5 aanhef en sub d onder vi van het Verdrig inzake de uitbanning van alle vormen van rassendiscriminatie. Op grond van de in art. 1 (leden 1 en 2) van dit Verdrag gegeven omschrijving van het begrip rassendiscriminatie, heb ik geconcludeerd dat dit Verúrag hier niet van toepassing is. 
erfopvolging betreft art. 8 EVRM, art. 16 lid 1 aanhef en sub h Vrouwenverdrag, en wat de testeervrijheid betreft art. 1 Eerste Protocol EVRM en, nogmaals, art. 8 EVRM. Art. 5 Zevende Protocol EVRM, waarin het recht op gelijke rechten en verantwoordelijkheden van civiclrechtelijke aard voor echtgenoten is gegarandeerd ${ }^{735}$, is door Nederland nog niet geratificeerd. Sommige auteurs wijzen op de bezwaarlijke gevolgen die de bekrachtiging van deze bepaling voor het IPR zal kunnen hebben ${ }^{736}$. Mede gezien de geringe vrijheid die blijkens de bewoordingen van de bepaling aan de Verdragstaten wordt gelaten om beperkingen aan dit recht te stellen, zal een beroep hierop al gauw tot gevolg hebben dat vele buitenlandse rechtsstelsels waarin de civielrechtelijke rechten en verantwoordelijkheden van echtgenoten niet gelijk zijn buiten toepassing bchoren te blijven en de erkenning van een volgens een dergelijk rechtsstelsel tot stand gekomen of beëindigde rechtsverhouding achterwege behoort te blijven. Zulks zou echter, aldus Engel, weinig zakelijk noch praktisch zijn ${ }^{737}$. In Frankrijk, waar art. 5 van het Zevende Protocol op 1 november 1988 in werking is getreden, heeft de Cour de cassation reeds verschillende malen, mede met een beroep op deze verdragsbepaling, geoordecld dat een in Marokko uitgesproken verstoting buiten aanwezigheid van de vrouw, terwijl de beide Marokkaanse echtgenoten in Frankrijk woonden, wegens strijd met de openbare orde niet kon worden erkend ${ }^{738}$. Inmiddels is wel reeds art. 16 van het Vrouwenverdrag voor Nederland in werking getreden. Zeker wanneer aan deze bepaling rechtstreekse werking zal worden verleend, moet worden geaccepteerd dat de ongelijke positie van echtgenoten ook in IPR-zaken niet zo makkelijk meer kan worden getolereerd. Hoe groot de vrijheid van Verdragstaten is om aan deze bepaling beperkingen te stellen, tracht ik in onderstaande $\$ 1$.b uiteen te zetten.

Uitdrukkelijk zij vermeld dat ook een beroep op algemene discriminatieverboden in het erfrecht niet uitgesloten is. Met name is hier te denken aan art. 26 IVBPR, waaraan in beginsel rechtstreekse werking wordt toegekend. De huidige ontwikkelingen met betrekking tot art. 26 IVBPR bieden m.i. nog onvoldoende houvast voor het trekken van conclusies met betrekking tot een gelijke behandeling in het erfrecht. Mitsdien is ervoor gekozen uitsluitend die verdragsbepalingen te behandelen die voor het erfrecht concretere aanknopingspunten bieden.

735. Dit recht is ook neergelegd in art. 23 lid 4 IVBPR. Anders dan in ar. 5 Zevende Protocol EVRM, is het recht in ar. 23 lid 4 IVPBR geformuleerd als een verplichting van de Staat, van Dijk/van Hoof 1990. 572.

736. Dubbink 1995, 456-459; Dubbink 1996, 56; Engel 1989, 43-44; Vonken, Reflexwerking 1993, 177 178.

737. Enge! $1989,43-44$

738. Cour de cassation (1 re chambre civile) 4 mei 1994 en 1 juni 1994, RCDIP 1995, 103 e.v.; Cour de cassation (1 re chambre civile) 31 januari 1995, RCDIP 1995, 569 e.v. 


\section{Rechten van erfopvolging}

\section{a. Art. 8 EVRM}

Art. 8 lid 1 luidt (in Nederlandse vertaling):

"Een ieder heeft recht op respect voor zijn privéleven, zijn familie- en gezinsleven, zijn woning en zijn correspondentic."

\section{Toepassingsbereik EVRM}

Art. 1 van het EVRM luidt (in Nederlandse vertaling): "De Hoge Verdragsluitende Partijen verzekeren een ieder die ressorteert onder haar rechtsmacht de rechten en vrijheden dic zijn vastgesteld in de Eerste Titel van dit Verdrag. "Het EHRM heeft in een arrest van 7 juli 1989 bepaald dat dit artikel een begrenzing aan de werkingssfeer van het Verdrag stelt, en dat het hier in het bijzonder een territoriale begrenzing betreft ${ }^{739}$ : "Art. 1 Convention, which provides that the High Contracting Parties shall secure to everyone within their jurisdiction the rights and freedoms defined in Section I', sets a limit, notably territorial, on the reach of the Convention. In particular, the engagement undertaken by a Contracting State is confined to 'securing' (...) the listed rights and freedoms to persons within its own 'jurisdiction'. Further, the Convention does not govern the actions of States not partics to it, nor does it purport to be a means of requiring the Contracting States to impose Convention standards on other States. "Het Verdrag beoogt de rechten en vrijheden van een ieder, ongeacht diens nationaliteit, die ressorteert onder de rechtsmacht van een Verdragsluitende Staat, te beschermen. De begrenzing wordt niet bepaald door de internationaliteit van een geval, maar betreft vooral ecn territoriale begrenzing. Het Verdrag strekt zich niet uit tot handelingen van niet-Verdragstaten; het treedt (onder meer) niet in de wetgeving van niet-Verdragsluitende Staten. Dat betekent ook dat niet-Verdragsluitende Staten, waartoe Marokko behoort, bij hun regelgeving niet gehouden kunnen worden aan de bepalingen van het EVRM. Voor de Nederlandse rechter die volgens de verwijzingsregel het recht zou moeten toepassen van een niet-Verdragstaat, betekent dit dat hij zich niet kan uitlaten over de geldigheid als zodanig van dit recht wanneer hij strijd zou constateren met bepalingen uit het EVRM. Wel is hij bij zijn beslissing gehouden het EVRM in acht te nemen. Dat wil zeggen dat hij bij de toepassing van vreemd recht niet in strijd mag handelen met de verdragsbepalingen ${ }^{740}$.

\section{Art. 8 EVRM}

Art. 8 EVRM, waarin het recht op respect voor het gezinsleven is neergelegd, is een ieder verbindende verdragsbepaling. Een inmenging in het gezinsleven is blijkens het tweede lid van art. 8 EVRM toegestaan indien deze bij wet is voorzien en in een demo-

739. EHRM 7 juli 1989, Publ. EHRM Seric A vol. 161, Soering, par. 86.

740. Aldus ook Engel 1989, 34; P. Mayer 1991, 654-657; van Loon, Wisselwerking 1993, 145-146; Vonken, Reflexwerking 1993, 171-174. 
cratische samenleving noodzakelijk is in het belang van de nationale veiligheid, de openbare veiligheid of het economisch welzijn van het land, het voorkomen van wanordelijkheden en strafbare feiten, de bescherming van de gezondheid of de goede zeden of voor de bescherming van de rechten en vrijheden van anderen ${ }^{741}$. Een eerste vereiste is dat de inmenging bij wet moet zijn voorzien. Het EHRM heeft hieraan enkele nadere criteria gesteld ${ }^{742}$. De inmenging moet in de wet voldoende bepaald en voldoende toegankelijk zijn ("formulated with sufficient precision" 743 en "adequately acces-sible" ${ }^{744}$ ). Bij het begrip "wet" wordt verwezen naar het recht van de Verdragstaat ("domestic law") 745 . Deze verwijzing kan dus in IPR-zaken waarin wordt verwezen naar de toepasselijkheid van cen buitenlands rechtsstelsel, niet worden opgevat als een verwijzing naar het aangewezen toepasselijke vreemde rechtsstelsel, maar moet geacht worden betrekking te hebben op de (toepassing van de) verwijzingsregel zelf en de op grond hiervan toepasselijke wet ${ }^{746}$. Deze combinatie leidt immers tot de beperking van het verdragsrecht. Dat zou dan betekenen dat zowel de verwijzingsregel als het aangewezen recht voldoende bepaald en toegankelijk moeten zijn ${ }^{747}$. Wat de verwijzingsregel betreft zou ter discussie kunnen worden gesteld of de in art. 3 leden

741. Het gebruik maken van de in het tweede lid van art. 8 gegeven mogelijkheid om beperkingen te stellen ata het in het eerste lid gegaranderde recht, kan leiden tot een resultaat waarin onderscheid wordt gemaakt nateen in an. 14 EVRM verboden discriminatiegrond. Of voor een dergelijk onderscheid een rechtvaardiging bestaat zal afzonderlijk worden besproken. Bij de bespreking van het tweede lid van art. 8 EVRM zal enkel worden onderzocht wanneer voor een beperking van het recht op respect voor het gezinsleven een rechtvardiging kan bestaan.

742. EHRM 26 april 1979, Publ. EHRM Serie A vol. 30, Sunday Times, par. 49. Herhaald in EHRM 26 maart 1987, Publ. EHRM Serie A vol. 116, Leander, par. 50-51; EHRM 24 mei 1988, Publ. EHRM Serie A vol. 133. Müller, par. 29; EHRM 30 mant 1989, Publ. EHRM Serie A vol. 152, Chappell, par. 56.

743. "Formulated with sufficient precision to enable the citizen to regulate his conduct. He must be able if need be with appropriate advice - to foresee, to a degree that is reasonable in the circumstances, the consequences which a given action may entail". Sunday Times, par. 49.

744. "Adequately accessible: the citizen must be able to have an indication that is adequate in the circumstances of the legal rules applicable to a given case". Sunday Times, par. 49.

745. Sunday Times, par. 47. "The phrase 'in accordance with the law' does not merely refer back to domestic law but also relates to the quality of the law, requiring it to be compatible with the rule of law; it thus implies that there must be a measure of protection in domestic law against arbitrary interferences by public authorities with the rights safeguarded by, inter alia, paragraph 1 of Article 8", EHRM 2 augustus 1984, Publ. EHRM Serie A vol. 82, Malone, par. 67; EHRM 24 maart 1988, Publ. EHRM Serie A vol. 130, Olsson, par. 61.

746. Over de vratg of vreemd recht in Nederland de status van recht heeft, schrijft Strikwerda dat het vreemde recht in ons burgerlijk proces een positie inneemt tussen feit en recht: het is geen feit omdat de procespartijen de inhoud van vreend recht niet behoeven te stellen en, bij tegenspraak, te bewijzen; de lagere rechter is ambtshalve gehouden de inhoud van buitenlands recht vast te stellen. Het is geen recht ondat de vaststelling van de inhoud van het vreemde recht aan de feitenrechter is voorbehouden en over de loepassing daarvan in cassatie niet geklaagd kan worden (art. 99 R.O.), Strikwerda 1995 , 55.

747. Hierover uitvoerig: Engel 1989, 21-24. Op p. 27 vraagt Engel zich af of de door het EVRM vereiste kenbaracid en toegankelijkheid van een "wet" die beperkingen op de verdragsrechten toestaat, de Verdragstaten er niet toe verplicht na te denken over een vereenvoudiging van het IPR 
2 en 3 van het Erfrechtverdrag neergelegde regels, en met name de hierin geformuleerde uitzonderingen wel voldoende bepaald zijn. Deze laten immers enige interpretatie en daarmee onzekerheid over de werking ervan ${ }^{748}$. De open formulering kan echter worden verklaard, en naar mijn mening ook worden gerechtvaardigd, vanuit de gedachte dat is gepoogd te voorkomen dat een rechtsstelsel wordt toegepast waarmee de erflater nauwelijks verbonden was. Wat het Marokkaanse erfrecht betreft kan met name de toegankelijkheidseis problematisch zijn als de wet zelf cen leemte of onduidelijkheid bevat en de leer van de islamitische rechtsschool zou moeten worden geraadpleegd. Het EHRM accepteert echter een zekere vaagheid ${ }^{749}$. Wanneer de vaagheid in de verwijzingsregel onvermijdelijk is, zal hierin niet snel reden kunnen worden gevonden om te concluderen dat nict voldaan is aan het vereiste van bepaaldheid en toegankelijkheid. Dat zich gevallen kunnen voordoen waarin dit wel het geval is, lijkt mij daarentegen ook gecnszins denkbeeldig ${ }^{750}$.

Een volgend vereiste is dat de inmenging noodzakelijk moet zijn in een democratische samenleving. Voor de inmenging moet een dringende maatschappelijke noodzaak bestaan ${ }^{751}$ en de inmenging moet proportioneel zijn met het oog op het te beschermen doel ${ }^{752}$. Ter beoordeling hiervan wordt blijkens rechtspraak van het EHRM in beginsel aan de Verdragstaten cen "margin of appreciation" gelaten ${ }^{753}$ opdat iedere Verdragstaat rekening kan houden met eigen rechtsopvattingen en rechtsverhoudingen. Regel is dat de beperkingsclausule restrictief moet worden geïnterpreteerd. Op p. 254 werd aangegeven dat uit de rechtspraak volgt dat bij het bepalen van de omvang van de beoordelingsvrijheid een aantal factoren een rol speelt. Dat de toekenning van erfaanspraken en de omvang van deze aanspraken tot de kern van het verdragsrecht van art. 8 bchoort en dat hierover een Europese consensus zou bestaan kan moeilijk worden aangenomen nu het EHRM in de zaak Marckx heeft bepaald dat deze rechten in samenhang met art. 14 EVRM moeten worden beoordeeld. Bij dit aspect wordt hieronder uitvoeriger stilgestaan. Van de genoemde factoren is hier vooral van belang of de grond voor de beperking in cen democratische samenleving noodzakelijk is. Een beperking van de erfaanspraken wordt in Marokkaanse nalatenschappen waarin Marokkaans erfrecht wordt toegepast, veroorzaakt door de verwijzingsregel waarin dit rechtsstelsel als toepasselijk wordt aangewezen en vervolgens door de beperkingen die uit de toepassing van dit Marokkaanse recht voortvloeien. Het toepassen en respecteren van dit recht ge-

748. Westbroek $1990,91-94$

749. EHRM 26 april 1979, Publ. EHRM Serie A vol. 30, Sunday Times, par. 49. Herhaald in EHRM 25 maar 1983. Publ. EHRM Serie A vol. 61, Silver, par. 88; EHRM 24 maan 1988, Publ. EHRM Serie A vol. 130. Olsson, par. 61; EHRM 20 november 1989, Publ. EHRM Serie A vol. 165, Markt internverlag GmbH en Klaus Beermann, par. 30.

750. Aldus ook Forder 1995, 318-319.

751. EHRM 7 december 1976, Publ. EHRM Serie A vol. 24, Handyside, par. 48.

752. EHRM 7 december 1976, Publ. EHRM Serie A vol. 24, Handyside, par. 49.

753. Onder meer EHRM 6 september 1978. Publ. EHRM Serie A vol. 28, Klass; EHRM 8 juli 1987. Publ. EHRM Seric A vol. 121, United Kingưom. 
schicdt op grond van belangen dic het IPR beoogt te dienen (respect voor het internationale karakter van de rechtsverhouding en respect voor de normen waarmee de erflater geacht wordt het nauwst te zijn verbonden). In principe zouden deze belangen moeten behoren tot de in het tweede lid van art. 8 genoemde beschermingsgronden, bijvoorbeeld de goede zeden of belangen (rechten en vrijheden) van anderen (een ander doelcriterium uit deze bepaling lijkt niet in aanmerking te komen). In de praktijk blijkt echter ook aandacht te worden geschonken aan - niet uitdrukkelijk in het tweede lid genoemde - algemeen belang-aspecten ${ }^{754}$. Bij de bescherming van de goede zeden of de belangen van anderen zou er een tamelijk ruime beoordelingsmarge voor de Verdragstaten bestaan ${ }^{755}$. Hoe moet de aan een Verdragsstaat toegestane marge worden beoordeeld wanneer de Verdragsstaat middels het verwijzingsrecht aangeeft dat een rechtsverhouding door een vreemd rechtsstelsel, in ons geval het rechtsstelsel van een niet-Verdragsstaat moet worden beheerst? ${ }^{756}$ Indien wordt geaccepteerd dat in de bescherming van IPR-belangen een democratische noodzaak is gelegen om het vreemde recht toe te passen, dan vlocit m.i. hicruit voort dat ook de marge om beperkingen aan het verdragsrecht van art. 8 te stellen wordt beoordeeld naar de normen van het vreemde te respecteren recht. Indien het vreemde recht echter beperkingen toelaat die de Nederlandse openbare orde-toets niet zouden doorstaan, behoeven deze niet te worden geaccepteerd, omdat het respect voor vreemd recht blijkens algemene regels van IPR zover niet gaat. Ook Engel zou in beginsel de marge willen beoordelen met inachtneming van de bijzonderheden van de derde Staat ${ }^{757}$. Anders dan ik zou hij de uiterste grenzen niet willen leggen bij de nationale openbare orde, maar bij de grenzen die door een autonome uitleg van het Verdrag worden aangewezen. Als ik hem goed begrijp doelt hij hiermee op een door het Verdrag bepaalde binnen de Verdragstaten geldende internationale openbare orde ${ }^{758}$. Mij lijkt deze benadering minder juist omdat bij het bestaan van een Europese consensus, een Europese openbare orde, er geen of slechts een geringe beoordelingsmarge voor de Verdragsstaat zou moeten zijn. Is respect voor vreemd recht geen democratische noodzaak, dan zouden de eigen Nederlandse normen moeten worden aangelegd. Het EHRM heeft zich over deze kwestie nog niet uitgelaten.

Over de vraag of uit het recht op gezinsleven erfrechtelijke aanspraken kunnen voortvloeien heeft het EHRM een uitspraak gedaan in de zaak Marckx ${ }^{759}$. Van belang zijn voorts de uitspraken van het Europese Hof inzake Inze ${ }^{7(x)}$, Johnston ${ }^{761}$, en Vermeire $^{762}$. Hieronder volgt een beknopte uiteenzetting van deze zaken voor zover deze van 
belang zijn voor het antwoord op de vraag of en in welke omstandigheden aan art. 8 een recht van erfopvolging kan worden ontleend.

\section{Marckx}

De zaak Marckx betrof het kind van een Belgische ongehuwde moeder. Zij had haar dochter, Alexandra, twee weken na de geboorte erkend, hetgeen volgens het op dat moment geldende recht noodzakelijk was om de juridische afstamming vast te leggen. Een jaar later adopteert de moeder het kind, en krijgt Alexandra de status van wettig kind. Volgens het op dat moment geldende Belgische erfrecht kon het kind zolang het niet door de moeder was erkend geen erfgenaam van haar zijn en vanaf de erkenning tot aan het moment van de adoptie waren de mogelijke erfrechtelijke aanspraken van het erkende onwettige kind ten opzichte van haar moeder beperkter als die van wettige kinderen. Anders dan wettige of gewettigde kinderen had een erkend onwettig kind geen erfopvolgingsrechten jegens de verwanten van de moeder. Ten aanzien van het in art. 8 genoemde gezinsleven overweegt het Hof het volgende: "Matters of intestate succession - and of disposition - between near relatives prove to be intimately connected with family life. Family life does not include only social, moral or cultural relations, for example in the sphere of children's cducation; it also comprises interests of a material kind, as is shown by, amongst other things, the obligations in respect of maintenance and the position occupied in the domestic legal systems of the majority of the Contracting States by the institution of the reserved portion of an estate (réserve héréditaire). Whilst inheritance rights are not normally exercised until the estate-owner's death, that is at a time when family life undergoes a change or even comes to an end, this does not mean that no issue concerning such rights may arise before the death: the distribution of the estate may be settled, and in practice fairly often is settled, by the making of a will or of a gift on account of a future inheritance (avance d'hoirie); it therefore represents a feature of family life that cannot be disregarded." (par. 52) "Nevertheless, it is not a requirement of Article 8 that a child should be entitled to some share in the estates of his parents or even of other near relatives: in the matter of patrimonial rights also, Article 8 in principle leaves the Contracting States the choice of the means calculated to allow everyone to lead a normal family life (...) and such an entitlement is not indispensable in the pursuit of a normal family life. In consequence, the restrictions which the Belgian Civil Code places on Alexandra Marckx's inheritance rights on intestacy are not of themselves in conflict with the Convention, that is if they are considered independently of the reason underlying them. Similar reasoning is to be applied to the question of voluntary dispositions" (par. 53). (...) "On the other hand, the distinction made in these two respects between "illegitimate" children and "legitimate" children does raise an issue under Articles 14 and 8 when they are taken in conjunction" (par. 54). Met betrekking tot het in het Belgische recht gemaakte onderscheid in rechten van erfopvolging tussen een onwettig kind en een wettig kind overweegt het Hof: "The Court considers that this difference of treatment, in support of which the Government put forward no special argument, lacks objective and reasonable justification" (par. 55). Met betrekking tot het in het Belgische recht gemaakte onder- 
scheid in rechten van erfopvolging van onwettige en wettige kinderen ten opzichte van verwanten van moederszijde overweegt het Hof: "Here again, the Court fails to find any objective and reasonable justification" (par. 56). De conclusie van het Hof is dan ook: "To sum up, Alexandra Marckx was the victim of a breach of Article 14, taken in conjunction with Article 8 , by reason both of the restrictions on her capacity to receive property from her mother and of her total lack of inheritance rights on intestacy over the estates of her near relatives on her mother's side" (par. 59).

\section{Johnston}

Johnston is gehuwd met een zekere vrouw M. Uit dit huwelijk zijn drie kinderen geboren. Johnston en zijn echtgenote wensen te scheiden, doch de Ierse wetgeving laat dit niet toe. $\mathrm{Zij}$ maken een huwelijksbeëindigingsovereenkomst. Johnston gaat een relatie aan en gaat samenwonen met een andere vrouw (W.). Hij kan niet met haar in het huwelijk treden omdat een echtscheiding met zijn eerdere echtgenote niet mogelijk was. Uit de relatic tussen Johnston en de tweede vrouw (W.) wordt een dochter (N.) geboren. Deze dochter heeft de status van onwettig kind en er kunnen geen familierechtelijke betrekkingen met haar worden gevestigd. Johnston, zijn tweede vrouw en de dochter zijn van mening dat er sprake is van een schending van art. 8 EVRM onder meer wat betreft de onmogelijkheid om op enigerlei wijze familierechtelijke betrekkingen met het kind te vestigen en wat betreft het gebrek aan erfaanspraken van het kind jegens zijn ouders. In het kader van art. 8 begint het Hof met het trekken van een vergelijking met de Marckx-zaak, en stelt "the Marckx case related solely to the relations between mother and child. However, the Court considers that its observations on the integration of a child within his family are equally applicable to a case such as the present" (par. 72). Het Hof verwijst in par. 74 nog naar de pogingen die in een groot aantal lid-Staten worden ondernomen om de juridische status van buiten het huwelijk geboren kinderen te verbeteren door verschillen tussen de status van wettige kinderen en onwettige kinderen te verminderen. Onder verwijzing naar de uitspraak in de zaak Marckx stelt het Hof dat "'respect' for family life, understood as including the ties between near relatives, implies an obligation for the State to act in a manner calculated to allow these ties to develop normally (...). And in the present case the normal development of the natural family ties between the first and second applicants" (Johnston en W.) "and their daughter requires, in the Court's opinion, that she should be placed, legally and socially, in a position akin to that of a legitimate child" (par. 74). "Examination of the third applicant's" (N's) "present legal situation, seen as a whole, reveals, however, that it differs considerably from that of a legitimate child". "(..) the absence of an appropriate legal regime reflecting the third applicant's natural family ties amounts to a failure to respect her family life" (par. 75). Er wordt een schending van art. 8 EVRM aangenomen jegens alle drie de verzoekers. Ten aanzien van de vraag of het ontbreken van erfrechten van het kind een schending oplevert van art. 14 in samenhang met art. 8 EVRM overweegt het Hof: "Since succession rights were included amongst the aspects of Irish law which were taken into consideration in the examination of the general complaint concerning 
the third applicant's legal situation (...), the Court (...) does not consider it necessary to give a separate ruling on this allegation" (par. 79).

Inze

$\mathrm{Mw}$ Inze is eigenaresse van cen boerderij. Zij heeft twee zonen. De oudste zoon is een buitenechtelijk onwettig kind. De tweede zoon is een binnen het huwelijk geboren wettig kind. Wanneer Mw Inze overlijdt zijn de erfgenamen haar echtgenoot en de twee kinderen. Er wordt in de Oostenrijkse wetgeving geen onderscheid gemaakt tussen de erfaanspraken van wettige en onwettige kinderen. Van toepassing is echter voorts het Karintische Erbhöfe Geselz van 1903 volgens welke de boerderij niet mag worden verdeeld bij de erfopvolging en waarin is bepaald dat het oudste wettige kind de gehele eigendom overneemt en de andere erfgenamen hun erfrechtelijk deel uitbetaalt. Dit zou tot gevolg hebben dat niet de oudste onwettige maar de jongere wettige zoon de eigendom van de boerderij overneemt. De oudste zoon maakt hiertegen bezwaar. Met betrekking tot de toepasselijke verdragsbepalingen constateert het Hof (par. 38) een verschil met de Marckx-zaak. In de onderhavige zaak heeft de eiser reeds een erfaanspraak verworven. De erfgenamen in deze zaak hebben hun volgens het Burgerlijk Wetboek toekomende deel reeds geacceptecrd. Het Hof overweegt dan ook dat "The estate was therefore the joint property of the applicant and his co-heirs, although none of them had an immediate right to a specific asset". Het Hof overweegt eveneens dat: "Article 1 of Protocol No. I in substance guarantees the right of property". En ten aanzien van de Karintische wet constateert het Hof (par. 39) dat deze "gives precedence to legitimate over illegitimate children. Accordingly, in the instant case the farm in question went to the younger, legitimate, son, whereas the applicant was, on the sole ground of his illegitimate birth, deprived of any possibility of obtaining it". Het Hof concludeert "that the facts at issue fall within the ambit of Article 1 of Protocol No. 1 and that Article 14 of the Convention, taken together with that provision, is therefore applicable" (par. 40). Vervolgens gaat het Hof na of er voor het onderscheid een rechtvaardiging bestaat. Ten aanzien daarvan overweegt het Hof: "For the purposes of Article 14, a difference of treatment is discriminatory if it "has no objective and reasonable justification", that is, if it does not pursue a "legitimate aim" or if there is not a "reasonable relationship of proportionality between the means employed and the aim sought to be realised". (...) "The Contracting States enjoy a certain margin of appreciation in assessing whether and to what extent differences in otherwise similar situations justify a different treatment in law; the scope of this margin will vary according to the circumstances, the subjectmatter and its background (...). In this respect, the Court recalls that the Convention is a living instrument, to be interpreted in the light of present-day conditions (see, amongst various authorities, the Johnston and Others judgment (...). The question of equality between children born in and children born out of wedlock as regards their civil rights is today given importance in the member States of the Council of Europe". "Very weighty reasons would accordingly have to be advanced before a difference of treatment on the ground of birth out of wedlock could be regarded as compatible with the Conven- 
tion (...)" (par. 41). In het onderhavige geval wordt onvoldoende rechtvaardiging voor het onderscheid aanwezig geacht.

\section{Vermeire}

De Belgische Astrid Vermeire is een erkend onwettig kind van haar vader. Na haar vaders overlijden wordt zij opgevoed door haar grootouders van vaders zijde. De grootmoeder overlijdt in 1975, dus voordat het EHRM in de zaak Marckx uitspraak heeft gedaan; de grootvader overlijdt ná het overlijden van de Marckx-uitspraak. De gewijzigde Belgische wet trad pas acht jaar na de Marckx-uitspraak, en ook na het overlijden van de grootvader, in werking. In de tussenliggende periode paste de Belgische rechter nog de oude wettelijke bepalingen toe waarin onderscheid werd gemaakt tussen natuurlijke onwettige en wettige kinderen. Astrid wil als natuurlijk kind vän haar vader delen in de erfenis van zowel haar grootvader als haar grootmoeder. Wat het ontbreken van erfaanspraken ten opzichte van de grootmoeder betreft neemt het EHRM geen schending aan van art. $14 \mathrm{j}^{\circ} 8$ EVRM: hoewel haar nalatenschap nog niet was afgewikkeld op het moment dat de uitspraak inzake Marckx was gedaan, is de erfopvolging effectief vanaf de datum van overlijden. Wat het ontbreken van het recht van erfopvolging jegens de grootvader betreft, neemt het Hof wel een schending aan van art. $14 j^{\circ} 8 \mathrm{EVRM}$. Het Hof verwijst hierbij direct naar de Marckx-uitspraak en overweegt: "The Marckx judgment held that the total lack of inheritance rights on intestacy, based only on the "illegitimate" nature of the affiliation, was discriminatory (...). This finding related to facts which were so close to those of the instant case that it applies equally to the succession in issue, which took place after its delivery" (par. 25).

\section{Voorlopige conclusies}

Uit de hiervoor besproken uitspraken kunnen verschillende conclusies worden getrokken met betrekking tot de vraag in hoeverre an het recht op respect voor het gezinsleven een recht van erfopvolging kan worden ontleend. In de uitspraak inzake Marckx geeft het Hof aan dat aan art. 8 op zichzelf niet bepaalde erfaanspraken kunnen worden ontleend. Wel zijn erfrechtelijke aangelegenheden nauw met het gezinsleven verbonden. Indien binnen het gezin ten aanzien van gezinsleden met wie de erflater een gezinsleven heeft onderscheid wordt gemaakt naar geboorte kan een geschilpunt rijzen in verband met art. 14 in samenhang bezien met 8 EVRM. De conclusie uit het Marckx-arrest op dit punt is dat het maken van onderscheid tussen erfaanspraken van wettige en onwettige kinderen jegens de moeder en haar verwanten een schending oplevert van art. $14 \mathrm{j}^{\circ} 8$ EVRM. In de Johnston en Vermeire arresten wordt deze conclusie overgenomen ten aanzien van het onderscheid naar geboorte ten opzichte van de vader en zijn verwanten. In de Vermeire zaak ging het om een erkend onwettig kind. In de uitspraak van het Hof wordt geen expliciete aandacht besteed aan het feit dat het kind was erkend, maar wordt aangegeven dat het maken van onderscheid uitsluitend op grond van de onwettige aard van de verwantschap niet is toegestaan. De onwettige verwantschap zonder erkenning was aan de orde in de zaak Johnston, waarin het Hof overwoog dat naar zijn oordeel art. 8 met zich meebracht dat in gevallen als de onderhavige - waarin van een duidelijk 
en langdurig gezinsleven sprake was en waarin de wet een huwelijk niet mogelijk maakte, en het kind mitsdien nict kon worden gewettigd - het onwettig kind zowel juridisch als sociaal geplaatst moest worden in een positie die verwant is aan die van een wettig kind. In de Inze-uitspraak wordt in meer algemene zin het belang aangegeven van een gelijkstelling van wettige en onwettige kinderen.

Het bestaan of bestaan hebben van een gezinsleven gecombineerd met het bestaan van bloedverwantschap lijken derhalve voldoende voor de conclusie dat het maken van onderscheid naar geboorte in het erfrecht strijd oplevert met art. $14 j^{\circ} 8$ EVRM. Dit kan voor de erfopvolging tussen kind enerzijds en de vader en diens verwanten anderzijds in ieder geval worden aangenomen als er sprake is van een erkenning of wanneer er sprake is geweest van een duurzaam samenleven tussen de moeder en de biologische vader en de onmogelijkheid om het kind te wettigen wordt veroorzakkt door de nationale wetgeving. Voor de erfopvolging tussen kinderen enerzijds en de moeder en haar verwanten anderzijds, is het bestaan van een gezinsleven en bloedverwantschap steeds voldoende.

Met deze uitspraken zijn niet alle gevallen opgelost. Deze rechtspraak geeft bijvoorbceld geen pasklare oplossing voor gevallen waarin wel sprake is van bloedverwantschap maar de vader het kind niet heeft erkend of er geen sprake is geweest van een duurzame samenleving, of voor gevallen waarin geen sprake is van bloedverwantschap, maar wel van het bestaan van familierechtelijke betrekkingen en een duurzaam samenleven. Het onderscheid naar geboorte in verband met de rechten die voortvloeien uit een respect voor het gezinsleven is ook in andere dan erfrechtelijke zaken in de rechtspraak van zowel het EHRM als die van de Hoge Raad aan de orde geweest. Enerzijds geeft deze rechtspraak een indicatie van omstandigheden waarin, daar waar het onderscheid naar geboorte een rol speelt, een gezinsleven (family life) kan worden aangenomen. Anderzijds blijkt uit deze rechtspraak ook dat de cisen die aan het bestaan van een gezinsleven moeten worden gesteld afhankelijk zijn van de rechten en bevoegdheden die men hieraan wenst te ontlenen ${ }^{763}$. Uit de rechtspraak van het EHRM volgt onder meer dat wanneer er sprake is van biologisch ouderschap, en er sprake is van een gezinsleven, de Staat de positieve verplichting heeft om ervoor te zorgen dat familierechtelijke betrekkingen kunnen worden gevestigd. Voor het aannemen van een gezinsleven zal ofwel een samenleven worden verlangd, ofwel een relatie die met een huwelijk op een lijn is te stellen (Keegan ${ }^{764}$ ), ofwel een relatie die voldoende bestendig is om feitelijke gezinsbanden te creëren (Kroon ${ }^{765}$ ). Wanneer het ontbreken van familierechtelijke

763. Vergelijk J. de Boer 1990, 42. Aldus ook de notitie inzake leefvormen in het familierecht van Staatssecretaris van Justitie, TwK 1994-1995, 22 700, 5, p. 6-7. Zie ook HR 19 november 1993, NJ 1994, 330; HR 17 december 1993, NJ 1994, 360; HR 22 december 1995, NJ 1996, 419.

764. EHRM 26 mei 1994. Publ. EHRM Serie A vol. 290. Aldus ook o.m. HR 10 november 1989, NJ 1990, 628; HR 22 oktober 1993, NJ 1994, 113; HR 19 november 1993, NJ 1994, 330.

765. EHRM 27 oktober 1994, Publ. EHRM Serie A vol. 297-C. 
betrekkingen niet is gelegen in de wil van de betrokkenen zelf maar voortvloeit uit de wettelijke onmogelijkheid om deze betrekkingen te vestigen, lijkt aan het ontbreken ervan niet veel waarde tc mogen worden gehecht, maar dient de positie van deze kinderen zoveel mogelijk op een lijn te worden gesteld aan die van wettige kinderen. De beoordelingsmarge die op dit punt aan de Verdragsstaten wordt gelaten is slechts gering ${ }^{7 f *}$. De wet die het vestigen van familierechtelijke betrekkingen onmogelijk makt, kan in IPR-zaken ofwel de Nederlandse wet ofwel een vreemde wet zijn. Een en ander in ogenschouw nemend zou hieruit moeten volgen dat wanneer sprake is van bloedverwantschap en van een gezinsleven, in het erfrecht geen onderscheid mag worden gemaakt naar geboorte. Wanneer geen sprake is van wettige verwantschap moet voor het onthouden van erfaanspraken ecn rechtvaardiging bestaan ${ }^{767}$. Een dergelijke rechtvaardiging ontbreckt als het ontbreken van familierechtelijke betrekkingen haar oorzaak vindt in de in de toepasselijke wet bestaande onmogelijkheid om deze te vestigen (tenzij voor deze onmogelijkheid een objectieve en redelijke rechtvaardiging bestaat). Het verbod om in het erfrecht onderscheid te maken naar geboorte zou dan niet alleen gelden in situaties zoals in de Johnston-zaak, waarin sprake was van een duurzaam samenwonen van de ouders, maar ook in andere gevallen waarin uit de feitelijke omstandigheden een gezinsleven kan worden afgeleid. Een recht van erfopvolging zou in deze situaties niet alleen behoren te bestaan tussen ouders en kinderen maar ook tussen hun ascendenten, afstammelingen en collateralen. Voor andere gevallen zal per situatie, met name met behulp van de jurisprudentie, moeten worden beoordeeld welke eisen aan een gezinsleven mogen worden gesteld wil een beroep op cen verboden onderscheid naar geboorte in het erfrecht (art. $14 \mathrm{j}^{\circ} 8 \mathrm{EVRM}$ ) kunnen slagen.

Het Marokkaanse erfrecht maakt niet alleen onderscheid naar geboorte, maar ook naar geslacht en naar godsdienst. Ook dit zijn gronden ten aanzien waarvan het maken van onderscheid door art. 14 EVRM wordt verboden. De vraag wordt dan relevant of ook zij die het slachtoffer dreigen te worden van een onderscheid naar geslacht of naar godsdienst, en die met de erflater een gezinsleven hebben gehad, zich kunnen beroepen op art. $14 \mathrm{j}^{\circ} 8$ EVRM. Het EHRM heeft in de zaak Marckx overwogen dat uit art. 8 EVRM niet het recht op bepaalde erfaanspraken kan worden afgeleid. Dit is begrijpelijk ten eerste omdat, zoals het Hof zelf ook in vergelijkbare bewoordingen heeft gesteld, een volledig gezinsleven ook kan bestaan zonder erfrechtelijke aanspraken; respect voor het gezinsleven gaat niet zover dat men bepaalde erfaanspraken zou kunnen ontlenen.

766. Kritisch over de wijze warop het EHRM in de zaak Kroon (zie noot 637) deze beoordelingsmarge heeft beperkt: Loenen 1996, 80-81. In de zaak Kroon had het Hof geoordeeld dat de in casu op grond van de Nederlandse wet bestaande onmogelijkheid om het vaderschap van het kind te ontkennen, waardoor de mogelijkheid ontbrak om familierechtelijke betrekkingen te vestigen met de vader met wie het kind een gezinsleven (i.c. LAT-relatie) had, strijd opleverde met art. 8 EVRM. Het Hof had slechts op de individuele belangen gelet en het algemeen belang van de gehele Nederlandse regelgeving niet in de belangenafweging betrokken.

767. Vergelijk in dit verband ook HR 17 januari 1997, RvdW 1997, 23c. 
Ten tweede vloeien erfaanspraken doorgaans voort uit het bestaan van verwantschapsbanden met de erflater en niet uit het gezinsleven. Belangrijker in dit verband is dat het Hof aangeeft dat ten aanzien van erfrechten geen onderscheid mag worden gemaakt tussen gezinsleden op door art. 14 verboden gronden. In het Marckx-arrest ging het om cen verboden onderscheid naar geboorte. Kan de uitspraak analoog worden toegepast wanneer het niet gaat om een onderscheid naar geboorte, maar naar een ander door art. 14 verboden onderscheid, bijvoorbeeld een onderscheid naar geslacht of naar godsdienst? In dat geval zou ook een dochter zich er op kunnen beroepen dat haar erfdeel even groot zou moeten zijn als dat van een zoon. Ook jegens een kind van de islamitische erflater dat zich heeft bekeerd tot het christendom zou dan geen erfbeletsel mogen gelden. Gezien de rechtspraak van het EHRM met betrekking tot het maken van onderscheid op grond van geslacht of godsdienst ligt een dergelijke analoge toepassing erg voor de hand. Op het maken van onderscheid op grond van geboorte, geslacht of godsdienst, en de vraag wanneer hiervoor nog een rechtvaardiging kan bestaan, heeft art. 14 EVRM betrekking. Bij de bespreking van dit artikel zal dan ook de essentie van de rechtspraak betreffende het onderscheid op grond van geslacht en godsdienst aan de orde komen.

\section{An. 14 EVRM}

Aan art. 8 EVRM kunnen op zichzelf geen erfaanspraken worden ontleend, maar mogelijk wel in samenhang met art. 14 EVRM. Art. 14 verbiedt het maken van onderscheid op welke grond ook ten aanzien van rechten en vrijheden dic uit het Verdrag voortvloeien. Voor een geslaagd beroep op art. 14 dient aan een drietal voorwaarden te zijn voldaan: er moet sprake zijn van gelijke gevallen (1), die verschillend worden behandeld (2), en voor het onderscheid in behandeling bestaat geen objectieve en redelijke rechtvaardiging (3).

Er dient allereerst sprake te zijn van "gelijke gevallen". In verband met het recht op respect voor het gezinsleven geldt dat als er sprake is geweest van een gezinsleven met de erflater en het enig onderscheidend criterium is geweest een grond waarop krachtens art. 14 het maken van onderscheid is verboden, er sprake is van gelijke gevallen. Een eventuele tegenwerping van de erflater of diens erfgenamen dat een onwettig kind niet zou behoren tot het gezin, en dat er mitsdien geen sprake is van gelijke gevallen, behoort naar mijn mening te worden gepasseerd. Weliswaar is niet geheel uitgesloten dat bij de tocpassing van art. 8 rekening kan worden gehouden met subjectieve of cultureel bepaalde opvattingen over het gezin en gezinsleven ${ }^{768}$, uit de rechtspraak van het EHRM kan worden afgeleid dat de sociale werkelijkheid bepalend is bij de vaststelling of er sprake is of is geweest van een gezinsleven. Indien in het erfrecht gelijke gevallen niet gelijk worden behandeld, is deze ongelijke behandeling alleen toegestaan wanneer hiervoor een "objective and reasonable justification" bestaat. Hiervoor moet aan twee voorwaarden zijn voldaan: met de afwijkende behandeling moet een legitiem doel 
("legitimate aim") worden gediend, en het middel en doel dienen in proportionele verhouding te staan: er moet een "reasonable relationship of proportionality between the means employed and the aim sought to be realised" bestaan. De Verdragsstaten wordt hierbij in beginsel een "margin of appreciation" gelaten. De omvang van deze marge is athankelijk van het onderwerp, de omstandigheden en de achtergronden van het geval $^{769}$. Wat het maken van onderscheid naar geslacht, geboorte en godsdienst betreft, heeft het EHRM deze ruimte vergaand ingeperkt. In verband met de mogelijkheid om onderscheid te maken naar geslacht heeft het Hof in de zaak Abdulazziz, Cabales and Balkandali ${ }^{77)}$ overwogen "(..) that the advancement of the equality of the sexes is today a major goal in the member states of the Council of Europe. This means that very weighty reasons would have to be advanced before a difference of treatment on the ground of sex could be regarded as compatible with the Convention". Het maken van onderscheid naar geslacht wegens cen (veronderstelde) rolverdeling tussen man en vrouw (waarbij de rol van de gehuwde vrouw is beperkt tot die van huisvrouw), zoals dit m.i. in het Marokkaanse erfrecht gebeurt ${ }^{771}$, is door het Europese Hof als zeer zwaarwegend argument al eens verworpen ${ }^{772}$. Ten aanzien van de mogelijkheid om onderscheid te maken naar geboorte heeft het EHRM in de zaak Johnston opgemerkt dat er binnen de lid-Staten pogingen worden gedaan om de juridische status van binnen en van buiten het huwelijk geboren kinderen zoveel mogelijk gelijk te stellen. In de Inze-uitspraak keert deze constatering in versterkte vorm terug waar het Hof stelt dat "The question of equality between children born in and children born out of wedlock as regards their civil rights is today given importance in the member States of the Council of Europe". Het Hof overweegt voorts dat "Very weighty reasons would accordingly have to be advanced before a difference of treatment on the ground of birth out of wedlock could be regarded as compatible with the Convention (...)". ${ }^{773}$ Ook ten aanzien van het maken van onderscheid op grond van godsdienst heeft het EHRM in het

769. EHRM 28 november 1984, Publ. EHRM Serie A vol. 87, Rasmussen, par, 40.

770. EHRM 28 mei 1985, Publ. EHRM Serie A vol. 94. De overweging werd herhaald in EHRM 22 februari 1994, Publ. EHRM Serie A vol. 280-B, Burghartz, par. 27.

771. Hierover P. 210.

772. EHRM 24 juni 1993, Publ. EHRM Serie A vol. 263, Schuler-Zgraggen, par. 64-67.

773. In het Marckx-arrest ontbrak overigens een expliciete verwijzing naar de "margin of appreciation". Volgens Schokkenbroek 1996, 35 was de reden hiervoor dat (in de ogen van het Hof) een behoorlijke rechtvaardiging voor het maken van onderscheid naar geboorte volstrekt ontbrak. Bij het beoordelen van de omvang van de beoordelingsmarge die een Verdragsstaat heeft, zou rekening kunnen worden gehouden met het al dan niet bestaan van een Europese consensus (zie p. 254). J. de Boer geeft in zijn noot bij het arrest van de HR 24 februari 1995, NJ 1995, 468, aan dat de geldende Europeesrechtelijke norm naar zijn mening wordt gegeven in art. 9 van het Europese Verdrag inzake de rechtspositie van buiten huwelijk geboren kinderen. Volgens deze bepaling moeten buitenechtelijke kinderen dezelfde erfaanspraken hebben ten opzichte van hun vader en moeder en hun verwanten, als de binnen een huwelijk geboren kinderen. 
Hoffmann-arrest beslist dat "a distinction based essentially on a difference in religion alone is not acceptible" 774 .

Al met al kan worden geconcludeerd dat er maar een kleine marge aan Verdragsstaten wordt gelaten om onderscheid te maken naar geslacht of naar godsdienst ${ }^{775}$, en ook de ruimte om onderscheid naar geboorte te maken gering is ${ }^{776}$. Alleen zeer zwaarwichtige redenen kunnen een dergelijk onderscheid rechtvaardigen. Hoewel het EHRM zich hicrover nog niet heeft uitgelaten is het m.i. niet aannemelijk dat de belangen die het IPR beoogt te beschermen en de argumenten die in het toepasselijke (vreemde) recht zouden gelden voor het gemaakte onderscheid, op zichzelf reeds zodanig zwaarwichtige redenen vormen dat hiermee het maken van onderscheid op grond van geslacht, godsdienst of geboorte wordt gerechtvaardigd.

De gelijkheid van echtgenoten in het familierecht heeft overigens verder nog haar neerslag gevonden in art. 16 van het Vrouwenverdrag en in het door Nederland niet bekrachtigde art. 5 van het Zevende Protocol bij het EVRM. Deze verdragsbepalingen zijn van belang daar waar het toepasselijke vreemde recht aan de gehuwde man en gehuwde vrouw ongelijke rechten of verantwoordelijkheden toekent.

\section{b. Art. 16 lid 1 aanhef en sub h Vrouwenverdrag}

Art. 16 lid 1 aanhef en sub h Vrouwenverdrag luidt (in Nederlandse vertaling):

"De Staten die partij zijn bij dit Verdrag, nemen alle passende maatregelen om discriminatie jegens de vrouw in alle aangelegenheden betreffende huwelijk en familierechtelijke betrekkingen uit te bannen, en verzekeren in het bijzonder, op basis van gelijkheid van de man en de vrouw:

(...)

(h) dezelfde rechten voor beide echtgenoten met betrekking tot eigendom, verwerving, beheer, bestuur en genot van en beschikking over bezittingen, hetzij om niet hetzij onder bezwarende titel."

In het Verdrag ontbreekt een bepaling waarin het toepassingsbereik is geregeld. Uit niets blijkt dat dit niet van toepassing zou zijn op internationaal privaatrechtelijke gevallen die worden beheerst door een ander recht dan dat van een Verdragsstaat. Opvallend is wel

774. EHRM 23 juni 1993, Publ. EHRM Serie A vol. 255, par. 36. In deze zaak werd door het Hof het toekennen van de voogdij over de kinderen aan de vader enkel omdat de moeder Jehova-getuige was, aangemerkt als een schending van ar. $14 \mathrm{j}^{\circ}$ art. 8 EVRM.

775. Schokkenbroek 1996, 207 geeft zelfs aan dat de marge niet wordt gebruikt ten aanzien van onderscheid op grond van geslacht of godsdienst.

776. De Nederlandse Hoge Raad acht een dergelijke ruimt zeker nog wel aanwezig. Met een verwijzing naar de uitspraken van het EHRM inzake Marckx en Vermeire, benadrukt de Hoge Raad de ruimte die aan de nationale wetgever is gelaten om middels een verantwoorde belangenafweging beperkingen aan het erfrecht van onwettige kinderen te stellen, HR 17 januari 1997, RvdW 1997, 23c. 
dat in de Nederlandse parlementaire behandeling van art. 16 van het Verdrag uitsluitend is onderzocht of het Nederlandse interne recht een toetsing aan deze bepaling zou kunnen doorstaan ${ }^{777}$. Met geen woord wordt gerept over het IPR en de mogelijke toepassing van buitenlands recht. Ik zie echter geen reden om art. 16 niet toepasselijk te achten wanneer het een verhouding met een internationaal karakter betreft ${ }^{778}$.

Over de vraag of art. 16 rechtstreekse werking heeft is het laatste woord nog niet gezegd. Uit het Verdrag zelf noch uit de wordingsgeschiedenis blijkt dat aan de bepalingen uit het Vrouwenverdrag directe werking toekomt. Art. 16 geeft aan de Verdragstaten de opdracht om alle passende maatregelen te nemen om discriminatie op het gebied van de in deze bepaling genoemde rechten en verantwoordelijkheden uit te bannen. Volgens de Nederlandse wetgever behoort de uitvoering van dergelijke opdrachten in de ecrste plaats tot de taak van de wetgever en het bestuur ${ }^{779}$. Hij wil echter niet op voorhand uitsluiten dat in concrete omstandigheden ook aan bepalingen die in eerste instantic tot de Verdragstaten zijn gericht rechtstreekse werking kan worden verleend. De beoordeling hiervan wordt aan de rechter overgelaten ${ }^{780}$. Het is derhalve niet uitgesloten dat in een gerechtelijke procedure met succes een beroep op art. $16 \mathrm{zal}$ kunnen worden gedaan.

Heeft art. 16 lid 1 aanhef en sub h betrekking op rechten van erfopvolging, en zo ja welke (materiële) rechten kan men dan aan deze bepaling ontlenen? Om met de eerste vraag te beginnen is het interessant te constateren dat tijdens de onderhandelingen over de verdragstekst uitdrukkelijk gediscussieerd is over de vraag of er een expliciete bepaling moest worden opgenomen over de (gelijke) erfrechtelijke positie van echtgenoten. Een aantal islamitische landen, waaronder Marokko, die in 1993 tot het Verdrag is toegetreden, had hiertegen bezwaar omdat een dergelijke bepaling in strijd zou zijn met de sharí' $a$. De westerse landen weigerden op hun beurt een bepaling te accepteren die weliswaar voorzag in gelijke rechten voor mannen en vrouwen bij erfopvolging, maar het nationale recht de mogelijkheid zou laten anders te bepalen. Het compromis, waarbij de bepaling inzake de gelijkheid in het erfrecht werd geschrapt, was voor de westerse landen aanvaardbaar omdat zij zich op het standpunt stelden dat de gelijke positie met betrekking tot erfopvolging tot op zekere hoogte kon worden geacht te zijn begrepen onder art. 16 lid 1 aanhef en sub $h$, dat onder meer voorziet in gelijke rechten bij verwerving van bezittingen ${ }^{781}$. Als naar Nederlandse opvatting onder dit artikellid ook de rechten van erfopvolging behoren, en een andere conclusie lijkt niet te zijn gerechtvaardigd, dan is dit in Nederland de uitleg die aan de verdragsbepaling wordt

777. TwK 1984-1985, 18950 (R 1281), 1-3, p. 28-32.

778. Zie ook mijn bijdrage in de bundel "Het Vrouwenverdrag ..." 1994, 256-258.

779. TwK 1984-1985, 18950 (R 1281), 1-3, p. 7-8; 6, p. 10.

780. TwK 1984-1985, 18950 (R 1281), nrs. 1-3, p. 8. Uitvoerig hierover Alkema en Zaaijer 1994, 18 e.v. Ten aanzien van art. 16: Holtrust en de Hondt 1984-1985, 333; Lijnzaad 1991, 1 1-12; Rutten 1994, 258-259.

781. TwK 1984-1985, 18950 (R 1281), 1-3, p. 5. 
gegeven. Deze uilleg kan dan nict anders zijn wanneer het recht zou moeten worden locgepast van een Staat die de rechten van erfopvolging niet onder de verdragsbepaling zou brengen. Dat betekent dat de toepassing van een rechtsstelsel dat onderscheid maakt tussen de erfrechtelijke aanspraken van de gehuwde vrouw en de gehuwde man in Nederland in beginsel strijd oplevert met art. 16 lid 1 aanhef en sub h van het Verdrag. Een dergelijke strijd kan alleen worden gerechtvaardigd wanneer er belangen in het geding zijn waaraan de Verdragstaat een hogere prioriteit mag geven dan aan het gelijkheidsbeginsel van art. 16. Onduidelijk is gelaten of er ruimte is voor een dergelijke belangenafweging en zo ja, hoc groot de beoordelingsvrijheid van de Verdragsstaten dan zou zijn. Als er al een beoordelingsmarge kan worden aangenomen dan zal er, wil men het verdragsrecht niet uithollen, sprake moeten zijn van zwaarwegende andere belangen. Deze zouden in IPR-zaken moeten worden gevonden in de belangen die de verwijzingsregel beoogt te dienen, in samenhang met de gronden die in het toepasselijke vreemde recht worden aangevoerd ter verklaring van het onderscheid tussen de gehuwde man en de gehuwde vrouw. In dat verband is ook van belang dat Nederland bezwaar heeft gemaakt zowel tegen de verklaring van Marokko om art. 2 van het Vrouwenverdrag, betreffende de verplichting van een Staat om matregelen te nemen ter uitbanning van discriminatic van vrouwen, slechts toe te passen voorzover dit niet in strijd komt met de shari ${ }^{\prime}{ }^{782}$, als tegen het voorbehoud dat Marokko met een beroep op de shari' $a$ heeft gemaakt bij art. $16^{783}$. Zowel deze verklaring als het voorbehoud worden door Nederland in strijd geacht met doel en strekking van het Vrouwenverdrag. Het ligt dan niet voor de hand dat een beroep op de shari' $a$ als rechtvaardiging kan worden geaccepteerd voor een ongelijke behandeling van man en vrouw. Ook op p. 214 heb ik geconcludeerd dat de toepassing van het Marokkaanse erfrecht waarin onderscheid wordt gemaakt tussen de erfaanspraken van de echtgenoten een toetsing aan de openbare orde m.i. in beginsel niet zal doorstaan. Dat betekent dat aan het gelijkheidsbeginsel veelal meer waarde wordt toegekend dan aan het respecteren van de verwijzingsregel uit het IPR en het als toepasselijk aangewezen recht. Deze belangenafweging zal ook bij art. 16 van het Vrouwenverdrag tot gevolg hebben dat het maken van onderscheid in erfaanspraken een ontoclaatbare inbreuk oplevert op art. 16 lid 1 aanhef en sub $h$.

Ecn geslaagd beroep op deze bepaling zal er dan toe moeten leiden dat de gehuwde vrouw en de gehuwde man gelijke crfaanspraken hebben. Het probleem is alleen het

782. Marokko geeft hierbij vervolgens aan: "It should be noted that certain of the provisions contained in the Moroccan Code of Personal Status according women rights that differ from the rights conferred on men may not be infringed upon or abrogated because they derive primarily from the Islamic Shariah, which strives, among its other objectives, to strike a balance between the spouses in order to preserve the coherence of family life."

783. Het voorbehoud bij art. 16 is overigens in het bijzonder gemaakt met het oog op de rechten en verantwoordelijkheden van mannen en vrouwen om in het huwelijk te treden en om het huwelijk te ontbinden. Gelijkheid van man en vrouw op deze punten wordt onverenigbaar met de sharí'a geach. Overigens is door Nederland eveneens bezwaar gemaakt tegen de door Marokko gedane verklaring bij art. 15 lid 4 (zie p. 202) en tegen het voorbehoud bij art. 9 lid 2. 
vaststellen van de omvang van dit recht. Art. 16 garandeert immers geen materiële rechten maar slechts de aanspraak op gelijke rechten. Dienen hier de rechten van de man als uitgangspunt te worden genomen? En welk rechtsstelsel dient hierbij als uitgangspunt te worden genomen als de erfopvolging van de man door een ander rechtsstelsel wordt beheerst als die van de vrouw? Op p. 246 heb ik op dit punt aangegeven verdedigbaar te vinden om wanneer volgens het toepasselijke buitenlandse recht de erfportie van de echtgenoot groter is dan die van de echtgenote, het deel van de echtgenoot als uitgangspunt te nemen. Bezitten beide echtgenoten de Marokkaanse nationaliteit en zou bij beider overlijden de erfopvolging door Marokkaans recht worden beheerst, dan zou de echtgenote bij het overlijden van haar man met een beroep op art. 16 in beginsel aanspraak maken op het erfdeel dat een echtgenoot naar Marokkaans recht zou ontvangen. Zou bij het overlijden van de vrouw de erfopvolging door Nederlands recht worden beheerst, omdat zij de Nederlandse nationaliteit bezit of Marokkaanse is, maar de verwijzingsregel niettemin zou leiden tot toepasselijkheid van Nederlands recht, dan zou haar echtgenoot een kindsdeel ontvangen. Met een beroep op art. 16 zou de vrouw bij het overlijden van haar echtgenoot, eveneens in beginsel aanspraak moeten kunnen maken op een kindsdeel, dat erfdeel dat een kind naar Marokkaans recht zou ontvangen. Hier is echter de vraag of er niet toch voldoende reden bestaat om het verschil in erfrechtelijke positie te rechtvaardigen. Het onderscheid wordt hier veroorzaakt door het feit dat de verwijzingsregel inzake de erfopvolging voor de man respectievelijk de vrouw verwijst naar de toepasselijkheid van verschillende rechtsstelsels. De verwijzingsregel kan op haar beurt weer worden gerechtvaardigd door de belangen die zij beoogt te beschermen, zoals het bereiken van een internationale beslissingsharmonie, een veronderstelde nauwste verbondenheid met een bepaald rechtsstelsel etcetera. Het zijn ook hier weer deze belangen die, als hiervoor de ruimte is, in een concreet geval dienen te worden afgewogen tegen het in art. 16 neergelegde gelijkheidsbeginsel. Bestaat bijvoorbeeld geen enkele verbondenheid (meer) met het rechtsstelsel dat toepasselijk is verklaard, en maakt dit stelsel een onderscheid tussen de erfaanspraken van de echtgenoten, dan zal het gelijkheidsbeginsel in de regel moeten prevaleren boven het respect voor het vreemde recht.

\section{Beschikkingsvrijheid}

\section{a. Art. 1 Eerste Protocol EVRM}

Art. 1 van het Eerste Protocol bij het EVRM luidt (in Nederlandse vertaling):

"Iedere natuurlijke of rechtspersoon heeft recht op het ongestoord genot van zijn eigendom behalve in het algemeen belang en onder de voorwaarden voorzien in de wet en in de algemene beginselen van internationaal recht. De voorgaande bepalingen tasten echter op geen enkele wijze het recht aan, dat een Staat heeft om die wetten toe te passen, die hij noodzakelijk oordeelt om het gebruik van eigendom te reguleren in overeenstemming met het algemeen belang of om de betaling van belastingen of andere heffingen of boeten te verzekeren." Het in dit artikel gegarandeerde recht geldt voor een 
ieder die ressorteent onder de rechtsmacht van een Verdragsluitende Staat (zie hierover p. 257). Art. 1 is een direct werkende verdragsbepaling. Burgers kunnen zich hierop rechtstrecks beroepen ter bescherming van hun eigendomsrechten.

In het Marckx-arrest heeft het EHRM bepaald dat aan deze bepaling geen erfaanspraken kunnen worden ontleend, maar dat de bepaling bescherming biedt voor reeds bestaande eigendomsaanspraken ${ }^{7.4}$. Wat het erfrecht betreft is de bepaling van belang als het gaat om het realiseren van reeds bestaande erfaanspraken ${ }^{785}$ en voor de beschikkingsvrijheid. Het is met name de vraag of de beperkingen die in het Marokkaanse erfrecht aan de testecrvrijheid worden gesteld een toetsing aan art. I Eerste Protocol EVRM kunnen doorstaan. Ten aanzien van art. 1 heeft het EHRM bepaald dat het recht om over zijn eigendommen te beschikken een traditioneel en fundamenteel aspect van het eigendomsrecht inhoudt ${ }^{786}$. Het artikel laat in het tweede lid een aantal beperkingen op dit recht toe. Algemeen geldt dat art. 1 aan Verdragsstaten een grote discretionaire bevocgdheid laat om beperkingen aan het eigendomsrecht te stellen: de "margin of appreciation" is hier ruim ${ }^{787}$. In het bijzonder wordt het aan Verdragstaten toegestaan om die wetten toe te passen die noodzakelijk worden geoordeeld om het gebruik van eigendom te reguleren in overeenstemming met het algemeen belang. In het Marckxarrest zegt het Hof hierover: "As regards 'the general interest', it may in certain cases induce a legislature to 'control the use of property' in the area of dispositions inter vivos or by will" ${ }^{78 s}$. Het stellen van een beperking aan de testeervrijheid is op zichzelf niet strijdig met art. 1 Eerste Protocol EVRM. Beperkingen zijn gerechtvaardigd op aan het algemeen belang ontleende gronden. Zoals gezegd, is de beleidsvrijheid hier groot. Indien de vrijheid om bij uiterste wil te beschikken in Nederland wordt beoordecld naar Marokkaans recht, met als gevolg dat aan deze vrijheid bepaalde (vergaande) beperkingen worden gesteld, zijn de Marokkaanse wet en de conflictregel die tot de toepasselijkheid van deze wet heeft geleid, gezamenlijk aan te merken als de in art. 1 Eerste Protocol EVRM bedoelde wetten. De belangen die deze beide regelingen beogen te dienen, moeten als noodzakelijk worden geoordeeld ter regulering van het gebruik van eigendom in overeenstemming met het algemeen belang, althans moeten een aantasting van de beschikkingsvrijheid kunnen rechtvaardigen. In $\$ 3 . A .4$.a (p. 223-228) heb ik uiteengezet hoe een dergelijke belangenafweging gemaakt zou kunnen worden. Ik heb hier geconcludeerd dat zich gevallen kunnen voordoen waarin aan het eigendomsrecht en het hieruit voortvloeiende vrije beschikkingsrecht meer waarde moet worden gehecht dan aan de belangen die het IPR en het Marokkaanse testamentair recht willen bescher-

784. Marckx. par. 50.

785. Vergelijk lnze, EHRM 28 oktober 1987, Publ. EHRM Serie A vol. 126, m.n. par. 35-40.

786. EHRM 13 juni 1979. Publ. EHRM Serie A vol. 31, Marckx, par. 63 met verwijzing naar EHRM 7 december 1976, Publ. EHRM Serie A vol. 24, Handyside, par. 62.

787. Van Dijk/van Hoof 1990, 503; Hartlief 1996, 141-143; Schokkenbroek 1996, 53.

788. Marckx, par. 64. 
men. In dergelijke gevallen zou cen beroep op art. 1 Eerste Protocol EVRM moeten slagen.

In het Marckx-arrest werd de vraag of de beperkte mogelijkheid van een ongehuwde moeder om ten behoeve van haar onwettig kind te beschikken strijdig was met art. 1 Eerste Protocol EVRM, in beginsel negatief beantwoord. Wel werd het verschil in de testecrmogelijkheden van gehuwde en ongehuwde moeders ten behoeve van hun wettige respectievelijk onwettige kinderen strijdig geacht met art. 14 j" art. 1 Eerste Protocol EVRM. Voor een dergelijk onderscheid achtte het Hof geen rechtvaardiging aanwezig ${ }^{789}$. In het Marokkaanse erfrecht wordt dit onderscheid niet gemaakt. Een onwettige afstamming ten opzichte van de moeder wordt gelijkgesteld met een wettige afstamming. Een vader daarentegen kan ten behoeve van zijn onwettige kinderen beschikken over maximaal eenderde van zijn actief vermogen, maar kan niet beschikken ten behoeve van zijn wettige kinderen. In het licht van de Marckx-uitspraak zou m.i. op dit punt eveneens een schending kunnen worden aangenomen van art. $14 \mathrm{j}^{\prime}$ art. 1 Eerste Protocol EVRM, tenzij de belangen die de conflictregel beoogt te dienen nog als rechtvaardiging zouden worden geaccepteerd.

\section{b. Art. 8 EVRM}

In de Marckx-zaak was nict alleen de vraag aan de orde of aan het door art. 8 EVRM beschermde gezinsleven erfaanspraken konden worden ontleend, maar eveneens of de beperking van de beschikkingsvrijheid van een ongehuwde moeder ten behoeve van haar onwettige kinderen, een toetsing aan art. 8 EVRM kon doorstaan. Bij de beschrijving van de Marckx-zaak op p. 261-262 werd reeds opgemerkt dat ook dit onderwerp bij de toepassing van art. 8 EVRM relevant is (zie de uit het arrest geciteerde paragrafen 52 en 53). De redenering die hat Hof ten aanzien van art. 8 geeft is dezelfde als werd gevolgd bij art. 1 Eerste Protocol EVRM (zie vorige paragraaf); op zichzelf is een beperking van de beschikkingsvrijheid niet in strijd met art. 8 EVRM, als deze onafhankelijk van de grond die voor de beperking geldt wordt beoordeeld ${ }^{790}$. Echter, het maken van onderscheid tussen de beschikkingsmogelijkheid van ongehuwde en gehuwde mocders ten behoeve van hun onwettige respectievelijk wettige kinderen, levert een schending op van art. $14 \mathrm{j}^{\circ}$ art. 8 EVRM als voor dit onderscheid geen objectieve en redelijke rechtvaardiging bestaat ${ }^{791}$.

Ook hier geldt dat in het Marokkaanse recht en de conflictregel voldoende grond moet worden gevonden om de beschikkingsbeperking te rechtvaardigen. Voor het antwoord op de vraag of de in het Marokkaanse recht geldende beperkingen aan de testeervrijheid

789. Marckx, par. 65.

790. Marckx, par. 6!.

791. Marckx, par. 62. 
strijdig kunnen worden geacht met art. 14 EVRM zij verwezen naar de vorige paragraaf.

\section{TOETSING AAN VERDRAGSBEPALINGEN OF AAN DE OPENBARE ORDE?}

Wanneer op grond van de conflictregel een rechtsstelsel toepasselijk wordt verklaard waarvan de toepassing op gespannen voet staat met in mensenrechtenverdragen neergelegde beginselen, rijst de vraag hoever de acceptatie van dit vreemde recht moet gaan. Er is sprake van een strijd tussen respect voor het toepasselijke recht, en hiermee het respecteren van IPR-belangen, enerzijds en een respect voor mensenrechten anderzijds. Uit de vorige paragrafen volgt dat bij een beroep op een rechtstreeks werkende verdragsbepaling, voor de toepassing van een recht dat leidt tot een schending van het in de verdragsbepaling neergelegde beginsel, meer ruimte bestaat naarmate aan de Verdragstaat een ruimere marge wordt gelaten om zelf de grenzen van het verdragsrecht af te bakenen. Dan immers is er meer ruimte om rekening te houden met het internationale karakter van het geval en hierin een argument en rechtvaardiging te vinden voor ecn beperking van het verdragsrecht. Aangegeven werd dat bij verdragsrechten van het EVRM de beoordelingsmarge die Verdragstaten hebben niet altijd even groot is. Factoren die hierbij onder meer van belang zijn is het al dan niet bestaan van een Europese consensus over de inhoud van het verdragsrecht of althans over (de omvang van) het bestaan van een "margin of appreciation", de vraag of de kern van het verdragsrecht wordt geraakt, de aard van het recht waarop inbreuk wordt gemaakt, en de aard van de beschermingsgrond die tot een beperking heeft geleid. Bestaat er voor Verdragstaten geen of een zeer geringe beoordelingsmarge, dan kan voor een schending van het verdragsrecht geen rechtvaardiging bestaan of er moct althans sprake zijn van een zeer zwaarwegende grond om aan het verdragsrecht een beperking te stellen. Het internationale karakter van de rechtsverhouding zou dan een dergelijke zeer zwaarwegende grond voor een beperking van het verdragsrecht moeten opleveren. Van een geringe beoordelingsmarge is sprake bij het verboden onderscheid op grond van geslacht, van godsdienst en van geboorte. Dat betekent dat de toepassing van een rechtsstelsel die leidt tot het maken van onderscheid op een van deze gronden, al gauw een schending zal opleveren van het verdragsrecht. Of hierbij tevens sprake zou zijn van een schending van de internationaal privaatrechtelijke openbare orde is dan eigenlijk niet meer van belang. Bestaat er voor Verdragstaten nog wel enige marge om de grenzen van een verdragsrecht af te bakenen, hetgeen bij het eigendomsrecht het geval is, dan bestaat voor een Verdragsstaat ook de mogelijkheid om binnen deze marge rekening te houden met het internationale karakter van het geval. Leidt de toepassing van een regel uit een vreemd rechtsstelsel tot strijd met de Nederlandse IPR-openbare orde, dan zal dit echter ook binnen de aan cen Verdragsstaat gelaten beoordelingsmarge niet worden geaccepteerd als rechtvaardiging voor een beperking van het verdragsrecht. Met andere woorden: de IPR-openbare orde bepaalt hier mede hoe de beoordelingsruimte die een Verdrag laat, moet worden ingevuld. Te verwachten is dan ook dat in dergelijke gevallen een beroep op een verdragsbepaling en een berocp op de exceptie van de openbare orde in de regel 
tot hetzelfde resultaat zullen leiden. Je zou je kunnen afvragen of de ene weg te verkiezen is boven de andere weg. Een nadeel bij een rechtstreeks beroep op een verdragsbepaling is dat hierbij een aantal theoretische hindernissen moet worden genomen (zie $\$$ A), waarvoor men bij een beroep op de openbare orde niet komt te staan, terwijl in beide gevallen een vergelijkbare belangenafweging zal plaatsvinden. Daar staat tegenover dat bij een beroep op een (rechtstreeks werkende) verdragsbepaling wordt getoetst aan (objectief geldend) hoger recht ${ }^{792}$, en de toepassing van vreemd recht dat een schending hicrvan oplevert achterwege moet blijven; bij de vraag of een beroep op de openbare orde zal slagen geldt als uitgangspunt dat vreemd recht wordt toegepast, tenzij er gronden zijn om hiervan af te wijken. Hierbij wordt doorgaans een terughoudende opstelling geadviseerd. Bij een rechtstreeks beroep op een verdragsbepaling moet derhalve worden gerechtvaardigd waarom een beroep op een mensenrecht eventueel niét kan slagen, terwijl bij een beroep op de openbare orde-exceptie moet worden gerechtvaardigd warom een beroep op ecn fundamenteel beginsel wél moet worden gehonoreerd. Een ander verschil is dat een beroep op een verdragsbepaling kan worden gedaan zowel bij de toepasselijkheid van Nederlands recht als bij de toepasselijkheid van buitenlands recht, terwijl een beroep op de openbare orde is beperkt tot gevallen waarin buitenlands recht toepasselijk is. Ten aanzien van het vereiste van "Binnenbezichung" bestaat eveneens een verschil. Aangenomen wordt dat het inroepen van de exceptie van de openbare orde in het algemeen ${ }^{793}$ alleen mogelijk is bij voldoende betrokkenheid met de Nederlandse rechtssfeer. Bij de toepassing van een mensenrechtenverdragsbepaling geldt een dergelijke beperking niet. Voor zover aan Verdragstaten ruimte wordt gelaten voor een belangenafweging, bestaat echter wel de mogelijkheid in deze afweging de betrokkenheid met de Nederlandse rechtssfeer mee te nemen.

Aan verdragsbepalingen die geen rechtstreekse werking hebben kunnen burgers niet rechtstreeks rechten ontlenen. Zij kunnen in het IPR wel nog van belang zijn bij het inroepen van de exceptic van de openbare orde. Je zou hier kunnen spreken van een indirecte werking van verdragsrechten.

Gezien de toenemende betekenis die wordt gehecht aan mensenrechten, rijst de vraag of niet iedere schending van een mensenrechtenverdragsbepaling zou moeten leiden tot cen schending van de internationaal privatrechtelijke openbare orde, en of het opnemen van een clausule in de conflictregels zelf niet wenselijk zou zijn. Via de art. 93 en 94 Gr.w. heeft een aantal verdragsbepalingen ${ }^{794}$ in Nederland rechtstreekse werking en behoort tot de Nederlandse rechtsorde. Een clausule in het IPR bepalende dat schending van een mensenrecht een schending van de openbare orde oplevert, zou in dergelijke

792. Hierover Hammje 1994, 506.

793. Met uitzondering van gevallen watin vreemd recht reeds niet door het zogenaamde buitengrenskriterium heen komt.

794. En daarmee ook de op deze verdragsbepaling betrekking hebbende rechtspraak van de internationale rechter wiens competentie door Nederland is anvaard (art. 46 EVRM). 
gevallen theoretisch niet nodig zijn ${ }^{795}$. Voor niet rechtstreeks werkende verdragsbepalingen zou een dergelijke clausule wel betekenis hebben, omdat deze dan indirect bij de openbare orde moeten worden getoetst. Een schending van art. 16 Vrouwenverdrag zou in cen dergelijk geval dan moeten leiden tot het buiten toepassing laten van vreemde rechtsbepalingen wegens strijd met de openbare orde. Hoewel dit m.i. wenselijk zou zijn, meen ik dat de IPR-rechtsopvattingen in Nederland zich nog niet zover ontwikkeld hebben ${ }^{7 \%}$.

Een vraag die allcreerst gesteld zou moeten worden is of in publiekrechtelijke verdragsbepalingen wel voldoende rekening wordt gehouden met het internationale karakter van privaatrechtelijke gevallen. Is dit niet het geval, dan zou het IPR zijn eigen weg kunnen blijven bewandelen. Het EHRM heeft zich nog niet uitgelaten over een toetsing van de tocpassing van het recht van cen niet-Verdragsstaat aan het EVRM. Uit de wel gedane rechtspraak van het EHRM kan m.i. niet anders worden afgeleid dan dat publiekrechtelijke verdragsbepalingen een algemene strekking hebben en zich ook uitstrekken tot internationaal privaatrechtelijke gevallen. De enige vraag die dan nog zou resteren of binnen de marge die aan Verdragstaten wordt gelaten, ruimte bestaat om in het internationale karakter van IPR-gevallen en hiermee ook in de gewenste internationale beslissingsharmonic cen rechtvaardiging kan worden gevonden voor een beperking van in internationale bepalingen neergelegde rechten, in die zin dat de toepassing van vreemd recht wordt gegarandeerd omdat hiermee recht wordt gedaan aan het internationale karakter van het geval, ook als dit leidt tot een beperking van verdragsrechten. Hiermee wordt onvermijdelijk een koppeling gelegd tussen internationaal publiekrecht en internationaal privaatrecht, nadat lange tijd voor veel onderwerpen sprake is geweest van een gescheiden ontwikkeling van beide rechtsgebieden.

795. Hierbij ga ik ervan uit dat geen sprake is van een verdragsconflict. Hierover noot 719.

796. Zie bijvoorbeeld het advies van Dubbink, noot 607, om niet over te gaan tot ratificatie van het Zevende Protocol bij het EVRM omdat art. 5 van dit Protocol vergaande gevolgen zou hebben in internationaal privaatrechtelijke gevallen. Deze opvatting wordt gedeeld door Vonken, Reflexwerking 1993, 177-178. Positief ten aanzien van het buiten toepassing laten van vreemd recht wanneer de toepassing hiervan zou leiden tot een ongelijkheid tussen echtgenoten is de Nederlandse wetgever bij de totstandkoming van de Wet conflictenrecht huwelijksbetrekkingen, zie noot 605 . 



\section{Erkenning en tenuitvoerlegging in Marokko}

De mogelijkheid van erkenning en tenuitvoerlegging in Marokko van in Nederland genomen beslissingen over de erfopvolging kan in verschillende omstandigheden van belang zijn. Dit zal met name het geval zijn wanneer de erflater vermogen in Marokko bezit, maar ook wanneer zich schuldenaren of schuldeisers van de erflater in Marokko bevinden. Of de medewerking in Marokko zal worden verleend is in theorie afhankelijk van het Marokkaanse IPR, in het bijzonder van de vraag of hetgeen in Nederland is vastgesteld voor crkenning en tenuitvoerlegging in aanmerking komt. Hoewel de goederen uit de nalatenschap (of schuldenaren en schuldeisers) zich in ieder willekeurig land kunnen bevinden, wordt in dit hoofdstuk uitsluitend uitgegaan van vermogen van de erflater dat zich in Marokko bevindt, en mitsdien van het belang van de Marokkaanse erkennings- en exccutieregels. Bevindt zich (eveneens) vermogen in een ander land, dan geldt ten aanzien van de erkenning en executie van de in Nederland vastgestelde erfopvolging betreffende deze goederen, vanzelfsprekend de IPR-regeling van het land waar zich deze goederen bevinden. Het gaat in dit hoofdstuk uitsluitend om de erkennings- en executiemogelijkheden van beslissingen inzake de erfopvolging genomen of getroffen door de Nederlandse rechter of bij authentieke akte. Niet wordt ingegaan op de vraag naar erkenning van bevoegdheden die aan personen in de afwikkelingsfase zijn toegckend. Ook blijven buiten beschouwing de gevallen waarin de erfgenamen zelf de erfopvolging en verdeling regelen. De mogelijkheid om de afwikkeling van de nalatenschap via de Marokkaanse diplomatieke vertegenwoordigingen in Nederland te regelen is besproken in hoofdstuk 3.

\section{$\S 1$. Verwijzingsregels inzake de erfopvolging}

De conflictregel inzake de erfopvolging is te vinden in art. $18 \mathrm{DCC}^{797}$. Hierin wordt bepaald dat de erfopvolging wordt beheerst door het nationale recht van de erflater. Het 
betreft hier een verwijzing naar intern recht ${ }^{798}$. Dit recht beheerst zowel de wettelijke erfopvolging als de innerlijke geldigheid en gevolgen van uiterste wilsbeschikkingen. Er wordt uitgegaan van een eenheidsstelsel. De erfwet is van toepassing op de vererving van zowel roerende als onroerende goederen die zich in Marokko bevinden ${ }^{7 \times}$. Voor de formele geldigheid van een uitcrste wilsbeschikking kent de DCC geen aparte verwijzingsregel. In de doctrine wordt veelal aangenomen dat de formele geldigheid van een testament, bij gebreke van een aparte regcling, moet worden vastgesteld aan de hand van het recht dat van toepassing is op grond van art. $10 \mathrm{DCC}^{800}$. Art. $10 \mathrm{DCC}$ bevat de algemene verwijzingsregel inzake de formele geldigheid van rechtshandelingen. Art. $10 \mathrm{DCC}$ kent cen facultaticve aanknopingsfactor: toepasselijk is hetzij het nationale recht hetzij het recht van de plaats waar de rechtshandeling wordt verricht ${ }^{801}$. Deze facultatieve aanknopingsfactor lijdt in twee gevallen uitzondering: 1 . als de rechtshandeling het personeel statuut betreft prevaleert het nationale recht; 2 . als het Marokkaanse recht bepaalde vormvereisten stelt ${ }^{802}$. De Marokkaanse rechispraak lijkt echter niet mee te gaan in de doctrine gehuldigde opvatting dat de formele geldigheid van een testament is onderworpen aan de conflictregel uit art. $10 \mathrm{DCC}^{803}$. In 1977 onderwierp het Cour suprême zowel de formele geldigheid als de materiële geldigheid van een testament aan cenzelfde rechtsstelsel ${ }^{804}$.

\section{$\S 2$. Erkenning en tenuitvoerlegging van rechterlijke beslissingen}

Voor zover Marokko partij is bij een Verdrag waarin tevens de tenuitvoerlegging van buitenlandse beslissingen is geregeld, gelden de regels van deze Verdragen. Marokko heeft met verschillende landen dergelijke verdragen gesloten ${ }^{805}$. Voorts is zij nog gebonden aan Verdragen die tijdens het Frans protectoraat zijn gesloten, welke Verdragen na de onathankelijkheid van Marokko van toepassing zijn gebleven. Tussen Marokko en Nederland bestaat geen Verdrag waarin de erkenning en tenuitvoerlegging van beslissingen is geregeld. De vraag naar de erkenning en tenuitvoerlegging van buitenlandse rechterlijke beslissingen wordt dan bepaald door de Marokkaanse executieregels die zijn neergelegd in de art. 430 en 431 van de Marokkaanse Code de procédure civile

798. Decroux 1960, 286.

799. De wijze van verkrijging is eveneens onderworpen aan het recht dat de erfopvolging beheerst. Betreft het echter in Marokko gelegen geregistreerd onroerend goed, dan werkt deze verkrijging alleen tegenover derden, als zij is ingeschreven, Decroux 1963, 245.

800. Decroux 1960, 290; Decroux 1963, 250.

801. Sarehane en Lahlou-Rachdi 1994, Fasc. 4, 21.

802. Sarehane en Lahlou-Rachdi 1994, Fasc. 4, 21.

803. Sarehane en Lahlou-Rachdi 1994, Fasc. 4, 20.

804. Cour supreme 23 februari 1977.

805. Marokko heeft Verdragen waarin ook de executie van buitentandse beslissingen is geregeld, gesloten met Frankrijk, België, Libië, Algerije, Tunesië, Senegal, Italië, Roemenië en Polen. Zie Sarehane en Lahlou-Rachdi 1994, Fasc, 4, 21. 
$(\mathrm{CPC})^{81 x^{3}}$. Deze bepalingen hebben volgens de bewoordingen ervan uitsluitend betrekking op de executic van buitenlandse rechterlijke beslissingen. $\mathrm{Zij}$ worden eveneens toegepast op executievragen betreffende arbitrale beslissingen en akten die zijn verleden ten overstaan van bevoegde openbare ambtenaren of functionarissen (art. 432 $\mathrm{CPC})^{807}$. Een regel voor erkenning van buitenlandse rechterlijke beslissingen ontbreekt. Over de vraag of buitenlandse rechterlijke beslissingen die het personeel statuut (incl. het erfrecht) betreffen in Marokko kunnen worden erkend, is de doctrine verdecld ${ }^{808}$. In zijn "Cours de licence" betreffende "Les conflits de juridictions" ${ }^{819}$ geft Moulay R'chid aan dat volgens hem buitenlandse beslissingen slechts van rechtswege gezag van gewijsde kunnen bezitten, als de Marokkaanse rechter is nagegaan of aan alle voorwaarden is voldaan die gelden voor het verkrijgen van een exequatur.

Het antwoord op de vraag welke voorwaarden gelden voor het verkrijgen van een exeq̨uatur, wordt gegeven in de art. 430 en $431 \mathrm{CPC}$. Art. 430 vangt aan met de zinsnede dat buitenlandse rechterlijke beslissingen alleen kunnen worden tenuitvocrgelegd nadat cen exequatur is verkregen. De exequatur dient te worden gevraagd bij de Rechtbank van de woonplaats of verblijfplaats van de gedaagde, of, bij gebreke hiervan, bij de Rechtbank van de plaats waar de tenuitvoerlegging moet worden gerealiseerd. Voor het verkrijgen van een exequatur geldt een aantal voorwaarden ten aanzien waarvan de aangezochte rechter moet nagaan of deze zijn vervuld. De Marokkaanse rechter behoeft de zaak niet zelf opnieuw te beslissen. Hij bchoeft evenmin een conflictenrechtelijke toets aan te leggen. De voorwaarden die de rechter moet onderzocken betreffen:

\section{De regelmatigheid ("régularité") van de beslissing}

Deze voorwaarde houdt twee dingen in, te weten ${ }^{810}$ :

a. respect van de rechten van verdediging ${ }^{811}$;

b. de beslissing moet in het land van herkomst gezag van gewijsde hebben en daar voor tenuitvoerlegging in aanmerking komen ${ }^{812}$, een en ander te beoordelen volgens het recht van het land waar de beslissing is genomen ${ }^{813}$.

806. Dahir 28 september 1974, B.O. $\mathrm{n}^{\circ} 3230$ bis, 30 september 1974, p. 1305.

807. Moulay R'chid. Cours 1989/1990, 3; Sarehane en Lahlou-Rachdi 1994, Fasc 4, 22.

808. Aldus Sarehane en Lahlou-Rachdi 1994, Fasc. 4, 23 en Moulay R'chid, Cours 1989/1990, 28-29 die, na enkele auteurs te hebben aangehaald die zich op het standpunt stellen dat een dergelijk gezag van gewijsde kan worden aangenomen, zelf aangeeft hierin niet te geloven en ook in de jurisprudentie geen bevestiging voor een dergelijke erkenning te hebben gevonden.

809. Moulay R'chid Cours 1989/1990, 29.

810. Moulay R'chid, Cours 1989/1990, 7-9; Sarehane en Lahlou-Rachdi 1994, Fasc 4, 22.

811. Hierover ook Deprez 1977, 254.

812. Hierover Mouly R'chid 1973 en 1977; Sarehane en Lahlou-Rachdi 1994, Fasc. 4, 22.

813. Moulay R'chid, Cours 1989/1990, 8. 


\section{De bevoegdheid van de buitenlandse rechter}

De rechter moet zowel internationaal als intern bevoegd zijn ${ }^{814}$. De interne bevoegdheid moet worden beoordceld an de hand van de interne bevoegdheidsregels van het land waar de beslissing is genomen ${ }^{815}$. Hoe de internationale bevoegdheid van de buitenlandse rechter moet worden beoordecld, bij gebreke van een verdragsregeling, geeft de Marokkaanse wet niet aan. De doctrine lijkt verdeeld te zijn ${ }^{816}$.

\section{De beslissing mag niet in strijd zijn met de Marokkaanse openbare orde}

Wanneer sprake is van strijd met de openbare orde is in Marokko, evenmin als in Nederland, cenduidig aan te geven. Het gaat bij de openbare orde om fundamentele beginselen van de Marokkaanse rechtsorde ${ }^{817}$. Tot deze beginselen behoren ook de beginselen uit de Islam en het islamitisch recht ${ }^{818}$. Deze beginselen betreffen niet alleen de godsdienst, maar vormen ook morele waarden, normen van beschaving, en van maatschappij en politick ${ }^{819}$. Tot deze fundamentele waarden uit de Islam behoren onder meer de gedachte dat buitenechtelijke relaties immoreel zijn en mede in verband hiermee ook het vestigen van familierechtelijke betrekkingen met buitenechtelijke kinderen. Geen twijfel bestaat er over het feit dat Marokkaanse moslims wat het personeel statuut en erfrecht betreft onderworpen zijn aan de Mudawwanah, en dat deze regel absoluut respect geniet, een regel van openbare orde is 820821 .

814. Moulay R'chid, Cours 1989/1990, 10; Sarchane en Lahlou-Rachdi 1994, Fasc. 4, 22.

815. Moulay R'chid, Cours $1989 / 1990,13$.

816. Volgens Deprez 1981, Fase 4-2, 14, (vervangen door Sarehane en Lahlou-Rachdi 1994) bestond destijds (tot 1981) in de doctrine nog de voorkeur om de internationale bevoegdheid van de buitenlandse rechter te beoordelen aan de hand van de Marokkanse competentieregels, als ware de zaak aan een Marokkaanse rechter voorgelegd. Bij zijn verwijzing naar de doctrine verwijst hij (uitshitend) naar Moulay R'chid, Lexéquatur 1973, 28. Moulay R'chid geeft in zijn Cours 1989/1990, 13 aan dat volgens hem de bevoegdheid van de buitenlandse recher alleen aan de hand van de Marokkaanse bevoegdheidsregels zou moeten worden beoordeeld als de bevoegdheid van de Marokkanse rechter wordt ingeroepen. Indien dit niet het geval is, dan zou de bevoegdheid moeten worden beoordeeld aan de hand van de competentieregels van het buitenlandse recht. De bevoegdheid van de vreemde rechter zou hij echter niet willen accepteren, zelfs niet als deze zou voldoen aan de Marokkanse competentieregels, wanneer de grond warop de bevoegdheid is angenomen door partijen kunstmatig is gecreëerd. Sarehane en Lahlou-Rachdi 1994, Fasc. 4, 22, opleren voor een beoordeling volgens de bevoegdheidsregels van het land war de beslissing is genomen.

817. Zie o.m. Moulay R'chid, Cours 1989/1990, 14-16.

818. Zic 0.m. Bourely 1962, 472; Bourely 1964, 4; Deprez 1981, 132 e.v; Moulay R'chid, Cours 1989/1990, 16-17; Moulay R'chid, Grandes lignes 1991, 24; Sarehane en Lahlou 1994, Fasc 4, 10.

819. Moulay R'chid, Grandes lignes 1991, 24.

820. Zie de in noot 818 opgenomen verwijzingen. Deze opvatting is ook mondeling bevestigd door onder meer een ambtenar van het Marokkaanse Ministerie van Justitie, deskundigen aan de Marokkaanse Universiteiten, Marokkaanse notarissen, zowel de latijnse als de islamitische, en Marokkaanse advocaten, die ik heb gesproken tijdens mijn werkbezoek in Marokko.

821. De beginselen uit de Mudawwanah zijn ook dwingendrechtelijk van toepassing op moslims die een andere nationaliteit dan de Marokkaanse bezitten (zie p. 157-158). Kritisch nierover Moulay R'chid, Grandes lignes 1991, 41-42. Het Marokkaanse moslimrecht behoeft daarentegen niet te worden toege- 
Overigens geldt in cle Marokkaanse verwijzingsregel inzake de erfopvolging, art. 18 DCC, evenals in andere personeel statuut zaken ${ }^{822}$, de nationaliteit als aanknopingsfactor zowel voor roerende als onrocrende zaken.

Beslissingen van buitenlandse rechters waarin een verdeling van de nalatenschap van een Marokkaanse (islamitische) erflater wordt vastgesteld die niet overeenstemt met een verdeling volgens de Mudawwanah zullen in Marokko mitsdien niet tenuitvoer gelegd kunnen worden wegens strijd met de Marokkaanse openbare orde. Concreet betekent dit bijvoorbecld dat wanneer het Nederlandse erfrecht is toegepast, of het Marokkaanse recht is toegepast maar enkele bepalingen wegens strijd met de Nederlandse openbare orde buiten toepassing zijn gelaten (zie hoofdstuk 6), of wanneer de voorvraag niet overeenkomstig Marokkaans recht is beantwoord (zie hoofdstuk 5), dan wel de beslissing op een ander punt niet voldoet aan het Marokkaanse recht, de beslissing niet of niet geheel kan worden tenuitvoer gelegd.

Enkele gevallen waarin de tenuitvoerlegging van Nederlandse rechterlijke beslissingen in Marokko op problemen zal kunnen stuiten, kunnen worden geillustreerd aan de hand van de volgende voorbeciden:

\section{Voorbeeld 1}

Een Marokkaanse erflater heeft als enige directe nabestaande een buitenechtelijke zoon, die hij in Nederland heeft erkend. Tor de nalatenschap behoort een in Marokko gelegen stuk grond. De zoon vraagt aan de Nederlandse rechter een verklaring voor recht dat hij enig erfgenaam is. Indien Nederlands recht de erfopvolging beheerst zal de zoon erfgenaam zijn en zal de rechter het verzoek toewijzen. Indien Marokkaans recht de erfopvolging beheerst zou de zoon geen erfgenaam zijn, tenzij de rechter van oordeel is dat het onthouden van erfaanspraken aan een buitenechtelijk erkend kind, ofwel het maken van onderscheid naar geboorte, strijd oplevert met de Nederlandse openbare orde dan wel met internationale Verdragen. In hoofdstuk 6 is aangegeven dat voor de Nederlandse rechter voldoende aanleiding aanwezig is om in dergelijke zin te beslissen. Een uitspraak van de Nederlandse rechter die leidt tot het resultaat dat de zoon erfgenaam is, en wel de enige erfgenaam, zal in Marokko noch worden erkend, noch voor tenuitvoerlegging in aanmerking komen. De zoon zal geen goederenrechtelijke rechten op het

past op Marokkaanse joden (zie p. 19 en 158). Gezien het coenemend belang van de lex fori, en daarmee van het Marokkaanse moslimrecht is het niet uitgesloten dat de morele waarden uit de Islam ook voor buitenlandse niet-moslims zullen gelden en dat buitenlandse beslissingen ten aanzien van buitenlandse niet-moslims, warin essentiele waarden uit de Islam worden miskend, niel voor erkenning en tenuitvoerlegging in Marokko in aanmerking komen wegens strijd met de openbare orde. Deprez 1981, 135-140; Moulay R'chid, Grandes lignes 1991, 24 c.v.: Sarehane en Lahlou-Rachdi 1994, Fasc. 4, 8, 10. Kritisch over deze opvatting zijn: Charfi 1987, 402; Deprez 1988, 273; Moulay R'chid, Grandes lignes 1991, 24 e.v.

822. Zie hoofdstuk $5 \$ 2$. 
stuk grond kunnen vestigen: hij kan geen eigenaar worden. De grond zal eigendom worden van een familielid van verder verwijderde graad, en bij het ontbreken hiervan hetgeen gezien de omvangrijke kring van personen die volgens Marokkaans recht erfgerechtigd kan zijn, zich niet snel zal voordoen -, treedt de Marokkaanse Staat op als erfgenaam. Wil de zoon naar Marokkaans recht kunnen erven, dan zal zijn afstamming naar Marokkaans recht dienen te worden vastgesteld ${ }^{823}$.

\section{Voorbeeld 2}

Een Marokkaanse erflater heeft als enige nabestaanden een wettige uit het huwelijk geboren zoon en een wettige uit het huwelijk geboren dochter. Tot de nalatenschap behoort een bankrekening op naam van de erflater bij cen Marokkaanse bank. De dochter vraagt aan de Nederlandse rechter een verklaring voor recht dat zij aanspraak heeft op de helft van de nalatenschap. Indien Nederlands recht de erfopvolging beheerst zal de rechter het verzoek van de dochter toewijzen. Indien Marokkaans recht de erfopvolging beheerst is het zeer waarschijnlijk dat hij het verzoek eveneens zal toewijzen. Het in het Marokkaanse recht gemaakte onderscheid naar geslacht zal hij immers wegens strijd met de Nederlandse openbare orde of met internationale Verdragen buiten toepassing dienen te laten. In Marokko zal deze uitspraak waarin aan de dochter een even grote aanspraak op de nalatenschap wordt toegekend als aan de zoon niet ten uitvoer kunnen worden gelegd. De bank is niet verplicht om de aanspraak van de dochter op de helft van het banktegoed te accepteren. Naar Marokkaans recht zou zij slechts gerechtigd zijn tot eenderde deel. De dochter heeft een verrekeningsrecht met betrekking tot goederen van de nalatenschap die zich in Nederland bevinden (art. 2 lid 2 WCEo).

\section{Voorbeeld 3}

Een Marokkaanse erflater heeft als enige directe nabestaanden zijn Nederlandse nietislamitische echtgenote met wie hij in Nederland ten overstaan van de ambtenaar van de burgerlijke stand in het huwelijk is getreden, en een uit dit huwelijk geboren zoon. Tot de nalatenschap behoort een in Marokko gelegen woning met inventaris. De zoon en echtgenote vragen de Nederlandse rechter een verklaring voor recht dat zij erfgenamen zijn en vragen hem om hun wettelijk erfdeel vast te stellen. Indien Nederlands recht de erfopvolging beheerst zal de rechter bepalen dat zowel de echtgenote als het kind erfgenaam zijn, en wel ieder voor een gelijk deel. Wanneer echter de erfopvolging wordt beheerst door Marokkaans recht, heeft de rechter een moeilijkere taak te vervullen. De vraag of de echtgenote erfgenaam is zal immers kunnen afhangen van twee factoren. De eerste betreft de voorvraag naar de geldigheid van het huwelijk. Deze zal in beginsel zelfstandig worden beoordeeld. In dit geval is er sprake van een geldig huwelijk. De tweede hobbel die de rechter dan moet nemen is de vraag of de nietislamitische godsdienst van de echtgenote een erfbeletsel oplevert danwel dat dit erfbeletsel wegens strijd met de openbare orde buiten toepassing moet worden gelaten. In hoofdstuk 6 (p. 221) heb ik voor de tweede mogelijkheid geopteerd. De vraag of de

823. Hierover p. 52-56. De mogelijkheden die hienoe in Nederland bestaan zijn beschreven op p. 177-178. 
zoon erfgenaam is, zal eveneens kunnen afhangen van verschillende factoren. De eerste betreft de voorvraag naar de afstamming. Wordt deze zelfstandig beoordeeld, dan zal wettige afstamming worden aangenomen. Wordt deze door de hoofdvraag geabsorbeerd, dan is er geen wettige afstamming. Als de zoon geen moslim zou zijn, het islamitisch geloof wordt immers verkregen door wettige afstamming van een moslim of door aanvaarding, dan zou hierin een erfbeletsel zijn gelegen. Het in de godsdienst gelegen erfbeletsel zou dan ook hier met cen beroep op strijd met de openbare orde buiten toepassing kunnen worden gelaten ${ }^{824}$. Als uiteindelijk wordt geconcludeerd dat zowel de echtgenote als de zoon erfgerechtigd zijn, zou dit bij toepassing van Marokkaans recht betekenen dat de echtgenote aanspraak makt op 1/8 deel van de nalatenschap ${ }^{825}$, en de zoon op $7 / 8$ deel. In Marokko zal deze uitspraak waarin zowel de echtgenote als de zoon als erfgenamen worden erkend, niet ten uitvoer kunnen worden gelegd. Noch de echtgenote noch de zoon kunnen goederenrechtelijke rechten vestigen op de in Marokko gelegen woning noch zijn zij gerechtigd over de rocrende zaken te beschikken. De goederen komen toe aan andere familieleden en bij gebreke hiervan aan de Marokkaanse Staat. Wil de zoon aanspraak kunnen maken op de vermogensbestanddelen in Marokko, dan zal de wettige afstamming van de zoon naar Marokkaans recht moeten worden vastgesteld ${ }^{826}$. De echtgenote kan alleen erven naar Marokkaans recht als de geldigheid van het huwelijk naar Marokkaans recht wordt vastgesteld ${ }^{827}$, en zij eveneens heeft verklaard moslim te zijn ${ }^{828}$.

Naast de in art. $430 \mathrm{CPC}$ gestelde materiële voorwaarden voor het verkrijgen van een exequatur, wordt in art. 431 CPC aangegeven welke bescheiden moeten worden overgelegd bij cen exequaturverzoek. Dit zijn: een authentiek afschrift van de beslissing, het origineel van de kennisgeving of ander geldend document, een bewijs van de bevoegde griffie inhoudende dat er tegen de beslissing geen verzet noch hoger beroep of beroep in cassatie meer mogelijk is, en eventueel een "gewaarmerkte" vertaling naar het Arabisch van een beëdigd vertaler van de genoemde bescheiden.

\section{$\S 3$. Erkenning en tenuitvoerlegging van authentieke akten}

In Nederland verleden authentieke akten inzake de erfopvolging betreffen vaak testamentaire beschikkingen. Tot de mogelijkheid van tenuitvoerlegging van dergelijke akten beperkt de onderhavige paragraaf zich ${ }^{829}$. Voor de tenuitvoerlegging van een

824. Zie p. 219-221.

825. Of als het erfdeel van de echtgenote op grond van het gelijkheidsbeginsel wordt gelijkgesteld aan dat van de echtgenoot: $1 / 4$ deel. Hierover hoofustuk $6 \$ 3$. A.1 en p. 246.

826. Hierover p. 52-56. Voor de mogelijkheden die hiertoe in Nederland bestaan zij verwezen naar p. 177 178.

827. Zie p. 165-167.

828. Zic nool 506 .

829. Buiten beschouwing blijven derhalve de onderhandse akten, Nederlandse verklaringen van erfrecht en vergelijke. 
buitenlandse authenticke akte is in Marokko steeds cen exequatur nodig 830 . De tenuitvoerlegging van buitenlandse akten is geregeld in art. $432 \mathrm{CPC}$. In dit artikel wordt bepaald dat akten die in het butenland zijn opgemaakt door een daartoe bevoegd verklaarde autoriteit voor tenuitvoerlegging in Marokko in aanmerking komen nadat een exequatur is verlecnd. Het verlenen van een exequatur wordt afhankelijk gesteld van dezelfde voorwaarden die gelden voor het verlenen van een exequatur aan buitenlandse rechterlijke beslissingen (art. 430 en $431 \mathrm{CPC}$ ). Bij een exequaturverzoek zal de Marokkaanse rechter zich beperken tot een onderzoek of volgens het recht van het land walar de akte is opgemaakt voldaan is aan de voorwaarde van authenticiteit, en of de bepalingen uit de akte waarvan tenuitvocrlegging wordt gevraagd niet in strijd zijn met de Marokkaanse openbare orde ${ }^{831}$.

\section{Bevoegde autoriteit}

Tot het opmaken van testamenten bij wege van authenticke akten is in Nederland in het bijzonder de Nederlandse notaris bevoegd. Hoewel in Marokko zelf de behandeling van nalatenschappen van moslims is opgedragen aan de bevoegdheid van de islamitische notarissen, de 'udîl, en de latijnse notaris in Marokko niet bevoegd is om dergelijke zaken zelfstandig te behandelen, staat er niets aan in de weg om de bevoegdheid van de Nederlandse notaris te accepteren.

2. Authenticiteit van de akte volgens het recht van het land waar de akte is opgemaakt Een in Nederland door een Nederlandse notaris opgemaakte akte inhoudende een testament, voldoet in Nederland aan de voorwaarden van authenticiteit (vgl. art. $183 \mathrm{Rv}$ ).

\section{Geen strijd met de Marokkaanse openbare orde}

Zoals hicrboven (p. 282) recds is opgemerkt geldt in Marokko dat toepassing van het Marokkaanse moslimrecht betreffende het personeel statuut en erfrecht op Marokkaanse moslims een regel van openbare orde is ${ }^{832}$. Dat betekent dat wanneer de Nederlandse notaris een testament voor cen Marokkaans onderdaan opmaakt, hij zich zal moeten houden aan de Marokkaanse voorschriften op dit terrein. Een dergelijk testament dient derhalve beperkt te rijn tot maximaal eenderde van de nalatenschap nadat de schulden zijn voldaan, en er mag niet worden beschikt ten gunste van wettige erfgenamen, behalve wanneer de andere erfgenamen hierin toestemmen. Worden deze regels niet in acht genomen, dan kan het testament in Marokko niet ten uitvoer worden gelegd wegens strijd met de openbare orde. In de Marokkaanse rechtspraak is een aantal keren de vraag aan de orde gesteld of een testament ten behoeve van een concubine in strijd was

830. Een afternatief' is dat de Nederlandse notaris in samenwerking met Marokkaanse 'udul akten tot stand brengt, in die zin dat de Nederlandse notaris de akte (inhoudelijk) opmaakt, waarbij hij het Marokkaanse recht respectect, en de Marokkaanse udul naar aanleiding hiervan een adoulaire akte opstelt.

831. Sarehane en Lahlou-Rachdi 1994, Fasc. 4, 22.

832. Ook voor de handelingsbek waamheid van een Marokkaanse erflater bij het opmaken van een akte geldt dat toepassing van diens nationale recht (art. 3 DCC) van openbare orde is. 
met de Marokkaanse openbare orde. In een uitspraak van 1947 bevestigde het Cour de cassation cen beslissing van het Cour d'appel van Rabat waarin een testament waarin werd beschikt ten behoeve van cen concubine en uitsluitend in het belang van deze concubine, "pour cause d'immoralité" nietig was verklaard ${ }^{833}$. In 1958 verklaarde het Cour d'appel van Rabat geldig een testament van een Fransman ten behoeve van zijn Marokkaanse moslim-concubine omdat hier het legaat was opgesteld met het oog op de belangen van de dochter ${ }^{83.4}$. In deze zelfde uitspraak verklaarde het Cour d'appel van Rabat ongeldig een legaat ten behoeve van een uit overspel geboren kind. In 1977 deed het Cour suprême twee tegengestelde uitspraken met betrekking tot een testament ten behoeve van een concubine ${ }^{835}$. De eerste uitspraak was van de administratieve kamer, de tweede valn de burgerlijke kamer. In het ecrste geval werd het testament van een Italiaan ten behoeve van zijn Marokkaanse israëlische concubine geldig verklaard, en werd beschouwd als de vervulling van een natuurlijke verbintenis om de toekomst van de concubine te verzekeren. In het tweede geval werd een testament van een Fransman ten behoeve van zijn Franse concubine nietig verklaard wegens strijd met de goede zeden, en mitsdien met de Marokkaanse openbare orde die iedere relatic welke is gebasecrd op een immorele grond verwerpt. Hoewel geen duidelijke lijn uit deze rechtspraak kan worden afgeleid, lijkı het motief dat aan de beschikking ten grondslag ligt een rol te kunnen spelen. Er moeten in ieder geval morcel aanvaardbare gronden zijn voor de begunstiging. Of en wanneer dit het geval is zal door de rechter moeten worden beoordeeld. Het beschikken ten behoeve van cen concubine en zelfs het beschikken ten behoeve van de echtgenoot(ote) met wie een burgerlijk huwelijk is gesloten, draagt het risico in zich dat deze beschikking in Marokko noch zal worden erkend noch tenuitvoer kan worden gelegd ${ }^{836}$.

833. Cour de cassation 7 april 1947. GTM 1947. p. 151.

8.34. Cour dappel Rabat 31 januari 1958, RMD 1960, p. 182.

83.5. Cour supreme (chambre administrative) 4 februari 1977, $n^{\circ} 23$, niet gepubliceerd, respectievelijk Cour suprême (chambre civile) 14 september 1977, $\mathrm{n}^{\circ} 512$, niet gepubliceerd. De arresten worden aangehaald in o.m. Decroux 1981, 164-165; Moulay R'chid, Grandes lignes 1991, 24; Sarehane en LahlouRachdi 1994, Fasc. 4. 10.

836. Bij mondelinge navraag in Marokko bleck de nening hierover verdeeld te zijn. Sommigen meenden dat een huwelijk waaraan naar Marokkaans recht een formeel gebrek kleeft niet gelijk kan worden gesteld aan een concubinaat. Volgens hen kon ten behoeve van de "burgerlijke stand-echtgenoot(ote)" worden beschikt. Anderen meenden dat een dergelijk testament wegens strijd met de Marokkaanse opentare orde in Marokko niet tenuitvoer gelegd zou kunnen worden. Een ongeldig huwelijk wordt, zolang de geldigheid hiervan niet naar Marokkaans recht is vastgesteld, immers gelijk gesteld aan een concubinaat. 

Hoofdstuk 8

\section{Conclusies}

I

Wanneer de verwijzingsregel inzake de erfopvolging verwijst naar de toepasselijkheid van het nationale recht van de erflater, wordt de erfopvolging van een Marokkaanse erflater in Nederland in principe beheerst door het Marokkaanse recht. Er wordt een rechtsstelsel toepasselijk verklaard dat is tot stand gekomen binnen een andere cultuur. Dit heeft geresulteerd in een systeem waarvan de normen en waarden op veel punten afwijken van die welke gelden in de Nederlandse samenleving. Er ontstaan daarom cultuurconflicten. Uitgangspunt in het internationaal privaatrecht is dat het door de conflictregel aangewezen vreemde recht, en daarmee de andere rechtscultuur, wordt gerespecteerd. Door aansluiting te zoeken bij het recht van de nationaliteit van de erflater wordt een vreemde rechtscultuur binnen de Nederlandse rechtsorde toegelaten, een rechtscultuur waaraan de betrokkene zijn persoonlijke identiteit kan ontlenen. Als echter door de toepassing van regels uit een andere rechtscultuur normen en waarden moeten worden aanvaard die strijdig zijn met in Nederland geldende waarden, ontstaan er ook in het internationaal privaatrecht cultuurconflicten ${ }^{837}$. Wanneer de toepassing van het nationale recht blijkt te leiden tot een schending van (andere) in Nederland geldende beginselen die hoog staan aangeschreven, rijst de vraag hoever de tolerantie voor een vreemde rechtscultuur moet gaan. Daarbij zij opgemerkt dat iemands nationale recht nict altijd een personificatie van zijn identiteit behoeft te zijn. Voor veel Marokkanen in Nederland zal een respect voor hun identiteit een respect voor de Islam impliceren. De wijze waarop en de mate waarin dit het geval is zal echter per concreet geval kunnen verschillen. In abstracto kan gezegd worden dat enerzijds het islamitische personenen familierecht, dat ook in Marokko is gecodificeerd, in de Islam en ook in moderne wetgeving nog van grote betekenis is. Anderzijds mag niet uit het oog worden verloren dat mede de religieuze oorsprong van dit recht er in de praktijk vaak nog aan in de weg staat dat dit recht inspeelt op maatschappelijke ontwikkelingen. Voor het Nederlandse 
IPR betekent dit dat wordt verwezen naar een rechtsstelsel waarvan de geldigheid niet zozeer wordt bepaald door maatschappelijke rechtsopvattingen maar door haar traditionele religieuze karakter. De normen en waarden uit een dergelijk rechtsstelsel kunnen dan ook niet altijd zonder meer worden vereenzelvigd met de persoonlijke identiteit van individuele Marokkanen. Bij de in het IPR noodzakelijk te maken afweging van het tolereren van een vreemde rechtscultuur enerzijds en een respect voor fundamentele beginselen van de Nederlandse rechtsorde anderzijds, spelen ook nog andere factoren cen rol, te weten de andere belangen welke de conflictregels beogen te dienen. Genoemd kunnen bijvoorbeeld worden een interne of juist een internationale beslissingsharmonic. Zelden zullen alle betrokken belangen bij de erfopvolging van een Marokkaanse erflater de toepasselijkheid van een en hetzelfde rechtsstelsel verlangen. Naarmate er minder belangen in het geding zijn die met een toepassing van het Marokkaanse erfrecht worden gediend - de nationaliteit heeft voor de erflater geen reële aanknopingswaarde, eventuele hinkende rechtsverhoudingen hebben voor de betrokkenen geen consequenties, er zijn geen (andere) Nederlandse belangen in het geding die een toepassing van het Marokkaanse recht vergen - wordt met een star vasthouden aan het Marokkaanse recht, aan het doel van het IPR voorbijgeschoten. Toepassing van Marokkaans recht geschiedt dan enkel nog op formele en niet op inhoudelijke gronden. Moeilijker wordt het al als de nationaliteit voor de erflater wel een reële aanknopingswaarde heeft, maar een onverkorte toepassing van het Marokkaanse erfrecht leidt tot cen schending van in Nederland geldende beginselen.

Bij het schrijven van de voorgaande hoofdstukken heeft bij mij steeds voorop gestaan het in streven naar resultaten die in het concrete geval rechtvaardig zijn, rekening houdend met alle in het geding zijnde belangen. Hierbij is uitgegaan van de thans binnen het Nederlandse IPR bestaande mogelijkheden om deze resultaten te bereiken. Uitgangspunt hierbij was dat de verwijzingsregel verwees naar de toepasselijkheid van het Marokkaanse erfrecht. Ik heb gewezen op een aantal binnen het Nederlandse IPR bestaande mogelijkheden die naast de verwijzingsregel kunnen worden aangewend om materieel bevredigende resultaten te bereiken. Hierbij heb ik aandacht besteed aan het leerstuk van de openbare orde-exceptie, maar ook aan leerstukken die in het IPR nog niet volledig tot ontwikkeling zijn gekomen en juist daarom ruimte bieden voor passend geachte oplossingen. Zo is in het vierde hoofdstuk gewezen op de mogelijkheid tot het erkennen van "droits acquis", waar het betreft de schenkingen die een erflater tijdens zijn leven heeft gedaan. Ook het accepteren van een rechtsverhouding als "fait accompli" - een leerstuk dat overigens in de IPR-schets uitdrukkelijk erkenning krijgt behoort tot deze mogelijkheden. In hoofdstuk 4 heb ik onderzocht of een door een Marokkaanse erflater gevestigde hubus kan worden aangemerkt als een trust in de zin van het Trustverdrag. Zekerheid hierover kan op dit moment nog niet worden verkregen. Mocht een hubus niet als trust in de zin van het Trustverdrag kunnen worden gekwalificeerd, dan zou het m.i. wenselijk zijn om bij het vaststellen van de omvang van het nalatenschapsvermogen van een erflater, die geheel buiten de Nederlandse rechtsordc om een deel van zijn vermogen tot hubus heeft bestemd, deze hubus en de 
hieruit voortvlociende rechtsverhoudingen, onder voorbehoud van een aantal weigeringsgronden, als "fait accompli" te accepteren. Het fait accompli-beginsel kan ook een rol spelen bij de bchandeling van voorvragen. Gedacht kan bijvoorbeeld worden aan buiten Nederland tot stand gekomen afstammingsrelaties. Ook een rechtsverhouding die in Nederland rechtsgeldig is tot stand gekomen zou als een "fait accompli" kunnen worden aanvaard, zij het dat hicraan dan een andere omschrijving wordt gegeven dan doorgaans in de literatuur geschiedt. Een dergelijke benadering zou ertoe kunnen nopen dat de vraag naar de geldigheid van in Nederland tot stand gekomen rechtsverhoudingen wanneer deze vraag als voorvraag rijst, zelfstandig wordt beoordeeld. Met behulp van een dergelijke benadering kunnen in Nederland gesloten huwelijken die in Marokko niet voor erkenning in aanmerking komen in het kader van de erfopvolging worden erkend.

Een ander middel dat kan worden gehanteerd is het gebruik maken van aanpassingsconstructies. Een dergelijke constructie kan worden gebruikt wanneer door de toepassing van verschillende rechtsstelsels een resultaat wordt bereikt dat door geen van deze rechtsstelsels is gewild. Een aantal schrijvers stelt zich op het standpunt dat het verschil in erfrechtelijke positie tussen man en vrouw in het islamitische erfrecht is gekoppeld aan het onderscheid in financiële verplichtingen tussen man en vrouw; de vrouw wordt in het familierecht financieel begunstigd ten opzichte van de man (geen onderhoudsverplichtingen en een recht op een bruidsgave) en behoort in het erfrecht derhalve minder aanspraken op de nalatenschap te hebben dan mannelijke erfgenamen. Het begunstigen van de vrouw in het familierecht en een gelijkstelling tussen man en vrouw in het erfrecht zou anders een dubbele "begunstiging" opleveren, die noch in het Marokkaanse recht noch in het Nederlandse recht, waar de vrouw immers in het onderhoudsrecht een gelijke positie heeft als de man, is beoogd. In het zesde hoofdstuk heb ik aangegeven dat voor het aannemen van een dergelijke koppeling in het Marokkaanse erfrecht onvoldoende grond bestaat, en ook in Nederland, waar de onderhoudsverplichting bovendien vaak anders wordt gewaardeerd, niet behoeft te worden geaccepteerd. Voor het aanpassen van de verwijzingsregel of van het verwijzingsresultaat is m.i. dan ook geen reden. Het tocpassen van een aanpassingsconstructie is voorts mogelijk wanneer cen kortsluiting ontstaat door toepassing van Marokkaans recht op de erfopvolging en toepassing van Nederlands recht op de afwikkeling van de nalatenschap. Een groot probleem dat zich hicrbij lijkt voor te doen is dat als gevolg van het feit dat bij de afwikkeling wordt uitgegaan van de saisine, terwijl bij de erfopvolging wordt uitgegaan van een overgang van rechten in het vermogen van de erflater, erfgenamen aansprakelijk kunnen worden gesteld voor schulden die hun erfportie overtreffen. Een tweede probleem is dat in het Marokkaanse recht dat de erfopvolging beheerst, geen rekening is gehouden met de mogelijkheid om een erfenis te verwerpen of beneficiair te aanvaarden, terwijl de gevolgen van de verwerping of aanvaarding volgens de wetgever zouden moeten worden beheerst door de erfwet. Maar een recht dat de verwerping niet kent, regelt uiteraard ook de gevolgen hiervan niet. De mogelijkheid van verwerping is in het Marokkaanse recht ook niet nodig omdat de te verdelen nalatenschap alleen uit activa bestaat. Hier dient een aanpassing plaats te vinden. Wil men het Marokkaanse erfrecht 
daadwerkelijk zoveel mogelijk respecteren, dan zou, mede gezien het uitgebalanceerde erfrechtsysteem en het dwingendrechtelijk karakter ervan, cen aanpassing m.i. moeten leiden tot de conclusie dat de verwerping in Marokkaanse nalatenschappen niet wordt aanvaard. De Nederlandse figuur van verwerping is feitelijk niet inpasbaar in het Marokkaanse erfrechtsysteem. Andersom kan het voorkomen dat vreemde rechtsfiguren uit het Marokkaanse recht die in het Nederlandse recht niet bekend zijn, moeten worden aangepast om binnen de toepasselijke wet te kunnen worden gehanteerd. Een dergelijke aanpassing zal in de regel worden voorafgegaan door een kwalificatievraag. Zodanige kwalificatievragen in het erfrecht kunnen rijzen bij de hubus, (de begunstigden van) een tanzill, en (erfgenamen krachtens) het verplicht testament.

Het werken met aanpassingsconstructies ter verkrijging van rechtvaardige resultaten is een methode die ook kan worden toegepast bij de behandeling van voorvragen. Stel dat een zelfstandige beoordcling van de voorvraag zou leiden tot een onaanvaardbaar resultaat, dan zou het op de weg liggen dit resultaat aan te passen. Gedacht kan bijvoorbeeld worden aan de echtgenoot uit een door verstoting ontbonden huwelijk, die al sedert geruime tijd geen contact meer met de erflater heeft gehad, terwijl de verstoting in Nederland niet wordt erkend. Deze echtgenoot zou bij een zelfstandige beoordeling van de voorvraag erfgenaam zijn. Of denk aan de kinderen of echtgenoot uit een consulair huwelijk, dat niet wordt erkend omdat een der echtgenoten ten tijde van de huwelijkssluiting Nederlander was. Zij zouden bij een zelfstandige beoordeling van de voorvragen geen erfgenamen zijn. Een aanpassing van de resultaten kan in dergelijke gevallen wenselijk zijn. In het erfrecht, waar erfaanspraken in de regel worden bepaald door familierechtelijke verhoudingen, kunnen voorvragen een belangrijke rol spelen. Dit is in het bijzonder het geval als deze familierechtelijke verhoudingen volgens het recht dat de erfopvolging beheerst anders worden beoordeeld dan naar Nederlands IPR. In het vijfde hoofdstuk heb ik laten zien dat over de geldigheid van tal van huwelijken, huwelijksontbindingen, en afstammingsrelaties, in Marokko anders wordt gedacht dan in Nederland. In het kader van de erfopvolging zullen keuzes moeten worden gemaakt over de wijze waarop de beoordeling van deze familierechtelijke verhoudingen dient plaats te vinden. Over de wijze waarop de voorvraag moet worden beoordeeld, is in het Nederlandse IPR weinig concreet geregeld. Aangenomen wordt wel dat cen zelfstandige beoordeling van de voorvraag voorop staat, maar dat op deze regel uitzonderingen zijn toegelaten. In deze uitzonderingssituaties kan een afhankelijke beoordeling van de voorvraag plaatsvinden. De bestaande openheid ten aanzien van de behandeling van de voorvraagproblematick makkt het mogelijk om gebruik te maken van allerlei technieken en correctiemiddelen die binnen het Nederlandse IPR beschikbaar zijn. Naast de zojuist besproken aanpassingsconstructie, wees ik ook reeds op de fait accompli-gedachte als oplossingsmechanisme. In het vijfde hoofdstuk heb ik ook stilgestaan bij een benadering via de zogenaamde rechtsvergelijkende methode, waarbij niet behoeft te worden gekozen voor een zelfstandige dan wel afhankelijke aanknoping van de voorvraag. In deze methode zou het bereiken van een rechtvaardig resultaat immers voorop staan. Met andere woorden: hoofdregel mag dan wel zijn dat voorvragen zelfstandig worden 
beoordecld, maar wanneer dit leidt tot onwenselijke resultaten moet een afwijking hiervan mogelijk zijn. Omdat in familierechtelijke verhoudingen waarbij Marokkaanse staatsburgers betrokken zijn de kans op het bestaan van hinkende rechtsverhoudingen groot is, en mede gezien het feit dat in het erfrecht grote betekenis zou moeten worden gehecht aan de wil van de erflater, ook met betrekking tot de vraag wie hij redelijkerwijze geacht kan worden tot zijn erfgenamen te wensen, zal m.i. per concreet geval moeten worden onderzocht op welke wijze de voorvragen het beste behandeld kunnen worden. In het vijfde hoofdstuk heb ik hiertoc een ecrste aanzet gedaan. Ik heb, in het zesde hoofdstuk, ook gewezen op de mogelijkheid tot het inroepen van de openbare orde-exceptie als juist een afhankelijke beoordeling van de voorvraag tot onwenselijke resultaten zou leiden.

De openbare orde-exceptie is wellicht het belangrijkste correctiemiddel dat bij de toepasselijkheid van Marokkaans erfrecht ter beschikking staat. Algemeen wordt aangenomen dat bij het inroepen van de openbare orde-exceptie terughoudendheid is geboden. De wetgever heeft dit bij de totstandkoming van de Wet conflictenrecht crfopvolging ook nog eens benadrukt. Deze terughoudendheid dient ook in acht genomen te worden als het Marokkaanse erfrecht als toepasselijk recht wordt aangewezen. Dit Marokkaanse erfrecht kent echter tal van regels die onmiskenbaar in strijd zijn met in Nederland geldende fundamentele rechtsbeginselen. De betekenis van deze beginselen wordt mede kracht bijgezet door het toenemende belang van in Verdragen verankerde mensenrechten. De Marokkaanse erfrechtregels kunnen in Nederland daarom ook niet worden toegepast zonder na te gaan of de resultaten ervan verenigbaar zijn met de Nederlandse openbare orde. Ik noem slechts de regels waarin onderscheid wordt gemaakt naar geslacht, regels waarin onderscheid wordt gemaakt naar geboorte, en regels waarin onderscheid wordt gemaakt naar godsdienst. In het zesde hoofdstuk heb ik getracht aan te geven in welke omstandigheden en ten aanzien van welke regels de openbare orde-exceptic zou kunnen worden ingeroepen. Hierbij ben ik tot slechts weinig concrete uitspraken gekomen. Dit houdt verband met het feit dat er tal van belangen in het geding kunnen zijn waarvan het naar mijn mening wenselijk zou zijn dat er acht op werd geslagen: het beginsel van gelijkheid van man en vrouw, het beginsel van gelijkheid van geboorte, het beginsel van gelijkheid van godsdienst, de beschikkingsvrijheid van de erflater, het respect voor de uiterste wil van de erflater, het respect voor de godsdienst van de erflater, het respect voor de persoon van de erflater, het respect voor het gezinsleven, het belang van de internationale beslissingsharmonie, het belang van de interne beslissingsharmonie, de belangen van de erfgenamen, de belangen van eventuele schuldeisers, de tenuitvoerlegging in het buitenland, de betrokkenheid van de Nederlandse rechtsorde etcetera. Bij de verwijzingsregel die abstract is en regelblind, kunnen niet al deze belangen in ogenschouw zijn genomen. Een aantal ervan wordt namelijk door de concrete omstandigheden bepaald. Bij de vraag naar het inroepen van de exceptie van de openbare orde bestaat wél de mogelijkheid om alle in het geding zijnde belangen zorgvuldig af te wegen en om voor al deze belangen een open oog te hebben. Naarmate in een concreet geval bepaalde belangen een grotere waarde hebben, 
behoort hieraan naar mijn mening een groter gewicht te worden toegekend. En omgekeerd zou naarmate bepaalde belangen een geringere waarde hebben, hieraan minder gewicht behoren te worden toegekend. Tot de fundamentele beginselen waaraan een zeer grote waarde wordt gehecht, behoren in ieder geval het beginsel van gelijkheid van geslacht, gelijkheid van godsdienst, en gelijkheid van geboorte. Voor een schending van het verbod van ongelijke behandeling naar godsdienst heb ik geen rechtvaardiging aanwerig geacht. Een schending van dit verbod behoort m.i. in de regel dan ook niet te worden geaccepteerd. Een schending van het verbod om onderscheid te maken naar geslacht zal naar mijn mening niet behoeven te worden geaccepteerd als er sprake is van een direct onderscheid. Is er sprake van een indirect onderscheid dan zullen ook andere in het geding rijnde belangen in de afweging een grotere rol kunnen vervullen. Het maken van onderscheid naar geboorte ten aanzien van personen met wie de erflater een gezinsleven had, zal m.i. in de regel niet behoeven te worden geaccepteerd. Was er geen sprake van een gezinsleven, dan kunnen ook hier weer andere factoren een rol galin meespelen.

De schending van fundamentele beginselen in het Marokkaanse erfrecht, heeft ook de vraag doen rijzen of de toepassing van dit recht kan worden getoetst aan direct werkende verdragsbepalingen waarin de bescherming van deze beginselen wordt gegarandeerd. Het gaat hierbij dan niet om de vraag of het eigen nationale recht kan worden getoetst aan het van hoger orde zijnde internationale recht, maar om de vraag of aan verdragsbepalingen rechtstreeks rechten kunnen worden ontleend door burgers wier rechtsverhouding krachtens het internationaal privaatrecht wordt beheerst door een buitenlands rechtsstelsel. De verdragsbepalingen die in dit verband zijn onderzocht zijn art. $8 \mathrm{j}^{\circ} 14$ EVRM (erfaanspraken als rechten die voortvloeien uit het recht op gezinsleven), art. 16 lid 1 aanhef en sub $h$ Vrouwenverdrag (gelijke rechten van man en vrouw ten aanzien van de verwerving van eigendom), art. 1 Eerste Protocol EVRM (het recht op testeervrijheid ontleend aan het eigendomsrecht) en art. 8 EVRM (beschikkingsvrijheid ten aanzien van gezinsleden als recht dat voortvloeit uit het recht op gezinsleven). Ik ben van mening en heb geconcludeerd dat de hier bedoelde toetsingsmogelijkheid in principe bestaat, en daarmee tot cen succesvol beroep op een verdragsbepaling kan leiden. Minimumvoorwaarden voor een beroep op een verdragsbepaling zijn steeds dat de betrokken gevallen vallen onder het tocpassingsbereik van het Verdrag en dat het gaat om rechtstreeks werkende bepalingen. Uit rechtspraak, met name die van het EHRM, volgt dat ten aanzien van een aantal verdragsrechten, de ruimte die Verdragstaten hebben om hieraan beperkingen te stellen, bijzonder gering is. Dit geldt in het bijzonder voor de gelijkheidsrechten ten aanzien van geslacht, geboorte en godsdienst. Dat betekent dat het toepassen van een vreemd recht dat strijd oplevert met een van deze discriminatieverboden al snel leidt tot een schending van een verdragsbepaling, en mitsdien niet kan worden geaccepteerd. Is de beoordelingsmarge van Verdragstaten groter, zoals bij het eigendomsrecht, dan kan een beperking van dit recht eerder geoorloofd zijn. Alsdan is er ook meer ruimte om aandacht te vragen voor de specifieke vreemde elementen van een internationale rechtsverhouding. Wel heb ik in het zesde 
hoofdstuk laten zien dat een beroep op verdragsbepalingen in internationaal privaatrechtelijke rechtsverhoudingen extra complicaties oplevert. Vaak kunnen aan verdragsbepalingen niet rechtstreeks materiële rechten worden ontleend. Dan dient eerst het toepasselijke nationale recht te worden vastgesteld. Vervolgens wordt de toepassing van dit recht getoetst aan het Verdrag. Enkele vragen die hierbij kunnen rijzen is of vreemd recht aan een verdragsbepaling kan worden getoetst, hoe clausules als "bij de wet toegestane beperkingen" moeten worden uitgelegd, en of in het internationale karakter van de rechtsverhouding een argument of zelfs een rechtvaardiging kan worden gevonden voor een bijzondere bejegening. Het internationaal privaatrecht blijft dan ook bij een toetsing aan verdragsbepalingen haar betckenis behouden.

In het voorgaande heb ik aangegeven dat van tal van technieken gebruik kan worden gemaakt om tot rechtvaardige resultaten te komen. Naarmate het aantal corrigerende factoren dat wordt gebruikt toeneemt, neemt het respect voor het Marokkaanse recht af. De belangen die met het gebruik van deze correctiemiddelen worden beschermd, mocten dit gebrek aan respect rechtvaardigen. Naarmate meerdere correctietechnieken worden toegepast om tot redelijke en billijke resultaten te komen, neemt ook de kracht van de verwijzingsregel af. Het abstracte en regelblinde karakter wordt niet langer geaccepteerd. In de rechtspraktijk blijkt het toepassen van dergelijke middelen op allerlei IPRterreinen plaats te vinden. Mede door deze oorzaak viert de discussie over een geschikte benaderingswijze van het IPR hoogtij, en spreekt men wel van een methodenstrijd in het IPR. Grofweg gesteld kunnen in deze "strijd" twee benaderingswijzen worden onderscheiden: ten eerste die waarin het systcem van de verwijzingsregels wordt verlaten en naar een andere methode wordt gezocht ${ }^{838}$, en ten tweede de benaderingswijze waarin wel wordt vastgehouden aan het systeem van verwijzingsregels maar waarin wordt gezocht naar een (passende) excepticclausule bij de verwijzingsregel. In het onderhavige boek is aan deze methodenstrijd nauwelijks aandacht besteed. Het groot aantal correctieen aanpassingsmiddelen waarvan ik gesuggereerd heb gebruik te kunnen maken, onderstreept de gebreken die aan een abstracte en blinde (Savignaanse) verwijzingsregel kleven, althans wanneer men, net als ik, cen belangenafweging en rechtvaardigheid in het concrete geval laat prevaleren boven ordening, rechtszekerheid en voorspelbaarheid ${ }^{839}$. Het huidige systeem van verwijzingsregels met correctiemogelijkheden biedt echter wel de mogelijkheid, en ik beschouw dit als een positief punt, om niet alleen rekening te houden met de omstandigheden van het geval maar ook met regels en beginselen uit verschillende rechtsstelsels.

838. Voor een bespreking van een groot aantal methoden van conflictoplossing kan worden verwezen naar Nova 1966.

839. Volgens Th.M. ue Boer 1993, 15 is dit een nieuw inzicht in het juridisch denken ten opzichte van de methode van von Savigny. Over de vermaatschappelijking van het conflictenrecht zie voorts: Strikwerda 1986, 3-27. 
In dit proefschrift is vanuit een praktische invalshoek een theoretische uiteenzetting gegeven van de wijze waarop in Nederland kan worden omgegaan met spanningen die ontstaan als gevolg van een confrontatie van het Marokkaanse erfrecht met de Nederlandse rechtsorde. Een niet gering aantal van de besproken problemen heeft zich in de praktijk reeds gemanifesteerd. Voor het overige is de mogelijkheid van het bestaan en ontstaan van problemen afgeleid uit in theorie bestaande spanningen. Hoewel ik een theoretische benadering van deze aspecten zinvol acht, en hopelijk anderen met mij, zal de toepassing ervan in de praktijk moeten plaatsvinden. Kan "de praktijk" uit de voeten met een systcem waarin de toepassing van meer "uitzonderingen" lijkt te worden voorgesteld dan een onverkorte tocpassing van de hoofdregel? In het voorgaande heb ik aangegeven dat wanneer wordt gestreefd naar aanvaardbare resultaten, het wenselijk is gebruik te maken van de openingen en technieken die het Nederlandse IPR biedt. De wijze waarop deze ruimte in concreto wordt ingevuld, zal voor een rechter een andere kunnen zijn dan voor bijvoorbeeld een notaris. Een rechter kan, veel meer dan een notaris, een rechtsvormende en beleidsmakende rol vervullen waarbij zijn beslissingen verder reiken dan het concrete geval. Zo zal een rechter naar mijn mening bij kennelijke strijd met de Nederlandse openbare orde niet mogen beslissen dat het erfdeel van een zoon twee keer zo groot is als dat van een dochter. Een notaris daarentegen zal, als "uitvocrder", beoordelen wat praktisch haalbaar is en zal dientengevolge vaak, naar ik verwacht, al dan niet terecht, ook of meer rekening houden met de vraag of de vastgestelde verdeling in de praktijk te realiseren is, dat wil zeggen geëxecuteerd kan worden.

Een Marokkaanse nalatenschap kan op verschillende manieren worden afgewikkeld: door de erfgenamen zelf, door de tussenkomst van Marokkaanse diplomatieke vertegenwoordigers en consulaire ambtenaren die in Nederland zijn geplaatst, of door inschakeling van Nederlandse autoriteiten. In dit boek zijn de verschillende aspecten belicht vanuit het Nederlandse IPR. Het Nederlandse IPR zal in ieder geval van toepassing zijn als Nederlandse autoriteiten worden ingeschakeld. Wensen de erfgenamen de nalatenschap op een andere wijze te verdelen, dan staat hun dit vrij. Dit gaat echter alleen goed zolang er geen Nederlandse autoriteit bij de zaak wordt betrokken, hetgeen bijvoorbeeld het geval zal zijn als erfgenamen of schuldeisers zich misdeeld voelen. Dan treedt immers het Nederlandse IPR in werking.

Welke invloed kan een erflater zelf tijdens zijn leven uitoefenen op de verdeling van zijn nalatenschap, wanneer bij zijn overlijden dit Nederlandse IPR in werking treedt? Allereerst is het zinvol om familierechtelijke verhoudingen zoveel mogelijk zeker te stellen. Wanneer het Marokkaanse recht de erfopvolging zal beheersen, hetgeen overigens lang niet altijd het geval zal zijn, bestaat vaak geen zekerheid over de wijze waarop familierechtelijke voorvragen zullen worden beoordeeld. Een burgerlijke standhuwelijk is in Marokko geen geldig huwelijk. Een consulair huwelijk waarbij een van de huwelijkskandidaten uitsluitend de Nederlandse nationaliteit bezat is in Nederland 
geen geldig huwelijk. Het al dan niet geldig zijn van het huwelijk kan consequenties hebben voor de afstamming van de kinderen. Een consulaire huwelijksontbinding levert in Nederland geen geldige huwelijksontbinding op. Een in Nederland uitgesproken echtscheiding wordt in Marokko niet altijd erkend. Wil men over deze zaken zekerheid verkrijgen, dan zal veelal een dubbele huwelijkssluiting of huwelijksbevestiging c.q. een dubbele huwelijksontbinding nodig zijn. In dit verband is het van belang te constateren dat Marokkaanse diplomaticke vertegenwoordigers en consulaire ambtenaren in Nederland (op dit moment) in vergaande mate bereid zijn om de geldigheid naar Marokkaans recht vast te stellen van naar Nederlands recht bestaande familierechtelijke verhoudingen. De geldigheid van Nederlandse burgerlijke stand-huwelijken waarbij wordt voldaan aan de Marokkaanse huwelijksvereisten, waarbij in het bijzonder is te letten op de godsdienst van de echtgenoten, kan via een consulaire procedure worden vastgesteld, zelfs nog ná het overlijden van ecn van de echtgenoten. Ook naar Nederlands recht gevestigde familierechtelijke betrekkingen met kinderen kunnen via een consulaire procedure naar Marokkaans recht worden aangenomen als hiervoor de naar Marokkaans recht vereiste getuigenverklaringen worden afgelegd.

Behalve gewenste zekerheid omtrent de erfgenamen, kan de erflater een bepaalde verdeling van zijn vermogen na zijn dood wenselijk achten. Hij kan een testament opmaken. Hierover wil ik slechts in algemene zin enkele opmerkingen maken. Heel algemeen gesteld kan in een dergelijke wilsbeschikking een keuze voor een tocpasselijk recht worden gedaan en kunnen materiële bepalingen worden opgenomen. Wordt een rechtskeuze voor Nederlands recht uitgebracht, dan is de belangrijkste beperking die aan de testecrvrijheid is gesteld de Nederlandse regeling omtrent de legitieme. Voorts dient rekening te worden gehouden met de beperkte executiemogelijkheden op vermogen dat zich in Marokko bevindt. Wordt de erfopvolging beheerst door Marokkaans recht, al dan niet op grond van een uitgebrachte rechtskeuze voor dit recht, dan kan, behoudens toestemming van de wettige erfgenamen, in beginsel slechts worden beschikt over maximaal eenderde deel van het vermogen en kan niet worden beschikt ten behoeve van wettige erfgenamen. Een ruimere beschikkingsvrijheid is mogelijk indien en voorzover deze beperkingen in Nederland wegens strijd met de openbare orde niet worden geacceptecrd. Executic van het testament op vermogen dat zich in Marokko bevindt is echter niet mogelijk voorzover het testament naar Marokkaans recht niet geldig is. Voorzover hierin echter een verdeling is opgenomen die beantwoordt aan het Marokkaanse intestaat-erfrecht, behoeft de weigering het testament te executeren niet problematisch te zijn omdat alsdan in Marokko in principe het intestaat-erfrecht zal worden toegepast. Het recht dat op de erfopvolging van toepassing is verklaard beheerst zowel de innerlijke geldigheid van het testament als het intestaat-erfrecht. Is dit het Marokkaanse recht, dan kan dit worden getoetst aan de Nederlandse openbare orde voorzover het betrekking heeft op vermogen waarover niet bij uiterste wil is beschikt. Dit is ook het geval wanneer Marokkaans recht van toepassing is op grond van een hiervoor uitgebrachte rechtskeuze. Het recht dat de erfopvolging beheerst geeft geen uitsluitsel over de wijze waarop voorvragen worden beoordeeld, zelfs niet als dit recht op grond 
van een rechtskeuze toepasselijk is. Mede met het oog hierop zal het verstandig zijn hicromtrent zekerheid te stellen dan wel in een testament zorgvuldig om te gaan met begrippen als echtgenoot(ote), kinderen, en dergelijke.

Een andere mogelijkheid die de erflater heeft om invloed te hebben op de verdeling van zijn vermogen is het doen van giften tijdens leven. Het doen van schenkingen tussen echtgenoten kan overigens in het bijzonder worden beperkt door het recht dat van toepassing is op het huwelijksvermogensregime. Voor het al dan niet bestaan van een inbrengverplichting van de schenkingen zij verwezen naar p. 112. Hier werd gewezen op de mogelijkheid om gedane schenkingen als "droits acquis" te respecteren, in die zin dat $z i j$ bij het overlijden van de schenker niet behoeven te worden ingebracht. Van een erkenning als "droit acquis" zou sprake kunnen zijn als ten tijde van de schenking de verwijzingsregel inzake de erfopvolging zodanig was en de schenker het vertrouwen mocht hebben dat op grond hiervan ten tijde van het overlijden van de schenker de nalatenschap zou worden beoordeeld door een recht dat geen inbrengverplichting van schenkingen kent. Hetzelfde geldt voor het vestigen van een hubus, als de gevolgen hicrvan niet reeds op andere wijze zouden worden erkend. Invloed op de omvang van het vermogen kan men in een huwelijk ook hebben via het huwelijksvermogensrecht, door het aanwijzen van een toepasselijk recht op het huwelijksvermogensregime, of door het opmaken van huwelijkse voorwaarden. Bevindt zich vermogen in Marokko, dan dient er rekening mee te worden gehouden dat een gemeenschap van goederen in Marokko niet behoeft te worden geaccepteerd. Bij Näherberechtigung kan de benadeclde echtgenoot enkel terugvallen op een verrekening op vermogen dat zich in Nederland bevindt.

Bestudering van aspecten van erfopvolging van Marokkaanse nalatenschappen blijft een bociende bezigheid. Niet voor wie van cenvoud houdt. Daar waar twee rechtsculturen samenkomen, elk met haar eigen normen en waarden, en elk met haar eigen rechtsfiguren, moet immers geschoven, gepast en gemeten worden. Ik pretendeer niet met mijn onderzoek met betrekking tot de Marokkaanse nalatenschappen alles reeds op zijn plaats te hebben gelegd. Wel hoop ik duidelijk te hebben gemaakt welke stukjes er naar mijn mening in de puzzel thuishoren, en hoe deze op de juiste plaats kunnen worden gelegd. 


\section{Samenvatting}

Over de afwikkeling van nalatenschappen van Marokkaanse erflaters die hun laatste gewone verblijfplaats in Nederland hadden, is weinig bekend. Het aantal gepubliceerde zaken waarin de Nederiandse rechter een oordeel heeft moeten vellen over het Marokkaanse erfrecht is al helemaal gering. Dat betekent niet dat bij het overlijden van Marokkanen in Nederland de erfopvolging eenvoudig is en dat de afwikkeling hiervan altijd probleemloos verloopt. Waarschijnlijk is dat het aantal sterfgevallen onder Marokkanen in Nederland, dat tot op heden nog relatief beperkt is, in de toekomst zal toenemen. Verondersteld mag worden dat dan ook het aantal gevallen waarin een erflater vermogen nalaat, hetzij in Marokko hetzij in Nederland hetzij elders, zal toenemen. Voor hen en hun familieleden zal het vaak van belang zijn te weten wat er na het overlijden met dit vermogen gebeurt. Wie behoren tot de erfgenamen? Op welk deel van de nalatenschap kunnen zij aanspraak maken? Wat zijn de executiemogelijkheden van rechterlijke beslissingen en authentieke akten in het land waar het vermogen zich bevindt? Tot 1 oktober 1996 gold in het Nederlandse IPR als hoofdregel dat de erfopvolging werd beheerst door het nationale recht van de erflater. Met de inwerkingtreding van de Wet conflictenrecht erfopvolging op 1 oktober 1996 zijn de regels uit het Erfrechtverdrag van 1989 indirect toepasselijk verklaard. Het wachten is op de inwerkingtreding van dit Verdrag. In de objectieve verwijzingsregel van dit Verdrag is de duur van het verblijf in Nederland in beginsel van doorslaggevende betekenis. Bij een onafgebroken verblijf vóor het overlijden in eenzelfde land van méér dan vijf jaren, is in beginsel het recht van de laatste gewone verblijfplaats toepasselijk; bij een onafgebroken verblijf vóór het overlijden van minder dan vijf jaren in eenzelfde land, is in beginsel het nationale recht van toepassing. Een rechtskeuze voor het nationale recht of voor het recht van de gewone verblijfplaats wordt uitdrukkelijk erkend. Op de erfopvolging van Marokkanen die naast de Marokkaanse de Nederlandse nationaliteit bezitten en die hun laatste gewone verblijfplaats in Nederland hadden, is, behoudens een rechtskeuze voor het Marokkaanse recht, het Nederlandse erfrecht van toepassing. Er wordt uitgegaan van een eenheidsstelsel: het aangewezen recht beheerst het gehele vermogen, ongeacht waar dit zich bevindt. Dit recht kan zich evenwel niet doorzetten als het recht van het land waar het vermogen is gelegen zich hiertegen verzet. Bij het 
onderzoek dat tot het onderhavige boek heeft geleid is alleen uitgegaan van gevallen waarin het Marokkaanse erfrecht toepasselijk is, hetzij op grond van de objectieve verwijzingsregel, hetzij op grond van cen voor dit recht uitgebrachte keuze. Getracht is om inzicht te geven in de bijzonderheden die zich bij de toepassing van Marokkaans erfrecht kunnen voordoen, wat de gevolgen kunnen zijn van de toepassing van dit recht, en hoe met deze gevolgen juridisch kan worden omgegaan. De verschillende aandachtspunten worden afzonderlijk besproken. Dat betekent dat informatie in concrete gevallen slechts zal kunnen worden verkregen door raadpleging van verschillende hoofdstukken en paragrafen. Getracht is wel om zoveel mogelijk dwarsverbanden te leggen door onderlinge verwijzingen naar relevante paragrafen.

Het Marokkaanse erfrecht is, evenals het Marokkaanse personen- en familierecht, na de onathankelijkheid van Marokko, in 1957 en 1958 gecodificeerd in de Code de statut personnel et des successions, ofwel de Mudawannah. Deze wet is uit het Arabisch vertaald naar het Nederlands, en is mitsdien ook toegankelijk voor Nederlandse juristen. De regels zijn gecodificerd naar westers model doch komen inhoudelijk overeen met het islamitische erfrecht van de malikitische rechtsschool. In verband hiermee wordt in het eerste hoofdstuk van dit bock een elementaire inleiding gegeven in het islamitische recht. Hieruit volgt dat de bron die aan het hedendaagse Marokkaanse erfrecht ten grondslag ligt weliswaar sterk door een menselijke inbreng is ontwikkeld doch een religieuze oorsprong heeft. De consequentic hiervan is dat het Marokkaanse personen-, familie- en erfrecht, hoewel de gelding hiervan van overheidswege is vastgesteld, geacht wordt een religieus karakter te hebben. In het cerste hoofdstuk wordt voorts aangegeven dat het islamitische recht in traditionele zin, waarop de Mudawannah is gebaseerd, een recht is dat reeds vele eeuwen geleden is tot stand gekomen. Het religieuze karakter van het Marokkaanse erfrecht en de trouw aan de opvattingen van oude islamitische rechtsgeleerden verklaren voor cen belangrijk deel de bijzondere betekenis van dit rechtsgebied voor moslims evenals de moeizame aanpassing van dit rechtsgebied aan maatschappelijke ontwikkelingen. Er zijn in de Islam verschillende rechtsscholen te onderscheiden die elk hun eigen gezaghebbende leerboeken hebben. In deze boeken is de shari' $a$, het islamitische recht, te vinden. In de Mudawwanah wordt naar de leer van de islamitische malikitische rechtsschool verwezen voorzover in de wet zelf zaken ongeregeld zijn gelaten.

Een beschrijving van het Marokkaanse erfrecht wordt gegeven in het tweede hoofdstuk. Zoals reeds is opgemerkt is de Marokkaanse wetgever hierbij trouw gebleven aan het islamitische malikitische erfrecht. Dit islamitische erfrecht wordt op zijn beurt wel geacht het resultaat te zijn van het handhaven van enerzijds het pre-islamitische mannenerfrecht en anderzijds de gelding van de regels van erfrecht die in de Koran zijn neergelegd. Het in het islamitische erfrecht gemaakte onderscheid tussen enerzijds de agnatische erfgenamen en anderzijds de koranische erfgenamen is in het Marokkaanse erfrecht gehandhaafd. Gevolg hiervan is dat dit recht twee categorieën erfgenamen kent. Aan de koranische erfgenamen, die voor de meerderheid uit vrouwen bestaan, komen 
vastgestelde erfporties toe. De omvang van deze porties wordt mede bepaald door de aanwezigheid van andere erfgenamen. De agnatische erfgenamen, zijnde allen mannen, delen in het restant. In navolging van het islamitische malikitische recht zou de bayt almâl, de Staatskas, gemakshalve de Staat te noemen, restant-erfgenaam zijn van de laatste categorie. Een in Marokko in 1962 ingevoerde wet heeft echter tot gevolg dat de Staat allecn opkomt in de nalatenschap als er geen andere erfgenamen zijn. De tweedeling tussen agnatische erfgenamen ( asaba-erfgenamen) en koranische erfgenamen wordt in veel gevallen doorbroken met name als er mannen en vrouwen tot de erfgenamen behoren dic in dezelfde verwantschapsgraad tot de erflater staan (bijvoorbeeld een dochter en een zoon, of een zus en een broer). De vrouwen (met uitzondering van die in opgaande linie) verliezen dan hun koranische aanspraak en worden "geconverteerd" in "asaba-erfgenamen, die delen in het restant. Alsdan is hun aanspraak de helft van die van de mannelijke verwant. In de paragrafen 3.B.6.a en 3.B.6.b van het tweede hoofdstuk wordt een overzicht gegeven van de verwanten die naar Marokkaans recht erfgenamen zijn en wat hun onderscheiden erfdelen zijn. De belangrijkste vernieuwing die de Marokkaanse wetgever ten opzichte van het islamitische erfrecht heeft doorgevoerd is de regeling met betrekking tot de plaatsvervulling, welke regeling vorm heeft gekregen middels het verplicht testament. Het Marokkaanse erfrecht is een intestaaterfrecht. De vrijheid om bij uiterste wil te beschikken is beperkt tot eenderde deel van het actief vermogen, en er mag niet worden beschikt ten behoeve van wettige erfgenamen. Het Marokkaanse erfrecht kent niet de saisine: na het overlijden van de erflater worden de schulden voldaan; de erfgenamen maken vervolgens aanspraak op de resterende activa. Het dwingende karakter van het Marokkaanse erfrecht is een van de redenen waarom in de praktijk niet zelden andere middelen worden aangewend om over eigen vermogen te beschikken. De twee belangrijkste middelen zijn wellicht het doen van schenkingen tijdens leven en het vestigen van een waqf, een zogenaamde islamitische trust. Ook deze twee rechtsfiguren worden in het tweede hoofdstuk aan de orde gesteld.

Een uiteenzetting van het Marokkaanse ertrecht is gegeven met het oog op de mogelijke toepasselijkheid hiervan op grond van de Nederlandse conflictregel inzake de erfopvolging. Zowel bij de erfopvolging als bij de afwikkeling van de nalatenschap dient het op de erfopvolging toepasselijke recht in acht te worden genomen. De afwikkeling kan echter ook plaatsvinden door tussenkomst van Marokkaanse consulaire of diplomatieke vertegenwoordigers die in Nederland zijn geaccrediteerd. De hierbij te volgen procedure wordt beschreven in hoofdstuk 3. Uit een klein veldonderzoek is gebleken dat in gevallen waarin voor deze procedure werd gekozen deze procedure werd gevolgd om de verdeling van vermogensbestanddelen die zich in Marokko bevonden te regelen.

De Nederlandse notaris, en in enkele gevallen de Nederlandse rechter, krijgt in internationale erfrechtzaken te maken met verschillende conflictregels. De belangrijkste betreffen de erfopvolging, de vorm van de uiterste wilsbeschikking, de bekwaamheid om bij uiterste wil te beschikken, en de vereffening en verdeling van de nalatenschap. 
Deze conflictregels worden besproken in het vierde hoofdstuk. Gewezen wordt op de vloeiende overgang die in het materiële recht bestaat tussen erfopvolging en erfafwikkeling, terwijl in het conflictenrecht deze twee gebieden worden ontkoppeld. De afwikkeling van nalatenschappen van Marokkaanse erflaters die hun laatste gewone verblijfplaats in Nederland hadden wordt beheerst door Nederlands recht. Wordt de erfopvolging beheerst door Marokkaans recht, dan ontstaan bij de erfafwikkeling aanpassingsproblemen, aangezien het Marokkaanse recht dat de erfopvolging beheerst, anders dan het Nederlandse erfrecht, de saisine niet kent. De meeste aandacht in het vierde hoofdstuk gaat uit naar het conflictenrecht inzake de erfopvolging. De verwijzingsregel wordt uitvoerig aan de orde gesteld omdat aan de hand hiervan zal moeten worden vastgesteld of Marokkaans recht van toepassing is. Hoewel is getracht de verwijzingsregel een zo gesloten mogelijk karakter te geven, zullen de hierin geformuleerde ontsnappingsclausules bij Marokkaanse erflaters niet altijd eenvoudig te hanteren zijn. De diverse conflictregels worden niet in extenso behandeld. De bespreking ervan blijft beperkt tot onderwerpen die relevant zijn met het oog op een mogelijke toepasselijkheid van het Marokkaanse recht op de erfopvolging. Bij de bespreking van deze onderwerpen wordt direct aangegeven wat de consequenties of moeilijkheden zouden zijn als de erfopvolging wordt beheerst door Marokkaans recht. Zo wordt bij de beschrijving van het materiële toepassingsgebied van de conflictregel inzake de erfopvolging, waaronder ook de inbrengverplichting wordt gebracht, gewezen op het feit dat tijdens leven gedane schenkingen naar Marokkaans recht in de meeste gevallen niet behoeven te worden ingcbracht. Ook goederen die voorwerp zijn van een door de erflater gevestigde waqf blijven buiten zijn nalatenschapsvermogen. Vanwege de grote gelijkenis met de trust wordt in hoofdstuk 4 in een aparte paragraf onderzocht of de Marokkaanse waqf kan worden aangemerkt als een trust in de zin van het op 1 februari 1996 voor Nederland in werking getreden Haagse Trustverdrag. In het bevestigende geval zou immers de vraag naar de geldigheid van een waqf worden beoordeeld door het op grond van dit Verdrag aangewezen recht, en zou de vraag naar erkenning zijn onderworpen aan de erkenningsregels uit dit Verdrag. Het belangrijkste relevante verschil tussen een trust in de zin van het Trustverdrag en de islamitische waqf lijkt te zijn dat aan de trust het vereiste wordt gesteld dat de trustee een titel met betrekking tot de trustgoederen bezit, terwijl de beheerder van een waqf een dergelijke titel in theorie niet heeft. Aangezien het echter niet geheel duidelijk is welke vereisten precies aan deze titel worden gesteld, kon niet op verantwoorde wijze worden geconcludeerd of de Marokkaanse waqf al dan niet kon worden aangemerkt als een trust in de zin van het Trustverdrag. Zou de Marokkaanse wagf niet onder het Trustverdrag vallen, dan wordt aanbevolen de geldigheid en erkenning hiervan te beoordelen op een aan de bepalingen uit het Trustverdrag analoge wijze.

Twee onderwerpen die om bijzondere aandacht vragen wanneer Marokkaans erfrecht toepasselijk is, zijn de mogelijk hinkende familierechtelijke verhoudingen en de openbare orde. Deze onderwerpen worden apart besproken in de hoofdstukken 5 en 6 . De hinkende familierechtelijke verhoudingen zijn het onderwerp van het vijfde hoofdstuk 
waarin zij worden besproken in het kader van de voorvraag bij de erfopvolging. Niet zelden zullen huwelijken die in Nederland geldig zijn in Marokko niet behoeven te worden erkend. Niet zelden zal een Marokkaanse huwelijksontbinding in Nederland niet behoeven te worden erkend en vice versa. Dit leidt in het kader van de erfopvolging tot vragen als: waren betrokkenen elkaars echtgenoten? Bestaat er wettige verwantschap ten opzichte van de erflater? Een eensluidende opvatting over de aanpak van dergelijke vragen ontbreekt in het Nederlandse IPR. Hoewel naar Marokkaans recht het geldige huwelijk de cnige relatic tussen man en vrouw is die wordt erkend en waarbinnen het hebben van sexuele gemeenschap is gelegitimeerd, is dit recht liberaal ten aanzien van de erkenning van het bewijs van het bestaan van een huwelijk of het bestaan van afstammingsbanden. Door gebruik te maken van dergelijke bewijsmiddelen hetzij in Marokko hetzij op Marokkaanse consulaire vertegenwoordigingen in Nederland, kan een aantal hinkende rechtsverhoudingen worden gerepareerd. Ook op het gebied van de huwelijksontbinding zijn afspraken gemaakt tussen de Nederlandse en Marokkaanse overheid, en wordt er momenteel gewerkt aan een verbetering van de samenwerking. In gevallen waarin er wel nog hinkende rechtsverhoudingen bestaan, leidt de onduidelijkheid in het Nederlandse IPR tot onzekerheid. In de literatuur wordt vaak een voorkeur uitgesproken voor een zelfstandige beoordeling van de voorvraag. Uitzonderingen hierop worden toegelaten, met name wanneer de samenhang tussen voorvraag en hoofdvraag hiertoe dwingt, Nederland nauwelijks belang heeft bij een zelfstandige beoordeling, of als een zelfstandige aanknoping leidt tot materieel onaanvaardbare resultaten. Met inachtneming van deze opvattingen worden in het vijfde hoofdstuk voor een aantal situaties keuzes voor een bepaalde benaderingswijze uitgesproken.

Eensgezindheid tussen Nederland en Marokko bestaat er niet over de regels uit het Marokkaanse erfrecht waarvan de toepassing in Nederland kan leiden tot een schending van in Nederland geldende fundamentele beginselen, maar aan de handhaving waarvan in Marokko een grote waarde wordt gehecht. Met de behandeling van die vraag wordt gekomen bij het punt van de internationaal privaatrechtelijke openbare orde die kan worden ingeroepen tegen de toepassing van vreemd recht. Hieraan is het zesde hoofdstuk gewijd. In dit hoofdstuk wordt ten aanzien van een groot aantal regels uit het Marokkaanse erfrecht onderzocht of toepassing ervan de toets van de openbare orde kan doorstaan. Het Marokkaanse erfrecht maakt onderscheid naar geslacht, naar geboorte en naar godsdienst. Het stelt vergaande beperkingen aan de beschikkingsvrijheid en wijkt op een aantal andere punten van het Nederlandse erfrecht af. Door schrijvers worden regels van erfrecht die wat de erfaanspraken betreft onderscheid maken naar geslacht, geboorte of godsdienst in de regel strijdig geacht met de openbare orde, zij het dat een enkele auteur aangeeft dat hierbij rekening is te houden met de omstandigheden van het concrete geval. Rechtspraak op dit specifieke punt ontbreekt. Marginaal is onderzocht wat de opvattingen in de ons aangrenzende landen ons op dit punt kunnen leren. Een complicerende factor bij de vraag naar het inroepen van de exceptie van de openbare orde bij een schending van fundamentele beginselen van de Nederlandse rechtsorde, wordt gevormd door een mogelijke verbondenheid van de erflater met het 
Marokkaanse erfrecht en zijn mogelijke wens tot toepassing van dit recht. Deze verbondenheid c.q. wil kan immers verband houden met een religieuze of culturele overtuiging, aan het respect waarvan in Nederland eveneens grote waarde wordt gehecht. Geconcludeerd wordt dat de toepassing van Marokkaanse regels van erfrecht welke leidt tot een onderscheid naar geslacht, geboorte of godsdienst in beginsel een schending oplevert van in Nederland geldende fundamentele beginselen. Ten aanzien van de Marokkaanse regels die op andere punten afwijken van Nederlandse beginselen, zal per concreet geval zorgvuldig moeten worden onderzocht of er een fundamenteel beginsel in het geding is dat wordt geschonden. Bij de vraag of een schending van een fundamenteel beginsel moet leiden tot het inroepen van de exceptie van de openbare orde zouden in ieder concreet geval alle in het geding zijnde belangen in de beoordeling moeten worden mecgewogen. Tot deze belangen behoren dan (in ieder geval) de belangen van de erflater, de belangen van de erfgenamen, algemene Nederlandse belangen (waaronder het respect voor fundamentele beginselen) en belangen die het IPR beoogt te dienen. Hierbij geldt dat naarmate het beginsel dat met de toepassing van de Marokkaanse regels wordt geschonden fundamenteler is, zoals het beginsel van gelijkheid naar geslacht, geboorte, en godsdienst, en de betrokkenheid met Nederland groter is, een beroep op de openbare orde eerder gerechtvaardigd is. Dit is niets nieuws. Wat in het zesde hoofdstuk wordt gedaan is trachten zo goed mogelijk aan te geven welke belangen in het geding kunnen zijn en welke waarde hieraan zou kunnen worden toegekend opdat tot een zo zorgvuldig mogelijke belangenafweging kan worden gekomen. Naast de mogelijkheid de exceptic van de openbare orde in te roepen ter afwering van Marokkaanse regels, wordt in het zesde hoofdstuk eveneens onderzocht of de toepassing van Marokkaans recht kan worden getoetst aan bepalingen uit mensenrechtenverdragen. Geconcludeerd wordt dat dit in principe mogelijk is indien het rechtstreeks werkende bepalingen betreft. Terwijl bij de overweging om de exceptie van de openbare orde in te roepen de beoordelingsruimte die de rechtstoepasser heeft relatief groot is en deze ruimte nauwelijks duidelijk is afgebakend, is de rechter wanneer hij gaat toetsen aan verdragsbepalingen gebonden aan de beoordelingsruimte die de verdragsbepalingen hem laten. Ten aanzien van enkele verdragsrechten uit het EVRM, in het bijzonder het recht op gelijke behandeling zonder onderscheid naar geslacht, geboorte of godsdienst, is deze beoordelingsvrijheid met name door het EHRM vergaand beperkt.

Tenslotte wordt in het zevende hoofdstuk onderzocht of in Nederland genomen beslissingen in nalatenschappen van Marokkaanse erflaters in Marokko kunnen worden ten uitvoer gelegd. Kennis hieromtrent is met name van belang als zich vermogen in Marokko bevindt. Wat de erkennings- en executiemogelijkheden in Marokko betreft is de belangrijkste bevinding dat het Marokkaanse familie- en erfrecht aldaar van openbare orde wordt geacht, althans in ieder geval als het (Marokkaanse) moslims betreft. Dat betekent dat in Nederland gegeven beslissingen die niet beantwoorden aan het Marokkaanse recht, in Marokko niet voor erkenning en tenuitvoerlegging in aanmerking komen. Wordt in Nederland de Nederlandse niet-islamitische echtgenote van een Marokkaanse islamitische man met wie zij (uitsluitend) een burgerlijke stand-huwelijk 
heeft gesloten, als erfgename aangemerkt, dan zal zij haar erfaanspraken als echtgenote niet geldend kunnen maken op vermogen in Marokko. Aldaar zal zij niet als wettig echtgenote worden aangemerkt, en bovendien kan zij als niet-moslim niet erven van een moslim.

In het concluderende achtste hoofdstuk wordt veel van hetgeen in eerdere hoofdstukken aan de orde is geweest bij elkaar gebracht. Er wordt gewezen op de confrontatie van twee verschillende rechtsculturen. Deze confrontatie vraagt om een bijzondere benadering, waarbij niet de rechtszekerheid maar alle in cen concreet geval in het geding zijnde belangen voorop staan. De huidige regels van Nederlands IPR bieden, mede vanwege hun onvolkomenheden en toegestane correctiemechanieken, de ruimte voor een dergelijke bijzondere benadering. De voorgestane benadering zal niet door iedere Nederlandse notaris in dank worden afgenomen. Mede daarom worden in het laatste hoofdstuk ook enkele praktische aanwijzingen gegeven voor toekomstige erflaters. 



\section{Summary}

Very little is known about the winding-up of estates of Moroccan testators who had their last habitual residence in the Netherlands. The number of published decided cases in which the court had to consider Moroccan succession law is very small indeed. This does not mean that succession upon the decease of a Moroccan national is easy and that the winding-up is without problems. It is very likely that the number of deaths among Moroccans in the Netherlands, which until now has been relatively small, will rise in the future. It may also be assumed that the number of cases in which a testator leaves assets, either in Morocco, in the Netherlands or elsewhere, will increase. For them and for their relations it is important to know what happens to the estate upon the decease of the person in question. Who are the heirs? To which part of the inheritance are they entitled? What possibilities of enforcement of judicial orders and execution of authentic instruments are there in the country where the assets are located? Until 1 October 1996, the principal rule of Dutch PIL was that succession was governed by the law of the testator's nationality. However, on that date, the Wet conflictenrecht erfopvolging (Conflict of Laws Succession Act) came into effect, granting indirect applicability to the rules of the Convention on the Law Applicable to Succession to the Estates of Deceased Persons, which has not yet come into force. Under the objective attributive rule of this Convention, in principle, the length of residency in the Netherlands is decisive. If a person resided in the same country for an uninterrupted period of more than five years prior to his/her decease, in principle, the law of the last habitual residence is applicable; if the person resided in a particularly country for an uninterrupted period of time of less than five years, in principle, the law of his nationality is applicable. A choice of law for the law of the nationality or the law of the habitual residence has been expressly recognized. Dutch law is applicable to the succession of Moroccans who, in addition to Moroccan nationality, possess Dutch nationality and who had their last habitual residence in the Netherlands, unless there has been an express choice for Moroccan law. The premise is a unitary system: the applicable law governs the whole of the estate, irrespective of where the assets are located. This law cannot be enforced, however, where the law of the country in which the assets are located, provides otherwise. 
For the purpose of this dissertation, only those cases have been studied in which Moroccan inheritance law is applicable, either pursuant to the objective attributive rule, or pursuant to an express choice for this law. The author has sought to provide an insight into the particularities which may occur when Moroccan law is applied; the possible consequences of its application; and the way in which the legal profession deals with these consequences. The various points of interests are discussed separately. This implies that for concrete cases information can be acquired only by consulting several chapters and sections. The author has endeavoured to provide as many connections as possible in the form of cross-references to relevant sections.

After Morocco became independent, in 1957 and 1958 its inheritance law, as well as its family law, was codified in the Code de statut personnel et des successions (Code of Personal Status and Succession), the Mudawannah. This Code has been translated from Arabic into Dutch, making it accessible to Dutch lawyers. The rules have been codified according to Western tradition, but their content is in conformity with the Islamic inheritance law of the Mâlikî school. In this connection, Chapter 1 offers a basic introduction to Islamic law. It follows that, although the source at the foundation of contemporary Moroccan inheritance law has been developed by human input, it has a religious origin. As a result, the Moroccan family and inheritance laws are deemed to have a religious character, in spite of the fact that they have been enacted by the State. In Chapter 1 it is further discussed that the traditional Islamic law, on which the Mudawannah is based, originated centuries ago. The religious character of Moroccan inheritance law and a loyalty to the views of the old Islamic jurists explain for the most part both its special significance to Muslims and its slow adaptation to social developments. There are various schools of law in Islam, each with their own authoritative text books. These books contain the shari' $a$, Islamic law. The Mudawwanah refers to the teachings of the Islamic Mâlikî school for cases not regulated by the Code.

In Chapter 2, the author discusses Moroccan inheritance law. As mentioned earlier, the Moroccan legislator has remained faithful to Islamic Mâlikî inheritance law. In its turn, this Islamic inheritance law is considered to be the result of the enforcement of preIslamic agnatic inheritance law on the one hand, and the inheritance rules of the Koran, on the other. The distinction under Islamic law between agnatic and Koranic heirs has been preserved in Moroccan inheritance law. As a result, the law recognizes two categories of heirs. To the Koranic heirs, the majority of whom are women, befall the portions fixed by the Koran. The size of these portions is co-determined by the existence of other heirs. The agnatic heirs, consisting of men only, share the remainder. Pursuant to Islamic Mâlikî law the bayt al-mâl, the Treasury, or simply put the State, would be heir to the remainder of the latter category. However, a Moroccan statute which came into effect in 1962 is responsible for the situation in which the State only figures as heir to the estate if there are no other heirs. On many occasions, the division between agnatic, or 'asaba, heirs and Koranic heirs becomes undone, in particular in cases in which there are male and female heirs related in the same degree of consan- 
guinity, for instance, a daughter and a son, or a sister and a brother. The women in these cases, with the exception of those in the ascending line, lose their Koranic inheritance rights and are converted into 'asaba heirs, who share in the remainder. Their portion is then half of that of the men. The relatives who are heirs under Moroccan law and their respective share are listed in sections 3.B.6. and 3.B.6.b of the second chapter of this study. The most important innovation which the Moroccan legislator has introduced in comparison to Islamic law is a regime of representation, which has been put in place through the obligatory bequest. Moroccan inheritance law is intestate inheritance law. The freedom to dispose by will has been limited to one-third of the assets; to dispose for the benefit of legal heirs is not permitted. Moroccan inheritance law does not include saisine: upon the death of the testator first the debts are paid; the heirs are entitled to the remaining assets. The mandatory character of Moroccan inheritance law is one of the reasons why in practice other means are often used to dispose of one's assets. The two most important ways are perhaps inter vivos gifts and the creation of a waqf, the Islamic variant of the trust. These legal concepts are also discussed in Chapter 2.

The exposé of Moroccan law was given in view of its possible application pursuant to Dutch choice of law rules. Both in succession and in winding up the estate, the appropriate inheritance law must be applied. The winding-up may, however, also take place through the intervention of Moroccan consular or diplomatic representatives accredited to the Netherlands. The procedure that must be followed in such cases is described in Chapter 3. A short field study has shown that in the cases in which this procedure was chosen, it was used to settle the distribution of the assets located in Morocco.

In international probate cases, Dutch civil-law notaries, and in a few cases Dutch judges, are confronted with various choice of law rules. The most important ones concern succession, the form of the last will, the capacity to dispose by will, and the liquidation and distribution of the inheritance. These choice of law rules are discussed in Chapter 4. The author points out the smooth transition in substantive law from succession to the winding-up of the deceased's estate, whereas in private international law these are two separate areas. The winding-up of the estates of Moroccan testators who had their last habitual residence in the Netherlands is governed by Dutch law. If the succession is governed by Moroccan law, problems of adaptation will arise in the winding-up, since the Moroccan law governing succession does not provide for saisine as does the Dutch law of inheritance. In Chapter 4 , the author focuses on the private international law relating to succession. The attributive rule is extensively discussed, since with the aid of this rule it can be established whether Moroccan law is applicable. Although an effort was made to give the attributive rule a maximum closed character, the escape clauses formulated under the rule cannot always be readily deployed in the case of Moroccan testators. The various choice of law rules are not extensively discussed; their discussion is limited to relevant subjects in view of a possible application 
of Moroccan law to the succession. When discussing these subjects, the author at the same time indicates what the consequences would be or what problems would arise if the succession were governed by Moroccan law. For instance, in discussing the substantive scope of application of the choice of law rule relating to succession, which also includes the obligation to restore or account for gifts, advancements or legacies, she points out that under Moroccan law in most cases inter vivos gifts do not need to be restored or accounted for. Property that is the object of a waqf created by the testator will also fall outside the estate. Because of its similarity to a trust, the author investigates in a separate section of Chapter 4 whether the Moroccan waqf could be seen as a trust within the meaning of the Hague Convention on the Law Applicable to Trusts and their Recognition, which came into force for the Netherlands on 1 February 1996. If this were the case, the question as to the validity of the waqf would be examined on the basis of the law designated by the Convention. Furthermore, the question of recognition would be subject to the recognition provisions of the Convention. The most important relevant difference between a trust within the meaning of the trust convention and the Islamic waqf seems to be that in the case of trusts the trustee possesses the (legal) title to the trust assets, whereas the administrator of a wagf, at least in theory, does not possess such a title. However, since it is not completely clear which requirements apply to this title, the conclusion as to whether the waqf could be considered a trust within the meaning of the trust convention could not be justified. Should the Moroccan trust not fall within the scope of the trust convention, the author advises that its validity and the recognition thereof be assessed in analogy to the provisions of the convention.

Two subjects which deserve special attention if Moroccan law is applicable are the possible limping legal (family) relations and public policy. These are discussed separately in Chapters 5 and 6 . The limping family relations are the subject of Chapter 5, where they are discussed within the context of the preliminary question concerning succession. Rather frequently, marriages which are valid in the Netherlands, do not require recognition in Morocco. Often, a Moroccan dissolution of marriage will not require recognition in the Netherlands and vice versa. In relation to succession this leads to questions such as: were the persons in question each other's spouses?; is there a blood relationship with the testator recognized in law? In Dutch PIL, there is no uniform view as to the way in which these questions should be approached. Although under Moroccan law, the only relationship between a man and a woman is a valid marriage, within which sexual intercourse is permitted, the law is liberal when it comes to the recognition of evidence of the existence of a marriage or of parentage. By using such means of evidence, either in Morocco or at Moroccan consulates, a number of limping legal relations may be repaired. Agreements have been also made between the Dutch and the Moroccan authorities concerning the dissolution of marriages. At present, they are working to improve cooperation. In those instances in which limping legal relations still remain, the vagueness of Dutch PIL has resulted in uncertainty for those involved. Academic writers often express a preference for an independent assessment of the preliminary 
question. Exceptions are permitted, in particular where: the coherence between the preliminary question and the principal issue so demands; the Netherlands has a negligible interest in having the preliminary question independently assessed; or if an independent assessment will yield unacceptable results from a substantive perspective. With these considerations in mind, the author discusses in Chapter 5 her choice for a particular approach in a number of situations.

No consensus has been reached between the Netherlands and Morocco on the rules of Moroccan inheritance law, whose enforcement is greatly valued in Morocco, but whose application in the Netherlands may cause a violation of fundamental principles respected in that country. Via a discussion of this question, the author arrives at the public policy aspect of private international law, which can be invoked against the application of forcign law, the subject of Chapter 6 . In this chapter, the applicability of a considerable number of rules of Moroccan inheritance law are examined against the public policy test. Moroccan inheritance law discriminates on the grounds of sex, birth and religion. It strongly limits the freedom of disposition and it deviates from Dutch inheritance law in a number of other aspects. Inheritance rules that discriminate on the grounds of sex, birth or religion as far as inheritance rights are concerned are held by most academic writers to be incompatible with public policy, although some of them argue that the actual circumstances of the case should be taken into account. There are no decided cases on this point. A cursory study has been made of the views prevailing in the countries bordering on the Netherlands. A complicating factor in answering the question of invoking the exception of public policy in the event of incompatibility with fundamental principles of the Dutch legal order, is formed by the possible connection of the testator with Moroccan inheritance law and his possible wish to have this law applied. This connection or, as the case may be, his will, may be the result of religious or cultural conviction, respect for which is also much valued in the Netherlands. The author concludes that application of Moroccan inheritance rules which will result in discrimination on the grounds of sex, birth or religion, in principle constitutes a violation of fundamental principles respected in the Netherlands. As to Moroccan rules that deviate from Dutch principles in other aspects, it must be examined in each particular case whether a fundamental principle is at issue and whether it has been violated. When the question needs to be considered as to whether a violation of a fundamental principle justifies invoking the exception of public policy, on every occasion all the interests should be weighed in order to assess the case under scrutiny. At any rate, these interests include those of the testator and the heirs, general interests of Dutch society, among which respect for fundamental principles, and the interests which PIL aims to serve. In this context, the rule is that the more fundamental the principle which is violated by the application of Moroccan rules, the sooner an appeal to public policy will be justified; this is nothing new. The author's intention with Chapter 6 is to indicate as best as possible the interests at issue and the value which should be attached to these in order to arrive at a judicious weighing of the interests. 
In addition to the possibility of invoking the exception of public policy to ward off the application of Moroccan rules, the author also examines in this chapter whether the application of Moroccan law can be tested against provisions from human rights conventions. She concludes that in principle this could be the case where the provisions have direct effect. Whereas, in assessing whether to invoke the exception of public policy, the margin of appreciation of the assessor is relatively wide and has not been properly defined, the judge, in testing against convention provisions, is bound to the margin of appreciation afforded him by the treaty provisions. In respect of a number of rights under the European Convention on Human Rights, in particular the right to equal treatment without discrimination on the grounds of sex, birth or religion, the margin has been dramatically restricted by the European Court of Human Rights.

Finally, in Chapter 7, the author examines whether decisions taken in the Netherlands in respect of the estates of Moroccan testators are enforceable in Morocco. The answer to this question is of particular importance in cases where there are assets in Morocco. The most important outcome of the investigation on recognition and enforcement in Morocco is that, in Morocco, Moroccan family and inheritance law is considered to be a matter of public policy, in any case where Moroccan Muslims are involved. This means that decisions taken by Dutch courts which are not compatible with Moroccan law, will not be eligible for recognition and enforcement. If, in the Netherlands, the Dutch non-Muslim spouse of a Moroccan Muslim male with whom she has entered into a Civil Registry marriage, is designated as his heir, she will not be able to enforce her rights of inheritance as far as the assets located in Morocco are concerned. In the latter country, she will not be recognized as a legally wedded wife, and furthermore, as a non-Muslim, she cannot inherit from a Muslim.

The concluding Chapter 8 provides an overview of what has been discussed in the preceding chapters. The clash between the two different legal cultures is highlighted. This confrontation calls for a special approach, in which all the interests at issue in a concrete case, rather than legal certainty, prevail. The existing rules of Dutch PIL allow for such a special approach, in part because of its imperfections and the correction mechanisms permitted by the regime. Dutch civil-law notaries will not take kindly to the approach proposed. For this reason also, the author offers a number of practical tips for future testators.

Translated by Louise Rayar 


\section{Résumé}

On sait peu de choses sur la liquidation des successions de de cujus marocains dont la dernière résidence habituelle se trouvait aux Pays-Bas. Le nombre d'affaires publiées dans lesquelles le juge néerlandais a dû se prononcer sur le droit successoral marocain est très réduit. Cela ne veut pas dire que, lors du décès de Marocains aux Pays-Bas, la succession soit aisée et que sa liquidation se déroule sans problèmes. Il est probable que le nombre des décès de Marocains aux Pays-Bas, jusqu'à présent encore relativement limité, ira en augmentant. On peut supposer qu'augmenteront également les cas où un de cujus laissera un patrimoine, soit au Maroc, soit aux Pays-Bas, soit ailleurs. Il importera souvent pour lui et pour ses parents, de savoir ce qu'il adviendra de ce patrimoine après le décès. Qui fait partie des héritiers? Quelle part de la succession ceux-ci peuvent-ils revendiquer? Quelles sont les possibilités d'exécution des décisions de justice et des actes authentiques dans le pays où se trouve le parrimoine? Jusqu'au ler octobre 1996, dans le DIP néerlandais, la règle a prévalu que la succession était régie part la loi de l'Etat dont le de cujus possédait la nationalité. Avec l'entrée en vigueur de la loi sur le droit des conflits de succession le ler octobre 1996, les règles de la Convention sur la loi applicable aux successions à cause de mort de 1989 ont été déclarées indirectement applicables. On attend l'entrée en vigueur de cette convention. Dans la règle de rattachement objectif de cette convention, la durée du séjour aux PaysBas a, en principe, une importance décisive. Dans le cas d'un défunt ayant résidé dans un Etat durant une période d'au moins cinq ans précédant immédiatement son décès, on applique en principe la loi de la dernière résidence habituelle; dans le cas d'un défunt ayant résidé dans un Etat durant une période de moins de cinq ans précédant immédiatement son décès, on applique en principe la loi de la nationalité. La désignation de la loi de la nationalité ou de la loi de la résidence habituelle comme loi applicable est expressément reconnue. La loi successorale néerlandaise s'applique aux successions de Marocains qui possèdent la nationalité néerlandaise à côté de la nationalité marocaine et dont la dernière résidence habituelle se trouvait aux Pays-Bas, à moins d'un choix du testateur pour le droit marocain. Le point de départ est un principe unitaire: La loi applicable régit l'ensemble de la succession, quelle que soit la situation des biens. Cependant cette loi ne peut aboutir si la loi du pays où se trouve le patrimoine s'y 
oppose. Dans l'étude à l'origine de ce livre, seuls les cas où la loi marocaine était applicable ont été pris en compte, soit sur la base de la règle de rattachement objectif, soit sur la base d'un choix exprimé en faveur de cette loi. On a tenté de comprendre les particularités qui peuvent apparaître lors de l'application de la loi successorale marocaine, quelles peuvent être les conséquences de l'application de cette loi, et, comment ces conséquences peuvent être traitées juridiquement. Les différents centres d'intérêt sont discutés séparément. Il faut donc consulter différents chapitres et paragraphes pour pouvoir trouver des informations sur des cas concrets. Toutefois on a essayé autant que possible d'établir des liaisons transversales au moyen de renvois réciproques entre les paragraphes appropriés.

Tout comme la loi des personnes et de la famille, la loi successorale marocaine a été codifiée après l'indépendance du Maroc, en 1957 et 1958 dans le Code de statut personnel et des successions, ou la Moudawwana. Cette loi a été traduite de l'arabe en néerlandais et est donc accessible aux juristes néerlandais. Les règles ont été codifiées suivant le modèle occidental mais leur contenu correspond à la loi successorale islamique de l'école juridique malikite. C'est pourquoi on présente dans le premier chapitre de ce livre une introduction élémentaire au droit musulman. Par conséquent, même si les fondements de la loi successorale actuelle du Maroc se sont développés grâce à un fort apport humain, ils ont une origine religieuse. On estime donc que la loi marocaine des personnes, de la famille et des successions a un caractère religieux bien que son application soit fixée par les pouvoirs publics. Le premier chapitre montre, en outre qu'au sens traditionnel, le droit musulman sur lequel est basée la Moudawwana s'est développé il y a plusieurs siècles. Le caractère religieux de la loi successorale marocaine et la fidélité aux conceptions des anciens juristes islamiques expliquent, pour une grande part, la signification singulière de ce domaine du droit pour les musulmans ainsi que la difficile adaptation de ce domaine du droit à l'évolution de la société. On distingue dans l'Islam diverses écoles juridiques qui possèdent, chacune, leurs propres livres qui font autorité. Dans ces traités on trouve la sharí 'a ou droit musulman. Dans la Moudawwana on se réfère à la doctrine de rite malikite dans la mesure où des affaires n'ont pas été réglées par la loi.

Le deuxième chapitre décrit la loi successorale marocaine. Comme cela a déjà été signalé, le législateur marocain est resté fidèle au droit successoral musulman de rite malikite. On estime que ce droit successoral islamique est lui-même le résultat du maintien, d'un côté, du droit successoral masculin préislamique et de l'autre, de l'application des règles de droit successoral énoncées dans le Coran. La distinction établie par le droit successoral islamique entre, d'une part, les héritiers agnats et d'autre part, les héritiers coraniques a été maintenue dans le droit successoral marocain. Il s'ensuit que la loi connaît deux catégories d'héritiers. Des parts d'héritage bien définies reviennent aux héritiers coraniques, en majorité des femmes. L'importance de ces parts est également déterminée par la présence d'autres héritiers. Les héritiers agnats, uniquement masculins, se partagent le reste. Selon le droit islamique malikite, le bayt 
al-mal, le Trésor public, appelé pour plus de commodité l'Etat, devraient être l'héritier du reste de la dernière catégorie. Cependant une loi adoptée au Maroc en 1962 a eu pour conséquence que l'Etat n'a vocation à recueillir une succession qu'en l'absence d'héritiers. Le partage en deux entre les héritiers agnats (les héritiers 'asaba) et les héritiers coraniques se présente dans de nombreux cas, en particulier quand les hommes et les femmes qui sont les héritiers ont le même degré de parenté avec le de cujus (par exemple une fille et un fils, ou, une soeur et un frère). Les femmes (à l'exception de celles en ligne ascendante) perdent leurs droits coraniques et deviennent des héritiers asaba qui ont une part du reste. Leur droit équivaut alors à la moitié de celui du parent masculin. Les paragraphes 3.B.6.a et 3.B.6.b du deuxième chapitre de cet ouvrage donnent un aperçu des parents qui sont les héritiers selon la loi marocaine et indiquent leurs différentes parts d'héritage. L'innovation la plus importante introduite par le législatcur marocain par rapport au droit successoral musulman, concerne le règlement relatif à la représentation, règlement qui rend le testament obligatoire. La loi successorale marocaine est une loi de succession intestat. On ne reconnait que des legs. La libre disposition, par testament, se limite à un tiers de l'actif et on ne peut pas disposer en faveur des héritiers légaux. La loi successorale marocaine ne connaît pas la saisine: après le décès du de cujus les dettes sont acquittées; puis les héritiers revendiquent 1'actif restant du patrimoine. Le caractère coercitif de la loi successorale marocaine est une des raisons pour lesquelles, dans la pratique, on a fréquemment recours à d'autres moyens pour disposer de ses biens. Faire des donations entre vifs et fonder un waqf, un trust islamique, sont peut-être les deux moyens les plus employés. Ces deux formes sont également traitées au deuxième chapitre.

L'exposé de la loi successorale marocaine vise à une applicabilité éventuelle de cette loi sur la base de la règle néerlandaise de rattachement en matière de succession. Il faut être attentif à la loi applicable à la succession aussi bien lors de la succession que lors de la liquidation de la succession. La liquidation peut avoir lieu par l'entremise de représentants consulaires ou diplomatiques marocains accrédités aux Pays-Bas. Le chapitre 3 décrit la procédure à suivre dans ce cas. Il ressort d'une petite enquête sur le terrain que dans les cas où on a fait le choix de cette procédure, celle-ci a été suivie pour régler le partage des éléments du patrimoine se trouvant au Maroc. Dans les affaires de succession internationales, le notaire néerlandais, et dans quelques cas le juge néerlandais, ont à faire à plusieurs règles de rattachement. Les plus importantes concernent la succession, la forme du testament, la capacité à disposer par testament et la liquidation et le partage de la succession. Ces règles de rattachement sont discutées dans le quatrième chapitre. Il y est signalé que dans la loi matériel le passage est aisé entre la succession et la liquidation de la succession, tandis que dans les règles de rattachement ces deux domaines sont séparés. La liquidation des successions de de cujus marocains qui avaient leur dernière résidence habituelle aux Pays-Bas est régie par la loi néerlandaise. Si la succession est régie selon la loi marocaine, des problèmes d'adaptation apparaissent étant donné que la loi marocaine régissant la succession, à la différence de la loi néerlandaise, ne connaît pas la saisine. Le quatrième chapitre 
S'attache essentiellement aux règles de rattachement en matière de succession. La règle de rattachement est examinée en détail parce que c'est elle qui permettra de déterminer si la loi marocaine est applicable. Bien qu'on tâche de donner à la règle de rattachement le caractère le plus fermé possible, les clauses échappatoires qui y sont formulées relatives aux de cujus marocains ne seront pas toujours aisément maniables. Les diverses règles de rattachement ne sont pas traitées in extenso. Leur discussion se limite aux sujets qui conviennent en vue d'une applicabilité possible de la loi marocaine des successions. La discussion de ces sujets est accompagnée de l'indicátion des conséquences et des possiblités d'une succession régie par la loi marocaine. Par exemple, lors de la description du champ matériel d'application de la règle de rattachement en matière de succession, dans laquelle on a également rangé l'obligation du rapport et de la réduction des libéralités, on signale le fait que, dans la plupart des cas, le rapport et la réduction des libéralités ne sont pas nécéssaires. Les biens qui appartiennent au waqf fondé par le de cujus ne font pas non plus partie de la masse successorale. Au chapitre 4, dans un paragraphe séparé, on examine la possibilité de considérer le waqf marocain, en raison de sa grande ressemblance avec le trust, comme un trust selon la Convention de La Haye sur les trusts entrée en vigueur aux Pays-Bas le ler février 1996. Si cette possibilité existait, on étudierait la question de la validité d'un waqf sur la base de la loi indiquéc par cette Convention et la question de la reconnaissance serait soumise aux règles de reconnaissance de cette Convention. La différence la plus importante entre un trust selon la Convention sur les trusts et le wagf islamique semble être que, dans le trust, le trustee doit avoir un titre relatif aux biens du trust, alors que l'administrateur d'un waqf n'a pas, en théorie, un tel titre. Cependant, comme les conditions fixées précisément à ce titre ne sont pas tout à fait claires, on ne peut pas conclure, raisonnablement, que le waqf marocain peut être considéré comme un trust selon la Convention sur les trusts. Si le waqf marocain ne relève pas de la Convention sur les trusts, il est conseillé alors d'apprécier sa validité et sa reconnaissance sur un mode analogue aux dispositions de la Convention sur les trusts.

Les relations familiales légales éventuellement boîteuses et l'ordre public constituent deux points qui demandent une attention particulière dans les cas où s'applique la loi successorale marocaine. Ces questions sont discutées séparément aux chapitres 5 et 6 . Les relations familiales légales boîteuses forment la matière du cinquième chapitre où elles sont examinées dans le cadre de la question préalable dans la succession. Fréquemment les mariages valides aux Pays -Bas n'auront pas à être reconnus au Maroc. Fréquemment une dissolution de mariage intervenue au Maroc ne devra pas être reconnue aux Pays-Bas et vice versa. Dans le cadre de la succession cela conduit à des questions telles que: les personnes concernées étaient-elles des conjoints? Existe-t-il une parenté légale avec le de cujus? Une conception unanime sur la manière d'aborder ces questions fait défaut dans le DIP néerlandais. Bien que selon la loi marocaine le mariage valide soit la seule relation reconnue entre un homme et une femme et qu'il rende légitimes les rapports sexuels, cette loi est libérale quant à la reconnaissance de la preuve de l'existence d'un mariage ou quant à l'existence de liens de filiation. L'utilisa- 
tion de ces preuves, soit au Maroc, soit dans les représentations consulaires marocaines aux Pays-Bas, permet de réparer un certain nombre de situations boîteuses. Des accords ont ćgalement été conclus entre les autorités néerlandaises et marocaines au sujet des dissolutions de mariage, et actuellement on travaille à améliorer la collaboration. Dans les cas où subsistent des situations boîteuses, l'imprécision du DIP néerlandais entraîne l'incertitude. La littérature préfère souvent un jugement autonome de la question préalable. Des exceptions sont permises en particulier lorsque le lien entre la question préalable et la question principale y pousse, lorsque les Pays-Bas n'ont guère intérêt à un jugement autonome, ou si un rattachement autonome a des conséquences matérielles inacceptables. Tenant compte de ces conceptions, le cinquième chapitre fait le choix d'une certaine forme d'approche pour diverses situations.

Les Pays-Bas et le Maroc ne sont pas d'accord sur les règles de la loi successorale marocaine dont l'application aux Pays-Bas peut entraîner une atteinte aux principes fondamentaux en vigueur aux Pays-Bas mais au maintien desquelles le Maroc attache une grande importance. En traitant cette question on aborde le thème de l'ordre public de droit privé international que l'on peut invoquer contre l'application d'une loi étrangère. Le sixième chapitre y est consacré. Ce chapitre examine au regard d'un grand nombre de règles de la loi successorale marocaine si son application peut résister à l'épreuve de l'ordre public. La loi successorale marocaine établit des distinctions selon le sexe, la naissance et la religion. Elle limite très fortement la liberté de disposer et diffère de la loi successorale néerlandaise sur plusieurs autres points. En général, les auteurs estiment contraires à l'ordre public les règles de droit successoral concernant les prétentions à l'héritage qui établissent des distinctions selon le sexe, la naissance ou la religion, même si l'un d'entre eux indique qu'il faut tenir compte des circonstances de chaque cas concret. Sur ce point spécifique la jurisprudence fait défaut. Quelques études marginales ont été faites sur ce que peuvent nous apprendre à ce sujet les conceptions des pays limitrophes. Un facteur de complexité supplémentaire au problème de l'invocation de l'exception de l'ordre public en cas d'atteinte aux principes fondamentaux du droit néerlandais, réside dans une solidarité éventuelle du de cujus avec la loi successorale marocaine et son éventuel désir de voir appliquer cette loi. Cette solidarité ou cette volonté peut être liée à une conviction religieuse ou culturelle au respect de laquelle aux Pays-Bas aussi, on attache une grande importance. On conclut que l'application des règles marocaines de la loi successorale qui aboutissent à une distinction selon le sexe, la naissance et la religion constituent en général une atteinte aux principes fondamentaux en vigueur aux Pays-Bas. En ce qui concerne les règles marocaines qui, sur d'autres points, divergent des principes néerlandais, il faudra étudier avec soin et pour chaque cas, s'il y a violation d'un principe fondamental. A la question de savoir si la violation d'un principe fondamental doit aboutir à l'invocation de l'exception de l'ordre public, il faudra, avant de se prononcer, soupeser tous les intérêts en cause dans chaque cas concret. Comptent (en tout cas) au nombre de ces intérêts, les intérêts du de cujus, les intérêts des héritiers, l'intérêt général néerlandais (e.a. le respect des principes fondamentaux) et les intérêts que le DIP se propose de 
servir. Ici on fait valoir la règle que plus le principe violé par l'application des règles marocaines est fondamental, comme le principe de l'égalité selon le sexe, la naissance et la religion, et plus la relation avec les Pays-Bas est forte, plus l'appel à l'ordre public est justifié. Ceci n'est pas nouveau. Ce qu'on a essayé de faire dans le sixième chapitre, c'est, du mieux possible, indiquer les intérêts en cause et la valeur qu'on peut leur attribuer afin de permettre une évaluation des intérêts la plus minutieuse possible. Outre la possibilité d'invoquer l'exception de l'ordre public pour rejeter les règles marocaines, le sixième chapitre cherche aussi à savoir si l'application de la loi marocaine peut être confrontée aux dispositions des conventions sur les droits de l'homme. On conclut, en principe, à cette possibilité s'il s'agit de dispositions directement applicables. Alors que le juge dispose d'une grande marge de jugement dans ses considérations sur l'invocation de l'exception de l'ordre public et que cette marge n'est pas clairement définie, en revanche, lorsque il met à l'épreuve les dispositions de ces conventions, il est tenu par la marge qu'elles lui laissent. Cette marge de jugement est extrêmement limitée, en particulier par la Cour européenne des droits de l'homme, en ce qui concerne quelques droits de la Convention européenne des droits de l'homme, spécialement le droit à un traitement égal sans distinction de sexe, de naissance ou de religion.

Pour finir le septième chapitre étudie l'exécution au Maroc de décisions prises aux Pays-Bas concernant des successions de de cujus marocains. La connaissance de ce sujet est particulièrement importante si des biens du défunt se trouvent au Maroc. En ce qui concerne les possibilités de reconnaissance et d'exécution, la constatation la plus importante est que la loi de la famille et des successions y est estimée d'ordre public, du moins dans tous les cas touchant un musulman (marocain). Ce qui veut dire que les décisions prises aux Pays-Bas qui ne sont pas conformes au droit marocain ne sont susceptibles ni de reconnaissance ni d'exécution. Même si l'épouse néerlandaise nonmusulmane d'un Marocain musulman avec qui elle a seulement contracté un mariage civil, est considérée comme héritière aux Pays-Bas elle ne pourra pas faire valoir ses prétentions à la succession sur des biens se trouvant au Maroc. Au Maroc, elle ne sera pas considérée comme l'épouse légitime et en outre en tant que non-musulmane elle ne peut pas hériter d'un musulman.

Le huitième chapitre conclut en regroupant beaucoup de ce qui a été étudié dans les chapitres précédents. On signale la confrontation entre deux cultures de droit différentes. Cette confrontation demande une approche particulière où ce n'est pas la sécurité juridique qui prévaut mais tous les intérêts en cause dans un cas concret. Les règles actuelles du DIP néerlandais, grâce à leurs imperfections ainsi qu'à leurs mécanismes de correction autorisés permettent cette approche particulière. Tous les notaires néerlandais n'apprécieront pas l'approche proposée, c'est pourquoi le dernier chapitre formule aussi quelques indications pratiques pour les futurs de cujus.

Traduit par Marie-Claude Dumas 


\section{Trefwoordenregister}

$A$

aanpassing $97,101,104,133,145$,

$149,153,185,199,203,208,224,294$

aansprakelijkheid voor schulden

$104,114,230$

aanwijzing van erfgenamen

- zic tanzil

acte d'hérédié

$47,90,95$

acte de mariage

166

acte de rípudiation

173

'adl

- zie 'udiul

adoptic

$43,126,152,156$,

$182 \mathrm{t} / \mathrm{m} \mathrm{185,217,228,229,261}$

Adoptieverdrag 1965

137,182

Adoptieverdrag 1993

183,184

athankelijkc aanknoping/beoordeling

$153 \mathrm{t} / \mathrm{m} 156,160,169$.

$175,176,179 \mathrm{t} / \mathrm{m} \mathrm{182,233}$,

$234,236 \mathrm{t} / \mathrm{m} 242,292,293$

afstamming

- onwettige

- wettige

afwikkeling

$215,220,221,274$

$52,53,179,181,185$,

$215,217,220,221$.

$238 \mathrm{t} / \mathrm{m} 240,274,285$

$3,5,9,10,90$,

$94,97,102 \mathrm{t} / \mathrm{m} \mathrm{104,109}$,

129. $133 \mathrm{t} / \mathrm{m} \mathrm{l} 135,138 \mathrm{t} / \mathrm{m} 140$.

$224,230,279,291,295$

afstemming

agnatische erfgenamen

57, 205

Akdariyya, geval van de

79

alimentatie

197

'amal

8,21
Ambassade

$6,93,161,163$, $165 \mathrm{t} / \mathrm{m} \mathrm{167,173}$

apostasie

- zie geloofsafval

art. I Eerste Protocol EVRM

$203,223,256,272 \mathrm{t} / \mathrm{m} 274,294$

an. 8 EVRM

$203,215,219,228$,

$238,256,257,262$,

$266,267,274,294$

ant. 14 EVRM

$202,203,215,219$.

$259,266,267,274$

art. 9 Europese Verdrag inzake de rechtspositie van buiten

huwelijk geboren kinderen

$49,122,127,137$,

$162,172,190,202$

art. 23 IVBPR

203

art. 26 IVBPR

$202,215,219,256$

art. 2 Universele Verklaring van

de Rechten van de Mens

$203,215,219$

art. 16 Universele Verklaring van

de Rechten van de Mens

art. 17 Universele Verklaring van

de Rechten van de Mens

203,208

art. 2 Verdrag inzake de Rechten van het Kind

203,215

art. 5 Verdrag inzake de uitbanning van alle vormen van rassendiscriminatie art. 16 Vrouwenverdrag $202,203,236$. $256,269 \mathrm{v} / \mathrm{m} \mathrm{272,277,294}$ art. 5 Zevende Protocol EVRM

$203,236,256,269$

'asaba bi-nafsihi $57 \mathrm{t} / \mathrm{m} 61,67,69,73,77$ 
'asaba bi-ghayrihâ

$57,58,60,61,64$ $65,69,70,73,77,80$

'asaba ma'a ghayrihâ $57 \mathrm{t} / \mathrm{m} 62,69,70,78$

authenticiteit

286

authenticke akte

$279,285,286$

260

autonome uitleg

'awl

$61,80,82,249$

B

bayt al-mâl

- zie Staat als erfgenaam

begrafeniskosten

$24,34,39,91,113,223$

bekwaamheid te beschikken bij testament

$35,102,103,109$,

$126,128,129,152,154$

bekwaamheid te verkrijgen

krachtens testament

beletselen voor erfopvolging

- zic erfbeletsel

beletselen te verkrijgen

krachtens testament

beneficiaire aanvaarding

130,131

beperkingsclausule

254,259

berbers

beschermingsbeginsel

$128,236,252$

beschikkingsvrijheid24, 108,113, $223 \mathrm{t} / \mathrm{m} 228$,

$244,248,255,272 \mathrm{t} / \mathrm{m} 274$,

$293,294,297$

bestaan

- van de legataris

35,37

- van de erfgenaam

43,45

- onzekerheid over

35,37

- verwacht

zie ongeboren vrucht

$36,38,45,46$

bevoegdheden van de vereffenaar

bevoegdheid

- zie rechtsmacht

bevolkingsgroepen

19,125

bigamie

- zie polygamie

binnengrenscriterium

bipatridie

bloedgeld

bloedverwantschap

$48,49,52,61,73$

$76,77,152,185,214$ $217,218,222,228,229$, $231,233,238,265,266$

boedelbeschrijving

bruidsgave

49, 50, $207 \mathrm{v} / \mathrm{m} 211,291$

$196,197,213$

buitengrenscriterium

burgerlijke stand-huwelijk $164 \mathrm{t} / \mathrm{m} \mathrm{166,178,}$
C

codificatie

$8,17 \mathrm{t} / \mathrm{m} \mathrm{19,210}$

$45,46,123$

competentie

- zie rechtsmacht

concubine

$54,226,286,287$

$90,94,130$

conservatoire maatregelen

consummatie

$50 \mathrm{t} / \mathrm{m} \mathrm{54,208}$

consulaat

$95,137,161,163$.

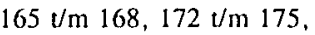

$177,181,184,235,236$

consulaire afwikkeling

van de nalatenschap

$94,95,138$

consulair huwelijk

$138,239,292,296$

consulaire huwelijksontbinding

$139,174,175,236,297$

consulaire verstoting

237

conversie

204

correctiemiddel

$154,292,293,295$

cultuur

$120,197,243,289,290$

cultuurconflict

289

curatele

- zie geestelijke stoomis

D

darar

deelvraag

dhawu al-arhâm

22

diplomaticke vertegenw'ordiging

137,279

droits acquis

$105,112,147,151,175$, $182,235,290,298$

E

echtscheiding

- zie huwelijksontbinding

Echtscheidingsverdrag 1967

170

Echtscheidingsverdrag 1970

170

eenheidsstelsel

144,282

effectiviteit

200

effectiviteitstoets

$117,127,128$

eigendomsrecht

146, 203, $223 \mathrm{t} / \mathrm{m} 225$.

$273,276,294$

erfbeletsel

$47,48,219,220,247$,

$267,284,285$

erfrechtregime, bijzonder

124

Europese consensus

$254,259,260,276$

exceptieclausule

253,295

executeur

$4,6,41,138,139$

executie

- zie tenuitvoerlegging

exequatur

$173,176,281,285,286$ 
F

fait accompli

$147,148,154$,

$175,290 \mathrm{t} / \mathrm{m} 292$

familierecht

$2,7,13,17,19,20$,

$94,137,157,200,211$,

$218,229,269,289,291$

familierechtelijke betrekkingen

9, 117, 177, 178, 179, $184,215,218,219,228,238$, $262,265,266,269,282,297$

familiestructuur

family life

- zie gezinsleven

$225,261,262,265$

al-farâ'id-erfgenamen

22,57

fatwì

15

figh

$8,9,14,16,17,23$

formele geldigheid testament

- zie vorm testament

forumkeuze

101,102

forum necessitatis

forum non conveniens

100,102

fraus legis

100,102

143,148

G

geboorte

$20,46,53,54,178,179$, $201,214 \mathrm{t} / \mathrm{m} 219,238 \mathrm{t} / \mathrm{m} 242$, $248,261,264 \mathrm{t} / \mathrm{m} 269,276$, $283,293,294$

geestelijk gestoorde

$35,47,48$ geestelijke stoornis geheime testament gelijkheidsbeginsel

202 vm 200,213 $214,219,232$, $245 \mathrm{t} / \mathrm{m} \mathrm{248,271,272}$

geloofsafval geslacht

$3,10,82,87$,

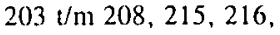
$234,248,268 \mathrm{v} / \mathrm{m} 271$.

$278,286,295,296$

geslachtsrijp

49.211

gevolgen van het testament

$41,42,280$ gewoonte(n) gewoonterecht

$13,14,21,23,195,209$

$13,19,206$ gezag van gewijsde gezinsleven

281

$205,217,218,220,221$,

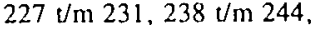
$250,253,259,262,263$, $266 \mathrm{t} / \mathrm{m} 269,276,295,296$

Gharrâ, geval van de 79 Gharrawâni, geval van de godsdienst

$3,6,10,25,35,47$, $48,52,120,157,158$, $170,201,202,219 \mathrm{l} / \mathrm{m} \mathrm{222}$, $242,243,248,266 \mathrm{t} / \mathrm{m} 269$, $276,282,284,285$, 293, 294, 297

goeder trouw $53,54,144,239$ graad

- van erfopvolging

$52,60,61,68$, $69,73,75 \mathrm{t} / \mathrm{m} 77,206$, $207,224,229,231,232,286$

- verwantschaps$22,49,60,61$, $68,69,73,75 \mathrm{vm} \mathrm{77}$, $207,214,231,233,234$ $195,202,215,219,228$

Grondwet

14, 15, 17, 206

$\mathrm{H}$

Hadith 13

hakam 13,17

handelsrecht 28,40

harâm 62

hermafrodiet 51,52 28,37

herroepen van testament hervorming

$13,17,25,85$, $202,203,208$

Himâriyya, geval van de 82

hinkende rechtsverhouding $3,290,293$

hiyal

homologatie (gehomologeerd) $90,166,173$ hubus (zie ook wayf)

- publieke

$31 \mathrm{t} / \mathrm{m} \mathrm{33}, 141$, $146 \mathrm{t} / \mathrm{m} \mathrm{151}, 203,292 \mathrm{t} / \mathrm{m} 294$ - familie/privé

$31 \mathrm{t} / \mathrm{m} \mathrm{33}, 141$,

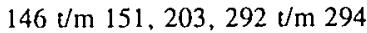

- beheer

$31 \mathrm{t} / \mathrm{m} \mathrm{33}, 141$

- liquidatie

$146 \mathrm{t} / \mathrm{m} \mathrm{151}, 203,292 \mathrm{t} / \mathrm{m} 294$

$31 \mathrm{t} / \mathrm{m} 33,141$,

$146 \mathrm{t} / \mathrm{m} \mathrm{151}, 203,292 \mathrm{t} / \mathrm{m} 294$

- testamentaire $31 \mathrm{t} / \mathrm{m} \mathrm{33}, 141$,

$146 \mathrm{t} / \mathrm{m} \mathrm{151}, 203,292 \mathrm{t} / \mathrm{m} 294$

onder levenden

$31 \mathrm{t} / \mathrm{m} \mathrm{33}, 141$, $146 \mathrm{t} / \mathrm{m} 151,203,292 \mathrm{t} / \mathrm{m} 294$

huwelijk

$3,5,10,16,20,27$, $46 \mathrm{t} / \mathrm{m} 54,94,137,138,143$,

$149,152,154,156 \mathrm{~d} / \mathrm{m} 182$,

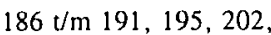

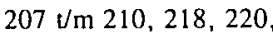
$223,228,233 \mathrm{t} / \mathrm{m} 241,262$, $265,268,269,284,285$. $287,291,292,296 \mathrm{v} / \mathrm{m} 298$ 
huwelijksbeletsel

huwelijksbevoegdheid

huwelijksdomicilie

huwelijkse voorwarden

$$
\begin{array}{r}
49,161,179,219 \\
161,163 \\
187,188,192 \\
187,188
\end{array}
$$

190 $\mathrm{t} / \mathrm{m} 192,298$

Huwelijksgevolgenverdrag $1905 \quad 186,187,189$ huwelijksontbinding

$3,20,51,52$, $137,139,152,156,157$. $170 \mathrm{~V} / \mathrm{m} 176,236 \mathrm{t} / \mathrm{m} \mathrm{240}$, $262,292,297$

huwelijksovereenkomst

$51,53,190$,

$191,208,210,262$

huwelijkssluiting

$51,54,165 \mathrm{t} / \mathrm{m} \mathrm{167}$, $177,181,186 \mathrm{v} / \mathrm{m} 191$. $208,238 \mathrm{t} / \mathrm{m} 240,292,297$

Huwelijksverdrag 1902

161,162

Huwelijksverdray 1978

$137,159 \mathrm{~V} / \mathrm{m} 161$, $167,169,180,187,188$

huwelijksvermogensrecht $109,156,157$. $186 \mathrm{t} / \mathrm{m} 188,190,192$, $197,208,298$

huwelijksvermogensregime

$109,152,186 \mathrm{t} / \mathrm{m} 192,298$ Huwelijksvermogensverdrag $1978 \quad 187 \mathrm{t} / \mathrm{m} \quad 189$ huwelijksvoltrekking $\quad 137,161,163,188$, $190,191,208$

I

'idda

$49,51,52$

idjmâ'

15

idjithâd

$15,18,25$

inbreng

$5,111 \mathrm{~V} / \mathrm{m} 113,130$, $201,212,298$

inkoring

$111 \mathrm{Um} 113$

insolventie

$143,144,149$

insteller

- van een hubus/waqf

$26 \mathrm{~V} / \mathrm{m} 33$

- van een trust

$142 \mathrm{~V} / \mathrm{m} 146$

internationale beslissingsharmonie

$153,252,272,278,290,293$

interne besissingsharmonie

153,293

interpersoneel recht

125

interpretatie

$14,15,23,25,251,259$

iquâr

54,239

istibrấ

J

al-Jabarî-regel

60

joden
$\mathrm{K}$

kafâla 184

khul' 51

Khuraqâ, geval van de 82

Koran $\quad 14,17,21 \mathrm{t} / \mathrm{m} \mathrm{23}, 57,206,207$

kwalificatie $\quad 3,6,104,128,134,142$,

$147,151,152,154,292$

L

lafif $\quad 41,47,51,55,90,166,167,177$

lasten verbonden aan de nalatenschap

34,43

lecftijd

$35,45,120,126,197,211$

legataris

$34 \mathrm{t} / \mathrm{m} 40,87,88,110,124$,

$135,135,139,140$

$24,34,39,43$

legaten

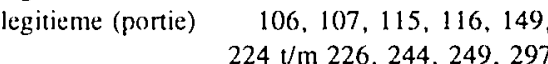

$207,209,210$

levensonderhoud

$29,90,91$

levering

lex causae

$103,104,151 \mathrm{Vm} 154$

lex fori

$103,104,128,145,148$.

$158,173,199,200,245$

lex loci actus

103

lex loci celebrationis

163

lex rei sitae

$1,103,108,111$

li ân

49,52

liquidatie

33,94

Lizardi-regel

128

M

maatschappelijke verantwoordelijkheden $\quad 207$

al-Mâlikiyyah, geval van $\quad 80$

al-Mâlikiyyah, geval analoog aan

81

margin of appreciation

$254,255,259$

$263,268,273,276$

meerderjarig(e)

$28,39,49$

meervoudige nationaliteit

117,128

mensenrechten

$195,196,201,202$,

$249,250,276,277,293$

methodenstrijd

6,295

Minbariyya, geval van de

84

minderjarig(e)

modernisering

monogamiebeginsel

17

$M u ' a ̂ d d a h$, geval van de

237,240

Mubâhala, geval van de

mufii

Mushtaraka, geval van de

$N$

Näherberechtigung $\quad 6,134,190 \mathrm{v} / \mathrm{m} \mathrm{192,298}$ nasab 


naturalisatie
natuurlijke verbintenis
nauwere banden
nauwste verbondenheid
nâzir
neo-idjihâd
netigheidsgrond
notaris
O
omzeilen van erfrecht
onafhankelijkheid
onderaanknoping
onderhoud
onderhoudsverplichting

onderhoudsverplichting

ongeboren vacht

onherroepelijke huwelijksontbinding

$25,26,150$

$20,124,157,280$

125,242

$29,31,207,209,210$

51,111 ,

$208 \mathrm{t} / \mathrm{m} 211,219,291$

$36,38,45,46$

onroerend goed

onterving

$3,99,127,146$

ontkenning vaderschap

ontucht

onwaardigheid

oordeel des onderscheids

opeisbare schulden

openbare orde

- exeptie van de

$6,9,10,97$

$122,150,154,159$,

hfdst $6,290,293$

$13,14,208$

91,95

overdracht

overeenkomst van erfopvolging

$37,108,109,123$

Overlevering

- zie Hadith

$\mathrm{P}$

patriarchaat

21,218

patriarchale samenleving

210

pensioen

110

persoonlijke gevolgen van

het huwelijk

personeel statuut

$2,3,7,8,19,20$.

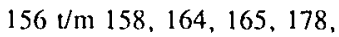

$242,280 \mathrm{t} / \mathrm{m} \mathrm{283,} 286$

plaatsvervulling

$43,85,233$

plichtenleer

- zie figh
polygamie
pre-islamitisch erfrecht

$8,9,14,16,17,23$

$19,49,158,234$

22
Q $q \hat{a} d \hat{\imath}$

Qiyâs

17. 29

15

$\mathrm{R}$

radd

rangorde

59

$39,59 \mathrm{v} / \mathrm{m} \mathrm{61,77}$,

$88,233,234$

realiteitstoets

117

rechteriijke bevoegdheid

- zie rechtsmacht

98

rechtskeuze

- erfopvolging $\quad 2,97,106 \mathrm{t} / \mathrm{m} 110,114$,

$117,118,121,123,168$,

$169,225,243,244,297,298$

- materieelrechtelijke

$114 \mathrm{~lm} 116$ - partiële

108,114

- huwelijksvermogensrecht $\quad 187 \mathrm{t} / \mathrm{m} 192$

- trust

142,148

rechtsmacht $\quad 98 \mathrm{t} / \mathrm{m} \mathrm{102}, 171,257,273$

rechtsschool/rechtsleer

- hanafitische

$15,18,22$

- hanbalitische

- malikitische

$16,18,22$

$7,8,13,15,181 / \mathrm{m} 23$,

$26 \mathrm{t} / \mathrm{m} \mathrm{30}, 33,46 \mathrm{t} / \mathrm{m} 52$,

$55 \mathrm{u} / \mathrm{m} \mathrm{57,200,211}$

$14,16,18,22$

- slafi'itische

- shi'itische

16

- sunnitische

$14 \mathrm{t} / \mathrm{m} \quad 16,23$

rechtstreekse werking $250,256,270,277$

rechtsvergelijkende methode

$168,169,174,234,292$

reconnaissance matrimoniale $166,177,178$

renvoi

$121,123,159$

retorsie

$6,134,190$

$\mathrm{S}$

saisine $\quad 3,43,91,104,130,134,291$

scheiding en deling van de nalatenschap 99

schenkingen

$5,24,26,91,109,111$.

$112,156,201,212,290,298$

schenkingen op sterfbed

91,112

schulden

$24,34,39,91,92,104$,

$113,114,130,131,134$,

$233,230,279,286,291$

sexuele gemeenschap

$53,218,239$

shari'a

$15 \mathrm{t} / \mathrm{m} 21,25,32,39$,

$52,157,202,270,271$

$23,57 \mathrm{Um} \mathrm{59,} 124$

$105,117,118$

staatloosheid

6. $99 \mathrm{t} / \mathrm{m} 101$

$13,16,17$

straf(proces)recht

substitutie 186 
successierechen

Sumna

14,23

$\mathrm{T}$

lalây

ramlik

tanzil

42,85

15,18

taqlîd

tasib

ratliq

tenuitvoerlegging

terres agricoles

testament

- aanbod

- aanvaarding

testeervrijheid (beperkingen aan)

- zic beschikkingsvrijheid

testimonium de auditu

53,55

tezkiya

41

toepassingsbereik

$108,126,142,189$. $190,252,259,271,296$

loestemning

$36,39,49,86,91$. $112,113,116,149,161$. $183,195,223,248,297$

14,15

Traditionisten

trust

$123,140 \mathrm{t} / \mathrm{m} \mathrm{150}, 290$

trustec

- titel

Trustverdrag

$142,143,146,147$

140 $1 / \mathrm{m} 149,290$

U

'udûl

$40,41,90,93,166$

uitsluiting

$3,60,61,111,130,131$

'Umariyyaran, geval van de

Umm al-furûkh, geval van de

83

usiul

$\mathrm{V}$

verbintenissenrecht

verdediging, rechten van

236,281

vereffening en verdeling

$43,90 \mathrm{t} / \mathrm{m} 92$

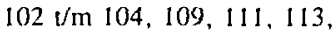
$114,129,130,134,135,139$

verhaal 149,150

verjaring

verkoop nalatenschapsvermogen

vermissing

$91,94,229$

$44 \mathrm{t} / \mathrm{m} 46$

verplicht testament $43,60,65,73$,

$85 \mathrm{v} / \mathrm{m} 90,112,132,134,205,292$

verrekening

$113,135,139,140,149$. $150,190 \mathrm{~V} / \mathrm{m} \mathrm{192,284,} 298$ verstoting

$20,51,52,158,171,172$, $173,175,236,237,256,292$

vervreemding $107,120,204$

verwantschap

- zie bloedverwantschap/afstamming

verwaterde nationaliteit

117,185

verwerping

$24,37,38,92,103,104$,

$114,130 \mathrm{v} / \mathrm{m} \mathrm{134,214}$ $230,245,291,292$

verwijzingscategorie

$102 \mathrm{v} / \mathrm{m} 105,128$,

$132,151,206$

volkenrecht $\quad 10,138,194,195,235,249$

volmacht

yoorbehoud

$94,95,229$

$115,121 \mathrm{t} / \mathrm{m} \mathrm{127,141}$ $145,202,271,291$

vooroverlijden

voorrangsregels

voorvraag

$30,43,85,112,205$

$122,145,148,154$

$6,9,10,97,151 \mathrm{t} / \mathrm{m} 156$

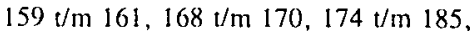

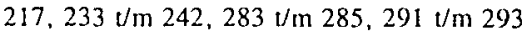

voorwaarden voor erfopvolging

43,44

voorwaarde testament

$35 \mathrm{t} / \mathrm{m} 42$

vorm testament

$40,41,102103,109$,

$125 \mathrm{t} / \mathrm{m} 128,152,280$

$26,36,38$

vruchtgebruik

$26,27,30,146$

W

wadf (zie ook hubus)

- beheer

$29,30,146$

- familie/privé

- onder levenden

$16,17,26,27,29 \mathrm{t} / \mathrm{m} 31$

- publieke

- testamentaire

$17,28,30,31$

$28,29,42$

werkingssfeer 257

Wet conflictenrecht erfopvolging (WCEo)

2, 4, 101, 105, $108 \mathrm{v} / \mathrm{m} \mathrm{113,}$ $129,130,135 \mathrm{v} / \mathrm{m} \mathrm{140,151,284}$

Wet conflictenrecht huwelijk (WCH) 138, 139 , $161 \mathrm{v} / \mathrm{m} 165,169 \mathrm{v} / \mathrm{m} \mathrm{171,177,236}$

Wet conflictenrecht huwelijks-

betrekkingen (WCHb)

190

Wet conflictenrecht huwelijks-

vermogensregime (WCHv) $189,191 \mathrm{t} / \mathrm{m} 194$ wettiging

178,217

Z

zakelijke rechten

zekerheidsrechten $143,144,149,150$

zelfstandige aanknoping/beoordeling $153 \mathrm{t} / \mathrm{m} \mathrm{156,159} \mathrm{t} / \mathrm{m} \mathrm{161}, 168 \mathrm{t} / \mathrm{m} 170$, $174 \mathrm{t} / \mathrm{m} 181,185,234,239,240,292$ zwangerschapsduur 36,46 


\section{Literatuur}

Aboe Zaid, N.H.

Ajetunmobi, M.A.

Akkermans, A.J.

Alkema, E.A.

Alkema, E.A. en Zaaijer, B.

Alkema, E.A.

Ammar, G.

Ammar, G.

Anderson, J.N.D.

Anderson, J.N.D.

Anderson, J.N.D.

Anderson, $N$.

Anderson. J.N.D.

Asser/Ploeg, van der P.W.

Perrick, S.

Audit, B.

Badaoui, A.H.

Baillie, N.B.E.

Bar, Chr. von

Bashir, M.

Batiffol, $\mathrm{H}$.
Vernieuwing in het islamitisch denken, Amsterdam, Bulaaq, 1996.

"Collection and Review of Cases of al-'awl (Pro-rata Reduction) in Shari'ah Law of Succession", IS, 1988, 209-221; 1988, 319-344.

"Verslag van de jaarvergadering van de Vereniging voor Burgerlijk Rech op 2 december 1994. Bespreking van de preadviezen van C.D. van Boeschoten en R.D. Vriesendorp, Het Haagse Trustverdrag 1994", WPNR, 1995 (6198), 701-705.

Noot bij HR I juli 1982, NJ 1983, 201.

"Artikelen 2, 3 en 24: de reikwijdte van het Vrouwenverdrag", in Heringa, A.W., e.a.: (red.), Het Vrouwenverdrag: een beeld van een Verdrag ..., Antwerpen/Apeldoorn, MAKLU, 1994, 15-29.

De reikwijdte van fundamentele rechten: de nationale en internationale dimensies, Preadvies voor de Nederlandse Juristenvereniging, Handelingen NJV 1995-I, Zwolle, W.E.J. Tjeenk Willink, 1995, 1-129.

"Du tenzil et du testament", $R M D, 1958,1-5$.

"De la représentation en justice de l'absent", RMD, 1960, 391-399.

"Recent Developments in Shari'a Law, IX: The Waqf System", The Muslim World 42, 1952, 257-276.

"Recent Reforms in Family Law in the Arab World", ZVR, 1963, 1-17.

"Recent Reforms in the Islamic Law of Inheritance", ICLQ, 1965, 349-365. Law Reform in the Muslim World, London, Athlone Press, 1976.

"Islamic Family Law", in: International Encyclopedia of Comparative Law, Vol. IV: Persons and Family, Tübingen 1983, 55-78.

Erfrecht, Zwolle, W.E.J. Tjeenk Willink, 12e druk 1996.

Droit international privé, Paris, Economica, 1991.

Du principe qu'en droit musulman la succession n'est ouverte qu'après acquittement des dettes, L'Egypte Contemporaine, 1914, 14-40.

The Moohummudan Law of Inheritance According to Aboo Huneefa and his Followers, Calcutta, 1832.

"Menschenrechte in Kollisionsrecht", in: Kaelin, W., e.a., Aktuelle Probleme des Menschenrechtsschutzes, Heidelberg. Müller Juristischer Verlag, 1994, 191-212.

The Manual of Auqaf Laws, Lahore, Lahore Book Service, 1977.

"Explanatory Report 1961", Actes et documents de la neuvième session de la Conférence de La Haye, Tome II: forme des testaments 1961. 
Batiffol, H, et Lagarde, P.

Bedoncha, G.

Berg-Eldering, L. van den

Berg-Eldering. L. van den

Berger, M.S. en

Kaldenhoven, J.H.

Bervoets, Th.M.

Blanc, F-P et Lourde, $A$.

Blanc, F-P et Zeidguy, R.

Boele-Woelki, K. en

Iterson, D. van

Boele-Woelki, K.

Boer, J. de

Boer, J. de

Boer, J. de

Boer J. de

Boer, Th.M. de

Boer, Th.M. de

Boer, Th.M. de

Boer, Th.M. de

Boeschoten, C.D. van

Boeschoten, C.D. van
Traité de droit international privé. Tome 1, Paris, Librairie générale de droit et de jurispnudence, $8 \mathrm{me}$ ed. 1993.

"Transmission des patrimoines en terroir oasien: idéal lignager et pratiques sociales à El-Mansûra (Tunisie)", in: M. Gast (ed.), Hériter en pays musulman: habus, lait vivamt, manyahuli, Paris, Centre National de la Recherche Scientifique, 1987, 75-88.

Marokkannse gezinnen in Nederland, Proefschrift. Alphen aan den Rijn, Samsom, 1978.

"Marokkaans familierecht in Nederland", in: Berg-Eldering. L. van den, Van gastarbeider tot immigram: Marokkanen en Turken in Nederland 1965 1985. Alphen aan den Rijn. Samsom, 1986.

De Mudawwanah, Marokkaans wetboek inzake personen-, familie-en erfrecht. Nijmegen, Ars Aequi Libri, 2e druk, 1997.

"Rechtskeuze", in: Jessurun d'Oliveira, H.U., e.a., Partij-invloed in het international privalarecht, Deventer, Kluwer, 1974, 31-45.

"Les conditions juridiques de l'accès au statut de concubine-mère en droit musulman malékite", ROMM n ${ }^{\circ} 36,1983,163-175$.

Code de stafut personnel et des successions (Moudawana). Dahirs des 22 novembre et 18 décembre 1957 et des 25 janvier, 20 février et 4 avril 1958 , Edition synopticue franco-arabe, Casablanca, Sochepress Universite, 1994.

"Naar een wettelijke regeling van het internationale afstammingsrecht", $H P S$, $1991,1,3-10(\mathrm{I}) ; 1991,2,28-36$ (II).

"Exception Clauses in Private International Law of the Netherlands", in: Kokkini-latridou, D. (red), Les clauses d'exception en matière de conflits de lois el de juridictions, ou le principe de proximité, Dordrecht, Nijhoff, 1994, 235-271.

Art. 8 EVRM: algemeen. Deel I, Preadvies voor de Nederlandse Juristenverenging, Handelingen NJV, Zwolle, W.E.J. Tjeerk Willink, 1990.

"De erfrechtelijke positic van het niet erkende buitenhuwelijkse kind ten opzichte van zijn biologische vader", in: Die, B.C. de (ed.), Liber Amicorum NBW, Arnhem/Deventer/Zwolle, Kluwer, 1991, 67-70.

Now, gods, stand up for bastards!, Oratie, Arnhem, Gouda Quint b.v.. 1993.

Noot bij HR 24 februari 1995, NJ 1995, 468.

Naar een gecodificeerd imernational privaatrecht, Preadviezen van Th.M. de Boer en M.V. Polak voor de Nederlandse Vereniging voor Internationaal Recht, Mededelingen NVIR $1990 n^{\circ} 101,51-161$.

De wisselwerking tussen materieel recht en conflictenrech, Preadvies voor de Nederlandse Vereniging voor Rechtsvergelijking, Deventer, Kluwer, 1993.

"Internationaal huwelijksvermogensrecht: een puzzel die nog steeds niet af is, Zimbabwe-arrest, HR 19 maart 1993, NJ 1994, 187", AAe 1994, 611619.

Noot bij HR 16 september 1994, NJ 1995. 169.

"Rechtsbegrippen in verdragen van de Haagse Conferentie voor internatio naal privaatrecht en het Nederlandse recht", RM Themis, 1993, 211-222.

Het Hagse Trustverdrag in Nederlands perspectief, Preadviezen van C.D. van Boeschoten en R.D. Vriesendorp voor de Vereniging voor Burgerlijk Recht, Lelystad, Koninklijke Vermande, 1994, 1-44. 
Böhmer, Chr. and Dyer. $\wedge$.

Borrmans, $M$.

Bos, H.A.

Bouckaert, F.

Boulanger, $F$.

Boulos, M.F

Bourcly, $M$.

Bourely, M.

Bousquet, G-H et Peltier, F.

Bousquet, G-H

Bousquet, G-H

Bousquet, G-H

Brakel, S. van

Breemhaar, W.

Brugman, J.

Brugman, J.

Bnugman, J.

Brunschvig, R.

Brunschvig, R.

Bruijn, J.T.P. de

Buskens, L.P.H.M.

Buskens, L.P.H.M.

Buskens, L.P.H.M.

Busson de Janssens, G.
"Preliminary Report 1976", Actes et documents de la treizième session de la Conférence de La Haye, Tome II: mariage 1978.

Statut Personnel et Famille au Maghreb de 1940 à nos jours, Paris/La Haye, Mouton, 1977.

"De rechtskeuze in het international erfrecht", WPNR, 1989 (5926), 469; 1989 (5927), 489; 1989 (5928), 514.

"Een appartement in Antibes, een 'resulting' trust in Engeland en het EEXVerdrag: beschouwingen over het arrest Webbs, mede in verband met het Trustverdrag", WPNR, 1995 (6176), 241-245.

Les successions internationales:problèmes contemporains, Paris, Economica 1981.

La succession en droit musulman. son origine et son évolution. Thèse, Paris, Jouve \& Che, 1925.

"Le droit international privé du Maroc indépendant", RCDIP 1962, 211-246; $1962,445-494$.

"Nouveaux aspects du droit international privé marocain", $R M D, 1964,3$ 11.

Les successions agnatiques mitigées: étude comparée du régime successoral en droit germanique et en droit musulman, L'Institut d'Etudes Orientales do la Faculté des Lettres d'Alger, Paris, Geuthner, 1935.

"Plaidoyer pour les faraídhs", RASJEP, 1951, 4-14.

Précis de droit musulman, principalement malékite et algérien. Alger. La Maison des Livres, 2 me ed. 1947.

Le droit musulman, Paris, Colin, 1963.

Grondslagen en beginselen van Nederlands internationaal privaatrecht, Zwolle, W.E.J. Tjeenk Willink, 3e druk 1953.

"Het Haags Testamentsvormenverdrag 1961", WPNR, 1980 (5541); 1981 (5588), 865-870; 1981 (5589), 881-885.

"The Islamic Law of Inheritance", in: M. David e.a. (ed.), Essays on Oriental Laws of Succession, Leiden, E.J. Brill, 1969, 82-91.

"Islamitisch erfrecht in drieluik", in: Bakelen, F.A. van, (red.), Recht van de Islam 2, Groningen, RIMO, 1984, 2-14.

"De shart'ah als rechtssysteem, enige algemene beschouwingen", in: Rutten, S.W.E., (red.), Recht van de Islam 11, Maastricht, RIMO, 1993, I-23.

"Un système peu connu de succession agnatique dans le droit musulman", in: Brunschvig, R., Etudes d'Islamologie II: droit musulman, Tome, Paris, G-P Maisonneuve et Larose, 1976, 53-65.

"De l'acquisition du legs dans le droit musulman orhodoxe", in: Brunschvig, R., Eucdes d'Istamologie, Tome II: droit musulman, Paris, G-P Maisonneuve et Larose, 1976, 103-118.

"Moslimse kalenders en feestdagen", in: Waardenburg, J., (red.), Islam. norm, ideaal en werkelijkheid, Houten. Het Wereldvenster, 2e druk 1987, 498-502.

"De "udul en hun rol in het Marokkaanse huwelijks- en echtscheidingsrecht". in: Rutten, S.W.E., (red.), Recht van de Islam 9. Maastricht, RIMO, 1992, 9-37.

"De recente hervorming van het Marokkaanse familierecht", in: Rutten, S.W.E., (red.), Recht van de Islam 12, Maastricht, RIMO, 1995, 59-96. Islamitisch recht en familiebetrekkingen in Marokko, Proefschrift, Leiden, 1993 (niet gepubliceerd). Een handelseditie is in bewerking en zal verschijnen bij uitgeverij Bulaaq Amsterdam.

Les wakfs dans le monde musulman, Paris, 1953. 
Bystricky, R.

Cardahi, Ch.

Carroll, L.

Cattan, $\mathrm{H}$.

Chafi, $M$.

Chati, M.

Chafi, M.

Charfi, M.

Chatti, S.M.

Cherbonneau, E. and

Sautayra, E.

Cherkasoui, $A$.

Cheshire, G.C.

Clavel, E.

Clavel, E.

Cohen, D.

Cohen Henriquez, E.

Cohen Henriquez, E. Cohen Henriquez, E.

Cohen Henriquez, E.

Cohen Henriquez, E.

Cohen Henriquez, E.

Cohen Henriquez, E.

Cohen Henriquez, E.

Coloner, A.
"Droit internationat privé et droits de l'homme", in: Liber amicorum Adolf F. Schnizzer, Genève, Faculté de Droit, 1979, 57-67.

"La conception et la pratique du droit international privé dans I'Islam". Rec.dC, 1937 II, Tome 60, 507-650.

"Ratification of Bequests in Sunni Testate Succession", IsCLQ, 1987. 103-109.

"The Law of Waqf", in: Khaddury, M. and Liebesny, H., (ed.), Law in the Middle East: Origin and Development of Islamic Law, Washington, The Midjle East Institute, 1955, Vol. 1, 203-222.

"L'enfant ne hors mariage au Maroc", RMDED, 1989, 133-152.

"Le conjoint survivant est-il un héritier réservataire en droit marocain?", RMDED, 1989, 207-220.

"Le legs obligatoire est-il une representation successorale en droit Marocain?", RMDED, 1991, 257-278/RMDC, 1991, 99-118.

"Influence de la religion dans le droit internationa! privé des pays musulmans", Rec.dC, 1987 III, Tome 203, 321-454.

Quintessence des partages successoraux - traduction et commentaire du Salaheddine Keshrid, Beyrouth, Dar Al-Gharb Al-Islami, 1991.

Droit musulman: du stutut personnel et des successions, 2 Vols., Paris, A. Maisonneuve, 1873-74.

"L'évolution du droit marocain à travers la législation", RJPEM, 1981, 17 1182.

Cheshire and North's private international law, London, Butterworths, 1992.

Droit musulman: du statut personnel et des successions d'après les différemts rites et plus particulièrement d'après le rite hanafite. Tome 2: des successions, Paris, L. Larose, 1895.

Droit musulman: le wakf ou habous d'après la doctrine et la jurisprudence (rites homéfite et malékite), 2 Vols., Le Caire, Imprimerie Diemer, 1896.

"La Convention européenne des droits de l'homme et le droit international privé français", $R C D I P, 1989,451-483$.

"Overzicht der Nederlandse rechtspraak: internationaal privaatrecht, erfrecht", WPNR, 1977 (5372), 5-10; 1980 (5512), 243-245; 1985 (5733), 238241; 1987 (5835), 238-241.

IPR-trends, Deventer, Kluwer, 1980.

"Trusts: ontmoetingen met Anglo-Amerikaanse trusts op het Europese continent en meer in het bijzonder in Nederland en de gevolgen daarvan naar huidig recht en volgens het Haagse Trustverdrag van 1 juli 1985", TVVS, 1986, 237-241 (I); 1986, 270-274 (II).

"De erkenning van Anglo-Amerikaanse trusts en buitenlandse vennootschappen", in: Beukenhorst, D.H., e.a., Offerhauskring vijfentwintig jaar, Deventer, Kluwer, 1987, 41-53.

"Grepen uit de praktijk van het internationale erfrecht II", in: Frielink, K., (red.), De internationale aspecten van het notariaat, Amhem, Gouda Quint, $1989,39-47$.

"Vervreemding en verbondenheid in het IPR", WPNR, 1989 (5930), 548550.

"Twee Haagse Verdragen: bespreking van de preadviezen van I.S. Joppe. W. Westbroek en K.D. de Lange, Twee Haagse Verdragen 1990", WPNR. 1990 (5972), 529-540.

"Polygamie in Nederland", FJR, 1990, 170-171.

"Le testament", RATMLJ, 1961. 
Colomer, A.

Colomer, $A$.

Colomer, $A$.

Coulson, N.J.

Coulson, N.J.

Coulson, N.J.

Coulson, N.J.

Coulson, N.J.

Damm, K-D

Decroux, P.

Decroux, P.

Decroux, P.

Decroux, P.

Decroux, P.

Decroux, P.

Deelen, J.E.J.Th.

Deprez, J.

Deprez, J.

Deprez, J.

Deprez, J.

Deprez, J.

Deprez, J.

Dörner, $\mathrm{H}$.

Droz, G.A.L.
Droit musulman, Tome I: les personnes - la famille, Rabat, La Porte/Paris, Librairie de Médicis, 1963.

Droit musulman, Tome II: la succession - le testament, Rabat, La Porte/Paris, Librairie de Médicis, 1968.

"Le statut musulman: généralités, sources, capacité, mariage, filiation", Jurisclasseur; Législation comparée Maroc, Fasc. 2-1, 1985. Aanvulling 1994.

"Representational Succession in Contemporary Islamic Law, SI, 1970. $101-108$.

"Succession in the Muslim Family", Cambridge, University Press, 1971. A History of Islamic Low, Edinburg, University Press, 2 nd ed. paperbackedition 1978.

"A Comparison of the Law of Succession in the Islamic and British Legal Systems", AJCL, 1978, 227-232.

"The Family in Islamic Law: Yesterday and Today", in: Schwind, F., (ed.), Studien zum Islamischen Rech, Wien, Verlag der österreichischen Akademie der Wissenschaften, 1983, 20-30.

Die Einwirkung der Grundrechte des Grundgesetzes auf das nach deutschem Internationalem Privatrecht anwendhare ausländische Sach-und Kollisionsrecht, Pfaffenweiler, Centaurus Verlags, 1993.

"Le régime successoral en droit international privé marocain", RJPUF, 1960, 285-292.

Droit privé, Tome II: Droit international privé, Paris, Librairie de Médicis/ Rabat, La Ponte, 1963.

"Le droit international privé marocain et les mariages mixtes", RJPIC, 1968 , 893-908.

Droil foncier marocain, Rabat, La Porte, 1977.

"Le droit international privé marocain: son évolution de 1956 à 1981", RJPEM, 1981, 153-170; Clunet, 1983, 346-359.

"La Convention franco-marocaine du 10 août 1981 relative au statut des personnes et de la famille et à la coopération judiciaire", Clunet, 1985, 49-101.

"H.R.-I.P.R.-H.B.", in: Dutilh, I.J., e.a. (red.), Met eerbiedigende werking, Deventer, Kluwer, 1971, 381-397.

"Pluralisme des statuts personnels, conflits interpersonnels", Jurisclasseur; Législation comparée Maroc, Fasc. 1, 1975.

"Un aspect inattendu de l' "échange inégal" en droit international privé? Les relations de statut personnel entre l'Islam et l'Europe vues à travers le cas franco-marocain", $R T D, 1975,19-72$.

"Le droit international privé marocain à travers les livres" (bespreking van A. Moulay R'chid, L'Exequatur 1973), RJPEM, 1977, 2, 249-267.

"La réforme de l'organisation judiciaire et de la procédure au Maroc (dahirs van 15 juli et 28 september 1974) et le droit international privé", RJPEM, $1977,3,45-74 ; 1978,4,49-93$.

"Bilan de vingt cinq annees de droit international privé au Maroc", RJPEM, 1981, 125-151.

"Droit international privé et conflits de civilisations: aspects méthodologiques: les relations entre systèmes d'Europe occidentale et sysièmes islamiques", Rec.dC, $1988 \mathrm{IV}$, Tome 211, 9-372.

"Zur Beerbung eines in der Bundesrepublik verstorbenen Iraners". IPRax, 1994, 33-37.

"Les principaux traités multilatéraux relatifs aux régimes matrimoniaux, successions et libéralités", in: Régimes matrimoniaux, successions et libéralités: 
Droz, G.A.L.

Dubbink, C.W.

Dubbink, C.W.

Dubbink, C.W.

Dulout, F.

Durand, B.

Duynstee, F.A.A. droit international privé ef droit comparé, Tome I, La Baconnière Neuchatel $1979,205-336$.

"Note introductive à la Convention de la Haye sur la loi applicable aux successions à cause de mort", RDU, 1989, 1, 213-216.

"De Estlandse nalatenschap", WPNR, 1949 (4077), 125-129; 1949 (4078), 137-140.

"Ratificatie van het Zevende Protocol bij het EVRM", NJCM, 1995, 439461 .

"Mensenrechten en de openbare orde in het internationaal privaatrecht", in: Kortmann, S.C.J.J., e.a. (red.), Op Rech, Zwolle, W.E.J. Tjcenk Willink, $1996,51-56$.

Le Habous dans le droit musulman et la législation nord-africaine, Alger, 1938.

Droit musulman: droit successoral, Paris, Litec, 1991.

"Het tustverdrag; een paasei of een lege dop?", WPNR, 1993 (6092), 370376.

Dyer, A. en Loon, J.H.A. van "Preliminary Report 1982", Actes et documents de la quinzième session de la Conférence de La Haye. Tome II: trusts - loi applicable et recomnaissance, 1985 .

Dyer, A.

"The trust as a Paradigm for the Management of Property Separate and Apart from its Beneficial Ownership", in: Anglo-Amerikaanse trusts en het Nederlandse recht, Preadviezen A. Dyer en J.H.A. van Loon voor de Nederlandse Vereniging voor Internationaal Recht, Mededelingen NVIR 1983 $n^{\circ} 87,3-42$.

Dijk, P. van en

Hoof, G.J.H. van

Ehricke, U.

Elgeddawy, A.K.

Engel, $\mathrm{C}$.

Fanuki, K.

Fauvelle, G.

Ferchiou, $S$.

Ferid-Firsching

Fischer, G.

Fleming, J.G.

Forder, C.J.

Fratcher, W.F. Gaillard, E. en Trautman, D.T.
De Europese Conventie in theorie en praktijk, Nijmegen, Ars Aequi Libri, 3e druk 1990 .

"Auswirkungen der Europäischen Menschenrechtskonvention auf das deutsche Kollisionsrecht", EuGRZ, 1993, 113-118.

Relations entre systèmes confessionnel et lä̈que en droit international privé, Tome X, Paris-V, Librairie Dalloz, 1971.

"Ausstrahlungen der Europäischen Menschenrechtskonvention auf das Kollisionsrecht", RabelsZ, 1989, 3-51.

"Orphaned Grandchildren in Islamic Succession Law", IS, 1965, 253-274.

Traité théorique et pratique de dévolution des successions musulmanes (rite malékite), Sétif, 1905.

"Le systeme Habus en Tunisie: logique de transmission et idéologie agnatique", in: Gast, M., (réd.), Hériter en pays musulman: habus, lait vivant, manyahuli, Paris, Centre National de la Recherche Scientifique, 1987, 5774.

Internationales Erbrecht: Frankreich (losbladig, tot en met bijwerking 1982).

"Gemeinschaftsrecht und Kollisionsrechtliches Staatsangehörigkeitsprinzip", in Bar, Chr. von, (ed), Europäisches Gemeinschaftsrecht und internationales Privatrecht, Köln, Carl Heymanns Verlag, 1991, 157-182.

"Changing Functions of Succession Laws", AJCL, 1978, 233-238.

Legal Establishment of the Parent-Child Relationship: Constitutional Principles, Proefschrift, Maastricht, 1995.

"The Islamic wakf", MisLR, 36, 1971, 153-166.

"Trusts in Non-Trusts Countries: Conflict of Laws and the Hague Convention on Trusts", AJCL 1987, 307-340. 
Gannagé, P.

Gerholm, T.

Goldman, B.

Goudsmit, H.R.

Grinten, W.C.L. van der Groot, G.R. de

Groot, G.R. de

Groot, G.R. de en

Rutten, S.W.E

Grove Grady, $\mathrm{S}$.

Hadraoui, T. et Monkachi, $M$. Hammje, P.

Hartlief, T.

Hayton, D.J. e.a. (red.)

Hebler, H-J

Heldrich, $A$.

Hensen, Chr.A.J.F.M.

Hensen, Chr.A.J.F.M

Hensen, Chr.A.J.F.M. Hensen, Chr.A.J.F.M

Heringa, A.W.

Heyning, S.H. en Marck, Q.J.

Heyning, S.H. en Marck, Q.J. Heyning. S.H. en Marck, Q.J. Holtrusi, N. en Hondt, I. de

Hondt, I. de en Holtrust, N.
"La coexistence des droits confessionnels et des droits lä̈cisés dans les relations privées internationales", Rec.dC, 1979 III, Tome 164, 343-423.

"Aspects of Inheritance and Marriage Payment in North Yemen", in: Mayer. A.E., (ed.), Property, Social Structure and Law in the Modern Middle East, New York, State University of New York Press, 1985, 129-151.

"La protection internationale des droits de l'homme et l'ordre public international dans le fonctionnement de la règle de conflit de lois", in: Batshaw, H., e.a., René Cassin Amicorum discipulorumque liber, Vol. 1: Problèmes de protection internationale des droits de l'homme, Paris, Pedone, 1969. 449-466.

Adoptie in het Nederlands Internationaal Privaatrecht, Preadviezen van H.R. Goudsmit en J.C. Schultsz voor de Nederlandse Vereniging voor Internationaal Recht, Mededelingen NVIR $1961 \mathrm{n}^{\circ} 45,3-33$.

"De rechtsfiguur van de trust", TvA, 1993, 225-229.

"Nationaliteitswetgeving", losbladige personen-en familierecht (tot en met supplement 118, maart 1996).

"Enkele opmerkingen over het islamitische recht, in het bijzonder over islamitische huwelijkscontracten", WPNR, 1979 (5482), 341-343; 1979 (5483), 361-367.

"Polygamie, naturalisatie, bigamie?", in: Rutten, S.W.E., (red.), Recht van de Islam 13. Maastricht, RIMO, 1996, 19-60.

A Manual of the Mahommedan Law of Inheritance and Contract, London, W.H. Allen and Co., 1869.

Etudes féminines: répertoire et bibliographie, Casablanca, Le Fennec, 1991. La contribution des principes généraux du droit à la formation du droit international privé, Paris, 1994.

"Het recht op eigendom onder het EVRM", NJCM, 1996 special: 45 jaar Europees Verdrag voor de Rechten van de Mens, 129-146.

Vertrouwd met de trust, Deventer, W.E.J. Tjeenk Willink, 1996.

"Islamisch-rechtliche Morgengabe: vereinbarter Vermögensausgleich im deutschen Scheidungsfolgenrecht, zu BGH 28 Januar 1987, IV b ZR", IPRax, 1988, 95-97.

"Das juristische Kuckucksei aus dem Morgenland", IPRax, 1983, 64-65.

"Islamitisch recht in en buiten rechte: de behandeling van Turkse en Marokkaanse boedels", in: Rutten, S.W.E., (red.), Recht van de Islam 7, Maastricht, RIMO, 1989, 92-115.

"Eén zwaluw toch zomer": reactic op S.H. Heyning en Q.J. Marck, Een zwaluw maakt nog geen zomer 1993, WPNR, 1993 (6097), 495-496.

"Marokkaanse erflaters", $J B N$, feb. 1993, 7-9.

"International privaatrecht; rechtspraakoverzicht internationaal huwelijksvermogensrecht", FJR, 1993, 145-148.

"Verdragsconflicten en de rechter", NJB, 1988, 1187-1191.

"Eén zwaluw makt nog geen zomer: de rechtskeuze in het internationale erfrecht", een nader advies, WPNR, 1993 (6089), 284-285. Naschrift, WPNR, 1993 (6097), 496.

"Rechtskeuze in het erfrecht", $J B N, 1993,3,9-10$.

"Nieuw IPR-erfrecht in de mak!!",WPNR, 1995 (6173), 195-198.

"Kroniek familierecht, VN-Verdrag en familierecht", Nemesis, 1984-1985. $331-333$.

"Met het afstammingsrecht naar de eenentwintigste eeuw", $N J B, 1996,749$ 754. 
Hoogstraten, M.H. van

Hooimeijer, B.

Husain, $A$.

Hijmans, I.H.

Hijmans van den Bergh, L.J.

Ibrahim, A.

Ibrahim, A.

Ihraï, $S$.

Imâm, A.

Jamous, R

Jayme, E.

Jayme, E.

Jayme, E.

Jayme, E.

Jessurun d'Oliveira, H.U.

Jessurun d'Oliveira, H.U.

Jessurun d'Oliveira, H.U.

Jessurun d'Oliveira, H.U.

Johansen, B.

Jones, $W$

Jong, A.H.M. de

Joppe, I.S.

Joppe, I.S.

Joppe, I.S

Joppe, I.S.
"Le droit international privé néerlandais et la question préalable", in: Ancel, M., e.a., De Conflictu Legum, Leiden, A.W. Sijthoff, 1962, 209-225.

"De algemene exceptieclausule in het internationaal privaatrecht". AAe, 1996, 227-234.

"Classification and Condition of Augaf", HI, 1989, 3, 3-28.

Algemeene problemen van internationaal privaatrecht, Zwolle, W.E.J. Tjeenk Willink, 1937.

"De Engelse "trust" en het Nederlands internationaal privaatrecht", in: Ancel, M., e.a., De Conflictu Legum, Leiden, A.W. Sijthoff, 1962, 254267.

"Blood Relationship as a Ground of Inheritance under Islamic Law", JUU, $1979,163-238$.

"Gifts made during Death Illness under Islamic Law", JUU, 1987, 59-93.

"Les droits de l'homme dans la constitution marocaine", in: Basri, D., e.a. (dir.), Le Maroc et les droits de l'Homme, Paris, l'Harmattan, 1994, 187207.

"Le droit de succession dans la religion islamique", in: Bulletin for International Fiscal Documentation, 1976, 367-379.

Honneur et "baraka": les structures sociales traditionelles dans le Rif, Thèse, Paris, Cambridge University Press, 1981.

"Gundgesetz und Neuorientierung des Internationalen Privatrechts", in: Mußgnug, R., (red.), Rechtsentwicklung unter dem Bonner Grundgesetz, Heidetberg, Decker und Müller, 1990, 127 e.v.

"Menschenrechte und Theorie des Internationalen Privatrechts", in: Jahresheft Internationale Juristenvereinigung, Osnabrück, 1991/1992.

"Klauselrichtlinie und Internationales Privatrecht: eine Skizze", in: Lebendiges Recht - von den Sumerern bis zur Gegenwart, Heidelberg, Verlag Recht und Wirtschaft, 1995, 575-584.

"Identité culturelle et intégration: le droit international privé postmoderne", Rec.dC, 1995, Tome 251, 9-268.

"De sluipweg van de partijwil", in: Jessurun d'Oliveira, H.U., e.a., Partijinvloed in het internationaal privaatrecht, Deventer, Kluwer, 1974, 5-21. "Openbare orde en rechtsvergelijking", in: Ancel, M., e.a., 't Exempel dwinght, Zwolle, W.E.J. Tjeenk Willink, 1975, 239-261.

"Internationale adoptie, nationaliteit en vreemdelingenrecht", in: Beukenhorst, D.H., e.a., Offerhauskring vijfentwintig jaar, Deventer, Kluwer, 1987, 105-121.

"Towards a European Private International Law?", in: Witte, B. de and Forder, C., (ed.), The Common Law of Europe and the Future of Legal Education, Deventer, Kluwer, 1992, 265-283.

The Islamic Law on Land Tax and Rent, London, Croom Helm, 1988. Al-Sirajiyyah or the Mahommedan Law of Inheritance, Calcutta, 1792 (herdruk: S.a.D.M. Sagawandi, Lahore, House, 1959).

"Betekenis en invloed van de Union Internationale du Notariat Latin bij de totstandkoming van de Haagse Verdragen", WPNR, 1993 (6092), 338-341. "Internationaalprivaatrecht: huwelijksvermogensrecht", losbladigepersonenen familierecht, titel 7 (tot en met supplement 121, augustus 1996).

Vademecum internationaal erfrecht, Deventer, Kluwer, 1980.

"Overzicht der Nederlandse rechtspraak: huwelijksvermogensrecht (19751978)", WPNR, 1980 (5511), 223-228.

"Rechtsvragenrubriek", WPNR, 1984 (5695), 265-267. 
Joppe, I.S.

Joppe, I.S.

Joppe, I.S.

Joppe, I.S.

Joppe, I.S.

Joppe, I.S.

Joppe, I.S.

Joppe, I.S.

Joppe, I.S.

Jordens-Cotran, L.

Jordens-Cotran, L.

Josephus Jitta, D

Juynboll, Th.W.

Kernkamp, W.J.A.

Khalîl ben Ish'ậ

Khan, $\mathrm{H}$.

Kisch, I.

Kleijn, W.M.

Kneller, D.

Knigge, A.

Kohler, Chr.

Kokkini-Iatridou, D. en
Overgangsrecht in het internationaal privaatrecht en het fait accompli. Proefschrift, Arnhem, Gouda Quint bv 1987.

"Rechtsvragennubriek:Internationaalprivaatrecht: huwelijksvermogensrecht; de uitdrukkelijke uitsiuiting door de erflater in art. 94 BW", WPNR, 1988 (5894), 647-648.

"Het Haags Huwelijksvermogensverdrag 1978 en zijn uitvoering en aanvulling in de Wet Conflictenrecht Huwelijksvermogensregime (WCH)", in: Twee Haagse Verdragen, Preadviezen van I.S. Joppe, W. Westbroek en K.D. de Lange voor de Koninklijke Notariele Broederschap, Deventer, Kluwer, 1990, 11-82.

"lets over het Erfrechtverdrag en het Trustverdrag", in: Hondius, E.H., e.a. (red.), Quod Licet, Deventer, Kluwer, 1992, 179-198.

"Artikelen 65-70 IPR-schets: erfrecht", WPNR, 1993 (6109), 733-738.

"Naschrift op reactie van M.J.A. van Mourik, naar aanleiding van de beantwoording op rechtsvraag nr. 10 'Huwelijksvermogensrechtelijke gemeenschap?'”, WPNR, 1994 (6148), 587.

"Naschrift op reactic van S.H. Heyning, naar aanleiding van de beantwoording op rechtsvraag nr. 21 'Rechtskeuze tijdens huwelijk ter verduidelijking van het tussen echtgenoten geldend huwelijksvermogensregime'", WPNR, 1995 (6179), 292-293.

"Het 'Haags Trustverdrag' in werking", WPNR, 1996 (6215), 181-190.

"Estate planning door middel van trust en testament", in: Schmidt, G.E. en Freedberg-Swartzburg, J.A., Het NIPR geannoteerd, 's-Gravenhage, T.M.C. Asser Instituut, 1996, 85-97.

"Enkele wijzigingen van de Marokkaanse familiewetgeving", $M R, 1993$, 211-217.

"Consulaire verstotingen, erkemningen en andere Marokkaanse zaken", $M R$, 1995, 3-7.

Internationaal privaatrecht, Haarlem, Tjeenk Willink \& Zoon, H.D., 1916. Handleiding tot de kennis van de Mohammedaansche Wet, Leiden, E.J. Brill, 1930.

De Islam en vrouw, Proefschrift, Amsterdam, Noord-Hollandsche Uitgeversmaatschappij, 1935.

Abrégé de la loi musulmane selon le rite de l'Imâm Mâlek, traduction nouvelle par Bousquet, G-H, Paris, A. Maisonneuve, Alger, La maison des Livres, Tome II: It statut personnel 1958; Tome III: le patrimoine 1961; Tome IV: judicature, droit pénal, affranchissements, statut successoral 1962. Istamic Law of Inheritance: a Comparative Study with Emphasis on Contemporany Problems, Lahore, 1980.

"Convention sur les conflits de lois en matiere de forme des dispositions testamentaires", WPNR, 1961 (4662), 47-49; 1961 (4663), 59-61.

"De trust in Nederland", in: Hartlief, T., e.a. (red.), CJHB: Brunner-bundel, Deventer, Kluwer, 1994, 209-216.

Der Rechtscharakter des Islâmischen Institutes wakf und des AngloAmerikanischen Institutestrust, Inaugural-Dissertation, Tübingen, Fotodnuck Präzis, 1966 ,

"Het Haags Trustverdrag (1987)", TVVS, 1994, 57-62

"Zur praktischen Bedeutung exotischer Rechte im Internationalen Privatrecht", in: Eisenmann, P., und Zieger, G., (hrsg.), Zur Rechtslage Deutschlands: innerstaatlich und international, München, Hanns Seidel Stiftung, 1990. 
Frohn, E.N.

Kokkini-latridou, D. en Frohn, E.N.

Kokkinj-latridou, D. en Frohn, E.N.

Kokkini-latridou, D.

Kokkini-Iatridou, D. en K. Boele-Woelki

Kokkini-latridou, D. en K. Boele-Woelki

Kollewijn, R.D.

Kooten, H. van

Koppenol-Laforce, M.E. Koppenol-Laforce, M.E.

Koppenol-Laforce, M.E.

Koppenol-Laforce, M.E. Koppenol-Laforce, M.E. en Vlas, $P$.

Koppenol-Laforce, M.E. Kosters, J. en Dubbink, C.W.

Kreuzer, K.

Krüger, $\mathrm{H}$.

Labuschagne, B.C.

Lagarde, $\mathrm{P}$.

Lange, K.D. de
"De voorvraag in het Nederlandse IPR", WPNR, 1987 (5835), 371-375; $1987(5836), 387-390 ; 1987(5837), 413-415$

"De voorvraag in het verdragenrecht", in: Kokkini-Iatridou, D., en Velden, F.J.A. van der, (red.), Eenvormig en vergelijkend privaatrech, Lelystad, Koninklijke Vermande BV, 1988, 73-126.

"De excepticclausules in het verdragenrecht: een verkenning", in: KokkiniIatridou, D., en Grosheide, F.W., (red.), Eenvormig en vergelijkend privaatrecht, Lelystad, Koninklijke Vermande BV, 1989, 215-264

"L'adoption en droit international privé néerlandais", in: Hondius, E.H., en Steenhoff, G.J.W., (ed.), Netherlands reports to the thirteenth International Congress of Comparative Law/Rapports néerlandais pour le treizième Congrès international de droit comparé, 's-Gravenhage, T.M.C. Asser-Instituut, $1990,93-134$

"Opmerkingen over de Schets van een algemene wet betreffende het IPR", NIPR, 1992, 477-550.

"De regeling van de "internationale rechtsmacht" in het voorontwerp van wet van 1993", NIPR, 1993, 319-364.

Het beginsel der openbare orde in het intermationaal privaatrecht, Den Haag, Nijhoff, 1917.

"De Anglo-Amerikaanse trust in het toekomstige internationaal privaatrecht", AAe, 1993, 637-643.

"Haags IPR Trustverdrag 1985", JuD, 1991, 22-23.

"De trust en het EEX", in: Christiananse, J.H., e.a. (red.), Tot vermaak van Slagter, Deventer, Kluwer, 1988, 95-115.

"De rechtsmacht van de Nederlandse rechter in het voorontwerp tot aanpassing van het Wetboek van Burgerlijke Rechtsvordering", TvCR, 1994, 510.

"To Trust or Not to Trust ..., WPNR, 1994 (6155), 737-738.

"Ruim baan voor buitenlandse trusts in Nederland", $S \& V, 1995,27-33$.

Proefschrift over het Haagse Trustverdrag (in voorbereiding).

Algemeen deel van het Nederlandse internationaal privaatrecht, Haarlem, De Erven F. Bohn N.V., 1962.

"Internationales Privatrecht und Bundesverfassungsgericht. Eine Fallstudie zur Durchsetzung von Grundrechten durch das Bundesverfassungsgericht", in: Klein, E., (hrsg.), Grundrechte, soziale Ordnung und Verfassungsgerichtsbarkeit, Heidelberg, Müller, 1995, 153-183.

"Probleme islamischen und nahöstlichen Privatrechts in Deutschland", in: Rutten, S.W.E., (red.), Recht van de Islam I0, Maastricht, RIMO, 1992, I00-123.

"Godsdienstvrijheid en Islam", in: Rutten, S.W.E., (red.), Recht van de Islam 14 (in bewerking en zal verschijnen bij RIMO Maastricht 1997).

"La nouvelle Convention de la Haye sur la loi applicable aux successions", RCDIP, 1989, 249-275.

"Verdrag inzake het recht dat van toepassing is op erfopvolging 1 augustus 1989", in: Twee Haggse Verdragen. Preadviezen van I.S. Joppe, W. Westbroek en K.D. de Lange voor de Koninklijke Notariële Broederschap, Deventer, Kluwer, 1990, 83-171. 
Lapanne-Joinville, J.

Lapanne-Joinville, J.

Lapanne-Joinville, J.

Lapanne-Joinville, J.

Lapanne-Joinville, J.

Lapanne-Joinville, J.

Lapanne-Joinville, J.

Lapanne-Joinville, J.

Lapanne-Joinville, J.

Lapanne-Joinville, J.

Layish, A.

Layish, A

Layish, A

Layish, A

Layish, A

Lemaire, W.L.G

Lequette, $Y$.

Lequette, $Y$.

Lerebours-Pigeonnière, $P$,

Leveau, $\mathrm{R}$.
"L'action en pétition d'hérédité", RMD, 1950, 65-69.

"La théorie des nullités de mariage en droit musulman malékite", RATMLJ, $1951,92-102$.

"La reconnaissance de paternité de l'enfant issu du concubinat légal", RMD, $1952,153-166$.

"La filiation maternelle naturelle en droit musulman malékite", $R M D, 1952$. 256-267.

"La rescision du mariage en droit musulman malékite", $R M D, 1952,431$ 450 .

"Les principes fondamentaux du droit de succession musulmane (rite Maléki(c)", Mémoires de l'Académie Imternationale de Droit Comparé, 3 Rome, 1953, 1-20.

"Les conflits de paternité en droit musulman (rite malékite)", RMD, 1956. 352-363.

"La reconnaissance de paternité légitime (istilhaq) en droit musulman malékite", RMD. 1957, 1-12.

"Le cose marocain du statut personnel", RMD, 1959, 97-125.

"Le droit musulman marocain moderne", in: Seidl, E., c.a., Orientalisches Recht, Leiden, E.J. Brill, 1964, 426-440.

"Wonan and Succession in the Muslim Family in Israel", AAS, 1973, 9, 23-62.

"Marriage, Divorce and Succession in the Druze Family", Leiden, E.J. Brill, 1982.

"The Mâlikî Family Waqf According to Wills and Waqfiyyât", BSOAS, $1983,1-32$.

"Bequests as an Instrument for Accommodating Inheritance Rules: Israel as a case study", ILS, 1995, 282-319.

"The Family Waqf and the Shari' Law of Succession According to Wagqfiyyat in the Sijill of Shari'a Courts", in: Baer, G., and Gilbar, G., (ed.), Social and Economic Aspects of the Muslim Waqf, New York, New York University Press, 1996, 18-44.

Nederlands internationaal privaatrecht: Hoofdlijnen, Leiden, A.W. Sijthoff 1968.

"Le droit international privé de la famille à l'épreuve des conventions internationales", Rec.dC, 1994 II, Tome 246, 9-234.

"Noot bij Cour d'appel de Paris (1 re ch.civ.) 14 juni 1994", RCDIP, 1995, 308-319.

"La Déclaration universelle des droits de l'homme et le droit international privé français", in: Le droit privé français au milieu du XXe siècle, Etudes offertes à Georges Ripert, Paris, Pichon, 1950, Tome I, 255-270.

Public Property and Control of Property Rights: Their Effects on Social Structure in Morocco, in: Mayer, A.E., (ed.), Property, social structure and law in the modern Middle East, New York, State University of New York Press, 1985, 61-84. 
Leijnse-Kolk, A.P.G.

Linant de Bellefonds, $Y$.

Loenen, M.L.P.

Loon, J.H.A. van

Loon, J.H.A. van

Loon, J.H.A. van

Loon, J.H.A. van

Lorenz, S.

Loubignac, $V$.

Lubbers, A.G.

Lubbers, A.G.

Luccioni, J.

Luccioni, J.

Luciani, J.D.

Lijnzaad, L.

Maher, V.

Maher, $V$.

Mahmood, T.

Malmström, A.
"Drie fora: forum actoris, forum non conveniens en forum necessitatis", NIPR, speciale aflevering: de internationale bevoegdheid van de Nederlandse rechter volgens de nieuwe bepalingen van het Wetboek van Burgerlijke Rechtsvordering 1996, 107-118.

Traité de droit musulman comparé, Paris/La Haye, Mouton, Tome I: Théorie générale de l'acte juridique 1965; Tome II: Le mariage, la dissolution du mariage 1965; Tome III: Filiation, incapacités, libéralités entre vifs 1973.

"Het Europese Hof voor de Rechten van de Mens als toetser of steller van de wet? Enkele beschouwingen naar aanleiding van de zaak Kroon", NJCM. 1996, special: 45 jaar Europees Verdrag voor de Rechten van de Mens, 75 82.

"Aanrakingspunten met het Nederlandse recht", in: Anglo-Amerikaanse trusts en het Nederlandse recht, Preadviezen A. Dyer en J.H.A. van Loon voor de Nederlandse Vereniging voor Internationaal Reclit, Mededelingen NVIR $1983 n^{\circ} 87,43-111$.

"The Hague Convention on the Law Applicable to Succession to the Estates of Deceased Persons", in: Hague Yearbook of International Law, Dordrecht, Nijhoff, $1989,48-58$.

"International Co-operation and Protection of Chiddren with Regard to Intercountry Adoption", Rec.dC, 1993 VII, Tome 244, 191-456.

"De wisselwerking tussen internationaal privaatrecht en rechten van de mens", in Dijk, D. van, e.a., Grensoverschrijdend privaatrecht, Deventer, Kluwer, 1993, 135-148.

"Islamisches Ehegattenerbrecht und deutscher ordre public: Vergleichsmal3stab für die Ergebniskontrolle", IPRax, 1993, 148-151.

"Du partage des successions musulmanes, on the traditional methods of calculation in the Maghrib", RASJEP, 1929, 1-32.

"Xe Congres van de Union internationale du Notariat Latin, Montevideo, oktober 1969: regels van het ipr toepasselijk op de overgang en op de verdeling van de nalatenschap", Maandblad voor het Notariaat, 1970, 135-137. "De authentieke akte in het internationaal privaatrech", in: Maeijer, J.M.M., Recht zo die gaat, Zwolle, W.E.J. Tjeenk Willink, 1976, 61-94. Les Habous au Maroc, Rabat 1928. (samenvatting: Le Habous au Maroc (J. Luccioni), GTM n ${ }^{\circ} 288,20$ oktober 1927, p. 289-290 en n ${ }^{\circ} 290,3$ november 1927 , p. 305-306).

Le habous au wakf (rites malékite et hanéfite), Thèse Algiers, Casablanca 1942. (samenvatting: Les habous au wakf (rites malékite et hanéfite) (J. Luccioni), GTM $n^{\circ}$ 921, 23 januari 1943, p. 9-11).

Traité des successions musulmanes (ab intestat), Paris, Emest Leroux, 1890. "Het kussen van een kikker", Nemesis, 1991, 2, 5-17.

Women and Property in Morocco: Their Changing Relation to the Process of Social Stratification in the Middle Atlas, London, Cambridge University Press, 1974.

"Women and Social Change in Morocco", in: Beck, L., and Keddie, N., (ed.), Women in the Muslim World, Cambridge, Harvard University Press, 1978.

"Islamic Family Wagf in Twentieth Century Legislation: a Comparative Perspective", IsCLQ, 1988, 1-20.

"Explanatory Report 1977", Actes ef documents de la treizième session de la Conférence de La Haye, Tome III: mariage, 1978. 
Manaf, $A$.

Marçais, W.

Mattheussens-Kroon, J.H.M.

Martiny, D.

Mayer, P.

Melchior, $\mathrm{G}$

Mercier, E.

Mercier, E

Mercier, $\mathrm{P}$.

Mergenthaler, E.

Mernissi, F.

Messaoudi, L.

Mejjers, E.M.

Milliot, L.

Milliot, L. et Blanc, F-P

Mir-Hosseini, $Z$.

Modisk-Touini, K.

Monéger, F.

Moors. A.

Moors, A.

Morand, M.

Mostermans, P.M.M.

Mostermans, P.M.M.

Mostermans, E.

Motzki, H.
Problèmes du couple mixte face au droit et à la société, Casablanca, Imprimeries Najah el Jadida, 1990.

Des parents et alliés successibles en droit musulman, London, Oxford University Press, 1931, Rennes 1898.

"Het polygame huwelijk in Nederland", HPS, 1993, 5, 11-13.

"Gemeinschaftsrecht, ordre public, zwingende Bestimmungen und Exklusivnormen", in: Bar, Chr. von, (ed.), Europäisches Gemeinschaftsrecht und internationales Privatrecht, Köln, Carl Heymanns Verlag, 1991, 211-242. "La Convention curopéenne des droits de l'homme et l'application des normes étrangères", RCDIP, 1991, 651-665.

Die Grundlagen des deutschen internationalen Privatrechts, Berlin, De Gnyter, 1932, 245-265.

Le hobous ou ouakof: ses règles et sa jurisprudence, Alger, 1895.

Le Code du Habous ou Ouakf selon la législation musulmane, Paris, 1899. Conflits de civilisations et droit international privé: polygamie et répudiation, Geneve, Librairie Droz, 1972.

"Das ausländische Ehthindernis der Religionsverschiedenheit", SIAZ, 1965 , 134-137.

"De politieke harem: vrouwen en de profeet". Breda, De Geus, 1991.

"La discrimination à l'égard de la femme en droit international privé marocain", RIDC, 1992, 947-957/RDE, 1991, 7, 43-54.

"Erfrechtelijke moeilijkheden op het gebied van het internationaal privaatrecht",WPNR, 1936 (3493), 609-612;1936 (3494), 621-625; 1936 (3495), 633-636; 1936 (3496). (641-645.

Démembrements du habous: manfâ, gza, guelsa, zina, istighrâq, Paris, Institut des Hautes Etudes Marocaines, 1918.

Introduction à l'élude du droit musulman, Paris, Sirey, 2e ed. 1987.

"Contrast between Law and Practice for the Moroccan Family: Patriarch and Matrifocality, Morrocan Studies, 1991, 39-52.

"Femnes, mariage et héritage chez les Sorfa du Tazerwalt (Maroc)", in: Gast, M., (ed.), Hériter en pays musulman: habus, lait vivam, manyahuli, Paris, Centre National de la Recherche Scientifique, 1987, 89-102.

"La convention franco-marocaine du 10 aout 1981 relative au statut des personnes et de la famille et à la coóperation judiciaire", RCDIP, 1984, 29 $69 ; 1984,267-288$.

"Gender Relations and Inheritance: Person, Power and Propeny in Palestine", in: Kandiyoti, Deniz, (ed.), Gendering the Middle East: Alternative Perspectives, London/New York, Tauris, 1996, 69-84.

"Vrouwen en bezit", in: Rutten, S.W.E., Recht van de Islam 14, Maastricht (in bewerking en zal verschijnen bij RIMO Maastricht 1997).

Etude sur la nature juridique du hobous, Alger, 1904.

"Rechtskeuze in het internationale erfrecht", WPNR, 1988 (5898), 717-724. "De objectieve verwijzing in het internationaal erfrecht: het Nederlandse IPR versus het Haagse Erfrechtverdrag", NIPR, 1989, 417-426.

"Party Autonomy: Why and When?", in: Boer, Th.M. de, e.a., Forty Years on: The Evolution of Posnwar Private International Law, Deventer, Kluwer, $1990,123-141$.

"Het ontstaan van het islamitische recht: de recente wetenschappelijke discussie", in: Rutten, S.W.E., (red.), Recht van de Islam 13, Maastricht, RIMO, 1996, 1-17. 
Moulay R'chid, $A$.

Moulay R'chid, $A$.

Moulay Rchid, A.

Moulay R'chid. A.

Moulay R'chid, A.

Moulay R'chid, A.

Moulay R'chid, A.

Moulay R'chid, A. Moulay R'chid, A.

Mundy, $M$.

Mus, J.B.

Nova, R. de

Offerhaus, J.

Omar, $\mathrm{Ch}$.

Operti Badan, D.

Othman, M.Z.b.H.

Oufir, H. El

Overbeck, A.E. von

Overbeck, A.E. von

Overbeck, A.E. von

Pastner, C.

Pauli, H-G

Pearl, D

Pesle, O.

Pesle, $\mathrm{O}$.
L'exéquatur des jugements étrangers en droit international privé marocain (du Protectorat à 1972), Rabat, Faculté des Sciences juridiquesm économiques et sociales, 1973.

Le régime de l'exéquatur des jugements étrangers en droit marocain après la réforme du code de procédure Civile, 1977.

La condition de la femme au Maroc, Rabat. Faculté des Sciences Juridiques Economiques et Sociales, 1985.

"Modernité et politiques législatives en matière de statut personnel dans les pays arabo-africains à majorité musulmane", in: Behnam, D., et Bouraoui, S., (ed.), Familles musulmanes et modernité: le défi des traditions, Paris, Publisud, 1986, 161-192.

"Ongelijkheid van godsdienst: een niet te overschrijden grens", HPS, 1988. 9/10, 72-76.

Cours de licence: les conflits de juridictions, Rabat, Faculté de Droit, 1989 1990 (niet gepubliceerd).

"Les grandes lignes de droit international privé marocain en matière de statut personnel", RDE, 1991, 7, 7-42.

La femme et la loi au Maroc, Casablanca, Le Fennec, 1991.

"Le droit international privé du Maroc indépendant en matière de statut personnel", in: Carlier, J-Y, et Verwilghen, M., (red.), Le statut persomnel des musulmans: droit comparé et droit international privé, Bruxelles, Bruylant, 1992, 143-177.

"The Family, Inheritance, and Islam: a Re-examination of the Sociology of Fara'id Law", in Al-Azmeh, A., (ed.), Jslamic Law: Social and historical Contexts, London, Routledge, 1988, 1-123.

Verdragsconflicten voor de Nederlandse rechter, Proefschrift, Zwolle, W.E.J. Tjeenk Willink, 1996.

"Historical and Comparative Introduction to Conflict of Laws", Rec.dC, 1966 II, Tome 118, 437-621.

Aampassing in het internationaal privaatrech, Amsterdam, Noord-Hollandsche Uitg. Maatschappij, 1963.

Les habous, Rabat, 1921

"L'adoption internationale", Rec.dC, 1983 II, Tome 180, 295-411.

"Institution of Waqf", $I C, 1984,55-62$.

"La codification du droit marocain", RJPIC, 1986, 391-401.

"Divers aspects de l'unification du droit international privé, spécialement en matiere de successions", Rec.dC, 1961 III, Tome i04, 529-633.

"Explanatory Repon 1984", Actes et documents de la quinzième session de la Conférence de La Hay'e, Tome II: trusts - loi applicable et reconnaissance, 1985.

"I'Article 8 du projet néerlandais et la clause d'exception", NIPR, speciale aflevering: studiedag van een algemene wet betreffende het internationaal privaatrecht 1994,36-43.

"Access to Property and the Status of Somen in Islam", in: Smith, J., (ed.), Women in Contemporary Muslim Societies, Rewisbury, Bucknell University Press, 1980, 146-186.

Islamisches Familien- und Erbrecht und ordre public, Dissertation, München, 1994.

A Texibook on Muslim Personal Law, London, Croom Helm, 2nd ed. 1987. Le testament dans le rite malékite, Rabat, Félix Moncho, 1932.

Le mariage chez les Malékites de l'Afrique du Nord, Rabat, Félix Moncho, 1936. 
Pesle, $\mathrm{O}$.

Pesle, $\mathrm{O}$.

Peters, E.

Peters, R.

Ploeg, P.W. van der

Ploeg, P.W. van der ca.

Polak, M.V.

Polak, M.V.

Polak, M.V.

Powers, D.S.

Pradelle, G. de La

Pritsch, E.

Raape, L.

Rahnân, M.H.

Reitner, $Y$.

Rigaux, F.

Rigaux, F.

Roberts, R.

Roelvink, H.L.J.

Roth, W-H

Rumsey, A.

Rumsey, A.

Rutten, S.W.E.
Exposé pratique des successions dans le rite malékite, Casablanca, 1940. La théorie et la pratique des habous dans le rite malékite, Casablanca, 1941. "The Status of Women in Four Middle Eastern Communities", in: Beck, L., and Keddie, N., (eds.), Women in the Muslim world, Cambridge Mass., Harvard University Press, 1978, 311-351.

"Het recht - recente ontwikkelingen", in: Waardenburg, J., (red.), Norm, ideal en werkelijkheid, Houten, Het Wereldvenster, 2e druk 1987, 296-312. Enkele erfrechtelijke hoofalstukken van internationaal privaatrecht, Preadvies voor de Broederschap der Notarissen in Nederland, Deventer, Kluwer, 1961. "Pays-Bas", in: Régimes matrimoniaux, successions et libéralités: droit international privé et aroit comparé. Tome II, Neuchatel, La Baconnière, $1979,177-294$.

Naar een gecodificeerd international privaatrecht!, Pre-adviezen van Th.M. de Boer en M.V. Polak voor de Nederlandse Vereniging voor International Recht, Mededelingen NVIR $1990 \mathrm{n}^{\circ} 101,3-48$.

Grenzeloos procederen: aspecten van Nederlands internationaal burgerlijk procesrecht, Nijmegen, Ars Aequi Libri, 1993.

"Structuur en methodologie van de IPR-schets", NIPR, speciale aflevering: studiedag van een algement wet betreffende het internationaal privaatrecht 1994, 13-21.

Studies in Qur'an and Hadith: The Formation of the Islamic Law of Inheritance, London, University of California Press, 1986.

"L'islam et le droit islamique en France", in: Rutten. S.W.E., (red.), Recht van de Islam 10, Maastricht, RIMO, 1992, 65-78; net vertaling naar het Nederlands door Van der Veiden, F.J.A., 79-91.

"Grundzüge des islamischen Intestaterbrechts", in: Mémoires de l'Académie Internationale de Droit Comparé, iii/3 Rome, 1953, 21-41.

"Les rapports juridiques entre parents et enfants", Rec.dC, 1934 IV, Tome 50, 40)1-544.

"The Role of Pre-islamic Customs in the Islamic Law of Succession", IsCLQ, 1988, 48-64.

"Family Wadf Entitlements in British Palestine (1917-1948)", ILS, 1995. 174-193.

"L'intervention des autorités consulaires dans la conservation, l'administration et la liquidation des successions", in: Annales de Droif et de Sciences Politiques 1957, 251-276; 1957, 327-359.

Droir international privé, Tome I: Théorie générale, Larcier Bruxelles, 1987; Tome II: Droit positive belge, Bruxelles, Larcier, 2me ed. 1993.

Das Familien-, Sklaven- und Erbrecht im Quran, Leipzig, Zentralantiquariat der DDR 2e ed., 1968.

"Art. 6:2 BW en het Nederlandse IPR", in: Dijk, D. van, e.a., Grensoverschrijdend privaatrech, Deventer, Kluwer, 1993, 219-230.

"Der Einfluß des Europäischen Gemeinschaftsrechts auf das Internationale Privatrecht", Rabelsz, 1991, 623-673.

Moohummudan Law of Inheritance and Rights and Relations Affecting it: Sunni Doctrine, Allen, W.H., \& Co, London, 2nd ed., 1880.

Al Serajiyyah, or the Mohammedan Law of Inheritance, London, 2 nd ed. . 1890 .

"Vrouwen en het internationaal privaatrecht", in: Heringa, A.W., e.a. (red.), Het Vrouwenverdrag: een beeld van een Verdrag ... . Antwerpen/ Apeldoorn, MAKLU, 1994, 255-272. 
Rutten, S.W.E.

Rijn van Alkemade, J. van

Rijn van Alkemade, J. van

Rijn van Alkemade, J. van

Rycx, J-F

Saad, A.Z.

Sarchanc, $F$.

Sarehanc, F.

Sarehane, F. et

Lahlou-Rachdi, N.

Schacht, J.

Schacht, J.

Schacht, J.

Scheuermann, T.

Sctumidı, T.S.

Schokkenbroek, J.G.C.

Schulesz, J.C.

Schultsz, J.C.

Schultsz, J.C.

Schultsz, J.C.

Scoles, E.F.

Sefrioui, $H$.

Sinay-Cytermann, A.
"Les relations juridiques familiales dans le droit successoral marocain et le Jroit privé néerlandais", in: Benhallam, , e.a., Le Maroc et la Hollande, Une approche comparative des grands intérêts communs, Rabat, Faculté des Lettres et des Sciences Humaines, 1995, 141-157.

"Verdrag betreffende de huwelijkssluiting en de erkenning van de geldigheid van huwelijken", $N J B, 1977,482-483$.

"Nieuwe regels van conflictenrecht betreffende het huwelijk", FJR, 1989, 220-225.

"Artikel 2 boek 6 Nieuw Burgerlijk Wetboek en het internationaal privaatrecht", in: Liber Amicortum NBW, Arnhem, Gouda Quint/Deventer, Kluwer/ Zwolle, W.E.J. Tjeenk Willink, 1991, 105-110.

"Regles islamiques et droit positif en matière de successions: présentation générale", in: Gast, M., (ed.), Hériter en Pays Musulman: habus, lait vivant, manyahuli, Paris, Centre National de la Recherche Scientifique, 1987. $19-41$.

Le "wakf" de famille: étude critique, Thèse, Paris, R. Guillon, 1928.

"La toi applicable au statut personnel des réfugies et des apatrides en droit international privé marocain", RMDED, 1989, 309 e.v.

"Le statut persomne!: droit commun: succession, testament, donation", Jurisclasseur, Législation comparíc Maroc, Fasc. 2-2, 1993.

"Conflits de lois: conflits de juridictions". Jurisclasseur, Législation comparéc Maroc. Fasc. 4, 1994.

"Problems of Modern Islamic Legislation", Studia Islamica, 1959, 99-129.

The Origins of Muhammadan Jurisprudence, Oxford, Clarendon Press, $3 e$ druk, 1959.

An introduction ro lslamic law, Oxford, Clarendon Press, 1965, paperbacked. 1982.

Statutenwechsel im internationalen Erbrecht, Dissertation, München, Beck. 1969.

"The Incidental Question in Private International Law", Rec.dC, 1992 II, Tome 233, 305-416.

Toetsing aan de vrijheidsrechten van het Europees Verdrag tot bescherming van de Rechen van de Mens, Proefschrift, Zwolle, W.E.J. Tjeenk Willink, 1996.

"De Nederlandse rechter en internationale adopties", WPNR, 1960 (4612). 13-16; 1960 (4613), 25-28.

Adoptie in het Nederlandse internationaal privaatrecht, Preadviezen van H.R. Goudsmit en J.C. Schultsz voor de Nederlandse Vereniging voor Internationaal Recht, Mededelingen NVIR $1961 n^{\circ} 45,34-82$.

"Noot bij HR 26 oktober 1984", NJ, 1985, 696.

"De algemene exceptieclausule in de IPR-schets", NIPR, speciale aflevering: studiedag van een algemene wet betreffende het intemationaal privaatrecht $1994,30-35$.

"The Hague Convention on Succession", AJCL, 1994, 85-123.

Les droits réels et l'influence pratique au Maroc, Collection des Etudes juridiques XIV/Collection des Etudes notariales V 1989.

"Noot bij Cour de cassation (I re chambre civile) 22 april 1986", Clunet. $1986,1025-1039$. 
Snouck Hurgronje, C.

Snijders, W.

Sonneveldt, F.

Steenhoff, G.J.W.

Stille, A.L.G.A.

Stille, A.L.G.A.

Stöber, G.

Stober, G.

Strikwerda, L.

Strikwerda, L.

Strikwerda, L.

Strikwerda, L.

Strikwerda, L.

Struycken, A.V.M.

Struycken, A.V.M.

Strijp, R.

Suhrawardy, A. al M.

Sumampouw, $M$.

Talbi, $\mathrm{Z}$.

Tanzil-Ur-Rahman

Tarâbulusî, I. jbn $\mathrm{M}$.

Tornauw, N. von

Trooboff, P.D.
Verspreide Geschriften. Deel I: Geschriften betreffende den Islam en zijne geschiedenis; Deel II: Geschriften betreffende het Mohammedaansche recht; Deel III: Geschriften betreffende Arabië en Turkije, Bonn, Kurt Schröder, 1923.

"Trustverdrag en Nederlands materieel recht", in: Dijk, D. van, e.a., Grensoverschrijdend privaatrecht, Deventer, Kluwer, 1993, 231-243.

"Het Haags Trustverdrag en zijn consequenties voor het Nederlandse belastingrecht", WPNR, 1993 (6092), 377-382.

"Haags Trustverdrag op 1 februari 1996 in Nederland in werking getreden", $J u D, 1996,4,9-12$.

"Enkele opmerkingen over de werking van mensenrechten en van de openbare orde in verband met het Erfrechtverdrag", in: Schmidt. G.E. en Freedberg-Swarzburg. J.A., (red.), Het NIPR geannoteerd. 's-Gravenhage, T.M.C. Asser-Instituut, 1996, 57-64.

"Het nieuwe Nederlandse internationale erfrecht", $F J R, 1996,216-223$.

"Habous Public' in Chaouen: zur wirtschaftlichen Bedeutung religiöser Stiftungen in Nordmarokko", Die Welt des Islams, 25, 1985.

"Habous Public" in Marokko: zur wirtschaftlichen Bedeutung religiöser Stiffungen in 20. Jahrhundert, Marburg/Lahu, Marburger Geographische Schriften, 1986.

Naar een gereduceerd conflictenrecht? Iets over bescherming, begunstiging en better law in het IPR, Oratie, Groningen, Wolters-Noordhoff, 1986.

"Nieuwe geluiden in het internationale erfrecht", WPNR, 1987 (5821), 149152.

Boekbespreking: P. Vlas, Internationaal privaatrecht in de spiegel van het nieuwe BW, RM Themis, 1993, 165-167.

Inleiding tot het Nederlandse Internationaal Privaatrecht, Groningen, Wolters-Noordhoff, 1995.

"Drie fora: forum actoris, fortum necessitatis en forum non conveniens", NIPR, speciale aflevering: de internationale bevoegdheid van de Nederlandse rechter volgens de nieuwe bepalingen van het Wetboek van Burgerlijke Rechtsvordering 1996, 95-106.

"Beantwoording rechtsvraag", AAe, 1974, 380-387.

"Het Haagse Erfrechtverdrag komt eraan", WPNR, 1993 (6092), 351-356. "Moroccon Immigrants and Inheritance in the Netherlands" (in bewerking en zal verschijnen bij The Onati International Institute for the Sociology of Law, Oñati).

The History of Muslim Legal Institutions with Special Reference to the Law of Watf, Calcutta, 1910.

"Internationaal procesrecht: Nederlandse en Europese activiteiten" (redactioneel), $N I P R, 1995,1-2$.

"La révélation coranique entant que fondement du droit successoral au Maroc", RJPIC, 1984, 251-265.

A Code of Muslim Personal Law, Vol. II, Karachi, Islamic Publishers, 1979. Droit musulman: le wakf, Alexandrië 1893 (trad: B. Adda et E.D. Ghatiounghi).

"Das Erbrecht nach den Verordnungen des Islams", ZVR, 1984, 116-208.

"The Growing Interaction between Private and Public International Law, in: Hague Yearbook of International Law, Dordrecht, Nijhoff, 1993:1994, 107. 114. 
Uniken Venema, C.A.E

Uniken Venema, C.A.E Uniken Venema C.A.E. en S.E. Eisma

Uniken Venema, C.A.E.

Ubertazzi, G.M.

Velden, F.J.A. van der

Velden, FJ.A. van der

Velden, F.J.A. van der

Velden, F.J.A. van der

Verhagen, H.L.E.

Verheul, J.P.

Verheul, J.P.

Verheul, J.P. en

Feteris, M.W.C.

Verheul, J.P.

Vlas, P.

Vlas, $P$.

Vlas, P.

Vlas, P.

Vonken, A.P.M.J.

Vonken, A.P.M.J.

Vonken, A.P.M.J.

Vonken, A.P.M.J.

Vonken, A.P.M.J.

Vonken, A.P.M.J.
"Anglo-Amerikaanse trusts in het Nederlandse recht: bespreking preadviezen van A. Dyer en J.H.A. van Loon 1983", WPNR, 1985 (5727), 86-96; 1985 (5728), 113-120; 1985 (5729), 141-148.

Trustrecht en bewind, Nijmegen, Ars Aequi Libri, 1985.

Eigendom ten titel van beheer naar komend recht, Preadvies Vereeniging Ilandelsrecht, Zwolle, W.E.J. Tjeenk Willink, 1990.

"Hel Haagse Trustverdrag: de in het Verdrag voorziene "externe werking" van Anglo-Amerikaanse trusts", WPNR, 1993 (6092), 362-369 (I); 1993 (6093), 391-397 (II); 1993 (6095), 447-453 (III).

"Règles de non-discrinination et droit international privé", Rec.dC, 1977 IV, Tome 157, 333-414.

"Kronick van het privattecht over 1984: XIV: internationaal privaatrecht", RM Themis, 1985, 240-244.

"De burgerlijke stand in Marokko", MR, 1986, 171-175.

"De burgerlijke stand in Marokko en de geboortedatum van Marokkanen", in: Rutten, S.W.E., (red.), Recht van de Islam 7, Maastricht, RIMO, 1989, 69-91.

"Verdrag van Brussel II: regels van bevoegdheid en erkenning van vonnissen in zaken van huwelijksontbinding in voorbereiding", NIPR, 1995, 3-4.

"Het Haagse Trustverdrag", in: Hayton, D.J., e.a. (red.), Vertrouwd met de Trust, Deventer, W.E.J. Tjeenk Willink, 1996.

De openbare orde als iweesnijdend zward, Leiden, Universitaire Pers, 1978.

"Overzicht der Nederlandse rechtspraak: internationaal privaatrecht, rechterlijke bevoegdheid", WPNR, 1986 (5792), 474-480 (II).

Rechssmacht in het Nederlandse internationaal privaatrecht, Deel 2, Apeldoorn/Antwerpen, MAKLU, 1986.

"Het huwelijksverdrag en de Wet conflictenrecht huwelijken", FJR, 1991, 122-124.

"Internationaal erfrecht in de praktijk", De Notarisklerk, 1980, 181-183.

Internationaal privaatrecht in de spiegel van het nieuwe $B W$. Oratie, Deventer, Kluwer, 1989.

"De regeling van de rechtsmacht in het voorontwerp van wet tot aanpassing van het Wetboek van Burgerlijke Rechtsvordering", NIPR, speciale aflevering: studiedag van een algemene wet betreffende het internationaal privaatrecht 1994, 6!-71.

"Inwerkingtreding Haags Trustverdrag", TVVS, 1996, 19

"Internationaal privaatrecht: internationale adoptie", losbladige personen-en familierecht, titel 12 (tot en met supplement 96, januari 1992).

"Internationaal privaatrecht: minderjarigheid", losbladige personen-en familierecht, titel 13 (tot en met supplement 111, september 1994).

Het internationale afstammingsrecht in perspectief, Proefschrift, Arnhem, Gouda Quint, 1987.

"Balancing Processes in International Family Law", in: Boer, Th.M. de, e.a., Forty Years on: the Evolution of Postwar Private International Law in Europe, Deventer, Kluwer, 1990.

"Substitutie-problemen op het terrein van het internationaal familierecht", $H P S, 1992,6,3-7$.

"Het intemationale huwelijkstecht", HPS, 1992, 7/8, 3-8 (I); 1992, 10, 3-8 (II). 
Vonken, A.P.M.J.

Vonken, A.P.M.J.

Vonken, A.P.M.J.

Vos, J.W.M. de

Voskuil, C.C.A.

Voskuil, C.C.A.

Vriesendorp, R.D.

Waters, D.W.M.

Waters, D.W.M.

Wengler, $W$.

Wengler, $W$.

Westbroek, W.

Westbroek, W.

Whitehead, $A$.

Winkler von Mohrenfels, P.

Wolde, M.H. ten

Wolde, M.H. ten

Wolde, M.H. ten

Wolde, M.H. ten

Wolde, M.H. ten

Wolde, M.H. ten

Zaid, A.M.
"Arikelen 1-10 IPR-Schets: algemene bepalingen", WPNR, 1993 (6104), 622-627.

"Rechtsverfijningen in een open IPR-systeem", in: Dijk, D. van, e.a., Grensoverschrijdend privaatrecht, Deventer, Kluwer, 1993, 299-314.

"De reflexwerking van de mensenrechten op het IPR", in: Cliteur, P.B., en Vonken, A.P.M.J., (red.), Doonwerking vanmensenrechten, Wolters-Noordhoff, Groningen, 1993, 153-185.

De notariële verklaring van erfrecht, Proefschrift, Arnhem, Gouda Quint, 1975.

Rechtsvinding aan de hand van buitenlandse rechtsregels: Vorfrage en verkregen rechten, Amsterdam, Scheltema \& Holkems N.V.. 1963.

Boekbespreking E. Cohen Henriquez, IPR-trends 1980, RM Themis, 1985. $102-104$.

Het Nederlandse goederenrecht en het Haagse Trustverdrag. Preadviezen van C.D. van Boeschoten en R.D. Vriesendorp voor de Vereniging voor Burgerlijk Recht, Lelystad, Koninklijke Vermande, 1994, 45-106.

"Explanatory Report 1988", Actes et documents de la seizième session de la Conférence de La Haye, Tome II: successions - loi applicable. 1990.

"The Institution of the Trust in Civil and Common Law", Rec.dC, 1995 , Tome 252, 113-454.

"Die Vorfrage im Kollisionsrech", RabelsZ, 1934, 8, 148-251.

"Nouvelles réflexions sur les questions préalables", RCDIP, 1966, 165-215.

"Het Haagse Verdrag inzake het recht dat van toepassing is op de erfopvolging", WPNR, 1989 (5926), 457-461.

"Verdrag inzake het recht dat van toepassing is op erfopvolging 1 augustus 1989", in: Twee Haagse Verdragen, Preadviezen van I.S. Joppe, W. Westbrock en K.D. de Lange voor de Koninklijke Notariële Broederschap 1990, Deventer, Kluwer, 1990, 83-157.

"Men and Women, Kinship and Property: Some General Issues", in: Hirshon, R., (ed.), Women and Property, Women as Property, London, Croom Helm, 1984, 176-193.

"Kollisionsrechtiche Vorfage und materielles Recht", RabelsZ, 1987, 2032.

"Internationale nalatenschap Nederland, Spanje", WPNR, 1990 (5950), $139-$ 141; 1990 (5961), 332-333.

"Noot bij het gemeenschappelijk Hof van Justitie van de Nederlandse Antillen en Aruba 22 oktober 1991", TAR, 1992, 55-59.

"Enkele opmerkingen over rechtskeuze in het internationaal erfrecht naar aanleiding van een cussenvonnis van de Rechtbank Den Haag 11 maar 1992, rolur. 91/5029", WPNR, 1992 (6065), 727-729.

"Recente rechtspraak: de vraag naar het toepasselijke recht op het huwelijksvermogensregime en HR 19.3.1993 RvdW 1993, 78, WPNR, 1994 (6124), 118-120.

Vereffening en verdeling in het Nederlandse internationaal erfrecht, Zwolle, W.E.J. Tjeenk Willink, 1995.

Internationaal en interregionaal erfrecht in het Koninkrijk der Nederlanden.

Proefschrift, Deventer, Kluwer, 1996.

The Islamic Law of Bequest, London, Scorpion, 1986. 



\section{Curriculum}

Susan Rutten werd op 4 oktober 1960 geboren te Breda. In 1979 behaalde zij haar VWO-diploma aan het Peelland College te Deurne. Vanaf 1979 studeerde zij rechten aan de Universiteit Utrecht waar zij in februari 1985 het doctoraal-examen Nederlands recht, afstudeerrichting privaatrecht, behaalde. Gedurende een jaar verrichtte zij onder verantwoordelijkheid van de Vereniging tot bestudering van het Recht van de Islam en het Midden Oosten (RIMO) onderzoek naar de invloed van islamitische normen en waarden in de Nederlandse rechtspraak. Dit onderzoek kreeg een vervolg van 1986 tot 1988 in welke periode zij als wetenschappelijk assistent verbonden was aan de vakgroep privaatrecht van de Universiteit Maastricht. Vervolgens werkte zij drie jaar bij de Faculteit der Rechtswetenschappen van de Open universiteit. Sinds 1991 is zij werkzaam als universitair docent privaatrecht bij de Universiteit Maastricht. 